DEPARTMENT OF THE INTERIOR

UNITED STATES GEOLOGICAL SURVEY

GEORGE OTIS SMITH, DireCTOR

Professional Paper 83

\title{
THE MIDDLE TRIASSIC MARINE INVERTEBRATE FAUNAS OF NORTH AMERICA
}

BY

JAMES PERRIN SMITH

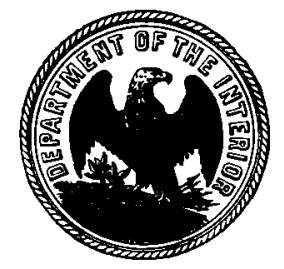

WASHINGTON

GOVERNMENT PRINTING OFFICE

1914 



\section{CONTENTS.}

列

Geography of the American Triassic

Interregional correlation of the Triassic

Faunal succession of the Triassic in western America

Faunal geography of the Middle Triassic of America

General relations of the Triassic faunas of the Old World and the New

Middle Triassic fauna of California._-_-

Inyo County --_-

Shasta County .

Middle Triassic fauna of Nerada

Affinities_-_-_-_-_- 6

Localities _._-_-_-_-_-_. 8

Middle Triassic species from Yevada allied to foreigu species_._-

Middle Triassic cephalopod genera of California and Nevada_-_.

Marine invertebrate fauna of the Middle Triassic of California and Nevada__-______...

Bibliography -_-_-_-

Systematic descriptions -

Cephalopoda

Order Ammonoidea._.

Suborder Tropitoidea

Tropitidæ -..-----

Tropigastrites -

Celtitidæ-

Celtites -0-1-0.--

Columbites

Haloritidæ -- - -

Acrochordiceras _-_-_-_- 38

Suborder. Arcestoidea

Popanoceratiden_-_-

Popanoceras_._- 40

Subgenus Parapopanoceras._.

Cyclolobidx --_---_-

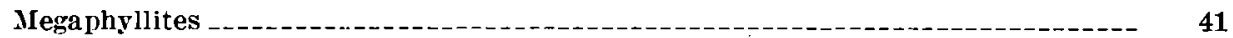

Arcestidæ -.-_-_-

Arcestes _...

Subgenus Proarcestes

Suborder Ptychitoidea _-

Ptychitidæ _._.

Subfamily Nannitinæ

Nannites_._.

Paranannites

Subfamily Ptychitine-_. 46

Ptychites_..._. 46

Suborder Lytoceratoidea

Lytoceratidæ _...... 48

Monophyllites

Suborder Pinacoceratoidea

Pinacoceratidx _._- 49

Sageceras _--1-

Longobardites _._.

Suborder Ceratitoidea

Gymnitidæ

Gymnites_._. 51

Subgenus Anagymnites -

Xenodiscidæ

Xenodiscus__._. 
Systematic descriptions-Continued.

Cephalopoda-Continued.

Order Ammonoidea-Continued.

Suborder Ceratitoidea-Continued. Page

Hungaritidæ

Hungarites__.

Dalmatites _.._- 58

Eutomoceras _-

Subgenus Halilucites _......... 64

Meekoceratidx_._- 65

Lecanites _-_-

Ceratitidie -_-

Tirolites _-_- 68

Dinarites _. 69

Cuccoceras _.

Ceratites_._.

A. Ceratites nodosi

I. Group of Ceratites rotuloides _. 80

II. Group of Ceratites occidentalis

III. Group of Ceratites kingi-_- 85

IV. Group of Ceratites elegans._- 86

v. Group of Ceratites bosnensis.

vI. Group of Ceratites humboldtensis _- 98

B. Ceratites circumplicati

VII. Group of Ceratites roiti and Ceratites erismi-_._. 104

C. Ceratites geminati. 109

Group of Ceratites blakei (Gymnotoceras)

Haydenites_._-

Beyrichites_...- 115

Balatonites

Trachyceratea _- 121

Nevadites _.

Trachsceras _._-_-_- $12 i$

Subgenus Anolcites

Subgenus Protrachyceras _.

Order Belemnoidea _..-138

Belemnitidie

Atractites

Order Nautiloidea _-

Orthocerals _.

Grypoceras _._-

Germanonatutilus_-_-_.

Paranautilus.-_- 142

Pelecspoda _...-

Pleuromya -_-_-_-

Daonella

Rhynchopterus _-_-_-_-_-_- 145

Modiomorpha _-_-_-_-_-_-_-_- 145

Corbula

Brachiopoda

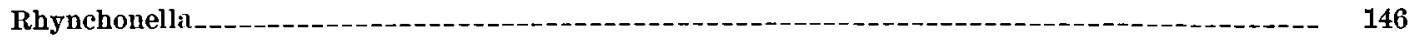

Terebratula _-_-_-_-_-_- 147

Spiriferina

Crinoidea

Pentacrinus

Index -

\section{ILLUSTRATIONS.}




\title{
THE MIDDLE TRIASSIC MARINE INVERTEBRATE FAUNAS OF NORTH AMERICA.
}

\author{
By Jimes Perrin Shith.
}

\section{INTRODUCTION.}

Many years ago Prof. Alpheus Hyatt and the writer planned a monographic treatment of the Triassic invertebrate faunas of America. When it became evident that Prof. Hyatt's advancing years would prevent the completion of this plan the writer prepared, with some assistance and advice from Prof. Hyatt, a synoptical introduction to the whole faunal work. This was published by the United States Geological Survey as Professional Paper 40, "The Triassic cephalopod genera of America," by Alpheus Hyatt and James Perrin Smith. This volume contained descriptions of the higher groups and all the genera known from the American Triassic at that time and also a fully illustrated description of a typical species under each genus and subgenus.

It was then intended that the writer should publish the remaining specific descriptions and illustrations in a single volume, but when the materials for the text and illustrations were brought together it was seen that they were too bulky for such treatment, and it was decided to divide the work into three volumes, on the marine invertebrate faunas of the Lower, Middle, and Upper Triassic of America. Of these three, the volume on the Middle Triassic is presented first because at the time this plan was made it was nearer completicn, and because in this fauna there were more new forms that might be anticipated in other publications.

As this volume is essentially a continuation of Professional Paper 40 the descriptions of the major groups and genera given in that work are not repeated, but all figures and descriptions of species of Middle Triassic cephalopods that appeared in Professional Paper 40 are here reprinted for convenience of reference.

The same plan will be followed in the papers on the Lower Triassic and the Upper Triassic marine invertebrate faunas, which are now well along toward completion. The work on the Lower Triassic faunas will be somewhat smaller and that on the Upper Triassic faunas somewhat larger than this volume.

\section{GEOGRAPHY OF THE AMERICAN TRIASSIC.}

During 'Triassic time the sea, which had covered the greater part of the Mississippi Valley and the Great Basin in the Pennsylvanian or "Upper Carboniferous," retreated westward until it was reduced to a large gulf in the Great Basin region. ${ }^{1}$ Sediments with marine fossils of the Lower Triassic are known on the North American continent only in eastern California and southeastern Idaho; marine fossils of the Middle Triassic are known only in California, central Nevada, and British Columbia; and Upper Triassic marine fossils are known only in northern California, central Nevada, eastern Oregon, western British Columbia, on Queen Charlotte and Vancouver islands, and on the shores of Alaska. The Triassic of the eastern United States is all nonmarine. 
During Lower Triassic time the gulf extended as far eastward as the Aspen Mountains of Idaho: during Middle Triassic time it retreated westward until its eastern border was in central Nevada; and at the end of the Triassic period the land had encroached still further, until the gulf was little more than a bay in northern California and central Nevada, with similar bays in western British Columbia.

Around this western gulf extended the inlets and continental basins in which were deposited the Triassic "Red Beds." These extend in a fringe around the marine sediments from the Grand Canyon region on the south along the Rocky Mountains into British Columbia.

As the sea retreated westward the brackish water and continental basins followed it, so that the Triassic "Red Beds" do not all belong to one horizon, but have a successively higher place in the geologic column toward the west. In Oklahoma the "Red Beds" contain Permian fossils of brackish-water origin; in northwestern Texas they contain fresh-water Triassic fossils. In southeastern Idaho the marine sediments of Lower Triassic age are overlain by barren red sandstones representing the Middle Triassic; and in northern California and central Nevada, after the Hosselkus limestone and Brock shale epoch, a period of erosion ends the Triassic, showing that much of the area of the Great Basin Sea had become dry land. Further than this the encroachment did not go, for in California and Nevada the next epoch, the Lower Jurassic (Lias), is characterized by a marine fauna, showing a renewed subsidence and transgression of the interior sea over a large part of the area that it had covered during the Lower Triassic.

The continental deposits of the Triassic in western America bear all the marks of products of an arid region, much like the region about the Caspian Sea to-day; but that the marine Triassic sediments were laid down in an arm of the greater ocean, and not in a closed basin like the Caspian Sea, is shown by the fact that their successive faunas show a close relation to forms that existed contemporaneously in other regions bordering on the Pacific Ocean and in the ancient Mediterranean Sea, or "Tethys," which in Mesozoic time covered a large part of southern Asia.

At the close of the Triassic came the culmination of that progressive elevation of the land that began in the Mississippi Valley at the beginning of the "Coal Measures" and extended gradually across the American continent until all that was left of the great interior sea was merely a gulf a few hundred miles across. This adds another chapter to the remarkably uniform history of North America which has been recorded in the rhythmical advance and retreat of the sea across its surface from the Cambrian to the Tertiary. Each period of subsidence, local or widespread, has been followed by a period of elevation in which the continent resumed approximately its former shape and extent. Whatever may have been the development of other continents, North America has been a unit since its history began to be recorded in the pre-Cambrian sediments laid down in the first sea that covered its surface.

\section{INTERREGIONAL CORRELATION OF THE TRLASSIC.}

The accompanying table exhibits the correlation of the Triassic faunas by regions. 
Interregional correlation of the Triassic.

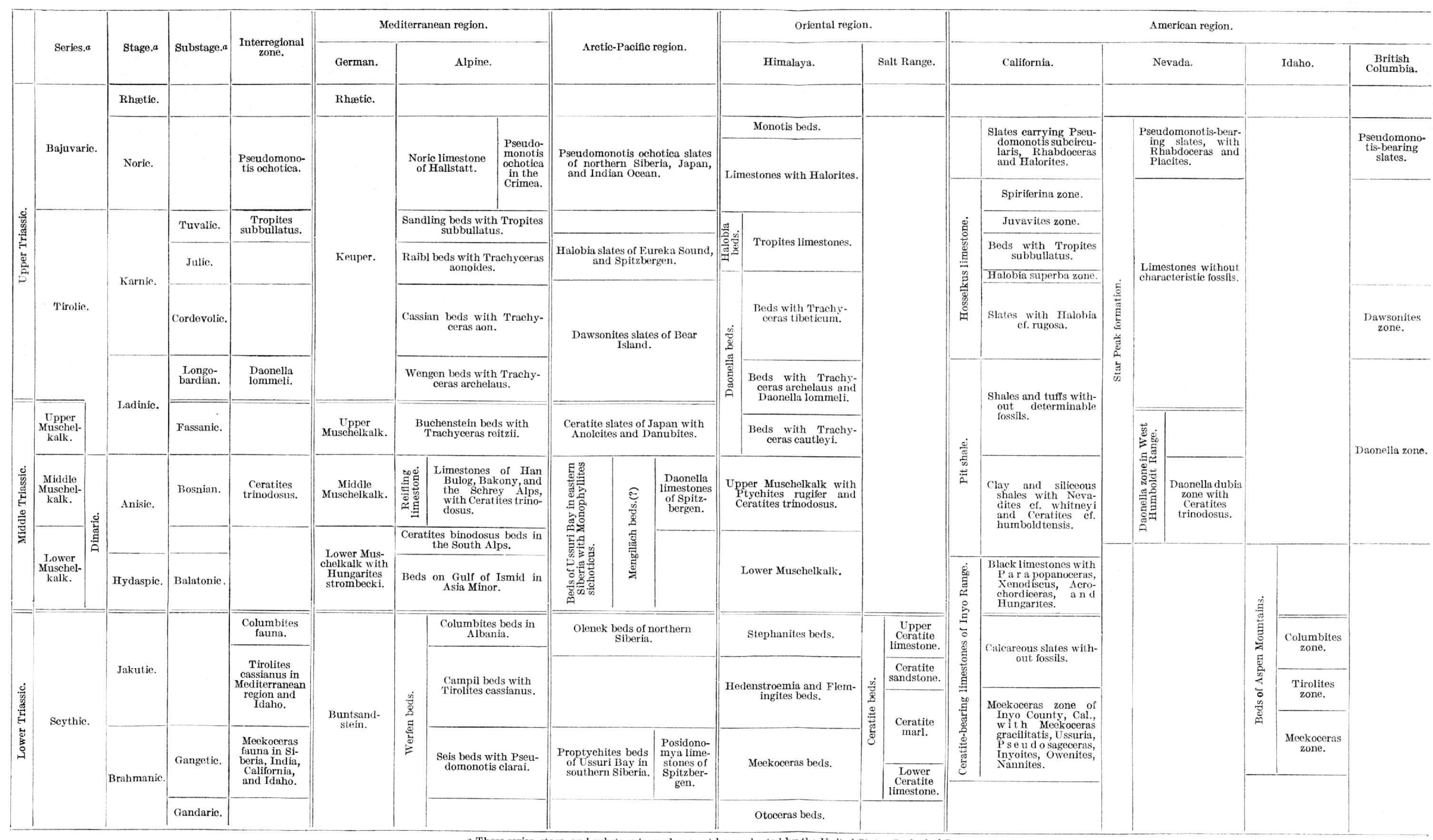

16279 -No. 83-14. (To face page 4.)

a These series, stage, and substage terms have not been adopted by the United States Geological Survey. 
FAUNAL SUCCESSION OF THE TRIASSIC IN WESTERN NORTH AMERICA. table:

The faunal succession of the Triassic in western North America is shown in the following Faunal succession of the western American Triassic.

\begin{tabular}{|c|c|}
\hline \multirow{3}{*}{ Upper Triassie. } & Pseudomonotis subcircularis zone (slates with a fauna of Boreal type, with some Mediterranean formsintermingled). \\
\hline & Tropites subbullatus zone (limestones with a Mediterranean fauna, and some Indian typesintermingled). \\
\hline & $\cdot$ \\
\hline \multirow[t]{2}{*}{ Middle Triassic. } & $\begin{array}{l}\text { Daonella dubia zone (limestones with a Mediterranean fauna, similar to that of the zone of Ceratites trinodosus, } \\
\text { and with some Indian types). }\end{array}$ \\
\hline & Parapopanoceras zone (beds with a mixture of Boreal and Indian types). \\
\hline \multirow{3}{*}{ Lower 'Triassic. } & $\begin{array}{l}\text { Columbites zone (beds with a Boreal fauna and some Indian types, survivors from the zone of Meekoceras graci- } \\
\text { litatis, intermingled with a few Mediterranean types). }\end{array}$ \\
\hline & Tirolites zone (beds with a purely Mediterranean fauna of the zone of Tirolites cassianus). \\
\hline & Meekoceras zone (beds with a purely Asiatic fauna; not found anywhere else except in India and Siberia). \\
\hline
\end{tabular}

FAUNAT GEOGRAPHY OF THE MIDDI, TRLASSIC OF AMERICA.

GENERAL RELATIONS OF THE TRIASSIC FAUNAS OF THE OLD WORLD AND THE NEW.

In the Middle Triassic certain kinship still persists between the marine faunas of western America and Asia, though this may be due as much to inheritance from similar ancestors as to immigration. Only a few species are now common to the two regions, and many genera, even, are different on opposite sides of the ocean. During the same period the kinship between the American and the Mediterranean faunas begins to be strong, especially in the nodose ceratites and other members of the Ceratitidx. In the zone of Ceratites trinodosus in the West Humboldt Range of Nevada, out of more than 100 species more than one-fourth are either identical with or very closely related to forms from this zone in the Mediterranean region. It is possible that during the Middle Triassic a connection was established between these regions through some other way than the Indian branch of the old central Mediterranean, or "Tethys." It is not likely, howerer, that it was through the Boreal region, for the Boreal Middle Triassic fauna is unlike that of the Mediterranean. The faunas of the American and of the Mediterranean regions during the Middle Triassic are more closely related to each other than either is to the Indian ar to the Boreal fauna.

MIDDLE TRIASSIC FAUNA OF CALIFORNIA.

INYO COUNTY.

The oldest fauna of the Middle Triassic in America is found in Inyo County, Cal., on the Union Wash trail from Owens Valley over the Inyo Range to Salinas Valley, about 3 miles southeast of the Reward mill. The fossiliferous beds consist of about 6 feet of black limestone, lying about 800 feet above the zone of Meekoceras gracilitatis, which occurs in the same canyon. These beds may possibly belong to the Jakutic horizon, but the occurrence in them of Parapopanoceras makes this improbable. Moreover, Hungarites and Acrochordiceras are lacking in the Meekoceras zone and in the Jakutic Columbites zone, of Idaho, and their appearance in America marks a later epoch than the Jakutic. The character of their fauna 
is not that of the Hedenstrœmia zone of Idaho, hence they are regarded as correlative with the Hydaspic zone of the Lower Muschelkalk of Europe. This horizon has been called the Parapopanoceras zone, and all fossils described from the Middle Triassic of California came from this locality and horizon.

Fauna of the Parapopanoceras zone in California.

Tirolites pacificus Hyatt aud Swith. Keyserlingites? sp. indet. Acrochordiceras inyoense Smith. Hungarites yatesi Hyatt and Smith. Paranannites oviformis Smith.

\author{
Parapopanoceras haugi Hyatt and Smith. \\ Xenodiscus bittneri Hyatt and Smith. \\ Xenodiscus multicameratus Smith. \\ Orthoceras sp. indet. \\ Undeterminable pelecypods.
}

Among these forms only Tirolites pacificus shows affinity to the Mediterranean fauna; the majority are still Asiatic. Hungarites yatesi is more similar to the Mediterranean forms than to the Asiatic, but this genus is widely distributed. The fauna has more affinity to that of the Arctic Middle Triassic (Muschelkalk) than to that of India, and it therefore seems possible, even probable, that at this time the American Triassic province was connected on the one side with the Mediterranean region and on the other side with the Boreal province, but not with the Indian region.

SIIASTA COUNTY, CAL.

At Silverthorns Ferry, on Pit River, in Shasta County, Cal., there is a series of about 1,500 feet of siliceous shales, called the Pit shale. They contain very few fossils, and those are badly preserved, but the writer has recognized in them a few characteristic forms.

Fauna of the Pit shale, California.

Nevadites ef. whitneyi Gabb.

Ceratites cf. humboldtensis Hyatt and Smith.
Arcestes cf. gabbi Meek.

Pentacrinus asteriscus (?) Hall and Whitfield.

The Pit shale lies several hundred feet below the Upper Triassic limestones of Brock Mountain, in a conformable series. The fossiliferous horizon at Silverthorns Ferry is probably equivalent to the Middle Triassic limestones of the West Humboldt Range, Nev., in spite of the lithologic difference.

\section{MIDDLE TRIASSIC FAUNA OF NEVADA.}

\section{AFFINITIES OF THE FAUNA.}

The Geological Surrey of California, J. D. Whitney, State geologist, discovered in the Humboldt Range of Nevada some füsiliferous limestones containing ammonites, referred by W. M. Gabb ${ }^{1}$ to the Upper Triassic, and correlated with the St. Cassian formation of the Alps. Most of the species were obtained in the canyons on the eastern flanks of the West Humboldt Range, although the data given by Gabb are rather meager.

About 10 years later the geological exploration of the fortieth parallel brought to light a considerable number of new species and genera from the Humboldt Range. These were described by F. B. Meek, ${ }^{2}$ and referred to the St. Cassian horizon of the Upper Triassic, though Prof. Alpheus Hyatt, who described the genera of cephalopods in the fauna, always adhered to the opinion that the formation belonged to the Middle Triassic. It is likely, however, that several different horizons are represented among the collections described by Gabb and Meek. "Halorites ramsaueri" Gabb and Pseudomonotis subcircularis Gabb were found in the Humboldt region. Both are characteristic of the uppermost Triassic in California, and in Nevada they occur only in the Pseudomonotis-bearing slates, more than 1,000 feet above the Middle Triassic beds. 
In several publications ${ }^{1}$ Dr. E. von Mojsisovics has referred the Humboldt fauna to the Upper Triassic, correlating it with the Fassanic substage of the Tirolic series and comparing it especially with that of the Ceratite beds of Rikusen, Japan, and the Buchenstein horizon of the Alps. If the West Humboldt rocks were the equivalent of the Buchenstein beds they would still belong to the Middle Triassic (Muschelkalk) horizon, but in fact the fauna of the West Humboldt rocks shows no affinity with that of the Rikusen beds of Japan and not a great deal with the Buchenstein horizon of the Mediterranean. Instead, the kinship is chiefly with the Ceratites trinodosus fauna of the Mediterranean region. The occurrence in these beds of Ptychites, Hungarites, Beyrichites, Acrochordiceras, Ceratites, and Balatonites would be enough to make certain the reference of the fauna to the Middle Triassic, as none of these genera in their typical forms occur higher up. Besides, many of the commonest species in the Middle Triassic of the West Humboldt Range are most closely related to characteristic species in the Muschelkalk zone of Ceratites trinodosus of the Alps and Bosnia. The upper Anisic stage is certainly represented in Nevada, and the higher beds of the Daonella dubia shaly limestone may represent the lower Ladinic.

The group of Ceratites elegans (Paraceratites Hyatt) is largely of Mediterranean occurrence, but is also represented in the Indian region. The Hollandites group is largely Indian: but it is represented in Nevada by several fine species. The group of Ceratites occidentalis is a Mediterranean type and occurs abundantly in Nevada. Gymnotoceras is of Boreal affinities but is far more abundant in Nerada than in the Boreal region. The species of Beyrichites and Acrochordiceras seem to be equally allied to Mediterranean and Indian types, but Longobardites, Sageceras, Cuccoceras, Anolcites, Protrachyceras, and Eutomoceras are decidedly Mediterranean in character. There are many species of Anolcites and Protrachyceras in the Middle Triassic of Nevada, and these groups are fairly well represented in the Middlle Triassic of the Mediterranean region, though almost unknown in that horizon in the rest of the world. The occurrence of Balatonites is similar to that of Anolcites. The genus Neradites is largely confined to Nevada, but is sparingly represented in the Mediterranean region.

The fauna listed below from the Daonella dubia zone of the West Humboldt Range of Nevada shows a strong affinity with that of Ceratites trinodosus of the Mediterranean region, but also shows many elements that belong more properly to the lower Ladinic, equivalent to the Buchenstein fauna of the Alpine province. Such a mingling of faunas has been described from Bosnia by $F$. von Hauer, ${ }^{2}$ and from Bakony in Hungary by $F$. Frech ${ }^{3}$ and by $G$. von Arthaber. ${ }^{4}$ The Han Bulog fauna and its equivalents show this mingling of Bosnian and Ladinic forms, which may be explained either by a mixing of the fossils in collecting from two horizons, or else by a surrival of species from the Ceratites trinodosus horizon into later time. The latter explanation has been adopted by the European stratigraphers and may very reasonably explain the same phenomenon in the American Daonella zone. The fauna of the restricted Ceratites trinodosus zone probably originated in the Mediterranean region and reached. America by migration through the Atlantic waters, but the Trachyceratea, which give the Ladinic aspect in America probably originated in the American region. Thus the West Humboldt fauna appears to be homotaxially equivalent both to the zone of Ceratites trinodosus and to the lower part of the Ladinic, but the predominance of the Bosnian elements shows that the relationship is closer with the Bosnian than with the Buchenstein fauna.

The work of Mojsisovies, " ̈̇ber einige japanische Triasfossilien," gives an exaggerated idea of the relationship of the American to the Arctic-Pacific Triassic faunas. Mojsisovics

1.Arktische Triasfaunen: Mém. Acad. imp. sci. St.-Pêtersbourg. ser. 7 , vol. 33, No. 6, 18s6. pp. 147-150; and Beiträge zur Kenntniss der obertriadischen Cephalopoden-Faunen des llimalaya : Denkschr. K. Ikad. Wiss. Wien, vol. 63, 1896, pp. 640-697.

2 Beitrüge zur Kenntniss der Cephalopoden aus der Trias von Bosnien, Part I, Denkschr. K. Acad. Wiss. Wien, vol. 63, 1892 ; Part II, idem, vol. 63, 1896; and Cephalopoden des Bosnischen Muschelkalkes von IIan Bulog bei Sarajevo, idem, vol. 54,1887 .

3 Neue Cephalopoden aus den Buchensteiner, Wengener und Raibler Schichten: Resultate der Wissenschaftlichen Erforschung des Balatonsees, vol. 1, pt. 1, 1903.

4 Die Alpine Trias des Mediterran-Gebietes: Lethara Geognosica, pt. 2 (Mesozoicum). vol. 1, 1906, p. 444. 
compared American and Japanese forms and named several American species, all based entirely on the figures published by Gabb and Meek. The reader not familiar with American Triassic species would infer that there was a close relation between the American and the Japanese species described in that work, which is far from being the case. The Japanese material was too poor and the American Triassic fauna known at that time was too meager for any opinion to be based upon it. Moreover, Mojsisovics had seen only the figures of Gabb and Meek.

The rich faunas collected by the writer in Nevada in the last few years fail to show any relationship whatever to the Japanese but do show such a distinctly Mediterranean character that if a paleontologist from Austria were set down in the Triassic area of the Humboldt desert he could hardly tell from the character of the fauna whether he was collecting in Bosnia or in Nevada.

\section{LOCALITIES OF MIDDLE TRIASSIC FOSSILS IX NEVADA.}

All the Middle Triassic fossils known from Nevada come from the central-western part of the State, chiefly from the West Humboldt Range, the East Range, and the Desatoya Mountains. In the reports of the United States Geological Exploration of the Fortieth Parallel all the rocks of this region lying between the Jurassic and the Archean were called Triassic and were divided into the Star Peak group and the Koipato group, all the fossils being assigned indiscriminately to the Upper Triassic. Of the fossils described by Gabb and Meek from the Star Peak formation, only Pseudomonotis subcircularis is known certainly to have come from the Upper Triassic. The others, so far as their horizon has been determined definitely, belong to the Middle Triassic and came from a bed of shaly limestone, not more than 200 feet thick, lying at the base of the Star Peak formation and more than 1,000 feet below the massive Upper Triassic limestone of the Star Peak formation.

The sequence of beds was seen best and fossils were most abundant and best preserved in the West Humboldt Range. From Star Peak southward the Triassic makes up the eastern face of the range for more than 30 miles. The Middle Triassic shaly limestone forms a broken band along the foothills and lower slopes of the range, and the massive Upper Triassic limestone forms rugged cliffs along the eastern face near the top.

The following table shows the columnar section of the rocks in the West Humboldt Range:

Columnar section of the West IJ umboldt Range.

\begin{tabular}{|c|c|c|c|}
\hline \multicolumn{3}{|l|}{$\begin{array}{l}\text { Lower Jurassic } \\
\text { (Lias). }\end{array}$} & \multirow{2}{*}{ Carries Arietites. } \\
\hline & & & \\
\hline \multirow{4}{*}{ Upper Triassic. } & \multirow{5}{*}{ 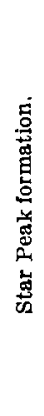 } & Pseudomonotis zone. & $\begin{array}{l}\text { Pseudomonotis subcircularis zone (slates, with Rhabdoceras and Ifalorites). Thickness about } \\
900 \text { feet. }\end{array}$ \\
\hline & & & Siliceous and tuffaceous beds, without fossils. Thickness unknown. \\
\hline & & & $\begin{array}{l}\text { Massive limestones, probably corresponding to the Hosselkus (Upper Triassic) limestone of the } \\
\text { California section. Thickness aljout 2,000 feet. }\end{array}$ \\
\hline & & & $\begin{array}{l}\text { Siliceous and tuffaceous beds without fossils, partly rhyolites, and other volcanic flows. Thick- } \\
\text { ness } 1,000 \text { to } 2,000 \text { feet. }\end{array}$ \\
\hline Middle Triassic. & & Daonella zone. & $\begin{array}{l}\text { Slaty limestones and tuff leds, hard at the top and grading over into shaly limestones and cal- } \\
\text { careous shales at the bottom. Thickness, } 1,000 \text { to } 1,500 \text { feet. The lower } 200 \text { feet contain nearly } \\
\text { all the fossils, which belong to the fauna of Ceratites trinodosus. }\end{array}$ \\
\hline \multicolumn{3}{|c|}{ Koipato formation. } & Siliceous beds, tuffs, graywackes, and igneous rocks, of unknown thickness. Without fossils. \\
\hline
\end{tabular}

The best locality for Middle Triassic fossils in Nevada is an isolated outcrop of the Daonella-bearing limestones on the eastern slope of Buffalo Peak, on a foothill called "Fossil Hill," 4 miles south of Fitting (formerly Foltz) post office, on the divide between Troy Canyon 
and the south fork of American Canyon, at an elevation of about 5,000 feet above the sea and 1,000 feet above Star Valley. At this place the Daonella-bearing limestones are reduplicated by repeated faulting and are exposed over a much larger area than is common with those soft beds. Moreover, they are not indurated, as are most of those beds, so that the fossils are abundant and well preserved. At this single locality the writer has collected in fire visits of from one to three weeks 130 species, of which 111 are ammonites. The local absence of induration, mineralization, and metamorphism has tended to the preservation of the fossils that once must have been abundant everywhere in the Daonella-bearing limestone.

The extreme heat of summer and the equally extreme-cold of winter have caused the shaly limestone to split readily, and the fossils are easily remored from the matrix. The collecting ground renews itself every few years by the work of the winter frosts in splitting open the slabs of limestone that line the hillside. When the writer first visited this locality in 1902 the hillside was literally covered with loose ammonites that had been set free from the matrix by the work of frost.

The species listed below are not all equally common, some being present in hundreds and others represented by a single specimen. The commonest forms are Ceratites, of the group of $C$. humboldtensis and $C$. blakei. Next in abundance would come Beyrichites, and third Nevadites. Arcestes probably comes next, and Ceratites, of the group of $C$. trinodosus, Tropigastrites, and Anolcites would follow in the order given. Wherever the beds are very shaly Daonella dubia is the commonest species. The statements as to the relative abundance of the species are based not on a single day's work, but on the experience of five seasons of collecting and on the relative abundance of the material obtained.

The fauna of Fossil Hill is listed in full below under the local lists of Middle Triassic fossils.

The same beds outcrop in Coyote Canyon, Cottonwood Canyon, and Buena Vista Canyon, and many of the same species were found at these localities, but the fossils are not nearly so abundant nor so well preserved.

A few species, enough to identify the horizon, were also found in the Daonella-bearing limestone on the sides of Star Canyon.

The Geological Survey of California and the Fortieth Parallel Survey party collected a few species at Dun Glen, East Range, Nev.

Another good collecting ground was discovered at New Pass, Desatoya Mountains, Nev., about 30 miles west of Austin. Here some excellent material was collected by the Geological Survey of California and by Dr. John C. Merriam.

A few species were found by the Geological Survey of California near Volcano, an abandoned mining camp about 30 miles southeast of Walker Lake, and a few in the Shoshone Mountains.

Local lists of Midlle Triassic fossils of Nevada.

Star Canyon, West Humboldt Range.

Trachyceras meeki Mojsisovics. subasperum Meek. Ceratites blakei Gabb.

Gymnites (?) perplanus Meek. Eudiscoceras whitneyi Meek. Orthoceras blakei Gabb.

\author{
Daonella dubia Gabb. \\ Aricula homfrayi (riabb. \\ Posidonomya stella liabb. \\ Spiriferina homfrayi Gabb. \\ Rhynchonella lingulata (aibb. \\ Terebratula humboldtensis Gabb.
}

Buena Vista Canyon, West Humboldt Range.

Tropigastrites halli Mojsisovics. Acrochordiceras hyatti Meek. Monophyllites. billingsianus Gabb. Arcestes gabbi Meek.
Longobardites nevadanus Hyatt and Smith. Cuccocer:as bonic-vistie Hyatt and Swith. Beyrichites rotelliformis Meek.

Balatonites hadleyi smitl. 
Ceratites organi Smith. ransomei Smith.

blakei Gabb.

Paranautilus multicameratus Gabb. Daonella moussoni Merian.
Modiomorpha ovata Meek. lata Meek.

Posidonomya stella Gabb.

Sphæra whitneyi Meek.

Pleuromya humboldtensis Gabb.

Coyote Canjon, Wost Humboldt Range.

Ceratites blakei Gabb.

| Rhynchonella sp. indet.

American district, west side of Buffalo Park, West Humboldt Range.

Nevadites whitneyi Gabb.

Sageceras gabbi Mojsisovics.

Tropigastrites halli Mojsisovics.

Daonella dubia Gabb.

Dun Glen, East Range (Pahute Mountains).

Trachyceras homfrayi Gabb.

Monophyllites billingsianus Gabb.

Paranautilus multicameratus Gabb.

Myophoria alta Gabb.

Rhynchonella squiplicata Gabb.

Spiriferina alia Gabb. homfrayi Gabb.

Pentacrinus astericus (?) Hall and Whitfleld.

Shoshone Meuntains (exact locality not known).

Balatonites kingi Smith. shoshonensis Hyatt and Smith.

Acrochordiceras liyatti Meek.

Volcano, about 30 miles southeast of Walker Lake.

Arcestes nevadanus Hyatt and Smith.

Virginia Mountains, southeast of Dayton.

Tropigastrites halli (?) Mojsisovics.

Daonella dubia Gabb. moussoni Merian.

Cottonwood Canyon, Wost Humboldt Range.

rthoceras blakei Gabb.

Nevadites whitneyi Gabb.

Trachyceras meeki Mojsisovics.

Ceratites blakei Gabb.

gabbi Meek.

humboldtensis Hyatt and Smith.

cf. trinodosus Mojsisovics.

Longobardites neradanus Hyatt and Smith.

Acrochordiceras hyatti Meek.

Beyrichites rotelliformis Meek.

Gynnites (:) perplanus Meek.

Arcestes gabbi Meek.

Tropigastrites halli Meek.

Celtites polygyratus Smith.

Atractites nevadensis Meek.

Cymbospondylus petrinus Leidy. piscosus Leidy.

Fossil Hill, south fork of American Canyon, West Humboldt Bange.

Tropigastrites lahontanus Smith.

louderbacki Hyatt and Smith.

halli Mojsisovics.

neumayri Mojsisovics.

powelli Smith.

rothpletzi Smith.

obliterans Smith.

trojanus Smith.

Celtites gabbi Smith. polygyratus Smith.

Columbites humboldtensis Smith. plicatulus Smith.

Arcestes hartzelli Smith. gabbi Meek. nevadanus Hyatt and Smith. quadrilabiatus Hauer.

Nannites contractus Smith.

Ptychites evansi Smith.

Megaphyllites septentrionalis Smith.

Monophyllites billingsianus Gabb.

Sageceras gábbi Mojsisorics.

Gymnites alexandræ Smith. calli Smith.

(?) perplanus Meek.

Anagymnites rosenbergi Smith. acutus (?) Hauer.

Hungarites fittingensis Smith.

Dalmatites minutus Smith. parvus Smith.

Eutomoceras breweri Smith. dalli Smith.

dunni Smith.

lahontanum Smith.

laubei Meek.

Iongobardites nevadanus Hyatt and Smith.

Lecanites parvus Smith.

nudus Smith.

rogdesi Hyatt and Smith.

crassus Smith. 
Beyrichites dunni Smith. falciformis Smith. osmonti Smith. rotelliformis Meek. tenuis Smith.

Dinarites desertorum Smith. (?) pygmæus Smith.

Ceratites altilis Smith. beecheri smith. crassicornu Smitl. ecarinatus Hauer. emmonsi Smith. fissicostatus Hauer. gilberti Smith. haguei Snith. humboldtensis Hyatt and Smith. karpinskyi Smith. kingi Smith. nevadanus Mojsisovics. occidentalis Smith. pilatus Smith. rotuloides Smith. spinifer Smith. tenuispiralis Smith. washburnel Smith. wea veri Smith. williamsi Smith.

(Paraceratites) clarkei Smith. cricki Smith. burckhardti Smith. gabbi Meek. newberryi Smith. taurus Smith. trinodosus Mojsisovics. trojanus Smith. vogdesi Smith. wardi Smith.

(Hollandites) montis-boris Smith. organi Smith.

(Philippites) argentarius Smith. lawsoni Smith.

(Gymnotoceras) blakei Gabb. beckeri Smith. cornutus Smith. rectangularis Smith.

Ceratites-Continued.

(Gymnotoceras) hersheyi Smith. meeki Mojsisovics. russelli Smith. spurri Smith. wemplei Smith.

Haydenites hatschekii Diener.

Acrochordiceras foltzense Smith. hyatti Meek.

Nevadites fontainei smith. humbóldtensis Smith. hyatti Smith. merriami Smith. sinclairi Smith. whitueyi Gabb.

Trachyceras barberi Smith. drakei Smith. dunni Smith. furlongi Smith. gabbi Smith. gracile Snith. americanum Mojsisovics. homfrayi Gabb (?). lahontanum Smith. meeli Mojsisovies. subasperum Meek.

Atractites elegans Smith. böckhi Stürzenbaum. neradensis Meek. solidus Smith. burckhardti Smith. clavatulus Smith.

Orthoceras blakei Gabb. campanile Mojsisovies.

Germanonautilus furlongi Smith.

Paranautilus multicameratus Gabb. Grypoceras whitueyi Gabb.

Daonella americana Smith. dubia Gabb. lindströmi Mojsisovics. moussoni Merian.

Rbynchopterus obesus Gabb. Sphæra whitneyi Gabb.

Cymbospondylus petrinus Leidy. piscosus reidy.

Now Pass, Desatoya Mountains.

Tropigastrites neumayri Mojsisovics.

Ceratites argentarius Smith.

cricki Smith.

humboldtensis Hyatt and Smith. newberryi Smith.

organi Smith.

trinodosus Mojsisovics.

weaveri Smith.

Trachyceras americanum Mojsisorics. Cuccoceras bonæ-vistæ Hyatt and Smith. Monophyllites billingsianus Gabb.

Acrochordiceras hyatti Meek.

Celtites gabbi Smith.

Gymnotoceras blakei Gabb.
Sageceras gabbi Mojsisovics. Beyrichites rotelliformis Meek. Eutomoceras laubei Meek. Arcestes gabbi Meek. Grypoeeras whitneyi Gabb. Orthoceras blakei Gabb. Daonella dubia Gabb. Sphæra whitneyi Gabb. Modiomorpha lata Meek. ? ovata Meek.

Spiriferina homfrayi Gabb. Rhynchonella alteplecta Böckh. Terebratula humboldtensis Gabb. Crmbospondylus piscosus Leidy. 


\section{MIDDLE TRIASSIC SPECIES FROM NEVADA ALLIED TO FOREIGN SPECIES.}

The Middle Triassic faunas of western Europe have long been the standard of the world, as they have been made so well known by the works of Hauer, Mojsisovics, Diener, and Arthaber. In more recent years the Middle Triassic faunas of India have become well known through the work of Diener.

During this epoch the waters of western America were connected with both the Indian and the Mediterranean waters. There was therefore a partial community of species between the Middle Triassic faunas of Nevada and those of India and Europe, and there were, moreover, in Nevada many species closely allied to forms in the foreign faunas, though not identical with them. The American species have been critically compared with the related foreign species, and the results compiled in a series of lists given below, showing the species from Nevada in one column and the foreign related form in the opposite column.

These comparisons bring out the facts of faunal geography as nothing else can. They show a much larger number of forms identical with or closely related to forms in the Middle Triassic fauna of the Mediterranean region. They also show that, though several species are identical with Indian species, those same forms nearly all occur in the Alpine province, so that the connection was probably made through the ancient "Tethys," though sporadic migrations directly between India and America, by way of the Asiatic coast, may have taken place.

The following lists indicate the relations of the fauna of Nevada to those of other regions:

Species closely related to the Indian Lpper lyuschelkalk fuuna.

Nevada.

India.

Ceratites trinodosus Mojsisories_-___.__-_____Ceratites trinodosus Mojsisovics.

C. cricki Smith.... himalayanus Blanford.

C. haguei Smith....... kuvera Diener.

C. humboldtensis Hyatt and Smith

C. trojanus Smith

Hollandites organi Smith___._. Hollandites roiti Oppel.

H. montis-bovis Smith.

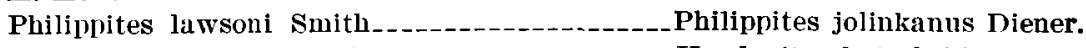

Haydenites hatschekii Diener-_-_-_-_._-_._Haydenites hatschekii Diener.

Beyrichites rotelliformis Meek_-_._-_-_-_-_Beyrichites khanikof Oppel.

B. falciformis Smith

Cuccoceras bon:e-ristæ Hyatt and Smith_._-___ Cuccoceras yoga Diener.

Nevadites humboldtensis Smith_______.____._evadites (") cautleyi Diener.

Protrachyceras homfrayi Gabb__.___._._._Protrachyceras cf. longobardicum (Diener).

Eutomoceras (Halilucites) dalli Smith__________Eutomoceras (Halilucites) sp. indet. Diener.

Acrochordiceras hyatti Meek._._._-______._. Acrochordiceras ef. carolinæ Mojsisovics.

Gymnites allexandrie Smith

Anagymnites rosenbergi Smith_..._._. Anagymnites cf. acutus Hauer.

Monophyllites billingsianus Gabb_

Arcestes hartzelli Smith

Tropigastrites halli Mojsisovics____________ Danubites" dritara shtra Diener.

Germanonautilus furlongi Smith

Orthoceras campanile Mojsisorics

Species closely related to the fauna of the Arctic Muschelkalk.

Nevada.

Spitzbergen.

Gymnotoceras blakei Gabb Crymnotoceras falcntum Mojsisovics.

G. wemplei Smith G. nathorsti Mojsisovics.

Daonella lindströmi Mojsisovics Daonella lindströmi Mojsisovics. 
Species showing affinities with Mediterranean fauna of the zone of Ceratites trinodosus.

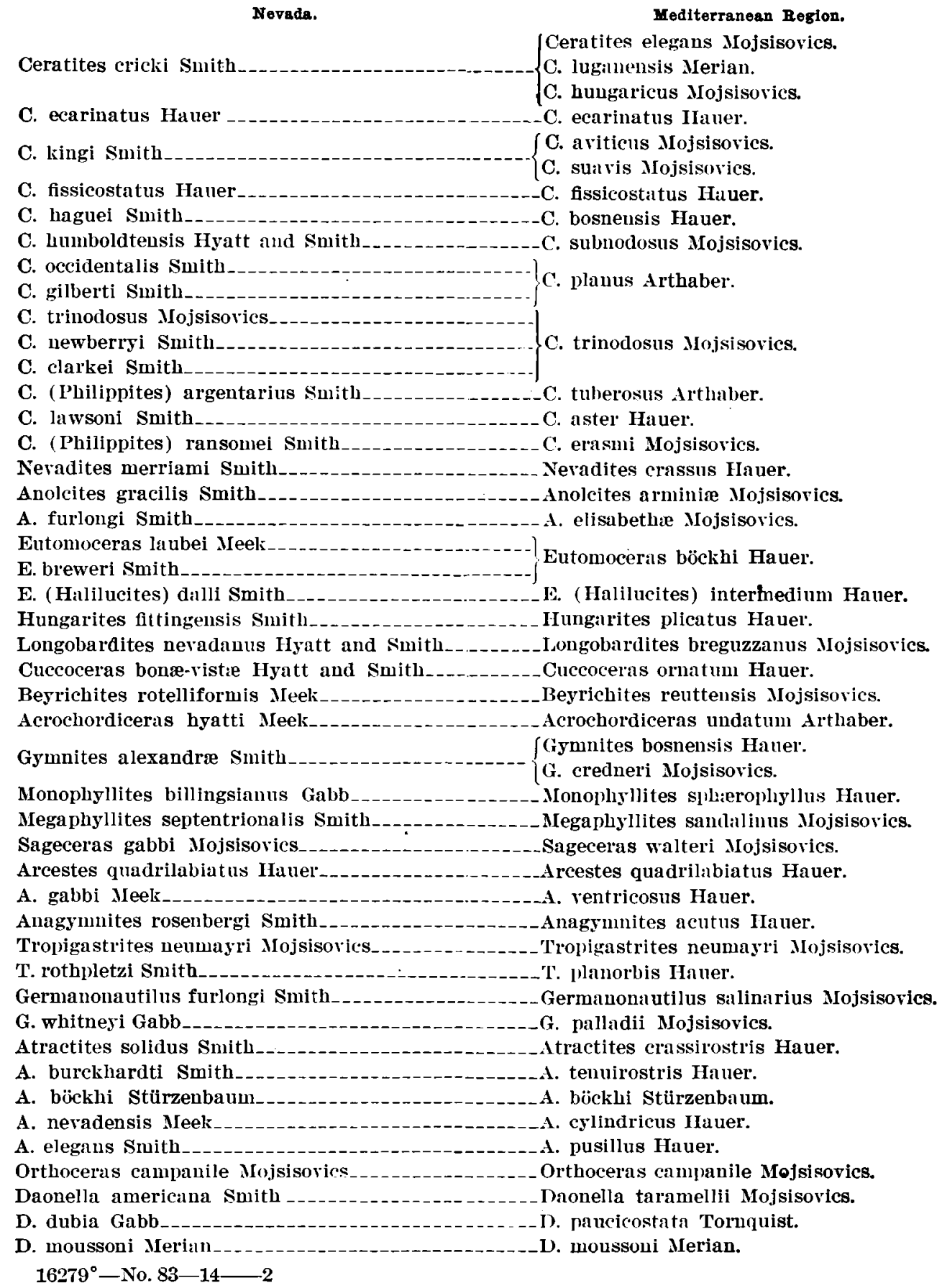


Species closely related to the fauna of the Bulog limestone of Sarajevo in Bosnia.

Nevada.

Bosnia.

Ceratites clarkei Snith

C. newberryi Swith._-_._-_._. Ceratites trinodosus Mojsisovics.

C. trinodosus Mojsisovies

C. falcifer Hauer.

C. occidentalis Smith

C. lenis Hauer.

C. ecarinatus Hauer-

C. ecarinatus Haner.

C. humboldtensis Hyatt and smith

C. subnodosus Mojsisovies (?).

C. fissicostatus Hauer

C. fissicostatus Hauer.

C. haguei sunith

C. bosnensis Hauer.

C. urgentarius Smith

C. aster Hauer.

Eutomoceras breweri Smith

E. laubei Meek.

E. dalli Smith_._._._. E. intermedium Hauer.

Cuccoceras bonte-vistre Hyatt and Smith_._._____Cuccoceras ornatum Hauer.

Gymnites alexandræ Smith_._._-_._._. Gynnites bosnensis Hauer.

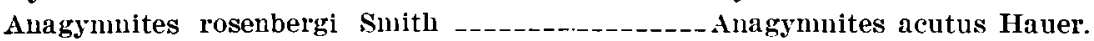

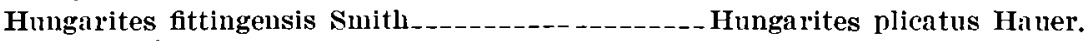

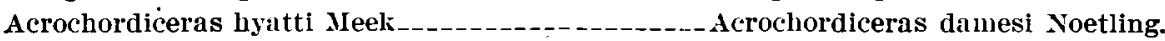

Neradites merriami Smith._.
N. hyatti Smith Nevadites crassus Hauer.

Monophyllites billingsianus Meek._. Monophyllites spherophyllus Hauer.

Tropigastrites rothpletzi Smith______.._____._Tropigastrites planorbis Hauer.

Arcestes quadrilabiatus Haner-__________________Arcestes quadrilabiatus Haner.

Germanonautilus furlongi Smith___________ Germanonautilus salinarius Mojsisovics.

G. whitneyi Gabb__._. Malladii Mojsisovics.

Atractites solidus Smith

A. burckhardti Smith

A. nevadensis Meek

A. elegans Smith

A. böckhi Stiirzenbaum___._._. bïckhi Stürzenbaum.

Species showing close affinitics with forms from the Schiechling Hcights, near IIallstatt, eastern Alps.

Nevada.

Ceratites trinodosus Mojsisovies

C. trojanus Smith

C. humboldtensis Hyatt and Smith.

Anolcites furlongi Smith.

Megaphyllites seytentrionalis Smith.

Conophyllites billingsianus Gabb

Gymnites alexandre Smith

Sageceras gabbi Mojsisovics

Anagymnites rosenbergi Suith

Tropigastrites neumayri Mojsisovics

Germanonautilus furlongi Smith

G. whitneyi Gabb_

Atractites solidus Smith

A. burckhardti Smith.

A. böckhi Stürzenbaum

Orthoceras campanile Mojsisovics.
Schiechling Heights.

Ceratites trinodosus Mojsisovics.

C. abichi Mojsisovics.

C. sulnodosus Mojsisovics.

-Anolcites elisabethre Mojsisovics.

A. arminire Mojsisovics.

Megaphyllites sandalinus Mojsisovics.

Mronophyllites sphærophyllus Hauer.

Gymnites bosnensis Hauer.

Sageceras walteri Mojsisovics.

Anagymnites acutus Hauer.

Tropigastrites neumayri Mojsisorics.

Germanonautilus salinarius Mojsisovics.

G. palladii Mojsisovies.

Atractites crassirostris Hauer.

A. tenuirostris Hauer.

A. bückhi Stiirzenbaum.

Orthoceras campanile Mojsisovics. 
Species closely related to forms from the Reifling beds in the Tyrol.

Nevada.

Ceratites trinodosus Mojsisovics C. occidentalis Suith

C. argentarius Smith

Nevadites whitneyi Gabb.

Anolcites furlongi Smith.

Sageceras gabbi Mojsisovics

Acrochordiceras foltzense Swith
Reifling.

Ceratites trinodosus Mojsisovics.

C. planus Arthaber.

C. tuberosus Arthaber.

Nevadites (?) altecostatus Arthaber. Anolcites elisabethie Mojsisovics. Sageceras wolteri Mojsisovics. Acrochordiceras undatim Arthaber.

Species closely related to the fauna of Lombardy.

\section{Nevada.}

Ceratites trinodosus Mojsisovics

C. kingi Smith

C. cricki Smith

C. rectangularis Smith

Beyrichites rotelliformis Meek___________eyrichites reuttensis Mojsisovics.

Longobardites nevadanus Hyatt and Smitl._._.___._ongobardites breguzzanus Mojsisovics. Megaphyllites septentrionalis Smith_____._._...Megaphyllites sandalinus Mojsisovics.

Species closely related to the fauna of the schrey Alps.

\section{Nevada.}

Ceratites cricki Smith

C. humboldtensis Hyatt and Smith

C. trinodosus Mojsisovics

C. trojanu; Smith

Acrochordiceras hyatti Meek-

Sageceras gabbi Meek

Arcestes gabbi Meek

Megaphyllites septentrionalis Smith

Germanonautilus furlongi Smith

G. whitneyi Gabb
Schrey Alps.

Ceratites elegans Mojsisovies.

C. subuodosus Mojsisovies.

C. trinodosus Mojsisorics.

C. abichi Mojsisovies. Acrochordiceras carolina Mojsisovics. Sageceras walteri Mojsisovies. Arcestes extralabiatus Mojsisovies. Megaplyyllites sandalinus Mojsisovies. Germanonautilus salinarius Mojsisovies. G. palladii Mojsisovics.

Specics closely related to the fauna of Bakony in Hungary.

Nevada.

Ceratites trinodosus Mojsisovics

C. kingi Smith

C. rectangularis Smith

C. humboldtensis Hyatt and Smith

C. clarkei Smith

Longobardites nevadanus Hyatt and Smit

Eutomoceras breweri Smith

E. liubei Meek

Nevadites whitneyi Gabb
Bakony.

Ceratites trinodosus Mojsisovics.

C. aviticus Mojsisovics.

C. cf. brembanus Mojsisovics.

C. subnodosus Mojsisorics.

C. loczyi Arthaber.

Beyrichites reuttensis Beyrich. Longobardites breguzzanus Mojsisovies.

Eutomoceras böclihi Hauer. 


\section{DISTRIBUTION OF MIDDLE TRLASSIC CEPHALOPOD GENERA OF CALIFORNIA AND NEVADA.}

The following table shows the occurrence of the Middle Triassic cephalopod genera of California and Nevada in the Lower, Middle, and Upper Triassic of North America, Asia, and the Mediterranean region of Europe.

Middle Triassic ammonite genera of America.

$[X$, very rare; $X X$, rare; $X X X$, common. $\rfloor$

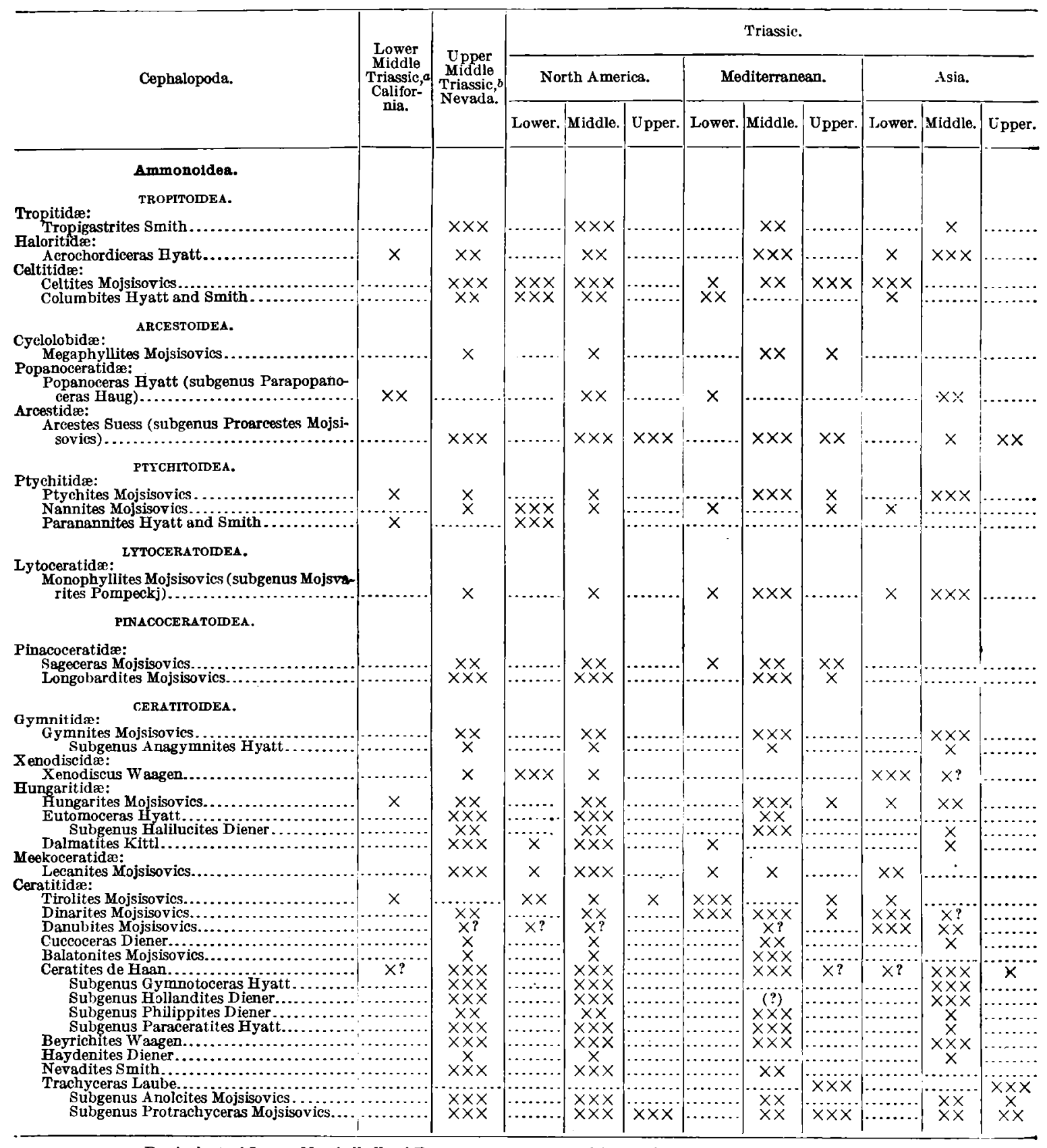


THE MIDDLE TRIASSIC MARINE INVERTEBRATE FAUNAS OF NORTH AMERICA.

\section{MARINE INVERTEBRATE FAUNA OF THE MIDDLE TRIASSIC OF CALIFORNLA AND NEVADA.}

The following table shows the genera and species of the marine fauna of the Middle Triassic of California and Nevada and gives references to their description and illustration in this work, together with their stratigraphic position and occurrence elsewhere:

Jarine invertcbrate fauna of the Middle Triassic of uestern North America.

\begin{tabular}{|c|c|c|c|c|}
\hline Name. & Page. & Illustration. & $\begin{array}{l}\text { Stratigraphic position } \\
\text { in America. }\end{array}$ & $\begin{array}{l}\text { Occurrence else- } \\
\text { where. }\end{array}$ \\
\hline Cephalopoda. & & & & \multirow{37}{*}{ Alpine province. } \\
\hline AMMONOIDEA. & & & & \\
\hline $\begin{array}{l}\text { Tropitoidea: } \\
\text { Tropitide- }\end{array}$ & & & & \\
\hline $\begin{array}{r}\text { Tropigastrites lahontanus Smith... } \\
\text { halli Mojsisovies................ }\end{array}$ & $\begin{array}{l}28 \\
27\end{array}$ & $\begin{array}{l}\text { Pl. XIX, figs. 14-21 } a, 24-26 \ldots \\
\text { Pl. VI, figs. 4-5b; Pl. XII, figs. } 1-5 ; \text { P1. XIV; } \\
\text { figs. } 7 \text { and 7a; Pl. XVIII, figs. 11-14a; } \\
\text { Pl. LXXXVIII, figs. 14-23. }\end{array}$ & $\begin{array}{l}\text { Daonella dubia zone.. } \\
\text {............................ }\end{array}$ & \\
\hline louderbacki Hyatt and Smith. & 29 & $\mathrm{Pl}$, XI, figs. 10-12; Pl. XVIII, figs. $3-6$ and & .....do. & \\
\hline neumayri Mojsisovies.. & 29 & Pl. XVIII, figs. 15-23; Pl. LXXXVIII, figs. & & \\
\hline $\begin{array}{l}\text { obliterans Smith............. } \\
\text { rothpletzi Smith........... }\end{array}$ & $\begin{array}{l}30 \\
31\end{array}$ & $\begin{array}{l}\text { P1. IXXXVII, figs. } 27-32 \ldots \ldots \ldots \ldots \\
\text { Pl. XIX figs. 1-13a, } 22 \text {, and } 23 ; \text { Pl. } \\
\text { LXXXVII, figs. } 24-26 \text {, }\end{array}$ & ..do & \\
\hline $\begin{array}{l}\text { trojanus Smith } \ldots \ldots \ldots \ldots \ldots \ldots \ldots \ldots \\
\text { powelli Smith } . \ldots \ldots \ldots \ldots \ldots \ldots \ldots\end{array}$ & 32 & 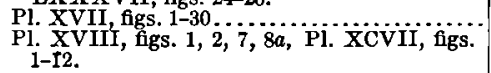 & & \\
\hline Celtitida- & & & & \\
\hline 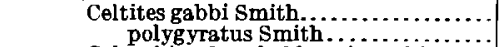 & $\begin{array}{l}34 \\
35\end{array}$ & $\begin{array}{l}\text { Pl. XVI, figs. } 6 \text { and } 7 ; \mathrm{Pl} . \mathrm{XX} \text {, figs. } 9-14 \ldots \\
\text { Pl. XX, figs. } 1-8 a \ldots \ldots\end{array}$ & ....do. & \\
\hline 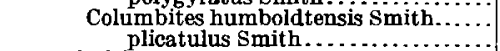 & $\begin{array}{l}36 \\
37\end{array}$ & $\begin{array}{l}\text { X1. XX, figs. 26-28; Pl. LXXXVII, figs 1-14 } \\
\text { Pl. XX, figs. } 15-25 \text {; Pl.LXXXVII, figs. } 15-23 .\end{array}$ & & \\
\hline $\begin{array}{l}\text { Haloritidæ- } \\
\text { Acrochordiceras alternans Smith...... }\end{array}$ & 38 & $\begin{array}{l}\text { Pl. XXXII, figs. 15-17; Pl. XXXIII, figs. } 4 \\
\text { and } 5 \text {. }\end{array}$ & ..... do & \\
\hline $\begin{array}{l}\text { foltzense Smith.............. } \\
\text { hyatti Meek } \ldots \ldots \ldots \ldots \ldots \ldots \\
\text { inyoense Smith.............. }\end{array}$ & $\begin{array}{l}39 \\
39 \\
40\end{array}$ & $\begin{array}{l}\text { Pl. XXXII, figs. } 13 \text { and } 14 \ldots \ldots \ldots \ldots \\
\text { Pl. IV, figs. } 8-11 ; \text { Pl. XV figs. } 5 \text { and } 5 a \ldots \ldots \\
\text { Pl. XXXIV, figs. } 11-13 \ldots \ldots \ldots \ldots \ldots \ldots\end{array}$ & $\begin{array}{l}\ldots . \text { do } \ldots \ldots \ldots \ldots \ldots \ldots \ldots \\
\text { Parapopanoceras zone }\end{array}$ & \\
\hline $\begin{array}{l}\text { Arcestoidea: } \\
\text { Popanoceratidæ- }\end{array}$ & & & Parapopanoceras zone. & \\
\hline $\begin{array}{l}\text { Popanoceras (Parapopanoceras) haugi } \\
\text { Hyatt and Smith. } \\
\text { Cyclolobidm- }\end{array}$ & 41 & $\begin{array}{l}\text { P1. XIII, figs. 1-22; Pl. XXXIV, figs. } 14 \\
\text { and 15. }\end{array}$ & d & \\
\hline Megaphylites septentrionalis Smith. & 42 & Pl. XXI, figs. 4-12...... & Daonelia dubia zone. . & \\
\hline $\begin{array}{l}\text { Arcestida- } \\
\text { Arcestes (Proarcestes) gabbi Meek }\end{array}$ & 43 & $\begin{array}{l}\text { Pl. XIV, figs. } 6 a-b ; \\
\text { Pl. XI. XXI, flgs. } 1 \text { and } 2 \text {; }\end{array}$ & & \\
\hline hartzelli Smith ................ & 43 & $\begin{array}{l}\text { Pl. XLVII, figs. } 1-3 ; \text { PI. XCHI, flgs. } 1 \\
\text { Pl. XCIII, figs. } 17 \text { and } 18 . . \ldots \ldots \ldots \ldots\end{array}$ & ....d & \\
\hline $\begin{array}{l}\text { nevadanus Hyatt and Smith... } \\
\text { quadrilabiatus Hauer........... }\end{array}$ & $\begin{array}{l}44 \\
44\end{array}$ & $\begin{array}{l}\text { Pl. V, figs. } 5-7 . \ldots \ldots \ldots \ldots \ldots \ldots \\
\text { Pl. X'CIII, figs. } 15 \text { and } 16 . \ldots \ldots \ldots \ldots\end{array}$ & $\begin{array}{ll}\ldots \text { do } \\
\ldots . \text { do }\end{array}$ & \\
\hline \multicolumn{4}{|l|}{$\begin{array}{l}\text { Ptychitoidea: } \\
\text { Ptyehitidæ- }\end{array}$} & \\
\hline Nannites contractus Smith....... & 45 & Pl. XXI, figs. 13-17a $\ldots \ldots$ & $\ldots$ do.............. & \\
\hline $\begin{array}{l}\text { Paranannites oviformis Smith......... } \\
\text { Ptychites meeki Hyatt and Smith..... }\end{array}$ & $\begin{array}{l}46 \\
47\end{array}$ & $\begin{array}{l}\text { PI. XXXIV, figs. } 16-17 \ldots \ldots \ldots \\
\text { Pl. VI, figs. } 6-12 . \ldots\end{array}$ & Parapopanoceras zone. & \\
\hline \multirow{2}{*}{\multicolumn{4}{|c|}{$\begin{array}{l}\text { evansi smith } \ldots \ldots \ldots \ldots \ldots \ldots \\
\text { Lytoceratoidea: } \\
\text { Lytoceratidæ- }\end{array}$}} & \\
\hline & & & & \\
\hline \multicolumn{4}{|l|}{$\begin{array}{l}\text { Pinacoceratoidea: } \\
\text { Pinacoceratidœ- }\end{array}$} & \\
\hline $\begin{array}{l}\text { Longobardites nevadanus Hyatt and } \\
\text { Smith. }\end{array}$ & 50 & $\begin{array}{l}\text { Pl. VI, figs. 13-18; Pl. VIII, figs. 16-20; Pl. } \\
\text { XII, figs. 6-9; Pl. XXX, figs. 13-16. }\end{array}$ & .....do & \\
\hline \multicolumn{4}{|l|}{$\begin{array}{l}\text { Ceratitoidea: } \\
\text { Gymnitidæ- } \\
\text { Gymnites alexandræ Smith............. }\end{array}$} & \\
\hline 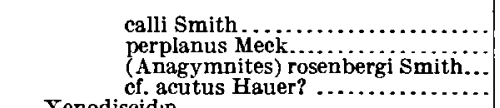 & $\begin{array}{l}53 \\
54 \\
55 \\
54\end{array}$ & 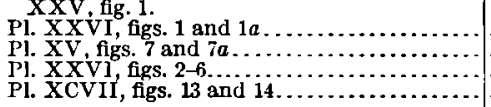 & 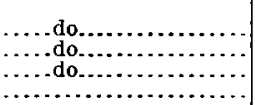 & \\
\hline $\begin{array}{l}\text { Xenodiscid:e- } \\
\text { Xenodiscus bittneri Hyatt and Smith.. }\end{array}$ & 56 & $\begin{array}{l}\text { Pl. I, figs. 5-15; Pl. II, figs. 1-13: Pl. XXXIV, } \\
\text { figs. 1-4. }\end{array}$ & Parapopanoceras zone. & \\
\hline$\underset{\text { Hungaritidæic }}{\operatorname{multicameratus~Smith........~}}$ & 57 & Pl. XXXIv, figs. $5-10 \ldots \ldots \ldots \ldots \ldots \ldots \ldots$ &. do & \\
\hline Hungarites fittingensis Smith. & 58 & Pl. XXIX, figs. 12-14; Pl. XC, figs. 5-7. & Daonella dubia zone .. & \\
\hline Dalmatites minutus Smith....... & $\begin{array}{l}58 \\
59\end{array}$ & 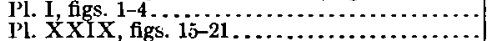 & $\begin{array}{l}\text { Parapopanoceras zone. } \\
\text { Daonella dubia zone.. }\end{array}$ & \\
\hline parrus Smith........... & 60 & Pl. XXX, figs. $1-12 \ldots \ldots \ldots$ & Dado................... & \\
\hline Eutomoceras breweri Smith. & 61 & Pl. XXVIII, figs. $1-7 \ldots \ldots \ldots \ldots$ & ...do & \\
\hline dalli Smith ................. & 64 & Pl. XXIX, figs. $1-11 \ldots \ldots \ldots \ldots$ & (............ & \\
\hline 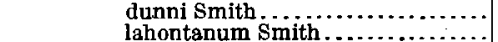 & $\begin{array}{l}62 \\
63\end{array}$ & $\begin{array}{l}\text { Pl. XXVII, figs. } 14-25 \ldots \ldots \ldots \\
\text { Pl. XXVIII, figs. \& } 11 \ldots \ldots \ldots \ldots \ldots\end{array}$ & & \\
\hline laubei Meek.... & 63 & $\begin{array}{l}\text { Pl. X figs. 7-11; Pl. Xiv figs. 8 } 8 a ; \text { Pl. } \\
\text { XXVI, figs. 7-9; Pl. XXVI, figs. 1-13; Pl. } \\
\text { XC, figs. 1-4. }\end{array}$ & .....do..... & \\
\hline
\end{tabular}


Marine invertebrate fauna of the Mildle Triassic of vestern North America-Continued.

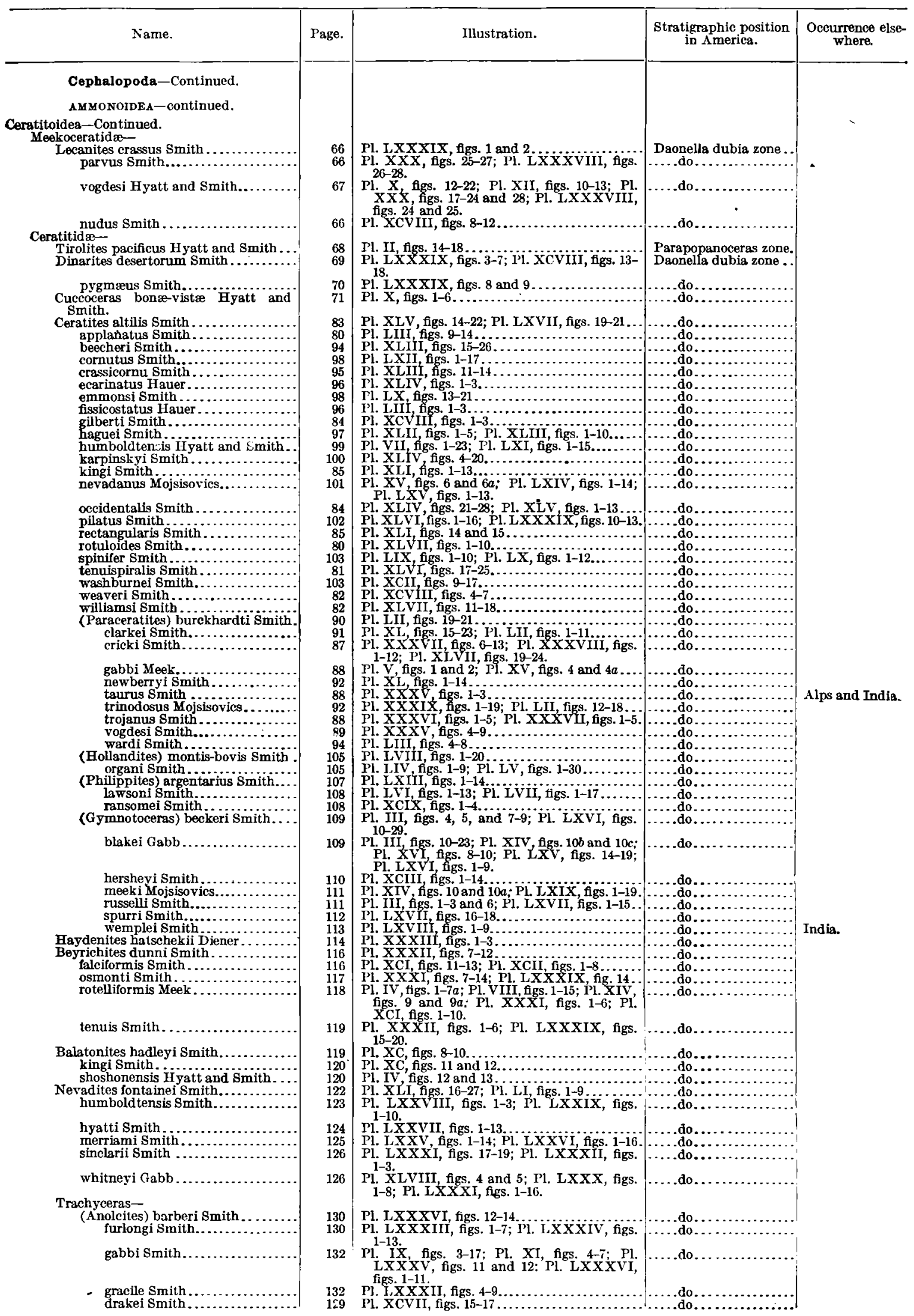


Marine invertebrate fauna of the Middle Triassic of western North America-Continued.

\begin{tabular}{|c|c|c|c|c|}
\hline Name. & Page. & Illustration. & $\begin{array}{c}\text { Stratigraphic position } \\
\text { in America. }\end{array}$ & $\begin{array}{l}\text { Occurrence else- } \\
\text { where. }\end{array}$ \\
\hline 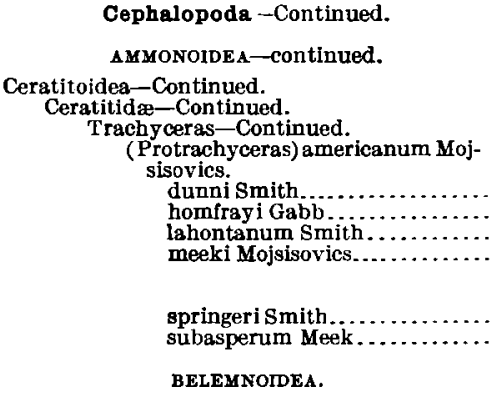 & $\begin{array}{l}133 \\
134 \\
134 \\
135 \\
135 \\
136 \\
137\end{array}$ & 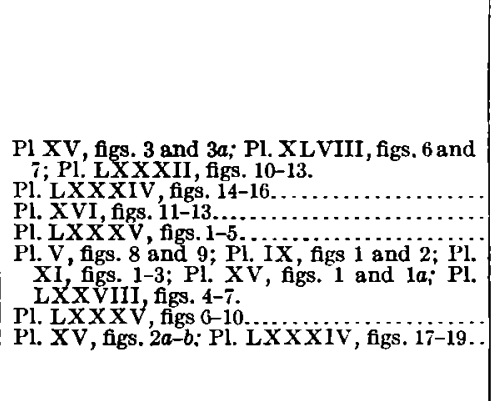 & 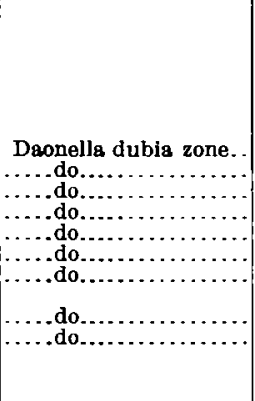 & \\
\hline 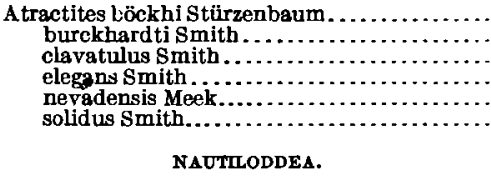 & $\begin{array}{l}138 \\
138 \\
139 \\
139 \\
139 \\
140\end{array}$ & 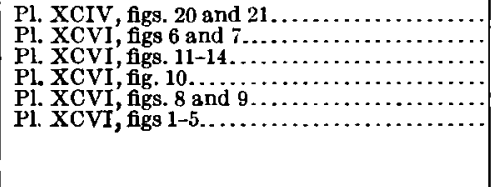 & 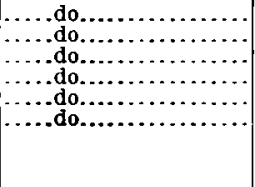 & Alps and India. \\
\hline 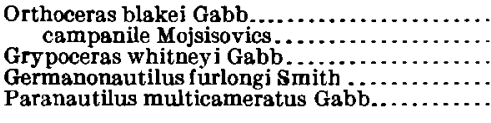 & $\begin{array}{l}140 \\
141 \\
141 \\
142 \\
143\end{array}$ & 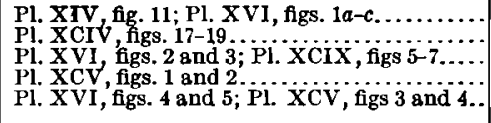 & 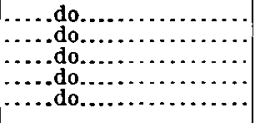 & Alps and India. \\
\hline 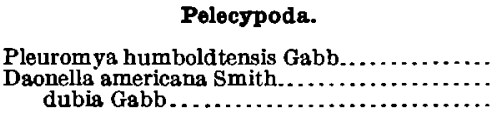 & $\begin{array}{l}143 \\
143 \\
143\end{array}$ & 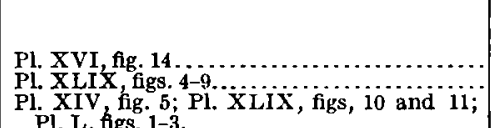 & ....do.. & \\
\hline 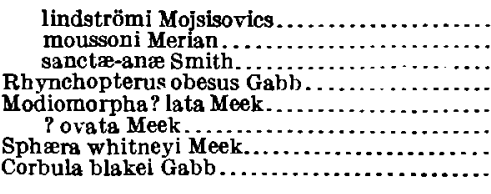 & $\begin{array}{l}144 \\
144 \\
145 \\
145 \\
146 \\
145 \\
\cdots \cdots\end{array}$ & 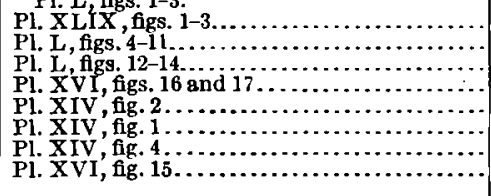 & 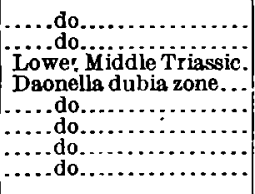 & $\begin{array}{l}\text { Arctic region. } \\
\text { Alpine province. }\end{array}$ \\
\hline 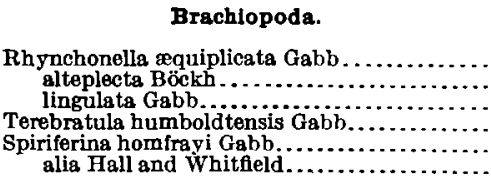 & $\begin{array}{l}146 \\
146 \\
147 \\
147 \\
147 \\
147\end{array}$ & 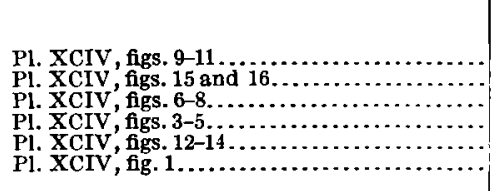 & 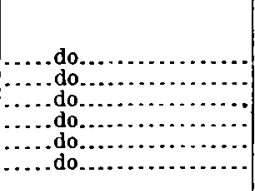 & Alpine province. \\
\hline 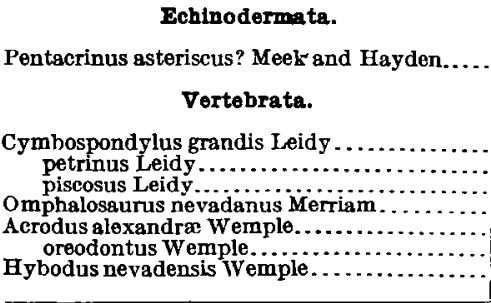 & 148 & 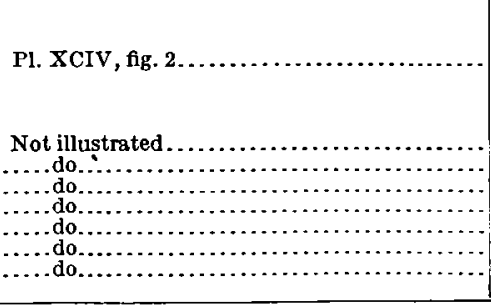 & 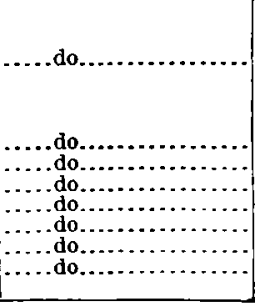 & \\
\hline
\end{tabular}




\section{BIBLIOGRAPHY.}

Airhagr, C., Ammoniti triasici (Muschelkalk) del Monte Rite in Cadore: Boll. Soc. geol. ital., vol. 24.

Arthaber. G. von, Die Cephalopodenfauna der Reiflinger Kalke: Beitr. Pal. und Geol. Oesterreich-Lngarns und des Orients, rol. 10, 1 s96.

- _ Das jüngere Paliiozoicum aus der Araxes-Enge bei Djulfa (Ueber das Paliozoicum in Hocharmenien und J'ersien, etc., by F. Frech and G. von Arthaber) : Beitr. Pal. und Geol. Oesterreich-Cngarns und des Orienta, vol. 12 , pt. 4, 1900.

_ Neue Funde in den Werfener Schichten und im Muschelkalke des südlichen Bakony, und Rerision der (ephalopodellfauna des Muschelkalles: Tiesultate der wissenschaftlichen wrforschung des Balatonsees, vol. 1 , pt. 1,1903 .

_- Die Alpine Trins des Mediterran-Gebietes : Lethiea Geognostica, II. Theil, Ias Mesozoicum, vol. 1. 1906.

- Veber die Entdeckung ron Intertrias in Albanien und ihre faunistische Bewertung: Mitt. geol. Gesell. Wien, vol. 1, 1908.

__ Die Trias von Albanien: Beitr. Pal. und Geol. Oesterreich-Tngarns und des Orients, rol. 24, 1911.

Ceber die Horizontierung der Fossilfunde am Ionte Cucco (italienische Carnia) mud iiber die systematische Stellung von Cuccoceras Dien. : Jahrb. K.-k. geol. Reichsanstalt, vol. 62, Heft 2. 1912.

Beyricir, H. L., Veber einige Cephalopoden aus dem Muschelkalke der Alpen und über rerwandte Arten: Abhandl. K. Akad. Wiss. Wien, 1967.

Boқcк I, J., Die geologischen Verhiiltuisse des siidlichen Theiles des Bakony: Mittheil. Jabrb. K. mugarischen geol. Anstalt, Budapest, vol. 2, 1S72.

Boznм, J., Leber die obertriadische Fauni der Bäreninsel: Kungl. Srenska Vetenskaps-Akademiens Handlingar, vol. 3T, No. 3, 1903.

Branco, W., Beobachtungen all Aulncoceris: Zeitschr. Deutsch. geol. Gesell., 1880.

—_ Beitraige zur Fntwickelungsgeschichte der fossilen Cephalopoden : I Palrentographica, new ser., rol. 26, pt. $1,18 \pi 9$; rol. $2 \bar{\tau}$, pt. 2,1880 .

Crark, W. B., The Mesozoic Echinodermatil of the Tnited States: Bull. C. S. Geol. Survey, No. 9i. 1893.

Diener. C., Cephalopoda of the Muschelkalk: Himalayan fossils, vol. 2. yt. 2, 1895 (Mem. Geol. Survey India, Pil. Indica, 15th ser.).

__ Triadische Cephalopodenfaunen der ostsibirischen Kiistenjrovinz: Mém. Com. géol. St.-Pétersbourg, vol. 14, Xo. 3, 1805 .

Cephalopoda of the Lower Trias: IIimalayan fossils, vol. 2, pt. 1. 1897 (Men. Geol. Survey India, Pal. Indica, 15th ser.).

__ Mittheilung iiber Cephalopoden-Arten aus der Trias des siidlichen Bakony : Resultate der wissenschaftlichen Erforschung des Balatonsees, vol. 1, pt. 1, Pal. Anhang. 1899.

— Die Triadische Cephalopoden-Fauma der Schiechlinghöhe bei Hallstatt: Beitr. Pal. und Geol. Oesterreich-Ungarns und des Orients, rol. 12. 1900.

—_ Entwurf einer Systematik der Ceratitiden des Muschelkalkes: Sitzungsher. K. Akad. Wiss. Wien, wol. 114, pt. 1, 1905.

Ueber einige Konvergenzerscheinungen hei triadischen Ammoneen : Sitzungsber. K. Akad. Wiss. Wien, vol. 114 , pt. 1,1905 .

Beiträge zur Kenntniss der mittel- und obertriadischen Faunen von Spiti : Sitzungsber. K. Akıd. Wiss. Wien, rol. 115. pit. 1. 190 \%.

- The fauna of the Himalayan Muschelkilk: Himalilyan fossils, vol. 5. Mem. No. 2, 1907 (Mem. Geol. Survey India, Pal. Indi(ai, 15th ser.).

L Ladinic, Carnic. and Norje fumne of Spiti : Men. Geol. Survey India, I'all. Indica, 15̄th ser., vol. 5, Mem. No. 3, 1909.

— The Trias of the Himalayas: Mem. Geol. Survey India, vol. 36, pt. 3. 1912.

Diener, Carl and Krafft, A. von, Lower Triassic Cephalopida from Spiti, Malla Johar, and Byans: Mem. Geol. Survey India, Pal. Indica. 15th ser., Mem. Xo. 1, 1909.

Dittmar, A. von, Zur Fauna der Hallstätter-Kalke: Geognost. Palaeont. Reitr., von Renecke, Schloenbach, und Waagen. vol. 1, 1sibs.

Escher von der Linti, A., Geologische Bemerkungen über das nördliche Vorariberg und einige angrenzenden Gegenten. 1s:\%.

Frech, F., Die Dyas : Lethea Palæozoica, vol, 2, Lieferung 3, 1901. and Lieferung 4, 1902.

- Einleitung des Mesozoienm und der 'Trias, und continentale Trias: Lethæa Geognostica, II, Theil, Das Mesozoicum, No. 1, Trias, Lieferung 1. 1903.

- Neue Cephalopoden aus den Buchensteiner, Wengener und Raibler Schichten des südlichen Bakony: Resultate der wissenschaftlichen Erforschung des Balatonsees, vol. 1, pt. 1, 1903.

_- Nachtrïge zu den Cephalopoden und Zreischalern der IBakonyer Trias: Resultate der wissenschaftlichen Erforschung des lialatonsees, vol, 1, pt. 1, Xachtrag. 1905.

—_ Die Zirkumpacifische Trias: Lethæa Geognostica, II, Theil, Das Mesozoicun, rol. 1, Lieferung 4, 1908. Trias, pp. 488-509.

Frech, F., and Renz, Cart, Nene Triasfunde auf IIydra und in der Argolis : Neues Jahrb., Beilage Band $25.190 \%$. 
Gabn, W. M., Description of the Triassic fossils of California and the adjacent Territories: Geol. Survey California, Palrontology, vol. 1, 1864.

Descriptions of some Secondary fossils from the Pacific States: An. Jour. Conchology, vol. 5, 1870.

Gemmellaro, G. G., I cefalopodi del Trias superiore della regione occidentale della Sicilia. 1904.

Griesbach, C. L., Palrontological notes on the Lower Trias of the Himalayas: Records Geol. Survey India, vol. $13,1880$.

Guembel, W.. Geognostiche Beschreilung des Bayerischen Alpengebirges, 1861.

HAAN, G. DE, Monographiæ Ammoniteorum et Goniatiteorum Specimen. 1825.

Hal.L, James, and Whitfield, R. P., Palæontology : U. S. Geol. Expl, 40 Par., vol 4, pt. 2. 1877.

IHAllik, F. von. Die Cephalopoden des Silzkammergutes aus der Sammlung des Fiirsten Metternicj, Wien, 1846. Teber neue Cephalopoden aus dem Rothen Iaymor von Aussee: Haidinger's Naturwissenschaftliche Abhandlungen, vol. 1, 1847.

- - Teber nene Cephalopoden aus den Marmorschichten von Hilllstatt und Aussee: Haidinger's Naturwissenschaftliche Abhandlungen, vol. 3, 1849.

- Beitrige zur Kenntuiss der Cephalopoden-Fauna der Hallstiitter Schichten : Denkschr. K. Akad. Wiss. Wien. vol. 9, 1855 .

I'aläontologiscle Notizen : Ber. K.-k. Akad. Wiss. Wien, vol. 24, 1857.

Nachtrag zur Kenntniss der Cephalopoden-Fauma der Hallstaitter Schichten: Sitzungsber. K. Akad.

Wiss. Wien, rol. 41,1860 .

— Cephalopodell aus der Lnteren Trias der Alpen: Sitzmgsber. K. Akad. Wiss. Wien, vol. 52, 1965.

Cephalopoden des Bosnischen Muschelkalkes von Han Bulog bei Sarajero: Denkschr. K. Akad. Wiss. Wien, vol. 54, 1888.

___ Beitrïge zur Kenntniss der Cephalopoden aus der Trias von Bosnien, Part I : Denkschr. Is. Akad. Wiss. Wien, vol. 59, 1892.

- Beiträge zur Kenntniss der Cephalopoden aus der Trias ron Bosnien, Part II: Denkschr. K. Akad. Wiss. Wien, rol. $63,1896$.

Havg, L., Les Ammonites du Permien et du Trias: Bull. Soc. géol. France, 3d ser., vol. 22, 1894. Études sur les Goniatites: Mêm. Soc. géol. France, No. 18. 189s.

Holzapfel, E., Die Cephalopoden des Domanik im südlichen Timan : Mém. Com. Géol. St.-Pétersbourg, vol. 12, Yo. 3, 1899.

Hyat, A., Genera of fossil cephalopods : Proc. Boston Soc. Nat. Ilist., vol, 22, 1883. Jura and Trias at Taylorville, California : Bul. Geol. Soc. America, rol. 3, 1892.

——Cephalopoda: Text-book of Palgontology, by K. A. von Zittel (translated by C. R. Eastman), 1900.

Hyatt, A., and Smiti, J. P., The Triassic cephalonod genera of America: Prof. Paper U. S. Geol. Survey No. 40. 1905 .

Kanpinsky, A., Ceber die Ammoneen der Artinsk-Stufe, und einige mit denselben verwandte Carbonische Formen: Mém. Acad. imp. sci. St.-Pétersbourg, 7 th ser., vol. 37, No. 2, 1889.

Kittr, Eknst. Die Cephalopoden der oberen Werfener schichten von IIuc in Dalmatien, sowie von anderen dalmatinischen, bosnisch-herzegowinischen und alpinen Lokalitäten: Abhandl. K.-k. geol. Reichsanstalt Wien, vol. 20 , pt. $1,1903$.

- Materialien zu einer Monographie der Halobiida und Monotidie der Trias : Resultate der wissenschalftlichen Erforschung des Balatonsees, vol. 1, pt. 1, Paleontologie. vol. 2. 1912.

Koninck, L. G., DE, Descriptions of sone fossils from India, discovered by Dr. A. Fleming, of Edinburgh: Quart. Jour. Geol. Soc. London, vol. 19, 1863.

Iadbr., G.. Die Fauna der Schichten von St. Cassian: Denkschr. K. Akatl. Wiss. Wien, vol. 30, 1869.

- Ceber Ammonites aon Münster und dessen Verwandte: Sitzungsber. K. Akad. Wiss. Wien, vol. 59, 1869.

IıNDSTRöM, G., Om Trias och Juraförstingar frín Spetsbergen, 1865.

MarTetr.I, A., Cefalopodi triasici di Boljevici presso Vir nel Montenegro: Palipontographia Italica, vol. 10, 1904.

_-_Contributo al Iuschelkalk superiore del Montenegro: Palkeontographia Italica, rol. 12, 1906.

McOor, F., Synopsis of the characters of the Carboniferous fossils of Ireland, 1844 .

Meek, F. B., Palrontology: U. S. Geol. Expl. 40th Par., vol. 4, pt. 1, 187 .

Meek, F. B., and Hayden, F. V., Proc. Acad. Nat. Sci. Philadelphia, vol. 10, $185 \mathrm{~s}$.

Palæontology of the Upper Missouri: Snithsonian Contributions to Knowledge. vol. 14, No. 172. 1865.

Merriam, J. C., Triassic Ichthropterygia from California and Nevadil: Bull. Dept Geology, Iniv. California, vol. 3, No. 4, 1902.

- A primitive ichthyosaurian limb from the Middle Triassic of. Nevada: Bull. Dept. Geologs, Univ. California, vol. 4, No. 2, 1905 .

Mojsisovics. E. von. Yeber die Gliederung der oberen Triasbildungen der östlichen Alpen: Jahrb. K.-k. geol. Reichsanstalt Wien, 1869.

- Beiträge zur Kenntniss der Cephalopoden-Fauna des Alpinen Muschelkalkes: Jahrb. K.-k. geol. Reichsanstalt Wien, 1869. 
Mojsisovics, E. von, Beiträge zur Kenntniss der Cephalopoden-Fauna der Oenischen Gruppe: Jahrb. K.-k. geol. Reichsanstalt Wien, 1870.

—_ Ueber das Belemnitiden-Geschlecht Aulacoceras: Jahrb. K.-k. geol. Reichsanstalt Wien, 1871, p. 41.

- Leber die Entwicklung von Ammoniten in der Carbonischen Formation Indiens: Verhandl. K.-k. geol. Reichsanstalt Wien, 1872.

- Das Gebirge um Hallstatt. Part I; Die Mollusken-Faunen der Zlambach und Hallstätter Schichten:

Abhandl. K.-k. geol. Reichsanstalt Wien, vol. 6, pt. 1, 1873.

- Ueber die triadischen Pelecypoden-Gattungen Daonella und Halobia, 1874.

- Die Dolomitriffe von Siidtirol und Venetien, 1878.

Vorläufige kurze Uebersicht der Ammoniten-Gattungen der Mediterranen und Juvavischen Trias: Verlıandl. K.-k. geol. Reichsanstalt Wien, 1879.

- (In Bittner's) Bericht über die Geolog. Aufnahmen in Judicarien und Val Sabbial Jahrb. K.-k. geol. Reichsanstalt Wien, 1981.

— Die Cephalopoden der Mediterranen Triasprovinz: Abhandl. K.-k. geol. Reichsanstalt Wien. vol. 10, 1892.

— Arktische Triasfaunen; Beiträge zur Paläontologischen Charakteristik der Arktisch-Pacifischen Triasprovinz: Mém. Acad. imp. sci. St.-Pétersbourg, 7th ser., rol. 33, Yo. 6. 1986.

- Ueber einige jalpanische Trias-Fossilien: Beitr. Pal. und Geol. Oesterreich-Ungarns und des Orients, vol. $6,1888$.

- Nachweis der Zone der Tropites subbullatus in den Hallstätter Kalken bei Hallein: Verhandl. K.-k. geol. Reichsanstalt Wien, 1889.

- Das Gebirge um Hallstatt, Part I; Die Cephalopoden der Hallstätter Kalke: Abhandl. K.-k. geol. Reichsanstalt Wien, rol. 6, pt. 2, 1893.

- Beitrïge zur Kenntniss der obertriadischen Cephalopoden-Faunen des Himalaya: Denkschr. K. Akad. Wiss. Wien, vol. $63,1896$.

Das Gebirge um Hallstatt, Part I; Die Cephalopoden der Hallstätter Kalke: Supplement-Heft Abhandl. K.-k. geol. Reichsanstalt Wien, vol. 6, pt. 1, 1st half, 1902.

Muenster, G. Graf zu, Ueher das Kalkmergel-Lager von St. Cassian in Tyrol, und die darin vorkommenden Ceratiten: Neues Jahrb., 1834.

— Beitrïige zur Geognosie und Petrifactenkunde des Südöstlichen Tirols, vol, 4, 1841.

Murchison, Verneuil, and Kexserlina, The geology of Russia in Europe and the Ural Mountains, Palæontology, vol. 2, pt. 3, 1845 .

Noetling, F., Die Entwicklung der Trias in Oberschlesien : Zeitschr. Deutsch. geol. Gesell., vol. 32, 1880.

Die asiatische Trias: Lethæa Geognostica, Part II, Das Mesozoicum, vol. 1, Trias, Lieferung 2, 1905.

Neumayr, M., Die Ammoniten der Kreide und die Systematik der Ammoniten: Zeitschr. Deutsch. geol. Gesell., vol, 27,1875 .

PhilipPI, E., Die Ceratiten des oberen deutschen Muschelkalkes: Palæontologische Abhandlungen von Dames und Koken, new ser., vol. 4, 1901.

Renz, C., Ueber Halobien und Daonellen aus Griechenland, nebst asiatischen Vergleichsstücken: Neues Jahrb., vol. 1,1906

Renz, C., and Frech, F. See Frech, F., and Renz, C.

Salomon, W., Geologische und palæontologische Studien über die Marmolata: Palæontographica, vol. 42, 1895.

Schellwien, E., Trias, Perm und Carbon in China: Schrift. Phys.-ökon. gesell. Königsberg, vol. 43, pp. 59-78, Pl. III, 1902 .

Simionescu, Joan, Fauna Amonitilior Triasici dela Hagighiol (Dobrogea) : Academia Romana, No. 34, 1913. SмIтH, J. P., The metamorphic series of Shasta County, Californi:l : Jour. Geology, vol. 2, No. 6, 1894.

_Classification of marine Trias: Jour. Geology, vol. 4, No. 4, 1896.

- Geographic relations of the Trias of California : Jour. Geology, vol. 6, No. 8, 1898.

The border line between Paleozoic and Mesozoic in western America: Jour. Geology, vol. 9. No. 6, 1901. Leber Pelecypoden-Zonen in der 'Trias Nord-Amerikas: Centralbl. Min., Geol. u. Pal., 1902.

- The comparative stratigraphy of the marine Trias of western America: Proc. California Acad. Sci.. 3d ser., Geology, vol. 1, No. 10, 1904.

The stratigraphy of the western American Trias: Festschrift Adolf von Koenen Gewidmet von seinen Schülern, etc., 1907.

- The Carboniferous ammonoids of America : Mon. U. S. Geol. Survey, vol, 42, 1903.

Smith, J. P., and Hyatt, A. See Hyatt, A., and Smith, J. P.

Smith, J. P., and Weller, Stuakt, Prodromites, a new ammonite genus from the lower Carboniferous: Jour. Geology, vol. 9, 1901.

Stoppani. A., Pétrifiacations d'F́sino, $185 \mathrm{~s}$.

Stürzenbaum, J., Adatok a Bakony Ceratites reitzi-szint faunájảnak ismeretéhez: Földtani közlöny, 18т5.

SUEss, E., Ueber Ammoniten : Sitzungsber; K. Akad. Wiss. Wien, rol. 30, 1869. 
Tommasi, A., La fauna del calcare rossi e grigi del Monte Clapsavon nella Carnia occidentale: Palæontographia Italica, vol. 5, 1899.

Tonnquist, A., Neuere Beiträge zur Geologie und Paläontologie der Lmgebung von Recoaro und Schio in Venetien, Part IV: Zeitschr. Deutsch. geol. Gesell., vol. 50, 1898.

ToulA, F., Eine Muschelkalkfauna am Golfe von Ismid in Kleinasien: Beitr. Pal. und Geol. OesterreichUngarns und des Orients, vol. 10, pt. 4, 1896.

Vouz, W., Beiträge zur geologischen Kenntniss von Nord-Sumatra: Zeitschr. Deutsch. geol. Gesell., vol. 51, pp. 1-61, 1899.

WaAgen, W.. Productus limestone fossils: Salt Range fossils, vol. 1, 1879 (Mem. Geol. Survey India, Pal. Indica, 13th ser.).

_ Preliminary notice on the Triassie deposits of the Salt Range: Records Geol. Survey India, vol. 25, 1892.

Vorlaüfige Mittheilung über die Ablagerungen der 'Trias in der Salt R:ınge: Jahrb. K.-k. geol. Reichsanstalt Wien, rol. 42, 1892.

Fossils from the Ceratite formation: Salt Range fossils, vol. 2, 1895 (Mem. Geol. Survey India, Pal. Indica, 13th ser.).

Wanner, J., Triaspetrifakten der Molukken und des Timorarchipels : Neues Jahrb., Beilage Band $24,1907$.

Weller, Stuart, and Smitir, J. P. See Smith, J. P., and Weller, Stuart.

Wemple, E. M., New Cestraciont teeth from the West-American Trias: Bull. Dept. Geology, Univ. California, vol. 5, No. 4, 1906.

White, C. A., Fossils of the Jura-Trias of southeastern Idaho: U. S. Geol. and Geog. Survey Terr., vol. 5, 1879.

_- Contributions to invertebrate palæontology No. 5, Triassic fossils of southeastern Idaho: U. S. Geol. and Geog. Survey Terr., vol. 12, pt. 1, 1880.

The Texan Permian and its Mesozoic types of fossils : Bull. U. S. Geol. Survey No. 77, 1891.

Whiteaves, J. F., Fossils of the Triassic rocks of British Columbia: Geol. and Nat. Hist. Survey Canada, Contributions to Canadian Palæontology, vol. 1, pt. 2, 1889.

Whitfield, R. P., and Hall, James. See Hails, James, and Whitfikld, R. P.

Zittel, K. A. von, Grundzüge der l'aliiontologie, 1895. 


\title{
SYSTEMATIC DESCRIP'IIONS.
} CEPHALOPODA.

\author{
- Order AMMONOIDEA.
}

Suborder TROPITOIDEA.

Forms with long body chamber, ammonitic, rarely ceratitic or goniatic, simple septa, strong sculpture, either lateral ribs or spines or ventral keel. The young are involute and subglobose, resembling in form and septa the Carboniferous family Glyphioceratidæ. Under this group are included Haloritidæ, Tropitidæ, Sibiritidæ, and Celtitidæ. Only the Tropitidæ, the Haloritidæ, and the Celtitidæ are known in the American Middle Triassic. The Sibiritidæ, which were common in the Lower Triassic, are as yet unknown in the Middle Triassic of America. The Celtitidie are the most primitive members of the Tropitoidea, and from them came the Tropitidx. The Haloritide and the Sibiritidæ are probably independent lateral branches of the primitive stock of Glyphioceratidæ.

\section{Family TROPITID $\not$ E Mojsisovics.}

Form evolute or involute, whorls usually laterally compressed but in the more primitive genera depressed. Surface with lateral ribs and ventral keel, usually bounded by depressions or furrows. Spines are usually confined to the umbilicus or the margin, but may be present on the sides. Body chamber long. Septa ammonitic, dolichophyllic, in all except some reversionary or primitive genera, in which they are goniatitic, or ceratitic. The young stages of all the more specialized Tropitidæ are robust, helmet shaped, with smooth sides, ventral keel, and simple septa, resembling the genus Tropigastrites, which may have preserved many of the primitive characters of the family. Below the Tropigastrites stage the young resemble Gastrioceras of the Glyphioceratidæ, from which group the Tropitidæ probably descended. Columbites is probably the connecting link with the Glyphioceratidx.

Styrites of the Upper Triassic also shows these primitive characters, although it is not regarded by the writer as the radicle of the Tropitidi, but rather as a reversionary genus, or one originating from arrest of development. The more primitive members of the Tropitidæ'do not show a Styrites stage in their ontogeny, but have evolute, trapezoidal young, with strong umbilical ribs, and no keel. This shows that the possession of a keel is not a primitive character of the Tropitidæ, but rather one acquired late in the history of the race. It is pushed back into the larval stages of Tropites and Paratropites, but Tropigastrites never has a true keel and takes on the acute shape of the venter only toward maturity.

Characteristic members of the Tropitidx are not known below the Upper Triassic, but Tropigastrites occurs in Nevada in beds that belong to the Middle Triassic. The greater part of this family is confined to the Karnic stage of the Upper Triassic of the Alps, in which horizon in the Alpine Province, in the Himalayas, and in California Tropitidæ are abundant. 
The group of Tropites subbullatus is greatly specialized and highly accelerated and consequently does not show the phylogeny of the race as well as more primitive forms. The chief characters of the Tropitida, as distinguished from the other members of the Tropitoidea, are the umbilical sculpture, the keel, the complication of the septa, and the increasing involution of the whorl. These characters appear in the order named in the phylogeny of the race, but. in the ontogeny of Tropites they do not appear in this order. Unequal acceleration has pushed back the keel into the larval stage until it appears before the umbilical ribs.

The Tropitida are represented in the Middle Triassic of America only by Tropigastrites Smith, of which the ontogeny is fully described below.

Genus TROPIGASTRITES Smith, gen. nov.

Type.-Tropigastrites trojanus Smith.

Evolute, low whorled, little embracing, widely umbilicate; whorls somewhat semilunar in shape, with the venter slightly raised in the middle and inclined to become acute, forming a sort of keel in the center. Surface ornamented with strong umbilical ribs that do not run high up the flanks. In youth the shell has constrictions and spiral lines like those of Gastrioceras and Columbites. The body chamber is at least a revolution in length.

Septa ceratitic or weakly ammonitic, with a divided ventral lobe, two laterals and an auxiliary on the outside; the inner septa consists of a divided antisiphonal lobe, flanked by a short, serrated lateral.

In early youth this group is exactly like Gastrioceras of the Carboniferous in the trapezoidal whorl, coarse umbilical ribs, spiral lines, and goniatitic septa. In later youth it is like Columbites of the Lower Triassic in its more rounded whorls, weaker constrictions and ribs, and ceratitic septa. At full maturity it has a higher whorl, weaker sculpture, more complex lobes, and the beginning of the keel characteristic of Tropites. It probably forms a connecting link between the Glyphioceratidæ of the Paleozoic and the Tropitidæ of the Upper Triassic. Tropigastrites might be included in Celtites, or it might be regarded as coming from that genus, but more likely it has come directly from Columbites. Certain species that have been described under the name of Celtites should be assigned to Tropigastrites, as Celtites neumayri Mojisisovics." Also "Danubites" dritarashtra Diener, of the Indian Muschelkalk, shows a strong resemblance to Tropigastrites and is apparently nearly allied to $T$. trojanus; the principal difference is that on the Indian species the umbilical ribs are weaker, and the whorl not so broad.

Some species previously assigned to Sibyllites Mojsisovics belong to Tropigastrites; Sibyllites planorbis Hauer ${ }^{2}$ was assigned by Hauer to Sibyllites, although it bears little resemblance to the type of that genus. In a recent paper, C. Diener ${ }^{3}$ has assigned this species to Japonites Mojsisovics, a genus supposed to be characteristic of the Middle Triassic of the Arctic-Pacific region. Also "Sibyllites" louderbacki Hyatt and Smith is certainly congeneric with $S$. planorbis, but neither bears any resemblance to "Ceratites" planiplicatus Mojsisovics," the Iype of Japonites. The American species at any rate differ from Japonites in their long body chamber, a character which is supposed to distinguish the Tropitoidea from the Ceratitoidea. A still better criterion is the fact that the development of these species points unequivocally to a gastrioceran ancestry, which is not true of any genuine members of the Ceratitidx.

\footnotetext{
1 Die Cephalopoden der IIallstätter Kalke: Abhandl. K.-k. geol. Reichsanstalt Wien, vol. 6, pt. 2, 1893, p. 348, Pl. CC, figs. $\bar{i}$ and 6.

2 Beitrïge zur Kenntniss der Cephalopoden aus der Trias von Bosnien, Part II : Denkschr. K. Akad. Wiss. Wien, vol. 63,1896, p. 271, Pl. XII, flgs. $1-8$.

${ }^{3}$ Entwurf einer Systematik der Ceratitiden des Muschelkalk: Sltzungsber. K. Akad. Wiss. Wien, vol. 114, pt. 1, 1905, p. 800 .

1 Ueber einige japanische Trias-Fossilien : Beitr. Pal. und Geol. Oesterreich-Ungarns und des Orients, vol. 6, 1888 , p. 170.
} 
Another species that resembles Tropigastrites is "Japonites" chandra Diener," which has far more resemblance to "Sibyllites" planorbis than to Japonites planiplicatus.

All the American species assigned to Tropigastrites are alike in the evolute form, wide umbilicus, low and little-embracing whorls, umbilical ribs, raised and acute venter, and long body chamber; and all, in youth, show a great resemblance to Gastrioceras in the strong umbilical ribs, low, semilunar or helmet-shaped whorls, spiral lines on the shell, constrictions, and goniatitic septa. In adolescence the septa are ceratitic. At maturity the lateral ribs become reduced to ribs on the umbilical shoulders, the whorl becomes higher and somewhat acute, the constrictions disappear almost entirely, the spiral lines become rery weak, and the septa tend to become slightly ammonitic, brachyphyllic. In Tropigastrites halli Mojsisovies and $T$. neumayri Mojsisovics, however, the indentations do not seem to reach quite to the top of the saddles, retaining more of the gastrioceran characters.

The following species of Tropigastrites are found in America:

Tropigastrites trojanus Smith: Whorls broad and low, with only a slight raising of the venter to form the keel. Umbilical ribs coarse and running high up the flanks. Senta weakly ammonitic.

Tropigastrites loulerbacki Hyatt and Smith: Whorls broad but higher and rounder than on T. trojanus. Umbilical ribs very weak. Septa distinctly ammonitic.

Tropigastrites pouelli Smith: Whorls broad and low, with the renter raised into a roof-shaped keel. Umbilical ribs weak, extending up on the flanks in weak folds. Septa ceratitic but with the serrations extending high up on the sides of the lobes.

Tropigastrites lahontanus Smith: Whorls low but narrower and more rounded than on T. louderbacki and more robust than on $T$. neumayri. Umbilical ribs weak. Form resembling $T$. halli but differing in the weak umbilical ribs. Septa ammonitic.

Tropigastrites halli Mojsisovics: Whorls low and robust but slenderer than on T. trojanus. Umbilical ribs very strong and running high up the flanks. Venter with high sharp central ridge. Septa hardly above the ceratitic stage but with the indentations extending high up the sides of the saddles.

Tropigastrites neumayri Mojsisovics: Whorls slenderer than on T. halli, more like T. lahontanus but not so robust. Venter more acute than on $T$. lahontanus; umbilical ribs weaker than on $T$. halli. Septa ceratitic but with the indentations extending high up on the sides of the saddles.

Tropigastrites rothpletzi Smith: Whorls slenderer than on T. neumayri, with higher and more acute venter, greater lateral compression, and weaker umbilical ribs. Septa distinctly ammonitic but with the indentations on the saddles exceedingly fine. This species is nearest of all this genus to Celtites in appearance. but differs from that genus in the ammonitic septa and the acute venter. Its nearest ally is "Sibyllites" planorbis Hauer.

Tropigastrites obliterans Smith: Whorls more compressed laterally than on $T$. rothpletzi, with higher venter, weaker sculpture, and simpler septa. Septa weakly ammonitic.

Tropigastrites is an important link in the genetic series from Gastrioceras of the Carboniferous to the typical Tropitidæ of the Upper Triassic. It is also a good illustration of the law of acceleration of development; it probably is a descendant of Columbites Hyatt and Smith, and, like Columbites, in its youth it is a typical Gastrioceras. But Columbites retains the gastrioceran characters until it is half-grown, at maturity never gets beyond the ceratitic stage of the lobes, and seldom acquires the acute venter. Tropigastrites, on the other hand, loses the close resemblance to Gastrioceras in the adolescent stage, becomes like Columbites when it is half grown, and then goes beyond that genus in acquiring the acute venter, the weekly ammonitic lobes, and in the obsolescence of the constrictions, the spiral lines, and the lateral sculpture. The abundance of these forms in the Middle Triassic of the American region shows that the Tropitidx were endemic in that region, while they seem to have been immigrants appearing unheralded in the Indian and the Mediterranean Triassic regions.

Occurrence.-Tropigastrites is common in the Middle Triassic, Daonella dubia zone of Nevada, where it is represented by eight species, described below. In the same horizon in the Mediterranean region it is represented by "Celtites" neumayri Mojsisovics, and in India it is doubtfully represented by "Danubites" dritarashtra.

1 Cephalopoda of the Muschelkalk: Himalayan fossils, vol. 2, pt. 2, 1895, p. 33, Pl. X, fig. 4 (Mem. Geol. Survey India. Pal. Indica, 15th ser.). 
Tropigastrites halli Mojsisovics.

Plate VI, figures 4 and 5; Plate XII, figures 1-5; Plate XIV, figures 7 and $\mathbf{7}$; Plate XVIII, figures 11-14; Plate I.XXXVIII, figures 14-23.

1896. Danubites halli, Mojsisovics, Beiträge zur Kenntnis der obertriadischen Cephalopoden-Faunen des Himalaya : Denkschr. K. Akad. Wiss. Wien, vol. 63, p. 124.

1877. Clydonites lavidorsatus, Meek, Palæontology: U. S. Geol. Expl. 40th Par., rol. 4, p. 109, Pl. X, figs. 7 and $7 a$.

1905. Celtites halli, Hyatt and Smith, The Triassic cephalopod genera of America; Prof. Paper U. S. Geol. Survey No. 40, p. 125, Pl. XV, figs. 4 and 5 ; Pl. IJXXV, figs. 1-5.

1911. Celitites gemmellaroi, Arthaber, Die Trias von Albanien: Beitr. Pal. und Geol. Oesterreich-Ungarns und des Orients, vol. 24, p. 266.

(Not 1864. Goniatites lavidorsatus, Gabb. Description of the Triassic fossils of California and the adjacent Territories: Geol. Surrey California, Palæontology, vol. I, p. 21, Pl. III, figs. 6 and $7=$ Celtites gabbi Smith. sp. nov.)

Form evolute, discoidal, laterally compressed, widely umbilicate. Whorls low, increasing very slowly in height; little embracing and little indented by the inner volutions. The umbilicus is very wide and shallow. The height of the whorl is about one-fourth of the total diameter of the shell, the width slightly greater than the height, and the indentation about one-sixth of the height. The width of the umbilicus is slightly more than half the total diameter of the shell. The outer whorl conceals about one-third of the next inner one. This ratio does not hold good for the inner volutions, which are more evolute than the outer ones. Surface ornamented with strong lateral ribs which run obliquely forward from the umbilical shoulders and become obsolete high up on the flanks. In a few specimens weak folds mav be observed crossing the venter. The cross section is helmet shaped, with high and sharpened venter at maturity and an approach to the formation of a keel.

Septa consisting of a divided ventral lobe, two laterals, and a small auxiliary, all serrated, and with even the saddles slightly indented, though not so greatly as in T. rothpletzi. The lobes become serrated at a diameter of about 12 millimeters. The antisiphonal lobe is bifid, flanked by a small, serrated lateral. The body chamber is more than a revolution in length.

This species is more robust than Celtites lcevidorsatus Haner, with which it was identified by Meek, and the accompanying faunas are not the same. Mojsisovics ${ }^{1}$ said that the species described by Meek was different specifically and generically from Gabb's "Goniatites lavidorsatus," and that the former belonged to Danubites; accordingly he renamed Meek's figures Danubites halli. The writer has visited the localities where both Meek's and Gabb's specimens were obtained and has collected numerous specimens at both places. They are not identical, Gabb's figure being based on a shell somewhat compressed laterally, with weaker sculpture, and without the acute venter. G. von Arthaber ${ }^{2}$ renamed this species Celtites gemmellaroi, under the impression that it was congeneric with Celtites halli Gemmellaro. But since the two species belong to different genera the specific name given by Mojsisovics will stand.

Tropigastrites halli Mojsisovics bears considerable resemblance to T. trojanus Smith but has a higher and narrower whorl, sharper venter, and fewer and coarser ribs. It also greatly resembles "Danubites" dritarashtra Diener."

The sharpening of the venter in his specimen Diener thought might be due to compression, and he also did not know the length of the body chamber. The ribs appear to be weaker on the Indian species, and the denticulations run higher up the sides of the saddles.

1 Beitrüge zur Kenntniss der obertriadischen Cephalopoden-Faunen des IIimalayas: Denkschr. K. Akad. Wiss. Wien, rol. 6s, 1896 , p. 124 .

2 Lie Trias von Albanien. 1911, p. 266

a Cephalopoda of the Muschelkalk: Himalajan Fossils, vol. 2, pt. 2, 1895, p. 20, 1'l. VIII, ffg. 1 (Mem. Geol. Survey India. Fal. Indica, 15th ser.). 
Dimensions of a typical adult specimen of Tropigastrites halli.

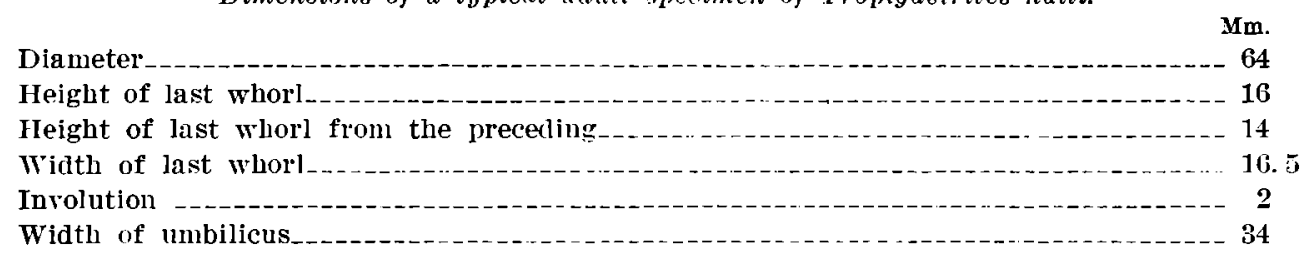

Horizon and locality.-Tropigastrites halli Mojsisovies was first described from the Humboldt mining region of Nevada, exact locality not given, but probably Cottonwood Canyon in the West Humboldt Range. The United States Geological Exploration of the Fortieth Parallel found it in the Middle Triassic Daonella zone of Buena Vista Canyon, West Humboldt Range. It is abundant in the Middle Triassic, Daonella zone, West Humboldt Range, Cottonwood Canyon, and on the divide between Troy Canyon and the south fork of American Canyon, associated with Beyrichites rotelliformis, Ceratites humboldtensis, Nevadites whitneyi, Protrachyceras meeki, Ceratites (Gymnotoceras) blakei, Longobardites nevadanus, Eutomoceras laubei, Arcestes gabbi, and cther species characteristic of the Middle Triassic.

Gabb cites Goniatites lievidorsatus from the east side of Owens Valley, 3 miles north of Owens Lake; hence it has been supposed that Tropigastrites halli occurred at that locality; but the Lower Triassic of Owens Valley has been studied carefully by the writer, and the Daonella dubia zone is lacking. However, Danubites strongi was found there, and it resembles $T$. halli, differing chiefly in its more robust whorl. This case of mistaken identity doubtless led to the error in citation. The beds in which Danubites strongi was found contain the Meekoceras fauna of the Lower Triassic.

\section{Tropigastrites LAmontaxts Smith.}

Plate XIX, figures 14-21 and 24-26.

Evolute, slender, widely umbilicate. Whorls low, broad, little embracing and little indented by the inner whorls. ITmbilical shoulders rounded, flanks curving gently upward without ventral shoulders to the keel-like ventral ridge. Surface ornamented with very weak umbilical ribs that do not reach high up on the flanks, and with weak spiral striæ. Body chamber more than a revolution in length. Septa distinctly ammonitic, but with the indentations on the saddles exceedingly fine.

Tropigastrites lahontanus is intermediate between T. louderbacki Hyatt and Smith and T. neumayri Mojsisovics, being slenderer than the former and more robust than the latter, a greeing with both in its weak sculpture. In form it greatly resembles $T$. halli, but differs in its weaker umbilical ribs and its more strongly ammonitic septa. It may possibly grade over into T. neumayri Mojsisovics, but on all the specimens examined the more robust whorl and more strongly ammonitic septa appear sufficient to separate the two.

The early stages of Tropigastrites lahontanus are exceeding like the adult form of Gastrioceras, with low, broad, trapezoidal whorls, broad flattened venter, and strong umbilical ribs, periodic constrictions, distinct spiral lines, and goniatitic septa. In adolescence the whorls become higher and the septa are ceratitic, the form then corresponding to Columbites of the Lower Triassic. Toward maturity the whorls become higher and somewhat acute and the septa become slightly ammonitic.

IIorizon and locality.-Rare in the Middle Triassic, Daonella dubia zone, Ceratites trinodosus subzone, on Fossil Hill, south fork of American Canyon, 4 miles south of Fitting post office (formerly Foltz), West Humboldt Range, Nev., associated with Ceratites trinodosus, C. humboldtensis, Nevadites whitneyi, Protrachyceras meeki, Acrochordiceras hyatti, Lonqobardites nevadanus, Sageceras gabbi, Daonella dubia, and other species. 
Tropigastrites Lolderbacki Hyatt and Smith.

Plate XVIII, figures 3-6, 9, and 10; Plate XI, figures 10-12; Plate LXXXVIII, figures 4-13.

1905. Sibyllites louderbacki, Hyatt and Smith, The Triassic cephalopod genera of America : Prof. Paper U. S. Geol. Survey No. 40, p. 58, Plate LXXIV, figures 10-12.

Form robust, evolute, widely umbilicate. Whorls low and increasing slowly in height, wider than high, deeply embracing and rather deeply indented by the inner whorls. Umbilical shoulders abruptly rounded, sides convex, sloping upward without ventral shoulders to the acute venter. The surface at maturity is nearly smooth, ornamented with weak umbilical ribs or folds that are nearly obsolete. In adolescence the umbilical ribs are strong and they are continued obliquely forward up the flanks. In that stage, too, the shell is markerl with distinct fine spiral lines and in form and septa is exactly like that of Gastrioceras. Body chamber more than a revolution in length. Septa slightly ammonitic at maturity, with slightly indented saddles and serrated lobes. There are three external lobes, a divided ventral, and two laterals. The antisiphonal lobe is flanked by a single, broad, internal lateral, also deeply serrated. The height of the whorl is one-third of the diameter of the shell, and the width is slightly greater than the height. The outer whorl embraces half of the inner and is indented by it to onefourth of the height.

Tropigastrites louderbacki is very closely allied to $T$. trojanus Smith, from which it differs in its weaker sculpture and higher, less-flattened, and more acute whorls. In youth the two species are very much alike, but the relative strength of the sculpture holds good even then. It also has a rather strong resemblance to "Japonites" chandra Diener but has stronger sculpture and less complex septa.

The strongly sculptured stage persists up to a diameter of about 20 millimeters, when the umbilical ribs become almost obsolete and the whorl becomes higher and finally low roof-shaped.

This species was assigned by Hyatt and Smith to the group of Sibyllites as used by Hauer, not by Mojsisovics. This group of species has since been assigned by Diener to Japonites, from which it differs in its long body chamber, stronger sculpture, and simpler septa. There is no doubt that this and the kindred species belong to the Tropitoidea, and form a transition between the primitive group of Celtites or Columbites and Tropites.

Horizon and locality.-Rather rare in the Middle Triassic Daonella dubia zone, Ceratites trinodosus subzone, on the divide between Troy Canyon and the south fork of American Canyon, 4 miles south of Fitting post office (formerly Foltz), West Humboldt Range, Nev., associated with Ceratites trinodosus, C. humboldtensis, Gymnotoceras blakei, Protrachyceras meeki, Nevadites whitneyi, Beyrichites rotelliformis, Daonella dubia, and other species.

Tropigastrites necmarir Mojsisovics.

Plate XVIII, figures 15-23; Plate Ixxxvili, figures 1-3.

2893. Celtites neumayri, Mojsisorics, Die Cephalopoden der Hallstittter Kalke: Ablandl. K.-k. geol. Reichsanstalt Wien, vol. 6 , pt. 2 , p. 348 , Pl. CC., figs. 5 and 6 , and text fig. on p. 348 .

1913. Celtites neumayri, Simionescu, Fauna Amonitilior Triasici dela Hagighiol (Dobrogea): Academia Romana, No. 34, p. 304, Pl. I, fig. 4.

Form evolute, moderately robust. Whorls low and increasing slowly in height, little embracing and little indented by the inner whorls. Umbilical shoulders abruptly rounded, sides convex, without ventral shoulders. Venter acute. Umbilicus wide and rather shallow. Weak umbilical ribs, which become nearly obsolete in age. Body chamber more than a revolution in length. Septa ceratitic, with entire saddles and serrated lobes. In youth the whorls $16279^{\circ}-$ No. 83-14-3 
are low, trapezoidal, and have relatively coarse umbilical ribs, and the venter is rounded. The acute tropitoid form is not developed until maturity.

This species differs from Tropigastrites trojanus in its slenderer whorl and weaker umbilical ribs but has so many affinities with that species that it must be congeneric with it. It was described as a Celtites but certainly is unlike $C$.epolensis, which is the type. It is more like Tropigastrites halli Mojsisovics, as figured and described by Hyatt and Smith. At maturity $T$. neumayri can readily be distinguished from the forms assigned to $T$. halli by the higher whorl and the weaker ribs.

Mojsisorics assigned this species to Celtites, but the shape of the whorl is lower and broader than that of any undoubted species of that genus, and this would throw it into the group of Tropigastrites trojanus.

The form is slenderer than that of Tropigastrites trojanus Smith, the sculpture is weaker, and the whorl higher. It has a greater resemblance to Tropigastrites halli Mojsisovics, but has rounder whorls and weaker ribs. In youth, like all species of this genus, it greatly resembles Gastrioceras of the Carboniferous and does not entirely lose this similarity even at maturity.

Dimchsions of the most typical specimen figured.

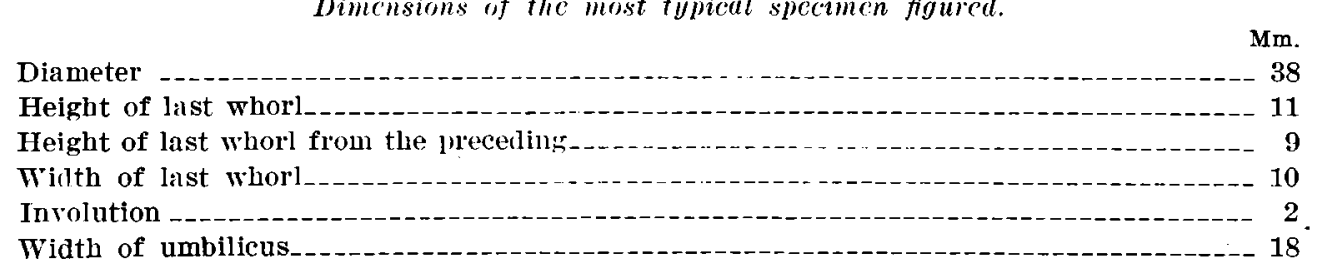

The height of the whorl is less than one-third of the diameter of the shell, and the width is slightly less than the height. The width of the umbilicus is slightly less than one-half of the diameter of the shell. In youth the whorls are low and broad, with stronger sculpture than at maturity.

The American specimens of this species seem to be identical with those figured by Mojsisorics from the same horizon in the Alps, and the faunal association is the same.

Horizon and locality.-Tropigastrites neumayri Mojsisovics was first found in the Middle Triassic, zone of Ceratites trinodosus, of the northern Alps. In Nevada it is quite common in the same horizon on Fossil Hill, on the divide between Troy Canyon and the south fork of American Canyon, 4 miles south of Fitting post office (formerly Foltz), West Humbolt Range, Nev., associated with Ceratites trinodosus, C. humboldtensis, Nevadites whitneyi, Protrachyceras meehi, Gymnotoceras blakei, Beyrichites rotelliformis, Sageceras gabbi, Daonella dubia, and other species.

Tropigastrites oblteraxs Smith, sp. nov.

Plate LXXXVII, figures $2 \bar{\imath}-32$.

Form moderately evolute, somewhat compressed laterally. Whorls of medium height, with sides gently convex and rising up to the high acute venter without ventral shoulders. Umbilicus broad and shallow, bordered by low and rather abrupt umbilical shoulders.

The surface of the mature shell is almost smooth, the characteristic lateral sculpture of Tropigastrites being obsolescent and reduced to very indistinct folds. The height of the whorl is more than one-third of the diameter of the shell, and the width is only two-thirds of the height. The width of the umbilicus is two-fifths of the diameter of the shell.

The septa are weakly ammonitic, brachyphylloid. The adolescent shell is highly sculp. tural, with about 15 umbilical ribs to a revolution,

Tropigastrites obliterans is closely allied with $T$. rothpletzi, but differs in its higher, flatter whorls, narrower umbilicus, less complex septa and more nearly obsolete sculpture. This species has departed further from the parent type, and is also more highly accelerated in development, for the venter begins to become acute at a diameter of 8 millimeters. 
Horizon and locality.-Very rare in the Middle Triassic, Daonella dubia zone, Ceratites trinodosus zone, of Fossil Hill, 4 miles south of Fitting post office (formerly Foltz), West Humboldt Range, Nev., associated with Ceratites trinodosus, $C$. humboldtensis, Nevadites whitneyi, Beyrichites rotelliformis Sageceras gabbi, Daonella dubia, and other species.

Tropigastrites Powelly Smith, sp. nov.

Plate XVIII, figures 1. 2. 7, 8, and 8a; Plate XCVII, figures 1-12.

Form evolute, robust, widely umbilicate. Whorls low, broad, with rounded umbilical shoulders, and sides gently convex, rising without ventral shoulders to the somewhat acute venter. The height of the whorl is slightly less than one-third of the cliameter of the spell and the width is one and a third times greater than the height. The outer whorl embraces three-fifths of the inner and is indented by it to one-third of the height. The width of the umbilicus is half the diameter of the shell. There is no true keel, but the venter is sharpened like the comb of a roof. The surface is ornamented with rather coarse umbilical ribs that are prolonged in fine, weak folds. These curve forward on the flanks and are continuous across the venter, forming a short ventral saddle. There are also, even at maturity, vestiges of constrictions parallel to the folds. In the adolescent stage these are strongly marked. The ribs are much stronger in the adolescent and early mature stages; in age they become weak. The length of the body chamber is more than a revolution.

The septa are ceratitic with strongly serrated lobes and rounded, entire saddle, but the serrations extend high up on the sides of the lobes. There are four external lobes, a short divided ventral, first and second lateral, and a small auxiliary; the antisiphonal lobe is flanked by a shorter internal lateral. The septa are exactly like those of Tropigastrites halli.

Up to the diameter of 15 millimeters the form and ornamentation reproduce exactly those of Gastrioceras, the whorl is low, gently rounded, the cross section is trapezoidal, the umbilical ribs are very strong, and there are numerous deep constrictions. Above the diameter of 15 millimeters the constrictions become fewer and weaker, the whorl higher and somewhat acute, giving a strong resemblance to Tropites of the Upper Triassic.

Tropigastrites powelli is the most robust species of this genus and shows the nearest approach to the characters of Tropites. The venter is more acute than on T. louderbaclii and higher than on $T$. trojanus. The umbilical ribs are weaker than on $T$. trojanus, and much stronger than on T. louderbacki. The indentation of the whorl is higher than on T. trojanus and lower than on $T$. louderbacki. The septa are exactly like those of $T$. halli and less complex than those of $T$. louderbacki.

The specific name is given in memory of Maj. J. W. Powell.

Horizon and locality.-Rather common in the Middle Triassic. Daonella dubia zone, Ceratites trinodosus subzone, of Fossil Hill, on the divide between Troy Canyon and the south fork of American Canyon, 4 miles south of Fitting post office (formerly Foltz). West Humboldt Range. Nev., associated with Ceratites trinodosus, Gymnotoceras blakei, Beyrichites rotelliformis, Nevadites whitneyi, Sageceras gabbi, Daonella dubia, and other species.

Tropigastrites rothPLETZi Smith, sp. nov.

Plate XIX, figures 1-13, 22, and 23; Plate LXXXVII, figures 24-26.

Form evolute, laterally compressed, widely umbilicate, whorls low and increasing slowly in height, higher than wide, somewhat helmet shaped but with venter rising to a sort of keel at maturity. Surface ornamented with weak umbilical folds, which in age are nearly obsolete. In youth the whorl is broad and low, with strong umbilical ribs and occasional weak constrictions. The surface in youth is ornamented with distinct fine spiral lines, which are obsolete at maturity. 
The body chamber is more than a revolution in length. The septa are weakly ammonitic, with slightly indented saddles and serrated lobes. The venter begins to form the acute central ridge at a diameter of 10 millimeters, but the ribs continue strong until a diameter of 25 millimeters is reached, nearly two revolutions farther toward maturity.

Dimensions of the type specimen.

$\begin{array}{lr}\text { Dimensions of the type specimen. } & \text { Mm. } \\ \text { Diameter } & \\ \text { Height of last whorl } & \\ \text { Height of last whorl from the preceding } & \\ \text { Width of last whorl } & \\ \text { Involution } & \end{array}$

The height of the whorl is one-fourth of the diameter of the shell, and the width is two-thirds of the height. The width of the unbilicus is one-half the diameter of the shell. The outer whorl embraces half of the inner and is indented by it to one-fourth of the height.

Tropigastrites rothpletzi is very closely related to "Sibyllites" planorbis Hauer, ${ }^{1}$ but is more robust, with stronger sculpture in youth, greater persistence of gastrioceran characters, earlier appearance of the sharpened venter, and less complex septa.

Diener " assigned "Sibyllites" planorbis to Japonites, but in the opinion of the writer it is a member of the Tropitidæ and belongs to Tropigastrites. The specific name is given in honor of Dr. A. Rothpletz.

Horizon and locality.-Rather common in the Middle Triassic, Daonella dubia zone, Ceratites trinodosus subzone, on the divide between Troy Canyon and the south fork of American Canyon, 4 miles south of Fitting post office (formerly Foltz), West Humboldt Range, Nev., associated with Ceratites trinodosus, C. humboldtensis, Gymnotoceras blalei, Nevadites whitneyi, Protrachyceras meeki, Beyrichites rotelliformis, Daonella dubia, and other species.

Tropigastrites nojanus Smith, sp. nov.

Plate XVII, figures $1-30$.

Very evolute, with wide umbilicus, whorls low, increasing slowly in height, deeply embracing. and deeply indented by the inner whorls; helmet shaped, with abrupt umbilical shoulders, sides convex rounding up to the acute renter without ventral shoulders. Ornamented with strong umbilical ribs. In youth the whorls are flattened, low and broad, trapezoidal in shape, exactly like Gastrioceras in form and septa, with the same umbilical ribs and periodic constrictions. At the diameter of about 30 millimeters the whorl becomes higher and finally angular, and the ribs become relatively smaller. The septa are weakly ammonitic, but with slightly indented saddles and serrated lobes. Body chamber more than a revolution in length.

This species in its ontogeny shows a clear transition from Gastrioceras of the Paleozoic to the Tropitidx. In adolescence, when the septa first become serrated, it is analogous to Columbites, and at maturity the whorl is lower and broader and the septa are slightly ammonitic. This is the most primitive member of the Tropitidæ, and connects that family with the ancestral Celtitidæ, and through them with the Glyphioceratidæ. It "has long been known that the Tropitidæ must have had an ancestor with umbilical ribs and simple septa, and Tropigastrites trojanus meets all the requirements of the transitional form.

Dimensions of the type specimen of Tropigastrites trojanus.

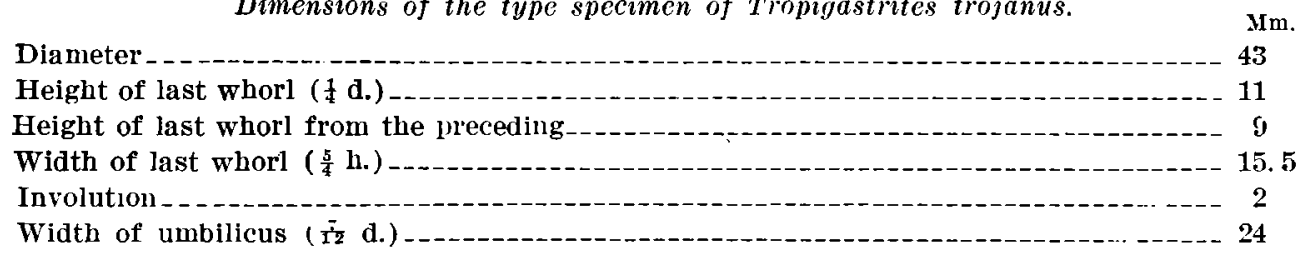

${ }^{1}$ Beitriige zur Kenntniss der Cephalopoden aus der Trias ron Bosnien, Part II : Denkschr. K. Akad. Wiss. Wien, vol. 63, 1896, p. 271, Pl. XII, figs. $1-8$.

antwurf einer Systematik der Ceratitiden des Muschelkalkes : Sitzungsber. K. Akad. Wiss. Wien, vol. 114, pt. 1, 1905, p. 800 . 
"Danubites" dritarashtra Diener ${ }^{1}$ is probably a Tropigastrites and very" similar to $T$. trojanus but has rather weak and fewer umbilical ribs.

Tropigastrites trojanus is the type of the new genus Tropigastrites, being the species of this group that unites more of the characteristics of Tropites and Gastrioceras.

Horizon and locality.-Rather common in the Middle Triassic, Daonella dubia zone, Ceratites trinodosus subzone, of Fossil Hill on the divide between Troy Canyon and the south fork of American Canyon, 4 miles south of Fitting post office (formerly Foltz), West Humboldt Range, Nev. It was associated with Ceratites trinodosus, C. humboldtensis, Gymnotoceras blakei, Beyrichites rotelliformis, Nevadites whitneyi, Sageceras gabbi, Eutomoceras laubei, Daonella dubia, and other species.

\section{Family CELTITID $\boldsymbol{E}$ Mojsisovics.}

Whorls evolute, slender, rounded or subquadratic in cross section, little embracing and little indented by the inner whorls.

Surface ornamented with umbilical or lateral ribs that usually become obsolete on the flanks, commonly also with weak spiral lines. The inner whorls often show varices ar constrictions. The septa are simple, being either goniatitic, or weakly serrated. The body chamber is long, more than a revolution in length. The young stages of all members of this family resemble Gastrioceras of the Carboniferous, from which group the Celtitidæ no doubt descended.

Celtites has usually been regarded as the radicle of the Tropitida, but the writer is of the opinion that, although it is nearly related to the ancestral stock of Tropites, it should rather be regarded as a lateral branch, degenerate in character. The earlier species of Celtites may have been connecting links between Gastrioceras and Columbites, but the species found in the higher horizons of the Triassic are merely little modified survivors.

Hyatt and Smith ${ }^{2}$ placed the Celtitidx under the Ceratitoidea, but this was done because of the inclusion of Xenodiscus in the family. It is pretty generally agreed now that Xenodiscus is allied to the group of Meekoceras and Ceratites and has no kinship with the true Celtitidæ.

The Celtitidæ, in the restricted sense, are represented in America by Celtites and Columbites in the Lower and Middle Triassic. Tropigastrites Smith might also be included in the family, but its more complex septa and its high acute venter show greater affinity to the Tropitidæ and afford a connecting link between Columbites and Tropites.

F. von Hauer has described, from the Middle Triassic of Bosnia, the genus Proteusites, ${ }^{8}$ with which also the group of "Ceratites" decrescens Hauer may be united. This group is characterized by robust form, wide umbilicus, semilunar cross section, strong lateral ribs, many constrictions, ceratitic or brachyphyllic septa, and semiglobose young. They certainly do not belong to the Ceratitoidea, but are descendants of the stock of Glyphioceratidæ. Philippi ${ }^{4}$ is inclined to unite Proteusites and its kindred with the Arcestidæ, but the strong sculpture in youth as well as age would forbid this. All the characters of Proteusites remind one strongly of Columbites, and this is especially true of Proteusites striatus Hauer, ${ }^{5}$ which agrees with Columbites in the lateral ribs, evolute whorl, and spiral lines on the shell, and differs only in its more numerous lobes and brachyphyllic saddles. The writer is of the opinion that Proteusites is a little-modified descendant of Columbites and a parallel development with Tropigastrites. The oldest member of this family, Paraceltites Gemmellaro, is confined to the Permian, whereas Celtites and Columbites are not found below the Triassic.

${ }^{1}$ Cephalopoda of the Muschelkalk; Himalayan fossils, vol. 2, pt. 2, 1895, p. 30, Pl. VIII, ffg. 1 (Mem. Geol. Survey Iudia, Pal. Indica, 15th ser.).

2 The Triassic cephalopod genera of Amerlca : Prof. Paper U. S. Geol. Survey No, 40, 1905, p. 121.

"Cephalopoden des Bosnischen Muschelkalkes von Han Bulog bei Sarajevo: Denschr. K. Akad. Wiss. Wien, vol. 54, 1888 , p. 27.

- Dle Ceratiten des oberen deutschen Muschelkalkes: Palæont. Abhandl. von Dames und Koken, new ser., vol. 4, 1901, p. 438 .

Beiträge zur Kenntniss der Cephalopoden aus der Trlas von Bosnien, Part I : Denkschr. K. Akad. Wiss. Wien, vol. 69, 1892 , p. 263, Pl. IV, figs. $1 a-c$. 
Either might be the connecting link with the Glyphioceratidæ, although Columbites is the more probable, for it is quite as primitive and in no sense degenerate.

From Gastrioceras of the Permian came Columbites of the Lower Triassic; this gave rise to Tropigastrites of the Middle Triassic, and from this came Tropites of the Upper Triassic. This gives one of the most perfect genetic series to be found among cephalopods, in which the ontogeny of each succeeding genus repeats the history of those that went before.

Two species of Columbites from the Middle Triassic are described below, but because they are too greatly modified from the ancestral type to give a good family record, the most primitive species of the genus from the Lower Triassic is figured for comparison with the young stages of Tropigastrites.

\section{Genus CELTITES Mojsisovics.}

1882. Celtites, Mojsisovics, Die Cephalopoden der Mediterranen Triasprovinz: Abhandl. K.-k. geol. Reichsanstalt Wien, vol. 10 , 1. 145.

1892. Celtites, Hauer, Beiträge zur Kenntniss der Cephalopoden aus der Trias von Bosnien : Part I, Denkschr. K. Akad. Wiss. Wien, vol. 59, p. 273.

1893. Celtites, Mojsisovics, Die Cephalopoden der Hallstätter Kalke: Abhandl. K.-k. geol. Reichsanstalt Wien, vol. 6, pt. 2 , p. 346 .

1895. Celtites, Waagen, Fossils from the Ceratite formation: Salt Range fossils, vol. 2, p. 69 (Mem. Geol. Survey India, Pul. Indica, 13th ser.).

1905. Celtites. Hyatt and Smith, The Triassic cephalopod genera of America: Prof. Paper U. S. Geol. Survey. No. 40 , p. 125.

1911. Celtites, Arthaber, Die Trias von Albanien: Beitr. Pal. and Geol. Oesterreich-Ungarns und des Orients, vol. 24, 1. 266 .

Type.-."Trachyceras" epolense Mojsisovics."

Centites gabbi Smith, sp. nov.

Plate XX, figures 9-14.

1864. Goniatites lavidorsatus, Gabb, Description of the Triassic fossils of California and the adjacent Territories: Geol. Survey California, Palæontology, vol. 1, p. 21, Pl. III, figs. 6 and 7.

(Not 1860. Ammonites lavidorsatus, Hauer, Nachtrag zur Kenntniss der Cephalopoden-Fauna der Halstätter Schichten : Sitzungsber. K. Akad. Wiss. Wien, vol. 41, p. 137, Pl. III, figs. 9 and 10.)

(Not 1877. Clydonites lavidorsatus, Meek, Palæontology: U. S. Geol. Expl. 40th Par., vol. 4, p. 109, Pl. X figs. 7 and $7 a=$ Tropigastrites halli, Mojsisovics.)

(Not 1896. Danubites halli, Mojsisovies, Beitrïge $\%$ Kenntniss der Obertriadischen Cephalopoden-Faunen des Himalaya : Denkschr. K. Akad. Wiss. Wien, vol. 63, p. 124.)

(Not 1905. Celtitcs halli, Hyatt and Smith, The Triassic cephalopod genera of America: Prof. Paper U. S. Geol. Survey No. 40, p. 125.)

Form evolute, widely umbilicate, with slender, little-embracing whorls, higher than wide, with sides somewhat flattened, incipient ventral shoulders, and rounder venter. The height of the last whorl is about one-fourth of the diameter of the shell, and the width is threefourths of the height. It embraces one-fourth of the inner volution. The width of the umbilicus is half the diameter of the shell. The length of the body chamber is considerably more than a revolution.

Septa goniatitic, according to Gabb, but none were visible on any specimens seen by the writer. The surface is ornamented with numerous fine umbilical ribs that die out on the sides. Gabb united this species with Celtites lavidorsatus Hauer, and Meek also figured another form under this name. Meek's species was afterwards renamed Danubites halli by E. von Mojsisovics, and has been assigned by the writer to the new genus Tropigastrites, a near ally of Celtites. Celtites gabbi is nearest to C. polygyratus Smith, but differs in its higher and more robust whorls, narrower umbilicus and weaker sculpture.

1 Die Dolomitriffe von Südtirol und Venetien, Wien, 1878, p. 57 ; and Die Cephalopoden der Mediterranen Triasprovinz: Abhandl. K.-k. geol. Reichsanstalt Wien, vol. 10, 1882, p. 149, Pl. XXIX, figs, 1 and 2 ; Pl. XXXVIII, fig. 13. 
Dimensions of a typical specimen of Celtites gabbi.

Diameter.- Mm.
Height of last whorl
Height of the last whorl from the preceding
Width of last whorl
Involution
Width of umbilicus.

The specific name is given in memory of W. M. Gabb, to whom American paleontologists owe a lasting debt of gratitude.

Horizon and locality.-Rare in the Middle Triassic, Daonella dubia zone, Ceratites trinodosus subzone, on Fossil Hill, south fork of American Canyon, 4 miles south of Fitting post office (formerly Foltz), West Humboldt Range, Nev., associated with Ceratites trinodosus, $C$. humboldtensis, Gymnotoceras blakei, Nevadites whitneyi,.Sageceras gabbi, Daonella dubia, and other species. It was first found in Cottonwood Canyon, West Humboldt Range, in the same horizon and association. This horizon in Nevada is lower than that of Celtites loevidorsatus in the Alpine province, and the associated faunas are entirely different.

Celtites polygyratus Smith, sp. nov.

Plate $\mathrm{XX}$, figures 1-8.

Very evolute, with slender, numerous, little-embracing whorls, a little wider than high, with flattened sides, rounded ventral shoulders, and arched venter. Surface with numerous fine umbilical ribs that run obliquely forward and disappear at the ventral shoulders and with a few weak constrictions or varices. Body chamber more than a revolution in length. Septa are goniatitic, with entire lobes and saddles.

Dimensions of the type specimen of Celtites polygyratus.

Diameter
Height of last whorl- $\begin{gathered}\text { Mm. } \\ \text { Height of last whorl from the jreceding }\end{gathered}$
Width of last whorl
Involution
Width of umbilicus.

The height of the whorl is less than one-fourth of the diameter of the shell, and the width is slightly greater than the height. The outer whorl embraces about one-fourth of the inner. The width of the umbilicus is slightly less than two-thirds of the diameter of the shell.

Celtites polygyratus Smith appears to be mast nearly related to the Upper Triassic species C. epolensis Mojsisovics, ${ }^{1}$ but has slightly weaker sculpture than is shown on the figures of the Mediterranean species. There are no other forms known from the Middle Triassic of the Mediterranean region that in any way resemble Celtites polygyratus, but in the American region there are several in the Middle Triassic and in the Lower Triassic that are closely related to it.

Celtites polygyratus is nearly allied to $C . g a b b i$ Smith, with which it is associated, but differs in the lower whorl, wider umbilicus, and stronger sculpture.

Horizon and locality.-In the Middle Triassic, Daonella zone, Ceratites trinodosus subzone, of Fossil Hill, on the divide between Troy Canyon and the south fork of American Canyon, 4 miles south of Fitting post office (formerly Foltz), West Humboldt Range, Nev., associated with Ceratites trinodosus, Eutomoceras laubei, Beyrichites rotelliformis, Nevadites whitneyi, Acrochordiceras hyatti, Sageceras gabbi, Daonella dubia, and other species.

${ }^{1}$ Die Cephalopoden der Mediterranen Triasprovinz: Abhandl. K.-k. geol. Reichsanstalt Wien, vol. 10, 1882, p. 149, 11. XXIX, figs. 1 and 2 , and Pl. XXXVIII, fig. 3 . 
Genus COLUMBITES Hyatt and Smith.

1905. Columbites, Hyatt and Smith, The Triassic cephalopod genera of America: Prof. Paper U. S. Geol. Survey No. 40 , p. 50.

1908. Columbites, Arthaber, Ueber die Entdeckung von Untertrias in Albanien: Mitt. Geol. Gesell. Wien, vol. 1, p. 277.

1911. Columbites, Arthaber, Die Trias von Albanien, Beitr. Pal. und Geol. Oesterreich-Ungarns und des Orients : vol. 24 , p. 260.

A Lower Triassic species of Columbites, $C$. spencei Smith, is described below for comparison with the primitive members of the Tropitidæ, as the Middle Triassic species of this genus appear to be somewhat degenerate and do not give the full history of the group.

Colvmbitas spencei Smith, sp. nov.

Plate IXX, figures 1-16; Plate IXXI, figures 1-16.

Form evolute, discoidal, robust. Whorls helmet shaped, slightly higher than wide, embracing half of the inner whorl, and indented by it to one-sixth of the height. Flanks and venter rounded, without rentral shoulders at the junction. Umbilical shoulders hardly developed. Umbilicus wide and shallow, being half the diameter of the shell. The surface is ornamented at maturity with rather weak lateral ribs that swing forward on the venter in a strong sinus, and weak constrictions at distant and irregular intervals. There are also weak spiral lines on the shell. The body chamber is more than a revolution in length. The septa are ceratitic, the saddles being entire, the ventral lobe divided and slightly serrated, the lateral lobe distinctly serrated, and the auxiliary goniatitic. Of the inner lobes the antisiphonal is bifid, and it is flanked by a simple lateral.

Up to a diameter of 10 millimeters this species is a typical Gastrioceras, having simple gastrioceran lobes, trapezoidal cross section, coarse umbilical ribs, and strong constrictions. At about 10 millimeters the septa become slightly serrated, but the gastrioceran form and sculpture persist until a diameter of about 35 millimeters is reached, when the whorl becomes higher and more compressed laterally, the shoulders become obsolete and the umbilical ribs become weaker and extend across the venter. These stages are figured on Plates LXX and LXXI.

Columbites spencei greatly resembles $C$. parisianus Hyatt and Smith, ${ }^{1}$ but differs from that species in the more robust form, stronger sculpture, and the persistence of the gastrioceran stage much later in life.

The specific name is given in honor of Mr. R. S. Spence, the discoverer of this fauna.

Horizon and locality.-Lower Triassic, Columbites zone, Paris Canyon, a mile west of Paris, Idaho, associated with Columbites parisianus, Ophiceras spencei, Prionolobus jacksoni, Meekoceras pilatum, Pseudosageceras intermontanum, and other species.

Columbites himmoldtexsis Smith, sp. nov.

Plate XX, figures 26-28; Plate LXXXVII, figures 1-14.

Form rather slender, evolute, widely umbilicate, with subquadratic cross section, flattened sides, rounded rentral shoulders and rounded renter. The width of the whorl is slightly greater than the height, and the width of the umbilicus is half the diameter of the shell. The surface is ornamented with numerous fine umbilical ribs running obliquely forward up the flanks but hardly reaching the shoulders. Between the ribs are numerous fine cross striæ. The length of the body chamber is more than a revolution. The septa are ceratitic, with serrated lobes and rounded entire saddles.

Columbites humboldtensis is closely allied with $C$.plicatulus Smith but differs in the higher, slenderer, and more deeply embracing whorls, and finer umbilical ribs. Both species show some

1 The Triassic cephalopod genera of America: Irof. I'aper L. S. Geol. Survey Yo, 40, 1905, p. 51, Pl. I, figs. 9-14: Pl. LXI, figs. 1-21; I'l. LXXII, figs. 1-24. 
resemblance to the group of Proteusites Hauer, but are not transitional from Columbites to that group. The writer is of the opinion that these tro species are somewhat degenerate descendants from Columbites of the Lower Triassic, and that Proteusites is a progressive descendant from the same group. The ontogeny is the same in all these, pointing to a gastrioceran ancestry; the characters of the parent genus persist almost until maturity in Columbites of the Lower Triassic, and the ornamentation of the shell in Proteusites still suggests Gastrioceras; but $C$. plicatulus and $C$. humboldtensis show resemblance to their Carboniferous ancestor only in the adolescent stage.

Horizon and locality.-Rather common in the Middle Triassic, Daonella dubia zone, Ceratites trinodosus subzone, on the divide between Troy Canyon and the south fork of American Canyon, 4 miles south of Fitting post office (formerly Foltz), West Humboldt Range, Nev., associated with Ceratites trinodosus, C. humboldtensis, Protrachyceras meeki, $P$. americanum, Nevadites whitneyi, Sageceras gabbi, Daonella dubia, and other species.

Colomites plicatulus Smith, sp. nov.

Plate XX, figures 15-25; Flate IXXXVII, figures 15-23.

Form evolute, widely umbilicate, whorls very low, little embracing, and increasing slowly in height. The sides are flattened; the venter and ventral shoulders are gently rounded. The height of the whorl is less than one-fourth of the diameter of the shell, and the width is twothirds of the height. The width of the umbilicus is more than half the diameter of the shell. The outer whorl embraces two-fifths of the inner. The surface is ornamented with rather coarse umbilical ribs that run obliquely forward up the flanks. The length of the body chamber is more than a revolution. The septa are ceratitic, with rounded, entire saddles, and distinctly serrated lobes. There is a short, divided external lobe, a rather large principal lateral, and a smaller auxiliary. The antisiphonal lobe is narrow and slightly bifid, flanked by a broad, serrated, internal lateral lobe.

Columbites plicatulus is closely allied with $C$. humboldtensis Smith, from which it differs in its more robust whorl, and fewer and coarser umbilical ribs. It also resembles Tropigastrites halli Mojsisovies but differs in its higher and rounder whorls and in its oblique umbilical ribs.

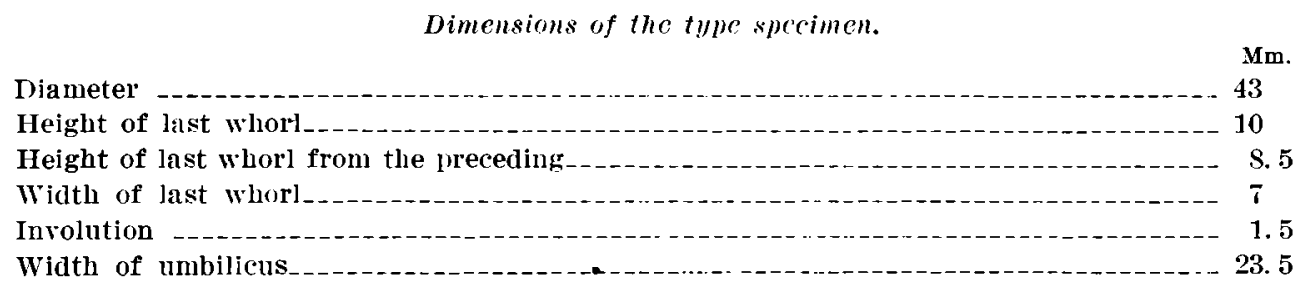

Columbites plicatulus is probably a somewhat degenerate descendant of the flourishing Columbites of the Lower Triassic. It shows some approach to the contemporary Proteusites Hauer but differs in the low stage of development of its septa and in its greater evolution.

Horizon and locality.-Rather common in the Middle Triassic, Daonella dubia zone, Ceratites trinodosus subzone, on the divide between Troy Canyon and the south fork of American Canyon, 4 miles south of Fitting post office (formerly Foltz), West Humboldt Range, Nev., associated with Daonella dubia, Ceratites trinodosus, C. humboldtensis, Nevadites whitneyi, Acrochordiceras hyatti, sageceras gabbi, and other species.

\section{Family HALORITID E Mojsisovies.}

Subglobose, involute genera, with lateral ribs, many crossing the venter, and in some groups with spines or knots on the ribs. No keels, or ventral furrows are known in this group, but the interruption of the ribs on the venter in some specimens gives the appearance of a 
furrow. The septa are ammonitic, dolichophyllic, or ceratitic. The young of this family resemble the Glyphioceratidx, and more especially the genus Pericyclus Mojsisovics, of the Carboniferous.

This family was formerly classed by Mojsisovics under the Tropitidæ, but it did not come from the main stock, being rather a parallel development from the same Carboniferous radicle but probably from different branches of the same family. The Haloritidxe are represented in the Middle Triassic of America only by Acrochordiceras Hyatt. In the Upper Triassic they are represented by Halorites, Homerites, Juvavites, Sagenites, Metasibirites, and Leconteiceras ${ }^{1}$ Smith, nom. nov. (= Leconteia Hyatt and Smith, ${ }^{2}$ a name preoccupied for a group of insects; Leontia ${ }^{3}$.

Stephanites Waagen is the oldest and probably the most primitive of the family, whereas Metasibirites Mojsisovies is a degenerate genus, reversionary to the ancestral type. It is possible that Proteusites Hauer should also be included in the Haloritida, because of its form and septa, but the writer is of the opinion that it is rather a modified descendant of Columbites and should thus be classed with the Celtitidr.

Genus ACROCHORDICERAS Hyatt.

1877. Acrochordiceras, Hyatt, Palæontology : V. S. Geol. Expl. 40th Par., vol. 4, p. 124.

1879. Acrochordiceras Mojsisovics, Vorläufige kurze Uebersicht der Ammoniten-Gattungen der Mediterranen und Juvavischen Trias: Verhandl. K.-k. geol. Reichsanstalt Wien, p. 139.

1880. Acrochordiceras, Noetling, Zeitschr. Deutsch. geol. Gesell., vol. 32, p. 334.

1882. Acrochordiceras, Mojsisovics, I)ie Cephilopoden der Mediterranen Triasprovinz: Abhandl. K.-k. geol. Reichsansta]t Wien, vol. 10, p. 140.

1887. Acrochordiceras, Hauer, Cephalopoden des Bosnischen Muschelkalkes von Han Bulog bei Sarajevo: Denkschr. K. Akad. Wiss. Wien, vol. 54, p. 22.

1892. Acrochordiceras, Hauer, Beitriige zur Kenntniss der Cephalopoden aus der Trias von Bosnien, Part I: Denkschr. K. Akad. Wiss. Wien, vol. 59, p. 272.

1895. Acrochordiceras, Waagen, Fossils from the Ceratite formation: Silt Range fossils, vol. 2, p. 89 (Mem. Geol. Survey India, Pal. Indica, 13th ser.).

1895. Acrochordiceras, Diener, Cephalopoda of the Mnschelkalk: Himalayan fossils, vol. 2, pt. 2. 1. 35) (Mem. Geol. Survey India, Pal. Indica, 15th ser.).

1895. Acrochordiceras, Diener, Triadische Cephalopodenfaunen der ostsibirischen Küstenprovinz: Mém. Com. géol. St.-Pêtersbourg, vol. 14, No. 3, p. 22.

1896. Acrochordiceras, Arthaber, Die Cephalopoden der Reiflinger Kalke: Beitr. Pal. und Geol. OesterreichUngarns und des Orients, vol. 10, pt. 1, p. 79, and pt. 2, p. 226.

1905. Acrochordiceras, Hyatt and Smith, The Triassic cephalopod genera of America : Prof. Paper I. S. Geol. Survey No. 40 , p. 177 .

1907. Acrochordiceras, Diener, The fauna of the Himalayan Muschelkalk: Himalayan fossils, vol. 5, Mem. No. 2, p. 99 (Mem. Geol. Surver India, Pill. Indica, 15th ser.).

ACrochordiceras alternans Smith, sp. nov.

Plate XXII, figures 15-17; Plate XXIII, figures 4 and 5.

Form robust, high whorled, laterally compressed, involute. Whorls high, with flattened convexed sides, broadly rounded ventral shoulders, and broad arched venter. The height of the whorl is more than half the diameter of the shell and the width is five-eighths of the height. The umbilicus is narrow, being less than one-fifth of the diameter of the shell. Surface ornamented with fine simple ribs that alternate on the renter, as in Juvavites Mojsisovics, but without interruption in the middle. Septa ceratitic, with four external serrated lobes, and the saddles slightly brachyphylloid.

1 Type, Lecontcia californica. Hyatt and Smith.

2 Tbe Triassic cephalopod genera of America : Prof. Paper U. S. Geol. Survey No. 40, 1905, p. 35.

Champion, G. C., Biologia Centrali-Americana, Coleoptera, vol. 4, 1893, pt. 2, p. 453. 
Dimensions of the thpe specimen of Acrochordiceras altermans.

Diameter
Height of last whorl
Width of last whorl
Width of umbilicus

The character of the ornamentation, consisting of undivided fine ribs, alternating on the venter.and without umbilical or lateral knots, is different from that of any described species of Acrochordiceras, but the differences are too slight for a generic separation.

F. von Hauer ${ }^{1}$ has described a species from Bosnia, Acrochordiceras enode Hauer, which resembles $A$. alternans but differs in having the ribs cross the venter without alternation and also has deeply digitate instead of ceratitic septa.

Horizon and locality.-Middle Triassic, Daonella dubia zone, Ceratites trinodosus subzone, north fork of Buena Vista Canyon, 2 miles west of Unionville, West Humboldt Range, Nev., associated with Cuccoceras bona-vista, Ceratites humboldtensis, Beyrichites rotelliformis, Acrochordiceras hyatti, Daonella dubia, and other species.

\section{Acrochordiceras foltzense Smith, sp. nov.}

Plate XXII, figures 13 and 14.

Form involute, robust, somewhat compressed laterally. Whorls high and deeply embracing, with convex sides and broadly rounded venter without distinct ventral shoulders. Umbilicus of moderate width, less than one-third of the diameter of the shell. Surface ornamented with simple, straight ribs that start from the umbilicus and run across the venter without interruption, becoming weak high up on the flanks. There are about 22 of these ribs to a revolution. There are no knots on the ribs and no bifurcation of them, but occasional intercalation on the flanks. The septa are unknown.

Horizon and locality.-Very rare in the Middle Triassic, Daonella dubia zone, Ceratites trinodosus subzone, on Fossil Hill, south fork of American Canyon, 4 miles south of Fitting post office (formerly Foltz), West Humboldt Range, Nev., associated with Ceratites trinodosus, C. humboldtensis, Gymnotoceras blakei, Nevadites whitneyi, Daonella dubia, and other species.

\section{ACrochordiceras hyatTI Meek.}

Plate IV, figures $8-11$; Plate $\mathrm{XV}$, figures 5 and $5 a$.

1877. Acrochordiceras hyatti, Meek, Palæontology: U. S. Geol. Expl. 40th Par., vol, 4, p. 124, Pl. XI, figs. 5 and $5 a$.

1905. Acrochordiceras hyatti, Hyatt and Smith, The Triassic cephalopod genera of America: Prof. Paper U. S. Geol. Survey, No. 40, p. 17s, PI. XXIII, figs. 8-1.1.

The original description is as follows:

Form robust, somewhat compressed laterally, moderately erolute. Whorl with flattened-convex sides, highly arched and broadly rounded venter, deeply embracing but not deeply indented by the inner whorl. The umbilicus is broad and deep, exposing nearly half of each of the inner whorls. The height of the whorl is one-half of the total diameter of the shell, and the width is four-fifths of the height. 'The indentation is one-fifth of the height. The width of the umbilicus is one-fourth of the total diameter of the shell.

The surface is ornanented with coarse, romded rils that run from the umbilicus straight across the venter without interruption. There are strong nodes on the flanks just above the umbilical shoulders, formed by the junction of two or three of the ribs. Between these nodes there are usually two ribs not joined, but the interval is irregular.

The septa are ceratitic, the saddles being rounded and entire, while the lobes are digitate. The external lobe is divided by a triangular siphonal notch into two short and nirrow branches; the first lateral lobe is

${ }_{1}$ Beitrïge zur Kenntniss der Cephalopoden aus der Trias von Bosnien, Part I : Denkschr. K. Akad. Wiss. Wien, vol, 59, 1892, p. 272, Pl. VII, fig. 1 . 
more than twice as long and very wide, digitate, with five long branches. The second lateral, or first auxiliary, is about half the length and breadth of the first, with four branches. On the umbilical shoulder is a second auxiliary smaller and simpler than the first.

Horizon and locality.-Meek's type specimen came from the Middle Triassic limestone of New Pass, Desatoya Mountains, Nev.; the specimen figured on Plate IV, figures 8-11, came from the same horizon, in the Shoshone Mountains, Nev. The writer found it also in the Middle Triassic of the West Humboldt Range, Nev., in Cottonwood Canyon, near the "Lucky Dog" mine, associated with Gymnotoceras blakei, Beyrichites rotelliformis, Nevadites whitneyi, Daonella dubia, and many other species.

Acrochordiceras inyoexse Smith, sp. nov.

Plate XXXIV, figures 11-13.

Form robust, moderately evolute, widely umbilicate; whorls low, broad, with narrow and rounded flanks and low, broad, and gently arched venter. Surface ornamented with strong but fine ribs that bifurcate on the flanks and run straight across the venter without interruption. Septa ceratitic, with rounded entire saddles, a divided ventral lobe, a large lateral, and a small auxiliary, all serrated.

Acrochordiceras inyoense differs from $A$. hyatti in its lower and broader whorl, simpler septa, and more numerous and finer ribs. It most closely resembles $A$. erucosum Arthaber ${ }^{1}$ but is more depressed and has no umbilical knots at the bifurcation of the ribs.

Horizon and locality.-Rather common in the lower Middle Triassic, Parapopanoceras zone, on the Union Wash, a mile east of the Union Spring, on the trail from Owens Valley to Salinas Valley, Inyo County, Cal., associated with Xenodiscus bittneri, Parapopanoceras haugi, Hungarites yatesi, and other species.

\section{Suborder ARCESTOIDEA.}

\section{Family POPANOCERATID F Hyatt.}

Genus POPANOCERAS Hyatt.

1883. Popanoceras, Hyatt, Genera of fossil cephalopods: Proc. Boston Soc. Nat. Hist., rol. 22, p. 337.

1886. Popanoceras, Mojsisivocs, Arktische Triasfaunen: Mém. Acad. imp. sci. St.-Pêtersbourg, ser. 7 , vol. 33, No. 6, p. 65.

1889. Popanocerıs, Karpinsky, Veber dic Ammoneen der Artinsk-Stufe, und einige mit denselben verwandte Carbonische Formen: Mém. Acad. imp. sci. St.-Pétersbourg, 7 th ser., vol. 37, No. 2, 1889, p. 67.

1891. Popanoceras, White, The Texan Permian and its Mesozoic types of fossils: Bull. U. S. Geol. Survey No. 77, p. 21.

1894. Parapopanoceras, Haug, Les Ammonites du Permien et du Trias: Bull Soc. géol. France, 3d ser., vol. 22 , p. 395.

1901. Popanoceras, Frech, Lethæa Palieozoica, vol, 2, Lieferung 3, p. 512.

1903. Popanoceras, Smith, Carboniferous ammonoids of America, p. 132.

Subgenus PARAPOPANOCERAS Haug.

1894. Parapopanoceras, Haug, Les Ammonites du Permien et du Trias: Bull. Soc. gêol. France, 3d sér., vol. 22, p. 395.

1902. Parapopanoceras, Mojsisovics, Die Cepllalopoden der Hallstitter Kalke: Supplement-Heft Ablandl. K.-k. geol. Reichsanstalt Wien, rol. 6, pt. 1, 1st half, p. 258.

1905. Parapopanoceras, Hyatt and Smith, The Triassic cephalopod genera of America : Prof. Paper, U. S. Geol. Survey, No. 40, p. 71.

1908. Parapopanoceras, Arthaber, Ueber die Entdeckung ron Lntertrias in Albanien: Mitt. Geol. Gesell. Wien, vol. 1, p. 259.

${ }^{1}$ Die Cephalopodenfauna der Reiflinger Kalke: Beitr. Pal. und Geol. Oesterreich.Cngarns und des Orients, vol. 10, 1896, p. 8., Pl. VII, figs. $9 a-c$. 


\section{Popanoceras (Parapopanoceras) haugi Hyatt and Smith.}

Plate XIII, figures 1-22; Plate XXXIV, figures 14 and 15.

1905. Popanoceras (Parapopanoceras) haugi, Hyatt and Smith, The Triassic cephalopod genera of America: Prof. Paper U. S. Geol. Survey No. 40, p. 71, Pl. LXXVI, Figs. 1-22.

The original description is as follows:

Subglobose, sides rounded, laterally compressed; venter highly arched, helmet shaped. Umbilical shoulders abrupt. Umbilicus rather wide, one-fourth of the diameter of the shell. Whorl deeply embracing, covering two-thirds of the inner whorl, and indented by it to one-fourth of the height. Height of whorl, two-thirds of the breadth and about two-fifths of the total diameter. Surface destitute of sculpture, only cross striæ being seen on the shell.

Septa of the Arcestes type with many lobes and saddles; the lobes are digitate and the serrations run high up on the sides of the saddles, but the tops are always rounded and entire. The external lobe is divided by a short and narrow siphonal saddle into two short and narrow lobes. The first lateral lobe is broader and longer, the second smaller than the first; following these is a series of three small anxiliaries, of which the last is directly on the umbilical suture. The internal septa consist of an antisiphonal lobe, long and narrow, flanked by two laterals, and an auxiliary on each side.

This species in early youth resembles Adrianites, then it passes through a distinct Popanoceras stage, with trifid principal lobes and bifid auxiliaries. Even at maturity the trifid nature of the lobes may still be seen. This form is a connecting link between Popanoceras and Arcestes and in its ontogeny gives a transition from the Glyphioceratidx to the Arcestida.

Horizon and locality.-Parapopanoceras haugi is common in the Middle Triassic of the Union Wash, a mile east of the Union Spring, Inyo Range, east side of Owens Valley and 15 miles southeast of Independence, Inyo County, Cal.

\section{Family CYCLOLOBID $A$ Zittel.}

Forms involute, robust, subglobose, narrowly umbilicate. Constrictions, or varices, usually present. Septa with numerous lobes and saddles, the lobes being serrated or digitate and the saddles usually phylloid. Body chamber long.

Range.-From the "Coal Measures" to the Upper Triassic.

In this family are included: Cyclolobus Waagen, Waagenoceras Gemmellaro, Hyattoceras Gemmellaro, Stacheoceras Gemmellaro, and Shumardites Smith of the Carboniferous and Megaphyllites Mojsisovics of the Triassic.

In the Triassic of America the family is represented only by Megaphyllites, in the Daonella dubia zone of the Middle Triassic of Nevada.

Genus MEgAPHYLLITES Mojsisovics.

1878. Megaphyllites, Mojsisovics, Die Dolomitriffe ron Südtirol und Venetien, Wien, p. 48.

1882. Megaphyllites, Mojsisovies, Die Cephalopoden der Mediterranen Triasprovinz: Abhandl. K.-k. geol. Reichsanstalt Wien, vol, 10, p. 190.

1902. Megaphyllites, Mojsisovics, Die Cephalopoden der Hallstätter Kalke: Supplement-Heft Abhandl. K.-k. geol. Reichsanstalt Wien, vol. 6, pt. 1, 1st half, p. 314.

1904. Megaphyllites, Martelli, Cefalopodi triasici di Boljevici presso Vir nel Montenegro: Palaontographia Italica, vol. 10 , p. 96.

Type.-Megaphyllites sandalinus Mojsisovics. ${ }^{1}$ No species is expressly cited as the type, but this one was the first figured and described after the generic diagnosis.

Generic characters.-Form laterally compressed, high-whorled, involute, subglobose. Surface smooth, without ornamentation, except periodic constrictions, chiefly on the body chamber, which is about three-fourths of a revolution long. Form like Arcestes, except in the compression, and phylloid lobes. Septa phylloid, with lobes deeply digitate, and dolichophyllic saddles.

This genus is represented by only a few species, chiefly in the Middle and Upper Triassic of the Mediterranean region. In America it is represented only by a single species, in the Middle Triassic, Daonella dubia zone, of the West Humboldt Range of Nevada.

1 Die Cephalopoden der Mediterranen Triasprovinz: Abhandl. K.-k. geol. Reichsanstalt Wien, vol. 10, 1882, p. 191, P1. LIII, figs, 1 and 2. 
Megaphyllites septentrionalis Smith, sp. nov.

Plate XXI, figures 4-12.

Form involute, subglobose, laterally compressed; whorls deeply embracing and deeply indented by the inner volutions. Umbilicus completely closed. Surface nearly smooth, without any ornamentation except the fine cross strix of growth; the constrictions on the body chamber, and some fine radial ribs on the last revolution of the mature shell.

Septa ammonitic, with rather weakly digitate lobes, and saddles slightly phylloid.

$$
\text { Dimensions of the type spccimen of Mcgaphyllites septentrionalis. }
$$

Diameter
Height of last whorl
Height of last whorl from the precerling
Width of last whorl
Involution
Width of umbilicus.

Megaphyllites septentrionalis differs from all Mediterranean species of this genus in the much slower increase in the height of the whorl. It has a rather close resemblance to $M$. obolus Mojsisovics, ${ }^{1}$ but differs in being more robust. It is also allied to $M$. sandalinus Mojsisovics, ${ }^{2}$ but is distinguished by its greater compression, and slower increase of the height of the whorl.

Horizon and locality.-Rather common in the Middle Triassic, Daonella dubia zone, Ceratites trinodosus subzone, on the divide between Troy Canyon and the south fork of American Canyon, 4 miles south of Fitting post office (formerly Foltz), West Humboldt Range, Nev.: associated with Ceratites trinodosus, C. humbolutensis, Gymnotoceras blakei, Protrachyceras americanum, Nevadites whitneyi, Beyrichites rotclliformis, Daonella dubia, and other species.

\section{Family ARCESTID A Mojsisovies.}

\section{Genus ARCESTES Suess.}

1865. Arcestes (in part), Suess, Ueber Ammoniten: Sitzungsber. K. Akad. Wiss. Wien, vol. 52, p. 76.

1869. Arcestes (in part), Laube, Die Fauna der Schichten von St. Cassian : Denkschr. K. Akad. Wiss. Wien, vol. 30, p. 86 .

1873. Arcestes (in part), Mojsisovics, Das Gebirge um Hallstatt, Part I; Die Mollusken-Faunen der Zlambach und Hallstätter Schichten: Abhandl. K.-k. geol. Reichsanstalt Wien, vol. 6, pt. 1, p. 71.

1879. Arcestes, Mojsisovics. Vorläufige kurze Tebersicht der Ammoniten-Gattungen der Mediterranen und Juvavischen Trias: Verhandl. K.-lk. geol. Reichsanstalt Wien, p. 134.

1882. Arcestes. Mojsisovics, Die Cephalopoden der Mediterranen Triasprovinz: Abhandl. K.-k. geol. Reichsanstalt Wien, vol. 6, p. 153.

1893. Arcestes, Mojsisovies, Die Cephalopoden der Hallstätter Kalke : Abhandl. K.-k. geol. Reichsanstalt Wien, vol. 6 , pt. 2 , p. 785 .

1896. Arcestes, Mojsisovics, Beiträge zur Kenntniss der obertriadischen Cephalopoden-Faunen des Himalaya : Denkschr. K. Akad. Wiss. Wien, vol. 63, p. 79.

1902. Arcestes, Mojsisovics, Das Gebirge um Hallstatt, Part I, Die Cephalopoden der Hallstätter Kalke: Supplement-Heft Abhandl. K.-k. geol. Reichsanstalt Wien, vol. 6, pt. 1, 1st half, p. 261.

1904. Arcestes, Gemmellaro, I cefalopodi del Trias superiore della regione occidentale della Sicilia, p. 255.

1905. Arcestes, Hyatt and Smith, The Triassic cephalopod genera of America : Prof. Paper U. S. Geol. Survey No. 40, p. 73.

1907. Arcestes, Diener, The fauna of the Himalayan Muschelkalk: Himalavan fossils, vol. 5, Mem. No. 2, p. 125 (Mem. Geol. Survey India, Pal. Indica, 15th ser.). 
Subgenus PROARCESTES Mojsisovics.

1893. Proarcestes, Mojsisovics, Das Gebirge um Hallstatt, Part I, Die Cephalopoden der Hallstätter Kalke: Abhandl. K.-k. geol. Reichsanstalt Wien, vol. 6, pt. 2, p. 785.

1896. Proarcestes, Mojsisovics, Beiträge zur Kenntniss der obertriadischen Cephalopoden-Faunen des Himalaya: Denkschr. K. Akad. Wiss. Wien, vol. 63, p. 655.

1902. Proarcestes, Mojsisovies, Das Gebirge um Hallstatt, Part I, Die Cephalopoden der Hallstätter Kalke: Supplement-Heft Abhandl. K.-k. geol. Reichsanstalt $W^{r}$ ien, vol. 6, pt. 1, 1st half, p. 259.

1905. Proarcestes, Hyatt and Smith, The Triassic cephalopod genera of America: Prof. Paper U. S. Geol. Survey, No. 40, p. 74 .

Arcestes (Pro.arcestes) gilbri Meek.

Pl. XIV, figures $6 a$ and $6 b$; Plate XXI, fgures 1 and 2 : Plate XIrIII. figures 1-3; Plate XCIII, figures 19 and 20 .

1864. Ammonites aussceanus; Gabb, Description of the Triassic fossils of California and the adjacent Territories: Geol. Survey California, Palreontology, vol. 1, p. 25, Pl. III, figs. 16 and 17.

1877. Arcestes gabbi, Meek, Palæontology : T. S. Geol. Expl. 40th Par., vol. 4, pt. 1, p. 121, Pl. X, figs. 6a-b.

1879. Arcestes gabbi, Whiteaves, Fossils of the Triassic rocks of British Columbia : Geol. and Nat. Hist. Survey Canada, Contrib. Canadian Palæontology, vol. 1, no. 3, p. 141.

Shell robust, involute, subglobose. Whorls deeply embracing and deeply indented by the inner whorls, helmet shaped in cross section. Umbilicus very narrow and deep. Surface provided with three or four deep, slightly sinuous constrictions to a revolution; these varices run obliquely forward from the umbilicus, and cross the venter with but slight curvature. Septa extremely complex, deeply digitate, and so close together that it is difficult to separate the succeeding septal lines; the siphonal lobe is deeply divided, and there are four laterals decreasing steadily in size toward the umbilicus, and two smaller auxiliaries.

Gabb identified this species with Arcestes ausseeanus Hauer, but the kinship with that species is not close. A. gabbi closely resembles A. extra7abiatus Mojsisovics, ${ }^{1}$ but appears to be slightly more compressed laterally; it is also closely allied with $A$. ventricosus Hauer, ${ }^{2}$ but differs from Hauer's figures in the straighter constrictions. Hauer has also described in the same work ${ }^{3}$ Arcestes bilabiatus, which differs from A. ventricosus only in being somewhat more compressed. Among the Arcestes of Nevada is one that seems to be an old age form of $A$. gabbi; this greatly resembles $A$. bilabiatus. The writer is of the opinion that Mojsisovies and Hauer have been entirely too strict in their specific discrimination.

Mojsisovics assigned $A$. gabbi to his genus Joannites, but it lacks the bifid saddles characteristic of Joannites and has the terminations usual on Arcestes.

Horizon and locality.-Very common in the Middle Triassic, Daonella dubia zone, Ceratites trinodosus subzone, of Fossil Hill, south fork of American Canyon, 4 miles south of Fitting post office (formerly Foltz), West Humboldt Range, Nev., associated with Ceratites trinodosus, C. humboldtensis, Nevadites whitneyi, Daonella dubia, and other species.

Arcestes (Proarcestes) hartzelli Smith, sp. nov.

Plate XCIII, figures 17 and 18.

Form very robust, globose, involute. Whorls broad and crescentic in cross section, embracing all of the inner volutions, and indented to more than half the height. Umbilicus very narrow, showing nothing of the inner whorls. Surface nearly smooth but with faint cross striæ of growth. The characteristic varices are nearly obsolete, being in only a few specimens faintly discernible. The septa are complex, of the usual Arcestes type, with the saddles not bifid but deeply digitate.

1 Mie Cephalopoden.der Mediterranen Triasprovinz: Abhandl. K.-k. geol. Reichsanstalt Wien, vol. 10, 1882, p. 154, L'l. XLVI, figs. 1 and 2.

a Beiträge zur Kenntniss der Cephalopoden aus der Trias von Bosnien, Part I : Denkschr. K. Akad. Wiss. Wien, vol, 59, 1892 , p. 277 , Pl. VII, fig. 3 ; Pl. IX, figs. $1 a-d$.

Op. cit., p. 278, Pl. $X$, figs. $1 a-c$. 
This species resembles Arcestes bramantei Mojsisovics but is more globose, with lower, broader whorls, and also lacks the prominent constrictions. It is nearest to Arcestes balfouri Oppel, as figured and described by Diener, ${ }^{1}$ but the details of the septa of $A$. hartzelli could not be made out with sufficient distinctness to warrant identification with that species.

The specific name is given in honor of Dr. J. C. Hartzell, who assisted the writer in collecting this fauna.

Horizon and locality.-Common in the Middle Triassic, Daonella dubia zone, Ceratites trinodosus subzone, of Fossil Hill, south fork of American Canyon, 4 miles south of Fitting post office (formerly Foltz), West Humboldt Range, Nev., associated with Ceratites trinodosus, C. humboldtensis, Nevadites whitneyi, Protrachyceras meeki, Beyrichites rotelliformis, Daonella dulbia, and other species.

\section{Arcestes (Proarcestes) nevadants Hyatt and Smith.}

Plate V, figures 5-7.

1905. Joannites nevadanus, Hyatt and Smith, The Triassic cephalopod genera of America: Prof. Paper U. S. Geol Survey No. 40, p. 76, pl. XXIV, figs. $5-7$.

The original description is as follows:

Involute, subglobose, laterally compressed. Whorl highly arched, with broadly rounded venter, deeply embracing and deeply indented by the inner whorl. The point of greatest breadth is at one-half the distance between the base of the whorl and the top of the next inner whorl. The height of the whorl is slightly less than one-half the total diameter, and the width is equal to the height; it is indented to somewhat more than one-half its height by the inner whorl. The umbilicus is open and deep, but narrow, being only slightly more than one-sixth of the total diameter, and exposing only the umbilical shoulders of the inner whorls.

The surface is smooth except for the constrictions, which occur about four to a revolution. These constrictions curve gently forward on the flanks, and then sharply forward on the venter, forming a broad and deep sinus.

The septa are complex, ammonitic, lobes and saddles all deeply digitate. The external lobe is rather deeply divided by a siphonal saddle. There are eight lateral lobes on each side, decreasing in size toward the umbilicus, but it is hardly possible to separate these into principal and auxiliary series.

This species is most nearly related to Arcestes gabbi Meek (Ammonites ausseeanus Gabb, not Hauer) but differs from that species in its wider umbilicus, more strongly digitate septa, and greater lateral compression.

Horizon and locality.-Middle Triassic, Upper Muschellalk, Volcano, Nev., J. D. Whitney Collection, Harvard University.

\section{Arcestes (Proarcestes) quadmilabiatus Haluer.}

Plate XCIII, figures 15 and 16 .

1887. Arcestes quadrilabiatus, Hauer, Cephalopoden des Bosnischen Muschelkalkes von Han Bulog bei Sarajevo: Denkschr. K. Alkad. Wiss. Wien, vol. 54, p. 20, Pl. IV, figs. 2a-b.

Form robust, globose; whorls deeply embracing, and deeply indented by the inner whorls. Cross section crescentic, the top of the inner whorl reaching two-thirds of the distance up from the bottom of the outer whorl. Sides convex, curving gradually up without shoulders to the broadly rounded venter. Umbilicus very narrow, almost closed. Surface ornamented with strong curved constrictions, four to a revolution. These curve forward on the flanks and make a slight backward bend toward the venter.

Arcestes quadrilabiatus from the Middle Triassic of Nevada agrees exactly with the figures and descriptions of $F$. von Hauer of the forms from Bosnia. This species closely resembles $A$. bramantei Mojsisovics but differs in its stronger and more numerous constrictions and somewhat less robust whorl. A. quadrilabiatus is more robust than $A$. gabbi, and less compressed than $A$. ventricosus, from which it also differs in the straighter constrictions.

${ }^{1}$ Cephalopoda of the Muschelkalk; Himalayan fossils, vol. 2, pt. 2, 1895, p. 83, Pl. XXVII, figs. 6 and 7 (Mem. Geol. Survey India, Pal. Indica, 15th ser.). 
Horizon and locality.-Rather rare in the Mirdle Triassic, Daonella dubia zone, Ceratites trinodosus subzone, of Fossil Hill, on the divide between Troy Canyon and the south fork of American Canyon, 4 miles south of Fitting post office (formerly Foltz), West Humboldt Range, Nev., associated with Ceratites trinodosus, C. humboldtensis, Nevarlites whitncyi, Beyrichites rotelliformis, Sageceras gabbi, Protrachyceras meeki, Daonella dubia, and other species. In Bosnia it was found in the same horizon, associated with a very similar fauna.

\section{Suborder PTYCHITOIDEA.}

\section{Family PTYCHITIDA Mojsisovics.}

\section{Subfamily NANNITIN E Diener.}

Genus NANNITES Mojsisovics.

1881. Nannites, Mojsisorics, Jalurb. K.-k. geol. Reichsanstalt Wien, p. 264.

1882. Nannites, Mojsisovics, Die Cephalopoden der Mediterranen 'Triasprovinz; Abhandl. K.-k. geol. Reichsanstalt Wien, vol. 10 , p. 210.

1897. Nannites, Diener, Cephalopoda of the Lower Trias: Himalayan fossils, vol. 2, pt. 1, p. 66 (Mem. Geol Survey India, Pal. Indica, 15th ser.).

1905. Nannites, Hyatt and Smith, The Triassic cephalopod genera of America : Prof. Paper U. S. Geol. Survey No. 40, p. 78.

1908. Nannites, Arthaber, Ueber die Entdecknng von Tntertrias in Albanien : Mitt. Geol. Gesell. Wien. vol. 1, p. 274.

Nannites contractus Smith. sp. nor.

Plate XXI, figures $13-17$.

Form robust, subglobose, involute, narrowly umbilicate. Whorls deeply embracing and deeply indented by the inner volutions, low helmet shaped. Surface smooth, destitute of ribs, constrictions, or other ornamentation. The form is globular, with nearly closed umbilicus up to a diameter of 7 millimeters, then the body chamber contracts, becoming much narrower than the inner whorls, and the umbilicus suddenly widens, showing egression, caused by a change in the rate of growth.

The septa are goniatitic, with a short divided ventral lobe, two laterals, and a short individual antisiphonal lobe, flanked by an internal lateral. This is a dwarf species, none larger than 12 millimeters in diameter having been found. The body chamber appears to be nearly a revolution in length.

Dimensions of the type specimen of Vannites contractus.

$\begin{array}{ll}\text { Dimensions of the type specimen of Vannites contrartus. } & \text { Mm. } \\ \text { Diameter } & \\ \text { Height of last whorl } & \text { Height of last whorl from the preceding } \\ \text { Width of last whorl } & \end{array}$

Nannites contractus is not nearly related to any of the described species of this genus, differing from them in its more globose form and in the contraction of the body chamber.

Horizon and locality.-Rather rare in the Middle Triassic, Daonella dubia zone, Ceratites trinodosus subzone, on the divide between Troy Canyon and the south fork of American Canyon, 4 miles south of Fitting post office (formerly Foltz), West Humboldt Range, Nev., associated with Ceratites trinodosus, C. humboldtensis, Gymnotoceras blakei, Protrachyceras americanum, Nevadites whitneyi, Beyrichites rotelliformis, Daonella dubia, and other species. $16279^{\circ}-$ No. $83-14-4$ 
Genus PARANANNITES Hyatt and Smith.

1905. Paranannites, Hyatt and Smith, The Triassic cephalopod genera of Imerica: Prof. Paper U. S. Geol. Survey No. 40 , p. 80.

1911. Paranannites. Arthaber. Die Trias von Albanien: Beitr. Pal. und Geol. Oesterreich-Ungarns und des Orients, rol. 24, p. 220.

\section{Paranaxites oviforisis Smith, sp. nov.}

Plate XXXIr, figures 16 and 17.

Form involute, robust, ovoid. Whorls low, broad, deeply embracing. Umbilicus nearly closed; flanks narrow and rounded; venter broad and gently arched. Surface smooth. Outer whorls devoid of constrictions, inner whorls with strong varices, three to a revolution, running straight across the venter from the umbilicus. Length of body chamber unknown.

Septa ceratitic, with a divided unserrated ventral lobe, a large lateral, and a small auxiliary, both serrated; the internal antisiphonal lobe is flanked by a pair of laterals on each side, but it could not be determined whether these are serrated.

\section{Dimensions of the type specimen of Paranannites oviformis.}

Dianeter
Height of last whorl
Height of last whorl from the preceding
Width of last whorl
Involution
Width of umbilicus.

The form of Paranannites oviformis resembles that of Ptychites latifrons Mojsisovies from the Arctic Triassic, but the American species is distinguished by its simpler septa and by the sculpture of the inner whorls. It may belong to Prosphingites, but the kinship with Paranannites appears to be stronger.

Horizon and locality.-Rare in the lower Middle Triassic, Parapopanoceras zone of the Union Wash, a mile east of the Union Spring on the trail from Orens Valley to Salinas Vallev, Inyo County, Cal, associated with Xenodiscus bittneri, Parapopanoceras haugi, Acrochordiceras inyoense, Hungarites yatesi, and other species.

\section{Subfamily PTYCHITIN A Diener.}

\section{Genus PTYCHITES Mojsisovics.}

1875. Ptychites, Mojsisovics (in Neumayr's Systematik del Ammonitiden) : Zeitschr. Deutsch. geol. Gesell., vol. 27, p. $S 82$.

1882. Ptychites, Mojsisovics, Die Cephalopoden der Mediterranen Triasprovinz: Abhandl. K.-k. geol. Reichsanstalt Wien, vol. 10 , p. 244.

1886. Ptychites, Mojsisovics, Arktische Triasfaunen: Mém. Acad. imp. sci. St.-Pêtersbourg, 7th ser., vol. 32, No. 6, p. 8 .

1888. Ptychites, Hauer, Cephalopoden des Bosnischen Muschelkalkes von Han Bulog bei Sarajevo: Denkschr. K. Alsad. Wiss. Wien, vol. 54, p. 38.

1892. Ptychites, Haner, Beitrïge zur Kenntuiss der Cephalopoden aus der Trias von Bosnien: Denkschr. K. Akad. Wiss. Wien, rol. 50, p. $2 \$ 4$.

1895. Ptychites, Diener, Cephalopoda of the Muschelkalk: Himalayan fossils, vol. 2, pt. 2, p. 62 (Mem. Geol. Survey India, Pal. Indici, 15th ser.).

1896. Ptychites, Toula, Eine Muschelkalkfauna am Golfe von Ismid in Kleinasien: Beitr. Pal. und Geol. Oesterreich-Ungarns und des Orients, rol. 10, p. 174.

1896. Ptychites, Mojsisovics, Bietrïge zur Kenntniss der obertriadischen Cephalopoden-Faunen des Himalaya : Denkschr. K. Akad. Wiss. Wien, vol. 63, p. 668.

1896. Ptychites, Arthaber, Die Cephalopodenfiuna der Reiflinger Kalke: Beitr. Pal. und Geol. OesterreichVngarns und des Orients, vol. 10. p. 95.

1898. Ptychites, Tornquist, Neuere Beitrïge zur Geologie und Paläontologie der Umgebung von Recoaro und Schio in Venetien, Part IV : Zeitschr. Deutsch. geol. Gesell., vol. 50, p. 659. 
1900. Ptychites, Diener, Die Triadische Cephalopoden-Fauna der Schiechlinghöine bei Hallstatt: Beitr. Pal. und Geol. Oesterreich-Ungarns und des Orients, rol. 12, p. 2i.

1905. Ptychites, Hyatt and Smith, The Triassic cepbalonod generil of America : Prof. Paper T. S. Geol. Survey No. 40, p. 86.

1907. Ptychites. Diener, The fauna of the Himalayan Muschelkalk: Himalajan fossils, vol. 5, Mem. No. 2, p. 119 (Mem. Geol. Survey of India, Pal. Indica. 15th series).

Ptychites er.insi Smith, sp. nov.

Plate XXI, figures 3 and $3 a$.

Form involute, laterally compressed. Whorls high and increasing rapidly in height, completely embracing, and deeply indented by the inner whorls. Umbilicus almost closed, sides flattened, venter narrowly rounded. Surface apparently smooth. Septa ammonitic, deeply digitate, as is usual with Ptychites.

Dimensions of the type specimen of Ptychites evansi.

Diameter
Height of last whorl
Height of last whorl from the preceding
Width of last whorl
Involution
Width of umbilicuss.

The specific name is given in honor of Dr. H. M. Evans, who assisted in collecting the Middle Triassic fauna.

Horizon and locality.-Very rare in the Middle Triassic, Daonella dubia zone, Ceratites trinodosus subzone, on the divide between Troy Canyon and the south fork of American Canyon, 4 miles south of Fitting post office (formerly Foltz), West Humboldt Range, Nev., associated with Ceratites trinodosus, C. humboldtensis, Gymnotoceras blakei, Nevadites whitneyi, Anolcites gabbi, Protrachyceras meeki, Beyrichites rotelliformis, Sageceras gabbi, Acrochordiceras hyatti, Daonella dubia, and other species.

\section{Pтrchites мгекi Hyatt and Smith.}

Plate VI, figures 0-12.

1905. Ptychites mecki, Hyatt and Smith, The Triassic cephalopod genera of America: Prof. Paper U. S. Geol. Survey No. 40, p. 87, Pl. XXV, figs. 6-12.

The original description is as follows:

Form robust, involate, laterally compressed. Whorl highly arched, with broadly rounded renter; deeply embracing and deeply indented by the inner whorl. The height of the whorl is one-half the diameter of the shell, and the width is equal to the height. It is indented to two-fifths of the height by the inner whorl and concen ls the inner whorl almost entirely. The umbilicus is deep, has steep inner walls, and the breadth is soinewhat less than one-fourth of the total diameter of the shell.

The surface is ornamented with fine radial folds that run from the umbilicus nearly straight across the venter. 'This sculpture is stronger on the young than on the mature shell. There are no constrictions visible, and no knots or spines.

The septa are ammonitic, but comparatively simple, not deeply digitate. The external lobe is divided by a small siphonal saddle; the first and second lateral lobes are of about the same size, and there is a smaller auxiliary on the umbilical shoulder. The body chamber is one revolution long.

Dimensions of the type specimen of Ptychites mecki.

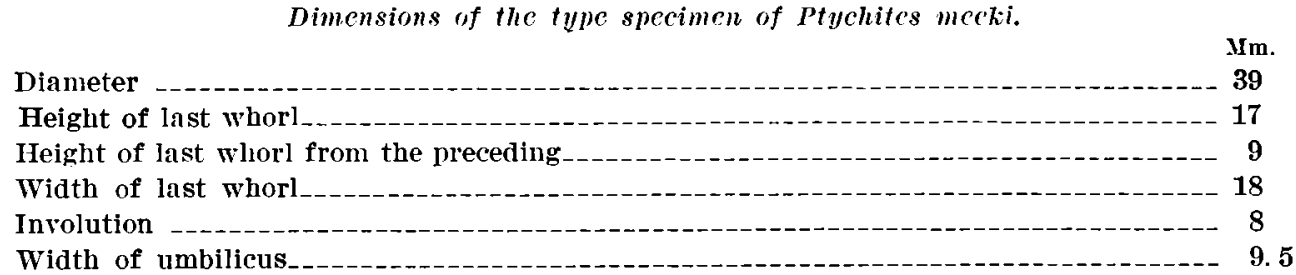

Horizon and locality.-Middle Triassic, lower Ladinic stage, Star Canyon, West Humboldt Range, Nev. Whitney collection, Harvard University. 


\section{Suborder LYTOCERATOIDEA. \\ Family LYTOCERATID A Neumayr. \\ Genus MONOPHYLLITES Mojsisovics.}

1879. Monophyllites, Mojsisovics, Vorläufige kurze Cebersicht der Ammoniten-Gattungen der Mediterranen und Juvavischen Trias: Verhandl. K.-k, geol. Reichsanstalt Wien, p. 135.

1882. Monophylites, Mojsisovics, Die Cephalopoden der Mediterranen Triasprovinz: Abhandl. K.-k. geol. Reichsanstalt Wien, vol. 10, p. 204.

1886. Monophyllites, Mojsisovics, Arktische Triasfaunen: MLém. Acad. imp. sci. St. Pétersbourg, 7 th series, vol. 33, No. 6, p. 72 .

1895. Monophyllites. Diener, Triadische Cephalopodenfaunen der ostsibirischen Küistenprovinz: Mém. Com. géol., St. Pétersbourg, rol. 14, No. 3, p. 29.

1895. Monophylites, Diener, Cephilopoda of the Muschelkalk: Himalayan fossils. rol. 2, pt. 2, p. 106 (Mem. Geol. Survey India, Pal. Indici, 15th series).

1902. Monophyllites, Schellwien, Trias, Perm und Carbon in China, p. 9.

1902. Monophyllites, Mojsisovies, Die Cephalopoden der Hallstätter Kilike: Supplement-Heft Abhandl. K.-k. geol. Reichsanstalt Wien, vol. 6, pt. 1, 1st half. p. 316.

1904. Monophyllites, Martelli, Cefalopodi triasici di Boljevici presso Vir nel Montenegro, Palæontoglaphia Italica, vol. 10, p. 99.

1905. Monophyllites, Hyatt and Smith, The Triassic cephalopod genera of America: Prof. Paper U. S. Geol. Survey No. 40. p. 93.

1907. Monophyllites, Diener, The fauna of the Himalayan Muschelkalk: Himalayan fossils, vol. 5 , Mem. No. 2, p. 105 (Mem. Geol. Survey India, Pal. Indica, 15th series).

1908. Monophyllites, Arthaber, Ueber die Entdeckung von Lntertrias in Albanien, Mitt. Geol. Gesell. Wien, vol. 1, p. 288.

1911. Monophyllites, Arthaber, Die Trias von Albanien: Beitr. Pal. und Geol. Oesterreich-Ongarns und des Orient, vol. 24, n. 232.

1913. Monophyllites, Simionescu, F'iunil Amonitilior 'Triasici dela Hagighiol (Dobrogea) : Academia Romana, No. 34 , p. 331 .

\section{Monophyilites billingsiants Gabb.}

Plate V, figures 3 and 4 ; Plate XXII, figures 1-5; Plate XLVIII, figures 8 and 9.

1864. Ammonites billingsianus, Gabb. Description of the Triassic fossils of California and the adjacent Territories: Geol. Survey California, Palæontology, vol. 1, p. 26, Pl. v, fig. 20.

1870. Ammonites billingsianus, Gabb, Description of some Secondary fossils from the Pacific States: Am. Jour. Conchology, vol. 5. p. 8, Pl. V, fig. 3.

1905. Monophyllites billingsianus, Hyatt and Smith, The Triassic cephalopod genera of America : Prof. Paper U. S. Geol. Survey No. 40, p. 94, Pl. XXIV, figs. 3 and 4.

The description by Hyatt and Smith is as follows:

From evolute, laterally compressed. Whorl low and increasing slowly in height, little embracing and not deeply indented by the inner rolution. Sides somewhat flattened, venter rounded, with indistinct abdominal shoulders. Umbilicus wide and shallow, exposing the greater part of the inner volutions. Umbilical shoulders abruptly rounded. The height of the whorl is more than one-third of the total diameter of the shell, and the breadth is about three-fourths of the height of the whorl. The width of the umbilicus is about one-third of the total dianeter of the shell. The surface is nearly smooth, being ornamented only with the flexuous striæ of growth. The septa are monophyllic, the saddles rounded, entire, contracted at the base, and the lobes are digitate. The external lobe is divided by a narrow siphonal sacldle into two bifid divisions; the first lateral is distinctly and symmetrically trifid; the second lateral unsymmetrically trifid. The auxiliary consists of three small secondary divisions of the umbilical lobe. Internal septa unknown. The septa as figured by Gabb ${ }^{2}$ are not correct, as he represents the first lateral lobe as bifid. The septa as represented in this paper are drawn from a specimen in the whitney collection, on which the septa were not visible until prepared by the writer.

This species is very closely related to Monophyllites spherophyllus Hauer. 
Horizon and locality.-Monophyllites billingsianus Gabb was found by the Geological Survey of California in the Middle Triassic of the East Humboldt Range, Nev. It is also found in the Daonella dubia beds of Fossil Hill, West Humboldt Range, Nev., associated with Ceratites trinodosus, Gymnotoceras blakei, Nevadites whitneyi, Daonella dubia, and other species.

\section{Suborder PINACOCERATOIDEA.}

\section{Family PINACOCERATID E Mojsisovics.}

\section{Genus SAGECERAS Mojsisovics.}

1872. Sageceras, Mojsisorics, Leber die Fntwicklung von Ammoniten in der Carbonischen Formation Indiens: Verhandl. K.-k. geol. Reichsanstalt Wien, p. 316

1873. Sageceris, Mojsisovics, Das Gebirge um Hallstatt: Abhandl. K.-k. geol. Reichsinstalt Wien, vol. 6, pt. 1 , p. 69 .

1879. Sageceras (in part), Waagen, Salt Range Fossils, rol. 1, p. 37 (Mem. Geol. Survey India, I'all. Indica, 13th ser.).

1882. Sageceras, Mojsisorics, Die Cephalopoden der Mediterranen Triasprovinz: Abhandl. K.-k. geol. Reichsanstalt Tien, vol. 10, p. 187 .

1905. Sageceras, Hyatt and Smith, The Triassic ceplalopod genera of America: Prof. Paper U. S. Geol. Survey No. 40, p. 97.

1908. Sageceras, Arthaber, Ueber die Entdeckung von Lntertrias in Albanien: Mitt. Geol. Gesell. Wieu, vol. 1, p. 281.

1911. Sageceras. Arthaber, Die Trias von Albanien : Beitr. I'al. und Geol. Oesterreich-Lngarus und des Orients, vol. 24. p. 203.

1913. Sageceras, Simionescu, Fauna Amonitilior Triasici dela Hagighiol (Dobrogea): Academia Iromana, No. 34, p. 329.

Sagechras gabri Mojsisovics.

Plate VI, figures 1-3; Plate XI, figures 8 and 9 ; Plate XII, figures 14 and 15; Plate XXI, figures 18-20.

1864. Goniatites haidingeri, Gabb, Description of the Triassic fossils of California and the adjacent Territories: Geol. Survey California, Palæontology, vol. 1, p. 22, Pl. V, figs. 8 and 10 (27 and 28).

1873. Sageceras gabbi, Jlojsisovics, Das Gebirge um Hallstatt: Abhandl. K.-k. geol. Reichsanstalt Wien, vol. 6, pt. 1, p. 71 .

1905. Sageceras gabbi, Hyatt and Smith, The Triassic cephalopod genera of America: Prof. Paper U. S. Geol. Survey No. 40, p. 97, Pl. XXV, figs. 1-3; Pl. LXXIV, figs. 8 and 9; Pl. IXXY, figs. 14 and 15.

(Not 1864. Goniatites haidingeri, Gabb, Description of the Triassic fossils of California and the adjacent Territories: Geol. Survey California, Palæontology, vol. 1, Pl. IV, fig. 10==Longobardites neradanus Hyatt and Smith).

(Not 1847. Goniatites haidingeri, Hauer, Ueber neue Cephalopoden aus dem Rothen Marmor von Aussee: Haidinger's Naturwiss. Abhandl, vol. 1, p. 264, Pl. VIII, figs. 9-11.)

The description by Hyatt and Smith is as follows:

Inrolute, discoidal, laterall $s$ compressed, whorls narrow, high, deeply embracing, and deeply indenter by the inner volutions. Umbilicus very narrow but exposing the inner volutions. The umbilical shoulders are abruptly rounded, the sides flattened, the venter narrow, channeled, with bicarinate edges.

The septa are lanceolate, divided into numerous long and narrow lobes and saddles. The saddles are rounded and entire, while the lobes are bifid, increasing in size from the venter toward the middle of the flanks, and then decreasing agiin toward the umbilicus.

Gabb included in his description of this species a young specimen of Longobardites, under the mistaken idea that it was the young of Sageceras. This explains the anomaly in Gabb's description, where it is stated that the septa of the young shell are serrated, while those of the mature shell are only bifid without serrations.

The young of this species up to a diameter of 6 millimeters resemble Sicanites; this shows that Sageceras comes directly from the same ancestral stcok as Medlicottia. It is not a descendant of Pseudosageceras, but rather a more primitive type. 
Sageceras gabbi is closely related to S. walteri Mojsisovics of the Alpine province; it is also nearly akin to Sageceras haidingeri Hauer, but, as Mojsisovics points out, it has fewer lobes at the same size.

Horizon and locality.-Middle Triassic, Humboldt mining region, Nev., and on the divide between the south fork of American Canyon and Troy Canyon, West Humboldt Range, Nev., in the Daonella dubia zone, Ceratites trinodosus subzone.

\section{Genus LONGOBARDITES Mojsisovics.}

1882. Longobardites, Mojsisovics, Die Cephalopoden der Mediterranen Triasprovinz: Abhandl. K.-k. geol. IReichsanstalt Wien, vol. $10, \mathrm{p} .184$.

1905. Longobardites, Hyatt and Smith, The Triassic cephalopod genera of America: Prof. Paper U. S. Geol. Survey No. 40, p. 132.

\section{Longobardites nevadanus Hyatt. and Smith.}

Plate VI, figures 13-18; Plate VIII, figures 16-20; Plate XI, figures 6-9; Plate XXX, figures 13-16.

1905. Longobardites nevadanus, Hyatt and Smith, The Triassic cephalopod genera of America: Prof Paper U. S. Geol. Survey No. 40, p. 132, Pl. XXV, figs. 13-18; Pl. LVIII, figures 16-20; Pl. I.XXV, figs. 6-9.

Hyatt and Smith's description is as follows:

Form involute, discoidal, lateralls compressed. Whorls narrow, high, and increasing rapidly in he.ght, completely embracing, and deeply indented by the inner rolutions. Side flattened convex, curving gently to the narrow venter. Umbilical shoulders rounded and scarcely perceptible. Abdominal shoulders scarcely developed, without shoulder angle. Venter acute, forming a sort of keel. The height of the whorl is slightly more than half the total diameter of the shell, the width is less than one-half of the height, and the indentation is about one-third of the height. The umbilicus is almost completely closed.

The surface of both shell and cast is smooth, being ornamented only with faint undulations on the shell parallel with the cross striæ of growth.

The septa are ceratitic, the saddles all rounded and entire, and the principal lobes are serrated. The external lobe is divided by a rather narrow and shallow siphonal saddle into two short, narrow branches; the first lobe on the side is bronder and longer. These two may be considered as the adventitions series. The third lobe on the side may be considered as the first principal lateral, being much larger and longer than the others. The fourth lobe is smaller than the second adrentitious lobe but serrated. The fifth is still smaller but also serrated. The sixth is slightly bifid, and the two remaining auxiliary lobes are goniatitic. In the early adolescent stage all the lobes are goniatitic, but they are nearly as numerous as at maturity; also even in the early mature stages there is no differentiation into an adventitions and a lateral series.

Longobarditcs nevadanus resembles $L$. zsigmondyi Boeckh, as figured by Mojsisovics, ${ }^{1}$ but is somewhat more robust than its Mediterranean congener, has fewer true auxiliaries, and more complex lobes. The close resemblance is emplasized by the associations of the two forms, the geologic horizon being the same for each and the accompanying faunas rery closely related.

Horizon and locality.--The Geological Survey of California, under J. D. Whitney, found this species in the Middle Triassic of New Pass, Desatoya Mountains, Ner. A small specimen of this was figured by Gabb ${ }^{2}$ as the young of Ceratites haidingeri (= Sageceras gabbi Mojsisovics), but it has no near kinship with Sageceras nor even any resemblance to it.

Longobardites nevadanus was found by the writer to be very common in the Middle Triassic Daonella beds on the divide between Troy Canyon and the south fork of American Canyon, 4 miles south of Fitting post office (formerly Foltz), West Humboldt Range, Nev., associated with Ceratites humboldtensis, Nevadites whitneyi, Beyrichites rotelliformis, Gymnotoceras blakei, Eutomoceras laubei, Sageceras gabbi, Daonella dubia, and other characteristic fossils. The writer also found L. nevadanus near the Lucky Dog mine in Cottonwood Canyon. West Humboldt Range, Nev., in the same beds and in the same association.

I Die Cephalopoden der Mediterranen Triasprovinz: Abhandl. K.-k. geol. Reichsanstalt Wien, vol. 10, p. 185, Pl. LII, flgs. $4 a-b$.

? Geol. Survey California, l'alæontology, vol. 1, Pl. IV, fig. 9. 
Suborder CERATITOIDEA.

\section{Family GYMNITID $A$ Waagen.}

Genus GYMNITES Mojsisovics.

1882. Gymnites, Mojsisovics, Die Cephalopoden der Mediterranen Triasprovinz: Abhandl. K.-k. geol. Reichsanstalt Wien, vol. 10, 1. 231.

1888. Gymnites, Inojsisovics, Ueber einige japanische Trias-Fossilien : Beitr. Pal. und Geol. Oesterreich-Ungarns und des Orients, rol. 6, p. 173.

1888. Gymnites, Hauer, Cephalopoden der Bosnischen Muschelkalkes ron Han Bulog bei Sarajero: Denkschr. K. Akad. Wiss. Wien, rol. 54, p. 36.

1892. Gymnites. Hauer, Beitrïge zur Kenntniss der Cephalopoden aus der Trias von Bosnien, Part I : Denkschr. K. Akad. Wiss. Wien, vol. 59, p. 281.

1895. Gymnites, Diener, Cephalopoda of the Muschelkalk: Himalayan fossils, vol. 2, pt. 2, p. 51 (Mem. Geol. Survey India, Pal. Indica, 15th ser.).

1900. Egoceras, Hyatt, Cephalopoda (in Zittel and Eastman, Textbook of Palieontology), p. 558.

1900. Gymnites, Diener, Die Trialische Cephalopoden-Fauna der Schiechlinghöhe bei Hallstatt: Beitr. Pal. und Geol. Oesterreich-Ungarns und des Orients, rol. 12, p. 20.

1902. Gymnites, Mojsisovies, Die Cephalopoden der Hallstätter Kalke: Supplement-Heft Abhandl. K.-k. geol. Reichsanstalt Wien, vol. 6, jt. 1, 1st half, p. 302.

1903. Gymnites, Frech, Netue Cephalopoden aus den Buchensteiner Wengener und Raibler Schichten : Resultate der wissenschaftlichen Erforschung des Balatonsees, vol. 1, pt. 1, p. 34.

1904. Gymnites, Martelli, Cephalopodi triasci di Boljevici presso Vir nel Montenegro: Palæontographia Italica, rol. 10. p. 104.

1907. Gymnites, Diener. The fauna of the Himalayan Muschelkalk: Himalayan fossils, vol. 5. Mem. No. 2. p. 108 (Mem. Geol. Survey India, Pal. Indica, 15th ser.).

Type.-Probably Ammonites incultus Beyrich, not expressly so designated.

Form laterally compressed, involute or moderately evolute, not deeply embracing. Surface nearly smooth, sometimes with low radial folds, and one or two spiral rows of lateral knots. Umbilicus open and usually wide.

Septa digitate and complex, consisting of an external first and second lateral lobe, and a long series of auxiliaries, which often are oblique. Body chamber short, so far as known, being not more than two-thirds of a revolution in length.

This group was at first supposed to be related to Psiloceras, but on naming the genus Mojsisovics ${ }^{1}$ placed it in the family Pinacoceratidæ, subfamily Ptychitinæ. The flattened involute members of the group resemble Ptychites, but this resemblance is purely external and does not indicate near kinship. The more evolute members of the group have rather strong folds and are very like Flemingites. Waagen ${ }^{2}$ classes Gymnites in the family Gymnitidx, along with Flemingites and Xenodiscus; Mojsisovies ${ }^{3}$ in a later work supposes it to have come from Daraelites Gemmellaro, but this does not seem probable to the writer. The young stages bear a stronger resemblance to Xenaspis, with which Gymnites agrees in lacking the spiral lines on the shell.

Occurrence-Gymnites is rather common in the Middle Triassic of the Mediterranean region, and is also known in the same horizon in the Oriental region, in the Muschelkalk of the Himalayas. A few species have been found in the Upper Triassic of the Mediterranean region. The occurrence of Gymnites in the Middle Triassic of Nevada is another link between the faunas of western America and the Oriental and Mediterranean regions.

The place where Gymnites originated is unknown. There are far more species of it in the Mediterranean region than in all others combined; but of Xanaspis, Xenodiscus, and Flemingites, from some one of which it is supposed to have originated, the two latter are

\footnotetext{
'Dle Cephalopoden der Mediterranen Triasprovinz: Abhandl. K.-k. geol. Reichsanstalt Wien, rol. $10,1882$. p. 231.

2 Fossils from the Ceratite formation: Salt Range fossils, vol. 2, 1895, p. 162 (Mem. Geol. Survey India, Pal. Indica, 15 th ser.).

I Ije Cephalopoden der Hallstätter Kalke : Supplement-Heft Abhandl. K.-k. geol. Reichsanstalt Wien, vol. 6. pt. 1, 1st Lalf, 1902, p. 302.
} 
unknown in European waters, and the first is represented by a single species. On the other hand, all three cccur in both southern Asia and western America, and either region might with equal grounds be claimed as the birthplace of Gymnites.

In America the genus is represented by two species, Gymnites alexandra Smith, and G. calli Smith, in the Middle Triassic of Nevada, and rather doubtfully by "Arcestes" perplanus Meek, from the same horizon and region.

Gruxites alexandre Smith, sp. nov.

Plate XXIII, figure 1; Plate XXIV, figures 1-12; Plite XXV, figure 1.

Form laterally compressed, moderately involute. Whorls high, but increasing very slowly in height, embracing half of the next inner whorl and indented to about one-third of the height. Umbilicus wide and shallow, being about one-third of the total diameter. The height of the last whorl is about two-fifths of the total diameter of the shell, and the width is somewhat less tlian half of the height. The umbilical shoulder is rounded, with gentle slope to the umbilicus. The sides are flattened and slope with moderate curre without abdominal shoulders to the highly arched venter. The greatest breadth of the whorl is in the middle.

The surface is nearly smooth but ornamented with low, broad radial folds and a row of 25 knots to a revolution in the middle of the flanks. The septa are very complex, deeply digitate; the first lateral lobe is the longest, the external and second lateral lobes being shorter but equally complex. Following the second lateral is a row of five simpler and smaller auxiliaries inclined obliquely backward, as is common in the more evolute species of Gymnites. The septa are almost exactly like those of $G$. credneri Mojsisovics. Length of body chamber unknown, as both specimens were chambered nearly to the end.

Dimensions of two specimens of Gymnites alexandra Smith.

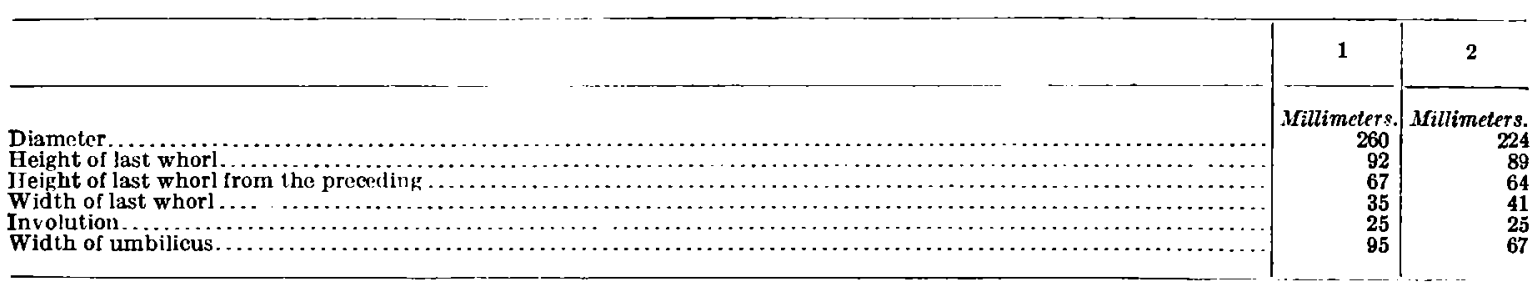

The larger specimen at diameter of 260 millimeters was chambered to the end, and as the body chamber was probably about two-thirds of a revolution the total diameter must have been about 400 millimeters. The larger specimen is chosen as the type of the species, because it shows the mature character of the septa. This is one of the largest and handsomest species of Gymnites known.

Gymnites alexandra Smith is very like G. credneri Mojsisovics, ${ }^{1}$ but has more knots on the flanks and is not so involute as the Mediterranean species. It resembles also G. jollyanus Oppel, as figured by Diener ${ }^{2}$; but the Asiatic species has the umbilicus narrower, the whorl flatter and more compressed, and the lateral knobs finer and more numerous.

Gymnites alexandra is very closely allied to G. bosnensis Hauer, ${ }^{3}$ but the American species is slightly involute, the widening of the umbilicus being slower and the increase in the height of the whorl somewhat more rapid. It also has no spiral ridge and the radial folds are stronger

\footnotetext{
${ }_{1}^{1}$ Die Cephalopoden der Mediterranen Triasprorinz: Abhandl. K.-k. geol. Reichsanstalt Wien, rol. 10, p. 237, Pl. LIX, figs. 1-s:.

= Cephalopoda of the Muschelkalk: Himalayan fossils, vol. 2, pt. 2, 1995, p. 51, Pl. X. fig. 7 ; Il. XI, fig. 1; Pl. XII, fig. 1 (Mem. Geol. Survey of India, I'al. Indica, 15th ser.).

${ }^{3}$ Cephalopoden des Bosnischen Muschelkalkes von llan Bulog bei Sarajevo: Denkschr. K. Akad. Wiss. Wien, vol. 54, 1888, p. 37, P1. VIII, Ggs. 1a-c, zone of Ceratites trinodosus.
} 
than on the Mediterranean species. $G$. alexandro Smith is intermediate between $G$. bosnensis Hauer and $G$. credneri Mojsisovics.

In youth up to a diameter of 25 millimeters the septa are ceratitic, resembling those of Xenaspis or the Meekoceratida. The lateral folds are stronger in youth, and up to a diameter of 50 millimeters the lateral row of tubercles is not yet developed. No specimens intermediate between the adolescent stage (diameter of 50 millimeters) and the large mature forms were found, and the two adult specimens were too valuable to be pulled apart to expose the young. At the diameter of 50 millimeters the septa characteristic of Gymnites are already developed.

The development of Gymnites has not been studied before, and the results given here are of interest as indicating the probable origin of the genus from Xenaspis or some other of the primitive types of the Ceratitoidea. At the diameter of 11 millimeters this resemblance to Xenaspis is especially strong, and only the size distinguishes the youthful Gymnites from the mature Xenaspis.

Horizon and locality.-Gymnites alexandro was found in the upper part of the Middle Triassic of the West Humboldt Range, Nev., on the divide between Troy Canyon and the south fork of American Canyon on Fossil Hill, about 4 miles south of Fitting post office (formerly Foltz). It was found along with Ceratites humboldtensis, Anolcites americanus, Beyrichites rotelliformis, and Daonella dubia in the Daonella zone. The two large specimens figured in this paper were collected by the field party of the University of California under the direction of Miss A. M. Alexander, to whose generosity the writer owes the specimens and in whose honor the specific name is given.

Gymattrs caldi Smith, sp. nov.

Plate XXVI, figures 1 and $1 a$.

Involute, discoidal, laterally compressed. Whorls deeply embracing and deeply indented by the inner whorls, high and increasing rapidly in height. Umbilicus narrow, with abruptly rounded umbilical shoulders. Venter narrowly rounded. The height of the whorl is nearly half the diameter of the shell, and the width is more than one-third of the height. The width of the umbilicus is less than one-sixth of the diameter of the shell. The outer whorl embraces three-fourths of the inner, and is indented by it to more than three-fourths of the height.

The septa are ammonitic, deeply digitate, as in $G$. alexandro.

The surface is smooth, without the ridges or knot that usually occur on Gymnites, but as the specimen is imperfectly preserved they may have been worn off.

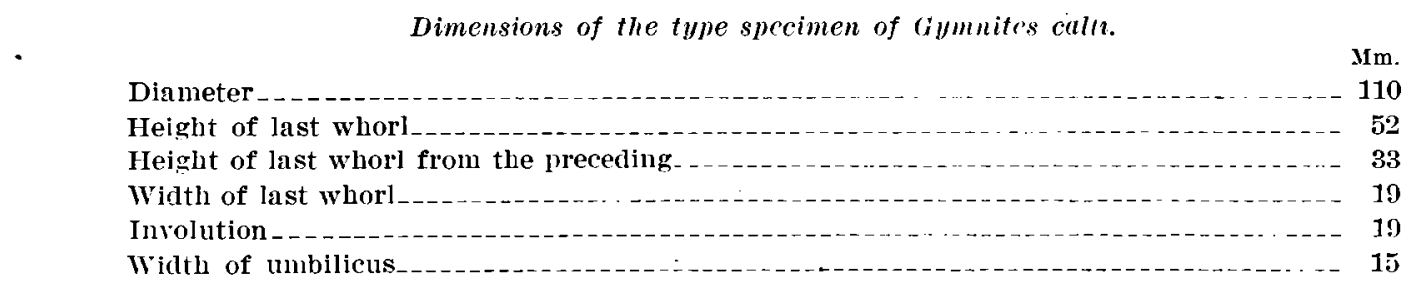

Gymnites calli resembles $G$. alexandre Smith but is more involute and has a narrower umbilicus.

The specific name is given in memory of Dr. R. E. Call.

Horizon and locality.-Very rare in the Middle Triassic, Dronella dubia zone, Ceratites trinodosus subzone, on the divide between Troy Canyon and the south fork of American Canyon, 4 miles south of Fitting post office (formerly Foltz), West Humboldt Range, Nev., associated with Ceratites trinodosus, C. humboldtensis, Gymnotoceras blakei, Protrachyceras meeki, Vevadites whitneyi, Sageceras gabbi, Daonella dubia, and other species. 
Gymnites Perplanus Meek.

Plate $\mathrm{XV}$, figures 7 and $7 a$.

1877. Arcestes perplanus, Meek, Palæontology : U. S. Geol. Expl. 40 Par., vol. 4, p. 120, Pl. XI, figs. 7 and $7 a$.

Form compressed, discoidal, moderately involute; whorls flattened, with nearly parallel sides and narrow rounded venter. Umbilical shoulders rounded, umbilicus shallow and wide, being about one-fourth of the diameter of the shell. Whorls increase rather slowly in height and embrace about two-thirds of the inner volutions. Surface smooth, without ornamentation. The septa were unknown to Meek, but the writer has observed them on a specimen in the United States National Museum; they are ammonitic of the Gymnites type.

Hyatt and Meek compared this species to Lecanites glaucus, to which it has not the slightest resemblance. It is much more compressed, involute and high whorled, with ammonitic septa, whereas Lecanites glaucus is evolute, low whorled, widely umbilicate, with goniatitic septa.

Horizon and locality.-Very rare in the Middle Triassic, Daonella dubia zone, Ceratites trinodosus subzone, of Buena Vista Canyon, West Humboldt Range, Nev.; also in the same horizon on Fossil Hill, south fork of American Canyon, 4 miles south of Fitting post office (formerly Foltz), West Humboldt Range, Nev.; associated with Ceratites trinodosus, $C$. humboldtensis, Nevadites whitneyi, Beyrichites rotelliformis, Daonella dubia, and other species.

\section{Subgenus ANAGYMNITES Hyatt.}

1900. Anagrmnites, Hyatt, Cephalopoda (in Zittel and Eastman, Texthook of Palaontology), p. 557.

1905. Anagymnites, Diener, Entwurf einer Systematik der Ceratitiden des Muschelkalkes; Sitzungsber. K. Akad. Wiss. Wien, rol. 114, pt. 1, p. 801.

Type-Anagymnites lamarcki, Oppel. ${ }^{1}$

Form evolute, discoidal, laterally compressed, widely umbilicate. Sides convex and venter high with sharp central ridge. Surface ornamented only with weak folds. Body chamber short. Septa ammonitic, dolichophyllic, with the auxiliaries inclined backward.

Up to this time only three species of this subgenus have been known-Anagymnites lamarcki Oppel and A. torrensii Diener, from the Middle Triassic of India, and A. acutus Hauer, from the same horizon in Bosnia. To this list is now added a fourth species, A. rosenbergi Smith.

Diener is of the opinion that Anagymnites is nearly allied to Japonites, and that both have been derived from some member of the Meekoceratidæ like Xenaspis, in which opinion the writer also agrees with him. Too few species have been described, and too little is known of their ontogeny to warrant a decided opinion as to the ultimate origin of this group, but it seems to be a subordinate branch of Gymnites.

Occurrence.-Anagymnites is rare in the Middle Triassic of India and the Mediterranean region and is represented in the same horizon in America by a single species.

\section{Granites (Anagynites) acutus Hauer.}

Plate XCVII, figures 13 and 14.

1892. Gymnitcs acutus, Hauer, Beitrüge zur INenntniss der Cephalopoden aus der Trias ron Bosnien, Part I: Denkschr. K. Akad. Wiss. Wien, vol. 59, p. 252 ; Pl. X, fig. 6 ; Pl. XI, fig. 2.

Form evolute, laterally compressed, widely umbilicate. Whorls without abruptly rounded umbilical shoulders and sides curving with gentle convexity without ventral shoulders up to the very high and acute venter. Surface nearly smooth, ornamented only with weak lateral folds. Septa unknown.

This species may not be identical with that described by Hauer from the Middle Triassic of Bosnia, for the septa are unknown and the specimen is not sufficiently well preserved for a positive identification. At any rate, the two are remarkably similar and the faunal association is the same.

1 Palacontologische Mittheilungen, vol. 1, pt. 3, 1863, p. 274, Pl. LXXV, fig. 3. 
Horizon and locality.-Very rare in the Middle Triassic, Daonella dubia zone, Ceratites trinodosus, subzone of Fossil Hill, south fork of American Canyon, 4 miles south of Fitting post office, West Humboldt Range, Nev., associated with Ceratites trinodosus, C. humboldtensis, Nevadites whitneyi, Sageceras gabbi, Daonella dubia, and other species.

Gymnites (Anagymnites) rosenbergi Smith, sp. nov.

Plate XXVI, figures 2-6.

Form evolute, discoidal, laterally compressed, and widely umbilicate. Whorls rather deeply embracing but not deeply indented by the inner whorls. Umbilical shoulders abruptly rounded, sides gently convex, sloping upward without ventral shoulders to the bluntly carinate venter. The surface is ornamented with weak folds but is otherwise smooth. The length of the body chamber is unknown. The septa are ammonitic but not deeply digitate, which may be due to the fact that the septa were not observed on any of the larger specimens.

The height of the whorl is two-fifths of the diameter of the shell, and the width is twothirds of the height. The width of the umbilicus is two-fifths of the diameter of the shell. The outer whorl embraces two-thirds of the inner and is indented by it to one-fourth of the height.

Anagymnites rosenbergi has a considerable resemblance to $A$. acutus Hauer, but differs from the Mediterranean species in its smaller size, weaker sculpture, and less acute venter.

The specific name is given in honor of Mr. L. M. Rosenberg, a mining engineer, who assisted the writer in collecting this fauna.

Horizon and locality.-Rare in the Middle Triassic, Daonella dubia zone, Ceratites trinodosus subzone, on the divide between Troy Canyon and the south fork of American Canyon, 4 miles south of Fitting post office (formerly Foltz), West Humbodlt Range, Nev., associated with Ceratites trinodosus, C. humboldtensis, Nevadites whitneyi, Beyrichites rotelliformis, Gymnotoceras blakei, Daonella dubia, and other species.

\section{Family XENODISCID $A$ Frech.}

Form evolute, discoidal, laterally compressed. Body chamber long. Surface ornamented with lateral ribs or folds. Septa goniatitic or ceratitic.

The Xenodiscidæ have commonly been regarded as a subfamily under the Tropitidæ, purely on account of their lateral ribs and long body chamber. But no member of the Tropitide has young stages in any way resembling Xenodiscus, and the characters on which that reference was based occur in other groups. The Xenodiscidæ can not have descended from the Glyphioceratida, in which group the ancestors of Tropites are to be sought, but from some member of the Prolecanitidx. The kinship of this group with the primitive members of the Ceratitidx, Hungaritidx, and Meekoceratidx is evident and acknowledged by all. Frech probably had this family in mind when he included the Tropitidæ in the suborder Ceratitoidea, although the true Tropitide can not have any kinship with it.

The Xenodiscidæ are known in the Permian of Asia, in the genus Xenodiscus; in other parts of the world they are not known below the Triassic. In America they are represented in the Middle Triassic by the genus Xenodiscus.

\section{Genus XENODISCUS Waagen.}

1879. Xenodiscus (in part), Waagen, Productus limestone fossils: Salt Range Fossils rol. 1, P. 32 (Mem. Geol. Survey, India, Pal. Indica, 13th ser.).

1895. Xenodiscus, Waagen, Fossils from the Ceratite formation: Salt Range Fossils, vol. 2, p. 161 (Mem. Geol. Survey, India, Pal. Indica, 13th ser.).

1897. Danubites, Diener, Himalıyan fossils, rol. 2, pt. 1, I) 24 (Men. Geol. Survey India, Pall. Indica, 15th ser.).

1902. Xenodiscus, Frech, Iethæa Palæozoica, vol. 2. pt. 4, p. $634 a$. 
1903. Proceratites, Kittl, Die Cephalonoden von Muć in Dalmatiẹ : Abhandl. K.-k. geol. Reichsanstalt Wein, vol. 20, p. 28.

1909. Xenodiscus, Diener and Krafft, Lower Triassic Cephalopoda from Spiti, Malla Johar, and Byans: Mem. Geol. Survey India, Pal. Indica, 15th ser., Mem. No. 1, p. 83.

Not 1886. Xenodiscus, Mojsisovics, Arktische Triasfaunen, Mém. Acad. imp. sci. St.-Pêtersbourg, 7 th ser., voi. 33, No. 6, p. 74.

Not 1895. Xenodiscus, Diener, Cephalopoda of the Muschelkalk: Himalayan Fossils, vol. 2, pt. 2, p. 110 (Mem. Geol. Survey India, Pal. Indica, 15th ser.).

\section{Xexomiscus ibitTneri Hyatt and Smith.}

Plate I, figures 5-15: Plate II, fignres 1-13; Plate xxxIV, figures $1-4$.

1905. Xenodiscus bittucri, Hyatt and smith, The 'Triassic cephalopor genera of America: Prof. Paper U. S. Geol. Survey No. 40, p. 123, Pl. XX, figs. 5-15; Pl. XXI, figs. 1-13.

The original description is as follows:

Evolute, discoidal, little embracing, and little indented by the inner volutions. Whorl low and increasing slowly in beight; sides flattened, venter rather narrow and highly arched, with indistinct abdominal shoulders. 'The height of the whorl is one-third of the total diameter of the shell, the width is two-thirds of the height, and the indentation by the inner volution is one-tenth of the height. The umbilicus is wide and shallow, being two-fifths of the entire diameter of the shell.

The shell is ornamented with distinct radial plications that begin on the abrupt umbilical shoulders and run nearly straight up the sides, bending forward at the abdominal shoulders. These plications become faint on the venter at maturity, but are very distinct in the adolescent stages; they are accompanied by numerous coustrictions, which become nearly obsolete at diameter of 20 millimeters.

The specimens are usually too much broken to show the length of the body chamber, but on two specimens it was seen to be at least one revolution in length.

The septa are ceratitic; the external lobe is divided by a short siphonal saddle into two short slightly serrated branches; the first lateral is longer and wider, distinctly serrated; the second lateral is similar. but much smaller; the auxiliary lobe is small and undivided, standing on the umbilical shoulder. The internal lobes consist of a goniatitic antisiphonal, flanked by a single internal lateral on each side. The external and internal saddles are rounded, and much wider than the lobes.

In the young stages the lobes are goniatitic. the whorls are low with almost rectangular cross section, and the radial sculpture nuch stronger in proportion to the size of the shells. The septa make the transition from the goniatitic to the ceratitic stage at the dimmeter of about 7 millimeters. The adolescent, unserrated stage probably corresponds to Paraceltites Gemmellaro.

Xenodiscus bittneri has a close resemblance to Xenodiscus himalayanus Griesbach, as figured by Diener, ${ }^{1}$ but its ribs are more numerous than on that species, and they cross the venter. It has a still closer resemblance to Xenodiscus? evolutus Waagen, ${ }^{2}$ from the upper Ceratite limestone of the Salt Range. Waagen's species seems to show a long body chamber, but the inner whorls are described as being smooth, unlike Xenodiscus bittneri. Certainly neither species is related to Dinarites.

In this species we have a survival of the Permian genus Xenodiscus in the bottom of the Middle Triassic, which in itself is not improbable, since its kindred form Xenaspis has also been found in the same horizon in Asia.

Horizon and locality.-In the lowest beds of the Middle Triassic, Inyo Range, east side of Owens Valley, Cal., on the Union Wash, about a mile east of the Union Spring, about 800 feet above the Meekoceras zone, which occurs on the sides of the same canyon. This locality is about 15 miles southeast of Independence. This species was first discovered by Mr. H. W. Turner. The specific name was given in honor of the late Dr. Alexander Bittner.

1 Cephalopoda of the lower Trias: Himalayan fossils, rol. 2, pt. 1, p. 41; Pl. XIV, fig. 14, $a, b, c$ (Mem. Geol. Survey India, Pal. Indica, 15th ser.).

${ }^{2}$ Fossils from the Ceratite formation: Salt Range fossils, vol, 2, p. 32, Pl. X, fig. 3 (Mem. Geol. Survey India, Pal. Indica, 13th ser.). 
Xenodiscus multicameratus Smith, sp. nov

Plate XXxIr, figures $\tilde{5}-10$.

Form evolute, laterally compressed, widely umbilicate. Whorls low and increasing slowly in height. Umbilical shoulders rounded, sides somewhat flattened, renter rather narrow and gently rounded. Umbilicus wide and shallow. Surface of the shell ornamented with fine, weak ribs running from the umbilicus across the venter. Septa ceratitic, with rounded saddles and three serrated lobes. The siphonal lobe is short and narrow, the first lateral broad and deep, and the auxiliary is rather broad and shallow.

Dimensions of the type specimen of Xenodiscus multicameratus.

Diameter
Height of last whorl
Height of last whorl from the preceding
Width of last whorl
Involution
Width of umbilicus

Xenodiscus multicameratus is closely related to $X$. bittner $i$, with which it is associated. but differs in its more rounded whorl, its much weaker sculpture, and in having its septa very close together.

Horizon and locality.-Rare in the lower Middle Triassic, Parapopanoceras zone, of the Union Wash, a mile east of the Union Spring, near the trail from Owens Valley to Salinas Vallev, Inyo County, Cal., associated with Xenodiscus bittneri, Parapopanoceras haugi, Acrochordiceras inyoense, and other species.

\section{Family HUNGARITID $\approx$ Waagen.}

\section{Genus HUNGARITES Mojsisovics.}

1870. Hungarites, Mojsisovics, Vorläufige liurze Cebersicht der Ammoniten-Gattungen der Mediterranen und Juvavischen Trias: Verhandl. K.-k. geol. Reichsanstalt Wien, p. 140.

1882. Hungarites, Mojsisovics, Die Cephalopoden der Mediterranen Triasprovinz: Abhandl. K.-k. geol. Reichsanstalt Wien, rol. 10, p. 221.

1886. Hungarites, Mojsisovies, Arktische Triasfaunen : Mém. Acad. imp. sci. St.-Pétersbourg, 7th series, vol. 33, No. 6, p. 87.

1896. Hungarites, Mojsisovics, Beiträge zur Kenntniss der obertriadischen Cephalopoden-Faunen des Himalaya : Denkschr. K. Akad. Wiss. Wein, rol. 63, p. 669.

1897. Hungarites, Diener, Cephalopoda of the Lower Trias: Himalayan fossils, rol. 2, pt. 1, p. 150 (Mem. Geol. Survey, India, I'al. Indica, 15th series ).

1898. Hungarites, Tournquist, Neuere Beiträge zur Geologie und Palïontologie der Ungebung von Recoaro und Schio in Venetien : Zeitschr. Deutsch. geol. Gess]l. rol. 50, p. 653.

1899. Hungarites, Diener, Mittheilung über Cephalopoden-Arten aus der Trias des siidlichen Bakony: Resultate der wissenschaftlichen Erforschung des Balatonsees, vol. 1, pt. 1, Pal. Anhang, p. 9.

1900. Hungarites, Arthaber, Das jüngere Paliiozoicum aus der Araxes-Euge bei Djulfa: Beitr. Pal. und Geol. Oesterreich-Cngarns und des Orients, vol. 12, 1. 220.

1901. Hunga rites, Frech, Lethica Palæozoica, vol. 2, Lieferung 3, p. 474.

1902. Hungarites, Frech, I.etliea Palæozoica, vol. 2, Lieferung 4, p. 635.

1903. Hungarites, Frech, Neue Cephalopoden aus der Buchensteiner, Wengener und Raibler Schichten des südlichen Bakony : Resultate der wissenschaftlichen Frforschung des Balatonsees, vol. 1, pt. 1, p. 10.

1905. Hungarites, Hyatt and Smith, The Triassic cephalopod genera of America : Prof. Paper [. S. Geol. Survey No. 40, p. 127.

1907. Hungarites, Diener, Iadinic, Carnic. and Noric faunæ of Spiti: Mem. Geol. Survey India. Pal. Indica, 15th series, vol. 5, Mem. No. 3, p. 18. 


\section{Hungarites fittingensis Smith, sp. nov.}

Plate XXIX, figures 12-14; Plate XC, figures 5-7.

Involute, high whorled, laterally compressed, with narrow umbilicus, flanks converging upward, indistinct ventral shoulders, and high blunt keel, without distinct marginal furrows. Surface ornamented only with low folds running from the umbilicus straight up nearly to the ventral shoulders. Length of body chamber unknown. Septa ceratitic, with rounded saddles, and five external serrated lobes.

Hungarites fitingensis resembles $H$. plicatus Hauer, ${ }^{1}$ but has no distinct furrow between the keel and shoulders, and the shoulders are less sharply defined than on the Bosnian species. Both belong rather to the group considered as typical Hungarites than to the arietiform group of "Hungarites" rusticus Hauer, which has been named Halilucites by Diener.

Horizon and locality.--Middle Triassic, Daonella dubia zone, Ceratites trinodosus subzone, on the divide between Troy Canyon and the south fork of American Canyon, 4 miles south of Fitting post office (formerly Foltz), West Humboldt Range, Nev., associated with Daonella dubia, Ceratites trinodosus, C. humboldtensis, Gymnotoceras blakei, Nevadites whitneyi, and other species.

\section{Hungarites yatesi Hyatt and Smith.}

Plate I, figures $1-4$.

1905. Hungarites yatcsi, Hyatt and Smith, The Triassic cephalopod genera of America: Prof. Paper U. S. Geol. Survey No. 40 , p. 129, Il. XX, figs. $1-4$.

The original description is as follows:

Conpressed, involnte, discoidal, deeply embracing, umbilicus closed, concealing the inner whorls, which indent the outer to two-fifths of the height. Sides flittened; greatest breadth a little less than half the height of the whorl, and at a point just above the rounded umbilical shoulder. Venter narrow, surmounted by a sharp central keel, flanked by sharp abdominal shoulder angles, above which the central keel rises distinctly. Surface ornamented with gently flexuous falcate ribs or folds and lines of growth, which bend forward gently to the shoulder angles. Septa ceratitic, lobes all serrated, saddles all rounded and entire; external lobe short, divided by a moderately deep siphonal saddle; first and second lateral lobes deeper; besides these there is one anxiliary on the sides and another on the umbilical shovider. Internal septa not seen.

This species is nearest to $I$. pradoi Verneuil, as figured by Mojsisovics ${ }^{2}$ from the Middle Triassic of Spain, but is not so highly sculptured, has the auxiliary series shorter, and has the abdomen narrower than on H.pradoi. The name is given in memory of the late Dr. L. G. Yates, in recognition of his contributions to the geology of California.

Horizon and locality.-Hungarites yatesi was found by $\mathrm{H}$. W. Turner in the Middle Triassic, on the Union Wash, about a mile east of the Union Spring, Inyo Range, Inyo County, Cal., about 15 miles southeast of Independence, associated with Parapopanoceras, Xenodiscus, Acrochordiceras, Ceratites, and Tirolites. The bed is about 800 feet above the Meelzoceras zone of the Lower Triassic, which outcrops on the sides of the same canyon.

Genus DALMATITES Kittl.

1903. Dalmatites, Kittl, Die Cephalopoden der oberen Werfener Schichten von Mué in Dalmatien: Abhandl. K.-k. geol. Reichsanstalt Wien, rol. 20. pt. 1, p. 72.

i907. Dalmatites, Diener, The fauna of the Himalayan Muschelkalk: Himalayan fossils, vol. 5, Mem. No. 2, p. 93 (Mem. Geol. Survey India, Pal. Indica, 15th ser.).

1 Beitrige zur Kenntniss der Cephalopoden aus der Trias von Bosnien, Part II : Denkschr. K. Akad. Wiss. Wien, rol, 63,1896 , p. 266 , Pl. JX, figs. 8-10.

s Die Cephalopoden der Mediterranen Triasprovinz: Abhandl. K.-k. geol. Reichsanstalt Wien, vol. 10, 1882, p. 225, Pl. XXXII, figs. 7 and $8 ; 1$ i. XXXIII, figs. 1 and 2. 
Type.-Dalmatites morlaccus Kittl, ${ }^{1}$ upper Werfen beds of Dalmatia.

Form high-whorled, laterally compressed, involute, narrowly umbilicate. Whorls deeply embracing and deeply indented by the inner volutions. Venter rises sharply to a narrow keellike ridge, without ventral shoulders. Septa ceratitic, with rounded entire saddles, and slightly serrated lobes, four in number, external two laterals, and a small auxiliary. Body chamber two-thirds of a revolution in length. Dalmatites resembles Hungarites, but differs in the simplicity of the septa, the absence of ventral shoulder angles, and in the weaker sculpture. From Eutomoceras it may be distinguished by the same characters. In general appearance it is closer to Longobardites, but differs in the greater simplicity of the septa; the more complex Longobardites may have developed out of the simpler Dalmatites by the addition of the auxiliary and the beginning of the adventitious series of lobes.

No genus is described in the Permian from which Dalmatites may have originated, but the writer has in his collection an undescribed species from the Chinati Mountains, Pennsylvanian, or "Upper Carboniferous," of Texas that has all the characters of Dalmatites, which, therefore, dates back at least to the "Upper Coal Measures." Diener has described a species from India, from the Muschelkalk.

Occurrence.-Dalmatites is represented in the Triassic of America by three species, one flom the Lower Triassic, Tirolites zone, of Idaho, and by D. minutus Smith, and D. parvus Smith from the Middle Triassic of the West Humboldt Range, Nev.

Dalmatites Minutes Smith, sp. nov.

Plate XXIX, figures 15-21.

Dwarf form with closed umbilicus, convex sides, and acute venter, without keel furrows or shoulder angles.

Surface ornamented at maturity with four or five coarse radial folds and no other sculpture. Septa ceratitic, with rounded saddles and four short serrated lobes.

In the adolescent stage the whorls are more convex, with rounded venter, and the sharpening of the venter begins at a diameter of 7 millimeters.

Dimensions of the type specimen of Dalmatites minutus.

$\begin{array}{ll}\text { Diameter. } & \text { Mm. } \\ \text { Height of last whorl } & \\ \text { Height of last whorl from the preceding } & \\ \text { Width of last whorl } & \\ \text { Involution } & \end{array}$

It differs from Dalmatites parvus Smith, with which it is associated, in being more robust, less compressed laterally, and in having much stronger radial folds. Both belong to the genus Dalmatites Kittl, established to include the primitive Hungarites-like forms. D. minutus Smith differs from $D$. morlaccus Kittl in its much stronger sculpture, but agrees with it in form and septa.

Horizon and locality.-Rare in the Middle Triassic, Daonella dubia zone, Ceratites trinodosus subzone, of Fossil Hill, on the divide between Troy Canyon and the south fork of American Canyon, 4 miles south of Fitting post office (formerly. Foltz), West Humboldt Range, Nev., associated with Ceratites trinodosus, C. humboldtensis, Nevadites whitneyi, Protrachyceras meeki, Acrochordiceras hyatti, Sageceras gabbi, Longobardites nevadanus, Daonella $d u b i a$, and other species.

1 Die Cephalopoden der oberen Werfener Schichten von Muć in Dalmatien : Abhandl. K.-k. geol. Reichsanstalt Wien, roi. 20 , pt. 1 , p. 73, Pl. IV, figs. 3-7. 
Dalmatites Parves Smith, sp. nov.

Plate XXX, figures 1-12.

Form involute, laterally compressed, with closed umbilicus, flattened sides, and acute venter, without ventral shoulders. Surface smooth without any other ornamentation except very weak lateral folds. Septa ceratitic with four external serrated lobes. The whorl is more compressed than on D. minutus Smith and the folds much weaker. The form has a great resemblance to the adolescent stage of Longobardites nevadanus Hyatt and Smith, but the venter is much less acute and there is a stronger tendency to form ventral shoulders. Dalmatites parvus also lacks the adventitious lobes that are characteristic of Longobardites and has only one auxiliary lobe while Longobardites has two or more. This species, along with $D$. minutus, belongs to a group unlike the typical Hungarites, and yet the characters are so similar that the writer did not think it advisable to establish a new genus or subgenus to include them. But Kittl ${ }^{1}$ has named the genus Dalmatites to include the primitive Hungarites-like forms. $D$. parvus Smith differs from D. morlaccus Kittl in its stronger sculpture but agrees with it in form and septa.

Horizon and locality.-Rare in the Middle Triassic, Daonella dubia zone, Ceratites trinodosus subzone, on the divide between Troy Canyon and the south fork of American Canyon, 4 miles south of Fitting post office (formerly Foltz), West Humboldt Range, Nev., associated with Ceratites trinodosus, C. humboldtensis, Gymnotoceras blakei, Protrachyceras meeki, Nevadites whitneyi, Beyrichites rotelliformis, Daonella dubia, and other species.

\section{Genus EUTOMOCERAS Hyatt.}

1877. Eutomoceras, Hyatt, Palieontology : C. S. Geol. Lxill. 40th Par., vol, 4, p. 126.

1896. Hungarites (in part), Hauer, Beiträge zur Kenntniss der Cephalopoden aus der Trias von Bosuien, Part II : Denkschr. K. Akad. Wiss. Wien, vol. 63, p. 250.

1900. Hungarites (in part), Arthaber, Das jüngere Paläozoicum aus der Araxes-Enge bei Djulfa: Beitr. Pal. und Geol. Oesterreich-Ungarns und der Orients, vol. 12, pt. 4, p. 220.

1905. Halilucites, Diener, Eutwurf einer Systematik der Ceratitiden des Muschelkalkes: Sitzungsber. K. Akad. Wiss. Wien, vol. 114, pt. 1, p. 776.

1905. Eutomoceras, Hyatt and Smith, The Triassic cephalopod genera of America : Prof. Paper U. S. Geol. Survey No. 40, p. 129.

(Not 1879. Eutomoceras, Mojsisovics, Vorläufige kurze Cebersicht der Ammoniten-Gattungen der Mediterranen und Juvavischen Trias: Verhandl. K.-k. geol. Reichsanstalt Wien, p. 136.)

(Not 1893. Eutomoceras, Mojsisovics, Die Cephalopoden der Hallstätter Kalke: Abhandl. K.-k. geol. Reichsanstalt Wien, vol. 6 , pt. 2, p. 283.)

Type.-Eutomoceras laubei Meek. ${ }^{2}$

As restricted to the type of Eutomoceras laubei Meek, the genus is common in the Middle Triassic of Nevada, where it is represented by $E$. breweri Smith, E. dalli Smith, E. lahontanum Smith, and E. laubei Meek; and in the zone of Ceratites trinodosus of the Mediterranean region, where it is represented by several species formerly assigned to Hungarites; $\Pi$. rusticus Hauer, $H$. obliquus Hauer, $H$. plicatus Hauer, $I$. arietiformis Hauer, and $H$. böckhi Hauer.

The group "Eutomoceras" sandlingense, which is also well represented in America but only in the Upper Triassic, has been renamed by Hyatt and Smith Discotropites. These species have no relationship with Eutomoceras but belong to the Tropitidæ, as their ontogeny clearly shows. The true Eutomoceras, on the other hand, belongs to the Ceratitoidea and is so closely allied to Hungarites that a separation of the two is uncertain. In fact, it is not impossible that Hungarites is scarcely more than a subgenus of Eutomoceras, as the characters of the two are so similar, and Eutomoceras must take precedence because it was named first.

1 Die Cephalopoden der oberen Werfener Schichten von Muć in Dalmatien: Abhandl. K.-k. geol. Reichsanstalt Wien, vol. 20 , pt. 1,1903 , p. 72 .

= U. S. Geol. Expl. 40th Par., vol. 4, p. 126, Pl. X, figs. 8 and $8 a$. 
The species described by F. von Hauer, ${ }^{1}$ Ceratites (Hungarites?) rusticus Hauer, $C$. (H.?) obliquus Hauer, $C$. (H.q) arietiformis Hauer, and $C$. (H.P) böchki Hauer, all belong to Eutomoceras Hyatt (not Mojsisovics) and are closely allied to forms in the zone of Ceratites trinodosus, Middle Triassic, of the West Humboldt Range, Nev. Diener ${ }^{2}$ says that these species do not belong to Hungarites and still are not typical Ceratites.

Hauer in describing the group of arietiform "Hungarites" thought that they were nearly allied to Paratropites Mojsisovics. But the young stages of Eutomoceras are clearly those of Ceratitoidea, and point to the Prolecanitidx as the ancestral stock, whereas the development of Paratropites and Discotropites ${ }^{3}$ show that they came from the Glyphioceratidæ.

Eutomoceras has a strong resemblance to Inyoites Hyatt and Smith from the Lower Triassic, Meekoceras zone, but differs in its stronger sculpture, lateral knots, ventral shoulders, marginal furrows, and solid keel. Inyoites may be the ancestral stock, but this is unlikely, for it is more highly specialized than the parent form of Eutomoceras should have been in the Lower Triassic; it is more probably a highly accelerated branch from the parent Dalmatites.

The genus Eutomoceras as thus limited is one of the most characteristic genera of the zone of Ceratites trinodosus, the middle Muschelkalk of the Mediterranean region.

Frech ${ }^{4}$ identifies (Hungarites) böckhi Hauer with H. mojsisovicsi Roth, although the identification seems to the writer to be somewhat doubtful. Now II. mojsisovicsi Roth was the type of Hungarites Mojsisovics, described in 1879. But (Hungarites) böckhi Hauer is certainly congeneric with Eutomoceras laubei Meek, the type of Eutomoceras Hyatt, described and figured in 1877. Should the two Mediterranean species prove to be really identical, then the genus Hungarites becomes merely a synonym for Eutomoceras, which must take precedence, because it has priority.

Diener ${ }^{5}$ regards $H$. pradoi Verneuil, $H$. mojsisovicsi Roth, and $H$. costosus as the typical Hungarites. But if $H$. mojsisovicsi Roth should be identical with $H$. böckhi Hauer, (which is Eutomoceras) then $H$. pradoi becomes the type of Hungarites, or else Hungarites is merely a synonym of Eutomoceras. Diener ${ }^{6}$ separates the group of Ceratites (Hungarites) musticus Hauer from the other arietiform "Hungarites" of the Mediterranean Muschellalk under the name of Halilucites Diener, as a subgenus under Ceratites. But the group of (Hungarites) rusticus differs from $H$. böckhi or $H$. mojsisovicsi only in being slightly more evolute and in possessing a little stronger ribs and more robust whorls. Halilucites then is either a synonym of Hungarites, which itself is hardly more than a subgenus of Eutomoceras, or it might be kept as a subgenus to include those species lacking the numerous irregular knots that occur on the shell of Eutomoceras laubei and its immediate kindred.

\section{Eutomocris breweri Smith, sp. nov.}

Plate XXVIII, figures $1-7$.

Form involute, laterally compressed, with high deeply embracing whorls, flattened sides, rounded abdominal shoulders, and very high keel, bordered by depressions which are real furrows in growth. The surface is ornamented with coarse ribs, usually bifurcating on umbilical knots and running up the sides in nearly straight lines, inclined slightly forward. At the ventral shoulders these ribs become suddenly finer and bend sharply forward, becoming obsolete at the marginal depression that borders the keel. At maturity there are no knots

1 Beiträge zur Kenntniss der Cephalopoden aus der Trias von Bosnien, Part II : Denkschr. K. Akad. Wiss. Wien, vol. 63,1896 , pp. $259,260,262$, and 264 , and I'ls. IX, figs. 1-7 and X, figs. 1-6.

¿ Die Triadische Cephalopoden-Fauna der Schiechlinghöhe bei llallstatt: Beitr. I'al. und Gcol. Oesterreich-Ungarns und des Orients, vol. 12, 1900, p. 10.

T The genus Discotropites Hyatt and Smith includes the Cpper Triassic species formerly included in Eutomoceras Hyatt.

- Neue Cephalopoden aus den Buchensteiner, Wengener und Raibler Schichten: Resultate der wissenschaftlichen Erforschung des Balatonsees, vol. 1, pt. 1, 1903, p. 10, Pl. III, figs. 2 and 3.

Idem, p. 90 .

- Entwurf einer Systematik der Ceratitiden des Muschelkalkes: Sitzungsber. K. Akad. Wiss. Wien, vol. 114, pt. 1, p. 775 ; and The fauna of the Himalayan Muschelkalk: Himalayan fossils, vol. 5. Mcm. 2, 1907, p. 59 (Mem. Geol. Survey India, Pal. Indica, 15th ser.).

$16279^{\circ}-$ \o. $83-14-5$ 
except on the umbilical shoulders, but in youth they are also visible on the lateral ribs. The height of the whorl is somewhat less than half the total diameter of the shell, and the width is somewhat less than two-thirds of the height. The outer whorl embraces about half of the inner and is indented by it to about one-fourth of the height. The width of the umbilicus is somewhat greater than one-fourth of the total diameter of the shell.

The septa are ceratitic, the saddles rounded and entire, and the lobes serrated. These are a short and rather broad external lobe, a large broad first lateral, a smaller second lateral, and two stil] smaller auxiliaries, the last being on the umbilical shoulder, barely outside of the umbilical suture.

Eutomoceras breweri is very closely allied with a Mediterranean species, (IIungarites) böckhi Haner, ${ }^{1}$ and may even be identical with it, for the accompanying faunas and the geologic horizon are the same, though the preservation of both the European and the American specimens is hardly good enough to warrant certain comparison of the two. Frech has identified IIungarites böckhi Hauer with (IIungarites) mojsisovicsi Roth from the Wengen beds of Hungary, but Hauer's species came from the zone of Ceratites trinodosus.

Dimensions of the t!lpe specimen of Eutomoceras breweri.

Diameter
Height of last whorl-
Height of last whorl from the preceding
Width of last whorl
Involution
Width of umbilicus.

Horizon and locality.-Eutomoceras breveri was found by the writer in the Middle Triassic, Daonella zone, Ceratites trinodosus subzone, on Fossil Hill, on the divide between Troy Canyon and the south fork of American Canyon, 4 miles south of Fitting post office (formerly Foltz), West Humboldt Range, Nev. It was associated with Daonella dubia, Beyrichites rotelliformis, Ceratites blakei, Ceratites trinodosus, Nevadites whitneyi, N. hyatti, and many other species characteristic of this horizon.

Eutomoceras dunni Smith.

I'late XXVII, figures 14-25.

1904. Eutomoceras dunni, Smith, The comparative stratigraphy of the marine Trias of western America: Proc. California Acad. Sci., 3d ser., Geology, vol. 1, No. 10, p. 381, Pl. XLIII, fig. 11; Pl. XLIX, fig. 4.

Shell involute, discoidal, laterally compressed. Whorls high, deeply embracing, and rather deeply indented by the inner volution. Sides slightly convex, sloping from the greatest breadth at the umbilical shoulder to the narrow acute venter with abruptly rounded abdominal shoulders. Venter surmounted by a high keel without any bent marginal furrows but with a sort of depression which in youth is a furrow. Umbilical shoulders abruptly rounded, umbilicus narrow and deep. The height of the whorl is half the total diameter of the shell and the width is two-thirds of the height; it is indented to one-fifth of the height by the inner whorl. The width of the umbilicus is one-fifth. The surface is ornamented with coarse ribs that bifurcate from coarse knots on the umbilical shoulder, branch again about one-third of the way up the flanks, and then curve sharply forward on the abdominal shoulders to the base of the keel, ending at a sort of depression. There are numerous small knots on the ribs, but these are not arranged in spiral rows, and the intercalary ribs do not fork on the flanks. The septa are ceratitic, with rounded entire saddles and serrated lobes, like those of Eutomoceras laubei.

Eutomoceras dunni is nearly related to E. laubei Meek but is more robust and has slightly higher keel, stronger ribs, and coarser and more numerous lateral knots. It also resembles

1 Belträge zur Kenntniss der Cephalopoden aus der Trias von Bosnien, Part II: Denkschr. K. Akad. Wiss. Wlen, vol. 63,1896, p. 264, Pl. $\mathrm{X}$, figs. 4-6. 
E. dalli Smith but is more involute, with less pronounced ventral furrows and shoulders and is slightly less robust.

Horizon and locality.-Rather common in the Middle Triassic, Daonella dubia zone, Ceratites trinodosus subzone, on Fossil Hill, on the divide between Troy Canyon and the south fork of American Canyon, 4 miles south of Fitting post office (formerly Foltz), West Humboldt Range, Nev., associated with Ceratites trinodosus, C. humboldtensis, Nevadites whitneyi, Protrachyceras meeli, Beyrichites rotelliformis, Sageceras gabbi, Daonella dubia, and other species.

$$
\text { Eutomoceras lahontanum Smith, sp. nov. }
$$

Plate XXviII, figures 8-11.

Form involute with narrow umbilicus. Whorls robust, deeply embracing, and rather deeply indented by the inner volutions, high and increasing rapidly in height. Flanks converge upward to the sharply defined angular rentral shoulders. Venter high, roof-shaped, with high sharp keel but without a distinct marginal furrow between the keel and the shoulders.

Surface ornamented with strong knots on the umbilical and ventral shoulders; there are about 12 umbilical knots and somewhat fewer marginal knots to a revolution. The umbilical knots begin in early youth, but the marginals do not begin until a diameter of 50 millimeters is reached. Rather coarse ribs start out from the umbilical knots and curve gently forward to the ventral shoulders, only every third or fourth rib being provided with a marginal tubercle.

The height of the whorl is nearly half the diameter of the shell, the width is approximately two-thirds of the height, and it is indented by the inner volution to one-fourth of the height. The width of the umbilicus is slightly more than one-fifth of the diameter of the shell. The outer whorl embraces two-thirds of the inner.

Dimensions of the type specimen of Eutomoceras lahontanum.

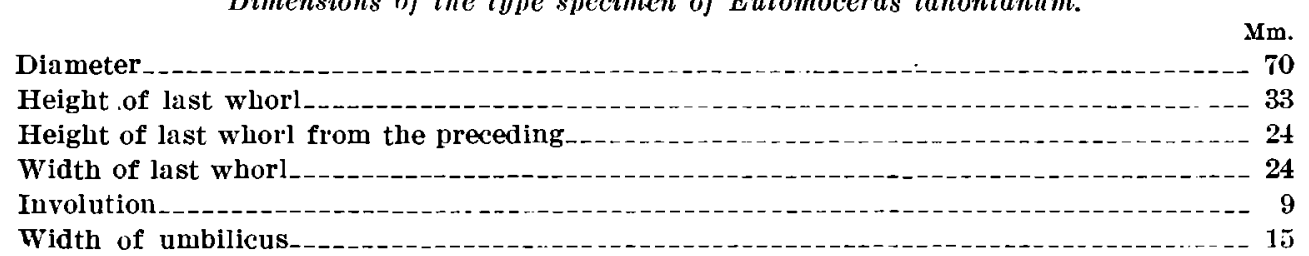

Septa ceratitic, with rounded saddles and five serrated lobes, a small ventral, large first lateral, smaller second lateral, and two small auxiliary lobes, decreasing in size toward the umbilicus. No species is known to which Eutomoceras lahontanum may be compared, but its affinities seem to be rather with Eutomoceras than with Hungarites or Ceratites (subgenus Paraceratites).

Horizon and locality.-Middle Triassic, Daonella dubia zone, Ceratites trinodosus subzone, on the divide between Troy Canyon and the south fork of American Canyon, 4 miles south of Fitting post office (formerly Foltz), West Humboldt Range, Nev., associated with Daonella dubia, Ceratites trinodosus, C. humboldtensis, Gymnotoceras blakei, Nevadites whitneyi, and other species.

\section{Eutomoceras LaUbei Meek.}

Plate X, figures $7-11$; Plate XIV, figures 8 and $8 a$; Plate XXVI, figures $7-9$; Plate XXVII, figures 1-13; Plate XC, figures $1-4$.

1877. Eutomoceras laubei, Meek, Palæontology : U. S. Geol. Expl. 40th Par., vol. 4, p. 126, Pl. X, figs. 8, $8 a$.

1905. Eutomoceras laubei, Hyatt and Smith, The Triassic cephalopod genera of America: Prof. Paper U. S. Geol. Survey No. 40, p. 131, Pl. LX, figures 7-11.

Hyatt and Smith's description is as follows:

Form involute, discoidal, laterally compressed. Whorls high and increasing rapidly in height, deeply embricing, and deeply indented by the inner whorls. Sides flattened, sloping from the abrupt umbilical 
shoulders to the distinct ventral angles. Abdominal shoulders narrow and angular, surmounted by a high, sharp ventral keel, bordered by weak marginal furrows. The keel is solid and shows on the cast almost as high as on the shell. The umbilicus is narrow, but open, with the greatest width of the whorl at the umbilical shoulders.

Surface of shell and cast ornamented with ribs and knots; the ribs bundle in twos and threes on knots on the umbilical shoulders and bifurcate a second time halfway up the flanks, bending sharply forward at the point of bifurcation and extending to the abdominal shoulders. There are knots on these ribs at irregular intervals, becoming more frequent in age.

The septa are ceratitic, consisting of a short divided ventral lobe, large first lateral, smaller second lateral, and three smaller auxiliary lobes, growing smaller and simpler toward the umbilicus. All the lobes are serrated, and all the saddles rounded and entire. The internal septa are unknown.

The height of the whorl at maturity is half the total diameter of the shell, the width three-fifths of the height, and the impression one-fourth of the height. The width of the umbilicus is slightly more than one-fifth of the total diameter of the shell.

'The sculpture resembles somewhat that seen on Hungarites, with which genus Eutomoceras is very closely allied.

Horizon and locality.-Eutomoceras laubei was found by the writer in the Middle Triassic Daonella beds, on the divide between Troy Canyon and the south fork of American Canyon, West Humboldt Range, Nev., on Fossil Hill, at a point about 1,000 feet above the valley and 4 miles south of Fitting post office (formerly Foltz). It was associated with Ceratites humboldtensis Hyatt and Smith, C. nevadanus Mojsisovics, Gymnotoceras blakei Meek, Beyrichites rotelliformis Meek, Anolcites meeli Mojsisovics, Acrochordiceras hyatti Meek, Sageceras gabbi Mojsisovics, Longobardites nevadanus Hyatt and Smith, Daconella dubia Gabb, and many other species characteristic of the Middle Triassic. This species was first discovered by the Geological Exploration of the Fortieth Parallel at New Pass, in the Desatoya Mountains, Nev., associated with Arrochordiceras hyatti Meek, and the single imperfect specimen found was chosen as the type of the genus Eutomoceras.

\section{Subgenus HALILUCITES Diener.}

1905. Halilucites, Diener, Entwurf einer Systematik der Ceratitiden des Muschelkalkes: Sitzungsber. K. Akad. Wiss. Wien, vol. 114, pt. 1, p. 775.

1906. Halilucites, Diener, The fauna of the Himalayan Muschelkalk: Himalayan fossils, vol. 5, Mem. No. 2, p. 38 (Mem. Geol. Survey India, Pal. Indica, 15th ser.).

Type.-Hungarites? musticus Haner. ${ }^{1}$

Form rather evolute, robust, widely umbilicate, arietiform. Whorls rather low, subrectangular, and increasing slowly in height, whereas the umbilicus increases rapidly in width. Surface ornamented with strong lateral ribs, either single or bifurcating, and ending on the abrupt ventral shoulders. Venter rather broad, with high median keel bounded by distinct furrows. Septa ceratitic, with entire saddles and serrated lobes, although the serrations in some species run rather high up the sides of the lobes. Length of body chamber unknown.

This group of arietiform "Hungarites" was regarded by Hauer as forming a transition from Hungarites to Ceratites, whereas Diener separates it as a subgenus under Ceratites, with which genus it is certainly allied, but not so closely as with Hungarites. There is, however, a perfect gradation from the group of Eutomocercs laubei, the type of Eutomoceras, to that of "Hungarites" rusticus, and the writer regards all these species as belonging to Eutomoceras in the broader sense, although recognizing the desirability of separating the arietiform species as a separate subgenus. Halilucites closely resembles Inyoites Hyatt and Smith from the Lower Triassic, Meekoceras zone, but differs from that genus in its stronger sculpture, more robust whorls, strong ventral shoulders, marginal furrows, and solid instead of hollow keel.

Halilucites is confined to the Middle Triassic, Bosnian stage, and is represented in the Mediterranean region by Eutomoceras (Halilucites) rusticum Hauer, E. (Halilucites) arietiforme Hauer, E. (Halilucites) intermedium Hauer, E. (Halilucites) planilateratum Hauer.

1 Beiträge zur Kenntniss der Cephalopoden aus der Trias von Bosnien, Part II : Denkschr. K. Akad. Wiss. Wien, vol. 63,1896 , p. $259, \mathrm{Pl}$. IX, figs. $1-4$. 
In the same horizon in the Indian region a kindred species is found. Among the American species of Eutomoceras only one, $E$. (Halilucites) dalli Smith, has the characters of Diener's subgenus.

\section{Eutomoceras (Halilucites) dalli Smith, sp. nov.}

Plate XXIX, figures 1-11.

Evolute, laterally compressed, wide umbilicus, whor!s high, but increasing slowly in height; sides only slightly convex, with abruptly rounded umbilical and ventral shoulders. Venter with high sharp keel bordered by deep furrows. Surface ornamented with coarse bifurcating ribs that start out from umbilical tubercles and branch alternately on lateral tubercles halfway up the flanks. The height of the whorl is slightly less than half the diameter of the shell, the width is two-thirds of the height, and it is indented by the inner volution to one-fourth of the height. The width of the umbilicus is one-fourth of the diameter of the shell. The septa are ceratitic, like those of the other typical members of Eutomoceras. The length of the body chamber is unknown.

Eutomoceras dalli has some resemblance to $E$. dunni but is more evolute and lacks the irregular knots of the group of $E$. laubei. It has a much greater resemblance to "Hungarites" intermedius Hauer and belongs to the arietiform group named Halilucites by Diener, but it is less arietiform than the Bosnian species, with shoulders less defined, sides more convergent, and coarser sculpture.

Horizon and locality.-Rare in the Middle Triassic, Daonella dubia zone, Ceratites trinodosus subzone, of Fossil Hill, south fork of American Canyon, West Humboldt Range, Nev., associated with Ceratites trinodosus, C. humboldtensis, Gymnotoceras blakei, Nevadites whitneyi, Daonella dubia, and other species.

\section{Family MEEKOCERATID E Waagen.}

Genus LECANITES Mojsisovics.

1882. Lecanites, Mojsisovics, Die Cephalopoden der Mediterranen Triasprovinz: Abhandl. K.-k. geol. Reichsanstalt Wien, vol. 10, p. 199.

1895. Leuanites, Waagen, Fossils from the Ceratite formation: Salt Range fossils, vol. 2, p. 275 (Men. Geol. Survey, India, Pal. Indica, 12th ser.).

1897. Lecanites, Diener, Cephalopoda of the Lower Trias: Himalayan fossils, vol. 2, pt. 1, p. 146 (Mem. Geol. Survey, India, Pal. Indica, 15th ser.).

1902. Lecanites, Frech, Die Dyas: Lethæa Palæozoica, vol. 2, Lieferung 4, p. 634.

1908. Lecanites, Arthaber, Ueber die Entdeckung von Untertrias in Albanien, Mitt. Geol. Gesell. Wien, vol. 1, 1908 , p. 268.

1911. Lecanites, Arthaber, Die Trias von Albanien: Beitr. Pal. und Geol. Oesterreich-Ungarns und des Orients, vol. 24, p. 237.

Type._"Ceratites" glaucus Muenster. ${ }^{1}$

Evolute, discoidal; little-embracing whorls, laterally flattened, and higher than wide. Wide umbilicus, whorls increasing slowly in height. Abdomen narrow, either flattened or rounded. Surface smooth, or sculptured with radial folds. Body chamber short, not more than three-quarters of a revolution in length. Septa goniatitic, lobes and saddles all entire. The external lobe is always divided by a siphonal saddle. There are always two lateral lobes present and commonly a small auxiliary.

Lecanites, even at maturity, has a strong resemblance to Gephyroceras, as described and limited by Holzapfel. ${ }^{2}$ Lecanites vogdesi closely resembles $G$. uchtense Holzapfel ${ }^{3}$ of the Upper

1 Ueber das Kalhmergel-Lager von St. Cassian in Tyrol: Neues Jahrb., 1834, p. 11, Pl. I, fig. 1 ; also In E. von Mojsisovics, Die Cephalopoden der Mediterranen Triasprovinz: Abhandl. K.-k. geol. Reichsanstalt Wien, vol. 10, 1882, p. 200, Pl. XXX, figs. 1-6 ; Pl. LIII, fig. 14.

2 Die Cephalopoden des Domanlk im südlichen Timan : Mém. Com. géol., St.-Pétersbourg, vol. 12, No. 3, 1899, p. 27.

Idem, Pl. V, figs. 4-7. 
Devonian of Russia. Gephyroceras is probably the ultimate radicle of Lecanites, and thus of the entire group of Ceratitoidea, but the intermediate or secondary radicle can hardly have been Prolecanities of the Carboniferous, since that genus is too greatly specialized. Nomismoceras may have been the secondary radicle but is too little known to warrant any decided opinion on the question. It is doubtful whether the Middle Triassic species of Lecanites are congeneric with the Lower Triassic forms assigned to this genus. The former may be fixed, or even retarded species, whereas the latter are progressive, radicle types.

Occurence.-Lecanites is known in the Lower Triassic of India, Albania. and California, in the Middle Triassic of Nevada, and in the Upper Triassic of the Alps.

LeCanites CRassts Smith, sp. nov.

Plate LXXXIX, figures 1 and 2.

From robust, evolute, laterally compressed, widely umbilicate. Sides gently convex, ventral shoulders abruptly rounded, venter arched. Whorls not deeply embracing, and increasing rather slowly in height. Umbilicus rather wide and shallow. The height of the whorl is nearly one-third of the diameter of the shell, and the width is slightly less than the height. The width of the umbilicus is half the diameter of the shell. The surface is ornamented with strong umbilical ribs that run high up the flanks and with fine spiral striæ. The septa are goniatitic, as on $L$. vogdesi.

Lecanites crassus is closely allied with $L$. vogdesi, from which it differs in the more robust whorl, stronger ribs, greater involution, and narrower umbilicus. The spiral striæ and the lateral ribs suggest a relationship to Ophiceras or to Flemingites, but the resemblance to $L$. vogdesi is so great that the species must be congeneric.

Horizon and locality.-Very rare in the Middle Triassic, Daonella dubia zone, Ceratites trinodosus subzone, of Fossil Hill, south fork of American Canyon, 4 miles south of Fitting post office (formerly Foltz), West Humboldt Range, Nev., associated with Ceratites trinodosus, C. humboldtensis, Nevadites whitneyi, Protrachyceras meeki, Beyrichites rotelliformis, Sageceras gabbi, Daonella dubia, and other species.

LeCanites nudes Smith, sp. nov.

Plate XCVIII, figures 8-12.

Form evolute, discoidal, widely umbilicate; whorls laterally compressed, low, and increasing slowly in height. The umbilical shoulders are abruptly rounded, the sides flattened convex, and the venter rather narrowly rounded. The surface is nearly smooth, ornamented only with very weak umbilical folds that are extended up the flanks in the striæ of growth. The septa are goniatitic, the lobes and saddles both being rounded and entire.

Lecanites nudus in form and septa is exactly like L. vogdesi, but differs in its very weak sculpture. It would have been treated as a variety under that species if any intergradation had been observed, but none such was found.

Horizon and locality.-Rare in the Middle Triassic, Daonella dubia zone, Ceratites trinodosus subzone, of Fossil Hill, south fork of American Canyon, 4 miles south of Fitting post office (formerly Foltz), West Humboldt Range, Nev., associated with Ceratites trinodosus, $C$. humboldtensis, Nevadites whitneyi, Eutomoceras laubei, Sageceras gabbi, Daonella dubia, and other species.

LECANites PARvUs Smith, sp. nov.

Plate XXX, figures 25-27; Plate LXXXVIII, figures 26-28.

Form evolute, umbilicus very wide and shallow; whorls miter-shaped in cross section, higher than wide, low, and increasing slowly in height, little embracing, and little indented by the inner volutions. Sides are convex; venter is narrowly rounded, without the ventral shoul- 
ders. The surface is nearly smooth but with fine flexuous cross striæ, in some specimens forming weak folds near the umbilical shoulder. In youth the whorls are more robust. The septa are goniatitic, the ventral lobe is divided, and there are also one small lateral unserrated lobe and an auxiliary. The body chamber is about three-fourths of a revolution in length.

Lecanites parvus has some resemblance to L. vogdesi Hyatt and Smith, with which it is associated, but the whorl is much more slender and the sculpture is much weaker. The shell also does not reach the size of $L$. vogdesi, the largest of the numerous specimens found not exceeding 31 millimeters in diameter.

Dimensions of the type specimen of Lecanites parvus.

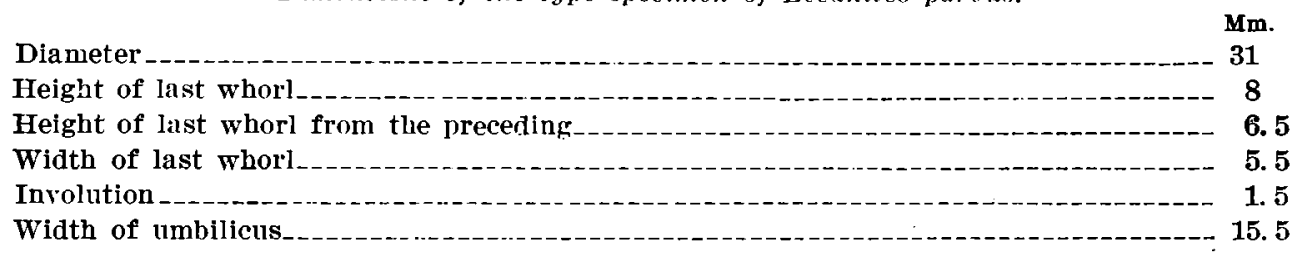

The height of the last whorl is about one-fourth of the diameter of the shell, and the width is less than three-fourths of the height. The width of the umbilicus is half the diameter of the shell.

Horizon and locality.-Rather common in the Middle Triassic, Daonella dubia zone, Ceratites trinodosus subzone, on the divide between Troy Canyon and the south fork of American Canyon, 4 miles south of Fitting post office (formery Foltz), West Humboldt Range, Nev., associated with Daonella dubia, Ceratites trinodosus, C. humboldtensis, Gymnotoceras blakei, Nevadites whitneyi, and other species.

LECANites vogDesi Hyatt and Smith.

Plate X, figures 12-22; Plate XII, figures 10-13; Plate XXX, figures 17-24; Plate LXXXVIII, figures 24 and 25.

1905. Lecanites vogdesi, Hyatt and Smith, The Triassic cephalopod genera of America: Prof. Paper $\mathbf{U}$. S. Geol. Survey No. 40, p. 139, Pl. IX, figs. 12-22 ; Pl. LXXV, figs. 17-24.

Shell evolute, discoidal, laterally compressed, not deeply embracing and not deeply indented by the inner whorls. Whorl low and increasing slowly in height, concealing about two-fifths of the inner volution, and being indented to about one-sixth of its height by that volution. Tmbilicus wide and shallow, somewhat more than one-third of the entire diameter of the shell.

The surface of both shell and cast is ornamented with rather coarse umbilical ribs, which bend forward and reach about halfway up the flanks, but become obsolete before the abdominal shoulder is reached. At maturity these ribs in some specimens become finer and sigmoidal in curvature, reaching to the ventral shoulders. Very fine spiral striæ were observed on the casts of some specimens, somewhat like those of Ophiceras, but none were visible on the outer shell of any of the numerous specimens collected.

The type specimen was somewhat distorted by crushing, making the height of the whorl appear greater, and the umbilicus narrower than on normal specimens. Numerous perfect specimens were found afterwards, which show the whorl to be lower and more robust, with stronger ribs than those of the type. Undistorted specimens resemble Ophiceras, but the goniatitic septa would forbid a reference to that genus.

Length of body chamber at least three-quarters of a revolution. Septa goniatitic, lobes and saddles all rounded and entire. The ventral lobe is short, divided by a shallow siphonal saddle; the first lateral lobe is deep and wide; the second lateral small and shallow. The first and second lateral saddles are large, almost equal in size, and broadly rounded. The internal septa consist of a large undivided antisiphonal lobe, flanked by a smaller internal lateral on each side. 
In the young stages the whorl is more robust, and the sculpture proportionally stronger, so that the young shell bears some resemblance to Dinarites, but it never has any os.'the umbilical knots which Dinarites is said invariably to have. Even in vouth Lecanites vogdesi is more compressed laterally than any species of Dinarites. The characters all point to the Meekoceratidæ rather than to the Ceratitidæ.

In the larval stage Lecanites vogdesi corresponds to the genus Paralecanites Diener, as shown on Plate XII, figures 10-13, where a young specimen in this stage of growth shows the following dimensions:

Dintensions of a young specimen of Lecanites rogdesi.

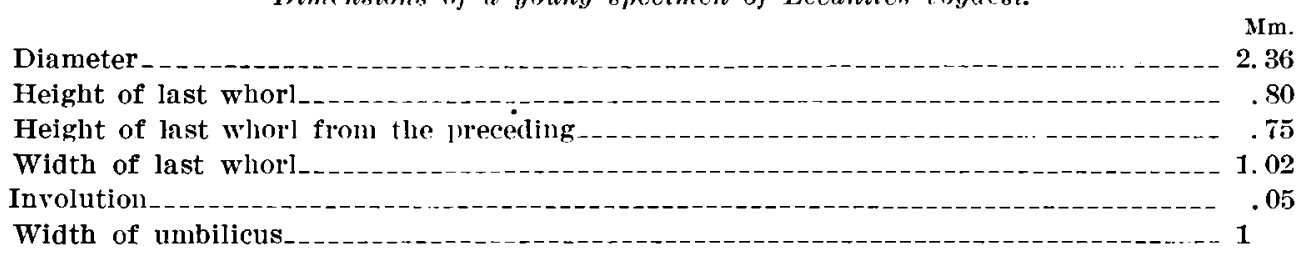

At this stage the whorl is very low and square in cross section, and the septa are exactly like those of Paralecanites.

IIorizon and locality.-Lecanites vogdesi was found by the writer to be very common in the Middle Triassic Daonella zone, on the divide between Troy Canyon and the south fork of American Canyon, West Humboldt Range, Nev., associated with Ceratites humboldtensis, Beyrichites rotelliformis, Acrochordiceras hyatti, Nevadites whitneyi, Daonella dubia, and many other species characteristic of the Middle Triassic.

\section{Family CERATITID E MOjsisovies.}

Genus TIROLITES Mojsisovics.

1878. Tirolites, Mojsisovics, Die Dolomitriffe von Südtirol und Venetien, Wien, p. 43.

1879. Tirolites, Mojsisovics, Vorläufige kurze Uebersicht der Ammoniten-Gattungen der Mediterranen und Juvavischen Trias: Verhandl. K.-k. geol. Reichsanstalt Wien, p. 138.

1882. Tirolites, Mrojsisovics, Die Cephalopoden der Mediterranen Triasprovinz: Abhandl. K.-k. geol. Reichsanstalt Wien, rol. 10, p. 64 .

1893. Tirolites, Mojsisovics, Das Gebirge um Hallstätt, Part I; Die Cephalopoden der Hallstätter Kalke: Abhandl. K.-k. geol. Reichsanstalt Wien, vol. 6, pt. 2, p. 588.

1902. Tirolites, Mojsisovics, Das Gebirge um Hallstiitt, Part I; Die Cephalopoden der Hallstätter Kalke: Supplement-Heft Abhandl. K.-k. geol. Reichsanstalt Wien, vol. 6, pt. 1, p. 324.

1903. Tirolites, Kittl, Die Cephalopoden der oberen Werfener Schichten von Mué in Dalmatien: Abhandl. K.-k. geol. Reichsanstalt Wien, vol. 20, p. 29.

1905. Tirolites, Hyatt and Smith, The Triassic cephalopod genera of America : Prof. Paper U. S. Geol. Survey No. 40, p. 158.

1908. Tirolites, Arthaber, Ueber die Entdeckung von Untertrias in Albanien: Mitt. Geol. Gesell. Wien, vol. 1, p. 275.

1911. Tirolites, Arthaber, Die Trias von Albanien : Beitr. Pal. und Geol. Oesterreich-Ungarns und des Orients, vol. 24, p. 250 .

\section{Tirolites Pacificus Hyatt and Smith.}

Plate II, figures 14-18.

1905. Tirolites pacificus, Hyatt and Smith, The Triassic cephalopod genera of America: Prof. Paper U. S. Geol Survey No. 40, p. 159, Pl. XXI, figs. 14-18.

The original description is as follows:

Evolute, widely umbilicate; whorls robust, subquadrate, low, and increasing slowly in height, little embracing, and little indented by the inner volutions. Sides of the whorls narrow and subangular; venter flattened: abdominal shoulders abrupt. The height of the whorl is one-third of the total diameter of the shell, the width is slightly greater than the height, and the indentation is only one-ninth of the height of the whorl. The width of the umbilicus is four-ninths of the total diameter of the shell. The surface is ornamented with fine radial ribs which cross the rentel, and with strong spines on the abdominal shoulders. 
The septa are slightly ceratitic; the ventral lobe is divided by a smill siphonal notch into two narrow, slightly su. + $d$ divisions. There is a serrated lateral lobe on the abdominal shoulders, and an unserrated small second ateral on the unbilical slope. The latter is narrow, pointed, and unserrated. This species has all the characters of the group of Tirolites spinosi, but is distinct from any described species in the development of the auxiliary lobe, in which character it agrees with Metatirolites.

Tirolites pacificus was found by the writer in the upper limestone beds, base of Middle Triassic, on the Union Wash, Inyo Range, Inyo County, Cal., about 15 miles southeast of Independence. It was associated with Hungarites, Ptychites, Xenodiscus, Acrochordiceras, and Parapopanoceras, in beds 800 feet above the Meekoceras beds.

\section{Genus DINARITES Mojsisovics.}

1882. Dinarites, Mojsisovics, Die Cephalopoden der Mediterranen Triasprovinz: Abhandl. K.-k. geol. Reichsanstalt Wien, vol. 10 , p. 5 .

1886. Dinarites, Mojsisovics, Arktische Triasfaunen: Mém. Acad. imp. sci. St.-Pétersbourg, 7th ser., vol. 33, No. 6. p. 9.

1895. Dinarites, Waagen, Fossils from the Ceratite formation: Salt Range Fossils, vol. 2, p. 23 (Mem. Geol. Survey, India, Pal. Indica, 13th ser.).

1895. Dinarites, Diener, Triadische Cephalopodenfaunen der ostsibirischen Küstenprovinz: Mém. Com. Gcol., St.-Pêtersbourg, vol. 14, No. 3, p. 11.

1895. Dinarites, Salomon, Geologische und palæontologische Studien über die Marmolata: Palæontographica, vol. 42 , p. 179.

1900. Aplococeras, Hyatt, Cephalopoda: Text-book of Palæontology, by K. A. von Zittel (translated by C. R. Eastman), p. 556.

1900. Plococeras, Hyatt, Cephalopoda: Text-book of Palæontology, by K. A. von Zittel (translated by C. R. Eastman), p. 556.

1900. Pseudodinarites, Hyatt, Cephalopoda: Textbook of Palseontology, by K. A. von Zittel (translated by C. R. Eastman), p. 559.

1902. Dinarites, Mojsisovics, Das Gebirge um Hallstatt; Die Cephalopoden der Hallstïtter Kalke: Supplement-Heft Abhandl. K.-k. geol. Reichsanstalt Wien, rol. 20, p. 12.

1903. Dinarites, Kittl, Die Cephalopoden der oberen Werfener schichten von Mué in Dalmatien: Abhandl. K.-k. geol. Reichsanstalt Wien, vol. 20, pt. 1, p. 12.

1907. Dinarites, Böhm (in J. Wanner), Triaspetrifakten der Molukken und des Timorarchipels : Neues Jahrb., Beilage-Band 24, p. 211.

(Not 1905. Dinarites, Hyatt and Smith, The Triassic cephalopod genera of America: Irof. I'aper U. S. Geol. Survey No. 40 , p. $161=$ Cuccoceras Diener.)

Din a RITES DEsertorum Smith. sp. nov.

Plate LXXXIX, figures 3-7, Plate XCVIII, figures 13-18.

Form robust, moderately evolute, widely umbilicate. Sides convex, curving to the broadly rounded venter without distinct ventral shoulders. The height of the whorls is one-third of the diameter of the shell and the width is slightly less than the height. The outer whorl embraces about half the inner and is indented by it to less than one-eighth of the height. The width of the umbilicus is about two-fifths of the diameter of the shell. The surface is ornamented with weak low folds that extend about one-third of the distance from the umbilical shoulders and become obsolete on the flanks. There are about twenty of these folds to a revolution. The septa are ceratitic, consisting of a divided ventral lobe, two laterals, all slightly serrated, and a small auxiliary on the umbilical suture.

Dinarites desertorum resembles Danubites fissiplicatus Mojsisovics, ${ }^{1}$ but is not quite so compressed as the Arctic species and has lower whorls. It also greatly resembles Dinarites avisianus Mojsisovics, ${ }^{2}$ but is somewhat more involute and has weaker sculpture.

1 Arktische Triasfaunen, Mém, Acad. imp. sci. St.-Petersbourg, Tth ser., vol. 33, No. 6, 1886, p. 26, Pl. IX, flgs. 18 and 19.

2 Die Cephalopoden der Mediterranen Triasprovinz: Abhandl. K.-k. geol. Reichsanstalt Wien, vol. 10, p. 13, Pl. XXVII, figs. 17-21. 
Dimensions of the type specimen of Dinarites desertorum.

$\begin{array}{ll}\text { Diameter } & \text { Mm. } \\ \text { Height of last whorl } & \mathbf{2 5} \\ \text { Height of last whorl from the preceding } & \\ \text { Width of last whorl } & \\ \text { Involution } & \text { Width of umbilicus.5 }\end{array}$

Horizon and locality.-Very rare in the Middle Triassic, Daonella dubia zone, Ceratites trinodosus subzone, on the divide between Troy Canyon and the south fork of American Canyon, 4 miles south of Fitting post office (formerly Foltz), West Humboldt Range, Nev., associated with Ceratites trinodosus, C. humboldtensis, Gymnotoceras blakei, Nevadites whitneyi, Protrachyceras meeki, Sageceras gabbi, Dnonella dubia, and other species.

Dinarites? PYgMeus Smith, sp. nov.

Plate LXXXix, figures 8 and 9.

Whorls robust, moderately evolute, with rounded cross section. Umbilicus wide and shallow. Surface ornamented with coarse lateral folds that run high up the sides, and in some specimens cross the venter, but become nearly obsolete on the periphery. The septa appear to be ceratitic but could not be exposed on the type specimen.

Dinarites pygmeeus is closely allied with $D$. desertorum but is more robust and has much stronger sculpture. This species may possibly belong to Danubites Mojsisovics, but the resemblance to the Mediterranean group of Dinarites makes this improbable.

Horizon and locality.-Very rare in the Middle Triassic, Daonèlla dubia zone, Ceratites trinodosus subzone, of Fossil Hill, south fork of American Canyon, 4 miles south of Fitting post oftice (formerly Foltz), West Humboldt Range, Nev., associated with Ceratites trinodosus, C. humboldtensis, Nevadites whitneyi, Protrachyceras meeki, Sageceras gabbi, Daonella dubia, and other species.

\section{Genus CUCCOCERAS Diener.}

1905. Cuccoceras, Diener, Entwurf einer Systematik der Ceratitiden des Muschelkalkes: Sitzungsber. K. Akad. Wiss. Wien, vol. 114 , pt. 1 , p. 798.

1892. Dinarites (in part), Hauer, Beiträge zur Kenntniss der Cephalopoden aus der Trias von Bosnien, Part I : Denkschr. K. Akad. Wiss. Wien, vol. 59, p. 259.

1905. Dinarites (in part), Hyatt and Smith, The Triassic cephalopod genera of America: Prof. Paper U. S. Geol. Survey No. 40, p. 161.

1907. Cuccoceras, Diener, The fauna of the Himilayan Muschelkalk: Himalayan fossils, vol. 5, Mem. No. 2, p. 84 (Mem. Geol. Survey India, Pal. Indica, 15th ser.).

1912. Cuccoceras, Arthaber, Leber die Horizontierung der Fossilfunde am Monte Cucco ( (italienische Carnia) und über die systematische Stellung von Cuccoceras Dien.: Jahrbuch K.-k. geol. Reichsanstalt, vol. 62 , Heft 2, p. 338.

Type.-" Trachyceras" cuccense Mojsisovics.

Form evolute, discoidal, laterally compressed, widely umbilicate, little embracing. Sides flattened, shoulders abrupt, venter rather narrow and low. Septa ceratitic, lacking the auxiliary lobe. Surface ornamented with ribs and constrictions that cross the venter without interruption. This group was formerly assigned to Dinarites, from which it differs in the flattened form and the constrictions.

Diener has grouped Trachyceras cuccense, "T." taramelli Mojsisovics, the Bosnian "Dinarites" labiatus Hauer and D. ornatus Hauer, and the Indian Cuccoceras yoga Diener under his new genus, to which must also be added "Dinarites" bonce-vistce Hyatt and Smith, which latter species is very closely related to "Dinarites" ornatus Hauer, and also to C. yoga Diener. 
Occurrence.-Cuccoceras occurs sparingly in the Middle Triassic Bosnian horizon of the Mediterranean region, India, and America. It is more abundant in the Alpine province and seems to be indigenous there.

Cuccoceras bon.e-viste Hyatt and Smith.

Plate $\mathrm{X}$, figures 1-6.

1905. Dinarites bona-vista, Hyatt and Smith, The Triassic cephalopod genera of America : Prof. Paper U. S. Geol. Survey No. 40, p. 162, Pl. LX. figs. 1-6.

Form evolute, discoidal, laterally compressed. Whorls low and increasing slowly in height. Sides flattened, with abruptly rounded umbilical shoulders, and narrow, rounded venter. Abdominal shoulders like the ventral, but less abrupt. The involution is very slight, being less than one-tenth of the height of the whorl. The umbilicus is wide and shallow. The height of the whorl is one-third of the total diameter of the shell, and the width is three-fifths of the height. The width of the umbilicus is two-fifths of the diameter of the shell.

The surface is ornamented with both ribs and constrictions. The ribs begin on the umbilical shoulders and run nearly straight up the sides and across the venter without interruption. although they become weaker at the abdominal shoulders. They divide into pairs at a point about halfway up the sides, and also new ribs are frequently introduced by intercalation, although at irregular intervals. The constrictions are parallel with the ribs and occur about eight to a revolution. This ornamentation shows on the cast as distinctly as on the shell.

The septa consist of a divided ventral lobe, a principal lateral lobe, and a small auxiliary. The lobes are slightly serrated, the saddles entire. The length of the body chamber is unknown, but is at least two-thirds of a revolution.

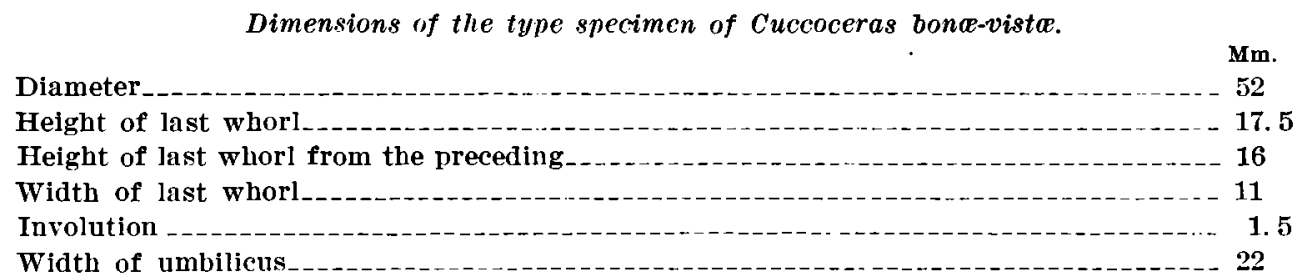

Cuccoceras bona-vistoe resembles the group of Dinarites circumplicati, but is unlike most other species of this genus. A similar species, "Dinarites" ornatus, has been described by F. von Hauer ${ }^{1}$ from the upper Muschelkalk, zone of Ceratites trinodosus. In describing this species Hauer says that it may possibly belong to another genus, on account of the constrictions, which are usually lacking on typical Dinarites. It is, however, nearer to this thar to any other genus, and Hyatt and Smith preferred not to found a new genus on such slight differences. Hauer's species has recently been assigned by Diener" to his genus Cuccoceras, and "Dinarites" bonoe-viste should also be classed in the same group.

Horizon and locality.-Cuccoceras bonce-vistce was found in the upper Middle Triassic, ${ }^{3}$ at Unionville, Buena Vista Canyon, West Humboldt Range, Nev., associated with Acrochordiceras hyatti, Beyrichites rotelliformis, and other species characteristic of that horizon. A single specimen of this species was also found in the same horizon and association in Star Canyon, near the Sheba mine, in the West Humboldt Range.

\footnotetext{
1 Beiträge zur Kenntniss der Cephalopoden aus der Trias von Bosnien, Part I : Denkschr. K. Akad. Wiss. Wien, vol. 59, 1892 , p. 259 , Pl. II, figs. $6 a-d$.

- Entwurf einer Systematik der Ceratitiden des Muschelkalkes: Sitzungsber. K. Akad. Wiss. W'ien, vol. 114, pt. 1, 1905 , p. 778 .

${ }^{3}$ Equivalent to the Upper Muschelkalk of Europe.
} 


\section{Genus CERATITES de Haan.}

1825. Ceratites, De Haan, Monographiæ Ammoniteorum et Goniatiteorum Specimen, p. 39.

1879. Ceratites (in part), Mojsisovics, Vorliufige kurze Cebersicht der immoniten-Gattungen der Mediterranen und Juvavischen Trias: Verhandl. K.-k. geol. Reichsanstalt Wien, p. 198.

1882. Ceratites, Mojsisovies, Die Cephalopoden der Mediterranen Triasprovinz; Abhandl. K.-k. geol. Reichsanstalt Wien, vol. 10 , p. 18 .

1886. Ceratites, Mojsisovies, Arktische Triasfaunen: Mém. Acad. imp. sci. St. Pétersbourg, 7th ser., vol. 33, No. 6. p. 19.

1887. Ceratites, Hauer, Cephalopoden des Bosnischen Muschelkalkes von Han Bulog bei Sarajevo: Denkschr. K. Akad. Wiss. Wien, vol. 54, p. 24.

1888. Ceratites, Mojsisovies, Ueber einige japanische Trias-Fossilien: Beitr. Pal. und Geol. OesterreichUngarns und des Orients, vol. 6, p. 168.

1892. Ceratites, Haner, Beiträge zur Kenntniss der Ceplalopoden aus der Trias von Bosnien, Part I: Denkschr. K. Alrad. Wiss. Wien, vol. 59, pt. 1, p. 260.

1993. Ceratites, Mojsisovics, Das Gebirge um Hallsintt, I'art I: Die Cephalopoden der Hallstätter Kalke: Abhandl. K.-k. geol. Reichsanstalt Wien, vol. 6, pt. 2, p. 397.

1895. Ceratites, Waagen, Fossils from the Ceratite formation: Salt Range fossils. vol. 2, p. 34 (Mem. Geol. Survey India, Pil. Indica, 13th ser.).

1895. Ceratites, Diener, Cephalopoda of the Muschelkalk: Himalayan fossils, vol. 2, pt. 2, p. 5 (Mem. Geol. Survey India, Pal. Indica, 15th ser.).

1896. Ceratites, Arthaber, Die Cephalopodenfauna der Reiflinger Kalke: Beitr. Pal, und Geol. OesterreichUngarns und des Orients, vol. 10, pt. 1, p. 43.

1896. Ceratites, Hauer, Beiträge zur Kenntniss der Cephalopoden aus der Trias von Bosnien, Part II: Denkschr. K. Akad. Wiss. Wien, vol. 68, p. 251.

1896. Ceratites, Toula, Eine Muschelkalkfauna am Golfe ron Ismid in Kleinasien: Beitr. Pal. und Geol. Oesterreich-Ungarns und des Orients, vol. 10, pt. 4, p. 166.

1897. Ceratites, Diener, Cephalonoda of the Lower Trias: Himalayan fossils, vol. 2, pt. 1, p. 20 (Mem. Geol. Survey India, Pal. Indica, 15th ser.).

1898. Ceratites, Tornquist, Neuere Beitriige zur Geologie und Paläontologie der Umgebung von Recoaro und Schio in Venetien, Part IV : Zeitschr. Deutsch. geol. Gesell., vol. 50, pt. 14, p. 59.

1900. Ceratites, Diener, Die Triadische Cephalopoden-Fauna der Schiechlinghöhe bei Hallstatt: Beitr. Pal. und Geol. Oesterreich-Ungarns und des Orients, vol. 12, p. 5.

1901. Ceratites, Philippi, Die Ceratiten des oberen deutschen Muschelkalkes: Pal. 'Abhandl. von Dames und Koken (Neue Folge), vol. 4, pp. 347-458

1902. Ceratites, Mojsisovics, Das Gebirge um Hallstatt, Part I; Die Cephalopoden der Hallstätter Kalke: Supplement-Heft Abhandl. K.-k. geol. Reichsanstait Wien, vol. 6, pt. 1, 1st half, p. 326.

1903. Cerntites, Arthaber, Neue Funde in den Werfener Schichten und im Muschelkalke des südlichen Bakony : Resultate der wissenschaftlichen Erforschung des Balatonsees, vol. 1, pt. 1, p. 24.

1904. Ceratites, Martelli, Cefalonodi triasiui di Boljerici presso Vir nel Montenegro: Pal. Italica, vol. 10, p. 80. 1905. Ceratites, Diener, Entwurf einer Systematik der Ceratitiden des Muschelkalkes: Sitzungsber. K. Akad. Wiss. Wien, vol. 114, pt. 1, p. 765.

1905. Ceratites, Hyatt and Smith, The Triassic cephalopod genera of America : Prof. Paper U. S. Geol. Survey No. 40, p. 168.

1906. Ceratites, Martelli, Contributo al Muschelkalk superiore del Montenegro: Palæontographia Italica, vol. 12 , p. 124.

1907. Ceratites, Diener, The fauna of the Himalayan Muschelkalk: Himalayan fossils, vol. 5, Mem. No. 2, p. 33 (Mem. Geol. Survey, India, PaI. Indien, 15th ser.).

1912. Ceratites, Arthaber, Ueber die Horizontierung der Fossilfunde am Monte Cucco (italienische Carnia) und über die systematische Stellung von Cuccoceras Dien. : Jalurb. K..-k. Geol. Reichsanstalt, vol. 62, Heft. 2. p. $3+2$.

Type.-“Ammonites" nodosus Bruguière, described by De Haan. ${ }^{1}$

This genus, which is the commonest and most widely distributed of Middle Triassic ammonites, as well as the most characteristic, is the most difficult of all to define. After De Haan introduced the name Ceratites, all ammonites with ceratitic septa were assigned to this genus, thus including species from the mcst diverse genera and even families. The type species is common in the Germanic basin but until recently unknown outside of that province, and so most of the writers that have dealt with Ceratites have described species from other provinces and other regions. It could not be expected that they would all agree with the type and 
hence these writers have had free rein to extend the genus as pleased them. They have thus extended the generic limits, which is allowable and necessary, but there has been little uniformity in their extensions. Further than this, they have overlooked the fact that the original type must be the typical form, and in many of their works treat the group of Ceratites nodosi as exceptional, and the Alpine and Asiatic forms as normal, which is unwarranted.

Waagen's ${ }^{1}$ monograph was the first to give a comprehensive, elastic, and exact definition of the genus Ceratites, and even his work was based entirely on Asiatic species, which depart considerably from the Germanic prototypes and probably do not even belong to this genus. Dr. A. Tornquist was the first to make a systematic comparison of the Germanic Ceratites with the Alpine and other groups, and to him is due the reestablishment of the group of nodosi in its real importance as comprising the typical and normal forms.

The monograph of Dr. E. Philippi on the Ceratites of the Germanic Trias has described fully the morphology of the Ceratites nodosi and has given a means of comparison of the extra-European forms with the typical species. In this work Dr. Philippi has restricted the genus to the group of nodosi, throwing out many forms hitherto regarded as subgenera. In the opinion of the writer he was justified in so doing, but still further elimination will be necessary before the genus becomes monophyletic.

The group of nodosi embraces forms of moderate involution, not deeply embracing but increasing rather rapidly in diameter, thus causing the umbilicus to be wide. The whorls are subquadratic in cross section, usually higher than wide, with square abdominal shoulders and flattened venter.

The sculpture consists of rios starting out from knots on the umbilicus and running nearly straight up the sides, either single or bifurcating. These ribs do not usually extend beyond the abdominal shoulders, which separate the sculptured sides from the ventral portion, usually destitute of all sculpture, except that in a few groups there is a low central ridge. The umbilical and abdominal shoulders are often provided with strong knots, which may also occur on the ribs on the sides. These knots, however, are not set close together as in Balatonites and Trachyceras.

The septa consist of rounded saddles and serrated lobes; the external lobe is divided by a siphonal saddle into two rather narrow branches. There are two laterals and a series of several small auxiliaries, which may be reduced to mere denticulations of a nearly straight saddle. The internal (antisiphonal) lobe is long, narrow, and bifid, flanked by a lateral and an auxiliary series, corresponding closely with the outside septa. In the more specialized forms the lobes may be weakly ammonitic. The body chamber is rather short, not more than three-quarters of a revolution in length.

Ceratites has a great resemblance to Hungarites, from which it differs in the rugose sculpture, the greater evolution, and more robust form. The two genera agree exactly in septation and this resemblance indicates their kinship. Hungarites is the older and more primitive form but can not be the ancestor of Ceratites. Mojsisovics has always regarded Dinarites as the radicle of this group, but this genus appears not to hare existed in the older part of the Lower Triassic in beds older than those containing Ceratites, whereas Hungarites occurs even in the Permian. This latter genus is usually classed with the Leiostraca, but this artificial classification can not separate groups that are manifestly closely related.

Mojsisovies ${ }^{2}$ attached to the genus Ceratites a multitude of so-called subgenera, most of which bear little resemblance to the group of nodosi and probably have little kinship with it; but as they do not occur in the American Triassic the writer can not enter into a critical discussion of them.

Ceratites is characteristic of the Middle Triassic of the Mediterranean, oriental, Arctic, and American regions, but in India and Siberia it is cited from the Lower Triassic. It has also

1 Fossils from the Ceratite formation: Salt Range fossils, vol. 2, 1895 (Mem. Geol. Survey India, Pal. Indica, 13th ser.;

a Das Gebirge um Hallstatt, Part I ; Die Cephalopoden der Iallstätter Kalke: Abhandl. K.-k. geol. Reichsanstalt Wien, vol. 6 , pt. 2,1893 , p. 397 . 
been described by Mojsisovics from the Upper Triassic of the Alpine province, although the forms ascribed to Ceratites are greatly modified from the original type of the nodosi, and probably not congeneric with it.

Mojsisovics ${ }^{1}$ regards the group of Ceratites robustus Keyserling (Keyserlingites Hyatt= Robustites Philippi) as the most primitive members of the genus Ceratites, characterized by the strong umbilical and shoulder knots, without lateral knots. Mojsisovics thought that this group developed out of the group of Dinarites spiniplicatus Mojsisovics, (=Olenikites Hyatt), which is quite likely; but the origin of Ceratites s. str. out of Keyserlingites is not so certain. A. Tornquist ${ }^{2}$ agrees with Mojsisovics in his theory that the binodosi developed out of the subrobusti, but E. R. Philippi ${ }^{3}$ says that the Ceratites subrobusti are not only not the ancestors of the true Ceratites nodosi but that they are not even Ceratites at all. According to him, the subrobusti came from Olenikites, but the true Ceratites came from Meekoceras Hyatt or some kindred form of the Meekoceratidæ. According to Mojsisovics the genealogy of Ceratites is as follows: Dinarites spiniplicati (Olenikites) $>$ Ceratites subrobusti (Keyserlingites) $>$ Ceratites s. str.; Dinarites nudi >Ceratites polaris (Arctoceras) >Ceratites circumplicati; Ceratites obsoleti (Danubites) >Ceratites geminati (Gymnotoceras). But of all these Philippi admits only the group of Ceratites nodosi as members of the genus Ceratites.

The Dinarites spiniplicati are known only in the Arctic region, and their descendants, the Ceratites subrobusti, only in the Arctic and the Indian regions. The Ceratites nodosi. (Ceratites s. str.), are abundant in the Mediterranean region and in the American region, rare in the Indian, and wholly unknown in the Arctic. The Ceratites geminati are abundant in the Arctic and American regions, doubtful in the Indian, and wholly absent in the Mediterranean. According to Philippi ${ }^{4}$ all the true Ceratites of the Muschelkalk of the Mediterranean region belong to the group of $C$. nodosi, which would speak for the community of origin of that portion of the genus, at any rate.

According to Tornquist, ${ }^{5}$ the Arctic region was the place of origin of the primitive Ceratites; these developed out of Olenikites, and the Mediterranean Ceratites nodosi originated from immigrants of the parent stock of Keyserlingites and not from endemic Dinarites. This view is in substantial harmony with that of Mojsisovics but diametrically opposed to that of Philippi. The writer is inclined to agree with Philippi that the nodosi came from some member of the Meekoceratidæ, though he accepts the phylogeny of the other so-called Ceratites substantially as Mojsisovies gave it. This would necessitate breaking up the old genus Ceratites, as Hyatt did; it does not, however, afford any justification for breaking up the Ceratites nodosi into several genera. Hyatt's genus Paraceratites, named with $C$. elegans as the type, can not stand independently because the group does not differ in any essential from the type of the genus Ceratites. C. Diener ${ }^{6}$ says that Ceratites luganensis Merian (of the group of $C$. elegans) is probably allied to the forms described by Hauer from Bosnia under the name of Hungarites. But the sculpture of the group of $\dot{C}$. elegans is that of typical Ceratites, whereas the Bosnian forms referred to belong to Eutomoceras Hyatt and are closely allied to E. laubei Meek, being all provided with a high ventral keel with marginal furrows. The group of $C$. elegans has no true keel but merely a slight sharpening of the venter along the middle. If a new name, however, should be given to the group of Ceratites with median

1 Das Gebirge um Hallstatt, Part I; Dle Cepbalopoden der Halistätter Kalke: Supplement-Heft Abhandl. K.-k. geol. Reichsanstalt Wien, vol. 6 , pt. 1, 1st half, 1902, p. 27 .

? Neuere Beitrïge zur Geologie und Paläontologie der Umgebung von Rocoaro und Schio in Venetien, Part IV, Zeitschr. Deutsch. geol. Gesell, vol. 50, No. 2, 1898, p. 227.

¿Die Ceratiten des oberen deutschen Muschelkalkes: Palæont. Abhandl. von Dames und Koken (new series), vol. 4, 1901, p. 89.

4 Idem, p. 97.

5 Neuere Beitrïge zur Geologie und Paläontologie der Umgebung von Recoaro und Schio in Venetien, Part IV: Zeitschr. Deutsch. geol. Gesell., vol. 50, No. 2 (1898), p. 227, and Centralblatt für. Min. Geol. und Pal., 1901, p. 391.

${ }^{\circ}$ Die Triadische Cephalopoden-Fauna der Schiechlinghöhe bei Hallstatt: Beitr. Pal. und Geol. Oesterreich-Ungarns und des Orients, vol. 12,1900, p. 10. 
keel, the name Paraceratites proposed by $\mathrm{Hyatt}^{1}$ will have to be used. Three years afterwards this same name was proposed by $\mathrm{E}$. Kittl ${ }^{2}$ for a group under Dinarites. In any case, whether Hyatt's name is adopted or not, the name proposed by Kittl must be changed.

A. Hyatt ${ }^{3}$ gave the name Eudiscoceras to a flattened Ceratites, but this name can only be a synonym as there are complete gradations connecting the compressed with the robust forms. The fragment upon which Eudiscoceras was founded is incapable of recognition, and the generic title will have to be dropped. The species which was the type of Eudiscoceras, $E$. gabbi Meek, probably belongs to the group afterwards named by Hyatt Paraceratites, but is too poorly preserved to warrant this reference.

According to Diener ${ }^{4}$ the genus Ceratites includes 12 divisions or subgenera, namely: (1) Ceratites s. str. (including Paraceratites Hyatt) ; (2) Hollandites Diener, the group of Indian circumplicati; (3) Philippites Diener, the group of Ceratites erasmi; (4) Peripleurocyclus Diener, a group rery like Acrochordiceras Hyatt; (5) Gymnotoceras Hyatt, the Arctic group of Ceratites geminati; (6) Salterites Diener, nearly allied to Keyserlingites Hyatt; (7) Haydenites Diener, a group apparently intermediate between Keyserlingites Hyatt and Acrochordiceras Hyatt; (8) Halilucites Diener, including the arietiform "Hungarites" of the Bosnian Muschelkalk; (9) Arctoceras Hyatt, the group of Ceratites polaris; (10) Keyserlingites Hyatt, the group of Ceratites subrobustus; (11) Florianites Hyatt, the Mediterranean group of Ceratites floriani; (12) Danubites Mojsisovics, the Arctic group of Ceratites obsoleti.

The writer is of the opinion that this grouping is in great need of revision, in the following respects: Halilucites comprises the arietiform Hungarites of the Bosnian Muschelkalk and is either a synonym or subgenus of Eutomoceras Hyatt, for the type species of Hungarites Mojsisovics is one of the arietiform group and closely allied with Eutomoceras laubei Meek, the type of Eutomoceras. It is an impossibility to distinguish Florianites Hyatt from the previously named Danubites Mojsisovics, and neither is an ancestor or a descendant of Ceratites s. str., hence they should not be regarded as subgenera under it. The group of Ceratites elegans, characterized by compressed whorls and ventral keel, is as distinct from the typical Ceratites nodosi as some of the subgenera recognized by Diener and should be included in the list, as Hyatt gave the name Paraceratites to this group.

The subgenus Salterites Diener seems to the writer to be too similar to Hollandites to justify a separation of the two. Haydenites, on the other hand, is too similar to Acrochordiceras to be included under Ceratites. Arctoceras Hyatt, group of Ceratites polaris, is nothing more than a synonym of Meekoceras, and though it may be an ancestor of Ceratites it can not be included even as a subgenus in the group under discussion. A fuller statement concerning this will be given below. Whether these groups of Ceratites should be regarded as subgenera or as independent genera depends at present upon the inclination of the individual writers. But eventually only those groups can be retained under Ceratites that have a common origin with C. nodosus.

The probable relations of the various groups of Ceratites found in the American Triassic are given below, but it must be borne in mind that these groups all occur together in the same berls and have not been found in their geologic sequence. The supposed genetic relations are based on the morphology of the species discussed, which is the best that can be done until the genetic series can be found in their stratigraphic sequence.

The most primitive group of Ceratites in the American Triassic is that of $C$. rotuloides, which, however, is not thought to have been the ancestor of its contemporaries but merely to have preserved little altered the characters of that ancestor. It retains many of the marks of the Meekoceratidæ, and will probably be found grading over into that group when the faunas of

\footnotetext{
${ }^{1}$ Cephalopoda (in Zittel and Eastman's Textbook of palæontology, 1900, p. 559 ).

2 Die Cephalopoden der oberen Werfener Schichten von Muć In Dalmatien: Abhandl. K.-k. geol. Reichsanstalt Wien, vol. 20 , pt. 1,1903 , p. 28.

8 U. S. Geol. Expl. 40th Par., vol. 4, 1877, p. 128.

Entwurf elner Systematik der Ceratitiden des Muschelkalkes: Sitzungsber. K. Akad. Wiss. Wien, vol. 114, pt. 1, 1905 , p. 791.
} 
the lower part of the Middle Triassic are better known. It may, however, be merely an atavistic, reversionary group.

Next in development comes the group of Ceratites occidentalis Smith, in which the simple lateral ribs begin to form marginal knots but without umbilical or lateral tubercles.

A step upward in complexity brings us to the group of Ceratites lingi Smith, in which there are umbilical and marginal tubercles and faint rudiments of a keel. From the group of $C$. kingi developed two divergent groups: $C$. cricki Smith (Paraceratites Hyatt), with its distinct ventral keel, and $C$. bosnensis Hauer, with its strong spines and development of the ventral shoulder sculpture. G. von Arthaber ${ }^{1}$ has recently proposed the subgeneric name Kellnerites for the group of Ceratites bosnensis Hauer. From the group of $C$. bosnensis developed Nevadites Smith and from that genus at least a part of the Trachyceratea.

The group of Ceratites humboldtensis Hyatt and Smith apparently is not an offshoot of the main stock of Ceratites but sprang from the Ceratites obsoleti, through the geminati (Gymnotoceras Hyatt). Thus the resemblance of the $C$. humboldtensis group to the nodosi is a convergence phenomenon and may possibly be due to atavism.

The group of circumplicati (Hollandites and Philippites of Diener) must have developed from an ancestor very similar to that of the geminati, and this same radicle gave rise to the genus Beyrichites Waagen, which has many of the characters of the geminati and of the circumplicati, hut in its development of the septa has gone farther than either, far enough to warrant: its separation as an independent genus.

The subrobusti (Keyserlingites Hyatt) are not certainly known in America, but a kindred group, Haydenites Diener, is found there. Both probably developed out of Olenikites Hyatt, of which the far-off ancestor is probably some member of the Meekoceratidæ.

It is clear that the so-called Ceratites of even the limited faunal province of Nevada constitute a highly complex aggregation of divergent and convergent groups, classed together because of their similarity. It is also clear that this similarity is due in some cases to really close relationship, in others to parallel development from kindred radicles, and in still others to convergence of stocks in which the remote ancestors were related, or to atavism. There may even be cases of convergence where the ancestral stocks were not closely related, but this is more difficult to prove. It seems probable that some of the species that are very similar are not nearly so closely allied as others that are very unlike. A case in point is the resemblance of the keeled group of Ceratites (Paraceratites) to Eutomoceras. But the resemblance is greatest at maturity, and the ontogeny of the two groups is not the same. Ultimately of course they are related, for both belong to the Ceratitoidea, but the divergence began before either Ceratites or Eutomoceras had originated. This convergence can not be charged to atarism, for neither group had an ancestor with ventral keel and sigmoidal ribs with lateral tubercles.

Another case is the resemblance of the group of Ceratites humboldtensis to the C. nodosi, but here we see a development along similar lines in two nearly allied, but slightly divergent, stocks.

The adults of the group of Ceratites bosnensis resemble the typical nodosi, but the young resemble Keyserlingites; whether this is accidental convergence or whether this is atavism in both groups can not now be decided. It may be that the tendency of nearly all the American Ceratites to form lateral knots or spines, at extreme maturity or old age, is an atavistic reversion to an ancestor like Olenikites or Keyserlingites. To demonstrate this would require a close study of the ontogeny not only of the American Ceratites, but also of those from other regions. No such study has yet been made, and is hardly possible with the material at present available. The writer, howerer, has made a careful study of the ontogeny of several species under each group represented in the American Triassic, and the remarks here given are based on that study.

1 Ueber die Iforizontierung der Fossilfunde am Monte Cucco, etc. : Jahrb. K.-k. geol. Reichsanstalt, 1912. vol. 62, Heft 2, p. 342. 
Philippi ${ }^{1}$ has expressed himself strongly in favor of the origin of Ceratites from Meekoceras. Diener also inclines somewhat doubtfully toward this opinion. The writer belieres that there can be no doubt as to the correctness of this theory, and he would go still further. selecting the group "Koninckites" as the probable ancestral group. Mojsisorics ${ }^{2}$ described the group of Ceratites polaris from the supposed Middle Triassic, Posidonomya beds, of Spitzbergen; of this group, $C$. lindströmi Mojsisovics differs from $C$. costatus Oeberg only in the serrations of the lateral lobes. In $C$. Iindströmi the first and second laterals are trifid, whereas in $C$. costatus the first lateral is four-pointed, and the second only bifid. But this difference is no greater than may be observed on many specimens of Neeloceras mushbachanum, where frequently the second lateral is only bifid, though it is usually trifid. ('. simplex Mojsisorics is probably only the young of $C$. costatus, and $C$. whitei Mojsisories is probably only the later adolescent stage of the same species; $C$. lindströmi is hardly more than a variety of $C$. costatus. All these are only Meekoceras, contemporaneous with and very closely allied to $M$. mushbachanum of the Lower Triassic, as will be seen from the figures of that species given in this work, for comparison with Ceratites. (See Pl. LXXII, figs. 1 and 2; Pl. LXXIII, figs. 1-6; Pl. LXXXIV, figs. 1-23.)

Meekoceras mushbachanum has already been sufficiently described. ${ }^{3}$ Additional material, collected since the former work was printed, shows much stronger relationship to the Ceratites polaris group than any specimens previously illustrated. Therefore a series showing the development of this species is figured in the present work. All these specimens came from the Lower Triassic, Meekoceras zone, of southeastern Idaho, chiefly from White's locality No. 1, 5 miles southeast of John Grays Lake; the locality of each specimen is indicated in the explanation of the plates. They were associated with Meekoceras gracilitatis White, Flemingites russelli Hyatt and Smith, Ussuria waageni Hyatt and Smith, I'scudosageceras intermontanum Hyatt and Smith, Cordillerites angulatus Hyatt and Smith, and many other species characteristic of this horizon.

In the larval stage, Meeleoceras mushbachanum is like Lecanites, which is probably the immediate ancestor of all the Meekoceratidæ, and thus of Ceratites. This stage is shown on Plate LXXIV, figures 20-23. At a diameter of 10 millimeters the septa are still goniatitic, but the whorl is already flattened and the lobes are more numerous. This stage resembles Ambites Waagen, although that genus was assigned by Waagen to the Noritidæ. This stage is shown on Plate LXXIV, figures 18 and 19. It a diameter of 14 millimeters the septa are already slightly ceratitic, Plate LXXIV, figures 16 and 17 , and the transition to Meekoceras has been made. At a diameter of 20 millimeters the shell resembles Ceratites simplex Mojsisovics, being compressed, nearly smooth, and involute; this is shown on Plate LXXIV, figures 11-15. At a diameter of 30 millimeters the shell resembles Ceratites whitei Mojsisovics, becoming more evolute and robust, and showing the beginning of the lateral folds or ribs. This stage is shown on Plate LXXIV, figures 5-10.

When maturity is reached the lateral ribs become sharply defined, the umbilicus is wider and the shell less compressed, and at a diameter of 85 millimeters the resemblance to Ceratites costatus Oelerg in very strong. The early mature stage is shown on Plate LXXIV, figures 1-3.

In later maturity the shell resembles C'eratites lindströmi Mojsisovics, which is probably only a synonym of $C$. costatus. At this stage the simple ribs are more numerous and finer in

${ }^{1}$ Die Ceratiten des oberen deutschen Muschelkalkes: Palæont. Abhandl. von Iramess und Koken (new series), vol, 4, 1901 , p. 89 .

2 Arktische 'Triasfaunen : Mém. Acad. imp. sci. St.-I'étersbourg, 7th ser., vol. 33, No. 6, 1886, pp. 29 et seq.

${ }^{3}$ Hyatt, Alpheus, and Smith, J. P., The Triassic cephalopod genera of America : Prof. Iaper [. S. Geol. Survey No. 40, 1905 , p. 149, Pl. XV, figs. 1-9; Pl. XVI, figs. 1-3; Pl. XVIII, figs. 1-7; Pl. LXX, figs. 8-10.

$16279^{\circ}-$ No. $83-14-6$ 
proportion to the size of the shell. This stage is shown on Plate LXXII, figures 1 and 2 ; and Plate LXXIII, figures 1-6.

As the group of Ceratites polaris is identical with Meekoceras and as this group was thought by Mojsisovics to belong to Ceratites, it is highly probable that this is the ancestral group from which Ceratites sprang. This is true, however, only of the nodosi, and their immediate kindred, for the ancestors of Gymnotoceras. Hollandites, and their allies must be sought in other groups of Meekoceras rather than in that of $M$. mushbachanum. Nor does the writer mean to assert that this particular species was the parent of Ceratites, for the group is well represented in India and Siberia, as well as in America, and the development may have taken place equally well in either one of these regions.

In the Ceratitidæ we have one of the most continuous and perfect genetic series to be found among fossils. Frcm the Gephyroceratidæ of the Devonian came Lecanites, and from this radicle were derived the Meekoceratidx. The group of Meekoceras mushbachanum seems to be the ancestor of the Ceratites nodosi, and their immediate allies. Some other member of the Meekoceratidæ may have given rise to the group of Ceratites bosnensis, for the American species of this group, though at maturity resembling the nodosi, in their youth show a decided resemblance to Keyserlingites. The group of $C$. bosnensis shows a perfect transition to Nevadites Smith and this in turn to Ancleites and the typical Trachyceratea. Thus the series may be traced from the most primitive Paleozoic ancestors to the most specialized ramifications of the race that disappeared at the end of the Triassic.

G. von Arthaber ${ }^{1}$ has recently proposed to subdivide further the Mediterranean Ceratites, adding the following subgenera: Semiornites Arthaber, type Ceratites cordevolicus Mojsisovics; Bulogites Arthaber, type $C$. multinodosus Hauer; Kellnerites Arthaber, type $C$. bosnensis Hauer. These subgeneric groups are not characterized, and the characteristic forms are not listed. It is not possible to determine what the limits of the groups are, and so the names can not be used until this is done. It seems to the writer that Bulogites and Kellnerites would fall together, the former name taking precedence.

Groups of Ceratites in the American Triassic.

A. Ceratites nodosi.

I. Group of Ceratites rotuloilcs Smith.

With neither umbilical, lateral, nor marginal knots. Branching ribs, usually forking on the sides and becoming obsolete on the ventral shoulders. This is the most primitive type of sculpture of the genus Ceratites. The nearest Luropean form is C. prettoi Tornquist. The septa are ceratitic, so far as they are known. This group is nearest to the ancestral Meekoceratidæ. Ceratites applanatus Smitl. Ceratites rotuloides Smith. Ceratites tenuispiralis Smith. Ceratites williamsi Smith. Ceratites weaveri Smith.

1I. Group of Ceratites occidentalis Smith.

With high whorls and compressed sides, as in group I, but with a development of marginal knots on the ventral shoulders at the ends of the ribs. The nearest European form is C. planus Arthaber. The septa are wealsly ammonitic, brachyphylloid.

Ceratites altilis Smith.

Ceratites occidentalis Smith. Ceratites gilberti Smith.

III. Group of Ceratites lingi Snith.

With umbilical and marginal tubercles. Ribs obsolescent. Faint rudiments of a keel, and square shoulders, showing a tendency toward Paraceratites Hyatt. The nearest European relative is C. suavis Mojsisovies.

Ceratites kingi Smith.

Ceratites rectangularis Snith.

Ueber die Horizonticrung der Fossilfunde am Monte cuceo (italionische Carnia) und iber die systematische Stellung von Cuccoceras Lien.: Jahrb. K. k. geol. Reichsanstalt, vol. 62, Heft 2, 1912, p. 342. 
A. Ceratites nodosi-Continued.

IV. Group of Ceratites elegans Mojsisorics (Paraceratites Hyatt).

With ventral keel, umbilical and marginal, and commonly with umbilical tubercles. The septa are ceratitic in all the American species. 'To this group belong the European $C$. elegans Mojsisovies, C. Mungaricus Mojsisovies, C. Iuganensis Merian, C. trinodosus Mojsisovies, and the Indian C. himalayanus. Paraceratites has a close similarity to Hungarites Mojsisovics, and Eutomoceras Hyatt, but there is no genetic relationship. Paraceratites developed out of keelless Ceratites of the Middle Triassic, probably through the group of $C$. kingi, but the ancestors of Hungarites and Eutomoceras already had a keel in the Permian.

1. Subgroup of Ceratites elegans with only lateral and marginal tubercles at maturity, but with umbilical tubercles in youth.

Ceratites cricki Smith.

Ceratitès gabbi Meek.

Ceratites taurus Smith.

Ceratites trojanus Smith.

Ceratites rogdesi Smith.

2. Subgroup of Ceratitcs trinodosus, with umbilical, lateral, and marginal tubercles. 'This is a purely artificial classification. and is merely a convenient grouping for identification.

Ceratites burckhardti Smith.

Ceratites clarkei Smith.

Ceratites newberryi Smith.

Ceratites trinodosus Mojsisovics.

Ceratites wardi smith.

V. Group of Ceratites bosnensis Hauer (Kellnerites Arthaber).

With sereral rows of tubercles or spines on the ribs, showing a transition to the Trachyceratea. The young of all the American species resemble Keyserlingites, probably indicating a derivation from that genus. From this group came Nevadites, the ancestor of Trachyceras.

Ceratites beecheri Smith.

Ceratites crassicornu Smith.

Ceratites ecarinatus Hauer.

- Ceratites fissicostatus Hauer.

Ceratites haguei smith.

VI. Group of Ceratites humboldtensis Hyatt and Smith.

With strong lateral and marginal tubercles, and commonly a weak keel ridge. The young of this group resemble Gymnotoceras, and even at maturity the forms show great affinity with the geminati. The septa are usually slightly ammonitic. This group has the greatest resemblance to the Germanic Ceratites nodosi, but this is probably due to convergence, or possibly to atarism, for the Germanic group seems to have been deriverl directly from Meekoceras. The nearest Mediterranean relative appenrs to be $C$. subnodosus Mojsisovics. The length of the body chamber is more than three-fourths of a revolution, much greater than in the group of C. nodosus.

Ceratites cornutus Smith.

Ceratites emmonsi Smith.

Ceratites humboldtensis Hyatt and Smith.

Ceratites karpinskyi Smith.

Ceratites nevadanus Mojsisovics.

Ceratites pilatus smith.

Ceratites spinifer Smith.

Ceratites washburnei Smith.

B. Ceratites circumplicati.

VIJ. Group of Ceratites voiti Oppel and Ceratites crasmi Mojsisovies.

With rounded venter, circumplicate sculpture. No spines nor keel. Septa usually slightly ammonitic, brachyphylloid.

1. Subgroup of Ceratites voiti Oppel, subgenus Hollandites Diener. With ribs weak ou the umbilicus, and strong on the higher parts of the flanks. Young resembling Gymnotoceras.

Ceratites montis-bovis Smith.

Ceratites organi Smith.

2. Subgroup of Ceratites erasmi Mojsisovies, subgenus Philippites Diener. With strong umbilical and weak lateral sculpture. Young resenbling Gymnotoceras, and general form very similar to Beyrichites.

Ceratites argentarius Smith.

Ceratites lawsoni Smith.

Ceratites ransomei Smith. 
C. Ceratites geminati.

VIII. Group of Ceratites blakei Gabb, subgenus Gymnotoceras Hyatt.

With strong sigmoidal branching ribs, a distinct ventral keel, and little development of lateral or shoulder tubercles. The septa are slightly ammonitic, brachyphylloid, on all the American species. This group includes the Arctic gcminati. It is well represented in the Aretic region, not at all in the Mediterranean, and very doubtfully in the Indian region. Ceratites beckeri Smith.

Ceratites blakei Gabb.

Ceratites hersheyi Smith.

Ceratites meeki Mojsisovics.

Ceratites russelli Smith.

Ceratites spurri smith.

Ceratites wemplei Smith.

\section{A. CERATITES NODOSI.}

\section{Aroup of Ceratites rotuloides.}

Ceratites applanatus Smith, sp. nov.

Plate LIII, figures 9-14.

Form involute, discoidal, laterally compressed. Whorls high, and increasing rapidly in height, deeply embracing, but not deeply indented by the inner whorls. Sides flattened, venter narrow and slightly rounded, with distinct but not sharp ventral shoulders. Umbilicus narrow and shallow. Surface ornamented with weak dichotomous sigmoidal ribs but without knots or spines. The ribs bend forward at the ventral shoulders and become stronger but do not form tubercles.

The height of the whorl is more than half the diameter of the shell and the width nearly two-thirds of the height. The width of the umbilicus is one-fifth of the diameter of the shell. The septa are unknown.

Ceratites applanatus resembles $C$. rotuloides but is flatter and thinner and has weaker sculpture. It also resembles Beyrichites tenuis but is distinguished by its stronger sculpture, its distinct shoulders, and somewhat flattened venter.

Horizon and locality.-Rare in the Middle Triassic, Daonella dubia zone, Ceratites trinodosus subzone, on the divide between Troy Canyon and the south fork of American Canyon, 4 miles south of Fitting post office (formerly Foltz), West Humboldt Range, Nev., associated with Ceratites trinodosus, Gymnotoceras blakei, Nevadites whitncyi, Beyrichites rotelliformis, Sageceras gabbi, Daonella dubia, and other species.

\section{Cerattes rotuloides Smith, sp. nov.}

Plate XIVII, figures $1-10$.

Involute, laterally compressed, with high narrow flattened whorls, and very narrow umbilicus. Venter narrow and rounded, without central ridge. The height of the whorl is half the diameter of the shell, and the width is two-thirds of the height. The outer whorl embraces a little more than half of the inner and is indented by it to about one-fifth of the height. The width of the umbilicus is less than one-fourth of the total diameter of the shell. The surface is ornamented with numerous fine ribs starting from the umbilicus, branching just above it, and running nearly straight up the flanks to the abdominal shoulders, where they bend slightly forward and become obsolete. There are no knots or spines on the shell. The septa are ceratitic, but the saddles are slightly ammonitic. 


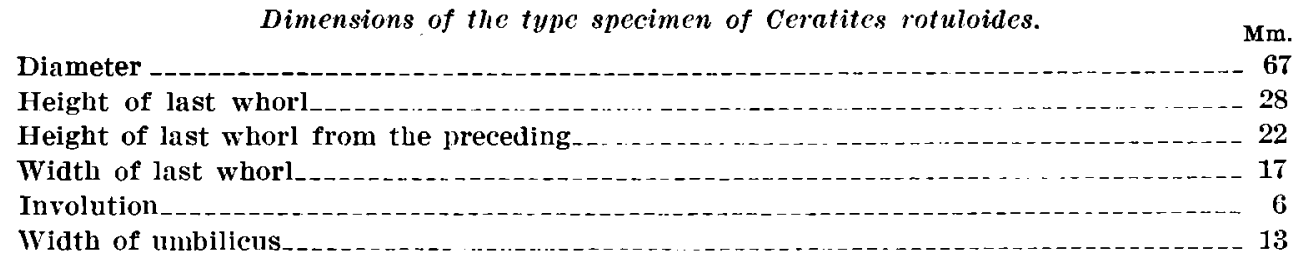

Ceratites rotuloides closely resembles $C$. prettoi Tornquist, ${ }^{1}$ but is somewhat more robust, and has stronger ribs. It also resembles $C$. occidentalis Smith but has more compressed whorl, finer and fewer ribs, and lacks the shoulder knots that characterize $C$. occidentalis.

Tornquist ${ }^{1}$ assigns Ceratites prettoi Tornquist, $C$. beneckei Mojsisovics, and $C$. vicarius Arthaber to the group of $C$. binodosus on account of their lack of umbilical sculpture. But the three species mentioned should rather constitute a group by themselves, to which also $C$. rotuloides Smith would belong. They do not belong with $C$. binodosus, although they may have developer out of that group by obsolescence of the sculpture.

Horizon and locality. - C. rotuloides Smith occurs in the Middle Triassic, Daonella zone, of Fossil Hill, on the divide between Troy Canyon and the south fork of American Canyon, 4 miles south of Fitting post office (formerly Foltz), West Humboldt Range, Ner. A few specimens were also found in the south fork of Cottonwood Canyon, West Humboldt Range. The fauna with which it was associated is that of the zone of Ceratites trinodosus.

Ceratites tencispiralis Smith, sp. nov.

Plate XLVI, figures 17-25.

From slender, evolute, widely umbilicate. Whorls low and increasing slowly in height, higher than wide, not deeply embracing nor deeply indented by the inner whorls. The sides are flattened, the ventral shoulders abruptly rounded, and the venter is somewhat convex, with a weak keel ridge. The surface is ornamented with distinct sigmoidal ribs that run nearly straight up the sides and bend sharply forward at the ventral shoulders. Some of these ribs bifurcate on the flanks, but there are no knots anywhere on the shell. There are about 23 umbilical and 36 marginal ribs to a revolution.

The outer whorl embraces five-eighths of the inner, and is indented by it to one-fifth of the height. The height of the whorl is two-fifths of the diameter of the shell, and the width is three-fourths of the height. The width of the umbilicus is nearly one-third of the diameter of the shell. The septa are ceratite, with rounded saddles and five external lobes, of which two are anxiliaries, the fifth low down on the umbilical shoulders.

Dimensions of the type of Ceratites tenuispiralis.
Diameter
Height of last whorl
Height of last whorl from the preceding
Width of last whorl
Involution
Width of umbilicus.

Ceratites tenuispiralis is closely allied with C. rotuloides Smith, but differs in its greater evolution, lower whorl, and stronger ribs. The species has an immature appearance and may be in the adolescent stage, but it is certainly not the young of any species known in the Middle

I Neuere Beiträge zur Geologie und Paläontologie der Umgebung von Recoaro und Schio in Venetien, Part IV : Zeitschr. Ieutsch. geol. Gesell., vol. 50, No. 4, 1898, p. 645, Pl. XX, fg. 3. 
Triassic of Nevada, for the writer has examined the growth stages of all the Ceratites of this formation and found no young of this character.

Horizon and locality.-Rather rare in the Middle Triassic, Daonella dubia zone, Ceratites trinodosus subzone, on the divide between Troy Canyon and the south fork of American Canyon, 4 miles south of Fitting post office (formerly Foltz), West Humboldt Range, Nev., associated with Ceratites trinodosus, C. humboldtensis, Protrachyceras meeki, Nevadites whitneyi, Gymnotoceras blakei, Beyrichites rotelliformis, Daonella dubia, and other species.

Ceratites weaveri Smith, sp. nov.

Plate XCYIII, figures $4-7$.

Form evolute, discoidal, laterally compressed rather widely umbilicate. Umbilical shoulders abruptly rounded, sides gently convex, curving up without abdominal shoulders to the narrowly rounded venter. The height of the outer whorl is two-fifths of the diameter of the shell, and the width is three-fifths of the height. The outer whorl embraces half of the inner and is indented by it to less than one-fourth of the height. The width of the umbilicus is one-third of the diameter of the shell. The surface is ornamented at maturity with fine, close-set, nearly straight ribs that run from the umbilicus up the flanks, curve gently forward toward the venter, and almost disappear in the middle. In youth strong umbilical ribs extend one-third of the distance up the flanks. The septa are ceratitic, with rounded entire saddles and four external serrated lobes.

Ceratites weciveri is most nearly related to $C$. williamsi, but has the whorl more compressed and slightly less involute, and has more numerous and weaker ribs. Like $C$. williamsi, it is a dwarf form and probably reversionary or retarded, for it is the most atavistic Ceratites in the fauna of Nevada and the one most nearly resembling the parent Meekoceras. It may, however, be a primitive form, little modified from the ancestral type.

The specific name is given in honor of Dr. Charles E. Weaver.

Horizon and locality.-Very rare in the Middle Triassic, Daonella dubia zone, Ceratites trinodosus subzone, of New Pass, Desatoya Mountains, Nev., from which locality the type came; also in the same horizon on Fossil Hill, 4 miles south of Fitting post office (formerly Foltz), West Humboldt Range, Nev.; in both places associated with Ceratites trinodosus, Trachyceras americanum, Daonella dubia, and other species.

Ceratites williamsi Smith, sp. nov.

Plate XIVII, figures 11-18.

Form moderately evolute, widely umbilicate, laterally compressed, slender. Sides flattened, venter narrowly rounded, without ventral keel ridge. Whorls rather deeply embracing and deeply indented by the inner whorls.

The height of the whorl is less than half the diameter of the shell, and the width is twothirds of the height. The outer whorl embraces two-thirds of the inner and is indented by it to less than one-third of the height. The width of the umbilicus is about one-fourth of the diameter of the shell. The surface is nearly smooth, being ornamented with rery weak sigmoidal ribs or folds, which are almost obsolete at maturity. The septa are unknown.

Dimensions of the type specimen of Ceratitcs williamsi.

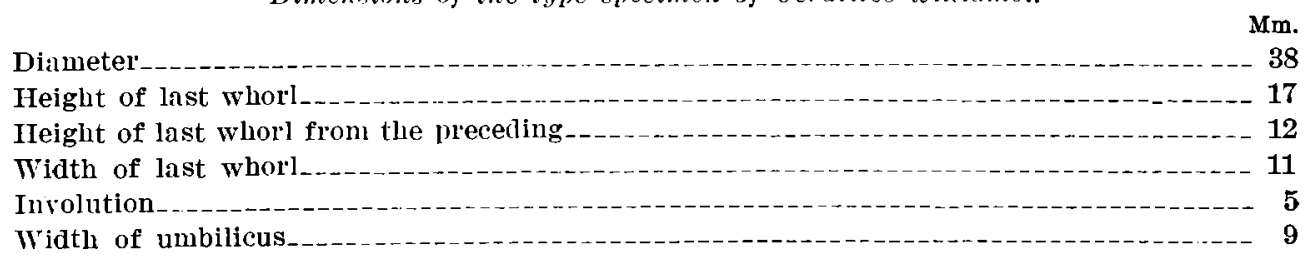


Ceratites williamsi belongs to the same group as $C$. rotuloides Smith but differs from that species in its greater evolution and weaker sculpture. It is more involute than $C$. tenuispiralis Smith and more compressed laterally. The specific name is given in honor of Prof. H. S. Williams.

The group to which $C$. williamsi belongs contains the most primitive members of true Ceratites and has departed least from the ancestral Meekoceras; it resembles Beyrichites, but this resemblance is due to convergence. The two genera are much more similar at maturity than they are in youth. Ceratites williamsi preserves by palingenesis the characters of Meekoceras, and Beyrichites shows an atavistic tendency to revert to that genus.

Horizon and locality.-Very rare in the Middle Triassic, Daonella dubia zone, Ceratites trinodosus subzone, of the north fork of Cottonwood Canyon, near the "Lucky Dog" mine, West Humboldt Range, Nev., from which locality the type specimen came. It was also found in the same horizon on the divide between Troy Canyon and the south fork of American Canyon, West Humboldt Range, associated with Ceratites trinodosus, C. humboldtensis, Protrachyceras meeki, Nevadites whitneyi, Beyrichites rotclliformis, Daonella dubia, and other species.

\section{Group of Ceratites occidentalis.}

Ceratites altilis Smith, sp. nov.

Plate XLV, figures 14-22; Plate LXVII, figures 19-21.

Form involute, discoidal, laterally compressed, narrowly umbilicate. Whorls high and increasing rapidly in height, deeply embracing but not deeply indented by the inner whorls. The sides are flattened, the umbilical shoulders abruptly rounded, the ventral shoulders square, and the venter rather narrow and flattened, slightly raised in the middle.

The height of the whorl is half the diameter of the shell, and the width is two-thirds of the height. The width of the umbilicus is one-fifth of the diameter of the shell. The outer whorl embraces four-fifths of the inner and is indented to one-fifth of the height by it. The surface is ornamented with fine flexuous dichotomous ribs that begin without tubercles on the ventral shoulders, curve forward on the flanks, and end in weak tubercles on the ventral shoulders. The septa are ceratitic but could not be prepared sufficiently for illustration.

Dimensions of the type specimen of Ceratites altilis.

Diameter.-
Height of last whorl.
Height of last whorl from the preceding
Width of last whorl.
Involution
Width of umbilicus.

Ceratites altilis is very closely allied to $C$. occidentalis, but is more compressed and has more numerous and finer ribs; it is also related to $C$. falcifer Haner, ${ }^{1}$ but is less robust and has the ribs coarser and fewer. From $C$. rotuloides it differs in having the ribs less sharply defined and in possessing the row of tubercles on the ventral shoulders.

The specimens of $C$. altilis thus far known are all small, and may be the adolescent stages of some larger form, but they do not belong to any known species, for the writer has series of the young of all the Ceratites in the Middle Triassic of Nevada.

Morizon and locality.-Very rare in the Middle Triassic, Daonella dubia zone, Ceratites trinodosus subzone, of Fossil Hill, south fork of American Canyon, 4 miles south of Fitting

1 Beitrïge zur Kenntniss der Ceplalopoden aus der Trias von Bosnien. Part II : Denksebr. K. Akad. Wiss. Wien, rol. 63, 1896, Pl. VIII, figs. 5 and 6. 
post office (formerly Foltz), West Humboldt Range, Nev.; associated with Ceratites trinodosus, C. humboldtensis, Nevadites whitneyi, Protrachyceras meelei, Beyrichites rotelliformis, Daonella $d u b i a$, and other species.

Ceratites gilberti Smith, sp. nov.

Plate XCVIII, figures 1-3.

Form slender, laterally compressed, rather evolute, and widely umbilicate. Whorls with gently convex sides, angular ventral shoulders, and narrow flattened venter. The outer whorl embraces two-thirds of the inner and is indented by it to one-fourth of the height. The height of the last whorl is less than half the diameter of the shell and the width is three-fifths of the height. The width of the umbilicus is slightly greater than one-fourth of the diameter of the shell. The greatest width of the whorl is the middle. The surface is ornamented with numerous fine, sharp, gently curving ribs that bend slightly backward high on the flanks, develop fine distinct knots on the square rentral shoulders, and continue across the venter, forming a welldefined sinus. There are also a very few weak lateral knots on the ribs. The septa are unknown.

Ceratites gilberti belongs to the group of $C$.occillentalis but is much more compressed, has finer sculpture, and is more evolute. It also resembles $C$. king $i$ but has more numerous and finer ribs and shoulder knots. It is nearest to $C$. planus Arthaber ${ }^{1}$ but is more compressed and more evolute and has more distinct sculpture.

The specific name is given in honor of Dr. G. K. Gilbert.

Horizon and locality.-Very rare in the Middle Triassic, Daonella dubia zone, Ceratites trinodosus subzone, of Fossil IIill, south fork of American Canyon, 4 miles south of Fitting post office (formerly Foltz), West Humboldt Range, Nev.; associated with C. trinodosus, $C$. occidentalis, Nevadites whitneyi, Beyrichites rotelliformis, Daonella dubia, and other species.

Ceratites occidextalis Smith, sp. nov.

Plate XI.IV, figures 21-2S; Plate XIV, figures 1-113.

Involute, high whorled, laterally compressed, deeply embracing, and deeply indented by the inner volutions. Venter narrow and rounded without central ridge. The height of the outer whorl is half the diameter of the shell, and the width is three-fifths of the height. It embraces three-fourths of the inner whorl and is indented by it to about one-fourth of the height. The umbilicus is narrow, being only one-fourth of the diameter of the shell.

The surface is ornamented with ribs that start out from the umbilicus, bifurcate just above the umbilical shoulders, curve gently forward to the abdominal shoulders, and end there in weak knots. Between each pair of branching ribs there is a single intercalary rib that also ends in a weak knot on the shoulders. There are neither umbilical nor lateral knots. The sculpture is stronger on young shells than at maturity. The septa are slightly ammonitic, brachyphylloid, the weak indentations reaching to the top of the saddles.

This species is nearly related to $C$. rotuloides Smith but differs in its more robust whorl, stronger ribs, and in the possession of ventral shoulder knots. It also greatly resembles $C$. planus Arthaber, of the Mediterranean region, but is more evolute and less compressed laterally. Old specimens become nearly smooth, and then the resemblance to $C$. planus is more marked.

Horizon and locality.-Very common in the Middle Triassic, Daonella dubia zone, Ceratites trinodosus, subzone, of Fossil Hill, south fork of American Canyon, West Humboldt Range, Nev., associated with Ceratites trinodosus, C. humboldtensis, Gymnotoceras blakei, Nevadites whitneyi, Beyrichites rotelliformis, Daonella dubia, and other species.

1 Die Cephalopodenfauna der Reiflinger Kalke: Beitr. Pal. und Geol. Oesterreich-Lngarns und des Orients, vol. 10, 1896, p. 45, Pl. IV, flg. 2. 


\section{Group of Ceratites kingi.}

Ceratites ringi Smith, sp. nov.

Plate XII, figures 1-13.

Form involute, laterally compressed, rather narrowly umbilicate. Whoris moderately high, with flattened sides, angular ventral shoulders, and narrow flattened venter without a central ridge. The height of the last whorl is less than half the diameter of the shell, and the width is two-thirds of the height. The inner whorl indents the outer to one-fifth of the height. The width of the umbilicus is nearly one-fourth of the total diameter of the shell.

The surface is ornamented with fine gently curved ribs that end in small tubercles on the ventral shoulders. There are no umbilical tubercles and only a few very weak lateral knots on the ribs. The septa are ceratitic, with entire saddles.

Ceratites kingi has some resemblance to $C$. rotuloides Smith, but differs in the possession of the ventral tubercles and angular shoulders. It also resembles somewhat $C$. prettoi Tornquist, ${ }^{1}$ but is more evolute than the Italian species and has straighter ribs and stronger ventral tubercles. $C$. kingi is related to $C$. aviticus Mojsisovics, ${ }^{2}$ but has more distinct sculpture, with stronger ribs and knots. It is also somewhat related to $C$. barrandei Mojsisovics, ${ }^{3}$ but is more evolute and has stronger sculpture with fewer lateral linots. C. kingi may be compared with $C$. planus Arthaber, ${ }^{4}$ but is more compressed and has stronger ribs and marginal tubercles. $C$. king $i$ is most nearly related to C. suavis Mojsisorics, but has slightly stronger sculpture.

Dimensions of the type specimen of Ceratites kingi.

Diameter
Height of last whorl
Height of last whorl from the preceding
Width of last whorl
Involution
Width of umbilicus.

The specific name is given in honor of the late Clarence King.

Horizon and locality.-Middle Triassic, Daonella dulia zone, Ceratites trinodosus subzone, on the divide between Troy Canyon and the south fork of American Canyon, 4. miles south of Fitting post office (formerly Foltz), West Humboldt Range, Nev., associated with Daonella dubia, Ceratites trinodosus, C. humboldtensis, Gymnotoceras blakei, Nevadites whitneyi, and other species.

Ceratites rectangularis Smith, sp. nov.

I'late XLI, figures 1.1 and 15.

Form robust, involute, high-whorled, laterally compressed, narrowly umbilicate. Sides flattened, ventral shoulders square, venter low and flattened, but with a distinct keel ridge. Surface ornamented with weak bifurcating ribs, and three rows of tubercles-umbilical, lateral, and marginal. The flattened sides and square shoulders are pronounced even in youth, but the tubercles do not appear until toward maturity. The height of the whorl is less than half the diameter of the shell, and the width is about equal to the height. The width of the umbilicus is about one-fourth of the diameter of the shell. The septa are unknown.

\footnotetext{
1 Neuere Beiträge zur Geologie und Paläontologie der Umgebung von Recoaro und schio in Venetien, Part IV: Zeitschr. Deutsch. geol. Gesell., vol. 50, No. 4, 1898, p. G54, Pl. XX, fig. ̈̈.

2 Lie Cephalopoden der Mediterranen Triasprovinz : Ibhandl. K.-k. grol. laeichsanstalt Wien, vol. 10, 1882, p. 24, Pl, XII, figs. 2 and 3 .

3 Idem, p. 25, Pl. XII, fig. 8.

1 Die Cephalopoden fauna der Reiflinger Kalke: Beitr. Pal. und Geol. Oesterreich-ingarns und des Orients, vol. 10, 1596 , p. 45, Pl. IV, figs. $2 a, b$, and c.
} 
Ceratites rectangularis is very closely allied with $C$. brembanus Mojsisovics, but appears to differ in its more robust whorl and weaker sculpture; it is less closely related to $C$. karpinskyi Smith, from which it differs in its finer ribs, more numerous tubercles, and in the possession of a ventral keel ridge.

It is probably transitional from the group of Ceratites kingi to Paraceratites, although the writer does not regard it as the radicle of the latter group but merely as showing a tendency to develop those characters that in their extremes mark Paraceratites.

Horizon and locality.-Very rare in the Middle Triassic, Daonella dubia zone, Ceratites trinodosus subzone, in the north fork of Cottonwood Canyon, near the "Lucky Dog" mine, West Humboldt Range, Nev., from which locality the type specimen came. It was also found in the same horizon on the divide between Troy Canyon and the south fork of American Canyon, West Humboldt Range. It was associated with Ceratites humboldtensis, C. trinodosus, Gymnotoceras blakei, P'rotrachyceras meeki, Nevadites whitneyi, Beyrichites rotelliformis, Daonella dubia, and other species.

\section{Group of Ceratites elegans. (Subgenus Paraceratites Hyatt.)}

1900. Paraceratites, Hyatt, Cephalopoda (in Zittel and Eastman's Textbook of palæontology, vol. 1, p. 559). (Not 1903. Paraceratites, E. Kittl, Die Cephalopoden der oberen Werfener Schichten von Muć in Dalmatien: Abhaudl. K.-k. geol. Reichsanstalt $W$ ien, vol. 20, pt. 1, p. 28.)

Type.-Ceratites elegans Mojsisovics, expressly named by Hyatt ${ }^{1}$ as the type, although he figures Ceratites trinodosus as a representative species. This group, which Hyatt regarded as an inclependent genus, is characterized by the possession of a ventral keel, distinct ventral shoulders, strong sigmoidal lateral ribs, and lateral, marginal, and commonly also umbilical knots. The septa are ceratitic in all the species in which the septa have been observed.

In the Mediterranean region Paraceratites is represented by a large number of species, including Ceratites trinodosus, $C$. elegans, $C$. hungaricus, and $C$. luganensis, all from the Alpine upper Muschelkalk. In India it is represented by Ceratites himalayanus and $C$. trinodosus. In Nevada the Middle Triassic has afforded a large number of characteristic species, Ceratites trinodosus Mojsisovics, C. clarkei Smith, $C$. cricki Smith, C. gabbi Meek, C. newberryi Smith, $C$. burckhardti Smith, $C$. taurus Smith, $C$. trojanus Smith, $C$.vogdesi Smith, and $C$. wardi Smith, all from the zone of Ceratites trinodosus.

This group resembles Eutomoceras Hyatt but differs from it in not having the keel separated from the rest of the venter by a furrow and in the simpler sculpture of most of the species.

Diener ${ }^{2}$ has recently given the name of Halilucites to the keeled group of "Ceratites" rusticus of the Muschelkalk of Bosnia, which he regards as a subgenus of Ceratites. But this group is most nearly allied to Eutomoceras Hyatt and can only be a synonym or a subgenus of Hyatt's genus, differing from the type only in the simpler ornamentation of the shell. Kittl's genus Paraceratites, named three years after Hyatt preoccupied the name, belongs to another group and will have to be renamed.

As restricted in this paper, the suogenus Paraceratites is known only in the upper part of the Muschelkalk, chiefly in the zone of Ceratites trinodosus, and only in the Mediterranean, the Indian, and the American regions.

Paraceratites is probably an offshoot of the less complex group of Ceratites kingi Smith, and its resemblance to Eutomoceras, Halilucites, and Hungarites is due rather to convergence than to near relationship.

1 Conhalopoda: Textbook of palipontology by K. A. ron Zittel (translated ly C. R. Fastman), 1900, p. 559.

s Entwurf einer Systematik der Ceratitiden des Muschelkalkes: Sitzungsber. K. Akad. Wiss. Wien, vol. 114, pt. 1, 1905 , p. 775 . 
I. Subgroup of Ceratites elegans.

Ceratites (Parachatties) cricki Smith, sp. now.

Plate XXXVII, figures 6-13; Plate XXXviII, figures 1-12; I'lite XIVII, figures 19 and 24.

Involute, laterally compressed. Whorls high and increasing rapidly in height. Sides flattened with rounded umbilical shoulders, rather distinct ventral shoulders, and a high, rather sharp keel-like ridge on the renter. The outer whorl embraces three-fifths of the inner and is indented by it to one-fifth of the height. The height of the whorl is three-sevenths of the diameter of the shell, and the width is four-fifths of the height. The width of the umbilicus is one-fourth of the diameter of the shell. The surface of the shell is ornamented with weak ribs and weak umbilical knots, about 14 to a revolution; strong lateral knots, 10 to a revolution, and two-fifths of the distance up the flanks; rather weak marginal knots on the ventral shoulders, 18 to 20 to a revolution, but nearly obsolete at a diameter of 40 millimeters. The shoulders cease to be distinct at a diameter of about 40 millimeters. The keel is strong all through life. The septa are ceratitic, with saddles entire and all the lobes serrated. There are a divided ventral lobe, two laterals, and two auxiliaries.

Dimensions of the type specimen of Ceratites cricki.

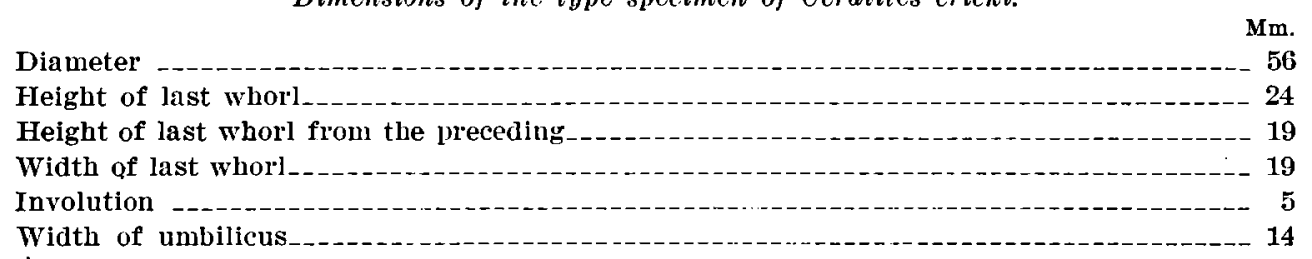

Up to a diameter of 25 millimeters Ceratites cricki is almost exactly like $C$. elegans Mojsisovics ${ }^{1}$ but has a somewhat higher keel and coarser lateral and marginal knots. From a diameter of 25 millimeters up to about 40 millimeters $C$. cricki is almost exactly like $C$. himalayanus Blanford, as figured by C. Diener. ${ }^{2}$ Above the diameter of 40 millimeters Ceratites cricki greatly resembles $C$. luganensis Merian as figured by Mojsisovics, ${ }^{3}$ but has the lateral ribs stronger, the marginal knots weaker, the shoulders less distinct, and the whorl more robust. Ceratites cricki also greatly resembles $C$. trojanus Smith and $C$. vogdesi Smith, with which it is associated, but at maturity it may easily be distinguished from them by the possession of a rather high keel. The distinguishing characteristics of these three nearly allied species are given under the description of $C$. trojanus. Ceratites cricki belongs to the same group as $C$. elegans Mojsisovics, to which group Hyatt gave the name Paraceratites. The writer is not of the opinion that this group should be separated from Ceratites, except as a subgenus, for there are all possible transitions from the group of Ceratites nodosus to that of $C$. elegans.

Horizon and locality.-Ceratites criclii is rather common in the Middle Triassic, zone of Ceratites trinodosus, on Fossil IIill, on the divide between Troy Canyon and the south fork of American Canyon, 4 miles south of Fitting post office (formerly Foltz), West Humboldt Range, Nev. It was associated with Ceratites trinodosus, $C$. trojanus, $C$. vogdesi, $C$. humboldtensis, Gymnotoceras bla7ici, Beyrichites rotelliformis, Nevadites whitneyi, N. hyatti, Sageceras gabbi, Daonella dubia, and many other forms characteristic of this horizon. It was also found in the same horizon at New Pass, Desatoya Mountains, Nev.

${ }^{1}$ Die Cephalopoden der Mediterranen Trlasprovinz: Abhandl. K. k. geol. Reichsanstalt Wien, vol. 10, 1882, p. 31, Pl. $\mathrm{IX}$, figs. 5 and 6.

2 Cephnlopoda of the Muschelkilk: Ilimalayan Fossils, vol. 2, pt. 2, 1895, p. 23, Fl. I, figs. 4 and 4 a (Mem. Geol. Survey India, Pal. Indica, 15th ser.1.

" Iie ('ephalopoden der Mediterranen Triasprovinz: Abhandl. K. k. geol. Reichsanstalt Wien, vol. 10, 1882, p. 33, Pl. XxxIX, figs. 7 and 8 . 
Ceratites (Paraceratites) gabii Meek.

Plate $\mathrm{V}$, figures 1 and 2 ; Plate $\mathrm{XV}$, figures 4 and $4 a$.

1877. Eudiscoceras gabbi, Meek, Palæontology : U. S. Geol. Expl. 40th Par., vol. 4, p. 128, Pl. XI, figs. 4 and $4 a$. 1905. Eudiscoceras gabbi, Hyatt and Smith, The Triassic cephalopod genera of America: Prof. Paper U. S. Geol. Survey No. 40, p. 179, Pl. XXIV, figs. 1 and 2.

Discoidal, involute, laterally compressed. Whorls high and increasing rapidly in height, narrow, with high cross section: sides gently convex, venter narrow with marginal keels, and a central keel in the median depression. The last whorl is deeply embracing, concealing about two-thirds of the inner volution; its height is three-sevenths of the total diameter of the shell. The umbilicus has abrupt inner walls, is shallow, and its width is about three-tenths of the total diameter. The surface is ornamented with flexuous ribs, which end in small knots, beading the marginal keels; these ribs become finer as the shell grows older. There are also weak umbilical and lateral knots. The septa are unknown.

Hyatt named a genus Eudiscoceras to include this somewhat doubtful species, but it probably belongs to the group of Cerotites elegans, as is shown by better specimens than the type.

Horizon and locality.-The type came from the Middle Triassic, Daonella dubia zone, of Cottonwood Canyon, West Humboldt Range, Nev.; the writer also found it in the same horizon on Fossil Hill, south fork of American Canyon, West Humboldt Range, Nev.

Ceratites (Paraceratites) tacrus Smith, sp. nov.

Plate XXXV, figures 1-3.

Form very robust, thickset, whorls broad and low, but increasing rapidly in height, deeply embracing, but not deeply indented by the inner whorls. Umbilicus wide and deep, exposing half of the inner whorls. Umbilical shoulders rounded, sides convex, with subangular ventral shoulders. Venter high, with sharp roof-shaped central ridge.

Surface ornamented with a few coarse ribs that begin on the umbilical shoulders and bifurcate midway on the flanks, ending in obscure shoulder knots. In the middle of the flanks there are strong spines at the bifurcation of the ribs, about seven to a revolution, and the shoulder knots number about fourteen. The height of the last whorl is three-sevenths of the diameter of the shell, and the width is somewhat greater than the height. The outer whorl embraces half of the inner. The width of the umbilicus is one-third of the diameter of the shell. This is the most robust of the keeled Ceratites in Nevada, and has departed furthest from the typical group of $C$. cricki. No kindred form is known in Europe or Asia.

Horizon and locality.-Very rare in the Middle Triassic, Daonella dubia zone, Ceratites trinodosus subzone, of Fossil Hill, south fork of American Canyon, West Humboldt Range, Nev., associated with Ceratites trinodosus, $r$. humbolltensis, Gymnotocerchs blakei, Nevadites witneyi, Daonella dubia, and other species.

\section{Ceratites (Paraceratites) trojaxts Smith, sp. nov.}

Plate XXXVI, figures 1-5; Plate XXXvil, figures 1-5.

Involute, laterally compressed, high whorled, with indistinct ventral shoulders and venter raised in a keel-like ridge. The outer whorl is deeply embracing and deeply indented by the inner volutions; the height of the whorl is half the diameter of the shell, and the width is two-thirds of the height. The umbilicus is one-fourth of the diameter of the shell. Up to a diameter of 35 millimeters the sides are ornamented with fine distinct flexuous lateral ribs, weak lateral knots, and a row of small marginal knots at the ends of the ribs on the ventral shoulders. Above the diameter of 35 millimeters the lateral ribs become almost obsolete: the 
lateral knots, which number about nine to a revolution, become very coarse, and the fine row of marginal knots become indistinct. There are no umbilical tubercles at any stage. The septa are ceratitic, with entire saddles and serrated lobes. The divided ventral lobe is flanked by two laterals and a small auxiliary.

Dimensions of the type specimen of Ceratites trojanus.

$\begin{array}{llr}\text { Diameter } & & \text { Mm. } \\ \text { Height of whorl } & \\ \text { Width of whorl } & \\ \text { Involution } & \end{array}$

Ceratites trojanus resembles $C$. abichi Mojsisovics ${ }^{1}$ but differs from the Mediterranean species in its wider umbilicus, fewer and coarser lateral spines, which stand higher up on the flanks, and in the entire saddles. In youth $C$. trojanus resembles $C$. elegans Mojsisovics, but is wholly unlike that species at maturity. It is more closely allied to two American species, and a comparison with them is given below.

C. trojanus, in youth like $C$. elegans but in age with lateral ribs almost obsolete, with few coarse lateral knots, and row of ventral knots indistinct. Without a high keel. Septa with one auxiliary lobe. Nine or 10 conrse lateral knots to a revolution, two-thirds of the distance up the flanks; 23 marginal knots, at maturity reduced to low knobs. Shoulders never so distinct as on $C$. cricki, but persist through life. The outer whorl embraces one-third of the immer.

Ceratites vogdesi Smith, in youth like C. elcgans but more robust; in age more evolute than $C$. trojanus, with whorl more nearly quadratic in outline. Faint umbilical knots in youth; 9 coarse lateral knots to a revolution, three-fourths of the distance un the flanks; 16 coarse marginal knots. The outer whorl embraces half of the inner. Septa with one auxiliary lobe.

Ceratites cricki Smith, in youth almost exactly like C. clegans but in age closely resembling $C$. luganensis. The lateral sculpture is like that of c. trojanus, but the venter hals a sharp keel. Selta with two auxiliary lobes.

It is rather difficult to separate these three species in youth, but $C$. trojanus is distinguished from $C$. vogdesi by its more rapid increase in the height of the whorl and from $C$. cricki by the absence of the high keel that characterizes the latter species.

Horizon and locality.-Common in the Middle Triassic, Daonella dubia zone, Ceratites trinodosus subzone, on Fossil Hill, south fork of American Canyon, West Humboldt Range, Nev., associated with C.trinodosus, C. humboldtensis, C. cricki, C. vogdesi, Nevadites whitneyi, Sageceras gabbi, Daonella dubia, and other species.

\section{Cer.atites (Pariceratites) vogdesi Smith.}

Plate XXXV, figures 4-9.

1904. Ceratites vogdcsi, Smith, The comparative stmigraphy of the marine Trias of western America: Proc. California Acad. Sci., 3d ser., Geology, vol. 1, p. 384, Pl. XLIII, figs. 7 and 8 ; Pl. XLIV, fig. 1.

Form robust, evolute, whorls subquadratic, a little higher than wide, with rather broad venter raised in the middle to a low central ridge, and with abrupt, subangular ventral shoulders. The umbilicus is rather wide and deep, with abruptly rounded umbilical shoulders. The outer whorl conceals more than half of the inner and is indented by it to about half of the height. The width of the whorl is about four-fifths of the height, and the height is about three-sevenths of the total diameter. The width of the umbilicus is one-third of the diameter of the shell.

The surface is ornamented with coarse radial ribs that start out from the umbilical shoulders, and develop strong spines about two-thirds of the distance up the flanks and again on

1 Die Cephalopoden der Mediterranen Triasprovinz: Abhandl. K.-k. geol. Reichsanstalt Wien, vol. 10, 1882, p. 21, Pl. XI, fig. 8 ; Pl. XXII, fig. 6 . 
the abdominal shoulders. There are nine principal ribs and lateral knots to a revolution and about $t$ wice as many spines on the shoulders. The intermediate ribs are weaker and do not develop spines.

The septa are ceratitic, with rounded entire saddles, and serrated lobes. The external lobe is divided by a shallow siphonal saddle into two short branches; the first lateral is deeper and broader; the second lateral about half as large; and the auxiliary consists of a series of denticulations distinctly separated from the third lateral saddle.

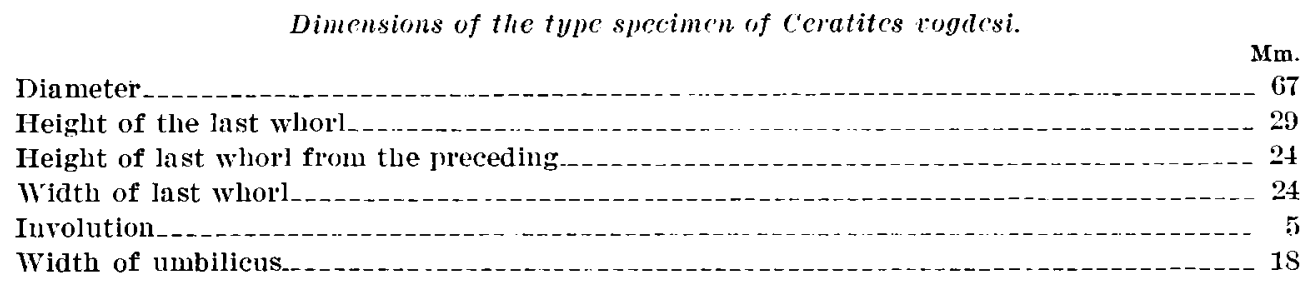

Ceratites vogdesi is closely related to $C$. trojanus Smith but is more evolute, with more robust whorls, lower venter, stronger and more angular shoulders, and stronger sculpture. The lateral knots are about the same in number in both species, but the marginal knots are fewer and coarser on $C$. vogdesi.

Ceratites vogdesi also resembles $C$. cricki Smith but is much more evolute and. robust, with squarer outline, stronger shoulders, lower venter, and much stronger sculpture. It has some resemblance to $C$. haguei Smith but is more robust, with broader whorls and fewer and coarser spines. It seems to be transitional from the group of $C$. elcgans to that of $C$. bosnensis, with some characteristics of each. But the writer does not mean to imply that this necessarily shows a genetic relationship, for the young of the group of $C$. bosnensis resemble Keyserlingites, which is not known to be the case with any species of Paraceratites.

Horizon and locality.-Rather rare in the Middle Triassic, Daonella dubia zone, Ceratites trinodosus subzone, of Fossil Hill, south fork of American Canyon, West Humboldt Range, Nev., associated with Ceratites trinodosus, C. cricki, C. trojanus, Nevadites whitneyi, Sageceras gabbi, Daonella dubia, and other species.

\section{Subgroup of Ceratites trinodosus.}

\section{Ceratites (Paraceratites) burckhardti Smith, sp. nov.}

Plate JaII, figures 19-21.

Whorls high, robust, increasing rapidly in height, trapezoidal in cross section, deeply embracing. The umbilical shoulders are abruptly rounded, the flanks slightly convex, the ventral shoulders nearly rectangular. The venter is rather broad and surmounted by a strong rounded keel ridge. At maturity the surface is ornamented with weak dichotomous ribs and three rows of tubercles. The umbilical row is weak and numbers 14 to a revolution; the lateral row is much stronger, is situated one-third of the distance up the flanks, and numbers 12 to a revolution; the tubercles on the ventral shoulders are elongated obliquely forward, weaker than the lateral row, and number 23 to a revolution. The height of the whorl is slightly more than half the diameter of the shell, and the width is half the height. The width of the umbilicus is less than one-fourth of the diameter of the shell. The outer whorl embraces about twothirds of the inner and is indented by it to one-fourth of the height. The septa are ceratitic but could not be exposed sufficiently for illustration. Ceratites burclihardti resembles $C$. trinodosus and $C$. nexberryi, especially in youth, but at maturity has a broader venter and more angular shoulders. The ventral tubercles are much weaker than on $C$. neviberryi and the ribs are weaker. In its obsolescent sculpture $C$. burckhardti resembles $C$. cricki, but its ventral shoulders are more angular and its keel lower. 
The specific name is given in honor of Dr. Carlos Burckhardt, paleontologist of the Geological Survey of Mexico.

Horizon and locality.-Very rare in the Middle Triassic, Daonella dubia zone, Ceratites trinodosus subzone, of Fossil Hill, south fork of American Canyon, West Humboldt Range, Nev., associated with Ceratites trinodosus, C. humboldtensis, Nevallites whitneyi, Beyrichites rotelliformis, Sageceras gabbi, Daonella dubia, and other species.

\section{Ceratites (Paraceratites) clakike Smith, sp. nor.}

Plate XI, figures 15-23; Plate IıI, figures 1-11.

Involute, discoidal, laterally compressed. Whorls high, narrow, deeply embracing, and increasing rapidly in height. Sides flattened, ventral shoulders subangular, venter narrow with low keel ridge in the middle. The height of the whorl is about half the diameter of the shell, and the width is four-sevenths of the height. The width of the umbilicus is less than one-fourth of the diameter of the shell. The surface of the shell is ornamented with fine flexuous ribs and umbilical, lateral, and marginal tubercles. The umbilical and lateral tubercles are of equal number, about 12 to 14 to a revolution, and the marginal tubercles number about 24 to 30 to a revolution, the increase being caused by the bifurcation of most of the principal ribs on the marginal tubercle and the occasional intercalation of a secondary rib also bearing a marginal knot like those of the primaries. The outer whorl in its involution tonches but does not cover the lateral row of tubercles.

Dimensions of typical specimens of Ceratites clarkei.

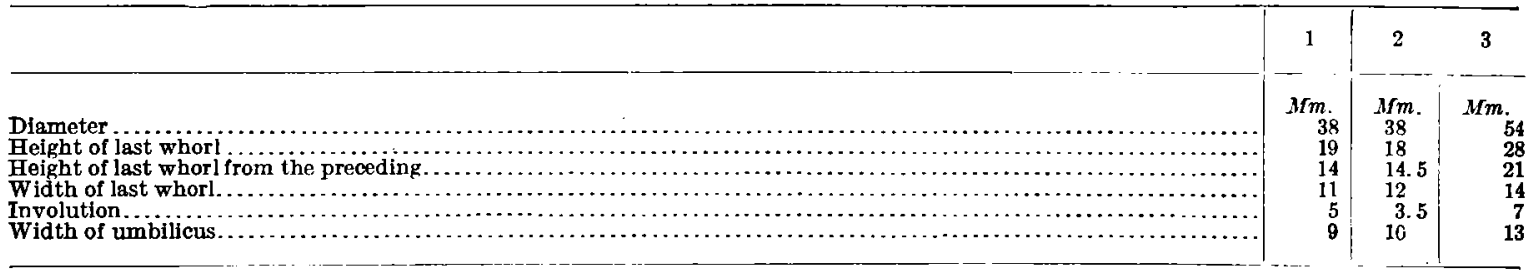

These dimensions (column 1 being those of the type specimen) show that with increasing size the umbilicus becomes relatively narrower, and the whorl higher in proportion to the diameter. The septa are ceratitic, with entire saddles and serrated lobes.

Ceratites clarke $i$ is very similar to $C$. trinodosus, with which it is associated, but differs in the more prominent keel, the greater compression of the whorl, narrower umbilicus, squarer shoulders, weaker ribs, and stronger tubercles. It is distinguished from $C$. brembanus Mojsisovics by the more compressed whorl, higher keel, narrower umbilicus, and weaker ribs. It is distinguished from $C$. hungaricus Mojsisovics by its greater involution, narrower umbilicus, and less numerous tubercles.

The members of the keeled group of Ceratites, or Paraceratites of Hyatt, are strikingly similar: and it would not be surprising if a larger series of specimens should show an intergradation of many so-called species. Probably also many species have been discriminated, and others confused, based upon stages of growth. Thus C. clarke $i$ at maturity greatly resembles the adolescent stage of $C$. cricki, whereas the adult stages of the two species have little resemblance.

The specific name is given in honor of Dr. John M. Clarke.

Horizon and locality.-Rather rare in the Middle Triassic Daonella dubia zone, Ceratites trinodosus subzone, on the divide between Troy Canyon and the south fork of American Canyon, 4 miles south of Fitting post office (formerly Foltz), West Humboldt Range, Nev., associated with Ceratites trinodosus, C. humboldtensis, Gymnotoceras blakei, Protrachyceras mecki, Vevadites whitneyi, Beyrichites rotelliformis, Daonella dubia, and other species. 
Ceratites (Paraceratites) newberry Smith, sp. nov.

Plate XL, figures 1-14.

Involute, discoidal, laterally compressed, with abruptly rounded umbilical shoulders, flattened sides, converging gently above, sharply defined angular ventral shoulders. Venter narrow, roof shaped, with a sharp ventral ridge or keel. Surface ornamented with umbilical lateral and marginal knots and with ribs bifurcating on the lateral knots and ending at the marginal tubercles.

The height of the whorl is half the diameter of the shell; the width is less than two-thirds of the height. The outer whorl embraces three-fifths of the inner whorl and is indented by it to one-fourth of the height. The septa are ceratitic, with rounded entire saddles.

This species in form and dimensions greatly resembles $C$. trinodosus, with which it is associated, but $C$. newberryi has a higher keel, fewer and coarser lateral knots, and becomes slightly more evolute and thicker with age. There are about 10 lateral and 24 marginal knots to a revolution. somewhat fewer than on $C$. trinodosus and $C$. clarkei.

Dimensions of the type specimen of Ceratites newberryi.

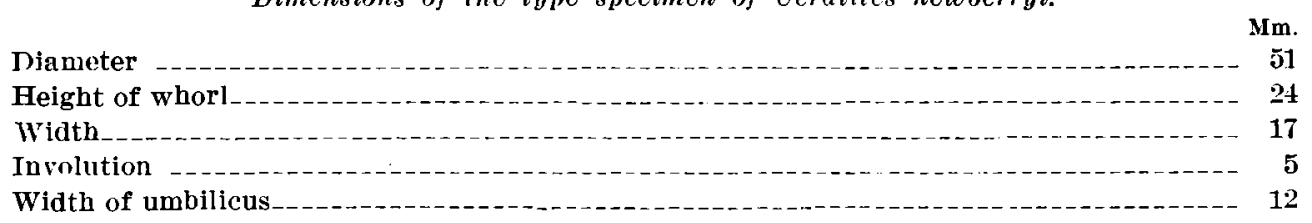

$C$. newberryi belongs to the group designated by Hyatt Paraceratites and shows the characters of this subgenus in a more pronounced degree than $C$.trinodosus, though less so than C. cricki.

The specific name is given in memory of Prof. J. S. Newberry.

Horizon and locality.-Rather common in the Middle Triassic, Daonella dubia zone, Ceratites trinodosus subzone, of Fossil Hill, south fork of American Canyon, West Humboldt Range, Nev., associated with Ceratites trinodosus, $C$. humboldtensis, Nevadites whitneyi, Beyrichites rotelliformis, Daonella dubia, and other species. It was also found in the same horizon at New Pass, Desatoya Mountains, Nev., from which locality the type specimen came.

Ceratites (Paraceratives) trinodosus Mojsisovics.

Plate XXXIX, figures 1-19; P'late LII, figures 12-18.

1882. Ceratites trinodosus, Mojsisovics, Die Cephalopoden der Mediterranen Triasprovinz: Abhandl. K.-k. geol. Reichsanstalt Wien, vol. 10, p. 29, Pl. VIII, ligs. 5, 6, †, 9; Pl. XXXVII, figs. 6 and 7 .

1896. Ceratites binodosus (not Hauer), Arthaber, Die Cephalopodenfauna der Reiflinger Kalke: Beitr. Pal. und Geol. Oesterreich-Ungarns und des Orients, vol. 10, p. 197, Pl. XXIII, fig. 1.

1896. Ceratites binodosus, Hauer, Beiträge zur Kenntniss der Cephalopoden aus der Trias von Bosnien, Part II : Denkschr. K. Akad. Wiss. Wien, vol. 63, p. 252.

1900. Ceratites trinodosus, Diener, Die Triadische Cephalopoden-Fauna der Schiechlinghöhe bei Hallstatt: Beitr. Pal. und Geol. Oesterreich-Cngarns und des Orients, rol. 10, 1. 5.

1904. Ceratites trinodosus, Milrtelli, Cefalopodi triasicidi Boljevici presso Vir nel Montenegro: Palæontographia Italica, vol. 10, p. 80, Pl. Y. Fig. $1 a-c$.

1906. Ceratites trinodosus, Arthaber, Die Alpine Trias des Mediterran-Gebietes: Lethen Geognostica, II. Theil, Das Mesozoicum, vol. 1, p. 271, Pl. XXXV, figs. 17 ate.

1907. Ceratites trinodosus, Diener, The fauna of the Himaliyan Muschelkalk: Himalayan fossils, rol. 5, Mem. No. 2, p. 48, Pl. III, fig. 5 (Mem. Geol, Survey India, Pal. Indica, 15th ser.).

Involute, discoidal, laterally compressed, with rather wide umbilicus and high whorls, increasing rapidly in height. Umbilical shoulders abruptly rounded, sides flattened, sloping gently to the sharply defined ventral shoulders. Venter raised in a median keel-like ridge. The surface is ornamented with numerous rather fine ribs that bifurcate on the middle of the 
flanks and end in fine knots on the ventral shoulders. Each rib usually begins in a fine umbilical knot, and the bifurcation of the ribs usually has a coarser lateral knot. At maturity the umbilical knots become weak, but the lateral and marginal knots become stronger. There are from 10 to 12 lateral knots and 20 to 30 marginal knots to a revolution, the number of marginals being at least twice as great as the laterals. The height of the whorl is slightly less than half the diameter of the shell, and the width is less than two-thirds of the height. The outer whorl embraces half the inner and is indented by it to nearly one-fourth of the height. The umbilicus is wide, being one-fourth of the diameter of the shell. The septa are ceratitic, the saddles being entire. There are four lobes distinctly visible, and a second small auxiliary stands just outside the involution, on the umbilical wall.

Ceratites trinodosus differs from $C$. binodosus in the greater number of lateral and marginal knots and in the wider umbilicus. It differs from Ceratites elegans Mojsisovics, with which it is associated in the Mediterranean region, in the more robust whorl and coarser sculpture. In America it is associated with several species with which it is closely allied, Ceratites cricki, Ceratites trojanus, and Ceratites vogdesi. From Ceratites cricki it is distinguished by the finer lateral knots, which stand in the middle of the flanks instead of some distance below the middle; by much more numerous marginal knots; by the more distinct shoulders; and by the much lower keel-like median ridge. It is distinguished from Ceratites trojanus by the finer and somewhat more numerous lateral knots, by the much more numerous and distinct marginal knots, and the greater development of the keel. The lateral knots on $C$. trojanus are two-thirds of the distance from the umbilicus to the shoulders, and at maturity they become very coarse, whereas the marginal knots become nearly obsolete.

Ceratites trinodosus is distinguished from $C$. vogdesi, which it resembles in youth, by the greater involution, narrower umbilicus, higher and more compressed whorl, and by the more numerous and finer lateral and marginal knots.

The group to which Ceratites trinodosus belongs, that of $C$. elegans, is very common in the Anisic horizon of the Middle Triassic. in the Mediterranean region and in America, and is represented in India by three species, $C$. trinodosus Mojsisovics, $C$. himalayanus Blanford, and C. thuillieri Oppel. This group is most common in the Bosnic substage, zone of Ceratites trinodosus, but some species are also found in the lower Ladinic, zone of Trachyceras reitzi. Hyatt $^{1}$ took $C$. elegans as the type of a new but undescribed genus, Paraceratites, and figured $C$. trinodosus as a typical form under this genus. But the relations to the normal nodose Ceratites seem to be too close to warrant the separation as an independent genus.

Dimensions of a typical specimen of Ceratites trinodosus.

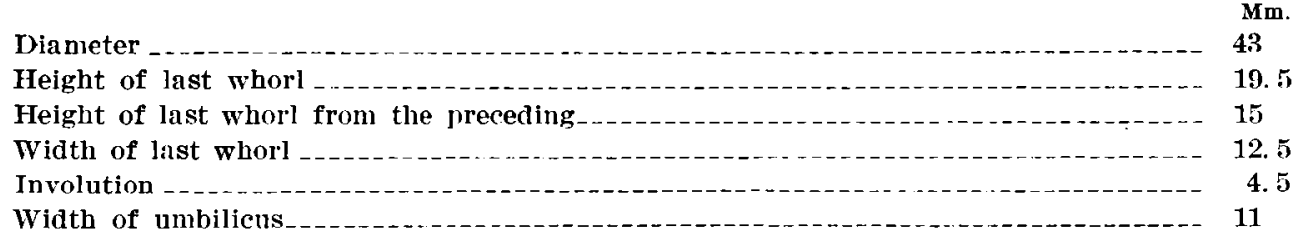

These dimensions are identical with those of the specimens from the Mediterranean region.

Ceratites trinodosus is associated with two very nearly related species of the same group, $C$. clarkei Smith and $C$. newberryi Smith, and is intermediate between them. It is less robust than $C$. newberryi and has finer sculpture and less pronounced keel; it is more robust than $C$. clarkei and has coarser sculpture and less compressed whorls. It is possible that with a larger series of specimens all three species would intergrade.

Horizon and locality.-Several specimens of Ceratites trinodosus Mojsisovics were found by the writer in the Middle Triassic, Daonella dubia zone, Ceratites trinodosus subzone, on Fossil Hill, on the divide between Troy Canyon and the south fork of American Canyon, 4

1 Cephalopoda: Text-book of Palæontology by K. A. ron Zittel (trauslated by C. R. Eastman), 1090, p. 559. $16279^{\circ}-$ No. $83-14-7$ 
miles south of Fitting post office (formerly Foltz), West Humboldt Range, Nev. They were associated with Ceratites humboldtensis, Gymnotoceras blakei, Beyrichites rotelliformis, Nevadites whitneyi, Protrachyceras meeli, Sageceras gabbi, Longobardites nevadanus, Daonella dubia, and a large number of other forms characteristic of this horizon. Ceratites trinodosus was first found in the Mediterranean region, in the Bosnic substage of the Middle Triassic, associated with a fauna closely allied to that of Nevada.

\section{Ceratites (Par.iceratites) wardi Smith, sp. nov.}

Plate LIII, figures 4-8.

Form involute, discoidal, laterally compressed. Whorls high, narrow, deeply embracing; sides flattened, with abruptly rounded umbilical shoulders and subangular ventral shoulders. Venter narrow, with very high and rounded keel. The umbilicus is rather narrow, being slightly more than one-fourth of the diameter of the shell. The surface is ornamented with very weak dichotomous ribs, and three rows of tubercles, all extremely fine. The umbilical row numbers about 18 to a revolution; the lateral row, which is situated one-third of the distance up the sides, numbers about 20 ; and the row on the ventral shoulders numbers about 30 to a revolution. The height of the whorl is about half the diameter of the shell and the width about two-thirds of the height. The outer whorl embraces about two-thirds of the inner. The septa are ceratitic, as on all the members of this group, but could not be exposed sufficiently for illustration.

\[ \text { Dimensions of the type specimen of Ceratites vardi. } \]
Diameter
Ieight of last whorl
Height of last whorl from the preceding
Width of last whorl
Involution -
Width of monbilicus.

Ceratites wardi resembles $C$. clarkei but is more compressed, has higher keel, weaker sculpture, and more numerous tubercles. It is more compressed than $C$. trinodosus and has more angular shoulders and higher keel. It is more compressed than $C$. brembanus and has weaker ribs, higher keel, and narrower umbilicus. $C$. wardi is nearest to $C$. hungaricus Mojsisovics but has narrower umbilicus and fewer lateral and marginal tubercles.

The specific name is given in memory of Prof. L. F. Ward.

Horizon and locality.-Very rare in the Middle Triassic, Daonella dubia zone, Ceratites trinodosus subzone, of Fossil Hill, south fork of American Canyon, 4 miles south of Fitting post office (formerly Foltz), West Humboldt Range, Nev.; associated with Ceratites trinodosus, C. humboldtensis, Nevadites whitneyi, Protrachyceras meeki. Beyrichites rotelliformis, Daonella dubia, and other species.

\section{Group of Ceratites bosnensis.}

Ceratites ibecheri Smith, sp. nov.

Plate XIIII, figures $15-26$

Form slender, laterally compressed, evolute, rather widely umbilicate. Whorls higher than wide, sides flattened, rentral shoulders square, venter narrow and flat without any trace of the keel ridge. Surface ornamented with fine but distinct bifurcating ribs and four rows of small tubercles. The ribs start out from umbilical tubercles, branch low down on the flanks at a second row, form in distinct knots on the ventral shoulders, and are continued obliquely forward on the margins of the venter, alternating on the opposite sides. 
The height of the whorl is two-fifths of the diameter of the shell and the width is fourfifths of the height. The outer whorl embraces only one-third of the inner and is but slightly indented by it. The width of the umbilicus is less than one-third of the diameter of the shell. The septa are ceratitic but could not be prepared sufficiently for illustration.

\[ \text { Dimensions of the type specimen of Ceratites beecheri. } \]
Diameter
Height of last whorl
Height of last whorl from the preceding
Width of last whorl
Involution
Width of umbilicus.

In the adolescent stage $C$. beecheri, like $C$. haguei, shows a rather strong resemblance to Keyserlingites. Ceratites beccheri belongs in the group of $C$. bosnensis Hauer, transitional from Ceratites to the Trachyceratea. It is related to $C$. haguei Smith but differs in its greater compression and weaker ribs and tubercles.

The specific name is given in memory of Prof. C. E. Beecher.

Horizon and locality.-Very rare in the Middle Triassic, Daonella dubia zone, Ceratites trinodosus subzone, on the divide between Troy Canyon and the south fork of American Canyon, 1. miles south of Fitting post office (formerly Foltz), West Humboldt Range, Nev., associated with Ceratites trinodosus, C. humboldtensis, Gymnotoceras blakei, Protrachyceras meeki, Nevadites whitneyi, Sageceras gabbi, Daonella dubia, and other species.

Ceratites crassicornu Smith, sp. nov.

Plate XLIII, figures 11-14.

Form robust, high whorled, moderately involute, somewhat compressed laterally, rather widely umbilicate. Sides somewhat flattened, ventral shoulders square, venter rather narrow and flattened, without a keel. The surface is ornamented with coarse bifurcating ribs and with three rows of strong tubercles, one on the umbilical shoulders, a second on the flanks high up toward the ventral shoulders, and a third at the ends of the ribs on the ventral margins. Between the principal ribs that start from the umbilical tubercles there are often two intercalary ribs that begin near the ventral shoulders and end in tubercles on the margins, as do the primary ribs. There are about 10 of the coarse lateral ribs and spines to 34 marginal ribs and tubercles to a revolution. The umbilical knots are of the same number as the laterals, but much weaker. The septa are unknown.

Dimensions of the type specimen of Ceratites crassicornu.

Dimensions of the type specimen of Ceratites crassicornu.
Diameter-ard
Height of last whorl
Height of last whorl from the preceding
Width of last whorl
Involution
Width of umbilicus

Ceratites crassicornu belongs to the group of $C$. bosnensis Hauer, which is transitional from Ceratites to Nevadites. It differs from $C$. beecheri Smith, also of this group, in its more robust whorl and stronger ribs and spines. From $C$. haguei Smith it differs in its broader whorl and fewer and coarser ribs and tubercles. In the adolescent stage $C$. haguei has a strong resemblance to Keyserlingites, which may partly confirm the theory of Mojsisovics that Ceratites descended from the subrobusti.

Horizon and locality.-Very rare in the Middle Triassic, Daonella dubia zone, Ceratites trinodosus subzone, on the divide between Troy Canyon and the south fork of American Canyon, 
4 miles south of Fitting post office (formely Foltz), West Humboldt Range, Nev., associated with Ceratites trinodosus, C. humboldtensis, Gymnotoceras blakei, Protrachyceras meeki, Nevadites whitneyi, Beyrichites rotelliformis, Daonella dubia, and other species.

\section{Ceratites ecarinatus Hauer.}

Plate XLIV, figures 1-is.

1896. Ceratites ecarinatus, Hauer, Beiträge zur Kenntniss der Cephalopoden aus der Trias von Bosnien, Part II : Denkschr. K. Akad. Wiss. Wien, vol. 63, p. 257, Pl. VIII, figs. 7-10.

1903. Ceratites ecarinatus, Arthaber, Neue Funde in den Werfener Schichten und in IIuschelkalke des südlichen Bakony: Resultate der wissenschaftlichen Erforschung des Balatonsees, vol. 1, p. 23, Pl. I, figs. $4 a-b$.

Form slender, evolute, whorls low and increasing slowly in height, little embracing and little indented by the inner whorls; cross section subquadratic, sides convex, with distinct subangular shoulders. Venter flattened and rather narrow, without a central keel ridge. Umbilicus wide. Surface ornamented with strong ribs and three rows of short stout spines or tubercles, one above the umbilical shoulders, one on the ventral shoulders, and a third on the margins of the venter. There are from 10 to 12 of the lateral ribs and tubercles to a revolution, and about 20 on the ventral border. The septa are ceratitic, with 4 external serrated lobes. The height of the whorl is one-third of the diameter of the shell, and the width is nearly equal to the height. The width of the umbilicus is more than one-third of the diameter of the shell.

The specimens from Nevada agree closely with the figures and descriptions of Hauer and Arthaber of specimens from the Mediterranean region, and as the accompanying faunas are very closely allied, in part identical, there is no reason to doubt the specific identity.

Horizon and locality.-Rare in the Middle Triassic, Daonella dubia zone, Ceratites trinodosus subzone, on the divide between Troy Canyon and the south fork of American Canyon, 4 miles south of Fitting post office (formerly Foltz), West Humboldt Range, Nev., associated with Ceratites trinodosus, C. humboldtensis, Protrachyceras americanum, Nevadites whitneyi, Sageceras gabbi, Daonella dubia, and other species.

\section{Ceratites fissicostatus Hauer.}

Plate IIII, figures 1-3.

1896. Ceratites fissicostatus, Hauer, Beiträge zur Kenntniss der Cephalopoden aus der Trias von Bosnien, Part II : Denkschr. K. Akad. Wiss. Wien, vol. 65, p. 255, Pl. VII, figs. 1-3.

Form moderately robust and evolute. Whorls low, broad, subrectangular in cross section, with prominent ventral shoulders, flattened sides, and broad venter, with low ventral keel. The height of the whorl is about three-eighths of the diameter of the shell, and the width is equal to the height. The width of the umbilicus is about three-eighths of the diameter of the shell. The outer whorl embraces three-fifths of the inner, and is inclented by it to one-fifth of the height.

The surface is ornamented with rather strong lateral ribs, and weak tubercles. The ribs begin on umbilical tubercles, develop weak spines in the middle of the flanks, and end in weak spines on the ventral shoulders. A few of the ribs bifurcate on the lateral tubercles. There are about 13 of the umbilical and lateral tubercles to a revolution and 19 on the ventral shoulders. The septa are not visible on the American specimen. The specimens from Nevada agree very closely with Hauer's figures and descriptions of specimens from the Middle Triassic from Han Bulog in Bosnia.

Ceratites fissicostatus resembles $C$. ecarinatus Hauer, with which it is associated in Bosnia and Nevada, but differs from it in possessing a keel and in the broader venter. From $C$. haguei it differs in its more robust whorl, greater depression, and fewer spines.

Horizon and locality.-Very rare in the Middle Triassic, Daonella dubia zone, Ceratites trinodosus subzone, on Fossil Hill, south fork of American Canyon, 4 miles south of Fitting 
post office (formerly Foltz), West Humboldt Range, Nev., associated with Ceratites trinodosus, C. humboldtensis, Eutomoceras laubei, Nevadites whitneyi, Protrachyceras meeli, Daonella dubia, etc. It was first found in the same horizon in Bosnia associated with a fauna very similar to that of Nevada.

Ceratites haguei Smith, sp. nov.

Plate XLII, figures 1-5; Plate XLIII, figures 1-10.

Form moderately evolute, laterally compressed, with wide umbilicus, flattened sides, and subrectangular cross sections higher than wide. Umbilical shoulders abruptly rounded, ventral shoulders rather angular, venter narrow and flattened. Surface ornamented with coarse ribs, provided with umbilical, lateral, and marginal spines. The marginal spines project above the ventral shoulders, alternating on the opposite sides, and thus give a strong resemblance to the Trachyceratea. The height of the whorl is two-fifths of the diameter of the shell, and the width is three-fifths of the height. The width of the umbilicus is one-third of the diameter of the shell.

Ceratites haguei resembles $C$. kuvera Diener ${ }^{1}$ but has strong spines instead of very weak knots on the ribs. It is also allied to $C$. bosnensis Hauer from the Muschelkalk of Bosnia, but has a more rudimentary keel ridge, shorter spines, and is more involute and less robust. It also resembles $C$. ellipticus Hauer, but is more compressed laterally and has more numerous spines. Ceratites haguei Smith, C. beecheri Smith, C. crassicornu Smith, C. ecarinatus Hauer, and $C$. fissicostatus Hauer all belong in the group of Ceratites bosnensis, which Arthaber ${ }^{2}$ says is transitional from Ceratites to Trachyceras. It seems also that Diener ${ }^{3}$ shares this view, for he states that Trachyceras is probably a polyphyletic genus, derived in part from Balatonites and in part from the group of Ceratites bosnensis. A further study of more complete material of this group will probably show the propriety of setting it aside as a subgenus under Ceratites, as has been done by $G$. von Arthaber, under the name Kellnerites, which group is insufficiently characterized.

The type specimen, which is somewhat distorted by pressure, has the following dimensions:

Dimensions of the type specimen of Ceratites haguei.

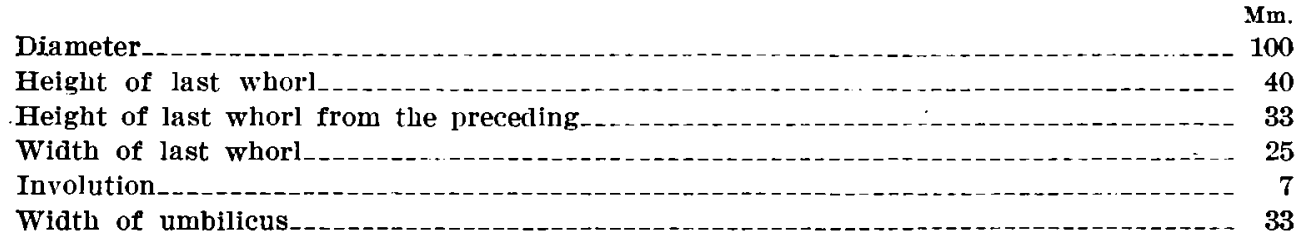

The specific name is given in honor of Mr. Arnold Hague.

In the adolescent stage $C$. haguei resembles Keyserlingites, which makes it probable that at least this group descended from the subrobusti. It does not prove, however, that the typical nodosi had this origin, for the resemblance of $C$. haguei to the nodosi may be purely a convergence phenomenon.

Horizon and locality.-Middle Triassic, Daonella dubia zone, Ceratites trinodosus subzone, on the divide between Troy Canyon and the south fork of American Canyon, 4 miles south of Fitting past office (formerly Foltz), West Humboldt Range, Nev., associated with Daonella dubia, Ceratites humboldtensis, C. trinodosus, Gymnotoceras blakei, Acrochordiceras hyatti, and other species.

1 Cephalopoda of the Muschelkalk: Ilimalayan fosslls, vol, 2, pt. 2, Pl. V, figs. $2 a-c$ (Mem. Geol. Survey India, Pal. Indica, 13th ser.), 1895.

2 Neue Funde in den Werfener Schichten und im Muschelkalke des sïdlichen Bakony : Resultate der wissenschaftlichen Erforschung des Balatonsces, vol. 1, pt. 1, 1903, p. 24.

antwurf einer Systematik der Ceratitiden des Muschelkalkes: Sitzungsber. K. Akad. Wiss. Wien, vol. 114, pt. 2. 1905 , p. 804 . 


\section{Group of Ceratites humboldtensis.}

Ceratites cornotus Smith, sp. nov.

Plate LXII, figures 1-17. •

Form moderately evolute, robust. Whorls low, broad, not deeply embracing. Umbilical shoulders abruptly rounded, sides convex, ventral shoulders square, venter broad and flattened, but with a weak central ridge, especially in youth. Surface ornamented with strong ribs that bifurcate in the middle of the flanks and also with intercalary ribs. The ribs are armed with strong spines at the point of bifurcation on the flanks, and all ribs end in strong knots on the ventral shoulders. The cross section of the whorl is trapezoidal. The height of the whorl is less than half the diameter of the shell, and the width is more than three-fourths of the height. The width of the umbilicus is less than one-fourth of the diameter of the shell. The septa are like those of $C$. humboldtensis, with serrated lobes and brachyphylloid saddles.

The length of the body chamber is more than three-fourths of a revolution, which is usual with members of this group. If this character should turn out to be constant it would serve as a distinguishing mark to separate the members of the group of $C$. humboldtensis from that of $C$. nodosi, in which the length of the body chamber is said to be only half a revolution.

Dimensions of the type specimen of Ceratites cornutus.

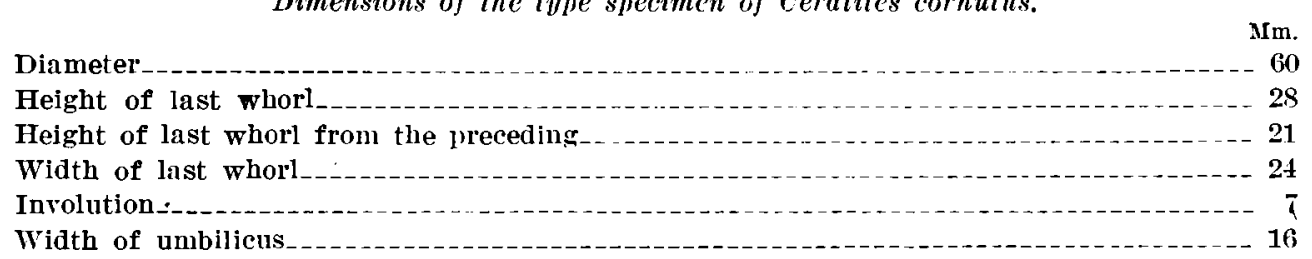

Ceratites cornutus is closely allied with $C$. humboldtensis $\mathrm{Hyatt}$ and Smith but has a broader whorl, flatter venter, weaker ventral ridge, and much stronger lateral spines and ventral tubercles. There are 10 lateral spines and 24 marginal knots. The lateral spines and the pronounced development of the nodose ventral shoulders appear at an earlier stage of growth than they do on $C$. humboldtensis. In this respect it agrees with $C$. emmonsi but differs from that species in its more robust whorl and stronger spines. C. cornutus is most closely related to C. spinifer, from which it is distinguished by its broader venter, more robust whorl, narrow umbilicus, and more complex septa. Up to the diameter of 14 millimeters the whorl is rounded and the form evolute. with simple ribs. At this stage the shell corresponds to Danubites. Shortly after this the shoulders begin to develop and the resemblance to Ceratites is seen. In this species there is no pronounced Gymnotoceras stage, as the lateral knots begin to form at the diameter of about 20 millimeters. The acceleration of development of $C$. cornutus is shown by the early age at which the indentation of the saddles appears; at the diameter of 30 millimeters the saddles are already brachyphylloid.

Horizon and locality.-Common in the Middle Triassic, Daonella dubia zone, Ceratites trinodosus subzone, on the diride between Troy Canyon and the south fork of American Canyon, 4 miles south of Fitting post office (formerly Foltz), West Humboldt Range, Nev., from which locality the type came. It was also found in the same horizon in the north fork of Cottonwood Canyon, in the same range. It was associated with Ceratites trinodosus, C. humboldtensis, Gymnotoceras blakei, Protrachyceras meeki, Nevadites whitneyi, Beyrichites rotelliformis, Daonella dubia, and other species.

\section{Ceratites emmonsi Smith, sp. nov.}

Plate I.X, figures 13-21.

Form evolute, with wide umbilicus. Low whorl, little embracing. Sides converging toward the venter; ventral shoulders angular, venter rather narrow, with raised central keel ridge. Surface ornamented with strong ribs that bifurcate on lateral spines and end in sharp knots 
on the ventral shoulders. There are 10 lateral spines and 24 marginals to a revolution. The umbilical knots are very weak but more numerous than the laterals. The outer whorl embraces three-fifths of the inner and is indented by it to one-fifth of the height. The largest specimen found had a diameter of 51 millimeters, with height of the outer whorl 24 millimeters, width 17 millimeters, and width of umbilicus 12 millimeters.

Ceratites emmonsi is closely allied to C. humboldtensis but is more compressed laterally, more evolute, has square shoulders and stronger spines. It differs from $C$. cornutus in the greater compression of the whorl and greater evolution. It is nearest to $C$. spinifer but differs in its more compressed whorl, less development of the spine, flatter sides, and narrower venter.

The specific name is given in honor of Mr. S. F. Emmons.

Horizon and locality.-Rare in the Middle Triassic, Daonella dubia zone, Ceratites trinodosus subzone. of Fossil Hill, south fork of American Canyon, West Humboldt Range, Nev., associated with Ceratites trinodosus, C. humboldtensis, Gymnotoceras blakei, Nevadites whitneyi, Sageceras gabbi, Daonella dubia, and other species.

\section{Ceratites incmoldensis Hyatt and Smith.}

Plate VII, figures 1-23; Plate I.XI, figures 1-15.

1905. Ceratites humboldtensis, Hyatt and Smith, The Triassic cephalopod genera of America: Prof. Paper U. S. Geol. Survey No. 40. p. 170, Pl. LVII, figs. 1-23.

The original description is as follows:

Moderately involute, deeply embracing, the outer whorl concealing about three-fifths of the inner and being indented to about one-fifth of its beight by it. Whorl of molerate height, nearly one-half of the diameter of the shell, and the width is four-fifths of the height. Greatest width at a point one-third of the distance above the base of the whorl. Cross section trapezoidal. Sides convex, widening to the lateral row of knots, then sloping steeply to the square abdominil shoulders. Venter broad and flattened, but with a low central ridge. Width of the venter one-half of the height of the whorl. Imbilical shoulders abrupt, inner slope vertical. Umbilicus wide and deep, the width being one-fourth of the dilmeter of the shell.

Surface ornamented with coarse ribs that start from the umbilical shoulders without distinct umbilical knots, branch at the strong lateril knots at one-third of the height of the whorl, then bend gently forward to the abdominal shoulders, where they end in strong marginal knots. At first these marginal knots lie opposite each other, but in old age they occuny alternate positions. Some of the ribs do not bifurcate and have no literal knots, but there is no regularity in the alternation, about every third rib being single. The full length of the body chamber could not be determined, but it is at least two-thirds of a revolution.

The septa are ceratitic but slightly brachyplylloid, the saddles being wavy and the principal lobes serratel. The external lobe is divided by a short, narrow siphonal notch into two short branches. The first lateral lobe. which lies just below the shoulder, is much wider and longer; the second lateral lobe is about one-half as large as the first and also serrated. These are followed by three small auxiliary lobes on the umbilical shoulder. The antisiphonal lobe is long, flanked by two internal laterals on each side. The external saddle lies on the abdominal shoulder, tlie first lateral saddle lies in the middle of the flank. and the second lateral lies on the row of lateral knots.

The foregoing description applies only to the mature shell. The young stages described and figured were broken out of large characteristic specimens, to avoid the danger of confusion with the other numerous species of Ceratites with which $C$. humboldtensis is associated.

The earliest stage obtained was 4.5 millimeters in diameter; it is evolute, with depressed broad, half-moon-shaped whorls, wide umbilicus, and surface ornamented only with a few straight umbilical ribs. This stage resembles Danubites.

At a diameter of 8 millimeters the whorl is as high as broad, the sides begin to flatten, and the ribs are much more numerous, still single, but they curve slightly at the round ventral shoulders. This stage is already adolescent and resembles Dinarites.

At 13 millimeters the flanks are differentiated in shape and sculpture from the slightly flattened venter. The ribs show the beginning of bifurcation and form incipient marginal knots at their ends on the shoulders.

At 18 millimeters the marginal knots become strong, the lateral knots begin to be distinct, and the ventral ridge begins to show. The shell at this stage is broader proportionately than at maturity; the umbilicus is wider, being one-third of the diameter. 
At 28 millimeters the whorl has become higher than wide, and the marginal knots are as distinct as at maturity. The lateral sculpture is not yet so rough as it becomes later, and this may be considered as marking the end of the adolescent stage.

At 33 millimeters the sculpture has taken on mature characters, although the saddles are still rounded and entire. This is considered as the beginning of maturity.

Ceratites humboldtensis has some resemblance to C. brembanus Mojsisovics ${ }^{1}$ of the Alpine Muschelkalk, but differs from that species in its more robust whorl and coarser lateral sculpture, and in lacking distinct umbilical knots. From C.trinodosus Mojsisovics, of the same group, it differs in its greater evolution, coarser sculpture, and more robust whorl.

Its nearest European relative is Ceratites subnodosus Mojsisovics, ${ }^{2}$ from which it differs in its fainter umbilical and stronger lateral knots. The ribs, shape of the whorl, sculpture, and involution are the same in both species. The associations of both species are virtually the same, and Ceratites humboldtensis may be considered as the American representative of $C$. subnodosus.

Horizon and locality.-Middle Triassic, Daonella zone, on the divide between Troy Canyon and the south fork of American Canyon, on Fossil Hill, 4 miles south of Fitting post office (formerly Foltz), West Humboldt Range, Nev., associated with Ceratites trinodosus, C. occidentalis. Nevadites whitneyi, Beyrichites rotelliformis, Longobardites nevadanus, Gymnotoceras blakei, Eutomoceras laubei, Sageceras gabbi, Acrochordiceras hyatti, Daonella dubia, and many other forms characteristic of the Middle Triassic. Ceratites humboldtensis was found by the writer to be very common at the above-mentioned locality, and also in Cottonwood Canyon, near the "Lucky Dog" mine, West Humboldt Range, in the same association. The horizon might very appropriately be named after this characteristic species. The writer also found at Silverthorns Ferry on Pit River, Shasta County, Cal., some poorly preserved Ceratites that probably belong to this species.

\section{Ceratites karpinsky Smith, sp. nov.}

Plate XLIV, figures 4-20.

Rather involute, laterally compressed. Whorls subrectangular in cross section, with flattened sides and broad flattened venter, rather deeply embracing, and indented to one-fourth of the height by the inner volutions. The height of the whorl is nearly half the diameter of the shell, and the width is four-fifths of the height. The umbilicus is wide, being one-fourth of the diameter of the shell.

The surface is ornamented with rather coarse ribs that fork on the sides and end on the square ventral shoulders in about 24 rather strong knots to a revolution. Before maturity there are about 12 lateral knots to a revolution, but these disappear when the shell is full grown at the diameter of 35 millimeters. In the early adolescent stage, diameter 7 millimeters, the form and sculpture are like Danubites. In later youth the whorl is rounded, without square ventral shoulders, and the surface is ornamented with fine lateral ribs and a faint suggestion of a keel, as in Gymnotoceras. At the diameter of 9 millimeters the ribs begin to fork. At the diameter of 13 millimeters the shoulders begin to develop and there are knots at the ends of the ribs on the shoulders. At this time the venter begins to flatten and the youthful ventral ridge disappears. At the diameter of 16 millimeters the lateral knots form, and the whorl takes on its mature character. At the diameter of 30 millimeters the lateral knots become obsolete, whereas those at the ventral ends of the ribs become constantly stronger. In growth the umbilicus becomes constantly narrower and the whorl higher. The involution takes place outside of the lateral tubercles, which are thus exposed in the umbilical area.

${ }^{1}$ Die Cephalopoden der Mediterranen Triasprovinz: Abhandl. K.-k. geol. Reichsanstalt Wien, vol. 10, 1882, p. 38, Pl. $\mathrm{X}$, figs. $1-4$.

${ }^{2}$ Idem, p. 33, Pl. X, figs. 9-11. 
Dimensions of the type specimen of Ceratites karpinskyi.

$\begin{array}{ll}\text { Diameter } & \mathbf{M m} \\ \text { Height of last whorl } & \mathbf{4 2} \\ \text { Height of last whorl from the precediug } & \\ \text { Width of last whorl } & \\ \text { Involution } & \end{array}$

Ceratites karpinskyi resembles $C$. occidentalis, from which it differs in its more robust whorls, broader venter, fewer and stronger lateral ribs, and stronger lateral and shoulder knots. It also has some resemblance to Ceratites trinodosus Mojsisovics, but differs from that species in its square cross section, lower whorl, broader and flatter venter, in the almost total absence of lateral knots at maturity, and in the stronger knots on the ventral shoulders.

At maturity Ceratites karpinslyi resembles the nodosi but in youth resembles first Danubites and later Gymnotoceras. If these resemblances indicate genetic relationships, then this species must be placed in the group of $C$. humboldtensis and the similarity to the nodosi ascribed to convergence.

The specific name is given in honor of Dr. A. Karpinsky, whose work on the phylogeny of Paleozoic cephalopods has become a standard for all students of this group.

Horizon and locality.-Ceratites karpinskyi Smith is quite common in the Middle Triassic, Ceratites trinodosus subzone, on Fossil Hill, on the divide between Troy Canyon and the south fork of American Canyon, 4 miles south of Fitting post office (formerly Foltz), West Humboldt Range, Nev. It was associated with Ceratites trinodosus, C. humboldtensis, Gymnotoceras blakei, Eutomoceras laubei, Acrochordiceras hyatti, Beyrichites rotelliformis, Sageceras gabbi, Nevadites whitneyi, $N$. hyatti, Protrachyceras meeki, Daonella dubia, and many other characteristic forms.

Ceratites nevadands Mojsisovics.

Plate XV, figures 6 and $6 a$; Plate LXIV, figures 1-14; Plate LXV, figures 1-13.

1888. Ceratites nevadanus, Mojsisovies, Ceber einige japanische Trias-Fossilien : Beitr. Pal. und Geol. Oesterreich-Lngarns und des Orients, rol. 6, 1888, p. 168.

1877. Gymnotoceras blakei (in part), Meek, Palæontology: U. S. Geol. Expl. 40th Par., vol. 4, Pl. XI, fig. 6 (not P1. X, figs. 10a-r).

Form robust, involute, narrowly umbilicate. Whorls somewhat wider than high, deeply embracing, cross section subquadratic, sides flattened-convex, shoulders abruptly rounded, venter broad and flat, without a trace of a ventral keel. The height of the whorl is about half the diameter of the shell, and the width is slightly greater than the height. The outer whor] embraces about two-thirds of the inner. The width of the umbilicus is about one-third of the diameter of the shell. The surface is ornamented with coarse bifurcating lateral ribs, strong lateral knots, and weaker marginal tubercles at the ends of the ribs. The lateral knots and ribs number about 10 to a revolution and the marginals about 28 . The septa are ceratitic, the saddles being rounded and entire.

In early youth, up to a diameter of nearly 10 millimeters, the form is like Danubites. About this time the septa becomes ceratitic and the ribs begin to fork, giving a strong resemblance to Gymnotoceras. At about 15 millimeters the shoulders become distinct, the shoulder tubercles begin to develop, and the shell has reached the Ceratites stage. The lateral tubercles become distinct at the diameter of about 30 millimeters and the shell has entered the mature stage.

Ceratites nevadlanus was included by Meek in Gymnotoceras blakei Gabb but was separated by Mojsisovies from that species. It is closely allied with $C$. humboldtensis Hyatt and Smith but differs in its more robust form, broader and flatter venter, stronger ribs and knots, and absence of ventral keel. These characters persist even in the adolescent stages. From $C$. 
cornutus Smith it differs in the weaker spines and ribs, lacking the strong ventral keel ridge, and in its weaker and more rounded ventral shoulders. Meek, who assigned this species to Gymnotoceras blakei, supposed that the flattening of the venter was an old-age character. But even the young of Ceratites nevadanus are robust and flattened, whereas those of G. blakei are invariably slender and laterally compressed. There is not the slightest resemblance between these two species at any stage of growth.

Horizon and locality.-Common in the Middle Triassic, Daonella dubia zone, Ceratites trinodosus subzone, of Cottonwood Canyon and the divide between Troy Canyon and the south fork of American Canyon, West Humboldt Range, Nev., associated with Ceratites trinodosus, C. humboldtensis, Gymnotoceras blakei, Protrachyceras meeli, Nevadites whitneyi, Beyrichites rotelliformis, Daonella dubia, and other species.

Ceratites pilatus Smith, sp. nov.

Plate XIVI, figures 1-16: Plate IXXXIX, figures 10-13.

Form rather involute, discoidal, laterally compressed. Whorls high and increasing rapidly in height, deeply embracing but not deeply indented by the inner whorls. Sides gently convex, with the greatest thickness in the middle of the flanks. Venter broad and flattened but gently raised in the middle. Ventral shoulders nearly rectangular, umbilical shoulders angular but not so square as the ventral. Umbilicus moderately wide and deep.

The height of the whorl is nearly half the diameter of the shell, and the width is threefourths of the height. The width of the umbilicus is less than one-fourth of the diameter of the shell.

The surface is ornamented with strong, sigmoidal, dichotomous ribs that start from the umbilical shoulder without knots, branch on low knots about half the distance up the flanks, and end in strong elongate tubercles on. the ventral shoulders. There are about 12 umbilical ribs to 28 marginal tubercles. The weak lateral knots are irregular in number, not all the lateral ribs forming them. There are also a few intercalary ribs beginning in the middle of the flanks, ending in marginal knots like those of the primary ribs. The septa are ceratitic, with four serrated lobes and very weakly brachyphylloid saddles. The body chamber is nearly three-fourths of a revolution in length.

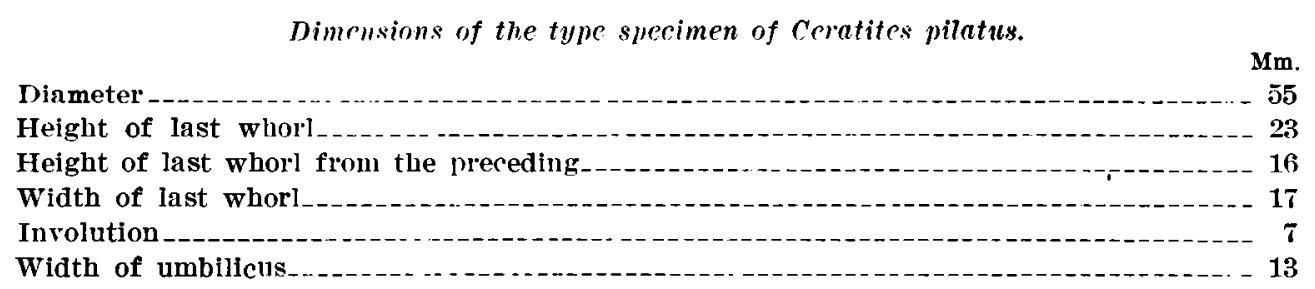

Ceratites pilatus greatly resembles $C$. occidentalis but is more evolute, robust. has stronger ribs and tubercles, and also differs in possessing the lateral knots. It also resembles $C$. humboldtensis but is more compressed and has weaker sculpture. C. pilatus is closely related to $C$. karpinskyi but differs from that species in the weaker shoulder knots, more prominent lateral tubercles, and more highly arched venter. The young, up to a diameter of 9 millimeters, resemble Gymnotoceras; then the shoulders begin to form, and at 15 millimeters it is already a typical Ceratites.

Horizon and locality.-Common in the Middle Triassic, Daonella dubia zone, Ceratites trincdosus subzone, of Fossil Hill, on the divide between Troy Canyon and the south fork of American Canyon, 4 miles south of Fitting post office (formerly Foltz), West Fumboldt Range, Nev., associated with Ceratites trinodosus, Gymnotoceras blakei, Nevadites whitneyi, Sageceras gabbi, Daonella dubia, and other species. 
Ceratites Spinifer Smith, sp. nov.

Plate IIX, figures 1-10; Plate I.X, figures 1-12.

Form robust, moderately evolute. Whorls low, broad, and not deeply embracing. Umbilicus rather wide. Umbilical shoulders abruptly rounded, sides ventricose, venter broad and flattened, with square ventral shoulders. The height of the whorl is about two-fifths of the diameter of the shell, and the width is slightly less than the height. The outer whorl envelops two-thirds of the inner and is indented by it to one-fourth of the height. The width of the umbilicus is one-third of the diameter of the shell. The surface is ornamented with strong ribs alternately bifurcating at long lateral spines and ending on the angular ventral shoulders, forming strong marginal knots. There is no keel on the venter but a very weak median ridge. The septa are ceratitic and not brachyphylloid as on $C$. humboldtensis.

\[ \text { Dimensions of the type specimen of Ceratitcs spinifer. } \]
Diameter
Height of last whorl
Height of last whorl from the preceding.
Width of last whorl.
Involution
Width of umbilicus.

Ceratites spinifer is in appearance a typical nodose ceratite, like the group of $C$. nodosus; but this resemblance is probably due to convergence, for the young stages of the nodosus group, so far as they are known, are like the Meekoceratidx, whereas $C$. spinifer and all its kindred of the group of $C$. humboldtensis in the adolescent stage are like Gymnotoceras. It is probable that the direct ancestor of Gymnotoceras was Danubites, and no such stage is known in the history of the nodosi. The more remote ancestor of both the nodosi and the group of $C$. humboldtensis was probably some simple member of the Meekoceratidx, such as Paralecanites. At any rate the resemblance of the two groups is not due to heredity from nodose ancestors nor can it be due to reversion by atarism to such ancestors. This seems to be a case of parallel development in related stocks, defined but not explained by the name convergence.

The ribs begin just above the umbilical shoulders and form the lateral knots about onethird of the way up the sides. There are 10 of the lateral spines and 28 of the marginal knots to a revolution, the excess of the marginals being caused by the intercalated ribs, which never form lateral spines but always end in tubercles on the shoulders.

Ceratites spinifer is intermediate between $C$. humboldtensis and $C$. cornutus; from the former it is distinguished by its wider umbilicus, square ventral shoulders, more flattened venter, weaker development of the keel ridge, and stronger spines and marginal tubercles; from $C$. cornutus it is distinguished by its wider umbilicus, more compressed whorl, and narrower venter. From $C$. nevadanus it is distinguished by its more compressed whorl, angular shoulders, and stronger knots and spines. Also, even at maturity, the saddles are entire, whereas on $C$. humboldtensis and $C$. cornutus they are slightly ammonitic.

Horizon and locality.-Common in the Middle Triassic, Daonella dubia zone, Ceratites trinodosus subzone, of Fossil Hill, south fork of American Canyon, 4 miles south of Fitting post office (formerly Foltz), West Humboldt Range, Nev., associated with Ceratites trinodosus, C. humboldtensis, Nevadites whitneyi, Protrachyceras meeki, Sageceras gabbi, Beyrichites rotelliformis, Daonella dubia, and other species.

Ceratites Washbernei Smith, sp. nov.

Plate XCII, figures 9-17.

High whorled, laterally compressed, rather evolute. Whorls increasing rapidly in height, deeply embracing but not deeply indented by the inner whorls. Sides gently convex, converging toward the subangular ventral shoulders. Venter low and flattened but with an indis- 
tinct keel ridge. Surface ornamented with distinct strong sigmoidal ribs that bifurcate in the middle of the flanks and curve forward to the ventral shoulders, ending there in weak tubercles. There are no real knots on the flanks but merely a thickening of the ribs at the bifurcation. There are about 20 lateral ribs and 35 marginals to a revolution. The height of the whorl is nearly half the diameter of the shell and the width is about two-thirds of the height. The outer whorl embraces two-thirds of the inner and is indented by it to less than one-fourth of the height. The width of the umbilicus is less than one-third of the diameter of the shell. The septa are slightly ammonitic, with serrated lobes and brachyphylloid saddles.

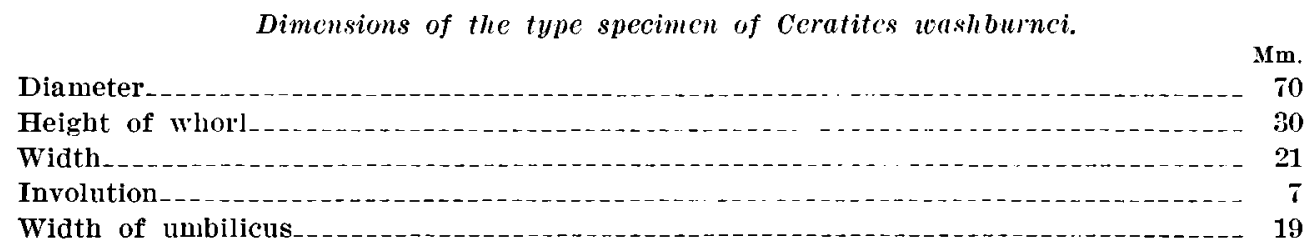

Ceratites washburnei is closely allied to $C$. humboldtensis but differs in its higher and more compressed whorl, narrower venter, more numerous and weaker ribs. It differs from $C$. occidentalis in its squarer shoulders, stronger sculpture, and distinct keel ridge.

The specific name is given in honor of Mr. Chester W. Washburne.

Horizon and locality.-Rare in the Middle Triassic, Daonella dubia zone, Ceratites trinodosus subzone, of Fossil Hill, south fork of American Canyon, West Humboldt Range, Nev., associated with Ceratites trinodosus, C. humboldtensis, Gymnotoceras blakei, Nevadites whitneyi, Beyrichites rotelliformis, Daonella dubia, and other species.

\section{B. CERATITES CIRCUMPIICATI.}

\section{Group of Ceratites voiti Oppel and Ceratites erasmi Mojsisovies.}

1. Subgroup of Ceratites voiti. (Subgenus Hollandites Diener.)

1905. Hollandites, Diener, Entwurf einer Systematik der Ceratitiden des Muschelkalkes: Sitzungsber. K. Akad. Wiss. Wien, vol. 114, pt. 1, p. 776.

1907. Hollandites, Diener, The fauna of the Himalayan Muschelkalk: Himalayan fossils, vol. 5, Mem. 2, p. 60 (Mem. Geol. Survey India, Pal. Indica, 15th ser.).

Type.-Ceratites voiti Oppel, of the groúp of Indian Ceratites circumplicati.

Subgeneric characters.-Form involute, rather high whorled, robust, with distinct lateral and weak ventral sculpture. The most distinguishing mark is the predominance of the lateral ribs and little development of knots. Most of the species have little sculpture on the inner whorls but toward the body chamber are provided with distinct ribs. Umbilical knots are rare; when present they do not appear earlier than the lateral but simultaneously with them, according to Diener. Septa ceratitic but with distinct brachyphyllic serration of the saddles. Philippi ${ }^{1}$ assumed that the group of Indian circumplicati was characterized by the absence of a distinct auxiliary saddle; this is true of most species of Hollandites, especially of the group of $C$. voiti Oppel, but not of all, and hence can not be used to distinguish this subgenus from the nodosi.

Ceratites zezianus Mojsisovics and $C$. petersi Mojsisovics are probably European representatives of this subgenus, but most of the members are found in the Indian province, where it is the commonest type of Ceratites. Hollandites is represented in Nevada by two typical species, Ceratites organi Smith and $C$. montis-bovis Smith, both of which are closely allied to Indian species.

'Die Ceratiten des oberen deutschen Muschelkalkes: Pal. Abhandl. von Dames und Koken (new series), vol. 4, 1901, p. 93. 
Diener ${ }^{1}$ formerly derived the Indian circumplicati (Hollandites) from the Arctic circumplicati (Artoceras Hyatt), but Philippi ${ }^{2}$ says the Arctic group does not belong to Ceratites at all but rather to the Meekoceratida. The writer is rather inclined to derive Hollandites from the ancestors of the Ceratites geminati, for the young show more of the sigmoidal ribs and ventral keel than do the adults. But Diener thinks that the young of Hollandites show a strong resemblance to Peripleurocyclus Diener, which itself is of unknown origin.

Ceratites (Hollanidites) montis-bovis Smith. sp. nov.

Plate IVIII, figures 1-20.

Form robust, high whorled, involute, laterally compressed. Whorls high and increasing rapidly in height, deeply embracing and not deeply indented by the inner rolutions. Umbilicus rather narrow but exposing the flanks of the inner whorls. Umbilical shoulders rounded, flanks gently convex, venter narrowly rounded, without shoulders and without a central ridge at maturity but in youth both shoulders and central ridge are present. The height of the whorl is less than half the diameter of the shell, and the width is more than three-fourths of the height. The outer whorl embraces two-thirds of the inner and is indented by it to about one-fifth of the height. The width of the umbilicus is less than one-fourth of the diameter of the shell.

The surface is ornamented with fine dichotomous sigmoidal ribs that branch low down on the sides and curre forward with a graceful swing, becoming obsolete near the venter. There are no knots on the shell. The septa are brachyphylloid, both lobes and saddles being slightly digitate.

Ceratites montis-bovis belongs to the subgenus Hollandites Diener, and is nearly related to $C$. voiti Oppel, as figured by C. Diener, ${ }^{3}$ but is slightly more robust and has the fourth lobe upon the flank and not on the umbilical shoulder, as in $C$. voiti. It also resembles $C$. ravana Diener, ${ }^{4}$ but is more involute, and has the ribs somewhat coarser. From $C$. organi it differs in the narrow venter, the absence of ventral shoulders, and in its weaker sculpture.

Dimensions of the type specimen of Ceratites montis-bovis.

Diameter
Height of last whorl
Ifeight of last whorl from the preceding.
Width of last whorl
Involution
Width of umbilicus

Horizon and locality.-Common in the Middle Triassic, Ceratites trinodosus subzone, on the divide between Troy Canyon and the south fork of American Canyon, 4 miles south of Fitting post office (formerly Foltz), West Humboldt Range, Nev., associated with Ceratites trinodosus, C. humboldtensis, Protrachyceras americanum, Nevadites whitneyi, Sageceras gabbi, Daonella dubia, and other species.

Ceratites (Holuanites) organi Smith, sp. nov.

Plate LIV, figures 1-9; Plate LY. figures 1-30.

Form robust; high whorled, moderately involute. Whorls increasing rapidly in height, deeply embracing, and indented rather deeply by the inner volutions. Sides compressed. gently convex; ventral shoulders rounded, venter broad, somewhat flattened, with faint keel ridge. Surface ornamented with strong ribs that bifurcate near the middle of the flanks and

1 Cephalopoda of the Muschelkalk: Himalayan fossils, rol. 2, pt. 2, 1895, p. 5 (Mem. Geol. Survey India, Pal, Indica. 15 th ser.)

2 Die Ceratiten des oberen deutschen Muschelkalkes: Pal. Abhandl. von Dames und Koken, new ser., vol. 4, 1901, p. 90.

3 Op. eit., Pl. II, figs. 1 and 2.

4 Idem, Pl. II, figs. 3-5. 
end in weak knots on the ventral shoulders. There are about 20 lateral ribs and about 40 at the ventral shoulders, the increase being caused by the bifurcation of most of the principal ribs and the intercalation of numerous secondary ribs on the flanks. On the ventral shoulders the lateral ribs divide still further, and these secondary ribs cross the venter without interruption but are very weak and can be seen only with strong illumination from one side. The height of the whorl is less than half the diameter of the shell, and the width is three-fifths of the height. The outer whorl embraces three-fourths of the inner, and is indented by it to onefourth of the height. The width of the umbilicus is less than one-fourth of the diameter of the shell. The body chamber is about two-thirds of a revolution in length. The septa are ceratitic, with deeply serrated lobes, and distinctly brachyphylloid saddles, more complex than on the Indian species of Hollandites. In this respect they resemble those of $C$. montis-bovis and agree with those of Beyrichites, but the circumplicate sculpture forbids a reference to the latter genus.

In youth the form is robust and involute, with rounded venter lacking the ventral shoulders, and the sculpture is strongly circumplicate. The shoulders begin to be distinct at the diameter of 35 millimeters. The septa cease to be typically ceratitic, and become brachyphylloid at the diameter of 30 millimeters. The young stages of $C$. organi and $C$. montis-bovis are very similar, but those of the former species are somewhat more robust and have stronger ribs. $C$. organi, up to the diameter of 12 millimeters, has a broad, low, rounded whorl, like Danubites, but at about this size the whorl begins to be higher and more compressed, as in Gymnotoceras. The septa become ceratitic at the diameter of about 7 millimeters.

Dimensions of the type specimen of Ceratites organi.

Diameter
Height of last whorl
Height of last whorl from the preceding
Width of last whorl
Involution
Width of umbilicus.

Ceratites organi resembles $C$. montis-bovis Smith but has coarser sculpture, distinct ventral shoulders, and stronger keel ridge. It is related to $C$. ravena Diener, ${ }^{1}$ but is more robust, has broader venter, narrower umbilicus, and fewer and coarser ribs; but in spite of the differences enumerated the two species are very much alike. $C$. organi closely resembles $C$. voiti Oppel of the Indian Muschelkalk but is more involute and has more complex septa. It is more compressed laterally than $C$. hidimba Diener, and also more involute.

The specific name is given in memory to Jiseph Organ, a pioneer miner of the West Humboldt Range, to whom the writer is indebted for many favors.

Horizon and locality.-Very common in the Middle Triassic, Daonella dubia zone, Ceratites trinodosus subzone, on the divide between Troy Canyon and the south fork of American Canyon, 4 miles south of Fitting post office (formerly Foltz), West Humboldt Range, Nev., associated with Ceratites trinodosus, $C$. humboldtensis, Protrachyceras americanum, Nevadites whitneyi, Daonelia dubia, and other species. It was also found in the same horizon and association at New Pass, in the Desatoya Mountains, Nev.

\section{Subgroup of Ceratites erasmi. (Subgenus Philippites Diener.)}

1905. Philippites, Diener, Entwurf einer Systematik der Ceratitiden des Muschelkalkes : Sitzungsber. K. Akad. Wiss. Wien, vol. 114, pt. 1, p. 772.

1907. Philippites, Diener, The fauna of the Himalayan Muschelkalk: Himalayan fossils, vol. 5, Mem. No. 2, p. 58 (Mem. Geol. Survey India, Pal. Indica, 15th ser.).

Type.-Ceratites erasmi Mojsisovies; the genus includes also $C$. aster Hauer and $C$. tuberosus Arthaber from the Mediterranean region and $C$. jolinkanus Diener from the Indian Muschelkalk.

1 Cephalopoda of the Muschelkalk: Himalayan fossils, vol. 2, pt. 2, 1895, p. 10, Pl. 1I, figs. 3 and 5 (Mem. Geol. Survey India, Pal. Indica, 15th ser.). 
Whorls robust, laterally compressed, involute, deeply embracing. Sculpture consists of strong umbilical ribs running up from knots on the umbilical shoulder and disappearing on the flanks, thus differing from Beyrichites, in which the lateral sculpture predominates over the umbilical. Septa brachyphylloid but only slightly so. Philippi ${ }^{1}$ thought this group belonged with Beyrichites, and certainly the differences in sculpture are but slight.

Philippites is mainly a Mediterranean group, but one species represents it in the Indian province; Ceratites argentarius and $C$. lawsoni in the American Middle Triassic also belong under Philippites, although they show some relationship to Hollandites.

The writer is of the opinion that Philippites had a common origin with Beyrichites and Hollandites, and that all three sprang from the geminati or from some group closely allied to that radicle.

Diener, in characterizing this subgenus, mentions the brachyphylloid saddles as a diagnostic character. Of the two American species, $C$. argentarius has brachyphylloid saddles, while the other, $C$. lawsoni, has the ordinary ceratitic type of lobes and saddles. This character can not have more than specific value. However, the young of $C$. argentarius resemble Danubites, while those of $C$. lawsoni resemble Olenikites and Keyserlingites. This difference may have a phylogenic significance, and Philippites itself may be of polyphyletic origin.

Ceratites (Philiplites) argentarius Smith, sp. nov.

Plate IXIII, fị̂res 1-14.

Form involute, robust, laterally compressed, high whorled, narrowly umbilicate. Sides convex, venter narrowly rounded, without ventral shoulders. Whorls deeply embracing and rather deeply indented by the inner volutions. Surface ornamented with a few coarse umbilical ribs, 12 to 14 to a revolution, otherwise smooth.

The height of the whorl is half the diameter of the shell, and the width is five-sixths of the height; the outer whorl embraces four-fifths of the inner, and is indented by it to nearly one-third of the height. The width of the umbilicus is less than one-third of the diameter of the shell. The septa are ceratitic, but the saddles are slightly brachyphylloid.

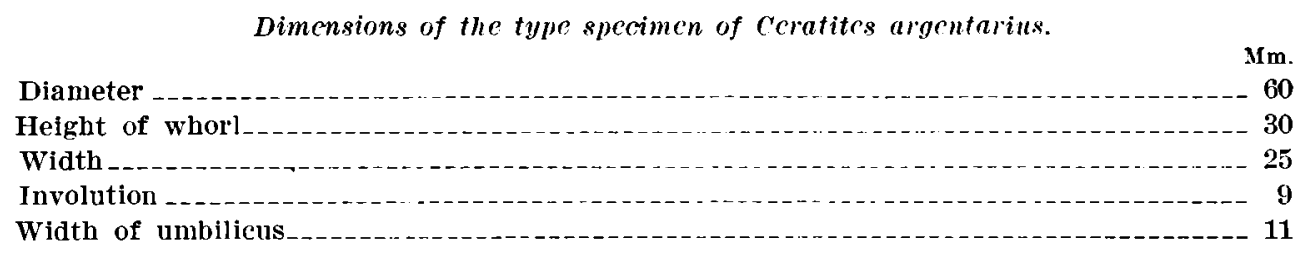

Ceratites argentarius belongs to the group named Philippites by Diener and is nearly related to $C$. tuberosus Arthaber but differs in its narrower venter and simpler septa. It is also allied to C. lawsoni Smith, with which it is associated, but differs in its finer and more numerous ribs, narrower venter, and more sloping sides. It might be regarded as an offshoot of Beyrichites, differing chiefly in the greater predominance of the umbilical instead of the lateral ribs; at any rate, this is the only essential character that separates it from the group of Beyrichites rotelliformis.

Horizon and locality.-Common in the Middle Triassic, Daonella dubia zone, Ceratites trinodosus subzone, of Fossil Hill, south fork of American Canyon, 4 miles south of Fitting post office (formerly Foltz), West Humboldt Range, Nev., associated with Ceratites trinodosus, C. humboldtensis, Nevadites whitneyi, Beyrichites rotelliformis, Daonella dubia, and other species.

${ }^{1}$ Die Coratiten des oberen deutschen Muschelkalkes: Pal. Abhandl. von Dames und Koken (new series), vol. 4, 1001, p. 87 . 


\section{Ceratites (Philippites) lawsoni Smith, sp. nov.}

Plate I.VI, figures 1-13; Plate LVII, figures 1-17.

Form robust, high whorled, involute, somewhat compressed laterally, narrowly umbilicate. Umbilical shoulders prominent and abruptly rounded, with an outward swelling caused by the large umbilical folds; flanks sloping gently toward the rather narrowly rounded venter. Ventral shoulders indistinct, venter low, with faint keel ridge. Surface ornamented with coarse umbilical folds, about 11 to a revolution, prolonged up the sides in fine sigmoidal ribs that end in weak tubercles on the ventral shoulders. These knots, which are almost obsolete at maturity, are about twice as numerous as the umbilical folds.

The height of the whorl is less than half the diameter of the shell, and the width is threefifths of the height. The outer whorl embraces three-fifths of the inner and is indented by it to one-third of the height. The body chamber is nearly two-thirds of a revolution in length. The septa are ceratitic, with rounded entire saddles, and serrated lobes.

Dimensions of the type specimen of Ceratites lawsoni.

Diameter
Height of last whorl
Height of last whorl frons the precerling
Width of last whorl
Involution.
Width of umbilicus.

Ceratites lawsoni belongs to the subgenus Philippites Diener, characterized by the predominance of the umbilical over the lateral and ventral sculpture. It differs from $C$. argentarius Smith, which belongs to this same group, in its coarser and fewer umbilical folds, and in the extension of these folds into sigmoidal ribs to the ventral shoulders. It is also more evolute, with wider umbilicus, more robust whorls, broader venter, and less complex septa.

Horizon and locality.-Very common in the Middle Triassic, Daonella dubia zone, Ceratites trinodosus subzone, on the divide between Troy Canyon and the south fork of American Canyon, 4 miles south of Fitting post office (formerly Foltz), West Humboldt Range. Nev., associated with Ceratites trinodosus, C. humboldtensis, Protrachyceras americanum, Nevadites whitneyi, Beyrichites rotelliformis, Daonella dubia, and other species.

Ceratites (Philippites) ransonei Smith, sp. nov.

Plate XClX, figures $1-4$.

Laterally compressed, discoidal, involute. Whorls high and narrow, with flattened sides, subangular shoulders, and low, narrow venter. The umbilicus is shallow and narrow, with steep walls bounded by abrupt shoulders. The outer whorl is less than half the diameter of the shell; the width is three-fcurths of the height. The outer whorl embraces three-fifths of the inner and is indented by it to nearly one-third of the height. The surface is ornamented with numerous strong lateral ribs that begin low down near the umbilical shoulders, curve gently forward on the flanks, become nearly obsolete, and cross the venter as very fine striæ with a strong forward bending sinus. The septa are ceratitic but not visible on the type.

Ceratites ransomei is related to $C$. argentarius and $C$. lawsoni, but differs from both in the greater lateral compression and weaker sculpture. The form is very much like that of $C$. erasmi Mojsisovics, but the lateral sculpture is weaker.

The specific name is given in honor of the discoverer of the species, Mr. F. L. Ransome, of the United States Geological Survey.

Horizon and locality.-In the Middle Triassic, Daonella dulia zone, Ceratites trinodosus subzone, at the Wheeler mine, Unionville, Buena Vista Canyon, West Humboldt Range, Nev., associated with Arcestes gabbi, Longobardites nevadanus, Monophyllites billingsianus, Ceratites organi, Acrochordioeras hyatti, Daonella moussoni, and other species. 


\section{Ceratites Geminati.}

\section{Group of Ceratites blakei. (Subgenus Gymnotoceras Hyatt.)}

1877. Gymnotoceras, Hyatt, in Meek, Palæontology: U. S. Geol. Expl. 40th Par., vol. 4, pt. 1, p. 110.

1904. Gymnotoceras, Smith, The comparative stratigraphy of the marine Trias of western America: Proc. California Acad. Sci.. 3d ser., Geology, vol. 1, No. 10, p. 385.

1905. Gymnotoceras, Hyatt and Smith, The Triassic cephalopod genera of America : Prof. Paper U. S. Geol. Survey No. 40, p. 172.

1905. Gymnotoceras, Diener, Entwurf einer Systematik der Ceratitiden des Muschelkalkes: Sitzungsber. K. A kad. Wiss. Wien, vol. 114, pt. 1, p. 774 .

Ceratites (Gymnotoceras) beckeri Smith, sp. nov.

Plate III, figures 4 and 5, 7-9; Plate I.XVI, figures 10-29.

1904. Ceratites (Gymnotoceras) blakei, Smith. The comparative stratigraphy of the marine Trias of western America : Proc. California Acad. Sci., 3d ser., Geology, vol, 1, No. 10, p. 386, Pl. XLIII, figs. 9 and 10; Pl. XIIV, figs. 2 and 3.

1905. Ceratites (Gymnotoceras) blakei, Hyatt and Smith, The Triassic cephalopod genera of America : Prof. Paper U. S. Geol. Survey No. 40, Pl. XXII, figs. 4 and 5; 7-9 (not 1-3, 6, 10-23).

Form robust, involute, somewhat compressed laterally, with gently convex sides, rounded shoulders, narrow venter raised in the middle in a low but distinct keel ridge. The umbilical shoulders are very abruptly rounded and the inner walls nearly vertical. The umbilicus is narrow, being about one-fourth of the diameter of the shell. The surface is ornamented with fine, sharp, dichotomous, sickle-shaped ribs that fork low down on the flanks and bend obliquely forward on the ventral shoulders without forming lateral or ventral tubercles. The height of the whorl is nearly half the diameter of the shell, and the width is about three-fourths of the height. The septa are ceratitic, but the saddles are weakly brachyphylloid, as in all species of the group of Gymnotoceras. The young are much more evolute and less ventricose than the mature form.

Ceratites beckeri differs from $C$. blakei in the more robust and rentricose form, narrower umbilicus, broader venter, and more distinct shoulders. It differs from $C$. russelli in the finer ribs, more ventricose form, and absence of shoulder knots. C. beckeri differs from $C$. meeki in the much finer and more numerous ribs and in the gently rounded shoulders.

Horizon and locality.-Very common in the Middle Triassic, Dronella dubia zone, Ceratites trinodosus subzone, on Fossil Hill, south fork of American Canyon, 4 miles south of Fitting post office (formerly Foltz), West Humboldt Range, Nev., associated with Ceratites trinodosus, C. humboldtensis, Nevadites whitneyi, Protrachyceras meeki, Beyrichites rotelliformis, Arcestes gabbi, Daonella dubia, and other species.

\section{Ceratites (Gymotoceras) blakei Gabb.}

Plate III. figures 10-23; Plate XVI, figures \$-10; Plate LXV, figures 14-19; Plate I,XVI, figures 1-9.

1864. Ammonites blakci. Gabb, Iescription of the Triassic fossils of California and the adjacent Territories: Geol. Survey California. Paleontology, rol. 1, 1S64, p. 24, P1. IV, figs. 14 and 15.

1905. Gymnotoceras blakei, Hyatt and Smith, The Triassic ceplatopod genera of America: Prof. Paper U. S. Geol. Survey No. 40, p. 173, Pl. XXII, figs. 10-23. (Not Pl. XXII, figs. 1-10.)

(Not 1877. Gymnotoceras blakei, Meek, Palæontologt, U. S. Geol. Expl. 40th Par.. vol. 4, p. 113, P1. X. figs. $10 a, b, c ; \mathrm{Pl} . \mathrm{XI}$, fig. 6.)

(Not 1904. Gymnotoceras blakei, Smith, The comparative stratigraphy of the marine Trias of western America: Proc. California Acad. Sci.. 3d ser., Geology, rol. 1, No. 10. p. 386, Pl. XIIII, figs. 9 and 10 ; Pl. XIIV, figs. 2 and 3.)

Type of Gymnotoceras Hyatt.

Form discoidal, laterally compressed. Whorls high and increasing rapidly in height, deeply embracing and deeply indented by the inner volutions. Umbilicus narrow. Sides $16279^{\circ}-$ No. $83-14-8$ 
flattened, ventral shoulders not distinct, venter rising above the shoulders in a keel. Surface ornamented with fine sharp falciform ribs that bifurcate not far above the umbilical shoulders, curve gently backward to the ventral shoulders, bifurcate again, and bend sharply forward on the shoulder slope. The ribs are fine on this part of the shell and become obsolete before the median ridge is reached. There are no knots developed on any part of the shell. The septa are slightly ammonitic, brachyphylloid, as on all species of Gymnotoceras. The height of the whorl is greater than half the diameter of the shell, and the width is two-thirds of the height. The outer whorl embraces four-fifths of the inner and is indented by it to about one-third of the height. The width of the umbilicus is about one-sixth of the diameter of the shell.

Ceratites (Gymnotoceras) blakei Gabb resembles Gymnotoceras meelki Mojsisovics but is more compressed, with higher whorls, more acute venter, weaker sculpture, and lacks the ventral shoulders and shoulder knots. It also resembles Gymnotoceras russelli Smith but is more compressed and has a higher venter and finer and more sigmoidal ribs than that species.

Much confusion has existed with reference to this species because of Gabb's poor figure and incomplete description. Meek first confused with it two species, one of which has since been named Gymnotoceras meeki Mojsisorics, and the other Ceratites nevadanus Mojsisovics. Afterward Smith and Hyatt and Smith confused with it the species named in this work Gymnotoceras russelli Smith and G. beckeri Smith. A comparison of Gabb's typical material with a large suite of specimens from the same localities and horizons has shown that Gabb's species is constant in characters, and does not intergrade with the three named above. The authors cited supposed that Gabb's specimen was the young of those afterward differently named, but large specimens of 60 millimeters diameter retain their high compressed whorls and absence of ventral shoulders and lateral knots.

Gymnotoceras blakei is not so common as $G$. meeki and $G$. russelli, the species formerly thought to be identical with it, but many typical specimens were found by the writer.

The form figured by Meek ${ }^{1}$ is not even a Gymnotoceras but belongs to the group of nodose Ceratites and has been rechristened $C$. nevadanus Mojsisovics.

Gymnotoceras blakei differs from Beyrichites rotelliformis in the stronger ribs, greater compression of the whorl, and raised ventral ridge. It resembles Beyrichites nanda Diener in form but lacks the lateral tubercles. It also resembles B. affinis Mojsisovics but differs in the greater ventral convergence and the more falciform ribs. It is still more like the form described under the name of $B$. affinis Diener, ${ }^{2}$ but the Indian form shows no tendency to develop the median ridge.

Horizon and locality.-Common in the Middle Triassic, Daonella dubia zone, Ceratites trinodosus subzone, of Fossil Hill, south fork of American Canyon, West Humboldt Range, Nev., associated with Ceratites trinodosus, C. humboldtensis, Nevadites whitneyi, Daonella dubia, and other species. It was also found in the same horizon in Buena Vista Canyon, and Cottonwood Canyon in the West Humboldt Range, and at New Pąss, Desatoya Mountains, Nev.

$$
\text { Ceratites (Grmnotoceras) hersheyi Smith, sp. nov. }
$$

I'late XCIII, figures 1-14.

Form robust, moderately evolute, low whorled, widely umbilicate, crass section trapezoidal, wider than high. The sides are convex, the ventral shoulders abruptly rounded, the renter rather narrow, with a strong keel ridge. The height of the whorl is less than half the diameter of the shell, and the width is greater than the height. The whorl is not deeply embracing, and the rate of increase is slow. The surface is ornamented with strong bifurcating sigmoidal ribs that form strong lateral knots and distinct tubercles on the ventral shoulders. In youth, both lateral and marginal knots are undeveloped. The septa are weakly brachyphylloid, as in all the species of this group of which the septa have been observed.

\footnotetext{
1 Palæontology : U. S. Geol. Expl. 40th Par., vol. 4, P1. XI, fig. 6.

2 Cephalopoda of the Muschelkalk: IIfmalayan fossils, vol. 2, pt. 2, 1895, p. 47, Pl. VIII, figs. 4 and 5 (Mem. Geol, Survey India, Pal Indica, 15th ser.).
} 
Ceratites hersheyi is intermediate between the characteristic species of Gymnotoceras and Ceratites s. str. It preserves at maturity the characters of the adolescent stage of $\mathrm{C}$. humboldtensis. This makes it probable that the group of $C$. humboldtensis, though externally showing all the characters of the nodosi, is an offshoot from the geminati and not from the immediate ancestors of Ceratites s. str. C. hersheyi is more evolute than $C$. meeki Mojsisovics, with lower whorl.

The specific name is given in honor of Mr. O. H. Hershey, in recognition of his geological explorations in the Great Basin region.

Horizon and locality.-Rare in the Middle Triassic, Daonella dubia zone, Ceratites trinodosus subzone, on the divide between Troy Canyon and the south fork of American Canyon, 4 miles south of Fitting post office (formerly Foltz), West Humboldt Range, Nev., associated with Ceratites trinodosus, C. humboldtensis, Protrachyceras meeki, Nevadites whitneyi, Beyrichites rotelliformis, Gymnotoceras blakei, Daonella dubia, and other species.

\section{Ceratites (Grinotoceras) meeki Mojsisovics.}

Plate XIV, figures 10a-c; Plate LXIX, figures 1-19.

1888. Ceratites meeki, Mojsisovies, Ueber einige japanische Trias-Fossilien : Beitr. Pal. und Geol. OesterreichUngarns und des Orients, vol. 6, p. 168.

1877. Gymnotoceras blakei (in part), Meek, Pilæontology: U. S. Geol. Expl. 40th P:ır., vol. 4, Pl. X, figs. 10 and $10 a$.

Form robust, involute, laterally compressed, whorls high, helmet shaped, with rounded but distinct ventral shoulders, high venter, and distinct ventral keel. Surface ornamented with strong bifurcating sigmoidal ribs, with protuberances on the flanks and ending in weak tubercles on the ventral shoulders. There are about 14 of the lateral ribs and 30 of the marginal ribs and tubercles to a revolution. The increase is caused by the bifurcation of most of the ribs, and the intercalation of many secondary ribs, but the number is not constant. The septa 'are ceratitic but weakly brachyphylloid, as in $C$. blakei.

Meek described this species under the name Gymnotoceras 7lakei Gabb, but Mojsisovics afterward gave it the name Ceratites meeki, using Meek's figures ${ }^{1}$ as the type.

C. meeki may grade over into the form described as C. blakei by Hyatt and Smith, ${ }^{2}$ but no transitions have been observed. That form is now regarded as a distinct species and is described in this work as $C$. russelli Smith. The ribs on $C$. meeli $i$ are coarser than on $C$. musselli and the form is much more robust and less compressed than in $C$. blakei.

Florizon and locality.-Very common in the Middle Triassic, Daonella dubia zone, Ceratites trinodosus subzone, of Fossil Hill, south fork of American Canyon, West Humboldt Range, Nev., associated with Ceratites trinodosus, C. humboldtensis, Nevadites whitneyi, Gymnotoceras blakei, Daonella dubia, and other species.

\section{Ceratites (Grmatoceras) Risseldi Smith, sp. nov.}

Plate III, figures 1-3 and 6; Plate IXVII, figures 1-15.

1905. Gymnotoceras blakiei, Hyatt and Smith, The Triassic cephalopod genera of America: Prof. Paper U. S. Geol. Survey No. 40, p. 173, Pl. XXII. figs. 1-3 and 6 (not Pl. XXII, figs. 4 and 5. and 7-23).

(Not 1864. Ammonites blakei, Gabb, Description of the Triassic fossils of California and the adjacent Territories: Geol. Survey California, Palreontology, vol. 1, p. 24, Pl. IV. figs. 14 and 15.)

(Not 1877. Gymnotoceras blakei, Meek, Palæontology: U. S. Geol. Expl. 40th Par., Vol. IV, p. 113, Pl. X, figs. $10 a-c$, which is C. meeki Mojsisovics.)

(Not 1904. Gymnotoccras blakei, Smith. The comparative stratigraphy of the marine Trias of western America: Proc. California Acad. Sci., 3d ser., Geology, vol. 1, No. 10, p. 386, Pl. XI.III. figs. 9 and 10 ; Pl. XLIV, figs. 2 and 3.)

1 Palæontology : I. S. Geol. Expl. 40th Par., vol, 4, Pl. X, figs. 10 and $10 a$.

2 The Triassic cephalopod genera of America : Prof. Paper U. S. Geol. Survey No. 40, 1905, p. 173, Pl. XXII, figs. 1-3. 
Form involute, robust, laterally compressed. Whorl deeply embracing but not deeply indented by the inner volution. Silles flattened convex; venter high and narrowed to a median keel. Abdominal shoulders narrow and sloping in early maturity, more abrupt later in life. Umbilicus rather narrow, and deep umbilical shoulders abruptly rounded, with steep inner walls. The height of the whorl is about half the total diameter, and the width is three-fourths of the height. The indentation is one-fourth of the height. The width of the umbilicus is about one-fifth of the total diameter.

The surface is ornamented with strong, radial, dichotomous ribs that branch on the flanks one-third of the way up from the umbilicus and bend sharply forward on the abdominal shoulders, becoming obselete at the median ridge or keel. At the point of bifurcation the ribs form low radially elongate knots and at the shoulders are developed weak tubercles, on which the ribs usually divide. These secondary ribs run obliquely forward almost to the central keel and sometimes even cross it. There are a few intercalary ribs, beginning midway on the flanks, forming the shoulder tubercles and the secondary riblets as do the primary ribs. The septa are ceratitic, brachyphylloid, the lobes being serrated, the saddles rounded and slightly serrated. The young shell is much more evolute than the mature form, as shown in the young specimens figured.

In the young the cross section of the whorl is nearly circular, with the exception of the impressed zone; the ribs are fine, and much straighter than at maturity, and in the earliest stages are present only on the umbilical shoulders. The body chamber is nearly or quite a complete revolution in length, and increases the resemblance to Paratropites, but the young stages a re not like those of the Tropitidæ.

Ceratites russelli is less compressed than $C$. Zlakei and has stronger ribs and more distinct shoulders. It is more compressed than $C$. mecki and has less distinct shoulders and weaker sculpture. It differs from $C$. beckeri in its much coarser ribs and the more distinct shoulders, as well as in the tendency to form shoulder knots.

The species here named Gymnotoceras russelli is in part the same as that figured and described by Hyatt and Smith (1905) under the name of Gymnotoceras blakei. Since that time an examination of Gabb's typical material has shown the two to be distinct, and the writer has also found numerous specimens that are identical with Gabb's type and illustrations and has not found any intergradations between the two. This species, which is named in honor of the late Prof. I. C. Russell, is by far the commonest species of Gymnotoceras in the Middle Triassic of Nevada.

The form figured by Meek ${ }^{1}$ does not belong to Gymnotoceras but to Ceratites s. str.

IIorizon and locality.-Ceratites (Gymnotocerrs) russelli Smith was found by the writer to be very abundant in the Middle Triassic, Daonella zone, of the West Humboldt Range, in Cottonwood Canyon, near the "Lucky Dog" mine; and on the divide between the south fork of American Canyon and Troy Canyon, about 4 miles south of Fitting post office (formerly Foltz), associated with Ceratites humboldtensis, Beyrichites rotelliformis, Nevadites whitneyi, Daonella dubia, and many other species characteristic of the Middle Triassic. It is also found in the same horizon at New Pass, Desatoya Mountains, Nev.

Ceratites (Gyinotoceras) spurri Smith, sp. nov.

Plate LXVII, figures 16-18.

Moderately involute, laterally compressed, high whorled, with narrow umbilicus, flattened sides, converging to the distinct ventral shoulders. Venter high, with angular roof-shaped central ridge. Surface ornamented with sharp sigmoidal ribs that start from the umbilical slope, form coarse lateral knots one-fourth of the distance above the flanks, and here branch in twos and threes. The ribs bend sharply forward high up on the flanks and form small tubercles on the ventral shoulders, continuing forward to the central keel ridge. There are about 11 .of

1 Palæontology : C. S. Geol. Expl. 40th Par., vol. 4, pt. 1, 1877, Pl. XI, fig. 6. 
the lateral knots to a revolution, and the number of marginal shoulder knots is approximately three times as great, for the intercalary ribs that start in the middle of the flanks end in tubercles similar to those of the primary ribs.

The height of the whorl is half the diameter of the shell, and the width is three-fourths of the height. The width of the umbilicus is about one-fifth of the diameter of the shell. The outer whorl embraces two-thirds of the inner and is indented by it to one-fifth of the height. The septa are like those of Ceratites blakei, with serrated lobes and weakly brachyphylloid saddles.

Ceratites spurri resembles $C$. wemplei Smith but is more compressed laterally, with narrower and higher roof-shaped venter, and has finer sculpture. It is also very like the Arctic Ceratites geminati figured by Mojsisovies, but is flatter and higher whorled than any species described from that group. It resembles $C$. blakei Gabb but is more robust and has much coarser ribs and tubercles.

Dimensions of the type specimen of Ceratites spurri.

$\begin{array}{lr}\text { Diameter } & \text { Mm. } \\ \text { Height of last whorl } & \\ \text { Height of last whorl from the preceding } & \\ \text { Width of last whorl } & \end{array}$

The specific name is given in honor of Mr. J. E. Spurr.

Horizon and locality.-Very rare in the Middle Triassic, Daonella dubia zone, Ceratites trinodosus subzone, on the divide between Troy Canyon and the south fork of American Canyon, 4 miles south of Fitting post office (formerly Foltz), West Humboldt Range, Nev., associated with Ceratites trinodosus, $C$. humboldtensis, Gymnotoceras blakei, Protrachyceras meeki, Nevadites whitneyi, Beyrichites rotelliformis, Daonella dubia, and other species.

Ceratites (Gymxotoceras) wemplei Smith, sp. nov.

Plate LXVIII, figures 1-9.

Robust, thick-whorled, moderately involute, with rather deep umbilicus. Umbilical shoulders rounded, sides strongly convex, and distinct ventral shoulders. Venter broad but highly arched, rising up in a high ridge in the middle. The height of the whorl is less than half the diameter of the shell, and the width is three-fourths of the height. The width of the umbilicus is one-fourth of the diameter of the shell. The outer whorl embraces one-third of the inner and is indented by it to nearly one-third of the height.

The surface is ornamented with coarse ribs and knots. The ribs start out from the umbilicus, fork at coarse lateral knots not far above the umbilicus, form a second row of finer knots on the ventral shoulders, then run obliquely forward on the shoulder slope, becoming finer and obsolete before the median ridge is reached. There are 12 of the coarse lateral knots and principal ribs to a revolution. but between the primary ribs there is usually an intercalary rib, which does not form a lateral knot but does form a shoulder knot as the primary ribs do.

The septa are rather simple but ammonitic, the saddles being slightly indented, though less so than the lobes. The ventral lobe is rather small, the first lateral broad and deep, the second lateral about as large as the ventral, and the auxiliary still smaller.

Dimeneions of the type specimen of Ceratites wemplei.

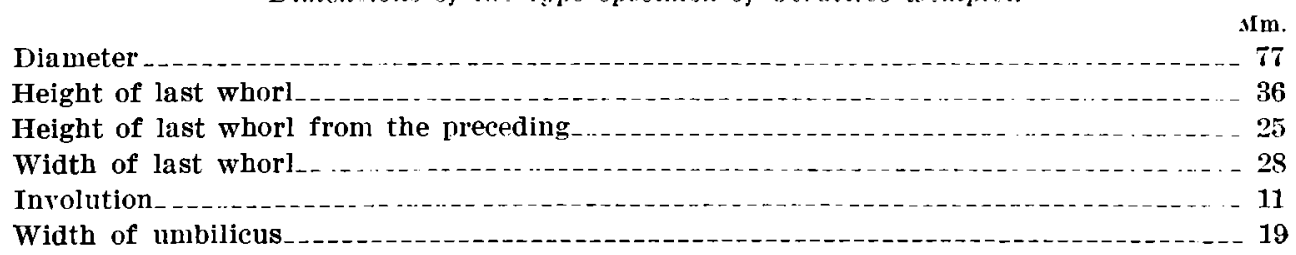


This species is a genuine member of the geminati, and belongs to Gymnotoceras in the broader sense given it by Diener. In its youth it greatly resembles Ceratites nathorsti Mojsisovies $^{1}$ of the Middle Triassic of Spitzbergen, but in age becomes much more robust than that species. This group is represented in Nevada by several species, and shows strong affinities with the Boreal fauna. It is not represented at all in the Mediterranean region, and in the Indian region only by doubtful forms. It differs from the other American species of Gymnotoceras in the strong development of the lateral and the shoulder knots, and in the less pronounced development of the ventral keel.

The specific name is given in honor of Miss Edna Wemple, in recognition of her contributions to Triassic paleontology.

IIorizon and locality.-In the Middle Triassic, Daonella dubia zone, Ceratites trinodosus subzone, of Fossil Hill, on the divide between Troy Canyon and the south fork of American Canyon, 4 miles south of Fitting post office (formerly Foltz), West Humboldt Range, Nev. It was associated with Ceratites trinodosus, $C$. cricki, $C$. humboldtensis, Gymnotoceras blakei, Beyrichites rotelliformis, Nevadites whitneyi, Protrachyceras americanum, P. meeki, Longoburdites nevadanus, Sageceras gabbi, Eutomoceras laubei, Daonella dubia, and other species.

\section{Genus HAYDENITES Diener.}

1905. Haydenites, Diener, Fntwurf einer Systematik der Ceratitilen des Muschelkalkes: Sitzungsber. K. Akad. Wiss. Wien, vol. 114 , pt. 1 , p. 790.

1907. Haydenites, Diener, The fauna of the Himalayan Muschelkalk: Himalayan fossils, vol. 5, Mem. No. 2, p. 72 (Mem. Geol. Survey India, Pal. Indica, 15th ser.).

Type.-Haydenites hatschelii Diener.

Form evolute, with wide umbilicus, broad, subrectangular, little-embracing whorls. The umbilical shoulders are rounded, the sides flattened and nearly parallel; the ventral shoulders are strong and angular. The venter is broad and low, with a slight arch but lacking both keel and furrow and not crossed by the ribs. The surface is ornamented with strong radial ribs, either simple or bifurcating, ending in large tubercles or spines on the ventral shoulders. The septa are ceratitic, with entire saddles and serrated lobes. In youth the venter is rounded and crossed by the ribs, which have lateral instead of marginal tubercles. In this stage the shell greatly resembles Acrochordiceras. Diener regards this group as a subgenus of Ceratites, closely allied to the subrobusti.

Occurrence.-Haydenites is at present represented by only one species, H. hatschekii Diener in India and in Nevada, where it occurs in the zone of Ceratites trinodosus of the Middle Triassic.

\section{Haydenttes matschenit Diener.}

Plate XXXIII, Figures 1-3.

1907. Haydenites hatschekii, Diener, The fauna of the Himalayan Muschelkalk: Himalayan fossils, vol. 5, Mem. No. 2, p. 72, Pl. VI, figs. $1 a$ and $z$ (Mem. Geol. Survey India, I’al. Indica, 15th ser.).

Form moderately evolute, with robust, subquadratic, little-embracing whorls, and wide, deep umbilicus. The umbilical shoulders are rounded, the sides flattened and nearly parallel, the ventral shoulders angular, and the venter broad and flattened.

The shoulders are armed with strong blunt spines, but the lateral ribs are obsolescent. In youth, up to a diameter of 90 millimeters, the whorl is rounded, with arched venter like Acrochordiceras, similar lateral knots or spines, and strong bifurcating ribs.

Horizon and locality.-Very rare in the upper Middle Triassic (upper Muschelkalk of Furope) Daonella dubia zone, Ceratites trinodosus subzone, of Buena Vista Canyon, West Humboldt Range, Nev., associated with Ceratites humboldtensis, Beyrichites rotelliformis, Cuccoceras bona-vista, Daonella dubia, etc. It was first found in the upper Muschelkalk of the Himalayas in India, associated with a similar fauna.

1 Arktische Triasfaunen: Mém. Acad. imp. sci. St.-Pétersbourg, 7th ser., vol. 33, No. 6, 1886, p. 53, Pl. IX, fig. 3. 


\section{Genus BEYRICHITES Waagen.}

1895. Beyrichites, Waagen, Fossils from the Ceratite formation: Salt Range fossils, vol. 2, p. 160 (Mem. Geol. Survey India, Pal. Indica, 13th ser.).

1896. Beyrichites, Arthaber, Die Cephalopodenfauna der Reiflinger Kalke: Beitr. Pal. und Geol. OesterreichLngarns und des Orients, rol. 10, pt. 2, p. 228.

1896. Beyrichites, Toula, Tine Muschelkalkfauna am Golfe ron Ismid in Kleinasien; Beitr. Pal. und Geol. Oesterreich-Ungarns und des Orients, vol. 10, pt. 4, p. 172.

1897. Beyrichites, Diener, Cephalopoda of the Lower Trias: Himalayan fossils, rol. 2, pt. 1, p. 74 (Mem. Geol. Surrey India, Pal. Indica, 15th ser.).

1898. Beyrichites, Tornquist, Neuere Beiträge zur Geologie und Palïiontologie der T'mgebung von Recoaro und Schio in Venetien, Part IV : Zeitschr. Deutsch. geol. Gesell., vol. 50, pt. 4, p. 658.

1902. Beyrichites, Mojsisovics, Das Gebirge um Hallstatt, Part I, Die Cephalopoden der Hallstätter Kalke: Supplement-Heft Alihandl. K.-k. geol. Reichsanstalt Wien, vol. 6. pt. 1, 1st half, p. 331.

1904. Beyrichites, Smith, The comparative stratigraphy of the marine Trias of western America: Proc. California Acad. Sci., 3d ser., Geology, vol. 1, No. 10, p. 378.

1905. Beyrichites, Diener, Entwurf einer Systematik der Ceratitiden des Muschelkalkes: Sitzungsber. K. Akad. Wiss. Wien, vol. 114, pt. 1, p. 791.

1905. Beyrichites, Hyatt and Smith, The Triassic cephalopod genera of America: Prof. Paper U. S. Geol. Survey No. 40 , p. 154.

1907. Beyrichites, Diener, The fauna of the Himalayan Muschelkalk: Himalayan fossils, vol. 5, Mem. No. 2, p. 82 (Mem. Geol. Survey India, Pal. Indica, 15th ser.).

Type.-"Ammonites" reuttensis Beyrich."

Involute, laterally compressed, deeply embracing, umbilicus narrow, sides slightly convex, venter narrowly rounded. Sides ornamented with weak ribs, which usually have a falciform bend. Septa of the ceratitic type but with even the saddles slightly denticulated, just in the transition to becoming ammonitic. Waagen established this genus to include "Meekoceras" reuttense Beyrich, $M$. khanikofi Oppel, and $M$. maturum Mojsisovics, of the Muschelkalk of the Alps, but he placed these in the family Ptychitidæ.

Diener ${ }^{2}$ showed that Beyrichites does not belong to the Ptychitidx, but he went to the other extreme and classed it as a subgenus under Meekoceras. In a later paper Diener ${ }^{3}$ places Beyrichites as an independent genus under the Ceratitidæ, and considers the resemblance to Ptychites as due to convergence. The young stages of the Ptychitidx are always globose, resembling the Glyphioceratidæ of the Carboniferous, whereas those of Beyrichites are invariably evolute and laterally compressed, with early adolescent stages like Lecanites and larval stages resembling Gephyroceras of the Devonian.

Mojsisovics ${ }^{4}$ says that Beyrichites belongs to the Ceratitidæe and that it developed out of Dinarites, which conclusion is only partly correct.

The writer, basing his opinion on studies of the development of several species, regards Beyrichites as an offshoot of the Ceratitida through Gymnotoceras. Some member of the Meekoceratidæ, possibly Meekoceras itself, was the more remote ancestor of the group. The writer further regards Beyrichites as a reversionary group and is of the opinion that its strong resemblance to Meekoceras is due to atavism. Beyrichites falciformis in the adolescent stage is a true Gymnotoceras, very like $G$. blakei, but at maturity has the falciform ribs almost obsolete. Beypichites rotelliformis has the falciform ribs reduced at a much earlier stage and is more strongly reversionary to Meekoceras at maturity. B. temis has still less of the character of Gymnotoceras preserved in its development, and $B$. osmonti has lost this stage almost entirely, being nearly smooth throughout life. The nearly smooth compressed whorl is in this genus an old-age character, pushed back by acceleration of development only a little way in

1 Ueber einige Cephalopoden aus dem Muschelkalke der Alpen und über verwandte Arten: Ahhandl. K. Akad. Wiss. Wien, 1867, p. 113, Pl. I, fig. 4.

2 Cepbalopoda of the Lower Trias: Himalayan fossils, vol, 2, pt. 1, 1897, p. 74 (Mem. Geol. Survey India, Pal. Indica, 15 th ser.).

${ }^{3}$ Entwurf einer Systematik der Ceratitlden des Muschelkalkes: Sitzungsber. K. Akad. Wiss. Wien, vol. 114, pt. 1, 1905 , p. 791

- Das Gebirge um Hallstatt, Part I; Die Cephalopoden der Hallstätter Kalke: Supplement Heft Abhandl. K.-k. geol. Reichsanstalt Wien, vol. 6, pt. 1, 1st half, 1902, p. 331. 
$B$. falciformis, still further in B. rotelliformis, and in B. tenuis and B. osmonti is pushed back so far in the ontogeny that the Gymnotoceras stage is lost entirely.

The resemblance of Beyrichites to the group of $C$ eratites rotuloides is due to a very natural convergence. Ceratites rotuloides is the most primitive group of true Ceratites and has departed least from the meekoceran ancestor, whereas Beyrichites is reverting by atavism toward that same ancestor.

The group of European species assigned by Waagen to Beyrichites probably includes some primitive species of Ceratites as well as the reversionary Beyrichites.

The species from the lower Muschelkalk of Asia Minor, assigned by F. Toula ${ }^{1}$ to Beyrichites, can hardly belong to that genus but are direct and little-modified descendants of Aspidites of the Lower Triassic. The writer is of the opinion that Nicomedites Toula is a valid genus and should be retained to include the progressive, highly specialized species of the Meekoceratidæ.

As thus defined this genus is confined to the Middle Triassic of the Alps, Asia Minor, India, and Nevada. Beyrichites is already represented in America by B. rotelliformis, and the writer has found in the Middle Triassic of Nevada several other forms of this genus, all apparently new.

Beyrichites dunis Smith, sp. nov.

Plate XXXII, figures $7-12$.

Involute, robust, narrowly umbilicate. Whorls high, with strongly convex sides, and narrowly rounded venter. The outer whorl is much higher than wide, deeply embracing, and deeply indented by the inner whorls. The surface is nearly smooth, ornamented only with the cross strix of growth and faint folds. The height of the whorl is half the diameter of the shell, and the width is three-fourths of the height. The width of the umbilicus is one-fifth of the diameter of the shell.

The septa are slightly brachyphylloid, with weak indentations of the saddles as in $B$. rotelliformis, with which species $B$. dunni is closely related. It differs in its more robust whorl, greater size, and weaker ribs. It is more nearly related to $B$. osmont $i$ but is distinguished from that species by its broader and more robust whorl and stronger sculpture.

The specific name is given in honor of Mr. L. F. Dunn, of Winnemucca, Nev., the discoverer of Fossil Hill.

Horizon and locality.-Rather common in the Middle Triassic, Daonella dubia zone, Ceratites trinodosus subzone, of Fossil Hill, south fork of American Canyon, West Humboldt Range, Nev., associated with Ceratites trinodosus, C. humboldtensis, Gymnotoceras blakei, Nevadites whitneyi, Beyrichites rotelliformis, Daonella dubia, and other species.

\section{BeYrichites Falciformis Smith, sp. nov.}

Plate XCI, figures 11-13; Plate XCII, figures 1-8.

Form involute, laterally compressed. Whorls high and increasing rapidly in height, deeply embracing, and not deeply indented by the inner volutions. Umbilicus narrow, with angular umbilical shoulders and nearly vertical inner walls. Flanks gently convex, converging without shoulders to the narrowly rounded venter; greatest thickness just above the umbilical shoulders. The height of the whorl is half the diameter of the shell, and the width is about two-thirds of the height. The outer whorl embraces nearly all of the inner, leaving only the edges of the umbilical shoulder exposed; it is indented by the inner whorl to one-eighth of the height. The width of the umbilicus is one-fiftl of the diameter of the shell.

The surface is ornamented with distinct sigmoidal ribs that start from the umbilical shoulder, curve gently backward on the flanks, then bend sharply forward near the venter, becoming obsolete before the apex of the venter is reached. The venter is crossed by distinct lines of

1 Eine Muschelkalkfauna am Golfe von Ismid in Kleinasien : Beitr. Pal, und Geol. Oesterrelch-Ungarns und des Orients, vol. 10 , pt. 4, 1896, pp. 172 et seq. 
growth parallel with the ribs, forming a prolonged crest, like that of Gymnotoceras. There are about 32 of these ribs, which do not bifurcate except in early youth. There are no spines or tubercles developed on the shell. The septa are weakly brachyphylloid, with the lobes distinctly serrated, and the saddle weakly indented, as in Beyrichites rotelliformis.

Beyrichites falciformis resembles $B$. rotelliformis but has the ribs more sharply defined, the venter narrower, and the whorl more compressed. It is also smaller, but does not resemble the young stages of $B$. rotelliformis. It is more closely allied to $B$. nanda Diener ${ }^{1}$ but has no tubercles on the later ribs, and the ribs are coarser. It is also compressed near the venter but not so greatly as $B$. nand $a$ and the septa are more complex than those figured by Diener, although his drawings were made from a smaller specimen.

Beyrichites falciformis resembles $B$. tenuis Smith but has much stronger sculpture and narrower venter. It also has some resemblance to the more compressed variety of Gymnotoceras blakei but differs in the simple coarse ribs, in the absence of the ventral keel, and in the greater involution.

Beyrichites falciformis is the nearest of all this group to the ancestral Gymnotoceras, which it greatly resembles in the late adolescent stage. At maturity, however, it is reversionary toward its more remote ancestor Meekoceras, as are all other species of Beyrichites. It is probable that the presence of specimens of this species among the forms collected by the United States Geological Exploration of the Fortieth Parallel, and identified as Beyrichites rotelliformis, led Hyatt to class that species under Gymnotoceras. Gabb probably included this along with $B$.rotelliformis under "Ammonites" blakei, for it is even more common than the type figured by him. Specific lines were not drawn so sharply in the time of Gabb and Meek as they are now, and they did not have at their disposal the abundant material since collected in Nevada. The writer has collected hundreds of specimens of Beyrichites in the West Humboldt Range. and the discriminations here made are based on that material.

Horizon and locality.-Common in the Middle Triassic, Daonella dubia zone, Ceratites trinodosus subzone, of Fossil Hill, south fork of American Canyon, 4 miles south of Fitting post office (formerly Foltz), West Humboldt Range, Nev., associated with Ceratites trinodosus, C. humboldtensis, Gymnotoceras blakei, Beyrichites rotelliformis, Nevadites whitneyi, Protrachyceras meeki, Sageceras gabbi, Daonella dubia, and other species.

BeYRichites osmontr Smith, sp. nov.

Plate XXXI, figures 7-14; Plate LXXXIX, figure 14.

Form laterally compressed, discoidal. Whorls deeply embracing and deeply indented by the inner volutions, high and increasing rapidly in height. Sides gently convex, umbilical shoulders subangular, with very steep inner slope, venter narrowly rounded. Surface nearly smooth, having only cross strix and a few weak folds. The height of the whorl is half the diameter of the shell, and the width is two-thirds of the height. The width of the umbilicus is less than one-fifth of the diameter of the shell. The septa are ceratitic, but with brachylloid saddles.

Dimensions of the type specimen of Beyrichites osmonti.

$\begin{array}{ll}\text { Diameter } & \text { Mm. } \\ \text { Height of last whorl } & \\ \text { Height of last whorl from the preceding } & \\ \text { Width of last whorl } & \\ \text { Involution } & \end{array}$

Beyrichites osmonti is very closely allied with $B$. rotelliformis but differs from that species in its lack of sculpture, which persists through life, whereas $B$. rotelliformis always shows lateral ribs or folds. B. osmonti also resembles $B$. dunni but differs in its more compressed whorls.

${ }^{1}$ Cephalopoda of the Muschelkalk: Himalayan fossils, vol, 2, pt. 2, 1895, p. 48, Pl. IX, figs. 8a-c (Mem. Geol. Survey India, Pal. Indica, 15th ser.). 
The specific name is given in honor of Mr. V. C. Osmont, who assisted the writer in collecting this fauna.

Horizon and locality.-Rare in the Middle Triassic, Daonella dubia zone, Ceratites trinodosus subzone, of Fossil Hill, on the divide between Troy Canyon and the south fork of American Canyon, 4 miles south of Fitting post office (formerly Foltz), West Humboldt Range, Nev., associated with Daonella dubia, Ceratites trinodosus, C. humboldtensis, Gymnotoceras blakei, Nevadites whitneyi, Sageceras gabli, Eutomoccras laubei, and other species.

Beyrichites Rotelliformis Meek.

Plate IV. figures 1-7; Plate VIII, figures 1-15; Plate XIV, figure 9; Plate XXXI, figures 1-6; Plate XCI, figures 1-10.

1877. Gymnotoceras rotelliformis, Meek, Palæontoolgy: I. S. Geol. Expl. 40th Par., vol, 4, p. 111, P1. X, figs. 9 and $9 a$.

1904. Beyrichites rotelliformis, Snith, The comparative stratigraphy of the marine Trias of western America: Proc. California Acad. Sci., 3d ser., Geology, vol. 1, No. 10, p. 379, Pl. XLV, fig. 5, Pl. XLIII. figs. 13 and 14.

1905. Beyrichites rotelliformis, Hyatt and Smith, The Triassic cephalopod genera of America : Prof. Paper U. S. Geol. Survey No. 40, p. 155; Pl. XXIII, figs. 1-11; P1. LVIII, figs. 1-15.

Involute, discoidal, lenticular, laterally compressed. Whorl high and increasing rapidly in height, with flattened convex sides and narrowly rounded venter. Umbilicus narrow, umbilical shoulders abruptly rounded, with very steep inner walls. The height of the whorl is slightly greater than half the total diameter, and the width is two-thirds of the height. It is indented to about two-sevenths of its height by the inner whorl. The width of the umbilicus is about one-sixth of the total diameter of the shell.

Surface ornamented with numerous simple, fine flexuous ribs and radial striæ of growth, with sigmoidal curve on the flanks and a sharp forward bend just below the abdominal shoulders. In youth the ribs are strongest on the flanks and become obsolete near the venter, but in age the ribs are weak low down on the flanks and become stronger near the ventral shoulders. They do not become obsolete in old age but are much weaker than at early maturity. The septa are ceratitic, but the saddles are slightly indented; the lobes are all distinctly serrated. The external lobe is divided by a short siphonal saddle. The first lateral is large, slightly digitate, the second lateral smaller and simpler, being followed by a smaller third lateral. The true auxiliary series consists only of denticulations below the auxiliary saddle. The septa are not like those of Ceratites (Gymnotoceras) blakei Gabb, with which species Gabb united it. The young shells are much more evolute, robust, and have rougher sculpture.

Beyrichites rotelliformis was assigned by Hyatt to his genus Gymnotoceras, but it is rather a descendant of that group, as shown by the writer in this paper.

Beyrichites rotelliformis is very similar to $B$. osmonti $\mathrm{Smith}$, from which it differs in its stronger sculpture. From $B$. dunni Smith it differs in its more compressed whorl and stronger falciform ribs. From $B$. falciformis Smith it may be distinguished by its less compressed whorl and slightly weaker ribs.

Beyrichites rotelliformis is most closely allied to B. khanikofi Oppel, as figured by Diener ${ }^{1}$ and by Frech, ${ }^{2}$ but has the falciform ribs slightly weaker and the septa somewhat simpler. But the similarity is so great that if these two species occurred in the same region and in the same faunal association most paleontologists would pronounce them to be identical. However, the resemblance is stronger between the mature forms than between the adolescent stages, as these are figured by Diener.

Beyrichites rotelliformis is exceedingly variable and as many species might be made out of it as have been described from the Indian province, but the writer has collected a large series

1 Cephalopoda of the Muschelkalk: IIimalayan fossils, vol, 2, pt. 2, 1895, Pl. IX, figs. 2, 3, and 9 (Mem. Geol. Survey India, Pal. Indica, 15th ser.).

${ }^{2}$ Die Zirkumpacifische Trias: I.ethæa Geognostica, II. Theil, Das Mesozolcum, I. Band, Trias, 2te Lieferung, 1905, P1. XVI, fig. 6. 
of specimens, more than a hundred, and they show a perfect intergraduation. Some are strongly sculptured in youth and are nearly smooth in age; others are nearly smooth in youth and become strongly sculptured in age. In the compression of the whorl there is also no constancy, some specimens being much thicker than others, but all are thicker than $B$. falciformis, thinner than $B$. dunni, and uniformily more strongly sculptured than $B$. osmont $i$.

Horizon and locality.-Beyrichites rotelliformis was found by the United States Geological Exploration of the Fortieth Parallel in the Middle Triassic limestone, Buena Vista Canyon; West Humboldt Range, Nev., from which place came the type; the Whitney Survey found it at New Pass, Nev. The writer found it very common in the Middle Triassic of Cottonwood Canyon, near the "Lucky Dog" mine, West Humboldt Range, and on the divide between Troy Canyon and the south fork of American Canyon, about 4 miles south of Fitting post office (formerly Foltz), in both places associated with Nevadites whitneyi, Ceratites humboldtensis, Acrechordiceras hyatti, Gymnotoceras Ilakei, Daonella dubia, and other species.

Beyrichites tenuis Smith, sp. nov.

Plate XXXII, figures 1-6; Plate IXXXIX, figures 15-20.

Form involute, laterally compressed, narrowly umbilicate; whorls flattened, high and increasing rapidly in height, deeply embracing, and deeply indented by the inner volutions. Umbilicus narrow, with steep inner walls. Venter very narrowly rounded. Surface with fine low sigmoidal ribs that are most distinct on the upper part of the flanks near the venter. The septa are similar to those of Beyrichites rotelliformis, but the saddles are more weakly brachyphylloid.

Beyrichites tenuis resembles $B$. rotelliformis but differs in the greater compression of the whorls, greater involution, and weaker sculpture. It is the flattest member of the genus Beyrichites and has the least resemblance of any of that group to the Ptychitidæ. In its compressed form it resembles $B$. falciformis Smith but is more compressed and has weaker sculpture.

Horizon and locality.--Rather rare in the Middle Triassic Dacinclla dubia zone, Ceratites trinodosus subzone, of Fossil Hill, south fork of American Canyon, West Humboldt Range, Nev., associated with Ceratites trinodosus, C. humboldtensis, Gymnotoceras blakei, Nevadites whitneyi, Protrachyceras meeki, Daonella dubia, and other species.

Genus BALATONITES Mojsisovics.

1879. Balatonites, Mojsisovics. Yorlä ufige kurze Tebersicht der Ammoniten-Gattungen der Mediterranen und Juvavischen Trias: Verhandl. K.-k. geol. Reichsanstalt Wien, p. 139.

1982. Balatonites, Mojsisovics. Die Cephalopoden der Mediterranen Triasprovinz: Abhandl. K.-k. geol. Reichsanstalt Wien, rol. 10. p. 77.

1887. Balatonites, Hauer, Cephalopoden des Bosnischen Muschelkalkes von Han Bulog bei Sarajevo: Denkschr. K. Akad. Wiss. Wien, vol. 54, p. 29.

1889. Arniotites. Hyatt. in Whiteaves. Fossils of the Triassic rocks of British Columbia: Contributions to Canadian Palaeontology, Geol. and Nat. Hist. Survey Canada, vol. 1, pt. 2, p. 144.

1892. Balatonites, Hauer. Beitrïge zur Kenntniss der Cephálopoden aus der Trias ron Bosnien, Part I: Denkschr. K. Akad. Wiss. Wien, vol. 59, p. 270.

1896. Balatonites, Arthaber. Die Ceplualopodenfauma der Reiflinger Kalke: Beitr. Pal. und Geol. OesterreichUngarns und des Orients, vol. 10, pt. 1, p. 60, and pt. 2, p. 198.

1903. Balatonites, Frech, Nene Cephilopoden aus den Buchensteiner, Wengener und Raibler Schichten: Resultate der wissenschaftlichen Erforschung des Balatonsees, vol. 1. pt. 1, p. 9.

1905. Balatonites, Hyatt and Smith, The Triassic cephalopod genera of America: Prof. Paper U. S. Geol. Survey No. 40, p. 165.

Balatoxites madLEy Smith, sp. nov.

Plate XC, figures 8-10.

Form evolute, widely umbilicate; whorls broad, low, little embracing, and little indented by the inner volutions. Sides very convex, ventral shoulders subangular, venter low and roof- 
shaped, surmounted by a high keel without bordering furrows. Surface ornamented with strong undivided lateral ribs that form strong spines high up on the flanks. There are 16 of these ribs and spines to a revolution. The septa could not be exposed sufficiently for illustration, but they appear to be ceratitic.

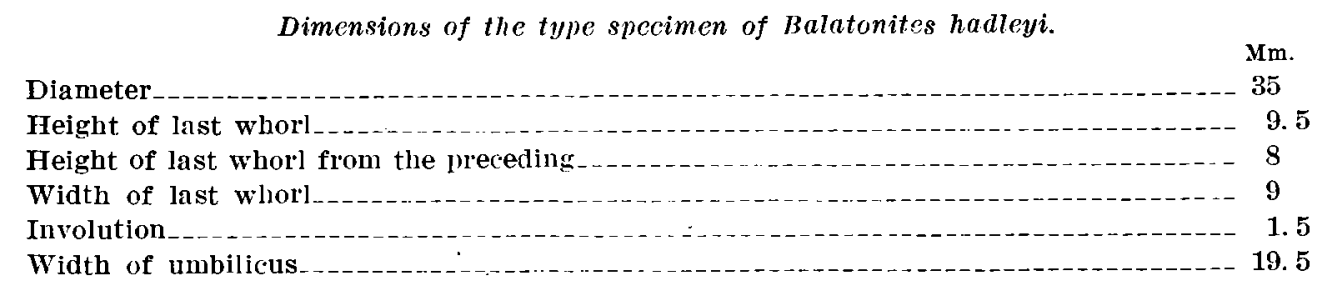

Balatonites hadleyi may belong to the subgenus Judicarites Mojsisovics, but the lateral spines are stronger than on any known species of that group. It has a strong resemblance to Margarites Mojsisovics of the Tropitidæ but lacks the furrows that border the keel and the septa appear to be ceratitic instead of ammonitic.

The specific name is given in honor of Mr. J. C. Hadley, a mining engineer, who assisted the writer in collecting the Middle Triassic forms.

Horizon and locality.-Very rare in the Middle Triassic, Daonella dubia zone, of the north fork of Buena Vista Canyon, 2 miles northwest of Unionville, West Humboldt Range, Nev., associated with Gymnotoceras blalei, Beyrichites rotelliformis, Cuccoceras bona-vista, Acrochordiceras hyatti, Daonella dubia, and other species.

\section{Balatonitrs mingi Smith, sp. nov.}

Plite XC, figures 11 and 12.

Form evolute, laterally compressed, discoidal, widely umbilicate. Whorls rather high, with flattened sides, distinct ventral shoulders, and acute roof-shaped venter. Surface ornamented with umbilical and shoulder tubercles, and fine bifurcating ribs. The umbilical tubercles number 21 to a revolution, and those on the shoulders 42 . The height of the whorl is twofifths of the diameter of the shell and the width one-third of the height. The width of the umbilicus is a little more than one-third of the diameter of the shell. Balatonites kingi has a greater resemblance to the Mediterranean species of that genus than the two other American forms.

Horizon and locality.-Very rare in the Middle Triassic, Daonella dubia zone, of the Shoshone Mountains, Nev., Whitney collection of Harvard University (exact locality not recorded and no other species known to have been collected with it).

\section{Balatonites shoshonexsis Hyatt and Smith.}

Plate IV, figures 12 and 13.

1905. Balatonites shoshonensis, Hyatt and Smith. The 'Triassic cephalopod genera of America : Prof. Paper U. S. Geol. Survey No. 40, p. 167, Pl. XXIII, figs. 12 and 13.

The original description is as follows:

Evolute, discoidal, widely umbilicate, laterally compressed. Whorls little embracing and little indented by the inner volution, low, and increasing slowly in height. The height of the whorl is about one-third of the total diumeter, and the width about two-thirds of the height. The width of the umbilicus is nearly one-half of the diameter of the shell. The umbilical shoulders are abrupt, the flanks slightly convex, with obtusely angular abdominal shoulders, and rather narrow venter, rising to the central angular ridge. The surface is ornamented with radial bifurcating ribs that run nearly straight across the venter, beading the central ridge. There is a row of knots at the beginning of these ribs on the umbilical shoulders, a second row of much larger knots on the niddle of the flanks, and a third, less prominent, on the abdominal shoulders. The central ridge is also provided with a row of small knots. This rorm, therefore, belongs to the group 
of Balatonites gemmati. The senta could not be seen in detail, being mostly covered by the shell; the sarldles are certainly rounded, but the serrations on the lobes could not be made out. This species does not seem to be nearly related to any known European form, but has all the marks of the genus.

Horizon and locality.-In the Middle Triassic, of the Shoshone Mountains, Nev, from longitude $117^{\circ} \mathrm{W}$., collected by the Whitney expedition. Only a single specimen was found, and this was loaned to the writer from the Whitney collection, in the Museum of Comparative Zoology of Harvard University.

\section{TRACHYCERATEA.}

Under Trachyceratea Mojsisovics included the rough-shelled forms in the immediate kinship of Trachyceras. They were supposed to be descendants of Tirolites through Balatonites, a view than can hardly be upheld any longer. K. A. von Zittel classed this group. under the Tropitidæ, but no other paleontologist seems to agree with him.

All the Trachyceratea have short body chambers and rough shells, ornamented with ribs and spines. Most of them have flattened venters, and a central furrow is found in the most characteristic members of the group. Balatonites, however, has a central keel ridge, and in the opinion of the writer should not be included. It does not belong to the genetic series and is probably a side branch from the same ancestors. Its similarity to Trachyceras in its ornamentation is most probably due to convergence. The definition as given above would also include Clionites, for this genus has the rough shell, ribs and spines, and ventral furrow. But Clionites is probably a reversionary form, having boen modified directly from some Trachyceras-like group.

The true Trachyceratea, as limited in this work, contain the following forms in the American Middle Triassic: Nevadites, Anolcites, Protrachyceras, Trachyceras, and Sirenites.

Nevadites Smith. Form robust, erolute, rough-shelled, withont ventral furrow, ribs ending in spines on the ventral shoulders, forming a connecting link with Ceratites of the group of C. bosnensis. Septa ceratitic. Nevadites hyatti Smith, $N$. humboldtensis Smith, N. merriami Smith, N. sinclairi Smith, $N$. whitneyi Gabb, N. fontainei Smith.

Trachyceras Laube. Including the subgenera Anolcites Mojsisovics, Protrachyceras Mojsisovics, and Jrachyceras s. str.

Anolrites Mojsisovies. Without ventral furrow but with ribs crossing the venter. Septa ceratitic. Anolcites furlongi Smith, A. gabbi Smith, A. gracilis Smith, A. barberi Smith, A. dralei Smith.

Protrachyceras Mojsisovics. With more involute form than Anoleites, whorls higher, spines reduced, and distiuct ventral furrow. Septa ceratitic or ammonitic.

Septa ceratitic, form transitional from Anolcites. Protrachyceras americanum Mojsisovics, $P$. meeki Mojsisovics, P. dunni Smith.

Septa ceratitic, form distinctly that of Protrachyceras, Protrachyceras lahontanum Smith, P. subasperum Meek.

Septa ammonitic, forming a transition to Trachyceras s. str., P. homfrayi Gabb, P. springeri Smith.

Genus NEVADITES Smith, gen. nov.

Type.-Nevadites merriami Smith.

Form evolute, robust; whorls subrectangular in cross section, little embracing, and increasing slowly in height. Sides and venter flattened. Umbilicus rather wide and deep. Ventral furrow lacking. Sculpture strong, consisting of lateral ribs and knots. The ribs end in knots on the ventral shoulders and do not cross the venter. The septa are ceratitic, the saddles rounded and entire, and the lobes are serrated. Body chamber short, so far as observed.

This genus is the most primitive of the Trachyceratea, and forms an intermediate link between Ceratites and Anolcites. In its adolescent stages Nevadites goes through stages of growth corresponding to Ceratites, and Anolcites in its development goes through stages corresponding to Nevadites. The species belonging to this genus have been assigned indiscriminately to Ceratites and Trachyceras, which shows its intermediate character.

This group is represented in America by Nevadites hyatti Smith, $N$. fontainei Smith, $N$. merriami Smith, $N$. whitneyi Gabb, $N$. humboldtensis Smith, and $N$. sinclairi Smith. In 
Europe it is certainly represented by Nevadites (Ceratites) crassus Hauer ${ }^{1}$ and probably by Ceratites altecostatus Arthaber. Arthaber ${ }^{2}$ says that Trachyceras developed out of Ceratites, and not out of Balatonites, as Mojsisovics supposed. This agrees perfectly with the results obtained by the writer in studies in the ontogeny of Nevadites whitneyi, N. merriami, and. $N$. hyatti, all of which, in the adolescent stage, are genuine Ceratites.

Nevadites did not come from Ceratites of the group of $C$. nodosus nor from that of $C$. elegans but from some member of the genus like Ceratites haguei Smith. It is not likely that this particular species was the ancestor, for it is a contemporary of Nevadites, but $C$. haguei is a form little modified from that ancestor. A morphological series showing the lines of evolution is seen in the following: Ceratites haguei Smith $>$ Nevadites hyatti Smith $>N$. whitneyi Gabb > Anolcites furlongi Smith > Protrachyceras meelei Mojsisovics > Trachyceras. This is not a genetic series, for they are all contemporaries in the zone of Ceratites trinodosus (except Trachyceras, which occurs in the zone of Tropites subbullatus), but it is a series showing unbroken progression in evolution, and the ontogeny of each of these species records the devolopment from the groups that stand lower in the series. Nevadites gets but little beyond Ceratites; Anolcites furlongi gets but little beyond Nevadites; Protrachyceras meeki is already transitional to Trachyceras-it has the furrow distinctive of Trachyceras, but its septa remain ceratitic. This is as far as evolution went in the zone of Ceratites trinodosus, but in the later beds the septa became ammonitic, as do those of all members of Trachyceras in the Upper Triassic. In Nevada above the zone of Ceratites trinodosus there are abundant remains of Trachyceras, but their preservation is poor and it was not possible to determine whether their septa are ceratitic or ammonitic.

Occurrence.-Nevadites is confined to the Middle Triassic, Ceratites trinodosus subzone, in which it is very common in Nevada, being represented by $N$. merriami Smith, $N$. hyatti Smith, $N$. sinclairi Smith, $N$. whitneyi Gabb, $N$. fontaine $i$ Smith, and $N$. humboldtensis Smith. It is also found in the Mediterranean region, where it is represented by Nevadites (Ceratites) crassus Hauer and doubtfully by (Ceratites) altecostatus Arthaber. It seems likely that Nevadites originated in America, though it is as yet impossible to determine this, for the beds below. the horizon of Nevadites in Nevada have vielded no fossils and the Mediterranean beds with Ceratites trinodosus contain no Ceratites that might have been the ancestral stock of Nevadites. The group of Ceratites bosnensis, which is thought to have been the ancestor of Nevadites, is not found below the horizon of Nevadites in either the Mediterranean or the American region.

It was thought best to treat this group as an independent genus rather than as a subgenus of Trachyceras. for it certainly has as great affinities with Ceratites as with the Trachyceratea. It can not be brought under the original diagnosis of Trachyceras, and it would be stretching that genus to an unwarranted extent to include these forms. Nevadites fontainei Smith shows an almost perfect transition from Ceratites, but can not have been the ancestor, as it is a contemporary of all the known species of the genus.

\section{Nevadites rontainei Smith, sp. nov.}

Plate XLI, figures 16-27; Plate LI, figures 1-9.

Evolute, with wide umbilicus. Whorls low and increasing slowly in height, little embracing and not deeply indented by the inner volutions. Cross section subrectangular. Umbilical shoulders abruptly rounded, sides nearly flat, ventral shoulders nearly rectangular, and venter gently convex but without any central keel ridge.

Surface ornamented with strong ribs and tubercles, of which there are three rows-umbilical, lateral, and marginal. The ribs start out from umbilical tubercles and usually fork at the second row of tubercles below the middle of the flanks, then curve gently forward to the third

1 Beitrïge zur Kenntniss der Cephalopoden aus der Trias von Bosnien, Part II : Denkschr. K. Akad. WViss. Wien, vol. 63,1896 , p. 259, P1. VIII, figs, 1 and 2.

2 Neue Funde in den Werfener Schichten und im Muschelkalke des südlichen IBakony : Resultate der wissenschaftlichen Erforschung des Balatonsees, vol. 1, pt. 1, 1903, p. 24. 
row on the ventral shoulders. The septa are ceratitic, with entire saddles and serrated lobes. The height of the whorl is three-eighths of the diameter of the shell, and the width is about three-fourths of the height. The width of the umbilicus is three-eighths of the diameter of the shell. There are 16 lateral tubercles, and 22 marginals to a revolution. The umbilical tubercles have the same number as the laterals but are almost obsolete at maturity.

Nevadites fontainei was at first assigned by the writer to the group of Ceratites bosnensis, but large specimens show too great a resemblance to Nevadites, hence it is assigned to that group, although it is clearly transitional. It is more evolute and robust than N. whitneyi; more compressed than $N$. hyatti and $N$. merriami; less compressed than $N$. sinctairi; and has finer sculpture and much slower rate of increase of the whorl than $N$. humboldtensis. Its affinities with Ceratites are much stronger than those of any other species of Nevadites known in the American region and it is a connecting link between Ceratites and Nevadites.

In old age the spines become very strong, and there are folds crossing the venter somewhat as in Anolcites. In the early adolescent stages $N$. fontaine $i$ has a strong resemblance to Keyserlingites. If this resemblance is phylogenetic, it goes far toward confirming the theory of Mojsisovics that Ceratites originated in Keyserlingites; but this does not necessarily apply to all groups of Ceratites, for that genus is probably polyphyletic.

Nevadites fontainei, which is named in honor of Prof. W. M. Fontaine, has some resemblance to Ceratites vogdesi Smith, but the whorl is more nearly rectangular in cross section, the venter is flatter, and the ribs fork below the middle of the flanks instead of above the middle, as in $C$. vogdesi.

It bears a striking resemblance to Reiflingites Arthaber, but this Mediterranean genus is said to have a long body chamber, and to belong to the Tropitidæ. The writer does not believe that Reiflingites is anything more than a Ceratites with long body chamber. Still, the sculpture of $N$. fontaine $i$ is different from that of any species assigned by Arthaber to Reiflingites and would place the American species in the near kinship of the group of $C$. haguei and $C$. beecheri, forms apparently transitional from Ceratites to Nevadites Smith and closely allied to the Mediterranean group of Ceratites bosnensis Hauer. $N$. fontainei differs from $C$. bosnensis Hauer in its more robust and less compressed whorl, shorter spines, and in the absence of the ventral keel.

Horizon and locality.-Middle Triassic, Daonella dubia zone, Ceratites trinodosus subzone, on the divide between Troy Canyon and the south fork of American Canyon, 4 miles south of Fitting past office (formerly Foltz), West Humboldt Range, Nev., associated with Daonella dubia, Ceratites trinodosus, C. humboldtensis, Gymnotoceras blakei, Nevadites whitneyi, and other species.

Nevadites hummoldtexsis Smith, sp. nov.

Plate LXXviIr, figures 1-3; Plate IXXIX, figures 1-10.

Form moderately evolute, robust; whorls low and increasing slowly in height, not deeply embracing, and little indented by the inner volutions. Cross section subquadratic, slightly higher than wide. Umbilical shoulders abruptly rounded, sides strongly convex, ventral shoulders square and angular. Venter broad, with slight concavity. Umbilicus wide and rather deep, showing the greater part of the inner whorls.

Surface ornamented with strong ribs, alternately bifurcating near the middle and ending in spines on the ventral shoulders. There is a second row of knots or spines on the flanks at the forking of the ribs and on the alternate simple ribs. The flat ventral band is smooth. The septa are ceratitic, with entire saddles and four serrated lobes.

Nevadites humboldtensis is nearest to $N$. hyatti Smith, from which it differs in being more evolute and more compressed laterally, with slenderer volutions. The two species are so similar and so constantly associated as to suggest the possibility that they are male and female of the same species. 
Nevadites humboldtensis also has some resemblance to Trachyceras reitzii Boeckh but is more robust, has squarer cross section, and lacks the rentral furrow. It also resembles $A$ nolcites furcosus Mojsisovies, of the zone of Ceratites trinodosus, but has coarser sculpture, fewer nocles, and even less indication of a ventral furrow. Ceratites ecarinatus Hauer ${ }^{1}$ has a strong resemblance to the young of Nevadites humboldtensis and may be the young of a similar species.

Dimensions of the type specimen of Nevadites humbolatensis.

IIm.

Diameter.

Height of last whorl

Height of last whorl from the preceding

Width of last whorl

Involution_._.

Width of umbilicus_._.

Horizon and locality.--Rather common in the Middle Triassic Daonella dubia zone, Ceratites trinodosus subzone, on the divide between Troy Canyon and the south fork of American Canyon, about 4 miles south of Fitting post office (formerly Foltz). West IIumboldt Range, Nev., associated with Ceratites trinodosus, C. humboldtensis, Gymnotoceras blakei, Nevadites merriami, N. whitneyi, Acrochordiceras hyatti, Daonella dutia, and other species.

Nevadites ilyatTi Smith.

Plate I.XXVII, figures 1-13.

1904. Trachyceras (Anolcites) hyatti, Smith, The comparative stratigraphy of the marine Trias of western America : Proc. California Acad. Sci., $3 d$ ser., Geology, vol. 1, No. 10, p. 389, Pl. XLIII, fig. 12, Pl. XIV, figs. 1 and 2.

Form very evolute. Whorls robust, subquadratic, broad, low and increasing slowly in height. little embracing, and little indented by the inner whorls. Umbilical shoulders abruptly rounded, sides strongly convex, ventral shoulders square, venter broad and flat, without furrow but with a slight concavity formed by the raising of the shoulders in a marginal ridge. The umbilicus is very wide and deep. The height of the whorl is more than one-third of the diameter of the shell, and the width is greater than the height. The width of the umbilicus is two-fifths of the diameter of the shell. The surface is ornamented with strong ribs and spines. The ribs divide on strong spines in the middle of the flanks and then run obliquely forward to the square ventral shoulders, where they end in a row of smaller spines. In youth the ribs have also umbilical tubercles, but these become obsolete at maturity. There are, therefore, three rows of knots or spines in youth, and only two at maturity. There are no intercalary ribs, the number of lateral spines being 13 to 15 , and the marginal knots on the divided ribs being 26 to 30 to a revolution. The septa are ceratitic, with rounded entire saddles and four serrated lobes, the external lobe being short and rather narrow, the first lateral broad and deep, the second lateral and the auxiliary small.

Nevadites hyatti differs from $N$. whitncyi in being much more robust and evolute, with coarser and fewer knots and ribs. It is closer to $N$. humboldtensis, from which it differs in the more robust whorl and in lacking the fine intercalary ribs. From $N$. merriami it differs in the rounder cross section and in the fewer and coarser ribs and knots; it may be distinguished from $N$. crassus Hauer by the same characters.

IIorizon and locality.-Rather rare in the Middle Triassic, Daonella dubia zone, Ceratites trinodosus subzone, of Fossil Hill, south fork of American Canyon, 4 miles south of Fitting post office (formerly Foltz), West Humboldt Range, Nev., associated with Ceratites trinodosus, C. humboldtensis, Gymnotoceras blakei, Nevadites whitneyi, Beyrichites rotelliformis, Sageceras gabbi, Daonella dubia, and other species.

1 Beitrïge zur Kenntniss der Cephalopoden aus der Trias von Bosnien, Part II : Denkschr. K. Akad. Wiss. Wien, vol. 63, 1896, p. 257, Pl. VIII, figs. 7-10. 
Nevadites Merriami Smith, sp. nov.

Plate LXXV, figures 1-14; Plate I.XXVI, figures 1-16.

This species is the type of Neradites Smith, gen. nov.

Form evolute. Whorls subquadratic in cross section, little embracing, and little indented by the inner volutions, slightly higher than wide and increasing slowly in height. Sides flattened, only slightly convex, with abruptly rounded umbilical shoulders, and square ventral shoulders. Venter flat and broad, without any furrow. Surface ornamented with strong lateral ribs which start from the umbilical shoulder and fork in strong lateral knots about halfway up the sides, bend obliquely formard, and end in strong knots on the ventral shoulder. Between these primary ribs there is usually an intercalary rib, beginning on the flank and ending in similar knots to those of the primary ribs. The number of the marginal knots is, therefore, approximately twice that of the laterals. There are no umbilical knots at maturity, thongh they are present on young shells.

The primary ribs do not always bicurfate on the flanks, and the intercalary ribs are not regular in distribution, hence the proportion of lateral to marginal knots is not constant.

The septa are ceratitic, saddles entire, and the lobes all serrated. The small divided external lobe falls on the ventral shoulder angle, the large first lateral high up on the flanks above the lateral knots; the small second lateral falls on the umbilical shoulders; and the smaller anxiliary lobe falls on the umbilical slope. The outer whorl embraces about one-third of the inner and is indented by it to about one-fifth of the height. The height of the whorl is about two-fifths of the diameter of the shell and the width is seven-eighths of the height. The width of the umbilicus is slightly more than one-third of the diameter of the shell.

Nevadites merriami is most nearly related to Nevadites (Ceratites) crassus Hauer, ${ }^{1}$ but is slightly less robust and has stronger lateral and marginal knots. The intercalary ribs on $N$. merriami begin above the middle of the flanks, whereas in $N$. crassus Hauer they begin on the umbilical shoulder and are as strong as the bifurcating primary ribs. In $N$. crassus the proportion of lateral to marginal knots is about $2: 3$, and in $N$. merriam $i$ it is approximately $1: 2$.

Nevadites merriami is closely related to $N$. hyatti $\mathrm{Smith}_{,}{ }^{2}$ but differs in its squarer cross section and finer and more numerous lateral and marginal knots. Nevadites merriami is intermediate between $N$. hyatti Smith and $N$. whitneyi $G a b b$, being broader than the latter and squarer than the former. It is more robust than $N$. humboldtensis Smith, with finer and more numerous ribs and knots.

Dimensions of the type specimen of Yevadites merriami.

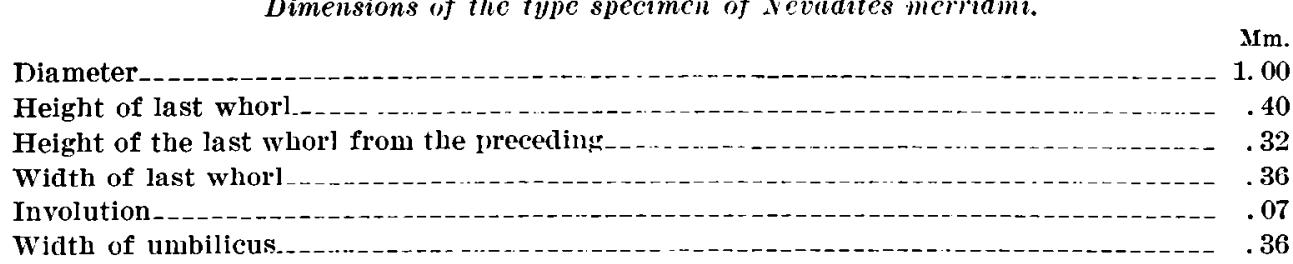

The specific name is given in honor of Prof. J. C. Merriam, of the University of California. Horizon and locality.-Common in the Middle Triassic, Daonella dubia zone, Ceratites trinodosus subzone, on the divide between Troy Canyon and the south fork of American Canyon, 4 miles south of Fitting post office (formerly Foltz), West Humboldt Range, Nev., associated with Ceratites trinodosus, C. humboldtensis, Gymnotoceras blakei, Daonella dubia, and other species.

\Beiträge zur Kenntniss der Cephalopoden aus der Trias ron Bosnien, Part II : Denkschr. K. Akad. Wiss. Wien, Vol. 63,1896 , p. 259 , Pl. VIII, figs. 1 and 2 .

2 The comparative stratigraphy of the marine Trias of western America : I'roc. California Acad. Sci., 3d ser., Geology, vol. 1, 1904, p. 389, Pl. XLIII, fig. 12, and Pl. XLV, figs. 1 and 2. $16279^{\circ} \longrightarrow$ No. $83-14-\longrightarrow 9$ 
Nevadites sinclairi Smith, sp. nov.

Plate IXXXI, figures 17-19; Plate LXXXII, figures 1-3.

From evolute, widely umbilicate. Whorls robust, somewhat compressed laterally, higher than wide, increasing slowly in height, little embracing and little indented by the inner whorls. The height of the last whorl is more than one-third of the diameter of the shell and the width somewhat less than the height; it embraces one-fourth of the inner whorl, and is indented by it to about one-eighth of the height. The width of the umbilicus is about two-fifths of the diameter of the shell.

The surface is ornamented with strong sharp ribs and tubercles, the ribs alternating on tubercles on the ventral shoulder and dividing at another row of knots more than halfway up the flanks. All ribs, whether primary or intercalary, end in strong tubercles on the strongly defined angular ventral shoulders. The intercalary ribs have only the marginal row of tubercles. but the primary ribs have all three, umbilical, lateral, and marginal. The venter is only slightly concave but without a furrow.

There are about 36 marginal and 14 lateral tubercles to a revolution. The umbilical row is fewer in number and less coarse than the lateral row. The intercalary tubercles are irregular, in some specimens lacking entirely, and in others reaching to the umbilicus but never forming umbilical tubercles. Nevadites sinclairi is closely allied to $N$. humboldtensis Smith but is more evolute and slender and has a more compressed whorl. It is more slender and evolute than $N$. hyatti Smith and has more numerous and finer ribs and spines. It is less compressed than $N$. whitneyi, with fewer and coarser ribs and spines and has a more nearly quadratic cross section. Septa ceratitic, with entire saddles and four external serrated lobes, all of which are small except the first lateral.

The specific name is given in honor of Dr. W. J. Sinclair, of Princeton University.

Horizon and locality.-Common in the Middle Triassic, Daonella dubia zone, Ceratites trinodosus subzone, of Fossil Hill, south fork of American Canyon, West Humboldt Range, Nev., associated with Ceratites trinodosus, C. humboldtensis, Gymnotoceras blakei, Nevadites whitneyi, Beyrichites rotelliformis, Acrochordiceras hyatti, Daonella dubia, and other species.

\section{Nevadites whitneyi Gabb.}

Plate XLVIII, figures 4 and 5 ; Plate IXXX, figures 1-8; Plate IXXXI, figures 1-16.

1864. Coratites vohitneyi (in part), Gabb, Description of the Triassic fossils of California and the adjacent Territories: Geol. Survey California, Palæontology, vol. 1, p. 23. Pl. IY, fig. 11 (excluding figs. 12 and $12 a)$.

1886. Arpadites whitneyi, Mojsisovies, Arktische Triasfaumen: Mém. Acad. imp. sci. St.-Pétersbourg, 7 th ser., vol. 33 , No. 6 , p. 149 .

1896. Arpadites whitneyi, Mojsisovics, Beiträge zur Kenntniss der obertriadischen Cephalopoden-Faunen des Himalaya : Denkschr. K. Akad. Wiss. Wien, rol. 63, p. 696.

(Not 1877. Trachyccras whitneyi, Meek, Palæontology: C. S. Geol. Expl. 40th Par., vol. 4, 1. 116, Pl. XI, figs. 3 and $3 a$.)

Rather evolute, robust. Whorls subquadratic, higher than wide, deeply embracing but not deeply indented by the inner whorls, increasing rapidly in height in age. Sides flattened, with the greatest breadth of the whorl below the middle. Umbilical shoulders abrupt but slightly rounded. Umbilicus wide and deep. Ventral shoulders square, venter broad and flattened, without any trace of furrow but with the ends of the ribs rising above the general level of the border. The height of the whorl is less than half the diameter of the shell, and the width is somewhat less than the height. The outer whorl embraces more than half the inner and is indented to only about one-sixth of its height. The width of the umbilicus is one-third of the diameter of the shell.

The surface is ornamented with strong ribs that start from umbilical knots and usually bifurcate about a third of the distance up the flanks, ending in strong marginal spines on the 
ventral shoulders. At the lateral bifurcation there are often weak knots, but these become almost obsolete at maturity. In youth the sculpture is much stronger and the lateral knots are usually present. The septa are ceratitic, the saddles being entire, and the four lobes serrated.

Nevadites whitneyi is closely allied with $N$. hyatti Smith, ${ }^{1}$ but differs from that species in the greater compression of the whorls, the finer ribs, narrower venter, and obsolescence of the lateral knots. It is more closely related to $N$. merriami, from which it differs in its somewhat finer ribs, obsolescence of the lateral spines, and more compressed and higher whorls. It is possible that these two species intergrade, but no intergradation has been observed in the large number of specimens of both species collected by the writer.

Meek $^{2}$ described and figured, under the name of Trachyceras whitneyi Gabb, another form from the same horizon, to which Mojsisovics afterwards gave the name Anolcites americanus Mojsisovics. This form was also figured by Gabb ${ }^{3}$ but differs from the true Nevadites whitneyi in the higher whorl, narrower venter, deep ventral furrow, rounded ventral shoulders, and strong lateral knots in the ribs, partly crossing the venter, and in having a second row of knots on the ventral shoulders.

Dimensions of a typical specimen of Nevadites whitncyi.

Diameter
Height of last whorl
Height of last whorl from the preceding
Width of last whorl
Involution
Width of umbilicus.

At this size the width of the flat venter is 11 millimeters.

Borizon and locality:-Very common in the Middle Triassic, Daonella dubia zone, Ceratites trinodosus subzone, of Fossil Hill, south fork of American Canyon, West Humboldt Range, Nev., associated with Ceratites trinodosus, C. humboldtensis, Gymnotoceras blakei, Protrachyceras meeki, Beyrichites rotelliformis, Sageceras gabbi, Monophyllites billingsianus, Daonella dubia, and other species. It was also found in the same horizon in Cottonwood Canyon, West Humboldt Range, from which locality Gabb's type came.

\section{Genus TRACHYCERAS Laube.}

1869. Trachyceras, Laube, Veber Ammonites a $n$ Münster und dessen Verwandte: Sitzungsber. K. Akad. Wiss. Wien, rol. 59, pt. 1, p. 7 .

1877. Trachyceras, Meek, Palæontology: C. S. Geol. Expl. 40th Par., vol. 4, pt. 1, p. 116.

3879. Trachyceras, Mojsisovics, Vorläufige kurze Uebersicht der Ammoniten-Gattungen der Mediterranen und Juravischen Trias. Verhandl. K.-k. geol. Reichsanstalt Wein, p. 140.

1882. Trachyceras (in part), Mojsisovics, Die Cephaloporen der Mediterranen Triasprovinz: Abhandl. K.-k. geol. Reichsanstalt Wein, vol. 10, p. 93.

1889. Trachyceras, Hyatt, in Whiteaves, Fossils of the Triassic rocks of British Columbia: Geol. and Nat. Hist. Survey of Canada, Contributions to Canadian Palaontology, vol. 1, pt. 2, p. 142.

1893. Trachyceras, MIojsisovics. Das Gebirge um Hallstatt, Part I; Die Cephalopoden der Hallstaitter Kalke: Abhandl. K.-k. geol. Reichsanstalt, W'ien, vol. 6, It. 2, p. 617.

1896. 'Trachcyceras, Mojsisovics, Beiträge zur Kenntniss der obertriadischen Cepha lopoden-Faunen des Himalaya: Denkschr. K. Akad. Wiss. Wien, vol. 63, p. 646.

1898. I'rotrachyceras, Tornquist, Neuere Beitrïge zur Geologie und Palïontologie der Umgebung von Recoaro und Schio in Venetien, Part IV : Zeitschr. Dentsch. geol. Gesell., vol. a0. p. 650.

1903. Trachyceras, Frech, Neue Cephalopoden aus den Buchensteiner, Wengener und Raibler Schichten des südlichen Bakony: Resultate der wissenschaftlichen Erforschung des Balatonsees, vol. 1, pt. 1, p. 21.

1904. Trachyceras, Smith, The comparative stratigraphy of the marine Trias of western America: Proc. California Acad. Sci., 3d ser., Geology, vol. 1, No. 10, p. 387.

1 The comparative stratigraphy of the marine Trias of western America : Proc. California Acad. Sci., 3d ser., Geology, vol. 1, No. 1, No. 10, 1904, p. 389, Pl. XIIII, fig. 12 ; Pl. XI.V, figs. 1 and 2.

2 Palæontology : U. S. Geol. Expl. 40th Par., vol. 4, p. 116, PI. XI, figs. 3 and $3 a$

s Description of the Triassic fossils of California and the adjacent Territories: Geol. Survey California, Palæontology, vol. 1, Pl. IV, figs. 12 and $12 a$. 
1005. Trachyceras, Hyatt and Smith, The Triassic cephalopod genera of America: Prof. Papers L. S. Geol. Survey No. 40, p. 191.

1907. Trachyceras, Diener, The fauna of the Himalayan Muschelkalk: Himalayan fossils, vol. 5, Mem. No. 2, 1. 94 (Mem. Geol. Survey India, Pal. Indica, 15th ser.).

1913. Trachyceras, Simionescu, Fauna Ammonitilior Triasici dela Hagighiol (Dobrogea) : Academia Romana, No. 31, p. 295.

Type.-_Ceratites" aon Münster ${ }^{1}$ and Mojsisovics."

Form moderately involute, somewhat compressed laterally, deeply embracing, but usually showing the inner volutions. Whorls higher than wide, with abrupt umbilical shoulders, somewhat flattened convex sides, rounded abdominal shoulders, and proportionally narrow venters, with a distinct central furrow bounded by tubercles. Body chamber short, not exceeding two-thirds of the last volution.

The surface is ornamented with ribs radiating from tubercles on the umbilical shoulders and running with gentle curves up the sides to the abdominal shoulders, where they curve forward. These ribs may bifurcate on the umbilicus, again on the sides, and more rarely, on the shoulders. Their ends form the rows of tubercles that border the central furrow. On the ribs are spiral rows of spines or tubercles, which give a rugose appearance to the shell and suggested the name of the genus. The spines may become almost obsolete on very old shells but are always present at early maturity. They show on the cast as well as on the shell, and, together with the central furrow, afford an easy means of identification of the genus. Constrictions do not appear at all on the shell or on the cast, and contractions of the body chamber have not been observed. Septa ammonitic but not deeply digitate, moderately dolichophyllic. The external lobe is always divided by a siphonal saddle and there are always two lateral lobes present, but the auxiliary lobe is absent in some specimens.

Mojsisovics ${ }^{3}$ divided this genus into three groups, or subgenera: Trachyceras s. str., characterized by having two rows of spines on each side of the central furrow; Protrachyceras Mojsisovics, with only a single row of spines on each side of the furrow; and Anolcites Mojsisovics, without a distinct furrow and with the ribs crossing the venter. As Trachyceras aon had the double spine rows, all Trachyceratea with this sort of ornamentation are placed under the typical section of the genus. This group is usually more involute and more compressed laterally and seems to have originated from the group with the single row. of spines bordering the furrow. Mojsisovics assumes that the genus Trachyceras in the broader sense developed out of Balatonites and that this in turn came from Tirolites. It is possible that some species of Trachyceras did descend from Tirolites, but it is more than doubtful if Balatonites is a connecting link in the series, for no Balatonites stage is seen in the development of any of the Trachy. ceratea. The writer, however, is of the opinion that most species of Trachyceras descended from Ceratites of the group of $C$. bosnensis, through Nevadites. Arthaber ${ }^{4}$ seems to share this opinion, although he, of course, makes no reference to Nevadites, as that genus is first described in the present work. Diener, ${ }^{5}$ on the other hand, thinks it probable that Trachyceras is polyphyletic, descended in part from Balatonites and in part from Ceratites.

K. A. von Zittel ${ }^{6}$ placed this genus in the family Tropitidæ, but without assigning any reason for the change. It need hardly be said, however, that the development of the Trachyceratea is wholly unlike that of the Tropitidx; that of the former points to an origin from the Prolecanitidæ, whereas the Tropitidæ seem to have come from the Glyphioceratidx. Prof. von Zittel was no doubt influenced by the resemblance of Sagenites to Trachyceras in placing the latter

${ }^{1}$ Leber das Kalkmergel-Lager von St. Cassian in Tyrol, und die darin vorkommenden Ceratiten: Neues Jahrb., 1834, p. 13 , Pl. 1, firs. 4 and 5 .

Die Cephalopoden der Mediterranen Triasprovinz: Abhandl. K.-k. geol. IReichsanstalt Wien, vol. 10, 1882, p. 129, P1. XXI, figs. 1-35, 37, and 38 .

${ }^{3}$ Des Gebirge um Hallstatt, Part I ; Die Cephalopoden der Hallstätter Kalke : Abhandl. K.-k. geol. Reichsanstalt Wien, 1893, vol. 6, pt. 2, p. 617 .

4 Neue Funde in den Werfener Schichten und im Muschelkalke des süđlichen Bakony : Resultate der wissenschaftlichen Erforschung des Balatonsees, vol. 1, pt. 1, 1903, p. 24.

E Entwurf einer Systematik der Ceratitiden des Muschelkalkes: Sitzungsber. K. Akad. Wiss. Wien, vol. 114, pt. 1, 1905 , p. 804 .

6 Grundzüge der Paläontologie, 1895, p. 405. 
genus in the Tropitidæ, but this resemblance is purely external and is one of the many puzzling convergence phenomena so often seen in the history of the ammonites, the young of the two groups being farther apart than the mature forms.

The origin of Trachyceras is indicated by the geologic sequence of the true Trachyceratea. The group of Ceratites nodosi is common in the lower, middle, and upper Muschelkalk; the group of Ceratites bosnensis does not appear until the middle Muschelkalk; then in America Nevadites is very common in the horizon of the European Bosnic substage, Ceratites trinodosus subzone, and is rare in the same horizon in the Mediterranean region. Anolcites is common in this same horizon in Nevada and is represented in the Mediterranean region by A. furcosus Mojsisovics, A. arminice Mojsisovics, and A. elisabetho Mojsisovics; also somewhat doubtfully in the Indian region. Protrachyceras also appears in this same horizon in Nevada but becomes more common in the Upper Triassic. In the Fassanic stage, Buchenstein epoch, Anolcites and Protrachyceras abound in the Mediterranean region, and Anolcites also occurs in Japan in this horizon.

The abundance of the true Trachyceratea in the Middle Triassic of America suggests this region as the place of their origin. The similarity of these forms to Mediterranean species and the rarity of Trachyceratea in the Middle Triassic of Asia suggests that during this epoch there may have been an Atlantic connection between the Mediterranean Sea and the Great Basin Sea of America, and that these waters were more intimately connected than either was with the Indian portion of the Tethys.

Trachyceras in the limited sense is confined to the Upper Triassic, but Protrachyceras ranges from the Muschelkalk to the upper Karnic, Anolcites ranges from Muschelkalk to middle Karnic, and the ancestral Nevadites is confined to the Middle Triassic.

In the Alpine province the entire genus became extinct in the middle Karnic, below the zone of Tropites subbullatus, but in the Himalayas it has been found in later beds, and in California Trachyceras is very abundant in the beds with Tropites subbulatus. The writer has collected in Shasta County, Cal., numerous specimens of the two groups in the same hand specimen, which would prove conclusively that there was no confusion of two horizons in collecting.

Subgenus ANOLCITES Mojsisovics.

1893. Anolcites, Mojsisovies, Das Gebirge um Hallstatt. Part I; Die Cephalopoden der Hallstaitter Kalke: Abhandl. K.-k. geol. Reichsanstalt Wien, vol. 6, pt. 2, p. 621.

1904. Anolcites, Smith, The comparative stratigraphy of the marine Trias of western America: Proc. California Acad. Sci., 3d ser., Geology, vol. 1, No. 10, p. 388.

1905. Anolcites, Hyatt and Smith, The Triassic cephalopod genera of America : Prof. Paper U. S. Geol. Survey No. 40 ; p. 196.

Trachrceras (ANolcites) draket Smith, sp. nov.

Plate XCVII, figures $15 \mathbf{5}-17$.

Form evolute, widely umbilicate. Whorls subrectangular in cross section, higher than broad, with abruptly rounded umbilical and ventral shoulders and gently rounded venter. The height of the last whorl is about one-third of the diameter of the shell, and the width is five-sixths of the height. The width of the umbilicus is somewhat more than one-third of the diameter of the shell. Surface ornamented with strong ribs that start from the umbilical slope, run nearly straight up the sides, and cross the venter without interruption, becoming higher as the ventral shoulder is reached. Knots are formed on many of the ribs at the ventral shoulder, and a few of the ribs divide on the flanks, but there is no regular alternation. The ribs do not run straight across the venter but have an irregular zigzag alternation from side to side. The septa are ceratitic, with serrated lobes and rounded entire saddles. 
Anolcites drakei is not nearly related to any other species in the American region. The specific name is given in honor of Dr. N. F. Drake.

Horizon and locality.-Very rare in the Middle Triassic, Daonella dubia zone, Ceratites. trinodosus stbzone, of Fossil Hill, south fork of American Canyon, 4 miles south of Fitting post office (formerly Foltz), West Humboldt Range, Nev., associated with Ceratites trinodosus, C. humboldtensis, Gymnotoceras blakei, Nevadites whitneyi, Sageceras gabbi, Daonella dubia, and other species.

Trachyceras (Anolcites) barberi Smith, sp. nov.

Plate LXXXVI, figures 12-14.

Form slender, rather involute, discoidal. Whorls of moderate height, laterally compressed. Sides nearly flat, umbilical shoulders abrupt. Venter flat and narrow, bordered by a row of short spines, but without a furrow. The umbilicus is nearly one-third of the diameter of the shell. The height of the whorl is about half the diameter of the shell, and the width is three-fifths of the height. The outer whorl embraces two-thirds of the inner and is indented by it to one-fifth of the height. The surface is ornamented with close-set strong radial ribs and seven rows of short spines, one on the umbilical shoulder, five on the flanks, and one on the ventral border. The septa are unknown.

Trachyceras barberi resembles T. gabbi Smith in its compressed form and flattened venter without furrow but differs from that species in its coarser ribs and more numerous close-set rows of spines. It also resembles $T$. hispanicum Mojsisovics but differs in its stronger sculpture.

The specific name is given in memory of the late William B. Barber, who assisted the writer in collecting this fauna.

Horizon and locality.-Very rare in the Middle Triassic, Daonella dubia zone, Ceratites trinodosus subzone, on Fossil Hill, south fork of American Canyon, 4 miles south of Fitting post office (formerly Foltz), West Humboldt Range, Nev., associated with Ceratites trinodosus, C. humboldtensis, Gymnotoceras blakei, Nevadites whitneyi, Sagereras gabbi, Daonella dubia, and other species.

\section{Trachychas (Anolcites) flrlongi Smith, sp. nov.}

Plilte IAXXIII, figures 1- $\overline{\mathbf{c}}$; I'late I.XXXIV, figures 1-13.

1904. Trachyceras (Anolcites) meeki (in part), Smith, The comparative stratigraphy of the marine Trias of western America: Proc. California Acad. Sci., 3d ser., Geology, vol. 1, No. 10, Pl. XLrV, fig. 4 (exclusive of text, and Pl. XLIV, fig. 3).

Moderately evolute, laterally compressed. Whorl robust, deeply embracing but not deeply indented by the inner volutions. Sides nearly vertical up to the ventral shoulders and then sloping gently inward to the ventral margin. Venter rather broad, nearly flat but slightly depressed without developing a furrow. The margins are higher than the center because of the ridges formed by the ends of the ribs. The umbilical shoulders are very abrupt and the umbilical wall very steep. The height of the whorl is somewhat more than two-fifths of the diameter of the shell, and the width is about three-fourths of the height. The outer whorl embraces one-third of the inner and is indented by it to only one-sixth of the height. The width of the umbilicus is two-sevenths of the diameter of the shell. The surface is ornamented with coarse ribs that start from knots on the umbilicus, run nearly straight two-thirds of the distance up the flanks, and fork at coarse knots on the ventral shoulders. The divided ribs then run obliquely forward to the ventral margin, develop a second row of finer knots halfway between the shoulders and the margin, and end in knots or short spines, which project above the venter, forming a ridge. Besides these principal ribs there are many intercalary ribs, 
beginning on the flanks above the umbilicus and without the bifurcation at the shoulders but forming the finer knots on the shoulder slope and on the marginal ridge. The coarse ribs do not cross the venter but are continued by low ridges across in diagonal alternating position from spine to spine.

The septa are ceratitic, the saddles being entire and all the lobes serrated. The divided ventral lobe is small and shallow, the first lateral very wide and deep, the second lateral about half as large, and the auxiliary small.

Dimensions of the tupe specimen of Trachyceras furlongi.

Diameter
Height of last whorl
Height of last whorl from the preceding
Width of whorl
Involution
Width of umbilicus,

Trachyceras furlongi is easily distinguished from Nevarlites whitneyi by its sloping shoulders, narrower venter, and the numerous lateral spines. It is also easily distinguished from Trachyceras (Protrachyceras) meeki Mojsisovics by its more robust whorl, less numerous spines, and its broader venter without the furrow that characterizes T. meeki. It is also associated with Trachyceras (Anolcites) gabbi Smith, but that species has a narrower umbilicus, more compressed whorl, narrower venter, and more numerous spines. In early youth $T$. furlongi and $T$. gabbi are very similar, the former species being more robust, with coarser ribs and knots. The young stages of $T$. furlongi are very similar to $T$. (Anolcites) elisabetho Mojsisovics of the zone of Ceratites trinodosus of the Alpine Province but differ from the European species in the wider and flatter venter and in having only four instead of five rows of spines.

Dimensons of a half-groun specimen of Trachyceras furlongi.

Dimensons of a half-groun specimen of Trachyceras furlongi.
Diameter
Height of last whorl.
Height of last whorl from the preceding.
Width of last whorl
Involution.
Width of umbilicus.

The writer was for a long time under the impression that the specimens here assigned to Trachyceras furlongi Smith belong to T. (Protrachyceras) americanum Mojsisovics, as they bear some resemblance to Gabb's figure of the type of that species. ${ }^{1}$ But a direct comparison with the type specimen of Gabb shows the difference. $T$. americanum has a distinct furrow even in early youth and $T$. (Anolcites) furlong $i$ never has any suggestion of a ventral furrow even in old age.

The specific name is given in honor of Mr. E. L. Furlong, of the University of California, to whom the writer is indebted for much assistance in collecting the fauna of the Middle Triassic.

IIorizon and locality.-Rather common in the Middle Triassic, Daonella dubia zone, Ceratites trinodosus subzone, on Fossil Hill, on the divide between Troy Canyon and the south fork of American Canyon, 4 miles south of Fitting post office (formerly Foltz), West Humboldt Range, Nev. It was associated with Ceratites trinodosus, Gymnotoceras blakei, Beyrichites rotelitiformis, Anolcites gabbi, A. gracilis, Protrachyceras meeki, P. americanum, Nevadites whitneyi, Sageceras gabbi, Acrochorliceras hyatti, Daonella dubia, and many other shells.

I Description of the Triassic fossils of California and the adjacent Territories: Geol. Survey California, Palaontology, vol. 1, Pl. IV, fig. 12 . 
Trachyceras (Anolcites) gabbi Smith, sp. nov.

Plate IX, figures 3-17; Plate XI, figures 4-7; Plate LXXXr, figures 11 and 12; Plate LXXXVI, figures 1-11.

1904. Trachyceras (Anolcites) meeki (in part), Smith, The comparative stratigraphy of the marine Trias of western Anerica: Proc. Callifornia Acad. Sci., 3d ser., Geology, vol. 1, No. 10, Pl. XLIY, fig. 3 (not fig. 4, which is T. furlongi Smith).

1905. Trachyceras (Anolcites) meeki (in part), Hyatt and Smith, The Triassic cephalopod genera of America : Prof. Paper U. S. Geol. Survey No. 40 (exclusive of text), Pl. LIX, figs. 3-17; Pl. LXXIV, figs. 4-7 (not Pl. XXIV, figs. 8 and 9 ; Pl. LIX, figs. 1 and 2 ; or Pl. LXXIV, figs. 1-3).

Involute, discoidal, laterally compressed. Whorls narrow, high, and increasing rapidly in height. Sides flattened, convex, ventral shoulders square, venter narrow and slightly concave, bordered by the rows of shoulder spines but without a true furrow. The umbilicus is narrow, being about one-fifth of the diameter of the shell. The outer whorl embraces about three-fifths of the inner and is indented by it to about one-seventh of the height. The height of the last whorl is less than half the diameter of the shell, and the width is about two-thirds of the height. The surface is ornamented with rather fine bifurcating ribs and with four rows of knots on the ribs, one on the umbilical shoulder, one in the middle of the flanks, one on the ventral shoulder, and a fourth on the border of the ventral furrow. The septa are ceratitic, with serrated lobes and entire saddles.

Trachyceras gabbi Smith is very closely related to $T$. furlongi Smith, from which it differs in its more compressed and slender whorl and finer ribs and knots. It also resembles $T$. meeki Mojsisovics but is distinguished by lacking the ventral furrow and by having a more compressed whorl, finer sculpture, and narrower umbilicus.

The specific name is given in memory of W. M. Gabb, paleontologist of the Geological Survey of California.

Horizon and locality.-Common in the Middle Triassic, Daonella dubia zone, Ceratites trinodosus subzone, on the divide between Troy Canyon and the south fork of American Canyon, 4 miles south of Fitting post office (formerly Foltz), West Humboldt Range, Nev., associated with Ceratites trinodosus, C. humboldtensis, Anolcites furlongi, Nevadites whitneyi, Sageceras gabbi, Beyrichites rotelliformis, Longobardites nevadanus, Gymnotoceras blakei, Daonella dubia, and other species.

Trachyceras (Anolcites) gracile Smith, sp. nov.

Plate IXXXII, figures 4-9.

Form slender, evolute, laterally compressed. Whorls low and increasing very slowly in height, little embracing and little indented by the inner whorls. Umbilicus wide and shallow. Sides flattened, ventral shoulders subangular. Venter narrow and flattened, without furrow. Surface ornamented with strong ribs, starting from weak umbilical knots and running nearly straight up the sides, ending in strong tubercles on the ventral shoulders. These ribs are mostly undivided and cross the venter without interruption but with a shallow depression. There are a few lateral knots in youth but at maturity these become obsolete. The septa are ceratitic, with entire saddles and four serrated lobes. The height of the whorl is about twofifths of the diameter of the shell, and the width is slightly more than half the height. The outer whorl embraces one-third of the inner and is indented by it to only one-tenth of the height. The width of the umbilicus is more than one-third of the diameter of the shell.

Anolcites gracilis is closely allied to $A$. arminire Mojsisovics, of the zone of Ceratites trinodosus of the Alpine province, but differs in being slightly more evolute and in having fewer lateral knots. In youth the resemblance is greater than in age.

Horizon and locality.--Rather rare in the Middle Triassic, Daonella dubia zone, Ceratites trinodosus subzone, of the West Humboldt Range, Nev.; in Cottonwood Canyon; and also 
on Fossil Hill, south fork of American Canyon, associated with Ceratites trinodosus, C. humboldtensis, Gy, notoceras blake i, Nevadites whitneyi, Protrachyceras meeki, Beyrichites rotelliformis, Acrochordiceras hyatti, Sageceras gabbi, Daonella dubia, and other species.

\section{Subgenus PROTRACHYCERAS Mojsisovics.}

1893. Protrachyceras, Mojsisorics, Das Gebirge un Hallstatt, Part I; Die Cephalopoden der Hallstätter Kalke: Abhandl. K.-k. geol. Reichsanstalt, Wien, vol. 6, pt. 2, p. 618.

1896. Protrachyceras, Mojsisovics, Beitrïge zur Kenntniss der obertriadischen Cephalopoden-Faunen des Himalaya: Denkschr. K. Akad. Wiss. Wien, rol. 63, p. 646.

1898. Protrachyceras, Tornquist, Neuere Beitrïge zur Geologie und Paläontologie der Ungebung von Recoaro und Schio in Venetien, Part IV : Zeitschr. Dentsch. geol. Gesell., vol. 50, p. 659.

1904. Protrachyceras, Smith, The comparative stratigraphy of the marine Trias of western America: Proc. California Acad. Sci., 3d ser., Geology, vol. 1, No. 10, p. 387.

1905. Protrachyceras, Hyatt and Smith, The Triassic cephalopod genera of America: Prof. Paper U. S. Geol. Survey No. 40, p. 193.

\section{Trachyceras (Protrachychas) americanum Mojsisovics.}

Plate Xr, figures 3 and $3 a$; Plate XLVIII, figures 6 and 7 ; Plate LXXXIr, figures 10-13.

1864. Ceratites whitneyi (in part), Gabb, Description of the Triassic fossils of California and the adjacent Territories: Geol. Survey of California, Palæontologt, vol. 1, p. 23, Pl. IV, figs. 12 and $12 a$ (not fig. 11).

1877. Trachyceras whitneyi, Meek, Geol. Expl. 40th Par. vol. 4, P. 116, Pl. XI, figs. 3 and $3 a$.

1886. Trachyceras americanum, Mojsisovies, Arktische Triasf:ıunen: Mém. Acad. imp. sci. St.-Pétersbourg, 7th ser., vol. 33, No. 6, p. 149.

1896. Anolcites americanus, Mojsisorics, Beiträge zur Kenntniss der obertriadischen Cephalopoden-Faunen des Himalaya: Denkschr. K. Akad. Wiss. Wien, rol. 63, p. 124.

Form robust, moderately involute, somewhat compressed laterally. Whorls rather deeply embracing but not deeply indented by the inner volutions. The height of the outer whorl is more than one-third of the diameter of the shell, and the width is slightly less than the height. The width of the umbilicus is approximately one-third of the diameter of the shell. The umbilical shoulders are abruptly rounded; the sides of the whorl flattened convex, with subangular ventral shoulders. The venter is rather narrow, with high ridges bordering a rather deep narrow furrow. The surface is ornamented with rather fine sharp ribs that run nearly straight up to the middle of the flanks, then bend forward to the ventral ridges. The alternate ribs bifurcate in the middle of the flanks. There are five rows of knots, one on the umbilical shoulders, a small one just above the umbilical shoulders, one in the mididle of the flanks, a third on the ventral shoulders, and a fourth on the ventral ridge. The alternate ribs do not reach the umbilicus but begin below the ventral shoulders and have only the two upper rows of tubercles. The alternation of the principal and secondary ribs is not regular, for in some specimens two primary ribs are adjacent without the intercalary rib. The ribs are much stronger than the tubercles, except in early youth, when the tubercles are more pronounced. The septa are ceratitic, with entire saddles and serrated lobes.

Gabb figured under the name of Ceratites whitneyi two distinct species, of which only the first ${ }^{1}$ can retain the specific name. Meek afterwards figured ${ }^{2}$ the form given by Gabb in figures 12 and $12 a$ of Plate IV of his work. Mojsisovics, recognizing the difference of the forms, proposed to retain the specific name for the first species, and renamed the second species Trachyceras americanum, ${ }^{3}$ using Gabb's figures as the type and classing with this the form figured by Meek. This confusion has caused much trouble-in recognizing the species, for the drawings of both Gabb and Meek are very poor, and the writer was able to recognize

${ }^{1}$ Geol, Survey California, Palæontology, vol, 1, 1864, Pl. IV, fig. 11.

2 Palæontology : C. S. Geol. Expl. 40th Par., Vol. IV, PI. XI, figs. 3 and $3 n$

3 Arktische Triasfaunen : Mém. Acad. imp. sci. St.-Pétersbourg, 7th ser., vol. 33, No. 6, 1886, p. 149. 
what really was meant by Trachyceras americanum only by comparison of the material with Gabb's original specimen of his Plate IV, figures 12 and $12 a$, which bears little resemblance to his illustrations.

In youth Protrachyceras americanum resembles Anolcites furlongi Smith but has more numerous and finer ribs and fewer tubercles. It also resembles $P$. meeki Mojsisovics, but has stronger ribs and five rows of knots instead of six.

The specimens assigned to Protrachyceras americanum were identified by direct comparison with Gabb's type specimen, the original of his Plate IV, figure 12.

Horizon and locality.-Rare in the Middle Triassic, Daonella dubia zone, Ceratites trinodosus subzone, on the divide between Troy Canyon and the south fork of American Canyon, 4 miles south of Fitting post office (formerly Foltz), West Humboldt Range, Nev., associated with Ceratites trinodosus, C. humboldtensis, Nevadites whitneyi, Sageceras gabbi, Daonella dubia, and other species. It was also found in the same horizon on the north fork of Cottonwood Canyon, West Humboldt Range, Nev.

Trachyceras (Protrachyceras) nunni Smith, sp. nov.

Plate LXXXIV, figures 14-16.

Form robust, somewhat compressed laterally. Whorls of medium height and increasing rather slowly. Umbilical shoulders abrupt, flanks gently convex, rounding without distinct shoulders to the narrow venter. The width of the umbilicus is one-fourth of the diameter of the shell. The venter is narrow and impressed with a distinct furrow, bordered by a row of stout spines. The height of the whorl is nearly half the diameter of the shell, and the width is two-thirds of the height. The outer whorl embraces two-thirds of the inner and is indented by it to one-sixth of the height. The surface is ornamented with strong slightly curved ribs and five rows of spines; one row is on the umbilical shoulder, three are on the flanks, and a fifth borders the ventral furrow. The septa are ceratitic, with rounded saddles and serrated lobes.

Trachyceras dunni resembles T. meeki, with which it is associated, in its compressed form and the moderately wide umbilicus but differs from that species in its stronger ribs and spines. As in T. meeki, the ribs and spines alternate on opposite sides of the ventral furrow and do not bundle on the umbilical shoulders, but usually bifurcate some distance up on the flanks.

The specific name is given in honor of Mr. L. F. Dunn, the discoverer of this fauna.

Horizon and locality.-Very rare in the Middle Triassic, Daonella dubia zone, Ceratites trinodosus subzone, of Fossil Hill, south fork of American Canyon, 4 miles south of Fitting post office (formerly Foltz), West Humboldt Range, Nev., associated with Ceratites trinodosus, C. humboldtensis, Gymnotoceras blakei, Nevadites whitneyi, Sageceras gabbi, Daonella dubia, and other species.

\section{Trachyceras (Protrachyceras) homprayi Gabb.}

Plate XrI, figures 11-13.

1864. Ammonites homfrayi, Gabb, Description of the Triassic fossils of California and the adjacent Territories: Geol. Survey, California, Palæontology, rol. 1, p. 26, Pl. IV, figs. 18 and 19.

Shell discoidal, involute, strongly compressed laterally. Whorls high, deeply embracing, and deeply indented by the inner whorls. Umbilicus narrow, less than one-fourth of the diameter of the shell. Umbilical shoulders abruptly rounded, sides flattened, venter narrow, with distinct furrow and marginal carinæ or ridges. Surface ornamented with numerous fine, sickleshaped ribs that start from the umbilical shoulders and end on the marginal carinæ. There are five rows of knots on the ribs, one on the umbilical shoulders, two on the flanks, a fourth 
on the sloping ventral shoulders, and a fifth on the marginal carinæ. The septa are distinctly ammonitic, lobes and saddles both being digitate.

Horizon and locality.-Described by W. M. Gabb as coming from the East Range, Humboldt mining region, Nev., associated with Monophyllites billingsianus. The writer has never found a specimen that could be determined positively as Trachyceras homfrayi, but has often found Monophyllites billingsianus, always in the Middle Triassic, Daonella dubia zone. All the specimens from the East Range probably came from the old mining camp at Dun Glen, and they appear to belong to the Middle Triassic, although they may be higher up than the zone of Ceratites trinodosus. Doubtful specimens were found by the writer on Fossil Hill, south fork of American Canyon, West Humboldt Range, Nev., in the Daonella dubia zone.

Trachyceras (Protrachyceras) lahontanum Smith, sp. nov.

Plate LXXXV, figures 1-5.

Evolute, widely umbilicate, somewhat compressed laterally. Whorls low and increasing slowly in height, rather deeply embracing but not deeply indented by the inner whorl. The height of the whorl is greater than one-third of the diameter of the shell, and the width is fivesixths of the height. The width of the umbilicus is about three-eighths of the diameter of the shell. The surface is ornamented with a strong ventral furrow, strong lateral ribs, and five rows of tubercles. The alternate ribs usually bifurcate about two-fifths of the distance up the flanks but not regularly. There are three rows of tubercles on the flanks, one on the ventral shoulders, and one on the ridge bordering the furrow at the end of the ribs. The furrow is deep, but the ribs cross it. The septa are ceratitic, consisting of four serrated lobes with rounded saddles.

Trachyceras lahontanum is more evolute than T. meeki Mojsisovics, with wider umbilicus and lower and broader whorls, with five rows of knots instead of six or seven. The ribs are stronger than on Trachyceras meeki and the knots much weaker. T. lahontanum bears a much greater resemblance to $T$. americanum Mojsisovics, from which it differs in its greater slenderness, wider umbilicus, and finer sculpture. This species is intermediate between Anolcites and Protrachyceras.

Horizon and locality.-Very rare in the Middle Triassic, Daonella dubia zone, Ceratites trinodosus subzone, on the divide between Troy Canyon and the south fork of American Canyon, 4 miles south of Fitting post office (formerly Foltz), West Humboldt Range, Nev., associated with Ceratites trinodosus, C. humboldtensis, Protrachyceras americanum, P. meeki, Nevadites whitneyi, Sageceras gabbi, Beyrichites rotelliformis, Acrochordiceras hyatti, Daonella dubia, and other species.

Trachyceras (Protrachyceras) meeki Mojsisovics.

Plate V, figures 8 and 9 ; Plate IX, figures 1 and 2 ; Plate XI, figures 1-3; Plate XV, figures 1 and $1 a$; Plate LXXVIII, figures 4-7.

1877. Trachyceras judicaricum (not Mojsisovies), Meek, Paleontology : C. S. Geol. Expl. 40th Par., vol. 4, p. 118, Pl. XI, figs. 1 and 1a.

1882. Trachyceras meeki, Mojsisovics, Die Cephalopoden der Mediterranen 'Triasprovinz: AbhandI. K.-k. geol. Reichsanstalt Wien, vol. 10, p. 108.

1896. Anolcites alphei, Mojsisovics. Beiträge zur Kenntniss der obertriadischen Cephalopoden-Faunen des Himalaya : Denkschr. K. Akad. Wiss. Wien, vol. 63, p. 696.

1905. Trachyceras (Anolcites) mecki, Hyatt and Smith, The Triassic cephalopod genera of America: Prof. Papel U. S. Geol. Survey Yo. 40, p. 196, Pl. XXIV, figs. 8 and 9 ; Pl. LIX, figs. 1 and 2 (not figs. 3-17) ; Pl. LXXIV, figs. 1-3 (not figs. 4-7).

(Not 1869. Trachyceras judicaricum, Mojsisovics. Ceber die Gliederung der oberen Triasbildungen der östlichen Alpen: Jahrb. K.-k. Geol. Reichsanstalt Wien, p. 133, Pl. III, fig. 4.)

(Not 1904. Trachyceras meeki, Smith, The comparative stratigraphy of the marine Trias of western America: Proc. California Acad. Sci., 3d ser., Geology, vol. 1, No. 10, Pl. XLV, figs. 3 and 4 (excepting the text).) 
Form evolute, robust, deeply embracing, but not deeply indented by the inner volution. Whorl increasing rather rapidly in height. Umbilicus wide and deep. Umbilical shoulders abrupt, flanks gently convex, abdominal shoulders gently rounded. Venter narrow, with deep central furrow. Surface ornamented with strong radial ribs and coarse spiral rows of knots. The ribs bundle in knots on the umbilical shoulders, curve gently forward on the flanks, and form coarse knots on the rentral border. There are rows of knots on the umbilical shoulder and the ridge bordering the ventral furrow and three or four on the flanks. The strongest knots are on the venter.

The ribs do not bundle in threes, as shown in the rather diagrammatic drawing published of the type. There are usually two ribs branching from an umbilical tubercle, and the alternate ribs do not usually bifurcate. The knots bordering the rentral furrow do not lie opposite each other but in alternate position. At extreme maturity the ribs become weaker and the knots stronger, until the appearance of the shell is greatly changed. Even in the early adolescent stages the furrow is well developed and the ribs do not cross the venter. The furrow begins at a diameter of 8 millimeters, when the species leaves the Anolcites stage and reaches that of Protrachyceras.

It is difficult to see why Meek identified this species as Trachyceras judicaricum Mojsisovics, from which it differs in its coarser and fewer ribs and knots; it has little resemblance to that species and the figures given by Mojsisovics are too poor for the identification. The earlier stages show a strong resemblance to Nevadites, much more than in later, more specialized species of Trachyceras.

Dimensions of the specimens of Trachyceras mecki figured on Plate XI, figures 1-3.

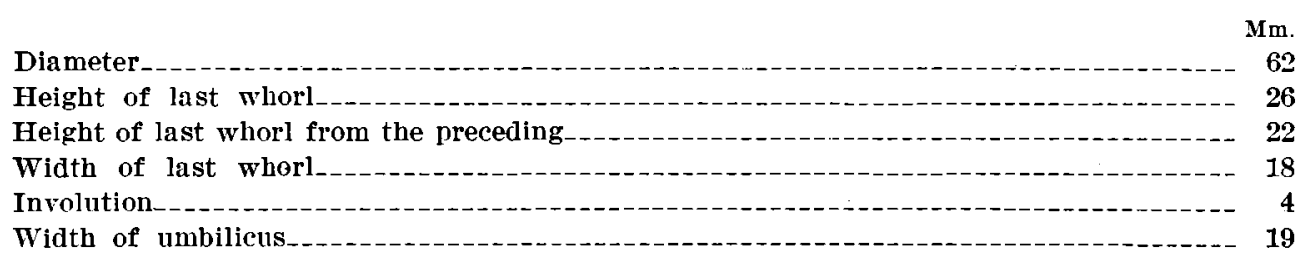

Horizon and locality.-Collected by the United States Geological Exploration of the Fortieth Parallel, in Middle Triassic, Cottonwood Canyon, West Humboldt Range, Nev. The writer found it rather common at that place, near the "Lucky Dog" mine; also in the same horizon, on divide between Troy Canyon and south fork of American Canyon, West Humboldt Range. In both places it was associated with Ceratites humboldtensis, Nevadites whitneyi, Beyrichites rotelliformis, Gymnotoceras blakei, Longobardites nevadanus, Arcestas gabbi, Daonella dubia, and many other species.

Trachyceras (Protrachyceras) sprixgeri Smith, sp. nov.

Plate LXXXY, figures $6-10$.

Form moderately involute, laterally compressed. Whorls rather high and increasing rapidly in height. Umbilicus wide and shallow; umbilical shoulders gently rounded, sides flattened convex, sloping upward without distinct ventral shoulders to the ridge bordering the ventral furrow. Surface ornamented with deep ventral furrow, sharp sigmoidal ribs, and five rows of knots. The alternate ribs usually bifurcate just above the umbilical shoulder, but not regularly. The height of the whorl is nearly half the diameter of the shell, and the width is three-fourths of the height. The outer whorl embraces half of the inner, and is indented by it to one-fifth of the height. The width of the umbilicus is one-fourth of the diameter of the shell. The septa are ammonitic, with four serrated lobes, and rounded slightly ammonitic saddles. 
Trachyceras springeri has some resemblance to T. meeki Mojsisovics but is more compressed and involute and has coarser ribs and knots in proportion to its size and a deeper furrow. It is also easily distinguished by its ammonitic septa. In shape and septa $T$. springeri resembles $T$. homfrayi Gabb but differs in its coarser ribs and fewer tubercles.

The specific name is given in honor of Mr. Wilbur Springer, of Unionville, Nev.

Horizon and locality.-Rare in the Middle Triassic, Daonella dubia zone, West Humboldt Range, Nev., exact locality unknown but either Cottonwood or Buena Vista Canyon, collected by the Whitney survey, and now deposited in the Whitney collection at Harvard University. The horizon of this species may be slightly higher than that of Ceratites trinodosus.

\section{Trachyceras (Protrachyceras) slbaspercm Meek.}

Plate XV, figures $2 a-b$; Plate LXXXIV, figures 17-19.

1877. Trachyceras judicaricum var. subasperum, Meek, Paleontology: L. S. Geol. Expl. 40th Par., vol, 4, 1. 118. Pl. XI, fig. 2.

1882. Trachyceras subasperum, Mojsisovics, Die Cephalopoden der Mediterranen Triasprovinz: Abbandl. K.-k. geol. Reichsanstalt Wien. vol. 10, p. 108.

1896. Protrachyceras subasperum, Mojsisovics, Beiträge zur Kenntniss der obertriadischen CephalopodenFaunen des Himalaya: Denkschr. K. Akad. Wiss. Wien, vol. 63. P. 124.

(Not 1869. Trachyceras judicaricum, Mojsisovics, Ueber die Gliederung der oberen Triasbildungen der östlichen Alpen: Jahrb. K.-k. geol. Reichsanstalt Wien, p. 133, Pl. III, fig. 4.)

Trachyceras subaspemem was originally described by Meek as a variety of $T$. judicaricum. Meek (not Mojsisories), but further collections and studies by the writer show it to be an independent species. It is very involute, laterally compressed, with narrow umbilicus, flattened sides, and narrow venter with distinct furrow. The surface is ornamented with fine umbilical knots, and weak ribs start out from these, bifurcating on the knots and again about one-third of the way up the flanks, but without developing knots at this second fork. About three-fifths of the distance up the flanks at about every third rib a coarse lateral knot develops, and the ribs become finer and bend forward. At half the distance between this row of coarse knots and the venter a row of very fine knots develops on the ribs. which end on the ventral shoulder in fine tubereles. In addition to the principal ribs starting from the umbilical knots there are also many intercalary ribs. The septa are ceratitic, like those of $T$. meeki.

Dimensions of the specimen of Trachyceras subasperum figured on Plate $L X X X I V$.

Diameter
Height of last whorl
Height of last whorl abore preceding
Width of last whorl
Involution
Width of umbilicus

The height of the whorl is less than half the diameter of the shell, and the width is two-thirds of the height. The width of the umbilicus is only one-sixth of the diameter of the shell.

T. subasperum is a true Protrachyceras and not Anolcites. It differs from Trachyceras meeki in its much finer ribs, fewer rows of knots, and the single row of coarse lateral knots, as well as in the more compressed whorl.

Horizon and locality.-In the Middle Triassic, Daonella dubia zone, Ceratites trinodosus subzone, of Fossil Hill, on the divide between Troy Canyon and the south fork of American Canyon, 4 miles south of Fitting post office (formerly Foltz), West Humboldt Range, Nev., associated with Ceratites trinodosus, C. humboldtensis, Nevadites whitneyi, Gymnotoceras blakei, Sageceras gabbi, Eutomoceras laubei, Daonella dubia, and other species. 


\section{Order BELEMNOIDEA.}

\section{Family BELEMNITID $\approx$.}

Genus ATrACTITES Guembel.

1861. Atractites, Guembel, Geognostische Beschreibung des Bayerischen Alpengebirges, p. 475.

1871. Aulacoceras (in part), Mojsisovics, Ueber das Belemnitiden-Geschlecht Aulacoceras: Jahrb. K.-k. Geol. Reichsanstalt, p. 41.

1880. Aulacoceras (in part), Branco, Beobachtungen an Aulacoceras: Zeitschr. Deutsch. geol. Gesell., p. 401.

1882. Atractites, Mojsisovics, Die Cephalopoden der Mediterranen Triasprovinz: Abhandl. K.-k. geol. Reichsanstalt Wien, vol. 10, p. 299.

1887. Atractites, Hauer, Cephalopoden des Bosnischen Muschelkalkes von Han Bulog bei Sarajevo: Denkschr. K. Akad. Wiss. Wien, vol. 54, p. 3.

1896. Atractites, Toula, Eine Muschelkalkfauma am Golfe ron Ismid in Kleinasien: Beitr. Pal. und Geol. Oesterreich-Lngarns und des Orients, vol. 10, pt. 4, p. 185.

1902. Atractites, Mojsisovies, Das Gebirge un Hallstatt, Part I; Die Ceplalopoden der Hallstätter Kalke: Supplement-Heft Abhandl. K.-k. geol. Reichsanstalt Wien, vol. 6, pt. 1, 1st half, p. 192.

1904. Atractites, Martelli, Cefalopodi triasici di Boljevici presso Vir nel Montenegro: Palæontographia Italica, vol. 10 , p. $\mathbf{1 3 7}$.

1905. Atractites, Hyatt and Smith, The Triassic cephalopod genera of America : Prof. Paper U. S. Geol. Survey No. 40, p. 204.

1907. Atractites, Diener, The fauna of the Himalayan Muschelkalk: Himalayan fossils, vol. 5, Mem. No. 2. p. 21 (Mem. Geol. Survey India, Pal. Indica, 15th ser.).

\section{Atrictites вöckнi Stïrzenbaum.}

Plate XCIV, figures 20 and 21.

1875. Orthoceras bückhi, Stürzenbaum, Adatok a Bakony Ccratites reitzi-szint faunájának ismeretéhez: Földtani közlöny, p. 254, Pl. IV, fig. 1.

1882. Atractites böckhi, Mojsisovies, Die Cephalopoden der Mediterranen Triasprovinz: Abhandl. K.-k. geol. Reichsanstalt Wien, vol. 10, p. 302, Pl. XCIII, figs. 12 and 13.

Phragmocone only known. Robust, Orthoceras-like but with marginal siphuncle. Cross section elliptical, the diameter in the symmetry plane being somewhat greater than the transverse diameter. The septum has a low saddle on the ventral side and a gentle backwardpointing curve on the flanks. The angle of increase of the phragmocone is small, and the chambers are shallow. The length of the phragmocone and the shape of the rostrum are unknown, only fragments having been found.

Horizon and locality.-Very rare in the Middle Triassic, Daonella dubia zone, Ceratites trinodosus subzone, of Fossil Hill, south fork of American Canyon, 4 miles south of Fitting post office (formerly Foltz), West Humboldt Range, Nev. It was first found in the Mediterranean region in the same horizon.

Atractites burck hardti Smith, sp. nov.

Plate XCVI, figures 6 and 7.

Form long, slender, with long phragmocone and conical, somewhat club-shaped guard. The cross section of the guard is elliptical, with the major diameter much greater than the minor, especially toward the lower part of the shell, where the guard is prolonged in a flattened dartshaped apex.

Atractites burckhardti is closely related to $A$. tenuirostris Hauer, ${ }^{1}$ but differs in its flattened instead of conical or subcylindrical guard. It differs from $A$. solidus Smith in its more slender form, and from A. macilentus Hauer in its more robust and flattened form.

1 Cephalopoden des Bosnischen Muschelkalkes von Han Bulog bel Sarajevo: Denkschr. K. Akad. Wiss. Wien, vol. 54, 1887, p. 6, Pl. I, figs. 1-3. 
The specific name is given in honor of Dr. Carlos Burckhardt, paleontologist of the Geological Survey of Mexico.

Horizon and locality.-Common in the Middle Triassic, Daonella dubia zone, Ceratites trinodosus subzone, on Fossil Hill, south fork of American Canyon, $t$ miles south of Fitting post office (formerly Foltz), West Humboldt Range, Nev, associated with Ceratites trinodosus, C. humboldtensis, Gymnotoceras blakei, Nevadites whitneyi, Beyrichites rotelliformis, Daonella $d u b i a$, and other species.

\section{Atractites clavatulus Smith, sp. nov.}

Plate XCVI, figures 11-14.

Form small, robust, contracted above and swelled out into a club shape below. The rostrum is prolonged into a sharp apex. The cross section of the rostrum is slightly elliptical, but the form is not so compressed as in most of the other species of Atractites in this fauna. The phragmocone is long and slender, reaching nearly to the club-shaped portion of the rostrum. The bulbous rostrum distinguishes Atractites clavatulus from all other species of the group, which resemble closely the Jurassic Belemnites.

A. clavatulus is very like $A$. pusillus but much more robust. It is easily distingnished from small specimens of $A$. solidus by its bulbous rostrum and by lacking the flattened hastate apex.

Horizon and locality.-Rather rare in the Middle Triassic, Daonella dubia zone, Ceratites trinodosus subzone, on Fossil Hill, south fork of American Canyon, 4 miles south of Fitting post office (formerly Foltz), West Humboldt Range, Nev, associated with Ceratites trinodosus, $C$. humboldtensis, Nevadites whitneyi, Daonella dubia, and other species.

\section{Atractites elegans Smith, sp. nov.}

Plate XCVI, figure 10.

Form long and slender, slightly clavate. Rostrum slightly contracted above, swelling out gently toward the lower part of the phragmocone. Cross section nearly circular, without marginal furrow. Beak blunt, not hastate. Phragmocone long and slender. This species is very like Atractites tenuirostris Hauer but differs in being more strongly clavate and somewhat more slender. It differs from $A$. burckhardti in its nearly circular cross section and in lacking the flattened apex.

Horizon and locality.-Rather common in the Middle Triassic, Daonella dubia zone, Ceratites trinodosus subzone, of Fossil Hill, south fork of American Canyon, 4 miles south of. Fitting post office (formerly Foltz), West Humboldt Range, Nev., associated with Ceratites trinodosus, C. humboldtensis, Gymnotoceras blakei, Nevadites whitneyi, Daonella dubia, and other species.

\section{Atractites nevadensis Meek.}

Plate XCVI, figures 8 and 9.

1877. Belemnites nevadensis Meek, Palæontology: U. S. Geol. Expl. 40th Par., vol. 4, pt. 1, p. 138, Pl. XII, figs. 7 and $7 a$, and figs. 8 (?) and $8 a$ (?).

Form robust, conical, subcylindrical, tapering gently. Cross section nearly circular at maturity but elliptical at the young end and somewhat flattened toward the apex. Phragmocone long and slender, tapering gently toward the protoconch. Rostrum robust and conical, not club-shaped as is usual with Atractites. 
Atractites nevadensis greatly resembles A. cylindricus Hauer ${ }^{1}$ and it is not unlikely that the two may be identical. However, the preservation is not good enough to warrant a positive identification.

Meek, in describing this species, assigned it to the Jurassic; but the writer has collected it in the Middle Triassic beds of the type locality in Cottonwood Canyon, where furthermore no Jurassic occurs. Meek also assigned figures 8 and $8 a$ of his Plate $\mathbf{I}$ to this species, but his figures clearly represent another though not determinable species.

IIorizon and locality.-Rare in the Middle Triassic, Daonella dubia zone, Ceratites trinodosus subzone, of Fossil Hill, south fork of American Canyon, 4 miles south of Fitting post office (formerly Foltz), West Humboldt Range, Nev.; also in Cottonwood Canyon; in both places associated with Ceratites trinodosus, C. humboldtensis, Gymnotoceras blakei, Nevadites whitneyi, Daonella dubia, and other species.

Atractites sol.ides Smith, sp. nov.

Plate XCYI, figures 1-5.

Form robust, somewhat club shaped, with the rostrum contracted above, swelling out toward the lower part of the phragmocone. The lower end of the rostrum is prolonged in a flattened hastate beak. The cross section is elliptical, with a slight longitudinal depression or furrow. The phragmocone is long and slender. The shape and general appearance of $A$. solidus are very similar to $A$. crassirostris Hauer of the Mediterranean region, but $A$. crassirostris shows no furrow in its cross section nor any flattening of the beak. A. solidus is more closely allied to $A$. burckhardti Smith, from which it differs in its more robust form and stronger furrow. The longitudinal section in the symmetry plane, showing the slender phragmocone and marginal siphuncle, might easily pass for $A$. crassirostris, the specific character not being visible in this section. If this species occurred in the Jurassic instead of the Triassic no one would have any hesitation in assigning it to Belemnites. It seems to the writer that the generic distinction is purely arbitrary.

Horizon and locality.-Very common in the Middle Triassic, Daonella dubia zone, Ceratites trinodosus subzone, of Fossil Hill, south fork of American Canyon, 4 miles south of Fitting post office (formerly Foltz), West Humboldt Range, Nev., associated with Ceratites trinodosus, C. humboldtensis. Nevadites whitneyi, Daonella dubia, and other species.

\section{Order NAUTILOIDEA.}

Genus ORTHOCERAS Breyn.

Orthoceras blaker Gabb.

Plate XIY, figure 11; Plate XVI, figures 1a-c.

1864. Orthoceras blakei, Gabb, Description of the Triassic fossils of California and the adjacent Territories: Geol. Survey California, Palreontology, vol. 1, p. 19, Pl. II I, figs. 1a-c.

1877. Orthoceras blakci甲, Meek, Palæontology : L. S. Geol. Expl. 40th Par.. vol. 4, p. 104, Pl. X, fig 11.

Shell small, slender, with angle of divergence about $11^{\circ}$ in youth but in age nearly cylindrical. The height of the chamber is about two-fifths of the diameter. Siphuncle central. Surface smooth. Orthoceras blake is very similar to $O$. campanile but differs in its more robust form and blunter apex in youth.

Horizon and locality.-Middle Triassic, Daonella dubia zone, Ceratites trinodosus subzone, Cottonwood Canyon, West HumboIdt Range, Nev.

1 Cephalopoden des Bosnischen Muschelkalkes von Han Bulog bel Sarajevo: Denkschr. K. Akad. Wlss. Wien, vol. 54, 1887 , p. 8 , Pl. I, figs. $7-9$. 
Orthoceras Cayraxile Mojsisovics.

Plate X(IY. figures $17-19$.

1869. Orthoceras campanile, Mojsisories. Beitrïge zur Kenntniss der Cephalopoden-Fauna des Alpinen Muschelkalkes: Jahrb. K.-k. geol. Reichsunstalt Wien, p. 590.

1852. Orthoceras campanile, Mojsisovies, Die Cephalopoden der Mediterranen Triasprovinz: Abhandl. K.-k. geol. Reichsanstalt Wien, vol. 10, p. 291, I'l. XCIII, figs. 1-4 and 11.

1887. Orthoceras campanile. Haner, Cephalopoden des Bosnischen Muschelkalkes von Han Bulog bei Sarajevo: Denkschr. K. Akad. Miss. Wien, rol. 54. 1. 11.

1895. Orthoceras campanile? Diener, Cephalopoda of the II uschelkilk: Himalayan fossils, vol. 2, pt. 2. 1). 87, Pl. XXVII, fig. 8 (Mem. Geol. Survey India, Pal. Indica, 15th sel.).

1896. Orthoceras campanile, Baner. Beitrige zur Kenntniss der Cephalopoden aus der Trias von Bosnien, Part II : Denkschr. K. Akil. Wiss. Wien, rol. 63, p. 240.

1904. Orthoceras campanile, Martelli, Cefilopodi triasici di Boljevici presso Vir nel Montenegro: Palæontographia Italica, rol. 10, p. 135.

Cone long, slencler, with angle of increase of $4^{\circ}$ or $5^{\circ}$. Surface smooth, siphuncle central, chambers wider than deep. At diameter of $T$ millimeters the chambers have a depth of approximately + millimeters. At a length of 130 millimeters the diameter of the shell is about 11 millimeters.

Orthoceras campanile is characterized by its long slender form and comparatively shallow chambers, its central siphuncle, and smooth surface.

Horizon and locality.-Rare in the Middle Triassic, Daonella dubia zone. Ceratites trinodosus subzone, of Fossil Hill, on the divide between Troy Canyon and the south fork of American Canyon, 4 miles south of Fitting post office (formerly Foltz), West Humboldt Range, Nev.. associated with Ceratites trinodosus, C. humboldtensis, Gymnotoceras blakei, Nevadites whitneyi, Daonella dubia, and other species.

Genus GRYPOCERAS Hyatt.

1883. Grypoceras, Hyatt, Genera of fosssil Cephnloporla : Proc. Boston Soc. Nat. Hist., vol. 22, p. 269.

1900. Grypoceras, Hyatt, Cephalopoda (in Zittel, Eastmin, Text-book of Palieontology), p. 521.

1902. Grypoceras. Mojsisovics, Das Gebirge um Irallstätt, Part I; Die Cephalonoden der Hallstätter Kalkes: Supplement-Heft Abhandl. K.-k. geol. Reichsanstalt Wien, vol. 6, pt. 1, 1st half, p. 227.

Form robust, laterally compressed, with flattened sides and venter, indistinct shoulders, and open umbilicus. Septa with broad shallow lateral lobe, and deep antisiphonal lobe. Chiefly confined to the Middle Triassic of the Mediterranean region.

Grypocekis whitseyi Gabb.

Plate XVI, figures 2 :inl 3 ; Plate XCIX, figures $5-\overline{7}$.

1863. Nautilus whitncyi, Gabb, Description of the Triassic fossils of California and the adjacent Territories: Geol. Survey California, Palreontologs, rol. 1, 1. 19, Pl. III, figs. 2 and 3.

Form almost exactly like $G$. palladii Mojsisovics ${ }^{1}$ differing only in the shallower lateral lobe of the septa. The form is compressed, moderately robust, and evolute, with open umbilicus. The two species may be identical, but the Nevada specimens appear to be a little more robust. A specimen from Unionville shows the deep dorsal lobe.

Horizon and locality.-Very rare in the Middle Triassic, Daonella dubia zone of the Buena Vista Canyon, near Unionville, West Humboldt Range; also on Fossil Hill, south fork of American Canyon, West Humboldt Range, Nev., associated with a fauna typical of the zone of Ceratites trinodosus.

2 Die Cephalopoden der Mediterranen Triasprovinz: Abhandl. K.-k. geol. Reichsanstalt Wien, vol. 10, 1882, p. 285, Pl. XCII, figs. $: a-b$.

$16279^{\circ}-$ Yo. $83-14-10$ 


\section{Genus GERMANONAUTILUS Mojsisovies.}

1902. Germanonautilus, Mojsisovies, Das Gebirge um Hallstütt, Part I, Die Cephalopoden der Hallstiitter Kalke: Supplement-Heft Abhandl. K.-k. Geol. Reichsanstalt Wien, vol, 6, pt. 1, 1st half, p. 235.

Type.-Nautilus bidorsatus.

Surface nearly smooth. Form evolute, widely umbilicate. Whorls broad and low, with trapezoidal cross section. Venter flat or concave. Siphuncle median. Septum simply curved, with broad shallow lateral lobe, and narrow annular lobe.

Germanonautilus is characteristic of the Middle Triassic of the Mediterranean region, in which horizon it occurs in America and in India. In the Alpine province it is also known in the Upper Triassic.

\section{Germanonautilus furlongi Smith, sp. nov.}

Plate XCV, figures 1 and 2.

Form robust, whorls low, broad and trapezoidal in cross section, little embracing, and little indented by the inner whorls. Sides converging toward the venter. Umbilicus about onefourth of the diameter of the shell. Umbilical shoulders subangular, inner walls very steep. Ventral shoulders rounded, venter broad and flat, without concavity. Siphuncle a little below the middle of the chamber.

Septa close together, with gentle backward curve or lobe on the flanks. Surface smooth, outer shell unknown.

\section{Dimensions of the type specimen of Germanonautilus furlongi.}

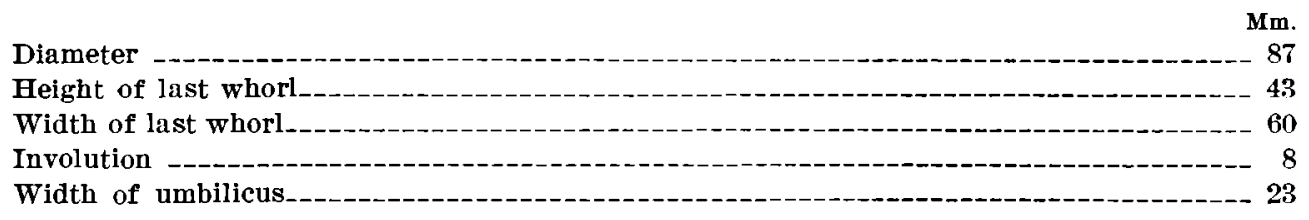

Germanonautilus furlongi is very closely related to $G$. salinarius Mojsisovics ${ }^{1}$ of the same horizon in the Alpine province but has the sides of the whorl somewhat more convergent and the umbilicus narrower. It is still closer to Germanonautilus sp. indt. Mojsisovics ${ }^{2}$ and may be identical with that unnamed species.

The specific name is given in honor of Mr. E. L. Furlong, of the University of California.

Horizon and locality.-Very rare in the Middle Triassic, Daonella dubia zone, Ceratites trinodosus subzone, of Fossil Hill, south fork of American Canyon, 4 miles south of Fitting post office (formerly Foltz), West Humboldt Range, Nev.

\section{Genus PARANAUTILUS Mojsisovics.}

1902. Paranautilus, Mojsisovics, Das Gebirge um Hallstatt, Part I, Cephalopoden der Hallstätter Kalke: Supplement-Heft Abhandl. IK.-k. geol. Reichsanstalt Wien, vol. 6, pt. 1, 1st half, p. 205.

Robust, involute, high whorled, narrowly umbilicate, with rounded sides, somewhat flattened venter. Septa simple, nearly straight, without antisiphonal lobe.

Type.-Nautilus simonyi Hauer.

This group, which is exceedingly primitive and retains many Paleozoic characters, is chiefly confined to the Muschelkalk of the Mediterranean region.

${ }^{1}$ Die Cephalopoden der Mediterranen Triasprovinz: Abhandl. K.-k. geol. Reichsanstalt Wien, vol. 10, 1882, p. 282, I'l. XCI, fig. 3.

2 Op. cit., p. 282, Pl. XCII, fig. 1. 
Paraniutilus multicameratus Gabb.

Plate XYI, figures 4 and 5 ; Plate XCY, figures 3 and 4.

1864. Nautilus multicameratus, Gabb, Description of the Triassic fossils of California and the adjacent Territories: Geol. Survey California, Palæontology, vol. 1, p. 20, Pl. II I, figs. 4 and 5.

Form smooth, rounded, with convex whorl, closely involute. Venter slightly flattened, ventral shoulders distinct but rounded. Septa simple, nearly straight, without distinct lobes and saddles, external or internal. Surface smocth, without ornamentation.

Horizon and locality.-Rare in the Middle Triassic, Daonella dubia zone, Ceratites trinodosus subzone, of the Buena Vista district; and of Fossil Hill, south fork of American Canyon, 4 miles south of Fitting post office (formerly Foltz), West Humboldt Range, Nev.

\section{PELECYPODA.}

Genus PLEUROMYA Agassiz.

Pleqromya humbolitensis Gabb.

Plate XVI, figure 14.

1864. Myacites (Panopaal) humboldtensis, Gabb, Description of the Triassic fossils of California and the adjacent Territories: Geol. Survey California, Palieontology, vol. 1, p. 28, Pl. V, fig. 22.

Shell inequilateral, beak about one-third of the distance from the point. Cardinal margin slightly elevated. Posterior end broader than the anterior, and somewhat more rounded. Surface marked with prominent concentric ribs.

Horizon and locality.-Buena Vista mining district, West Humboldt Range, Nev.

Genus DAONELLA Mojsisovics.

Daonella americana Smith, sp. nov.

Plate XI.IX, figures 4-9.

Form elongate and unsymmetric. the length being about twice the height and the beak being situated about one-third of the distance from the front to the rear. The beak is prominent and nearly smooth; the surface of the shell is ornamented with fine sharp radial ribs and with concentric wrinkles. The ribs are divided but not distinctly bundled, as in Daonella dubia. The areas near the hinge line hare the sculpture nearly obsolete. The concentric ridges become weak when the shell has reached a height of about 7 millimeters.

Daonella americana is distinguished from D. dubia Gabb by its much finer and less bundled ribs, from $D$. taramellii Mojsisovics by its greater symmetry, and from $D$. moussoni by its stronger radial ribs, weaker concentric wrinkles, and by the greater elongation of the shell.

Horizon and locality.-Common in the Middle Triassic Daonella dubia zone, Ceratites trinodosus subzone, of Fossil Hill, south fork of American Canyon, 4 miles south of Fitting post office (formerly Foltz), West Humboldt Range, Nev.; associated with Ceratites trinodosus, C. humboldtensis, Nevadites whitneyi, Sageceras gabbi, Daonella dubia. and other species.

Daonella debia Gabb.

Plate XIV, figure 5; Plate XLIX, figures 10 and 11; Plate I, figures 1-3.

1864. Halobia aubia, Gabb, Description of the Triassic fossils of California and the adjacent Territories: Geol. Survey California, Palseontology, vol. 1, p. 30, Pl. V, figs. 28a-b.

1874. Daonclla dubia, Mojsisovics, Leber die triadischen Pelecspoden-Gattungen Daonella und Halobia, p. 22.

1877. Halobia (Daonclla) lommeli, Meek, Palæontology : Y. S. Geol. Expl. 40th Par., vol. 4, p. 100, Pl. X, fig. 5.

1889. Halobia lommeli, Thiteaves, Fossils of the Triassic rocks of British Columbia: Geol. and Nat. Hist. Surver Canada, Contributions to Canadian Palæontology, vol. 1, pt. 2, p. 133. 


\section{4}

THE MIDDLE TRIASSIC MARINE INVERTEBRATE FAUNAS OF NORTH AMERICA.

1904. Daonclla dubia, smith, The comparative stratigraphy of the milrine Trias of western America: Proc. California Acad. Sci., 3d ser., Geology, vol. 1, No. 10, p. 405, Pl. Xl_IV, figs. 5 and 6.

1912. Daonclla dubia, Kittl, Materialien zu einer Monograplie der Halobidie und Monotide der Trias: Resultate der wissenschaftlichen Erforschung des Balatonsees, vol. 1, pt. 1, Palaeont. vol. 2, p. 73.

This species, which Meek united with Daonella lommeli, differs from the Alpine form in its more elongate shape and in its coarser ribs, bundling in pairs instead of threes or more. The concentric wrinkles are stronger and the beak is higher, projecting above the hinge line. There is no ear on the shell, but the hinge line is long and straight and near it the ribs become fainter. The type figure given by Gabb is of a negative cast, reversing the ribs and interspaces; Meek's figures are correct but poor.

Daonella dubia is nearly related to $D$. paucicostata Tornquist, from the Alps but is more highly arched and has a more prominent beak; it differs from $D$. indica Bittner in the bundling of the ribs. Daonella dubia is most nearly related to D. lindströmi Mojsisories, from which it differs chiefly in its finer ribs, with shallower furrows.

IIorizon and locality.-Very common in the Daonella dubia zone of the West Humboldt Range and the Desatoya Range, Nev.; associated with Ceratites trinodosus, Nevadites whitneyi, Daonella lindströmi, D. moussoni, and other species.

\section{Dhonella lindströmi Mojsisovics.}

Plate XLIX, figures 1-3.

1865. Halobia lımmeli, Lindström, Om 'Trias och Juraförstingar frán Slletsbergen, p. 6, Pl. II, fig. 9.

1874. Daonella lindströmi, Mojsisovics, Ceber die triadischen Pelecypoden-Gattungen Daonella und Halobia, p. 22, Pl. II, figs. 15-17.

Form robust, length about half the height; shell convex, with prominent beaks situated some distance anterior to the middle of the hinge line. Outline rounded in the front and rear. Surface ornamented with strong radial primary ribs that bundle in twos and threes and are divided into secondary ribs by fine furrows. The areas near the hinge line have the sculpture much weaker but not obsolete.

Daonella lindströmi resembles $D$. lommeli but differs in its coarser ribs with fewer in the bundles and in its greater elongation. It is more nearly allied to D. dubia Gabb but differs from that species in its greater convexity and much coarser ribs with deeper furrows.

Horizon and locality.-Rare in the Middle Triassic, Daonella dubia zone, Ceratites trinodosus subzone, of Fossil Hill, south fork of American Canyon, 4 miles south of Fitting post office (formerly Foltz), West Humboldt Range, Nev., associated with Ceratites trinodosus, $C$. humboldtensis, Nevadites whitneyi, Sageceras gabbi, Daonella dubia, etc. It was first found in Spitzbergen in the Daonella zone, associated with a Muschelkalk fauna.

\section{Daonelli moussoni Merian. \\ Plate 1, figures $4-11$.}

1853. Posidonomya muussoni, Escher von der Linth, Geologische Bemerkungen über das nördliche Vorarlberg, p. 93 , I'l. $V$, figs. $46-48$.

1857. Halobia lommeli, Haner, Paliiontologische Notizen, Ber. K.-k. Akad. Wiss. Wien. vol. 24, p. 155.

1858. Posidonomya moussoni, Stoppani, Pêtrifacations d'Ésino, p. 94, Pl. XIX, figs. 10 and 11 (7-9?).

1874. Daonella moussoni, Mojsisovies, Yeber die triadischen Pelecyloden-Gattungen Daonella und Ialobia, p. 9, Pl. III, figs. 18 and 19.

1907. Daonclla moussoni, Arthaber, Die Alpine 'Trias des Mediterran-Gebietes: Lethæa Geognostica, II. Theil, Mesozoicum, vol. 1, Pl. XXXr, fig. 16.

1912. Dannella moussoni, Kittl, Materialien zu einer Monographie der Halobiide und Monotida der Trias: Resultate der wissenschaftlichen Erforschung des Balatonsees, vol. 1, 1t. 1, Palleont., vol. 2, p. 35.

Form somewhat longer than high, rounded anteriorly and posteriorly. Beak low, projecting but little abore the hinge line, situated somewhat in front of the middle. The surface is covered with strong concentric wrinkles parallel to the striæ of growth, much stronger on and near the beak. The extremely fine radial ribs start out from the beak and increase by inter- 
calation. These are strongest in the middie of the shell, leaving the front and rear nearly smooth. There is no ear, as in Halobia, but the sculpture grow's weaker toward the hinge line, giving a suggestion of an ear.

Horizon and locality.-Rare in the upper portion of the Middle Triassic, Daonella dubia zone, Ceratites trinodosus subzone, of Fossil Hill, south fork of American Canyon, 4 miles south of Fitting post office (formerly Foltz), West Humboldt Range, Ner., associated with Ceratites trinodosus, Neradites whitneyi, Daonella dubia, and other species. In the Alps Daonella moussoni was found in the same horizon and in a similar fauna.

DaONELla saxct.e-AN.e Smith, sp. nor.

Plite I, figures 12-14.

Form unsymmetric, elongate, height three-fifths of the length; the beak is situated onefourth of the distance from the front to the rear of the hinge line; shell rounded anteriorly and posteriorly. Beak small but sharply defined. Surface reticulated by the intersection of fine radial and strong concentric ribs.

Dronella sanctre-ance is very closely related to D. böckihi Mojsisovics, of the Middle Triassic of the Alpine Province, but differs in its less symmetric shape and in the stronger concentric and radial ribs. 'This species, which is transitional from Posidonomya, was formerly listed by the writer as Pseudomonotis aff. $P$. clarci, which is clearly a mistake.

IIorizon and locality.-Rare in the Middle Triassic, near the head of Silverado Canyon (probably Bedford Canyon), Santa Ana Mountains, Orange County, Cal., associated with Rhynchonella sp. undt., and a rough-shelled ammonite not definitely determinable. Collected by H. W. Fairbanks.

\section{Genus RHYNCHOPTERUS Gabb.}

\section{Rhyschoptercs oliests Gabb.}

Plate XVI, figures 16 and 17.

1864. Rhynchopterus obesus, Gabb, Description of the Triassic fossils of California and the adjacent Territories: Geol. Survey California, Palæontology, vol. 1, 1. 32, Pl. V, figs. 30a-b.

Shell oblique, aviculoid, with prominent umbones in the middle of the hinge line. Hinge straight, ear acuminate, small; posterior margin broadly convex; anterior margin sinuous. Surface with irregular lines of growth.

Horizon and locality.-The type came from Rattlesnake Point, West Humboldt Range, near Humboldt, Nev.; the species is common in the Middle Triassic Daonella dubia zone of Fossil Hill, south fork of American Canyon, West Humboldt Range; also at New Pass, Desatoya Mountains, Nev.

Genus MODIOMORPHA Hall and Whitfield.

Modomorpha? ovata Meek.

Plate XIV, figure 1.

187т. Modiomorpha? ovata, Neek, Ialaentology: I.. S. Geol. Expl. 40th Par., vol. 4, p. 103, Pl. X, figs. 1 and $1 a$.

Shell oral, much compressed. Posterior side wider than the anterior and broadly rounded in outline. Anterior margin narrowly rounded above and sloping backward below, apparently slightly gaping in the middle. Cardinal borders shorter than the valves. Beaks depressed, and located about one-third of the distance from the front. Surface with concentric lines, sometimes obscure folds of growth.

Horizon and locality.-Middle Triassic, Daonella dubia zone, north fork of Buena Vista Canyon, West Humboldt Range, Ner. 
Modiomorphı? LAta Meek.

Plate XIY, figure 2.

1877. Modiomorpha lata, Meek, Palæontology : C. S. Geol. Nxpl. 40th Palr., vol. 4. Pl. X, fig. 2.

Shell transversely ovate, moderately convex on umbonal region and compressed behind. Posterior side distinctly wider than the anterior, broadly rounded. Anterior end short and truncated obliquely forward. Hinge line straight and about half as long as the shell. Beaks obtuse, depressed, and located about one-fifth of the distance from the front.

Horizon and locality.-Middle Triassic, Daonella dubia zone, north fork of Buena Vista Canyon, West Humboldt Range, Nev.

\section{Genus CORBULA Lamarck. \\ Corbula blakei Gabb.}

Plate XVI, figure 15.

1864. Corbula blakei, Gabb, Description of the Triassic fossils of California and the adjacent Territories: Geol. Survey California, Palæontology, vol. 1, p. 20, Pl. V, fig. 24.

Shell convex, subquadratic. Beak nearly central, large, prominent. Anterior margin regularly rounded, posterior abruptly truncated. Umbonal ridge angular, distinct. Surface with irregular concentric lines.

Horizon and locality.-Humboldt mining region, West Humboldt Range, Nev.

BRACHIOPODA.

Genus RHYNCHONELLA Fischer.

Rhynchonella foquiplicata Gabb.

Plate XCIV. figures 9-11.

1864. Rhynchonella aquiplicata, Gabb. Description of the Triassic fossils of California and the adjacent Territories: Geol. Survey California, Palseontology, vol. 1, p. 35, Pl. VI, figs. 37 and 37a-b.

Shell subglobose, strongly convex. Beak large, prominent, incurved. Hinge line short. Surface with 14 subequal rounded ribs, which begin on the ventral valve about one-third of the distance below the beak and on the dorsal valve opposite the hinge. There is no median sinus. Horizon and locality.-Middle Triassic, Cinnabar district, East Range, Nev.

\section{RhyNChONELJ.A ALTEPLECT Böckh.}

Plate XCIT, figures 15 and 16.

Shell small, trigonal. Dorsal and rentral valves conrex, slightly compressed, with low ridge on the former and shallow sinus on the latter. Ventral ridge with three plications, of which the central one is the weaker; sides with two additional plications. Dorsal sinus with two sharp plications, bounded by a pair of similar ones on the sides. Beak short and inconspicuous. This form is like the figures of the form from the brachiopod limestone below the Ceratites trinodosus zone of Bakony in Hungary. The American form agrees with the Mediterranean except in its small size, and the specimen found is probably immature.

Horizon and locality.-Very rare in the Daonella dubia zone, Ceratites trinodosus subzone, of New Pass, Desatoya Mountains, Nev. 
Rhynchonella Lingulata Gabb.

Plate XCIV, figures 6-8.

1864. Rhynchonella lingulata, Gabb, Description of the Triassic fossils of California and the adjacent Territories: Geol. Survey California, Palæontology, vol. 1, p. 34, Pl. VI, figs. 36 and $36 a-b$.

Shell ventricose, base subtruncate. Ventral valve with high ridge and deep sinus on the dorsal valve. Surface strongly plicate, with three ribs on the sinus, four on the median ridge, and two lateral ribs on each side, in both valves. Beaks short and slender.

Horizon and locality.-Middle Triassic, Star Canyon, West Humboldt Range, Nev.

Genus TEREBRATULA.

Terebratula humboldtensis Gabb.

Plate XCIV, figures 3-5.

1864. Terebratula humboldtensis, Gabb, Description of the Triassic fossils of California and the adjacent Territories: Geol. Survey California, Palæontology, vol. 1, p. 34, Pl. VI, figs. 36, a-b.

1877. Terebratula humboldtensis, Hall and Whitfield, Palæntology: U. S. Geol. Expl. 40th Par., vol. 4, pt. 2, p. 282, Pl. VI, figs. 22-24.

Shell oval, elongate, smooth, sides regularly curved. Lower, or dorsal valve with prominent beak, with foramen and delthyrium. Upper or ventral valve with shallow depression at the base. The surface is nearly smooth but shows numerous strong concentric growth lines and folds. The interior of the shell is unknown.

Horizon and locality.-Middle Triassic, Daonella dubia zone of Star Canyon, and Fossil Hill, south fork of American Canyon, West Humboldt Range, Nev.; Dun Glen, East Range, Nev.; New Pass, Desatoya Mountains, Nev.

\section{Genus SPIRIFERINA.}

Spiriferina homiraty Gabb.

Plate XCIY, figures 12 and 14.

1864. Spirifer homfrayi, Gabb, Description of the Triassic fossils of California and the adjacent Territories: Geol. Survey California, Paldeontology, vol. 1. 1). 35, Pl. VI, fig. 38.

187T. Spiriferina homfrayi, Hall and Whitfield, Palæontology: U. S. Geol. Expl. 40th Par., vol. 4, pt. 2, p. 281, Pl. VI, fjg. 18.

Shell long and narrow, with wide hinge area and beak not prominent. Upper valve with a broad median sinus and six subangular ribs on each side. Lower valve with a broad ridge corresponding to the sinus of the opposite valve and with fine lateral ribs. Interior of the shell unknown but referred to Spiriferina from the shape.

Ilorizon and locality.-Middle Triassic, Daonella dutia zone, Star Canyon, West Humboldt Range; Dun Glen, East Range; and New Pass, Desatoya Mountains, Nev.

\section{SPIRIFERINA ALIA Hall and Whitfield.}

Plate XCIV. figure 1.

18т7. Spiriferina alia, Hall and Whitfieh, Palaentology: I. S. Geol. Fxpl. 40th Par., vol. 4, pt. 2, Pl. VI. fig. 17.

Shell broader than high; valves rotund, with rounded hinge extremities. Beak of ventral valve incurved, slender. Middle of ventral valve with shallow depression or sinus. Surface marked by numerous fine radial costæ, eight on the sinus and twenty on each side of the valve. Dorsal valve unknown.

Horizon and locality.-In the Middle Triassic, Daonella dubia zone? of Dun Glen, Pahute Range (East Range), Nev. 


\section{ECHINODERMATA.}

Genus PENTACRINUS Miller.

Pentacrincs cf. asteriscts Meek and Hayden.

Plite XCIT: figure 2.

1858. Pentacrinites asteriscus?, Meek and Hayden, Proc. Acid. Nat. Sci. Philadelphia, vol. 10, p. 49.

1865. Pentucrinites asteriscus?, Meek and Hayden. Palieontology of the Upper Missouri : Smithsonian contributions to knowledge, vol. 14, No. 172. p. 67, Pl. III, fig. 2.

1877. Pentacrinites astcriscus?, Hall and Whitfield. Paleontology: U. S. Geol. Expl. 40th Par., vol. 4, p. 280. Pl. VI, fig. 16.

1893. Pentacrinus uhiteiq, Clarke, The Mesozoic Echinodermata of the United States: Bull. U. S. Geol. Survey No. 9T, I. $2 \overline{7}$, Pl. III, figs, $4 c-c$.

The form from Dun Glen. East Range, Nev., was doubtfully referred to P. asteriscus Meek and Hayden, which was first lescribed from the Jurassic. The writer has no new material from this region, and can only confirm the doubt, expressed by Hall and Whitfield, of the identity of the Jurassic and the Triassic forms. A species identical with that of Dun Glen, Nev., occurs in the Pit shale of California, associated with a poor fauna characteristic of the Middle Triassic.

Horizon and locality.-Rare in the Middle Triassic, Daonella dubia zone, Ceratites trinodosus subzone, of Dun Glen, East Range, Nev., also in the same horizon in the Pit shale, 1 mile west of Silverthorns Ferry on Pit River, Shasta County, Cal. 


\section{PLATES I TO XCIX.}

$16279^{\circ}-$ No. 83-14-—11 


\section{PLATE I.}

\section{Hongarites ratesi Hyatt and Smith (p. js).}

Figurks $1-4$. Side, front, and rear views (natural size), and septa $(X t)$ of the type specimen. Outline restored, als shown by the shading.

From Middle Triassic, Lnion Wash. Inyo lange, $1 \overline{5}$ miles southeast of Indepentence, Cal. Collection Lnited States Xational Museum.

Xenodisces bitTNeri Hyatt and Smith (p. j6).

ligures 5-7. Side, front, and rear views of the type specimen, showing the outer shell.

Figures S-10. Side, front, and rear views of a smaller specimen with shell removed, showing the sepha.

Figure 11. Septa $(\times 3)$ from the above specimen.

Figures 12-14. Side, front, and rear views $\left(X 1 \frac{1}{2}\right)$ of in adolescent specimen.

Figube 15. Septa $(X 6)$ from the above specimen.

From Middle Triassic, Inion Wash. Inyo Iange, 15 miles southeast of Independence, CaI. Collection United States Geological Survey. 

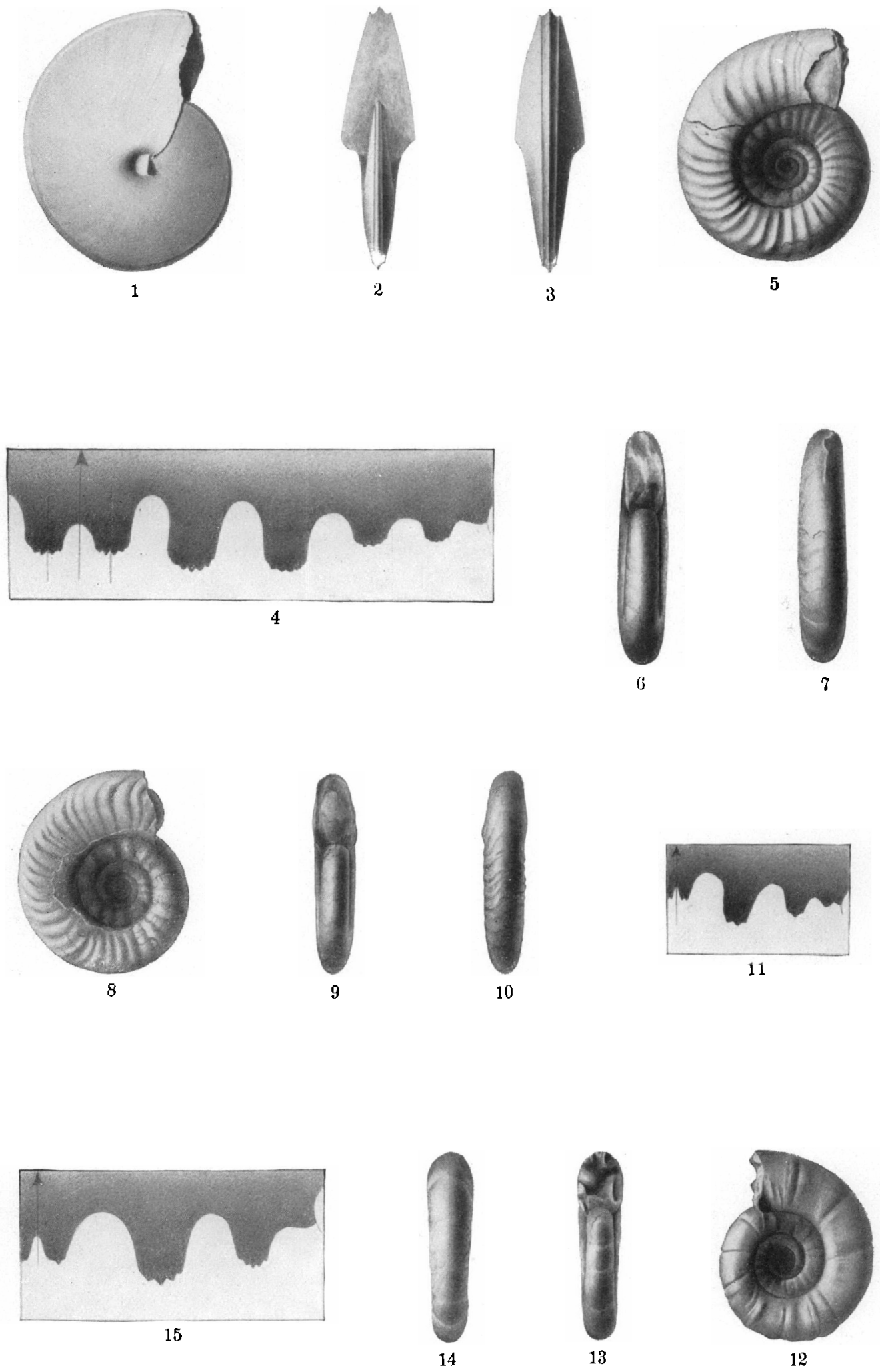

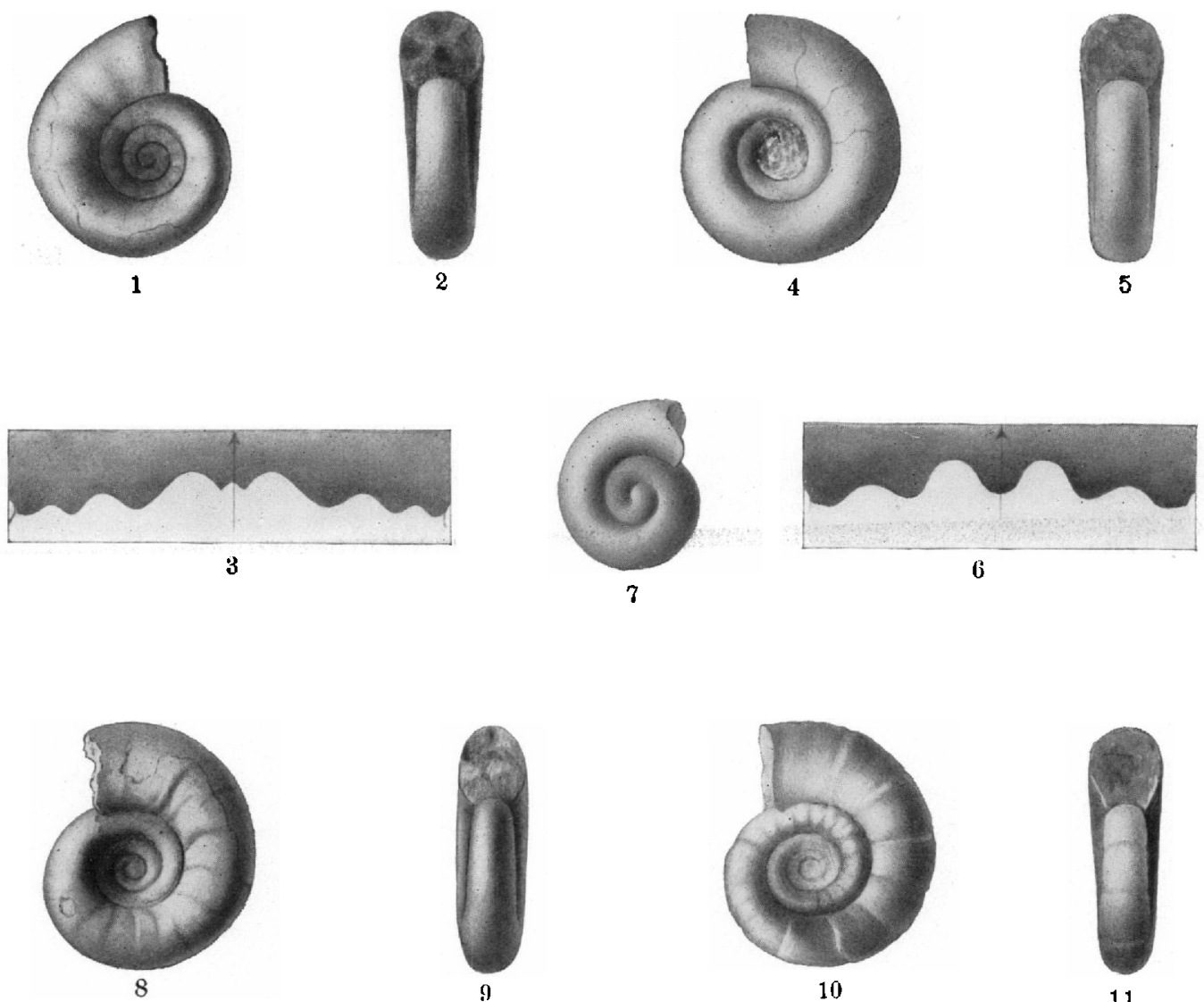

11

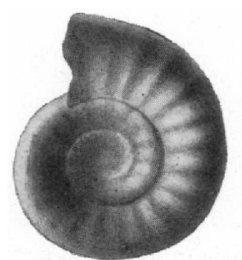

12

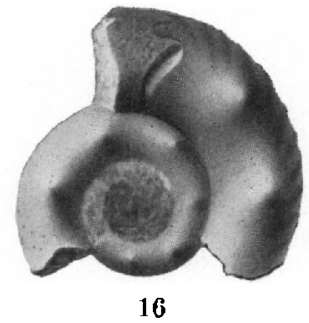

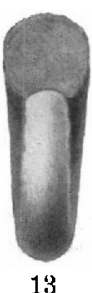

13
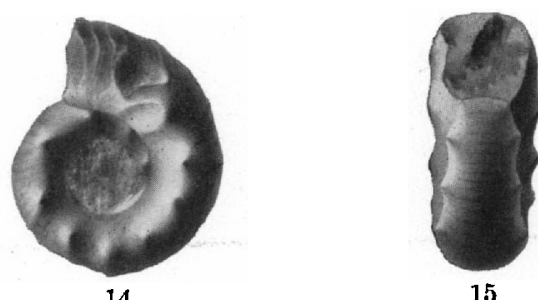

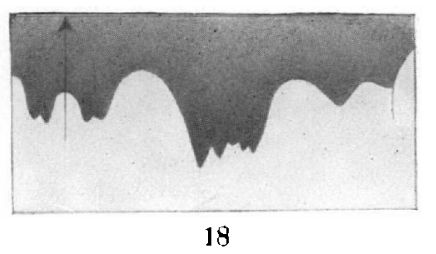

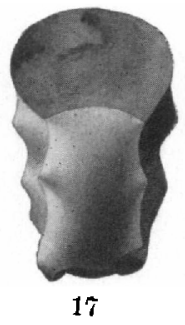




\section{PLATE II.}

\section{Xenodisces BiTTeri Hyatt and Smith (p. 56).}

Fugures 1, 2. Side and front views $(\times 6)$, beginning of aldolescent stage, corresponding to Paralecanites; diameter, 4 millimeters.

Figure 3. Septa $(\times 12)$ of the above specimen.

Figures 4, 5. End of larval stage $(\times 12)$, corresponding to Prolecanites; diameter 2.20 millimeters.

Figure 6. Septa $(\times 24)$ of the above specimen.

Figure 7. Early larval stage; diameter 1.25 millimeters.

Figubes 8,9 . Adolescent stage $(\times 2)$; diameter $1 \bar{j}$ millimeters.

Figures 10, 11. Adolescent stage $(\times 3)$; dinmeter 9.5 millimeters.

Figures 12, 13. Fnd of larral stige $(X+)$; diameter (i.5 millimeters.

From Middle Trialssic, Union Wash, Inyo Range, Inyo County, Cal. Collection United States National Museum.

\section{Tirolites Pacifices Hyatt and Smith (p. 68).}

Frgures 14, 15. Side and front views of the type.

Figcres 16-18. Side and front views $(X 2)$ and septa $(X 4)$.

From Middle Triassic, Union Wash, Inyo Range, Inyo comty, Cal. Collection United States National Museum. 


\section{PLATE III.}

\section{Ceratites (Gymnoteceras) russelli Smith, sp. nov. (p. 111).}

Figurr.s 1-3. Type specimen.

Figure 6 . Septa of an adult specimen $(X 2)$.

Ceratites (Gymnotoceras) beckeri Smith, sp. nov. (p. 109).

Figurses 4, 5. Side view (uatural size) and septa $(\times 2)$.

Figuris $7-9$. Side and front view (natural size) and septil $(X 2)$; diameter, 30 millimeters.

\section{Ceratites (Gymnotoceras) blakei Gabb (p. 109).}

Figtris 10, 11. Side view (natural size) and septa $(\times 2)$, adolescent stage; diameter, 23 millimeters.

Figures 12-14. Adolescent stage $\left(X 1 \frac{1}{2}\right)$; diameter, 18 millimeters.

Figuris 15-17. Adolescent stage $\left(X 1 \frac{1}{2}\right)$; diameter. 13 millimeters.

Figures 18-20. Early adolescent stage $(\times 3)$; diameter, 8 millimeters. Corresponds to Danubites.

Figubes 21-23. Larval stage $(X 4)$; diameter, 6.5 millimeters. Corresponds to Dinarites.

From Middle Triassic, Danclla dubia zone. Fossil Hill, south fork of Americin Canyon, West Humboldt Range, Ner. Collection of J. L'. Smith. (Reprint of I'l. XxII, I'rof. Pialer, L. s. Geol. Survey No. 40, 1905.) 


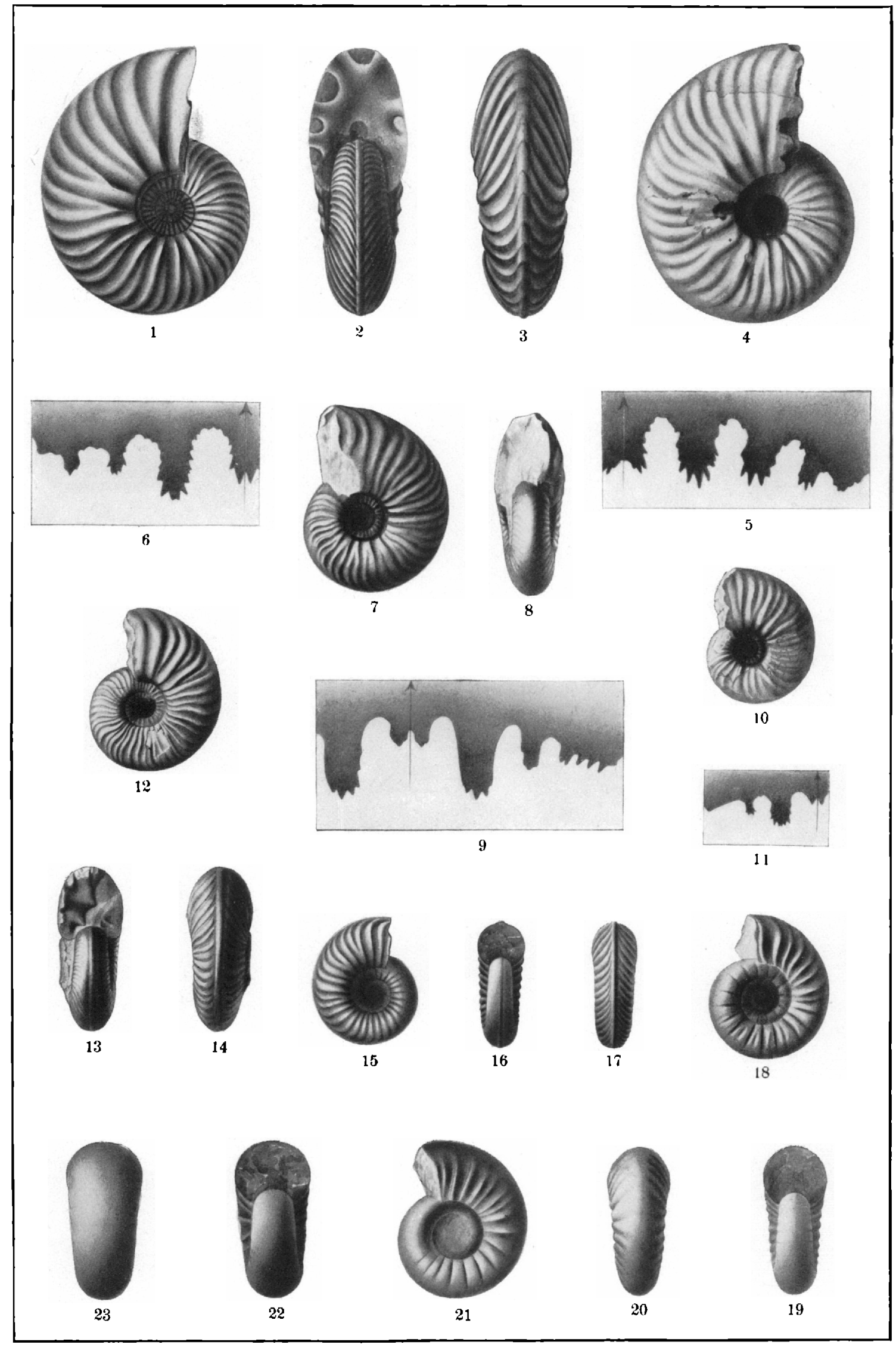




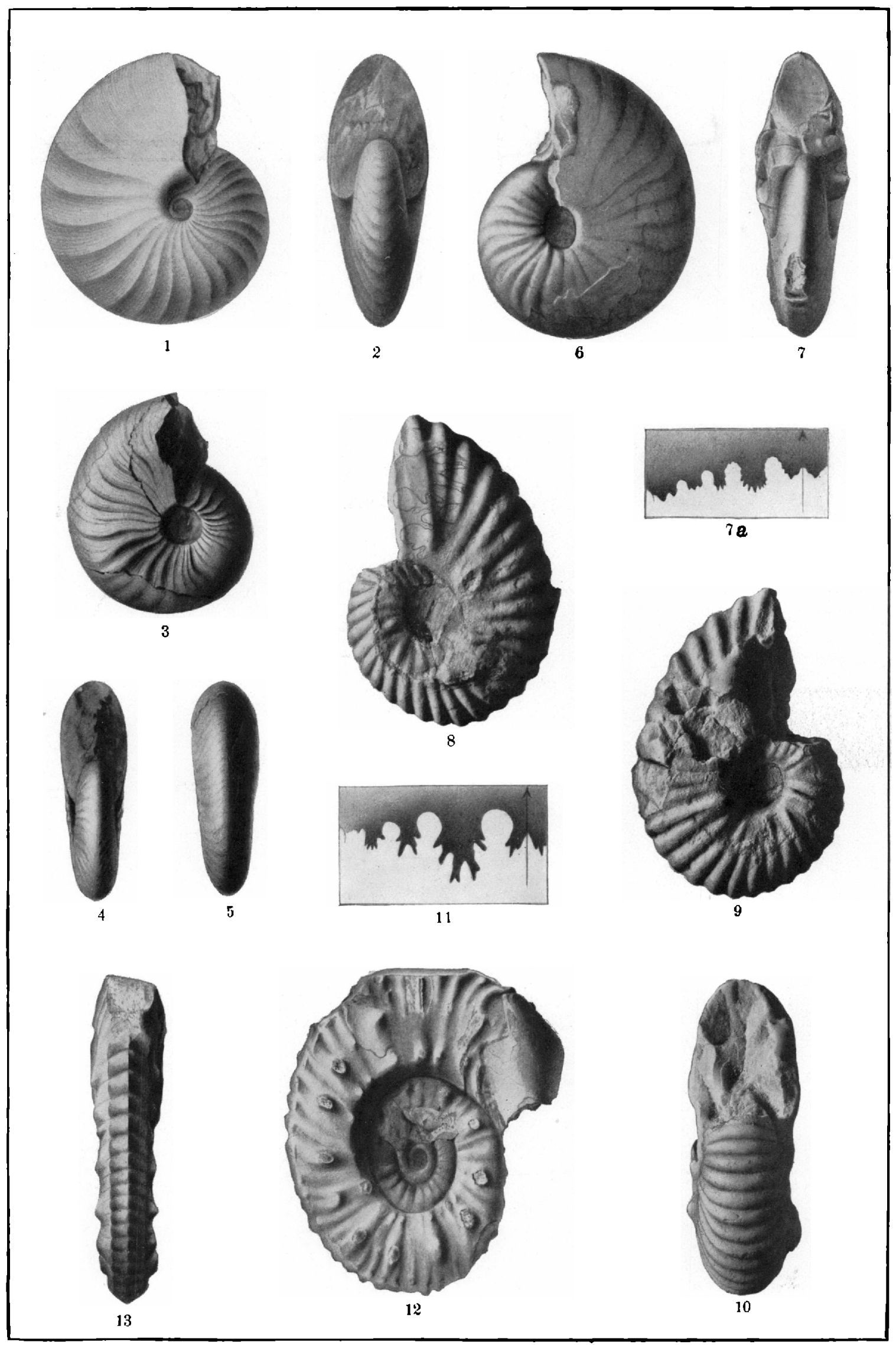




\section{PLATE IV.}

Beyrichites rotelliformis Meek (p. 118).

Figures 1, 2. Side and front views of Meek's tyle (figured in U. S. Geol. Expl. 40th Par., vol. 4, pt. 1, Pl. X, figs. 9 and $9 a$ ).

Figures 3-5. Side, front, and rear views of specimen.

Figures 6, 7 . Specimen showing the septa.

Figure $7 a$. Septa of the sume specimen.

From Middle Triassic, Nev. Figures 1 and 2 from Buena Vista Canyon, West Humboldt Range; figures 3-Ta from divide between Troy Canyon aud South Fork of American Canyon, West Humboldt Range. Collection of J. P. Smith.

Acrochordiceras Hyat'ti; Meek (p. 39).

Figures 8-11. Right and left sides. front, and septa.

From Middle Trinssic, Shoshone Mountains, Ner. Whitney collection.

Balatonites shoshonensis Hyatt and Smith (p. 120).

Figures 12,13 . Side and rear views of the tyle.

From Middle Triassic, Ner. Shoshone Mountains, longitude $117^{\circ} \mathrm{W}$. Whitney collection.

$16279^{\circ}-$ No. $83-14-12$ 


\section{PLATE V.}

Ceratites (Parachratites) gabri Meek (p. 88).

Figures 1, 2. Side and rear views (from li. S. Genl. Expl. 40th Par., vol. 4, 1t. 1, I'l. XI, figs. 4 and $4 a$ ). From Middle Triassic, Cottonwood Canyon. West Humboldt Range, Ner.

\section{Monophyllites imllingsiaxis Gabb (p. 48).}

Figures 3, 4. Side riew and septa.

From Middle Triassic, Ealst Range, Humboldt Mountalins, Ner. Whitney collection.

Arcestes (Prodrcestes) xevadaxt's Hyatt and Smith (p. 44).

Figures : $:-\bar{\imath}$. Sille and front views and septa.

From Middle Triassic. Volcano, Nev. Whitner collection.

Trachyceras (Protrachiyceras) mefer Mojsisovics (p. 135).

Figures 8. 9. After Meek (I.. S. (jeol. Expl. 40th Par., wol. 4, Pl. XI, figs. 1 and $1 a$ ).

From Iiddle 'Triassic, Cottonwood Canyon, West Humboldt Range, Nev.

154 


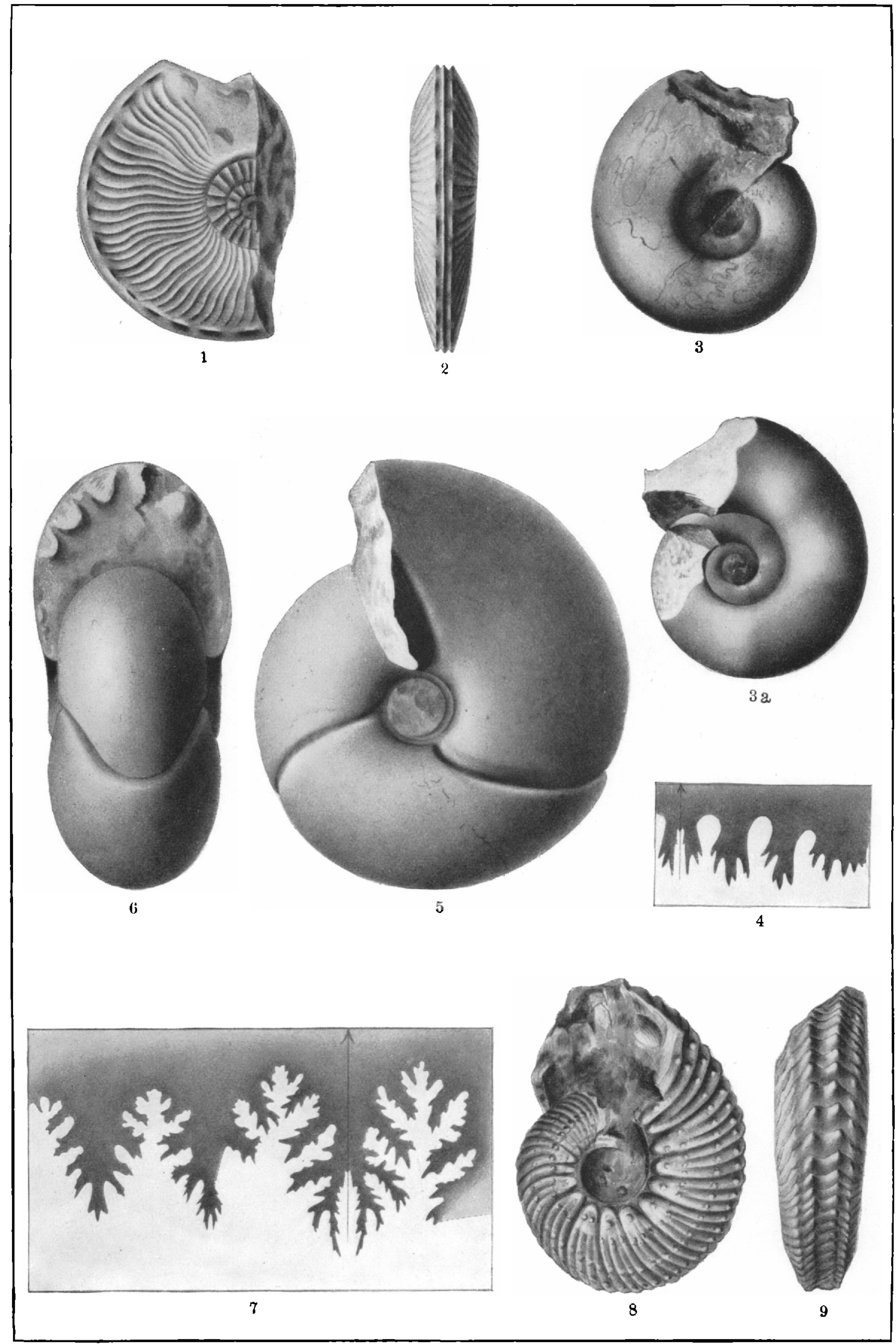




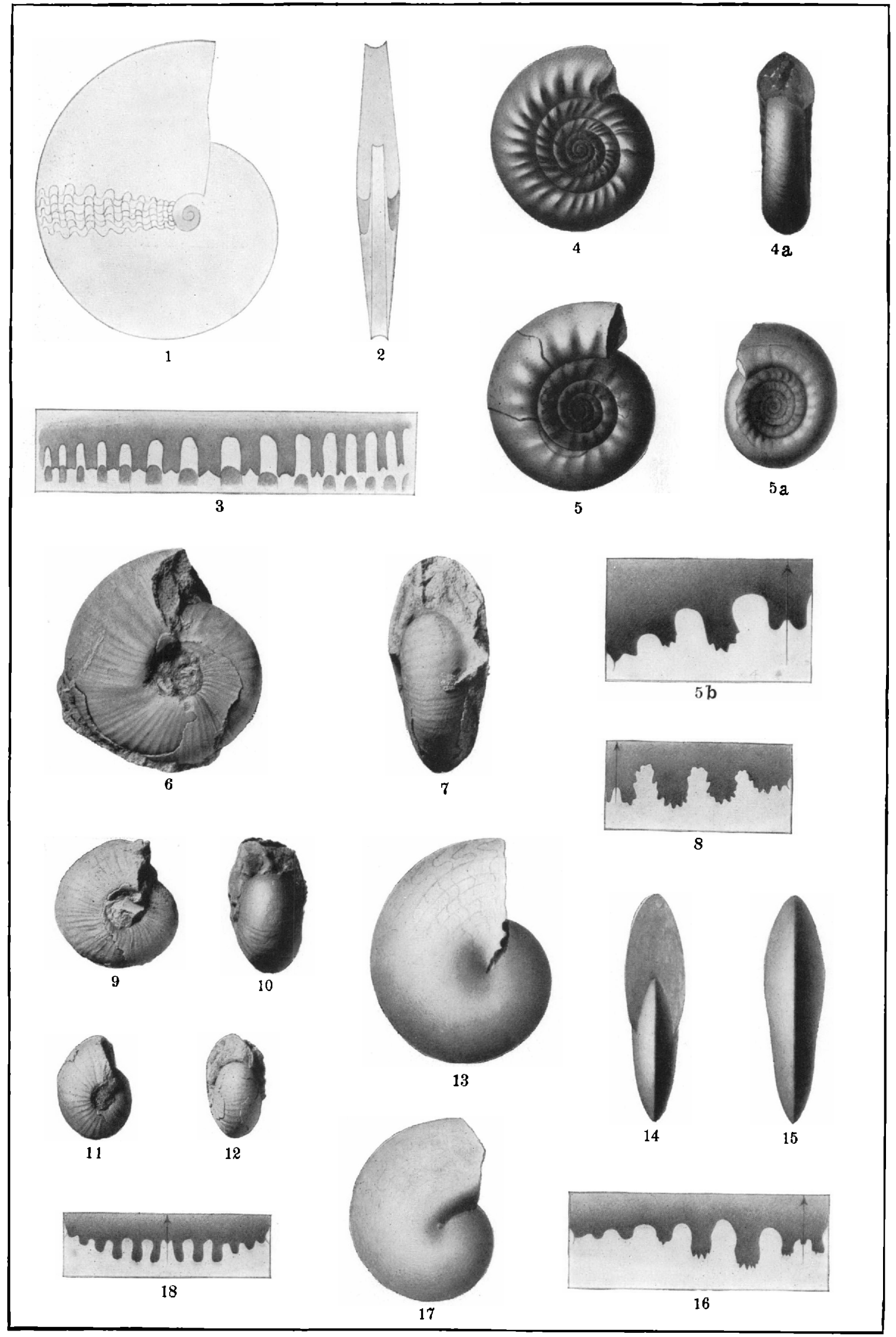




\section{PLATE VI.}

Sageceras gabbi Mojsisovics (p. 49).

Figures 1-3. Side and front views and septa (copied from Geol. Survey California. Palæontology, vol. 1, Pl. V, figs. 8 and 10 ).

From Middle Triassic, West Humboldt Range, Ner.

Tropigastrites inali. Mojsisovics (p. 27).

Figures $4,4 a$. Side and front views (natural size).

Figure 5. Right side (natural size) of another specimen.

Figures 5 $t, 5 t$. Side view (natural size) and sejt:a $(\times 3)$ of another specimen.

From Middle Triassic, on divide between north side of Troy Canyon and south fork of American Canyon, Humboldt Range, Ner. Collection of J. P. Smith.

Ptychites Meeni Hyatt and Smith (p. 47).

Figures 6-8. Side and front views (natural size) and septa $(\times 2)$ of the tyle.

Figures 9, 10. Side and front views of an adolescent specimen.

From Middle Triassic, Star (:Inyon, West IIumboldt Range, Nev. Whitney collection, Harvard Vniversity.

Figures 11, 12. Side and front views of a still smaller specimen.

\section{Longobardites nevadancs Hyatt and Smith (p. ̌0).}

Figures 13-16. Side, front, and rear views $(\times 2)$ and septa $(\times 3)$ of the type specimen.

Figures 17,18 . Sille view and septa (both $\times 3$ ) showing septa in the goniatite stage.

From Middle Triassic, New Pass, West Humboldt Range, Nev. Whitney collection, Harvard University. 


\section{PLATE VII.}

Ceratites humboldtexsis Hyatt and Smith (p. 99).

Figures 1-3. Side, front, and rear views of an adult specimen, showing the beginuing of the rough sculpture characteristic of maturity.

Figures 4, 5. Side view (nitural size) and septa $(\times 2)$ of a mature form.

Figures $6,6 a, 7$. Cross section and side view (from the same specimen), showing the increalse in breadth and squareness of the whorls.

Figures S-11. Sille, front, and rear views (naturil size) and septa $(\times 2)$, of a specimen at the beginning of maturity.

Figures 12, 13. Side and rear views (natural size), showing the end of the adolescent stage.

Figures 14-16. Side, front, and rear views ( $X 11$ ), adolescent stare; diameter 18 millimeters.

Figures 17,18 . Side and rear views $(\times 2)$, adolescent stage; diameter 13 millimeters.

Figures 19-21. Side, front, and rear views $(X 3)$, early adolescent stage; diameter 8 millimeters.

Figures 22, 23. Side and front views $(X 5)$, larval stage; diameter 4.5 millimeters.

From Middle Triassic (Daonella zone), on the divide between Troy Canyon and the south forls of American Canyou, West IIumboldt Range, Nev. Collection of J. P. Swith. 


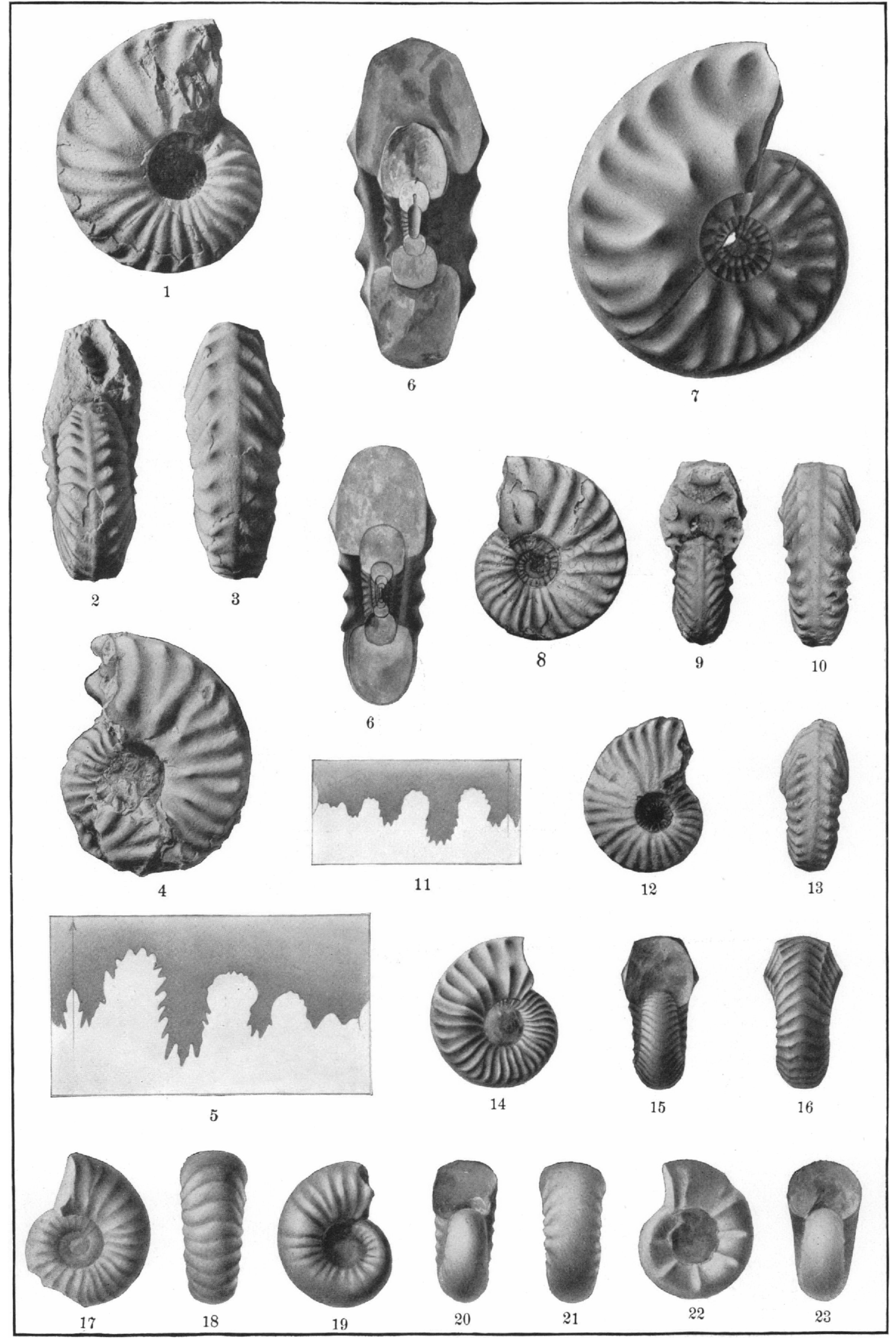



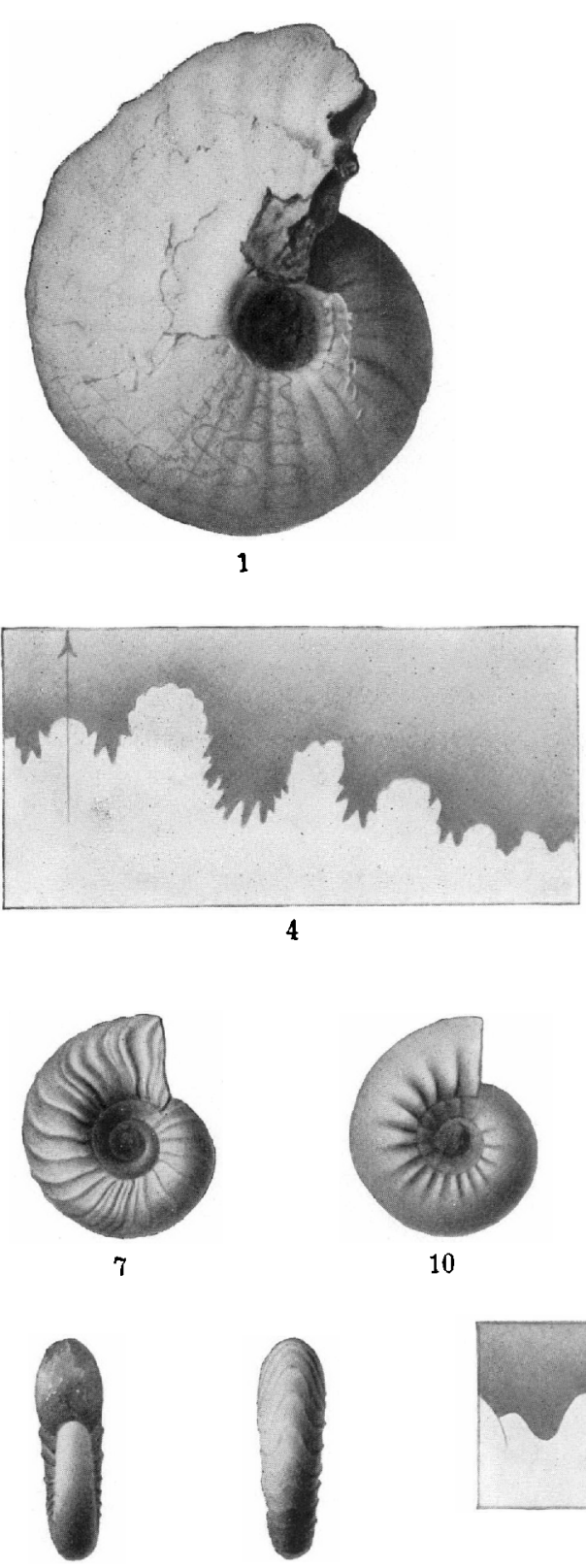

8

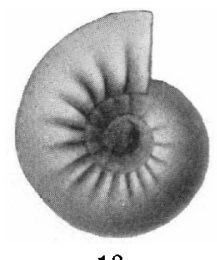

10
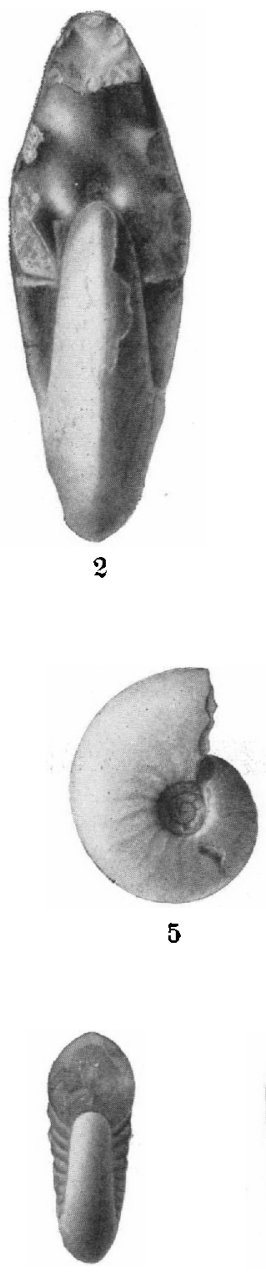

11
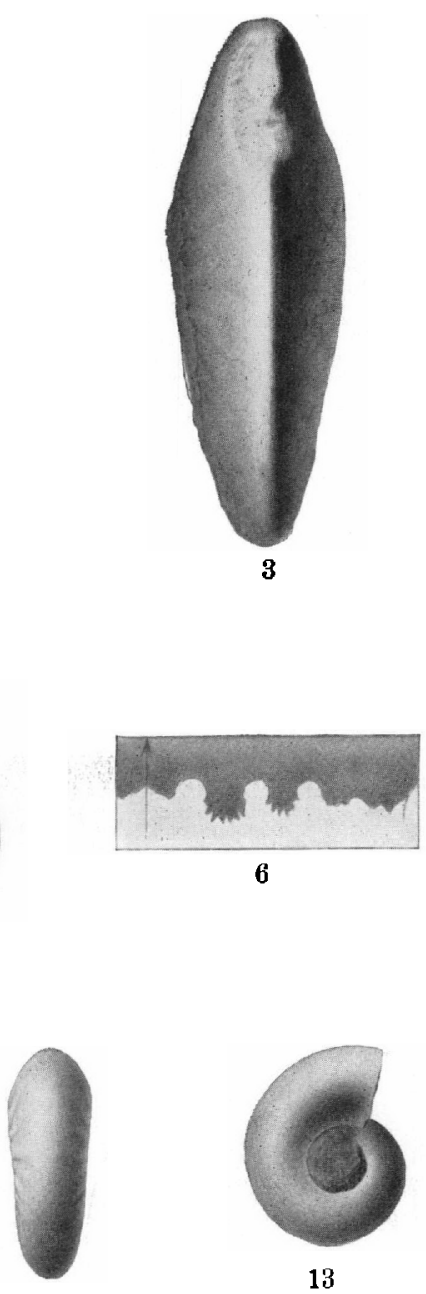

12
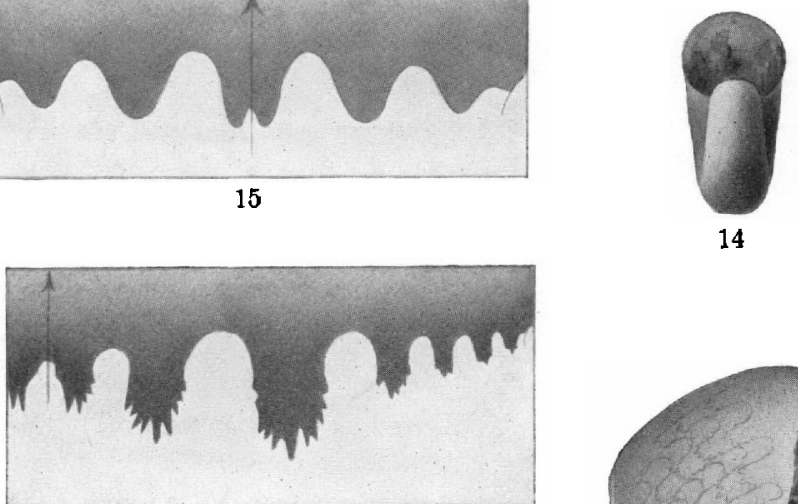

18
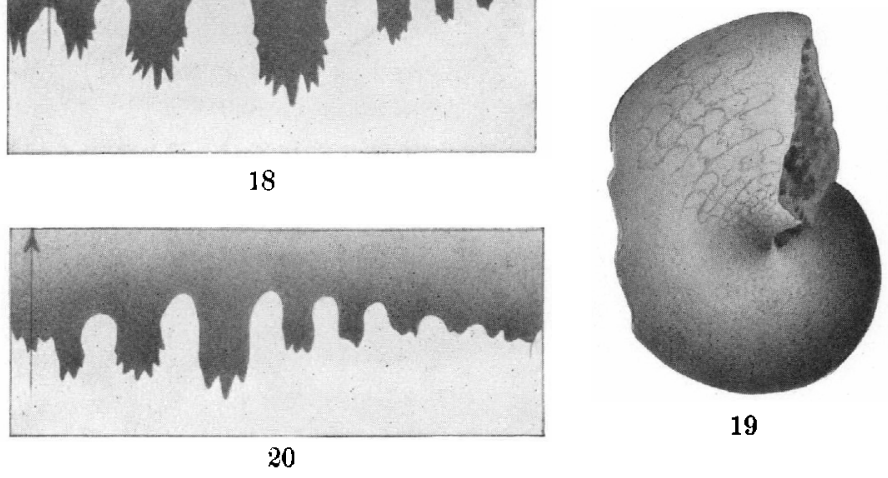


\section{PISATE VIII.}

Beyrichites RotelLiformis Meek (p. 118).

Figures 1-4. Side, front, and renr views and septa.

Figures 5, 6. Side view (nitural size) and septa $(\times 2)$ of an alolescent specimen; diameter 24 millimeters. Figures $7-9$. Side, front, and rear views $\left(X 1 \frac{1}{2}\right)$ adolescent stage; diameter 15 millimeters.

Figures 10-12. Side, front, and rear views $(X 2)$, adolescent stige; diameter 11.5 millimeters.

Figupes 13-15. Side and front views $(\times 6)$ and seltit $(X 12)$, end of larval stage: diameter ;.4 millimeters.

From Middle Triassic, on divide between Troy Canyon and south fork of American Canyon, West Ilumboldt Range, Ner. Collection of J. F. Simitl.

Iongobardites nevadanis Hyatt and Smith (p. 50).

Jutivars 16-1S. Side and front views (natuml sime) and septa $(\times 2)$.

Figurfs 19, 20. Side view (natural size) and septa $(\times 2)$.

From Middle Triassic, on divide between Troy (anyon and south fork of American Canyou, West Humboldt Range, Nev. Collection of J. P. Smith.

$16279^{\circ}-$ No. $83-14-13$ 


\section{PLATE IX.}

Trachyceras (Protracinyceras) meeki Mojsisovics (p. 135).

Figures 1, 2. Side and front views of an old specimen. This specimen shows the beginning of obsolescence of sculpture in old age.

Trachyceras (Axolcites) gabbi Smith, sp. nov. (p. 132).

Figures 3-6. Side, front, and rear views $(\times 2)$ and septa $(\times 3)$, adolescent stage. diameter 25 millimeters. Figures $7-9$. Side, frout, and rear views $(\times 2)$, adolescent stage; diameter 14 millimeters. Figures 10-12. Side, front, and rear views $(\times 2)$, adolescent stage; diameter 10 millimeters.

Figures 13-15. Side, front, and rear views $(X 3)$, showing transition from larval to adolescent stage; diameter 6 millimeters.

Figubes 16, 17. Side and front views $(\times 4)$, larval stage, corresponding to Tirolites; diameter 4.5 millimeters.

From Mirlde Triassic (Dannella zone), West Humboldt Range, Ner. Figures 1 and 2, from Cottonwood Canyon, near "Lucky Dog" mine; Figures 3-17, from divide between Troy Canyon and south fork of American Canyon. Collection of J. I'. Smith. 


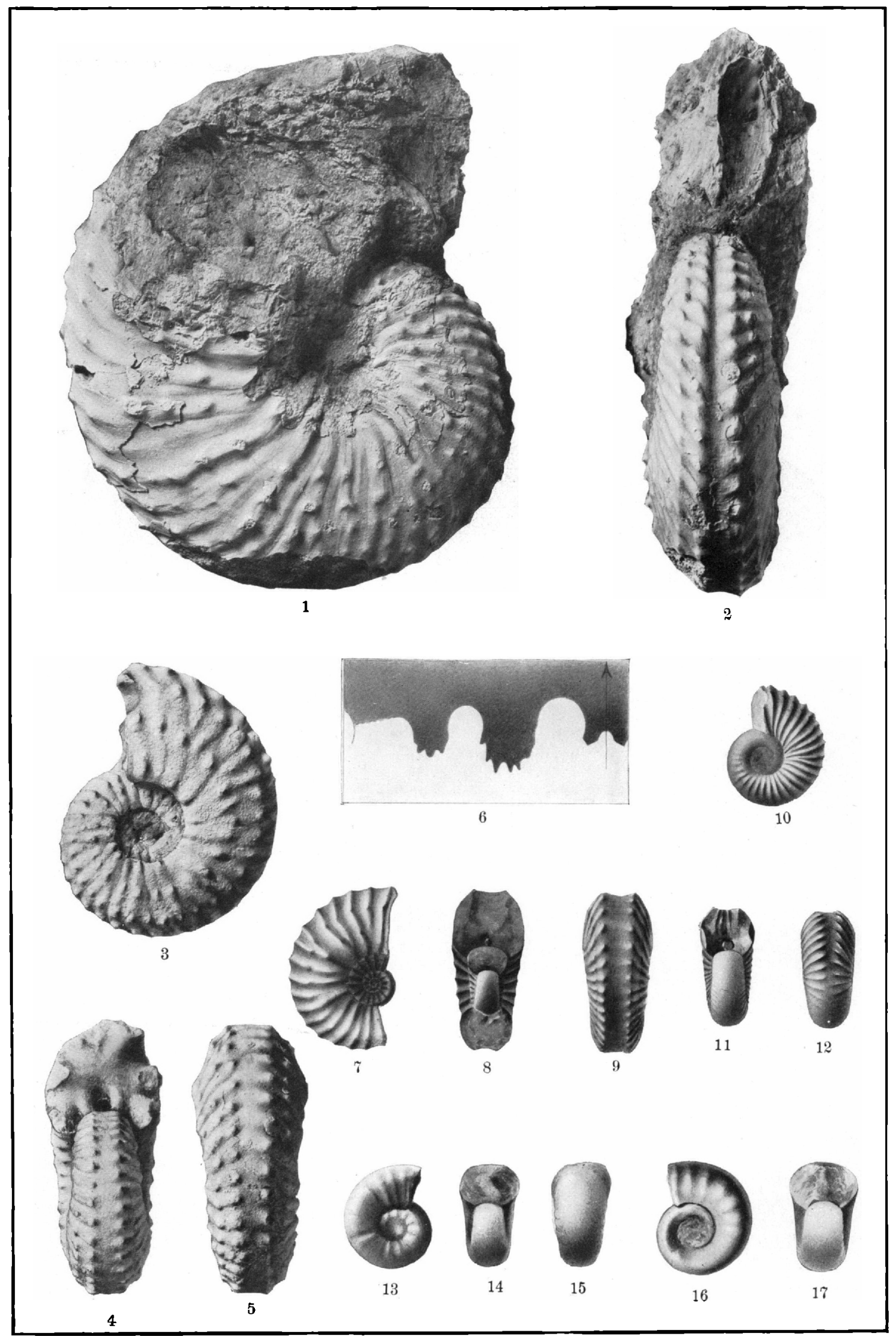




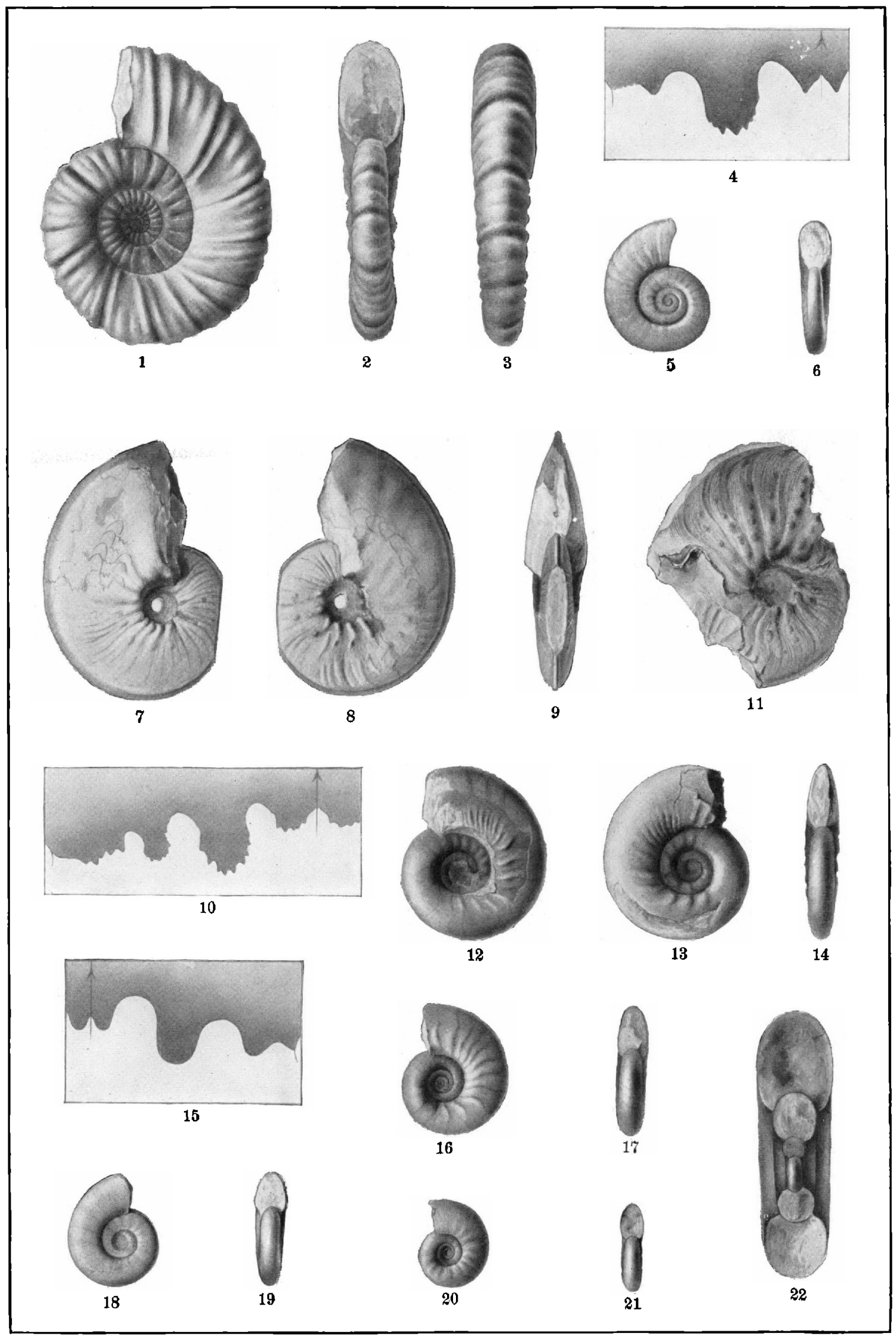




\section{PLATE X.}

\section{Cuccoceras bon a-vista Hyatt and Smith (p. 71).}

Figure 1. Left side.

F'IGURE 2. Front.

Figure 3. Rear view (natural size) of the type.

Figure 4. Septa $(\times 2)$ of the same specimen.

Figures 5, 6. Side and front views of a smaller specimen.

From Middle Triassic (Daonella zone) at Lnionville, Ruena Vista Canyon, West Humboldt Range, Nev. Collection of J. P. Smith.

Eutomoceras latbei Meek (p. 63).

Figures 7-9. Right side, left side, and frout views.

Figure 10. Septa $(X 2)$ of the same specimen.

FIGURE 11. Right side view (natural size) of another specimen, showing the ornamentation.

From Middle Triassic (I aonella zone) on the divide between Troy Canyon and the south fork of American Canyon. West Humboldt Range, 4 miles south of Fitting post office (formerly Foltz), Humboldt County, Nev. Collection of J. P. Smitll.

\section{LECANiTES rogdesi Hyatt and Smith (p. 67).}

Figures 12-14. Left side, right side, and front riews (natural size) of type specimen.

Figure 15. Septa $(X 4)$ of the silme speciment.

FIgURes 16, 17. Side and front views of a smaller specimen, showing the greater evolution in youtl.

Figures 18, 19. Side and front views (natural size) of a specimen just changing from aldolescence to maturity; diameter 19 millimeters.

Figures 20-22. Adolescent specimens; diameter 15.5 millimeters.

Figure 20. Left side (natural size), whole specimen.

FIGURE 21. Front view (natural size), whole siecimen.

Figure 22. Same specimen $(X 3)$ with broken part of whorl removed, to show the cross section and the larval whorl inside.

From Middle Triassic (Daonella zone) on the divide between Troy Canyon and the sonth fork of American Canyon, West IIunboldt Range, 4 miles south of Fitting post office (formerly Foltz), Humboldt County, Nev. Collection of J. P. Smith. 


\section{PLATE XI.}

Trachyceras (Protrachyceras) meeki Mojsisovics (p. 135).

Figures 1-3. Side, front, and rear views.

From Middle Triassic, Cottonwood Canyon, near Lucky Dog mine, West Humboldt Range, Nev.

Collection of J. P. Smith.

Trachyceras (Axolcites) gabbi Smith, sp. nov. (p. 132).

Figures 4. 5. Side and rear views, adolescent stage; diameter, 23 millimeters.

Figures 6, 7 . Side and front views $(\times 2)$, enrlier adolescent stage, broken whorl, showing the larval stage inside; diameter, 13 millimeters.

From Middle Triassic, from divide between Troy Canyon and south fork of American Canyon, West Humboldt Range, Nev. Collection of J. P. Smith.

Sageceras gabbi Mojsisorics (p. 49).

Frgures 8, 9. Side and front riews of an old specimen.

From Middle Triassic, from divide between Troy Canyon and south fork of American Canyon, West Humboldt Range, Ner. Collection of J. P. Smith.

Tropigastrites louderback i Hyatt and Smith (p. 29).

Figures 10, 11. Side and front views (natural size).

Figure 12. Septa $(X 31)$.

From Middle Triassic, from divide between Troy Canyon and south fork of American Canyon, West Humboldt Range, Nev. Collection of J. P. Smith. 
PROFESSIONAL PAPER 83 PLATE XI

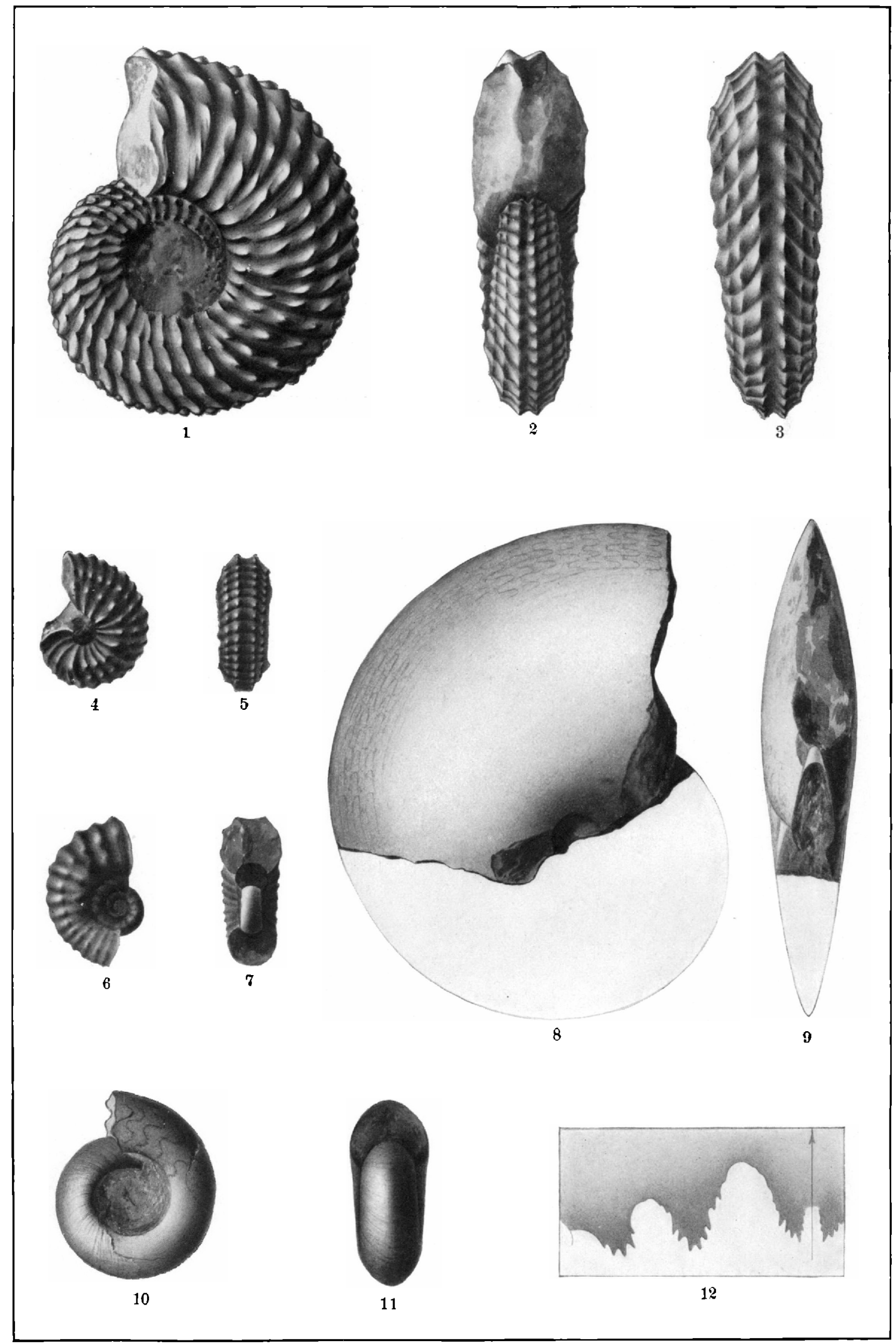




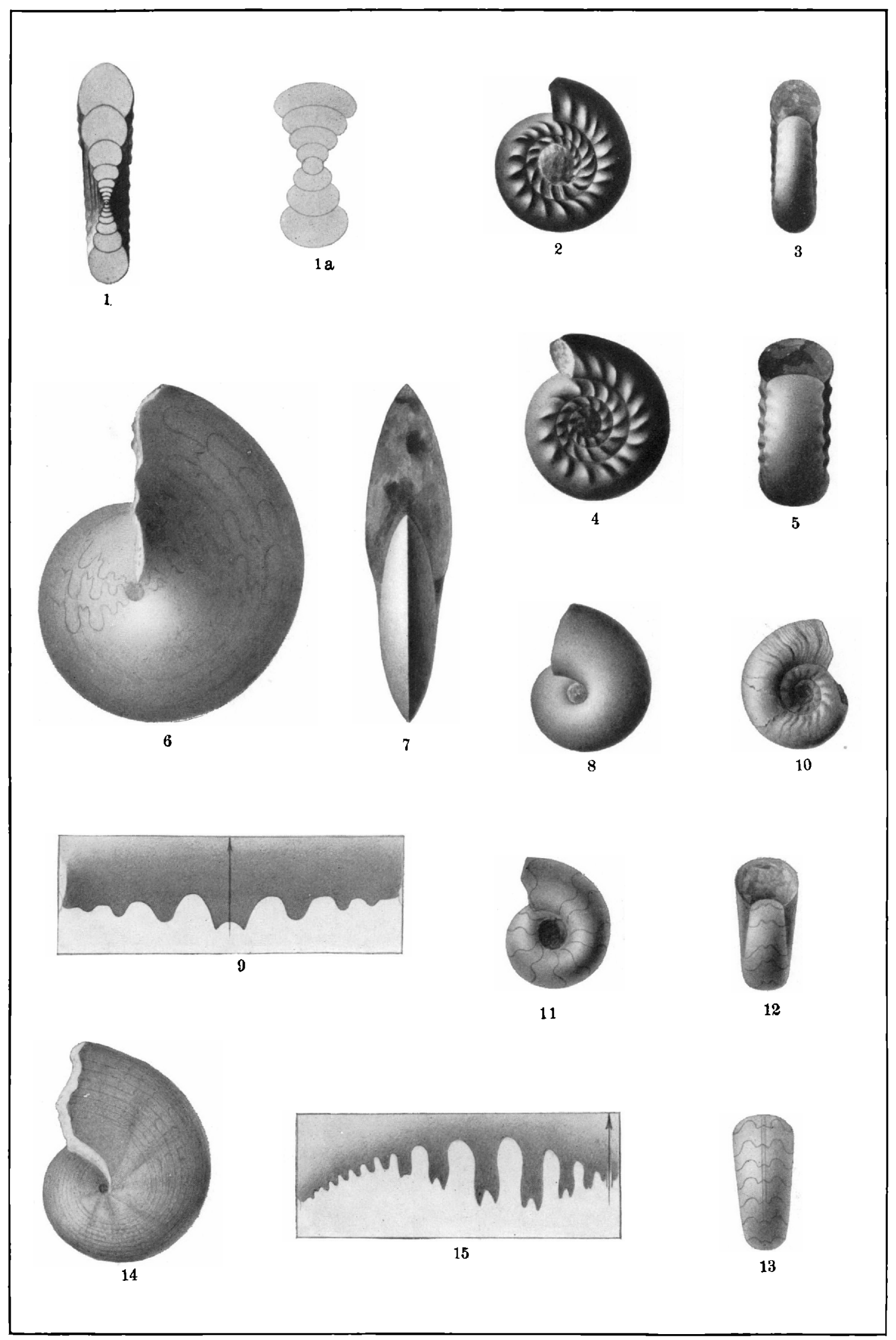




\section{PLATE XII.}

Tropigastrites inall Mojsisovics (p. 27).

Figure 1. Cross section (natural size), mature specimen.

Figuri 1a. Inner whorls (enlarged) of the same.

Figures 2, 3. Adolescent stage $(\times 2)$; diameter, 13 millimeters.

Figures 4, 5. Adolescent stage $(X 4)$; diameter, 7 millimeters.

From Iiddle Triassic, on the divide between Troy Canyon and the soutl fork of American Canyon, West Humboldt Range. Ner. Collection of J. I'. Smitl.

Loxgobardites nevadaxis Hyatt and Smith (p. 50).

Figures 6. 7. Enlarged twice.

Figures 8 , 9. Side view $(\times 6)$ and senta $(\times 12)$, larral stage; diameter, 4 millimeters.

From Middle Triassic, on the divide between Troy Canyon and the south fork of American Canyon, West Humboldt Range, Ner. Collection of J. P. Smith.

LeCANITES rogdesi IIyatt and Smith (p. 67).

Figure 10. Side view, early adult stage; diameter, 29 millimeters.

Figures 11-13. Side, front. and rear views $(X 10)$, larral stige, corresponding to labralemanites; diameter. 2.36 millimeters.

From Middle Triassic, on the divide between Troy Canyon and the south fork of American Canyon, West Humboldt Range, Ner. Collection of J. P. Smitlı.

Sigeceras gabbi Mojsisorics (p. 49).

Figtre 14. Side view ( $\times 2$ ), adolescent stage; diameter. 15 millineters.

Figure 15. Septa $(X 4)$ from the same.

From Middle Triassic. on the divide between Troy Canyon and the south fork of American Canyon, West IImmboldt Range, Nev. Collection of J. P. Smith. $16279^{\circ}-$ No. $83-14-14$ 


\section{PLATE XIII.}

\section{Popanoceras (Parapopanoceras) haugi Hyatt and Smith (p. 41 ).}

Figures 1-3. Side, front, and rear views.

FiaUre 4. Septa $(X 3)$ of another specimen.

Figures 5. 6. Side and fiont of a smaller specimen.

Figure 7 . Septa $(X 3)$ of the above specimen.

Figures 8,9 . Side and frout $(\times 2)$ broken so as to show the inner whorls.

Figure 10. Septa $(X 4)$ of the above specimen.

Figures 11-14. Side, front, and rear views $(X 3)$ and septa $(X 6)$, adolescent stage, corresponding to Popanoceras; diameter, 9.5 millimeters.

Ficures 15-17. Side and front riews $(\times 6)$ and septa $(\times 12)$, early adolescent (Adrianites) stage; diameter, 4.5 millimeters.

Figcres 18-20. Side and front riews $(\times 10)$ and septa $(\times 20)$, larval (Puralegoceras) stage; diameter, 2.88 millimeters.

Figures 21, 22. Liear view $(\times 10)$ and septa $(\times 20)$, larval (Gastrioceras) stage.

From Middle Triassic, Union Wash, Inyo Range, Inyo County, Cal. Collection United States National Museum. 


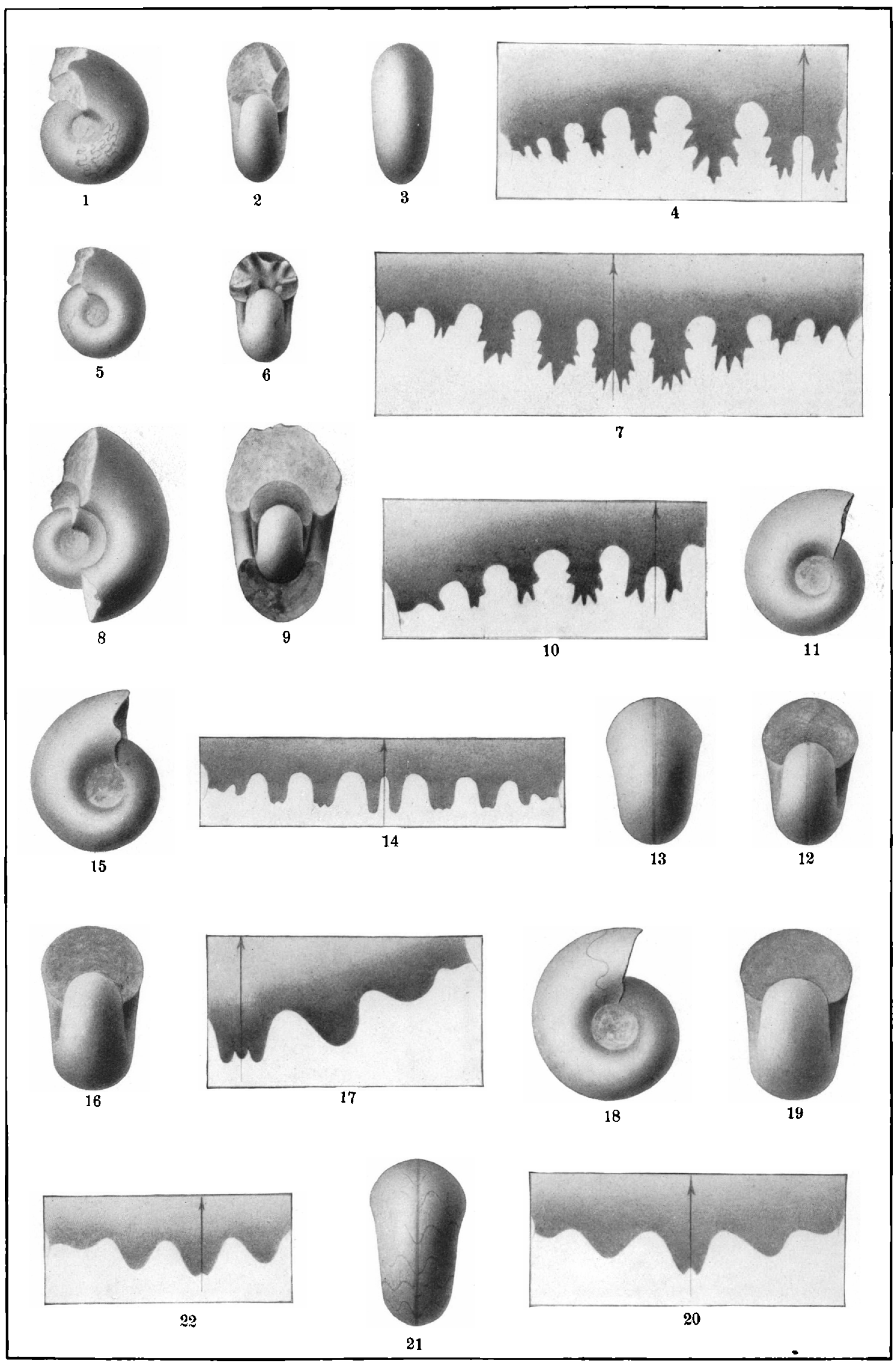




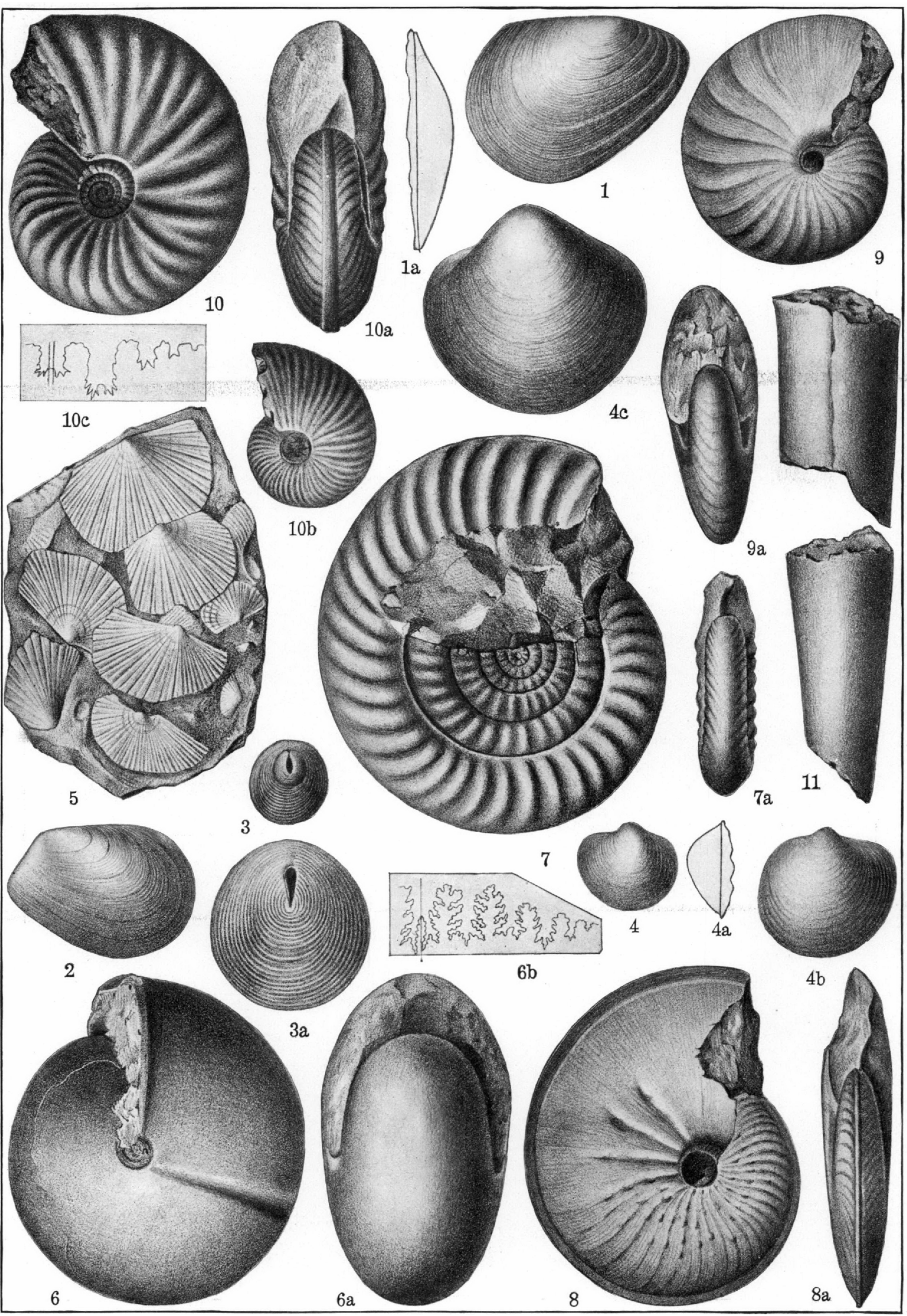




\section{PLATE XIV.}

Figcres 1, 1a. Modiomorpha ovata Meek (p. 145).

Figcre 2. Modionompina? Lata Meek (p. 146).

Figcre 3. Discina sp.

Figtres $4 a-c$. Sphera whitseyi Meek.

Figere 5. Daovella dubia Gabb (p. 143).

Figcres 6 $a-b$. Arcestes (Proancestes) gatibi Meek (p. 43).

Figtres $7,7 a$. Tropigastrites ilaldi Mojsisovics (p. 27 ).

Figlres 8, 8a. Ectomoceras latrei Meek (p. 63).

Figures $9,9 a$. Beyricinites rótelliformis Meek (p. 118).

Figcres 10, 10\%. Ceratites (Grmótoceras) meeik Mojsisovics (p. 111).

Figures 10Z, 10c. Ceratites (Grmxotoceras) blakei Gabb (p. 109).

Figure 11. Orthoceras biakei Gabb? (p. 140).

All figures on this plate are copied from Meek (U. S. (Geol. Expl. 40th Par., vol. 4, pt. 1. Pl. X). All the specimens came from the upler Middle Triassic (upper Muschelkalk borizon of Europe) of Nevada, from the localities given in the text, from New Pass in the Desatoya Mountains, and Cottonwood and Bueni Vista canyons in the West Humboldt Range. 


\section{PLATE XV.}

Figures 1, 1a. Trachyceras (Protrachyceras) meeni Mojsisovics (p. 135).

Figlres 2, 2a-b. Trachyceras (Protrachyceras) subaspercy Meek (p. 137).

Figcres 3, $3 a$. Trachyceras (Protrachyceras) americandm Mojsisovies (p. 133).

Figures 4, 4a. Ceratites (Paraceratites) gabbi Mojsisovics (p. 88).

Figlres $\check{5}, \check{5} a$. Acrochordiceras hyatti Meek (p. 39).

Figcres 6, 6a. Ceratites nevadanes Mojsisovics (p. 101).

Figcres $7,7 a$. Gruxites penplaxes Meek (p. 54).

All figures on this plate are copied from Meek (U. S. Geol. Expl. 40th Par., vol. 4, pt. 1, Pl. XI). All the originils are deposited in the Cnited States Nationil II useum, and came from the Middle Triassic, Dronella dubia zone of the West Humboldt and Desatoya ranges in Nevadi, from the localities cited in the text. 


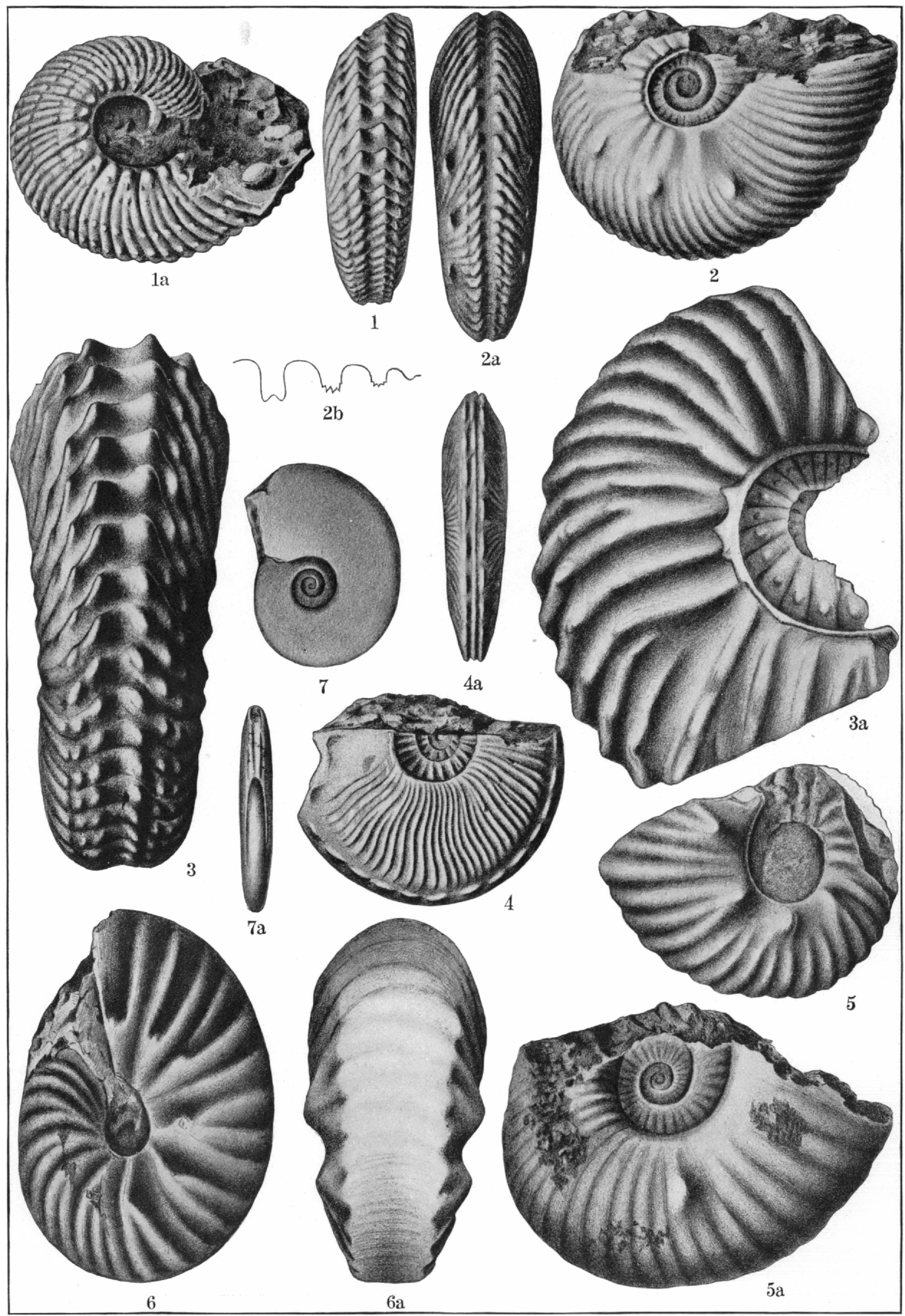




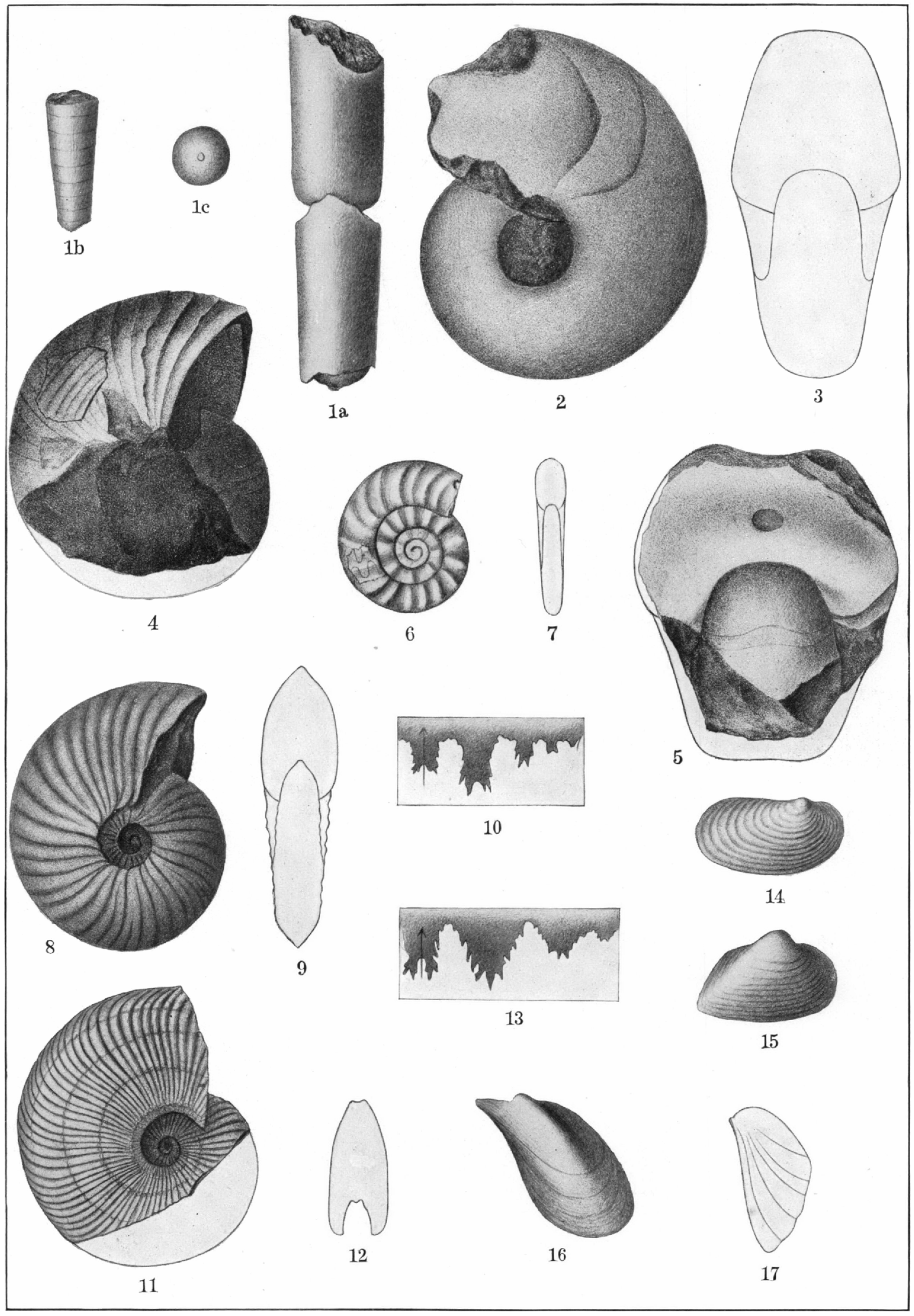




\section{PLATE XVI.}

Orthoceras blakei Gabb (p. 140).

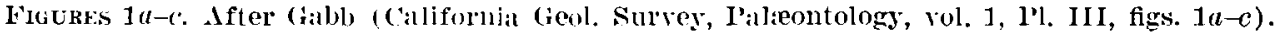

Grypockras wintweyt Gabb (p. 141).

Figeklis 2, 3. After Gabb (idem, I'l. III, figs. 2 and 3 ).

Paraxautiles menticamerates Gabb (p. 143).

Figures 4. 5. After Giabb (idem, I'l. III. figs. 4 and 5).

Celtites gabibi Smith (p. 34).

Figures 6, 7 . After Gabb (inlem, I'l. II I, figs. 6 and $\mathbf{\imath}$ ).

Ceratites (Gymnotoceras) blakei Gabb (p. 109).

Figures 8-10. After (iabb (idem, I'l. IY, figs. 14-15).

Trachyceras (Protrachyceras) homfrayi Gabb (p. 134).

Figcres 11-13. After Gabb (iclem, I'l. II, figs. 1S-19).

Pleuromya incmboldtexsis Gabb (p. 143).

Figtire 14. After Gabb (idem, I'l. V; fig. 22).

Corbula blakei Gabb.

Figcre 15. After Gabb (idem, Pl. V, fig. 24).

Rirccirorteris onests Gabb (p. 145).

Frours 16, 17. After Gabb (idem. Pl. V, figs. $30(1-b)$ ).

All specimens figured on this plate are from the Middle Triassic, Dannclla dubia zone, from the

West II mboldt and Desatoya ranges of Nevada, from the localities cited in the text. $16 \div-79^{\circ}-\mathrm{No.} 83-1+-1 \mathrm{~J}$

165 


\section{PLATE XVII.}

Tropigastrites tromaxis Smith, sp. et gen. nov. (p. $3: 2)$.

Figuris 1-3. Side, front, and reall of the type (natural size).

Figure 4. Septa of the type $(\times 2)$.

Figur 5. Side view of another specimen, to slow the sculpture.

Figures 6-8. Side, front, and rear of a specimen in the ealrly adult stilge (naturall size) : (liameter 2i.s millimeters.

Figure 9. Septa of the above specimen $(X \quad 5)$; diameter 24 millimeters.

Figure 10. Septa of the sime suecimen $(X 3)$; dialmeter 31 millimeters.

Figures 11, 12. Side and front riews, late adolescent stage $(X 2)$; diameter 1!) millimetel's.

Figtre 13. Septil of the above specimen $(\times 4)$.

Figure 14. Cross section, early adult stage (nitural size).

Figures 15, 16. Adolescent stage $(\times 2)$; diameter 12 millimeters.

Figure 17 . Septa of the above specimen $(X 4)$; diameter 10 millimeters.

Frgures 18, 19. Inner coil of the above specimen, adolescent stage ( $X 22)$ : dinmeter 10 millimeters, sirle and front.

Figures 20-22. Side, front, and rear, early adolescent stage $(X 2)$ : diameter $\$$ millimeters.

Figure 23. Side view, larval stage $(X 10)$ : diameter 2 millimeters.

Figures 24-26. End of larval stige $(X 5)$, corresponding to Gastrioceris: diameter 4.5 millimeters.

Figure 27 . Septa of the silme $(\times 10)$.

Figurrs 28-30. Larval stage $(X 5)$; diameter 3.5 millimeters.

From Middle Triassic, Daonella zone, Iossil Hill, south fork of American Canyon, West IImmboldt Range, Ner. All specimens fionred on this plate wore collected by J. P. Smith, and are in the collection of the United States Geological Survey. 


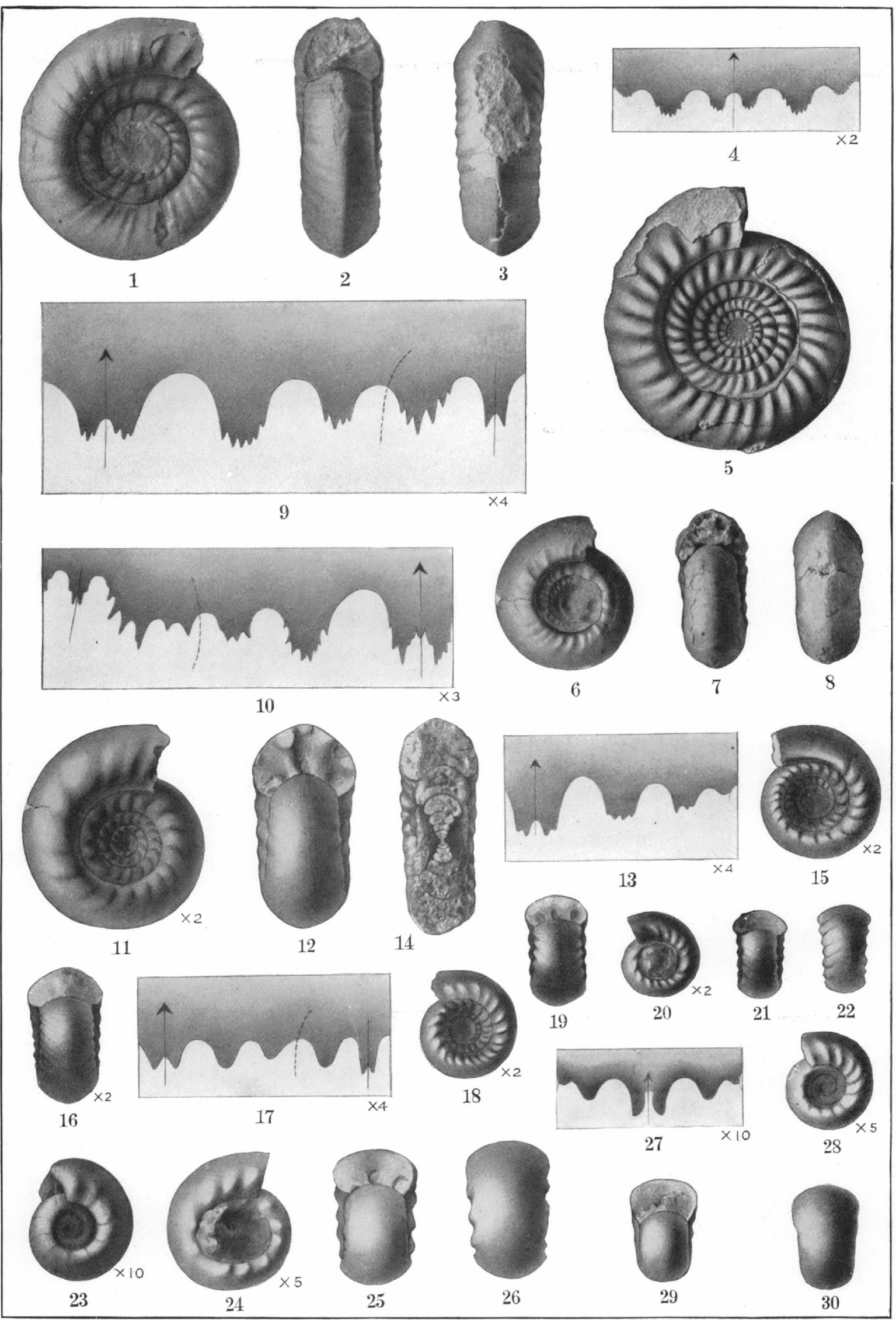



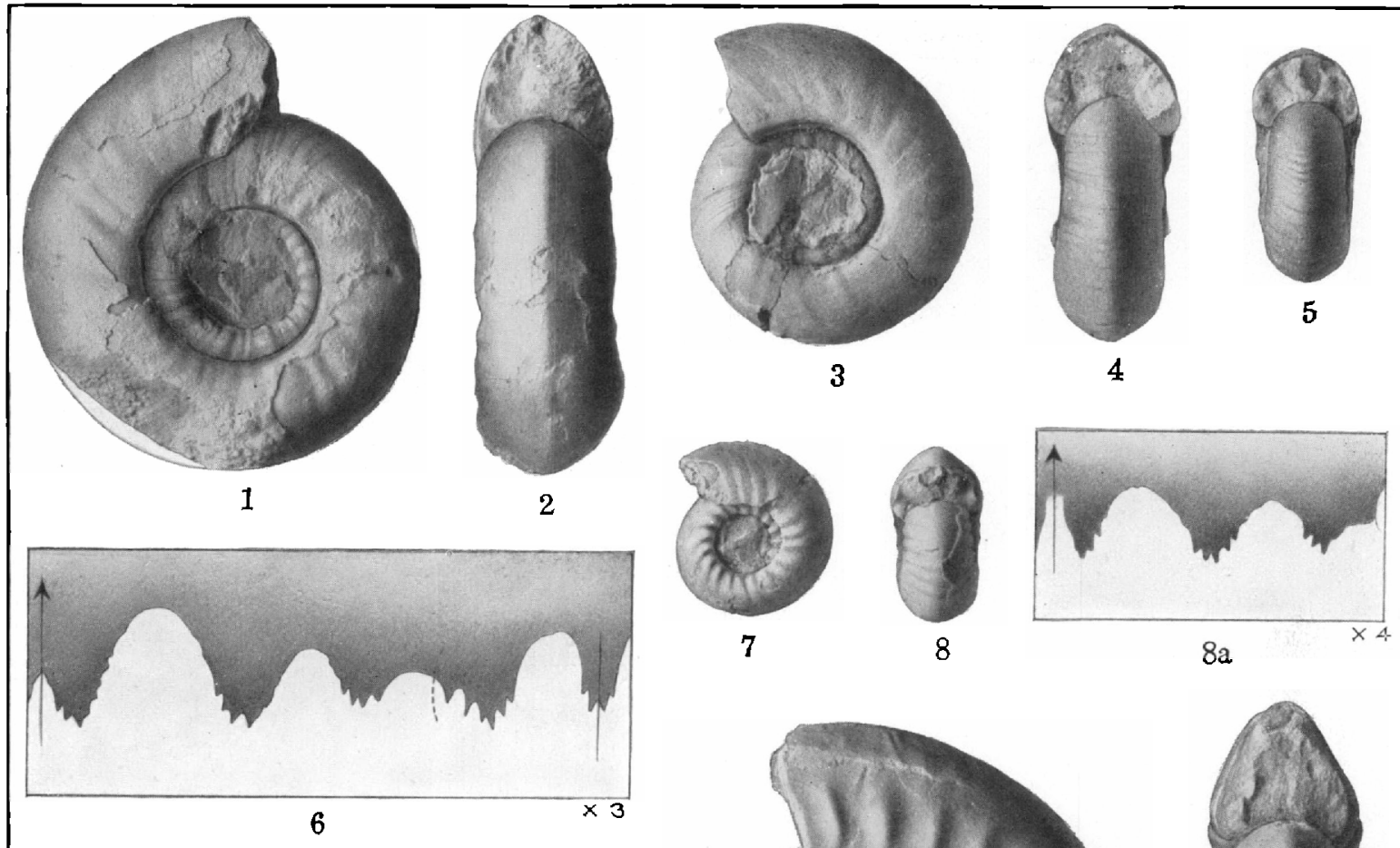

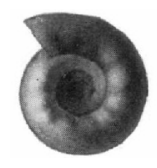

9

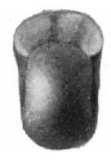

10
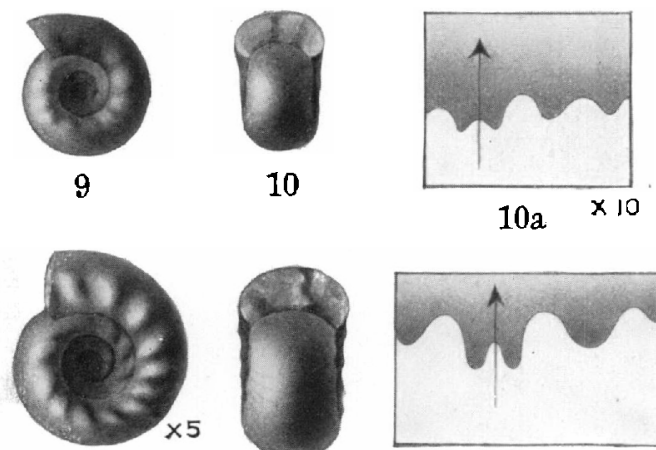

13

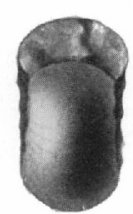

14

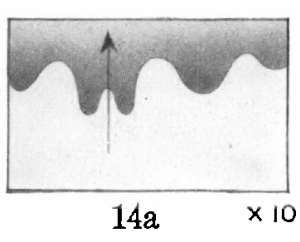

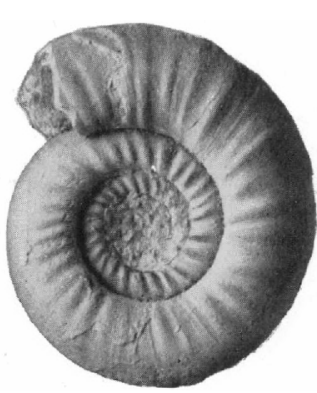

15

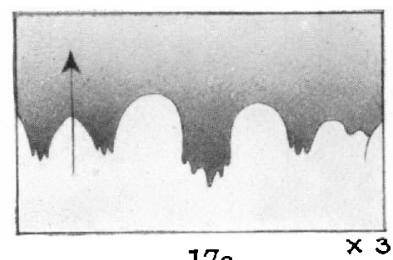

17a

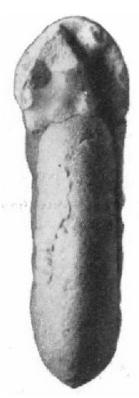

16

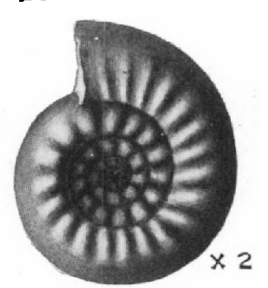

18

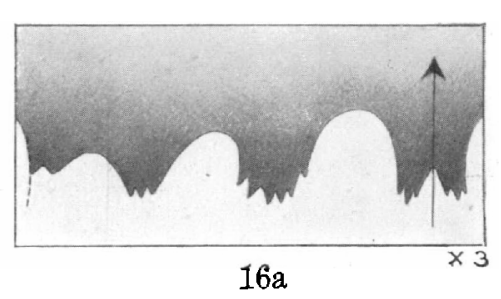

11

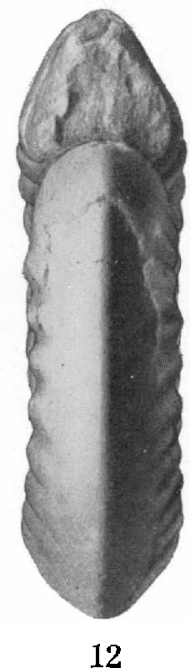

12

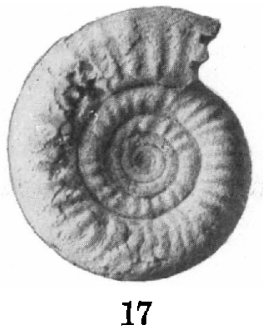

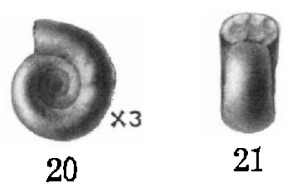
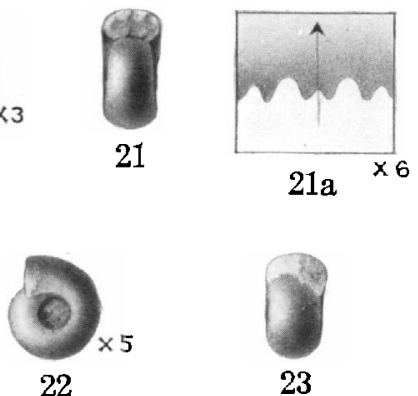


\section{PL.ATE XVIII.}

Tropig.astrites Poweld Smith, sp. nov. (p. 31).

Figures 1. 2. Side and front views of a mature specimen (natural size).

Figures 7,8 . Side and front views (natural size), date adolescent stage: diameter 21 millimeters.

Figure $8 a$. Septa of the above specimen $(X 4)$.

Tropigastrites locderbacki IIyatt and smith (p. 29).

Figures 3, 4. Side and front views, miture stage (natulanl size) : diameter 87 millimeters.

Figure 5. Front view of the above specimen, with five-twelfths of a revolution removed (natural size); diameter 30 millimetors.

Figure 6. Septa of the above specimen $(X 3)$; diameter 30 millimeters.

Ficukrs 9, 10. Side and front views $(X 5)$, larval stage: dialmeter 3 millimeters.

Figcre 10 $r$. Septil of the above $(\times 10)$.

Troprgastrites mim.i Mojsisovics (p. 27).

Figcres 11. 12. Side and front views (natural size).

Figcres 13-14. Side and front views $(X 5)$. larval stilge, diameter 4 millimeters.

Figuri 14a. Septil of the above specimen $(X 10)$.

Tropigastmites xeumami Mojsisovics (p. 29).

Fig Urfs 15, 16. Side and front riews (natural size).

Figure 16a. Septil of the above specimen $(X 3)$.

Figure 17. Side view, early adult stage (natural size) ; diameter 30 millimeters.

Figure 17a. Septa of the same specimen $(X 3)$.

Figures 18,19 . Side and front views $(X 2)$, adolescent stage: diameter $1: 3$ millimeters.

Figures 20, 21. Fnd of 1:arial stage $(X 3)$ : diameter 4 millimeters.

Figure $21 a$. Septil of the above $(\times 6)$.

Figures 22, 23. Lalrial stilge $(X 5)$; diameter + millimeter's.

All specimens figured on this plite were collected by J. P. Smith in the Midale Triassic, Daonella dubia zone, on Fossil IIIl, on the divile between 'Troy canyon and the south fork of American Canyon, West IImboldt lange, Ner. They are all in the collection of the Tuited States reological survey. 


\section{PLATE XIX.}

Tropigastrites rothpletzi Smith, sp. nov. (p. 31).

Figures 1, 2. Side and front views of the type (natural size).

Figure 3 . Septa of the above specimen $(\times 3)$.

Figures 4, 5. Side and front views of a larger sjecimen (natural size).

Figures 6, 7. Side and front views, early adult stage (natural size); diameter 19 millimeters.

Figures 8 , 9. Adolescent stage $(X 3)$; diameter 6 millimeters, side and front.

Figures 10, 11. Late larral stilge $(X 4)$; diameter 4 millimeters.

Figures 12,13 . Larral stage $(X 5)$; diameter 3 millimeter's.

Figure 13a. Sejta of the same slecimen $(X 10)$.

Figures 22, 23. Adult stage (uatural size) ; diameter 51 millimeters.

Tropigastrites lahontanes Smith, sp. nov. (p. 28).

Figures 14, 15. Type specimen (natural size).

Figure 15a. Septa from the type $(X 4)$.

Figures 16, 17. Early adult stage (natural size); diameter 28 millimeters.

Figures 18, 19. Early adult stige (natural size); diameter 22 milimeters.

Figure 19a. Septa from the same specimen $(X+)$.

Figures 20,21 . Ialrval stage $(X 5)$; diameter 3.5 millimeters.

Figure 21a. Septa of the above specimen $(X 10)$.

Figures 24-26. Adolescent stage ( $X 3$ ) ; corresponding to the gronl) of Gastrioceras listeri; diameter 8 millimeters.

All specimens figured on this plate, except the one represented by figures 4 and 5 , were collecied by J. I'. Smith in the Middle Triassic, Daonella abia zone, on the divide between Troy Canyon and the south fork of American Canyon, West Humboldt Range, Nev. The original of figures 4 and 5 came from the same horizon in Cottonwood Canyon, West Humboldt Range. The originals of fjgures 1-5 and 14-15 are in the collection of $J$. P. Smith; all others are in the collection of the Lnited States Geological Survey. 


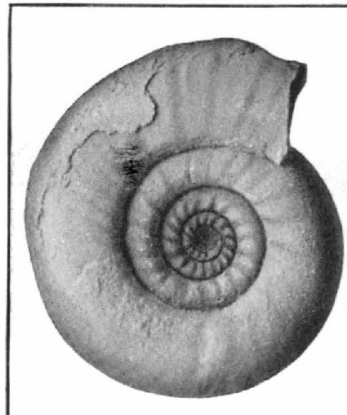

1

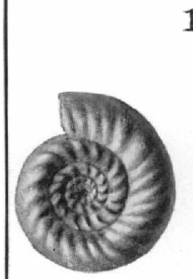

6

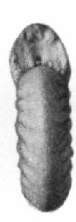

7

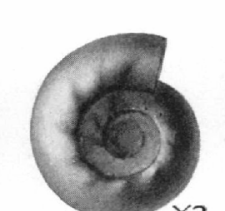

8
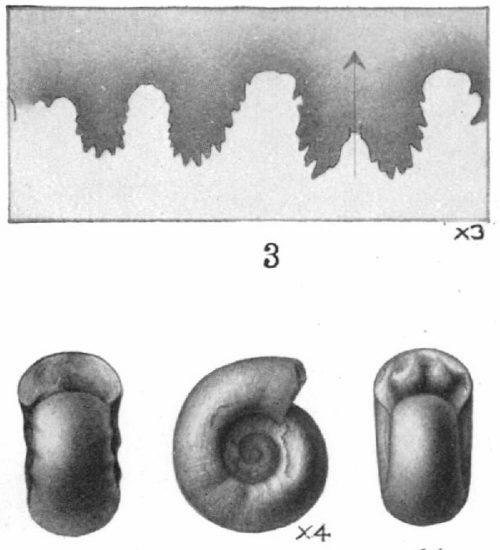

9

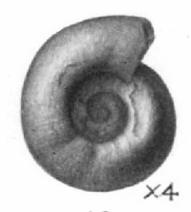

10
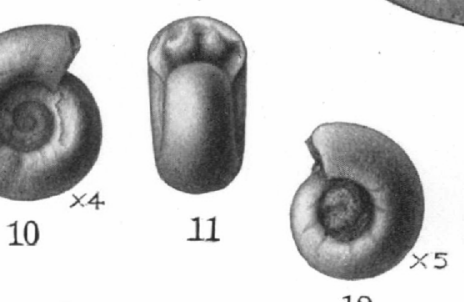

12

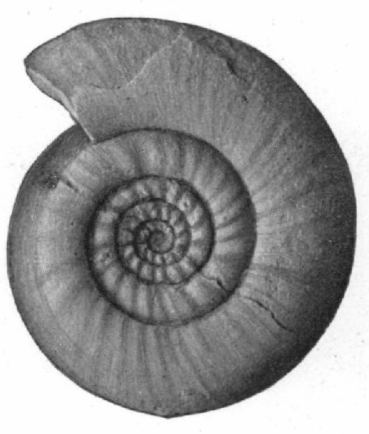

4

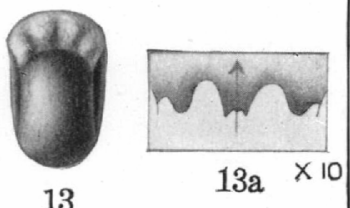

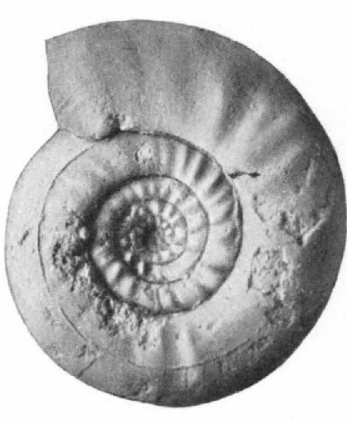

14

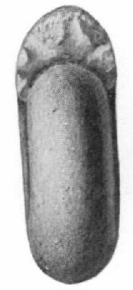

17

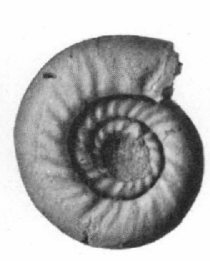

18

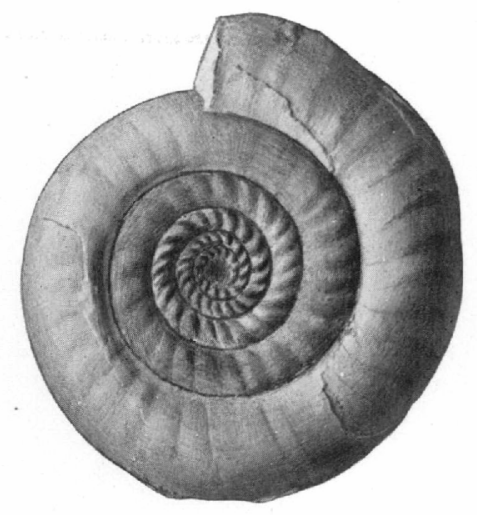

22

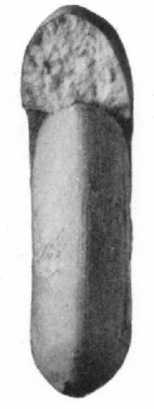

15

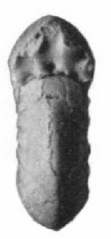

19
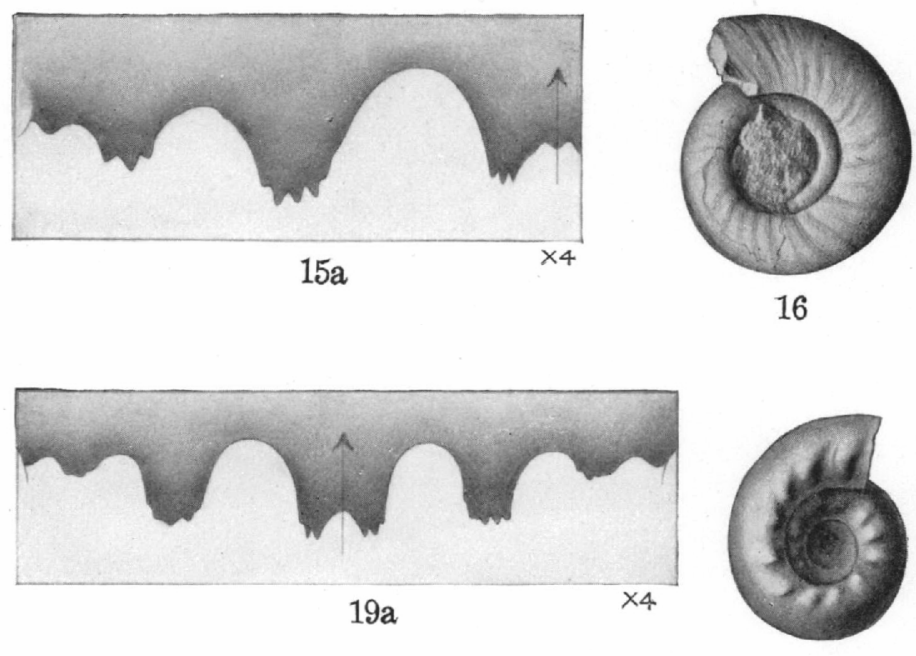

20

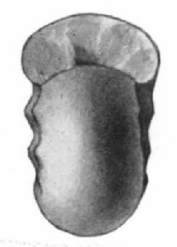

21
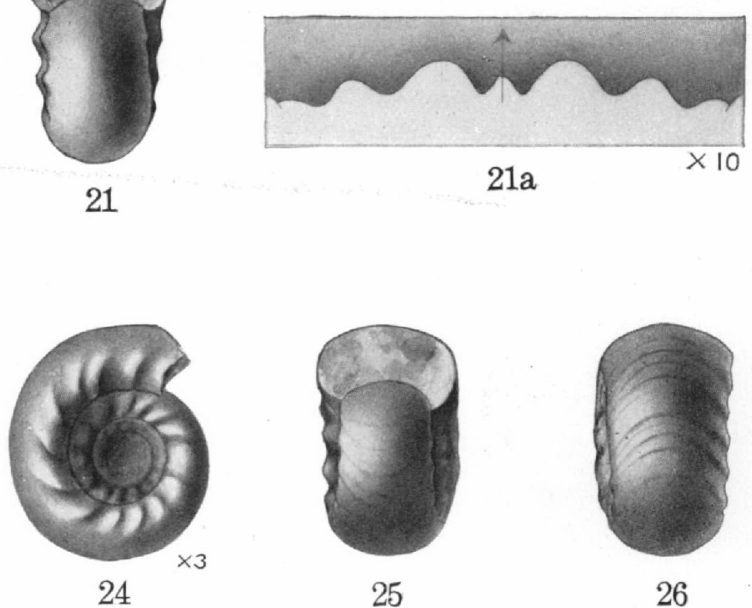

23
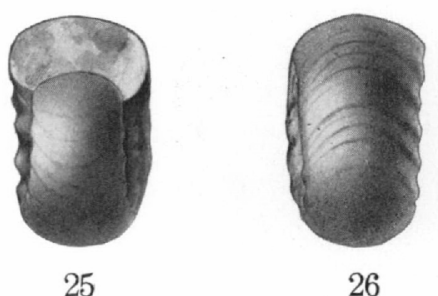


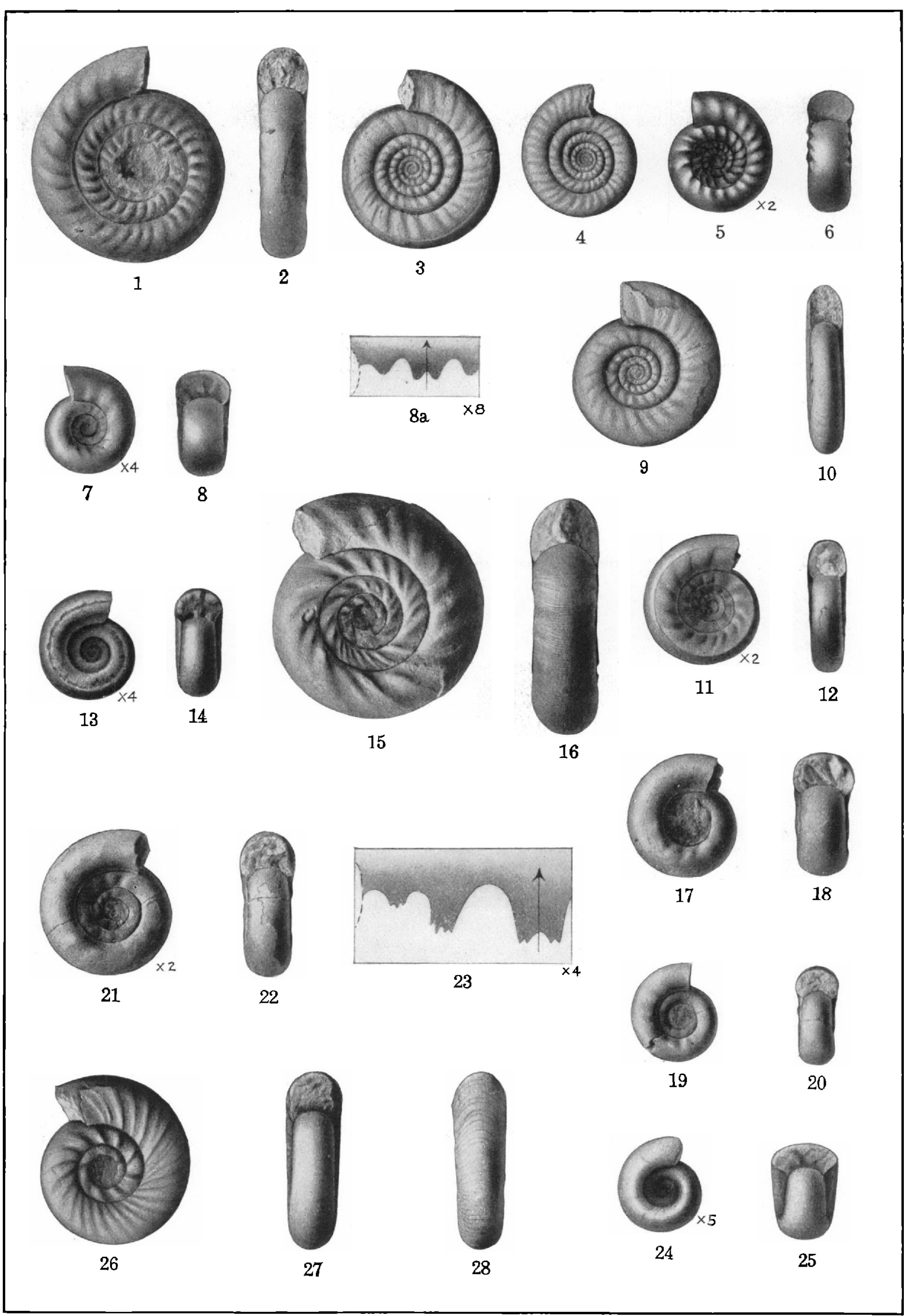




\title{
PLATE XX.
}

\author{
Celtites polygyratus Smith, sp. nov. (p. 35).
}

Figures 1, 2. Side and front views, type specimen (natural size).

FIGURE 3. Side view of a younger specimen, adult stage (natural size).

Figure 4. Side view, early maturity (natural size).

Figures 5, 6. Side and front views $(\times 2)$, late alolescent stage; diameter 11 millimeters.

Figures 7,8 . Adolescent stage $(\times 4)$; diameter 4.25 millimeters.

Figure $8 a$. Septa of the same specimen $(\times 8)$.

Celtites gabbi Smith, sp. nov. (p. 34).

Figures 0, 10. ddult stage (natural size).

Figures 11, 12. Adolescent stage $(\times 2)$; diameter 11.5 millimeters.

Figures 13,14 . Early adolescent stage $(X 4)$; diameter 4.5 millimeters.

Columbites plicatules Smith, sp. nov. (p. 37).

Figures 15, 16. Type specimen (natural size).

Figures 17, 19. Adult stage (natural size); diameter 27 millimeters.

Figures 19, 20. Same specimen, with seven-eighths of a rerolution of the whorl removed (natural size); diameter 18 millimeters.

Figures 21, 22. Same specimen, with seven-eighths more of a revolution of the whorl removed $(X 2)$; diameter 11 millimeters.

Figure 23. Septa of another specimen $(\times 4)$; diameter 16 milimeters.

Figures 24, 25. Early adolescent stage $(X 5)$; diameter 3 millimeters.

Columbites humbold'texsis Smith, sp. nov. (p. 36).

Figures 26-28. 'Type specimen (natural size).

All specimens figured on this plate were collected by J. P. Smith in the Middle Triassic, Daonella dubia zone, south fork of American Canyon, West Humboldt Range, Ner. The originals of figures 1-8 are in the collection of J. P. Smith. The originals of figures 9-28 are in the collection of the United States Geological Survey.

$16279^{\circ}-$ No. $83-14-16$ 


\section{PLATE XXI.}

Arcestes (Proarcestes) gabib Meek (p. 43).

Figures 1, 2. Adult stage.

Ptrcintes evansi Smith, sp. nov. (p. 4i ).

Figures 3, 3a. Side view and septa of the tyle (natural size).

Megaphyllites Septentrionalis Smith, sp. nov. (p. 42).

Figdres 4, 5. Type specimen (natural size).

Figure 6. Adult stage, showing the sculpture (natural size).

Figures 7 , s. Adult stalge $(\times 2)$.

Figure 9. Septa of the same specimen $(X 4)$.

Figukes 10, 11. Early adult stage $(X 2)$; diameter 10 millimeters.

Figure 12. Septa of the same specimen $(X 4)$.

Naxnites coxtractus Smith, sp. nov. (p. 45).

Figcres 13-15. Type slecimen $(X 2)$; diameter 13 millimeters.

Figures 16, 17. Early adult stage $(X 2)$; diameter (j.5 millimeters.

Figure $17 a$. Septa of the same specimen $(X 4)$.

Sageceras gabibi Mojsisovies (p. 49).

Figures 18-20. Adult stage (natural size).

All specimens figured on this plite were collected by .J. P. Smith, in the Middle Triassic, Daonella dubia zone, Fossil Hill, soutl fork of American Canyon, West Humboldt Range, Nev. They are all the property of the United States Geological Survey, except the original of figures 18-20, which is in the collection of J. P. Smith. 


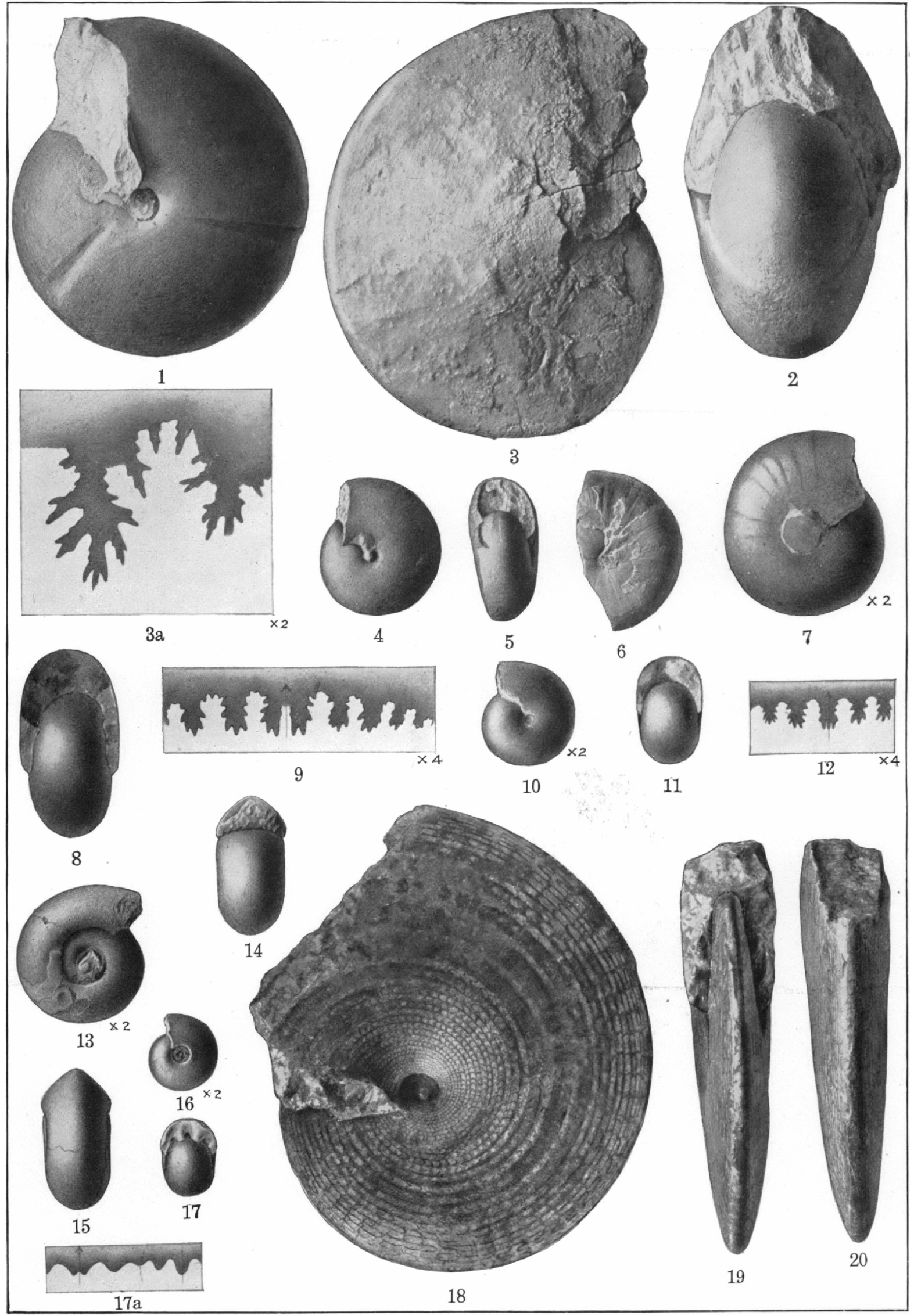




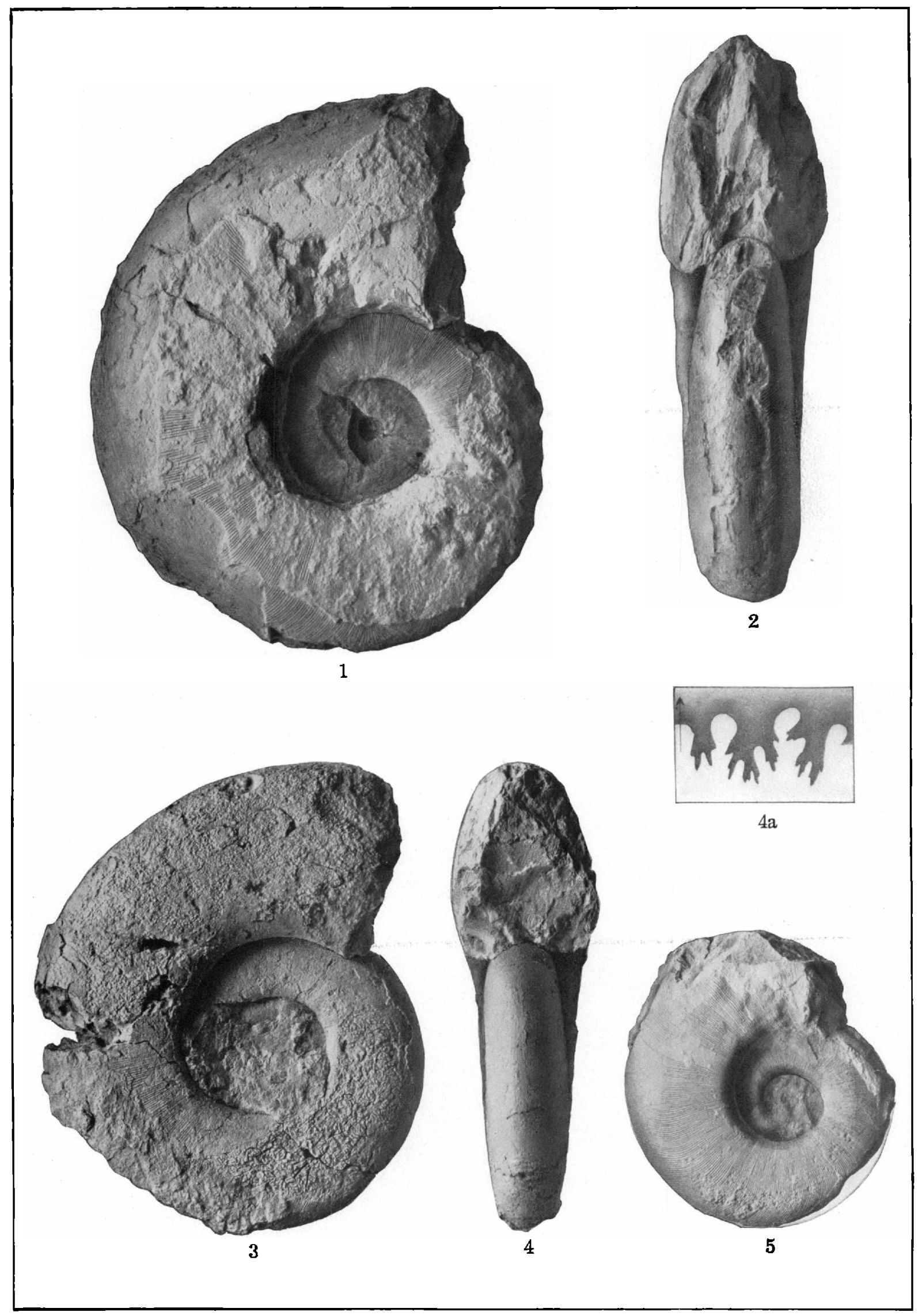




\section{PLATE XXII.}

Monopiryllites billingsianus Gabb (p. 48).

Figures 1, 2. Side and front views (natural size).

Figures 3, 4. Side and front views (natural size).

Figure 4a. Septa of the same (natural size).

Figure 5. Early adult stage, slowing the surface of the shell.

All specimens figured on this plate came from the Middle Triassic, Dannella dubia zone, Fossil Hill, sonth fork of American Canyon, West Humboldt lRange, Ner. The original of figures 1 and 2 is in the collection of J. P. Smith; the other's are in the collection of the United States Geological Survey. 


\section{PLATE XXIII.}

Gymnites alexandre Smith, sp. nov. (p. 52).

Figure 1. Type specimen, slightly reduced.

From Middle Triassic, Daonolla dubia zone, Fossil Hill, sonth fork of Americaln Canyon, West Humboldt Range, Ner. Collection of J. P. Smith. 


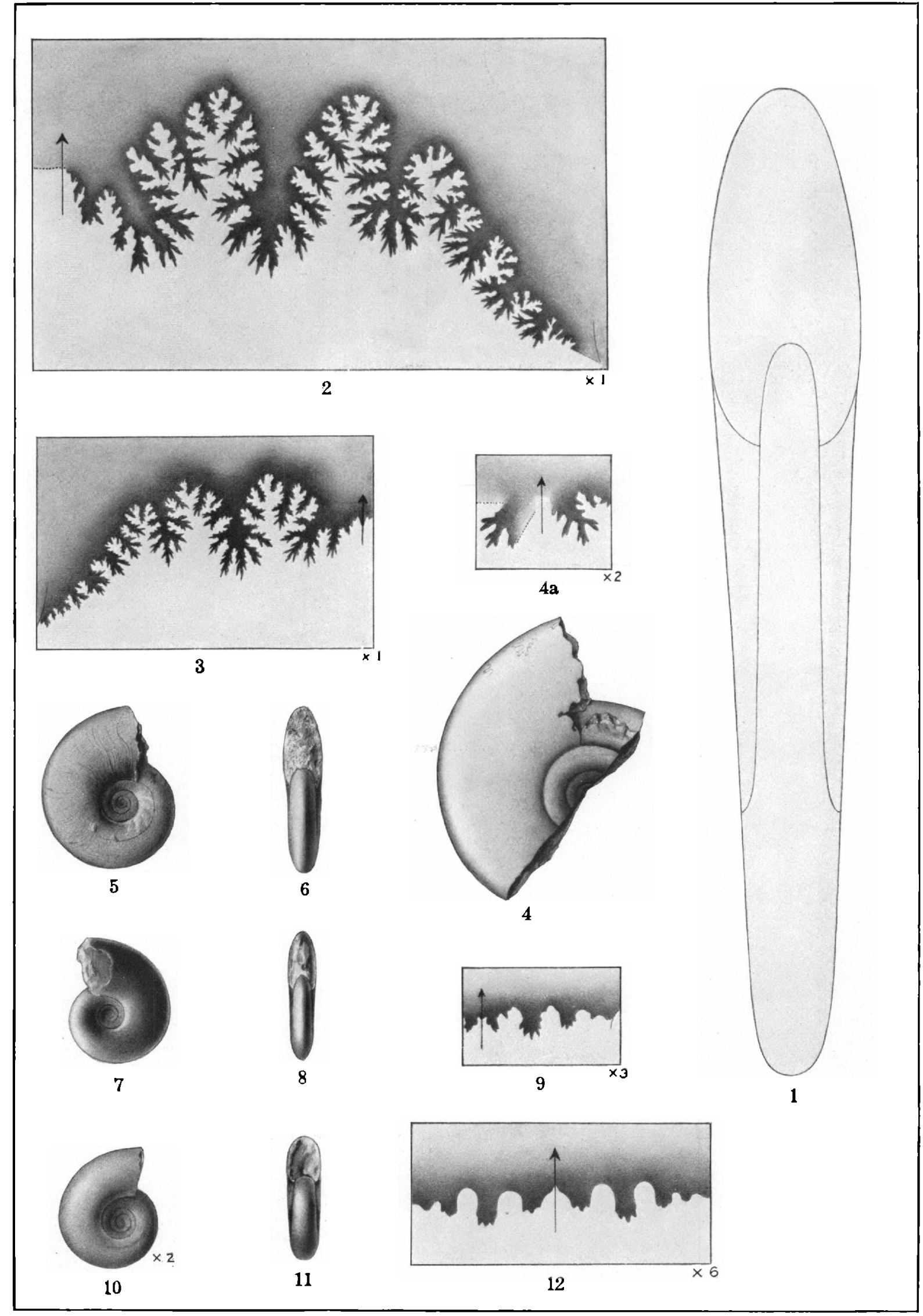




\title{
PLATE XXIV.
}

\author{
Gymnitris alexandras Smith, sp. nov. (p. 22$)$.
}

Figures 1, 2. Front view and septa of the type (figured on Pl. XxIII, fig. 1), septa slightly reduced; cross section two-thirds of natural size.

Figure 3. Septa of the cotype (natural size) (figured on I'l. XXY, fig. 1).

Figure 4. Adolescent stage (natural size) ; diameter, 50 millimeters.

Figure $4 a$. Septa of the same specimen $(\times 2)$.

Figures 5, 6. Adolescent stage (natural size) ; diameter, 39 millimeters.

FIGURfs 7, 8. Adolescent stage (natural size); diameter, 23 millimeters.

Figurf. 9. Septa of the same specimen $(\times 3)$.

Figures 10, 11. Early adolescent stage $(\times 2)$; diameter 11 millimeters.

Frgure 12. Septa of the same specimen $(\times 6)$.

From Middle Triassic, Daonclla dubia zone, Fossil IIill, south fork of American Canyon, West Humboldt Range, Nev. The originals of figures 1-3 are in the collection of J. P. Smith; those of figures $4-12$ are in the collection of the United States Geological Survey.

$16279^{\circ}-$ No. $83-14-17$ 


\section{PLATE XXV.}

Gymnites alexandres Smith, sp. nov. (p. 52).

Figdre 1. Cotype (natural size) (septa figured on Pl. XXIV, fg. 3).

Middle Triassic, Daonclla dubia zone, Fossil Hill, south fork of American Canyon, West Humboldt Range, Nev. Collection of J. P. Smith.

174 


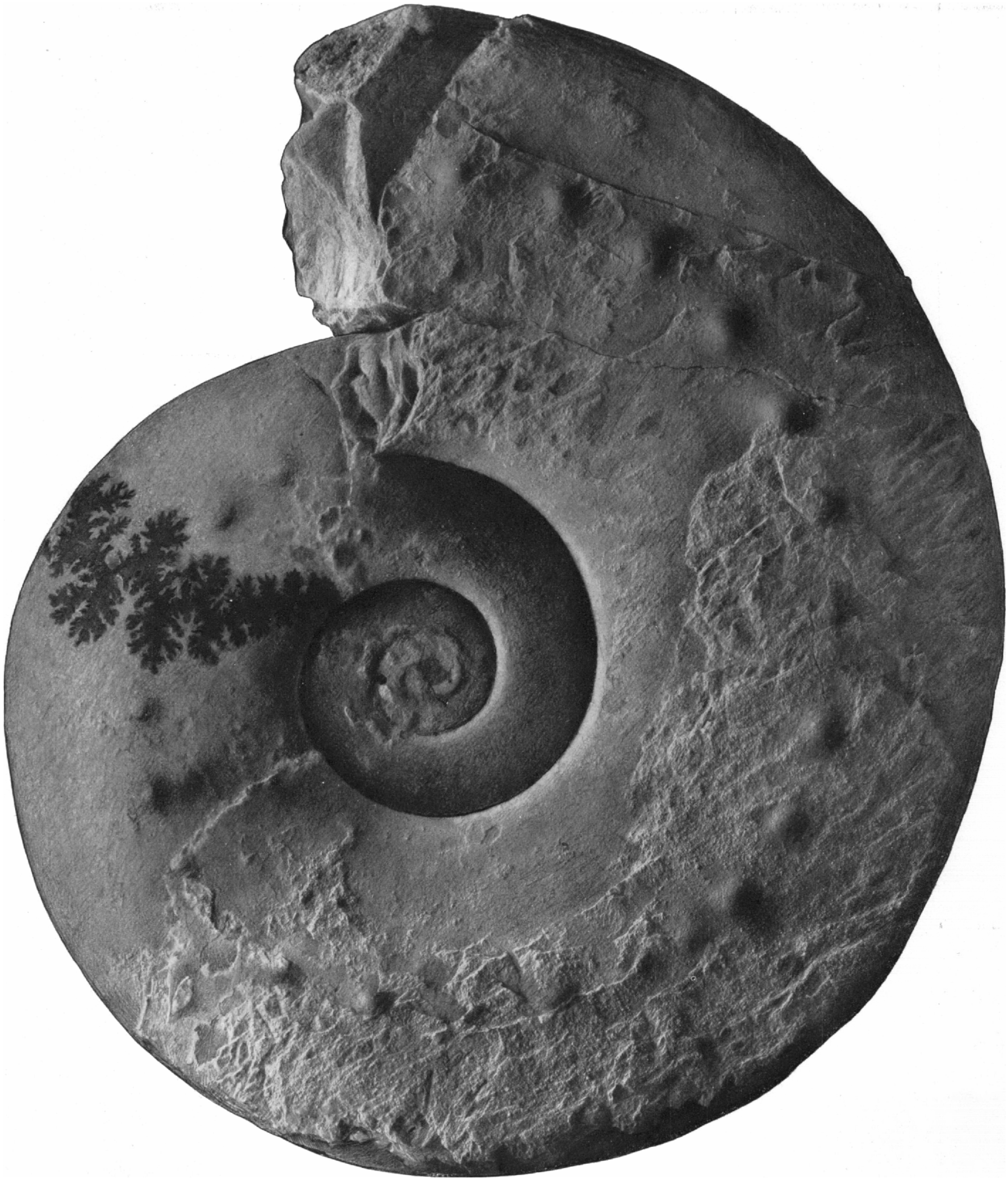




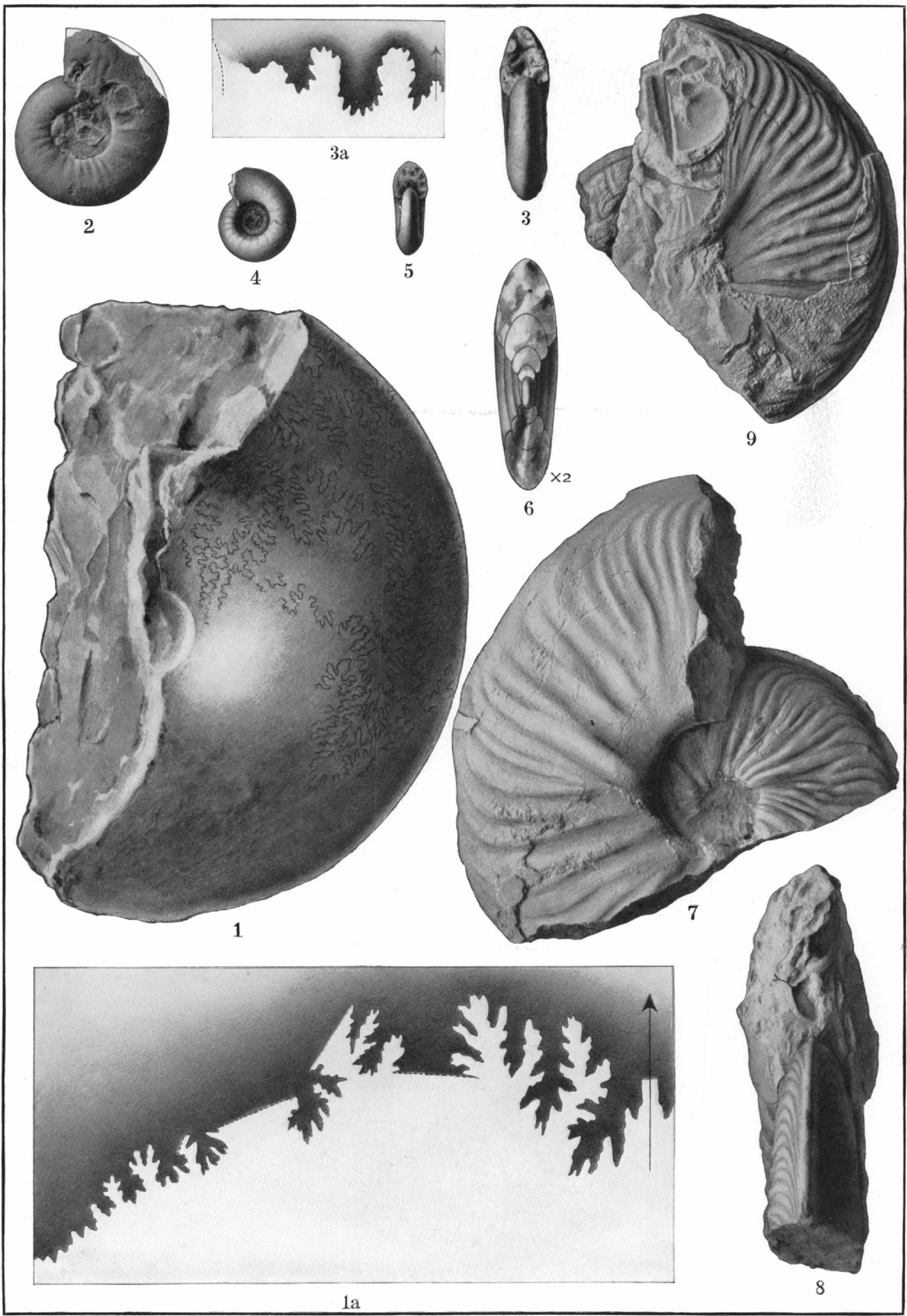




\section{PLATE XXVI.}

Granites calli Smith, sp. nov. (p. 52 ).

Figures 1, 1a. Side view and septa (natural size).

Granites (Axigyunites) rosenbergi Smith (p. 范).

Figures 2, 3. Type specimen (natural size).

Fugure: $3 a$. Septa of the type $(\times 3)$.

Figures 4, 5. Early adult stage (natural size); diameter 16 millimeters.

Figure 6. Cross section $(X 2)$; diameter 21 millimeters.

Eutomoceras tatrbet Meek (p. 63).

Figures $\bar{\tau}, 8$. Old-age characters.

Figure 9. Sculpture and aperture at maturity.

All specimens figured on this plate are from the Middle Triassic Daonella dubia zone, Fossil Hill, West Humboldt Ringe. Nev., and are in the collection of the Lnited States Geological survey. 


\section{PLATE XXVII.}

Ettonockras Latbei Meek (p. 63).

Figtres 1, 2. Early adult stige (natural size).

Figures :3, 4. Lalrly adult stage ( $X 2)$; dialmeter 2.; millimeters.

Figures $\tilde{0}-\bar{\tau}$. Late adolescent stage $(X 3)$; diameter 9 millimeters.

Figures 8-10. Adolescent stilge $(X 3)$; diameter ( $)$ millimeters.

FIGUREs 11-12. Larral stage $(\times 5)$; dimeter 2.50 millimeters.

FIGURE 13. Septa of the sime specimen $(X 10)$.

Eitonoceras dixxi Smith, sp. nov. (p. 62).

Figures 14-16. Type specimen refiguret.

Figure 17. Septa from an adult specimen $(\times 2)$; diameter 50 millimeters.

Figtres 18, 19. Old specinen, showing mature sculpture.

Figures 20, 21. Early adult stage (naturil size) ; diameter 32 millimeters.

Figures 22, 23. Late adolescent stage $(X 2)$; diameter 20 millimeters.

Figures 2.1, 25. Adolescent stage $(X 2)$; diilmeter 16 millimeters.

All specimens figured on this plate came from the Middle Triassic, Daonclla dubia zone. Fossil Hill, south fork of American Cinyon, West Humboldt Range, Nev. All are in the collection of the United States Geological survey, except the original of figures $14-16$, which is in the collection of J. P. Smith. 


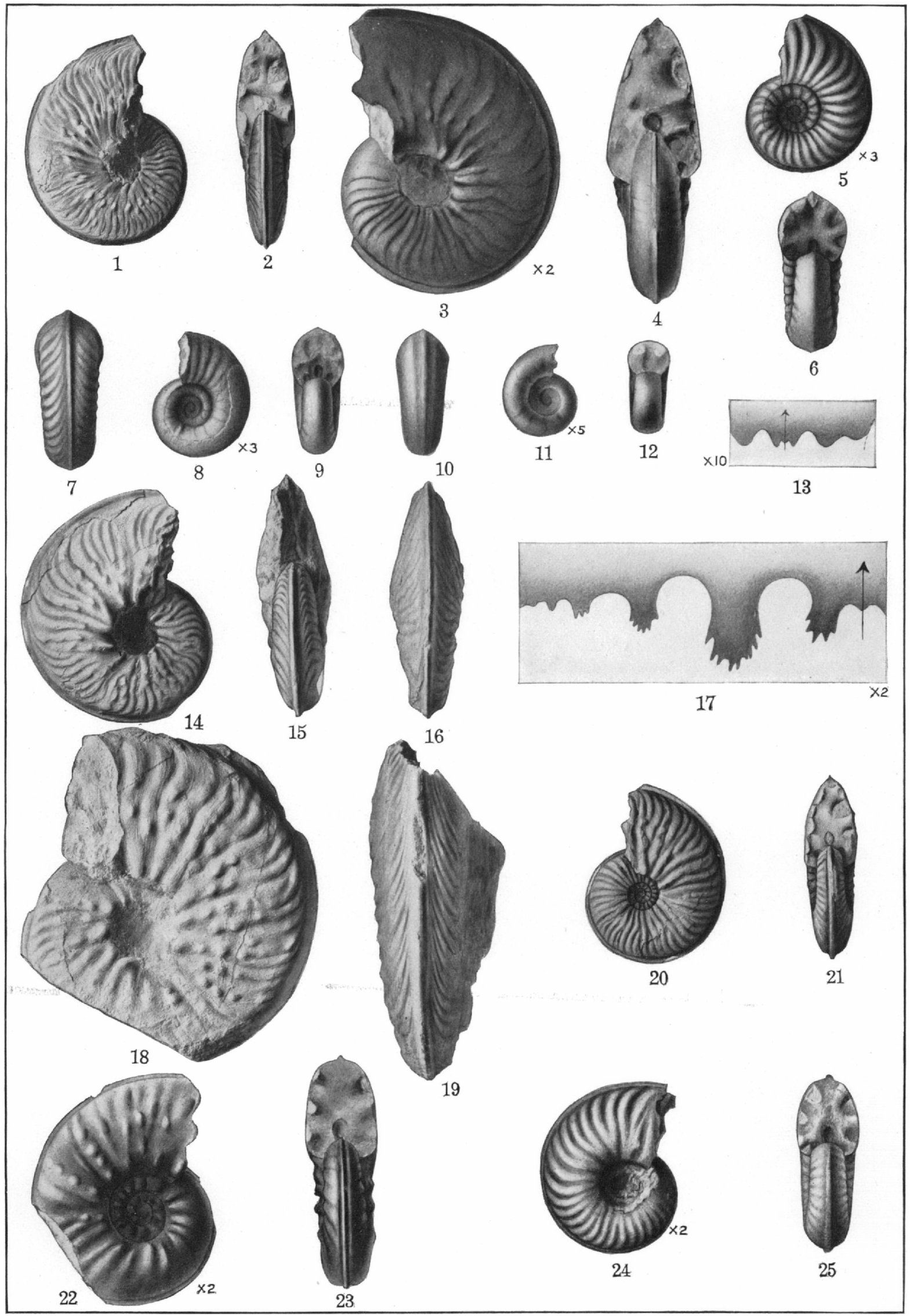




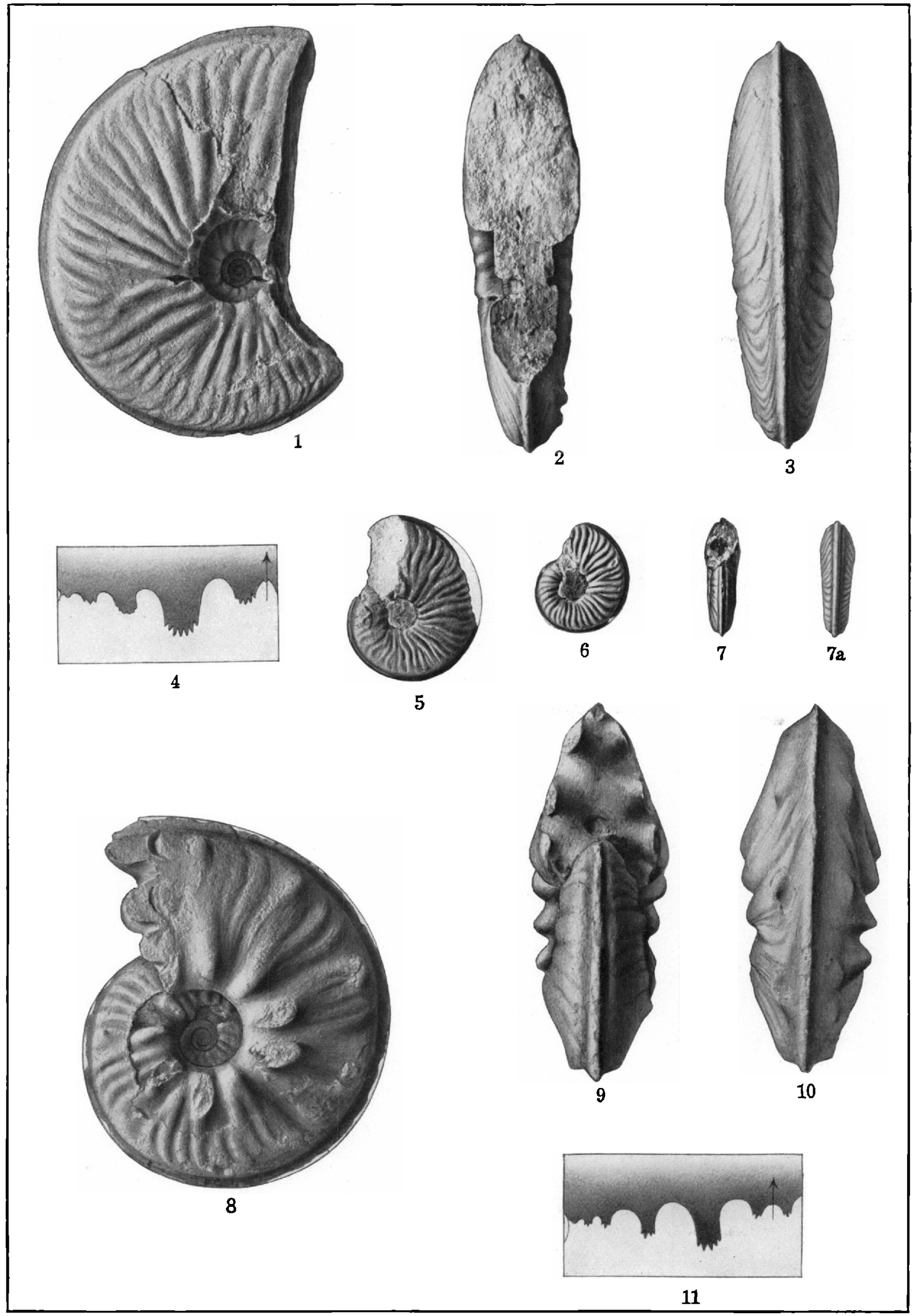




\section{PLATE XXVIII.}

Eutomochras meweri Smith, sp. nor. (p. 61).

Figures 1-4. Type specimen (natural size).

Figure 5. Adolescent stage (natural size).

Figubes 6, 7. Adolescent stage (natural size).

Ettomoceras mamovitaxt ar Smith, sp. nov. (p. 63).

Figures 8-11. 'Type specimen (natural size).

The originals of all figures on this plate are from the Middle 'Triassic, Dannolla dubia zone, Fossil Hill, south fork of Americin Canyon, West Humboldt Range, Ner. The originals of figures 1-4 in the collection of J. I'. Smith; those of figures 5-11 in the collection of the United States Geological Survey.

$16279^{\circ}-$ No. $\$ 3-14-18$ 


\section{PLATE XXIX.}

Eutomoceras (Haliblcites) dihli Nmith, sp. nor. (p. 64).

Figukes 1-4. Tyle specimen (natural size).

Figure 5. Septa from another specimen (natural size).

Figures 6-8. Early adult stage (natural size); diameter :32 millimeters.

Figures $9-11$. Larval stage $(X 5)$; diameter 3.5 millimeters.

Huxgarites mittixgexsis smith, sp. nov. (p. 58).

Figures 12-14. Small specimen.

Dalifatites minutes Smith, sp. nov. (p. כ9).

Figures 15, 16. Tyle specimen $(\times 2)$; diameter 21 millimeters.

Figtres 17,18 . Early adult stage $(X 2)$; diameter 11 millimeters.

Figure 19. Septa of the same spocimen $(X 6)$.

Fugunes $20 \% 1$. Idolescent stage $(X 3)$; diameter s millimeters.

All specinens figured on this plate are from the Middle Triassic, Daonclla dubia zone, Fossil Hill, sonth fork of American Canyon. West Humboldt Range, Ner. The originals of figures 1-14 are in the collection of the United States Geological Survey; those of figures $15-21$ are in the collection of J. I'. Smith. 

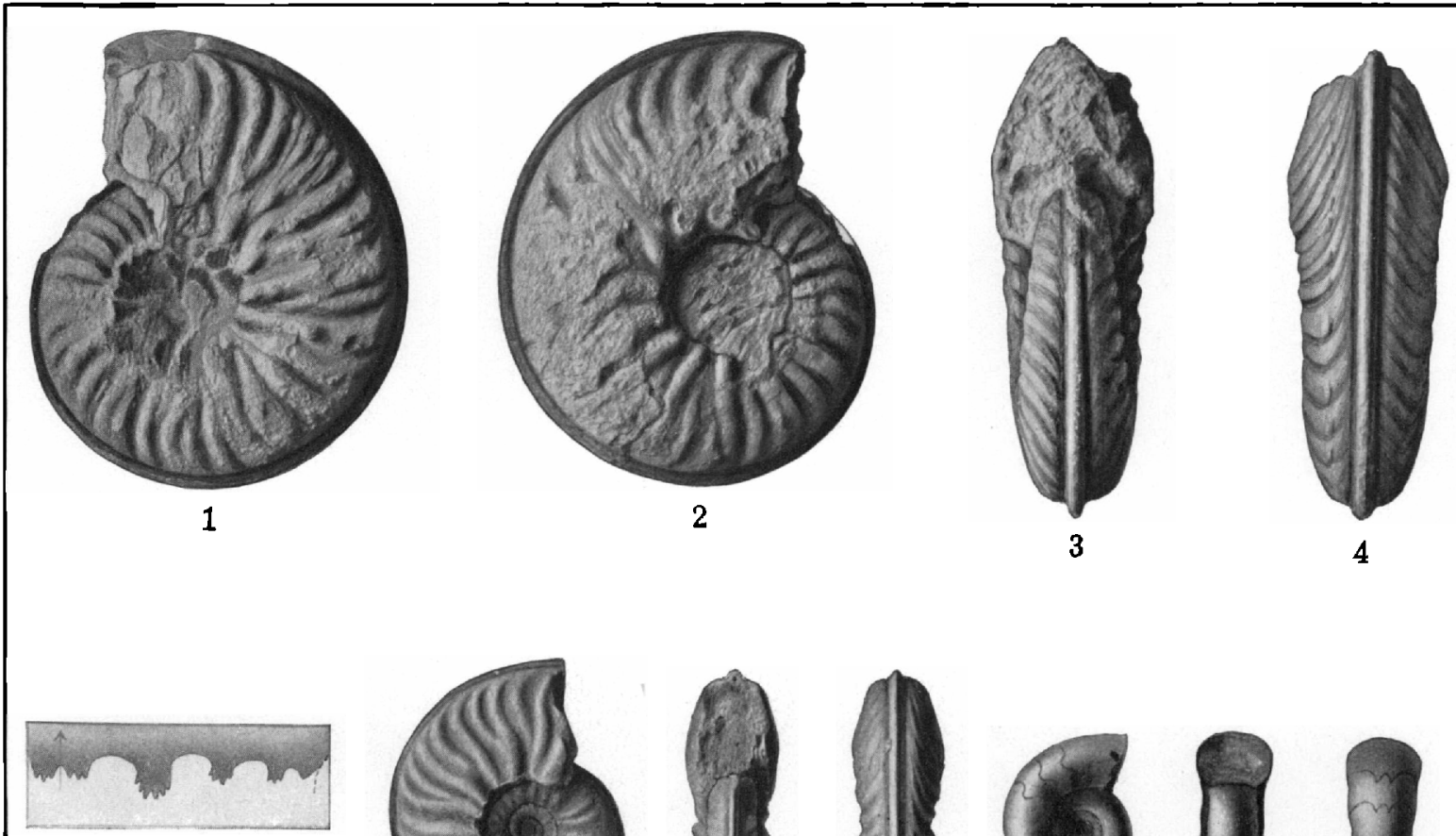

5
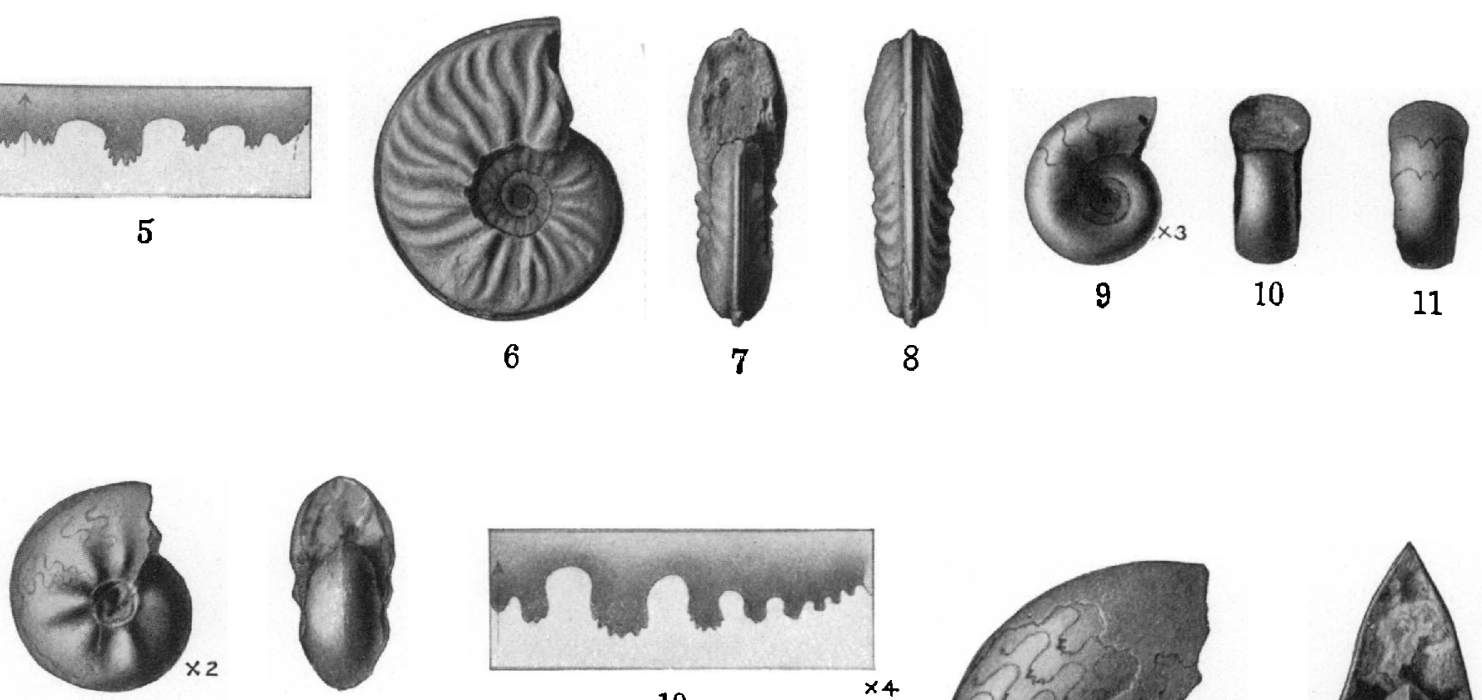

17

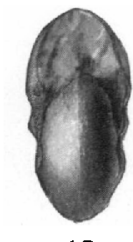

18

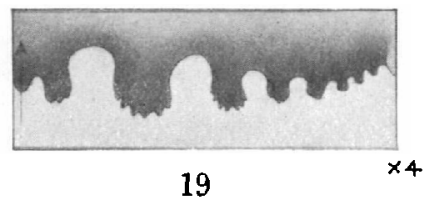

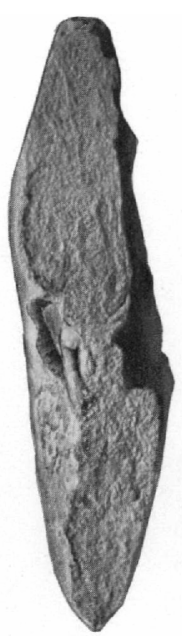

13

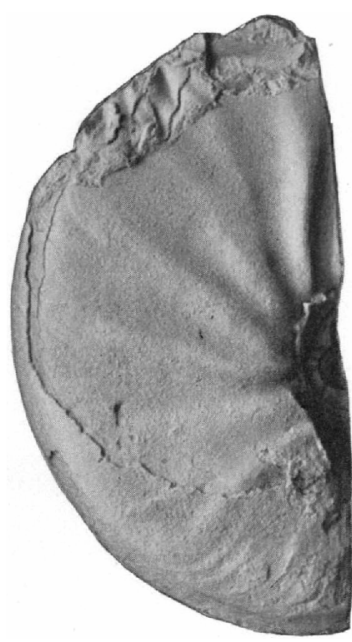

12

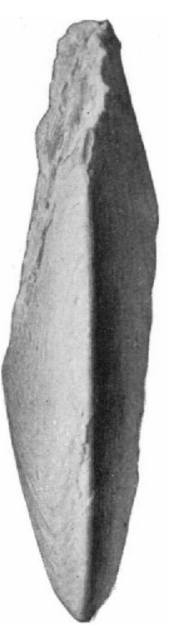

14

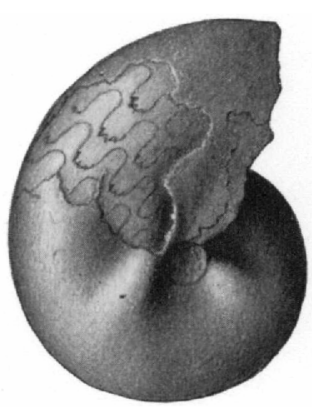

15
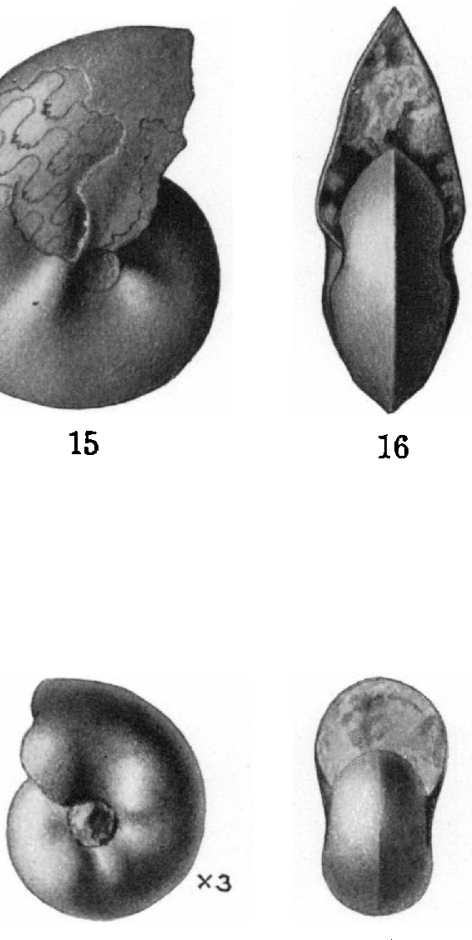

20

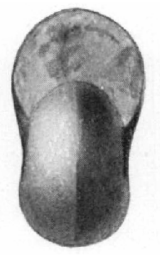

21 


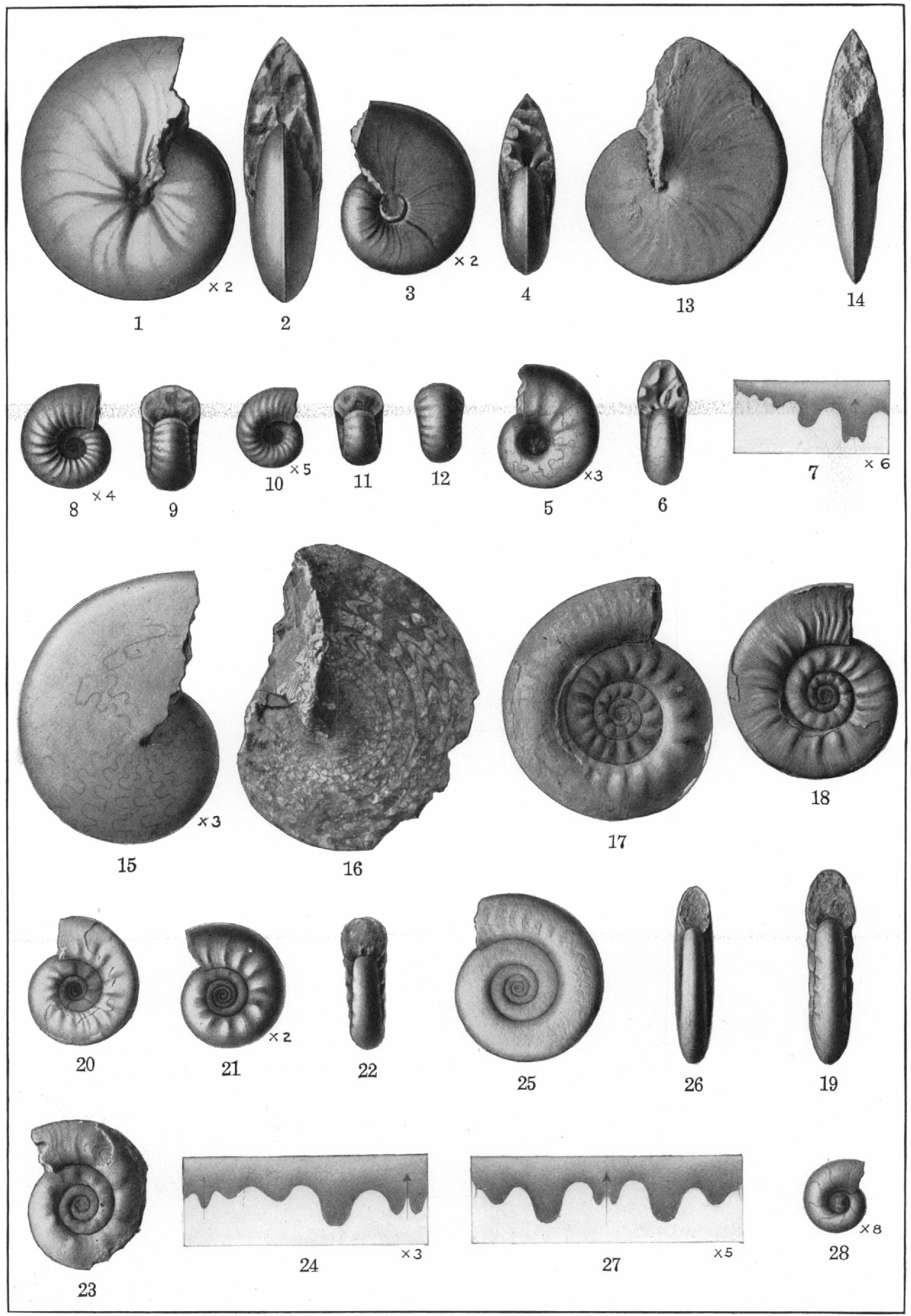




\section{PLATE XXX.}

Dalmatites parvus Smith, sp. nov. (p. 60).

Figures 12 . Type specimen $(\times 2)$, diameter 23 millimeters.

Figures 3 , 4. Early adult stage $(X 2)$, diameter 15 millimeters.

Figures 5, 6. Adolescent stage $(X 3)$, corresponding to Lecinites; diameter 7 millimeters.

Figure 7. Septa of the silme specimen $(X 6)$.

Figures 8,9 . Adolescent stage $(X 4)$; diameter 4.5 millimeters.

Figures 10-12. Larval stage $(X 5)$; diameter 2.5 millimeters.

Iongobardites Nevadaxcs Hyatt and Smith (p. 50).

Figures 13, 14. Adult specimen (natural size).

Figure 15. Adolescent stage ( $X 3$ ), showing transition from goniatitic to ceratitic lobes; diameter 12 millimeters.

Figure 16. Adult stage (uitural size).

Lacanites vogidesi Hyatt and Smith (p. 67).

FIGURE 17. Adult stage, showing transition to old-age chalricters.

Figurfs 18, 19. Adult stage, showing faint spiral lines on the cast.

Figure 20. Early adult stage (natural size).

Figures 21, 22. Adolescent stage $(\times 2)$; diameter 11 millimeters.

Figure 23. Adult stage (natural size).

Figure 24. Septa of the same specimen $(\times 3)$.

Figure 28. Larval stage $(X 8)$; diameter 1.5 millimeters.

Lecanites Parve's Smith, sp. nov. (p. 66).

Figures 25, 26. Type specimen (natural size).

Figure 27. Septa of another specimen $(\times 5)$.

All species figured on this plate are from the Middle Triassic, Daonella dubia zone of Fossil Hill, West Humboldt Range, Ner. The originals are the property of the United States Geological Survey, except that of figures 1 and 2, which is in the collection of J. P. Smith. 


\section{PIATE XXXI.}

Beyricittes ROTLLLIFonmis Meek (p. 118).

Figures 1, 2. Old-age characters.

Figures 3, 4. Side view and septa (natural size).

Figurrs 5, 6. Early adult stage (natural size).

Beyricintes osmoxt Smith, sp. nov. (p. 117).

Figures 7, 8. Type (natural size).

Figures 9, 10. Cotype, sille view (natural size) and septa $(\times 2)$.

Figures 11, 12. Larly adult stage, side view (uatural size), and septa $(\times 3)$.

Figures 13, 14. Adolescent stage $(\times 2)$; diameter 14 millimeters.

The originals of all figures on this plate came from the Midlle Triassic, Daonclla dubia zone, Fossil Hill, south fork of American Canyon, Test Humboldt Range, Ner., and belong in the collection of the Lnited States Geological Survey. 


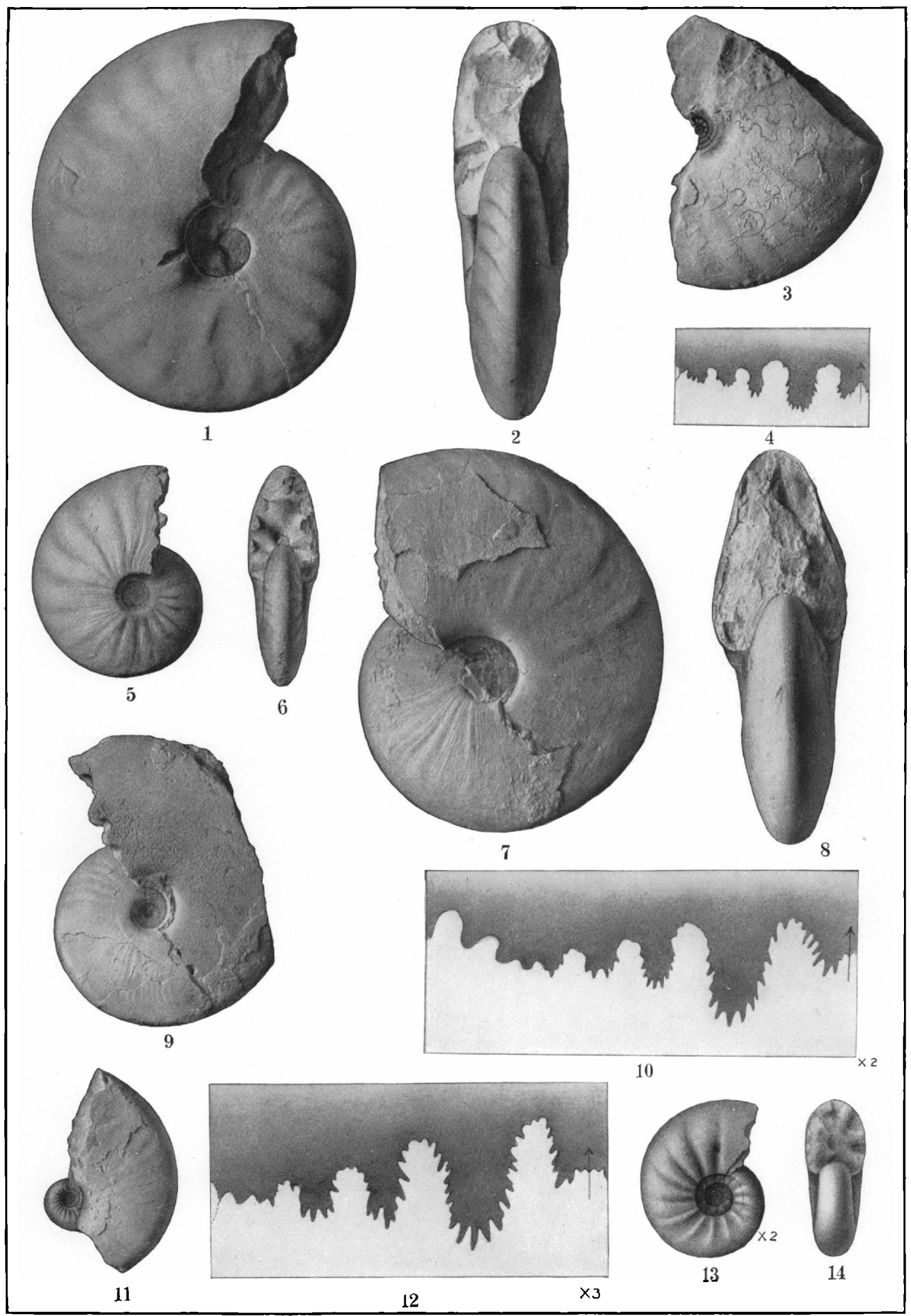




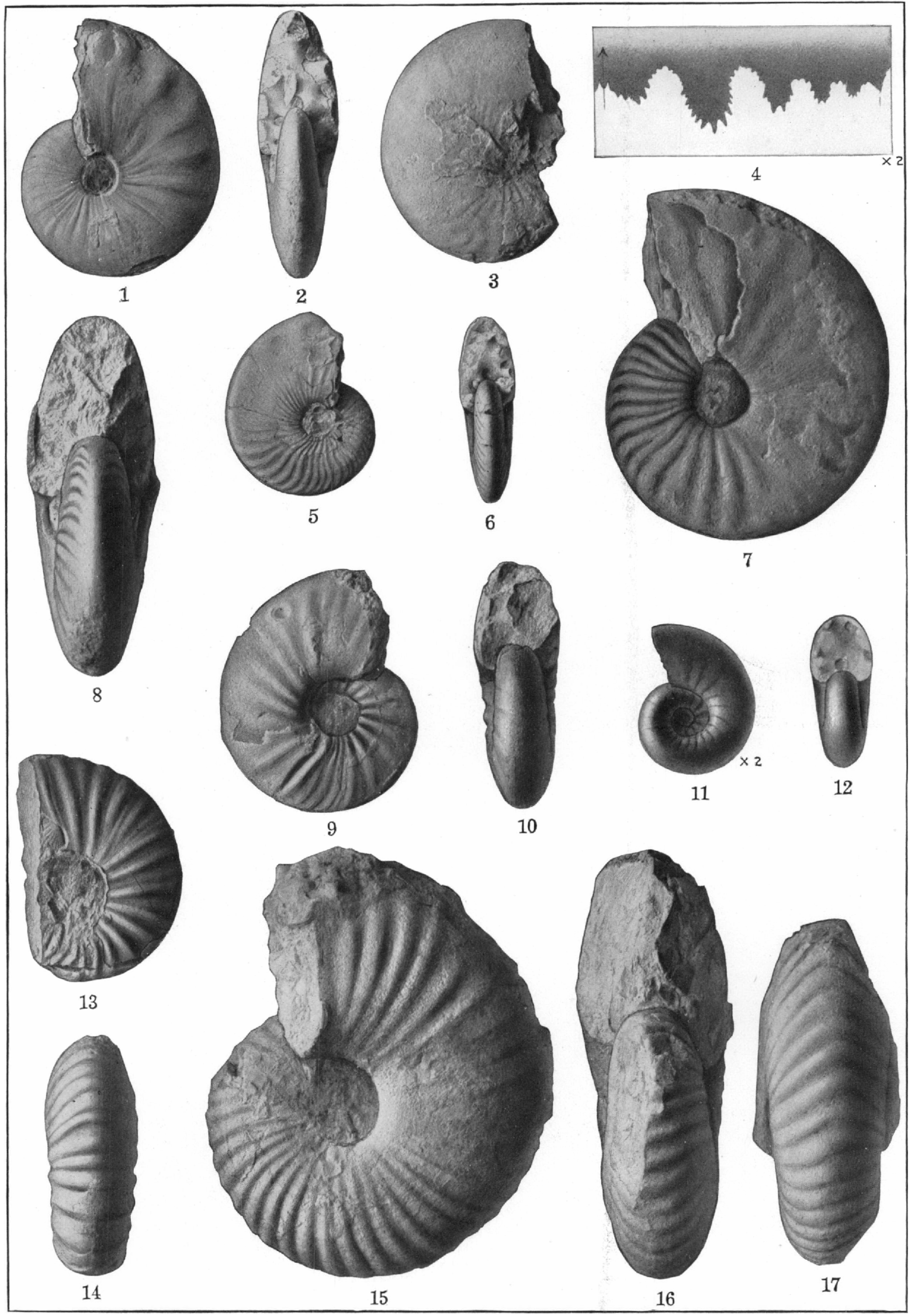




\section{PLATE XXXII.}

Beyrichitres textis Smith, sp. nov. (p. 119).

Figtres 1, 2. Type specimens.

Figuks 3,4 . Adult specimen, side view (natural size), and septa ( $\times 2$ ).

Figures 5, 6. Larly adult stage (natural size).

Beyrichites doxis Smith, sp. nov. (p. 116).

Figrars 7 , 8. Type specimen.

Figuras 9, 10. Warly mature stage.

Figures 11. 12. Adolescent stage $(\times 2)$; diameter, 13 millimeters.

ACrochondckras rontzkNse Smith, sp. nov. (p. 39).

Figurk:s 1:;, 14. 'Type specimen.

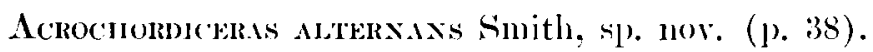

Figurs. 15-17. 'Type specimen.

The originals of figures 1-14 were found in the Middle Triassic Daonclla dubia zone, on the sonth fork of American Canyon, West I Iumboldt Range, Nev.; those of figures 15-17 are from the same horizon, north fork of Buena Vistal Canyon, West Humboldt Range, Nev. The originals of figures $7-14$ are deposited in the collection of the Tnited States Geological Surrey; those of figures 1-6 and 15-17 are in the collection of J. P. Smith.

$16279^{\circ}-$ No. $83-14-19$ 


\section{PLATE XXXIII.}

\section{Ha ydenites matscheki Diener (p. 114).}

Figures 1, 2. Mature characters.

Figurf 3. Adolescent stage.

Acrociordiceris ilternans Smith, sp. nov. (p. 38).

Figures 4, 5. Adolescent stage.

All specimens figured on this plate came from the Middle Triassic, Daonclla dubia zone, Buena Vista Canyoll, West Humboldt Range. Nev., and all are in the collection of the Inited States Geological Survey, excent the original of figures 4 and 5 , which is in the collection of J. P. Smith. 


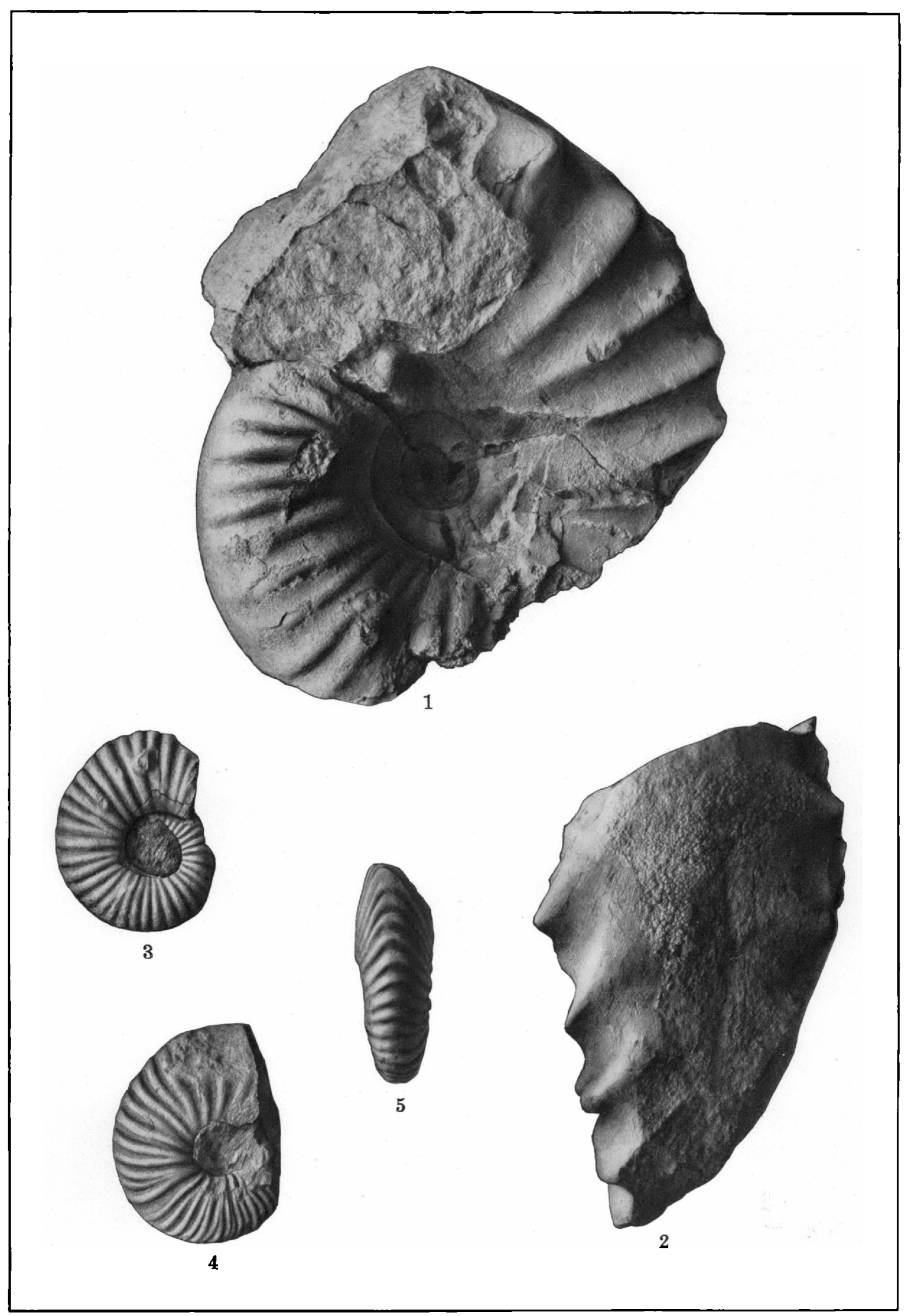




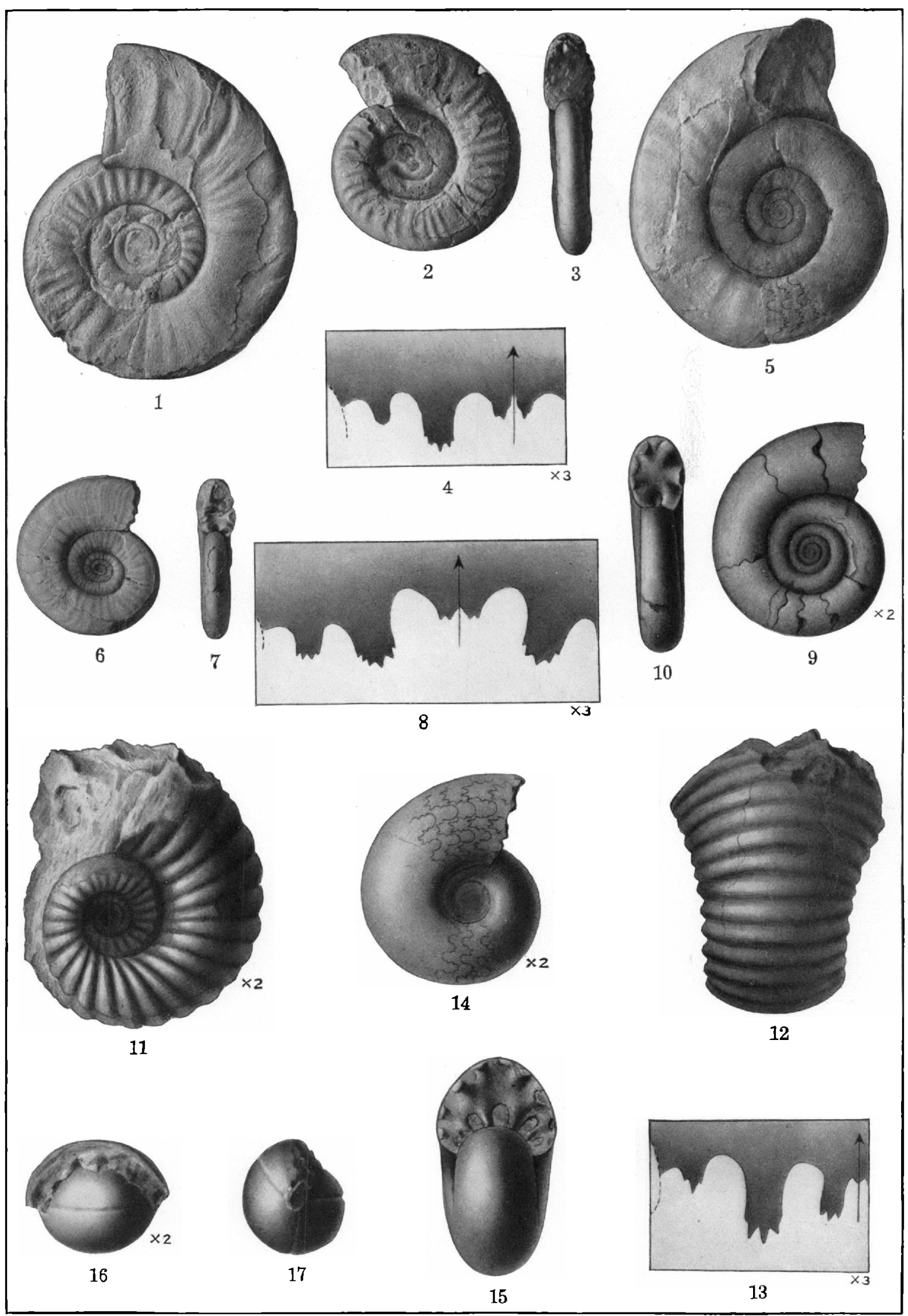




\section{PLATE XXXIV.}

Xenodiscis Ritreneri Hyatt and Smith (p. 56 ).

Figure 1. Sculpture at maturity.

Figures 2, 3. Early mature stage (natural size).

Figure 4. Septa of the same specimen $(x 3)$.

Xexodiscus Mlluticanifrates Smith, sp. nov. (p. 57).

Figere 5. Type specimen.

Figures 6, 7. Septa (natural size).

Figure 8. Septa of the silme specimen $(\times 3)$.

Figures 9,10 . Adolescent stage $(X 2)$; diameter 20 millimeters.

ACrochordiceras inyoexse Smith, sp. nov. (p. 40).

Figures 11, 12. Type specimen $(\times 2)$; diameter 25 millimeters.

Figure 13. Septa from another specimen $(X 3)$.

Popanoceras (Parapopanoceras) mitgi Hyatt and Smith (p. 41).

Figures 14, 15. Diameter 19.5 millimeters $(X 2)$.

Paranamites oriformis Smith, sp. nor. (p. 46).

Figures 16. 17. 'Type specimen $(X 2)$; diameter 10 millimeters.

All specimens figured on this plate are from the Iower Lorizon of the Middle Triassic, Union Wash, Inyo Range, Inyo County, Cal., and are in the collection of the United States Geological Survey. 


\section{PLATE XXXY.}

Ceratites (Paraceratites) talrts Smith, sp. nov. (p. 88).

Figures 1, 2. Type specimen.

Figure 3. Fragment of an old specimen, showing the strong spines.

Ceratites (Paraceratites) vogidesi Smith (p. 89).

Figires 4-6. Tyle specimen (original of Pl. XIIV, fig. 1, and Pl. XI.III, fig. 7, J. P. Smith, The comparative stratigraply of the marine Trias of western America; Proc. California Acad, Sci., 34 ser., (xeology, rol. 1, No. 10, 1904).

Figures 7-9. Early mature staige.

All specimens figured on this plate are from the Middle Triassic. Daonella dubia zone, Fossil Hill, West Humboldt Range, Nev., and are in the collection of the United States Geological Surveg. 


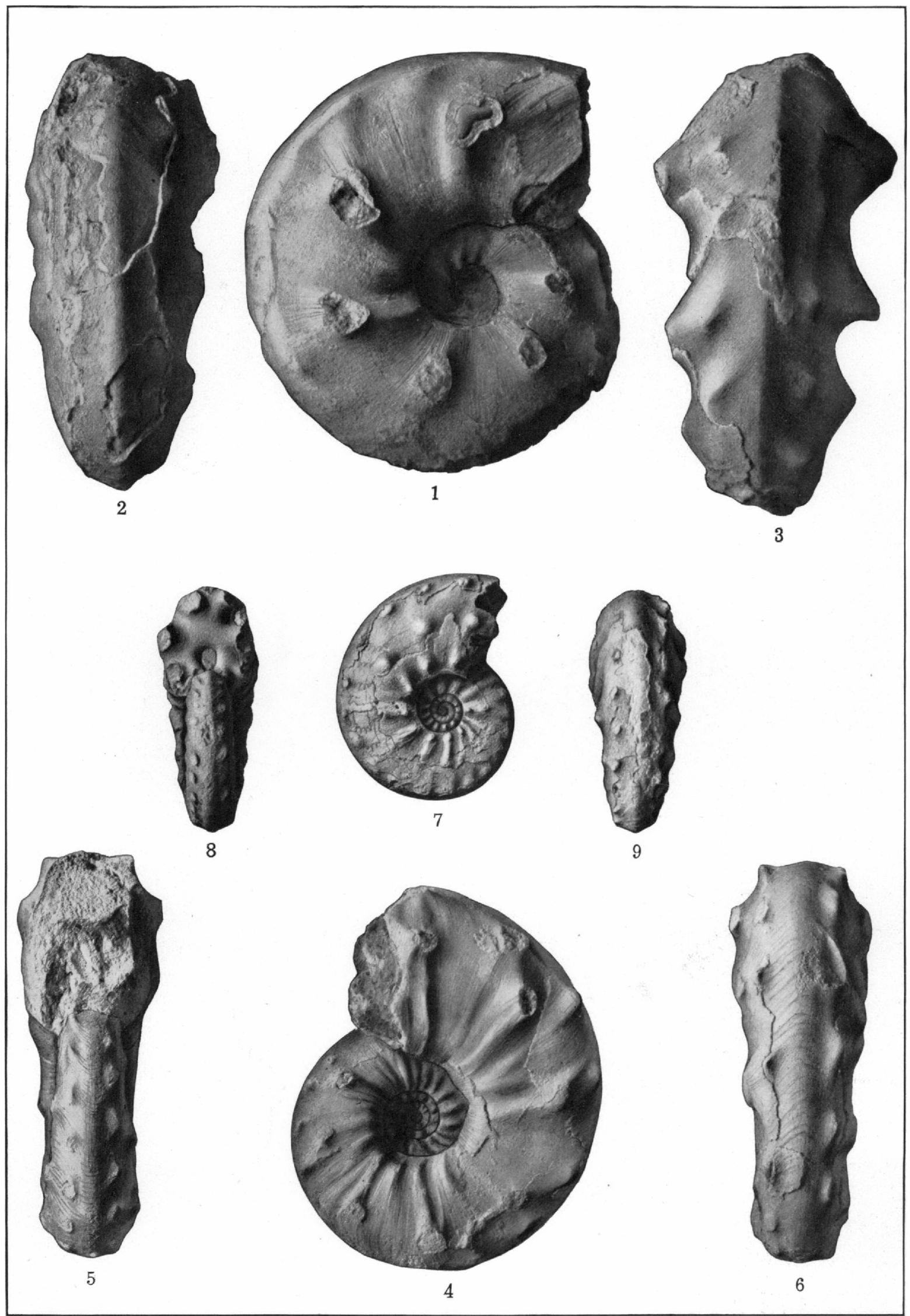




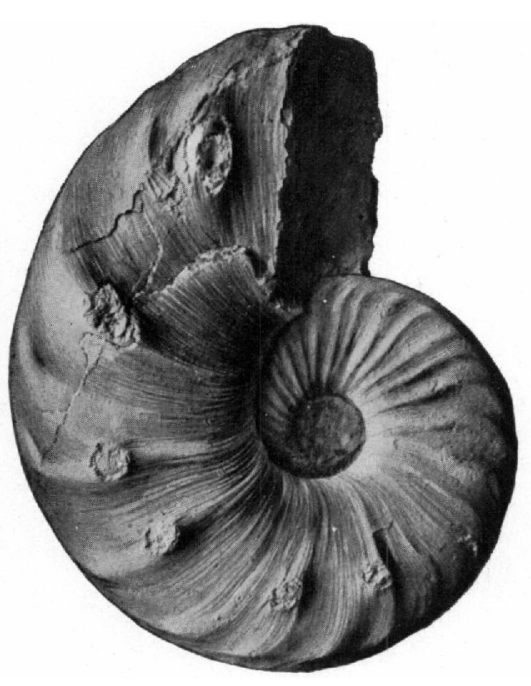

1
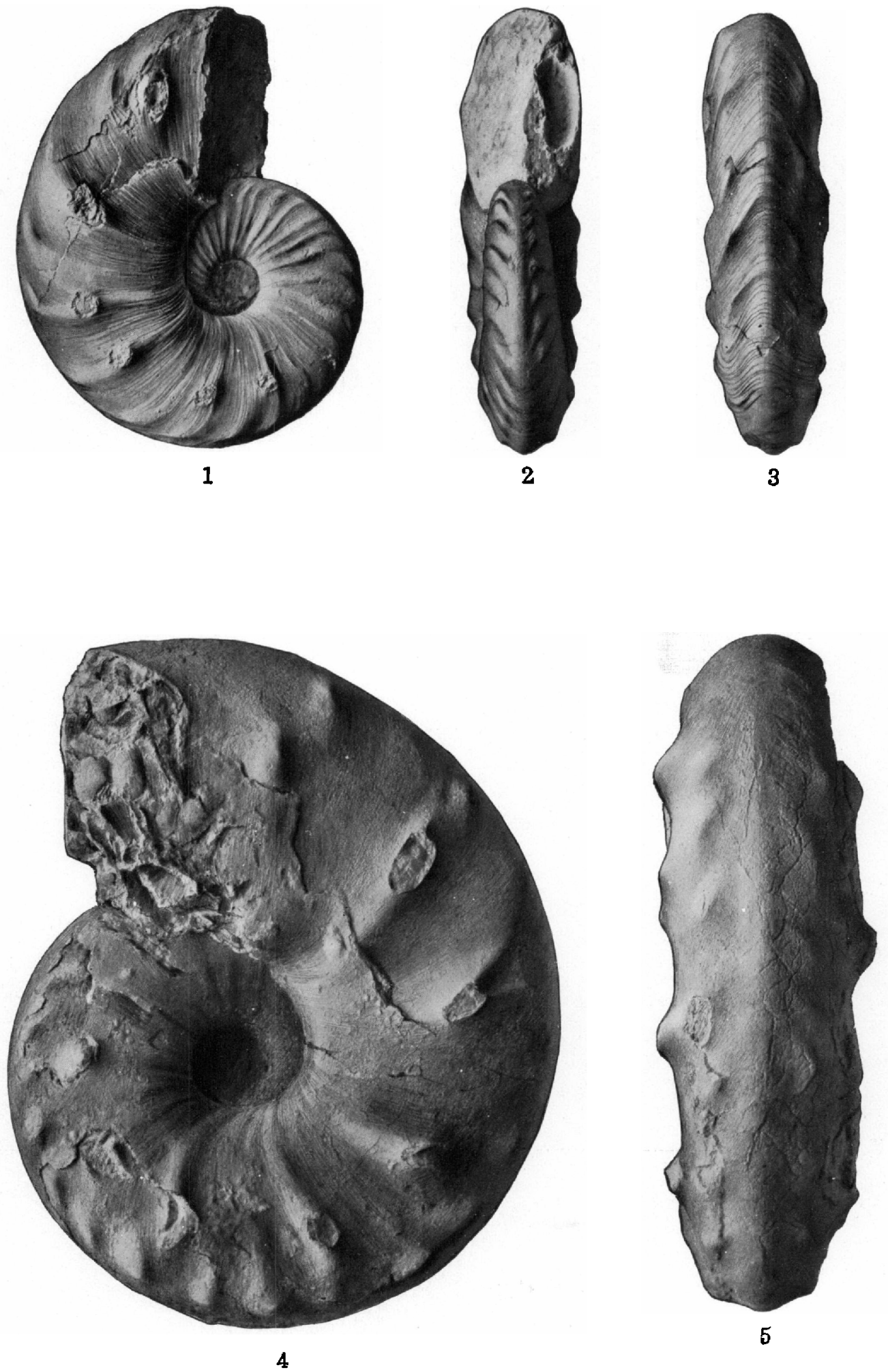


\section{PLATE XXXVI.}

Ceratites (Paraceratites) trojaxls Smith, sp. nov. (p. 88).

Figtikes 1-3. Type specimen.

Figures 4, 5. Old-age characters.

All specimens figured on this plate are from the Midille Triassic, Daonella dubia zone, Fossil Hill, West Humboldt Range, Ner., and are in the collection of the Lnited States Geological Survey.

$16279^{\circ}-\mathrm{No} .83-14-20$ 


\section{PLATE XXXVII.}

Ceratites (Paraceratites) trojayus Smith, sp. nov. (p. 88).

Figures 1-3. Ornamentation and septa.

Figures 4, 5. Transition from adolescent to mature chatracters.

Ceratites (Paracer.ttites) cricki Smith, sp. nov. (p. 87).

Figures 6-9. Type specimen (New Pass. Desatoya Mountains, Nev., collection of .J. I'. Smith).

Figurks 10,11 . Fally maturity.

Figures 12, 13. Transition from adolescence to maturity.

The originals of figures $1-5$ and $10-13$ are from the Middle Triassic, Daonella dubia zone, of Fossil Hill, West Humboldt Range, Nev., and are in the collection of the Uniter States Geological Survey. The original of figures $6-9$ is from the same horizon, New Pass, Desatoya Mountains, Nev. 


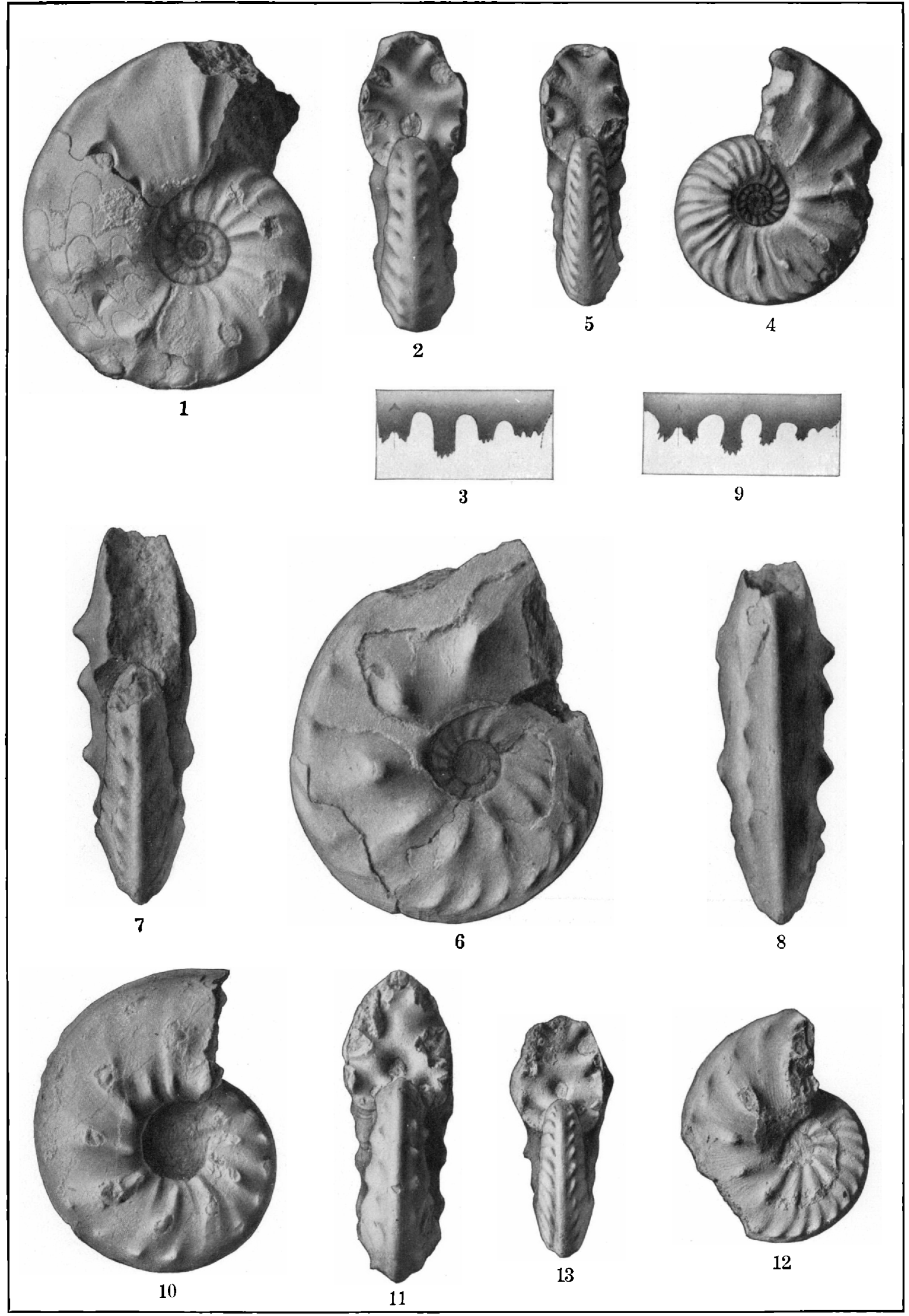




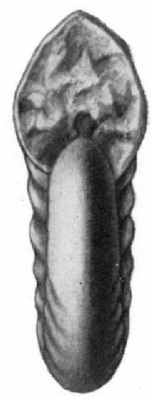

10
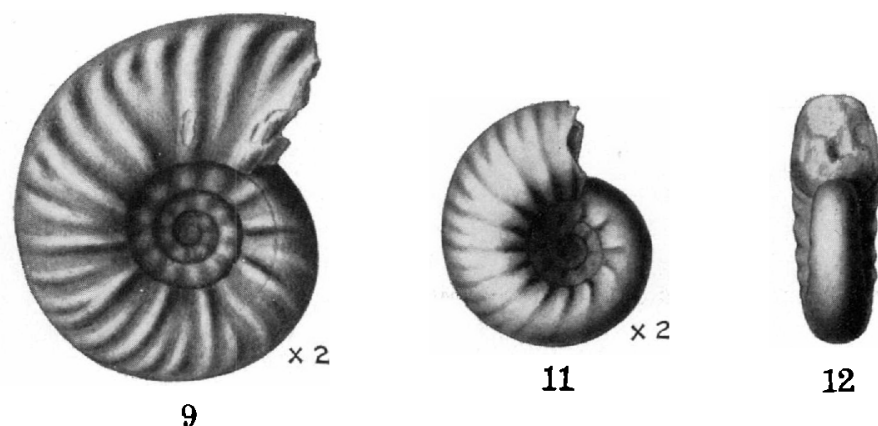

12
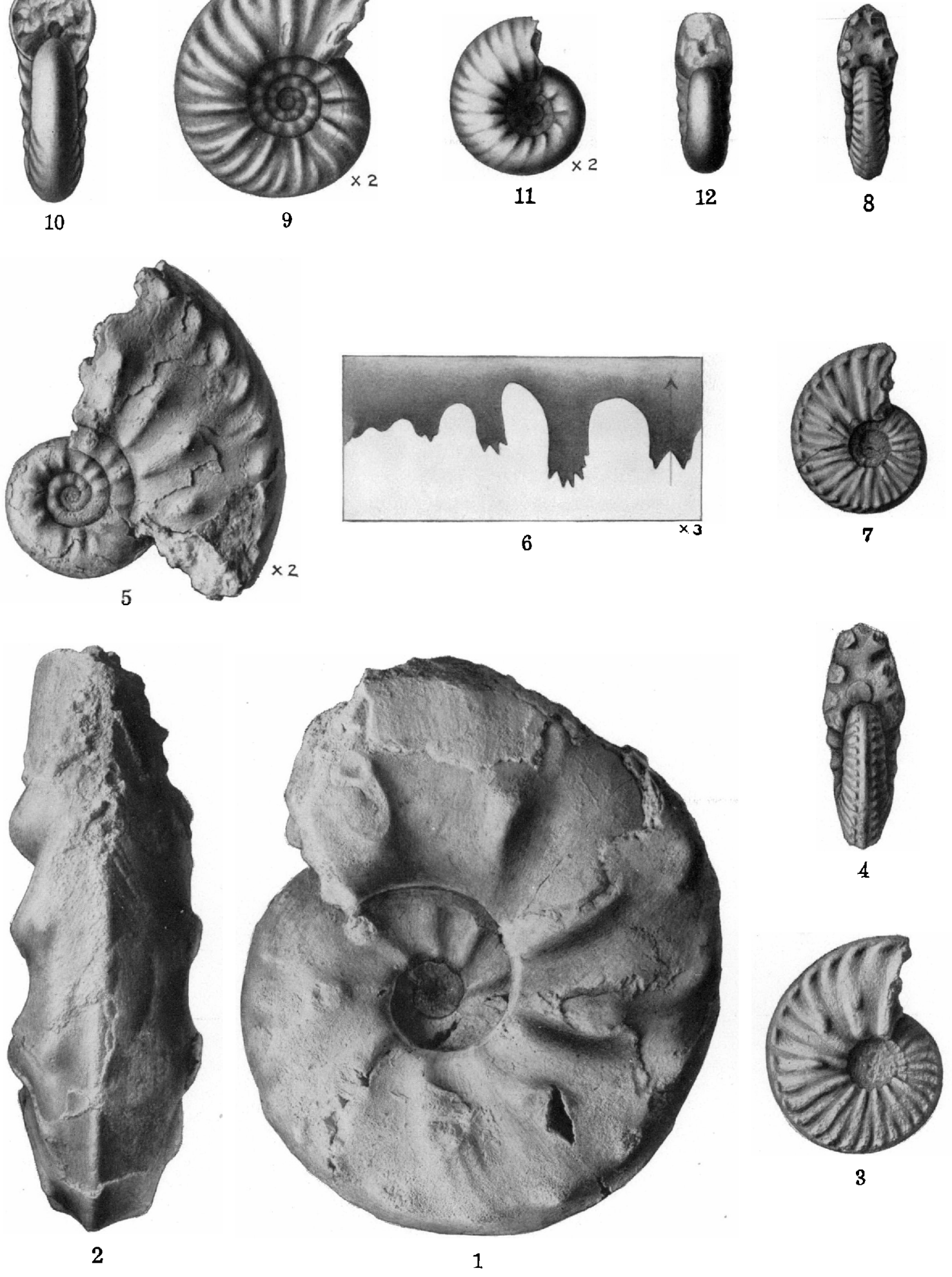


\section{PLATE XXXVIII.}

Ceratites (Paraceratites) cricki Smith, sp. nov. (p. 87).

Figures 1, 2. Old-age cliaracters.

Figures 3, 4. Late adolescent stage (natural size); diameter 36 millimeters.

Figcris 5, 6. ddolescent stige (natural size) and septa $(\times 3)$.

Figures 7,8 . Adolescent stage (natmral size); diameter 28 millimeters.

Figures 9, 10. Adolescent stage $(\times 2)$; diameter 20 millimeters.

Figures 11, 12. Adolescent stage $(X 2)$; diameter 13 millimeters.

All specimens figured on this plate are from the Middle Triassic, Daonella dubia zone, of Fossil Hill, West Humboldt Range, Nev., and are in the collection of the United States Geological Survey. 


\section{PLATE XXXIX.}

Ceratites (Paraceratites) trinodosus Mojsisovics (p. 92).

Figures 1. 2. Mature characters.

Figures 3-5. 'Typical form.

Figure 6. The three rows of tubercles.

Figure 7 . Septa (natural size).

Figure 8. Sejta of sime specimen $(\times 2)$.

Figures 9, 10. Beginning of mature characters.

Figures 11-13. Adolescent stage $(\times 2)$; diameter 18 millimeters.

Figures 14-16. Adolescent stage $(\times 2)$; diameter 13 millimeter's.

Figures 17-19. Early adolescent stage $(X 3)$; diameter 10 millimeters.

The originals of all figures on this plate are from the Daonella dubia zone, Middle Triassic of Fossil Hill, West Humboldt Range, Nev., and are in the collection of the United States Geological Survey, except figures $3-5,7-10$, and $17-19$, which are in the collection of J. P. Smitl. 


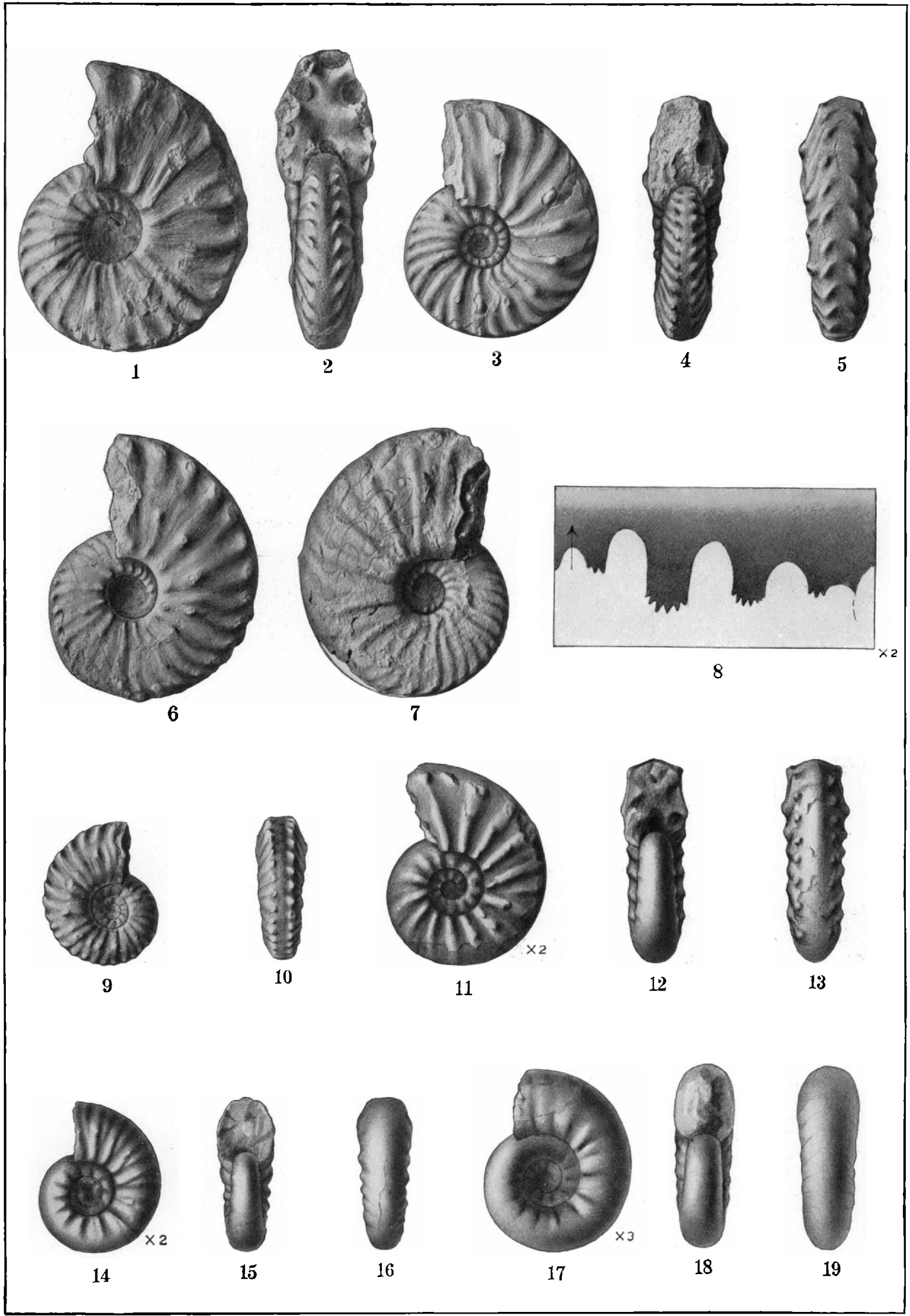


U. S. GEOLOGICAL SURVEY

PROFESSIONAL PAPER 83 PLATE XL

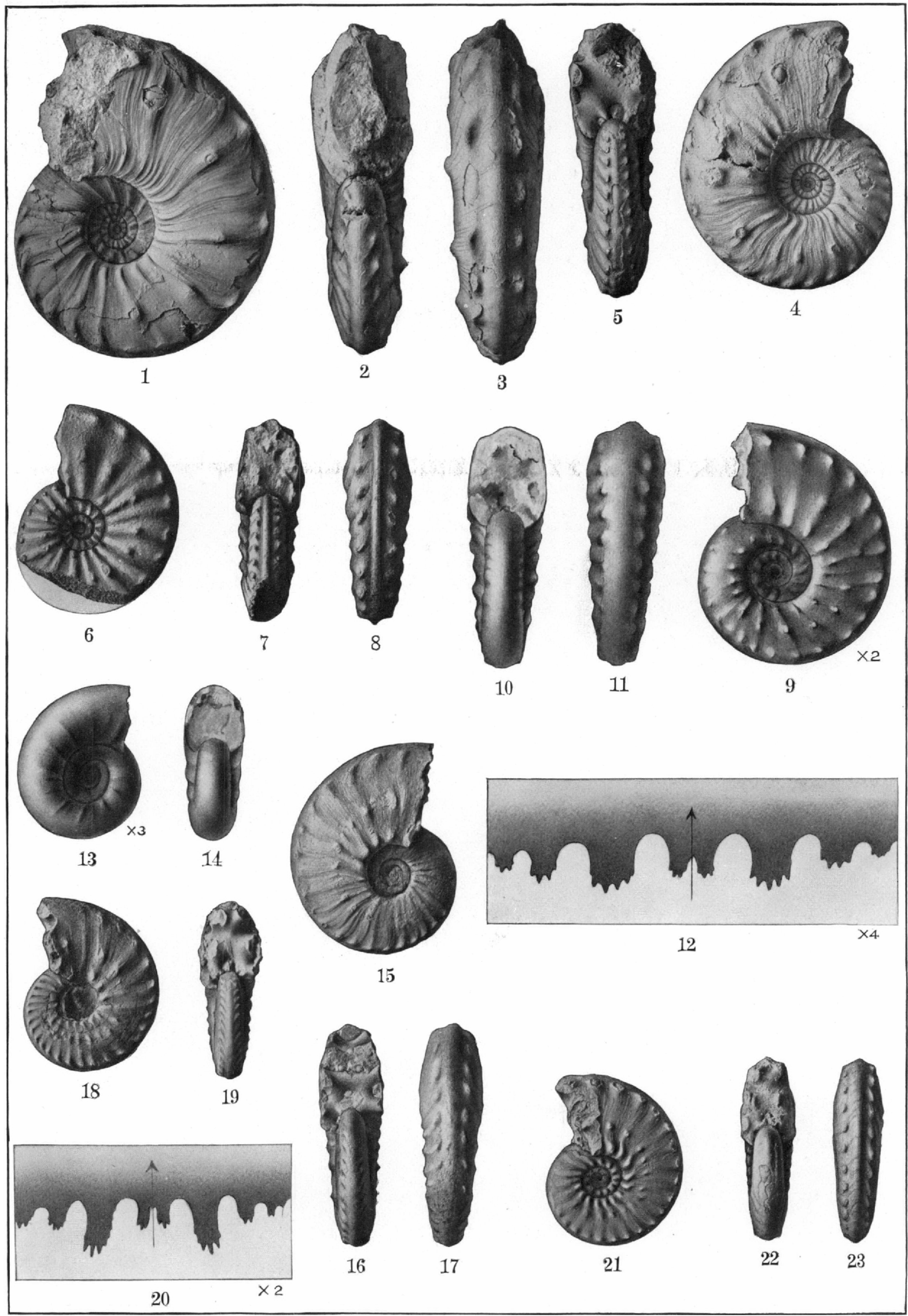




\section{PLATE XL.}

Ceratttes (Paraceratttes) newberryi Smith, sp. nov. (p. 92).

Figures 1-3. Type specimen (from Dannolla aubia zone, New Pass, Desitoyil Mountains, Nev., collection of J. I’. Smith).

Figure $3 a$. Septa of the same specimen $(\times 2)$.

Figures 4, 5. Transition from early to full maturity.

Figurfs 6-8. Transition from adolescence to maturity.

Figures 9-11. Adolescent stage $(\times 2)$; dianeter 21 millimeters.

Figure 12. Septa of the same specimen $(X 5)$.

Figures 13,14 . Adolescent stage $(\times 3)$; diameter 9 millimeter's.

Ceratites (Paraceratites) clarisei Smith, sp. nov. (p. 91).

Figures 15-17. Adult specimen.

Figures 18-20. Early mature stage. shell (natural sime) and septil ( $\times 2)$.

Figures 21-23. Younger shell, adolescent stage.

All specimens figured on this plate are from the Middle Triassie, Dannclla dubia zone, Fossil Hill, West Humboldt Range. Nev., and are in the collection of the Cnited States Geological Survey, with the exception of the specimen shown in figures 1-3.

$16279^{\circ}-$ No. $83-14-21$ 


\section{PLATE XLI.}

Ceratitres hingi Smith, sp. nov. (p. 85).

Figures 1-3. Type specimen (natural size).

ligure $3 a$. Septa of the type $(\times 2)$.

Figure 4. Early mature stage.

Figures 5, 6. Transition from adolescence to maturity.

Figures 7,8 . Lalte aldolescent stage (natural size); diameter 23 millimeters.

Figtre 9. Adolescent stilge (natural size); diameter 19 millimeter's.

Figlris 10,11 . Alolescent stage $(\times 2)$; dialmeter 16 millimeters.

Fiatris 12, 13. Adolescent stage $(\times 2)$; diameter 10 millimeters.

Cerattes mectaxgl Lams smith, sp). nov. (p. 85).

Figures 14, 15. 'Type sprecimen.

Nevadites roxtanei Smith, sp. nov. (p. 1:22).

Figurfs 16, 17. Adult specimen.

Figures 18, 19. Younger mature specimen.

FIGURLs 20, 21. 'Transition from adolescence to maturity (natural size) ; diameter 31 millineter's.

Figdre 22. Septa of the same specimen $(X 2)$.

Figure 23. Adolescent stage (nitural size); diameter 23 millimeters.

Figures 24, 25. Adolescent stage $\left(\times 1 \frac{1}{2}\right)$; diameter 15 millimeters.

Figures 26, 27. Adolescent stage $(X 2)$, showing resemblince to Keyserlingites; diameter 9 millineters.

All specimens figured on this plate are from the Middle Triassic. Daonclla dubia zone, of Fossil Hill, sonth fork of Americaln Canyon. West Humboldt Range, Nev., and are in the collection of the United States Geological Survey. 


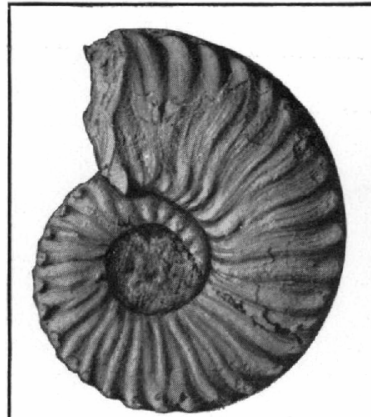

1

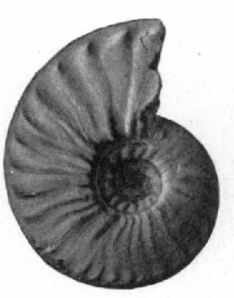

5

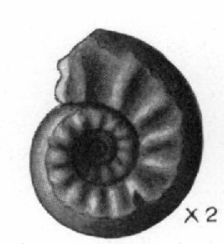

12

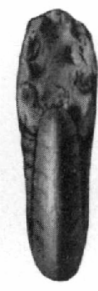

6

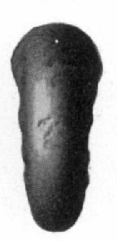

13

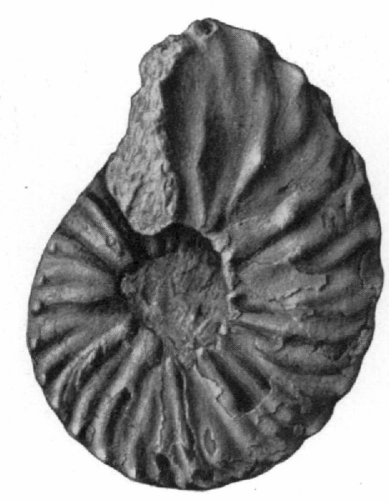

14

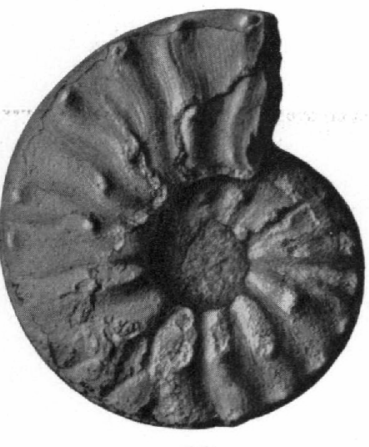

18

17

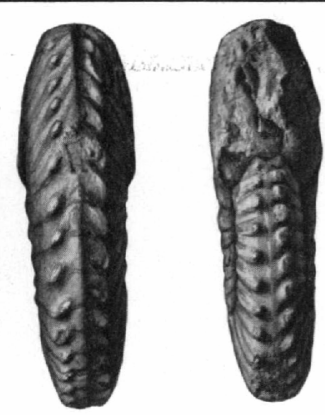

2

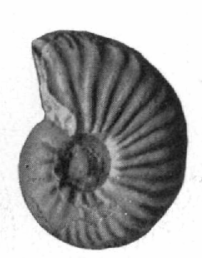

7
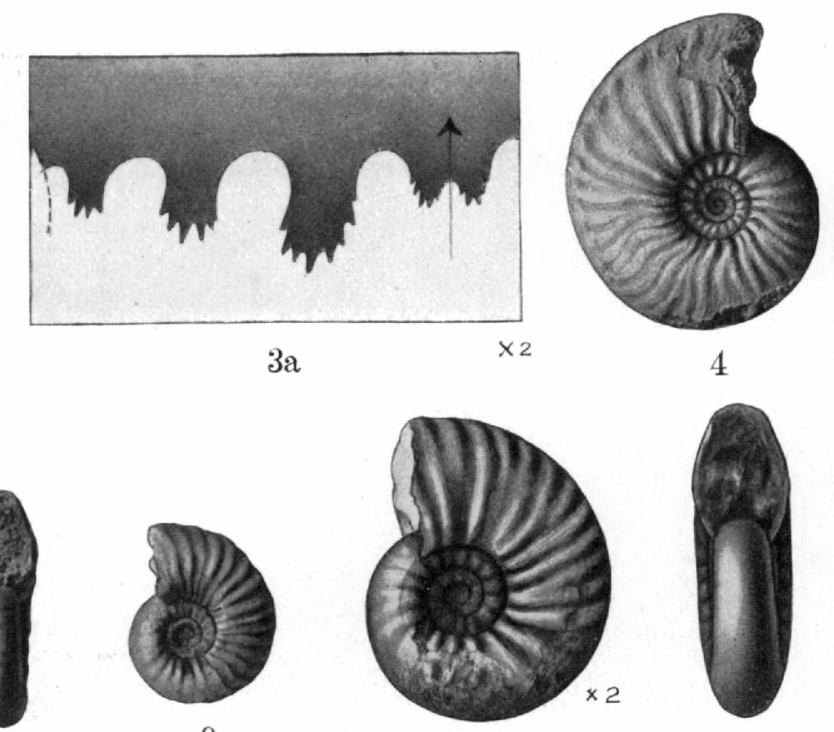

10

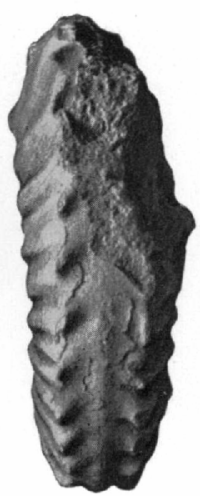

15

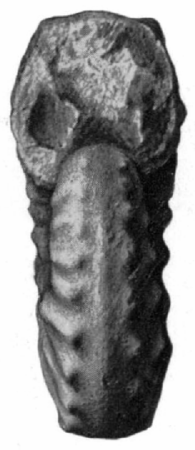

19
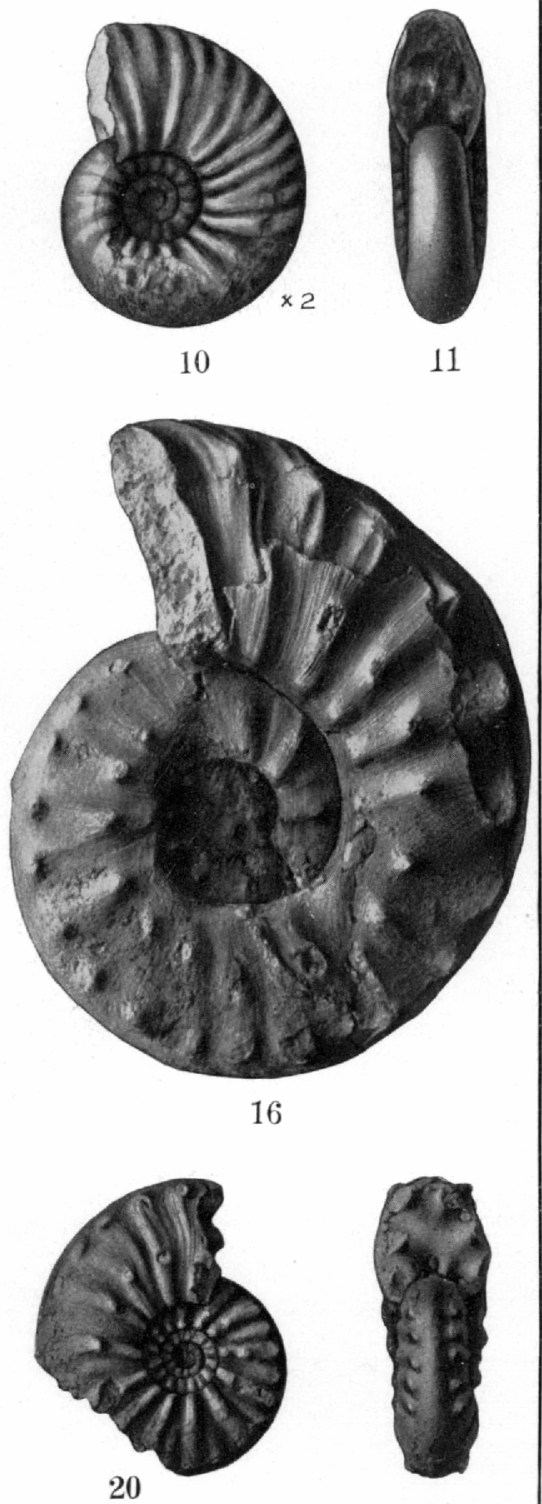

21

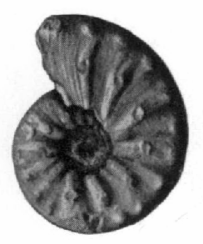

23
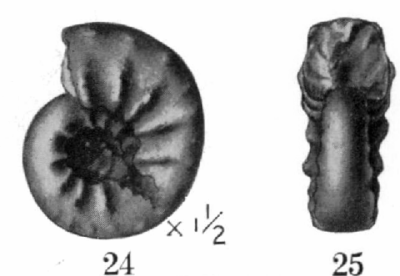

25

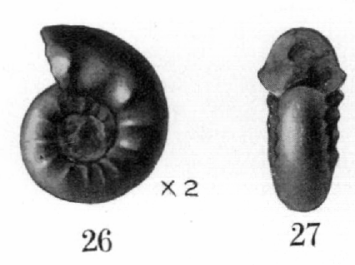




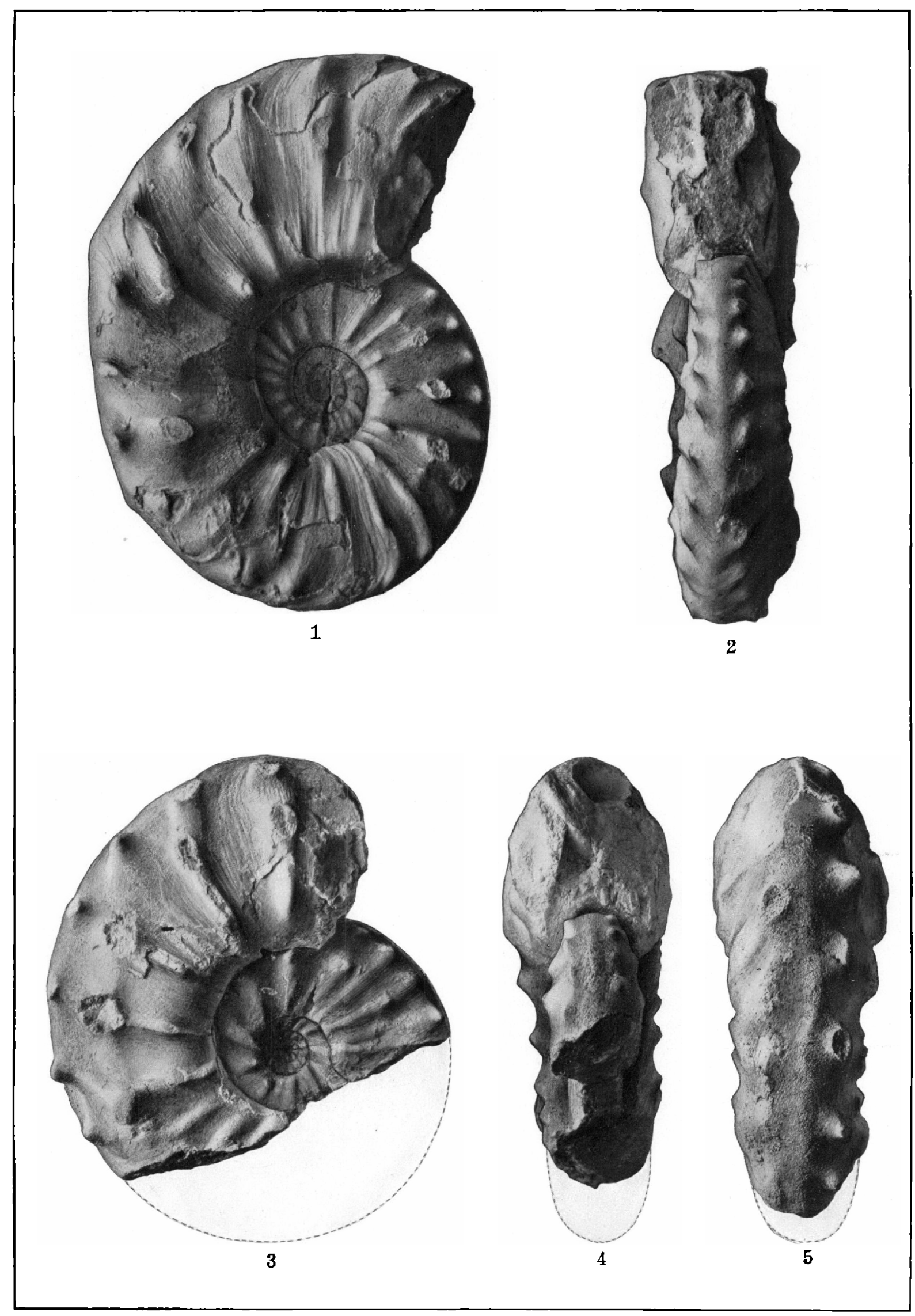




\section{PLATE XLII.}

Ceratites haguei Smith, sp. nov. (p. 97).

Figures 1, 2. Type specimen.

Figures 3 -5. Mature stage.

The specimens figured on this plate are from the Middle Triassic, Daonella dubia zone, of Fossil Hill, south fork of American Canyon, West Humboldt Range, Nev,, and are in the collection of the United States Geological Survey. 


\section{PLATE XLIII.}

Ceratites inglei Smith, sp. nor. (p. 97).

Frgures 1, 2. Early mature stage.

Figure 2a. Septa of the same specimen $(\times 3)$.

Figures 3-5. Lilte adolescent stage (uiltural size).

Figures 6,7 . Adolescent stage $(X 2)$; diameter 18 millimeters.

Figurfs 8-10. Adolescent stage $(X 2)$. showing resemblince to Keyserlingites: diameter 13 millimeters.

('eratites crassicorst Smith, sp. nov. (p. 95).

Fitictis 11, 12. Type specimen.

Figures 13, 14. Adolescent stage $(X 2)$, showing resemblanco to Keyserlingites: dianterer 1.j millimeters.

Cenatites ibeecheri Smith, sp. nor. (p. 94).

Figures 15-17. 'Tyle specimen.

Figures 18-20. Transition from adolescence to maturity.

Figures 21, 22. Late adolescent stage; diameter $2 \pm$ millimeters.

Figures 23, 24. Adolescent stage $\left(\times 1 \frac{1}{2}\right)$; diameter 10 millimeters.

Figures 25, 26. Adolescent stage $(\times 2)$ : showing resemblance to Korserlingites: diameter 15 millimeters.

All specimens figured on this plate are from the Midlle Triassic, Daonclla Iubia zone, of Fossil Hill, south fork of American Canyon, West Humboldt Range, Nev., and are in the collection of the Cnited States cieological Surves, excent the originals of figures 11-1i, which are in the collection of J. P. Smith. 


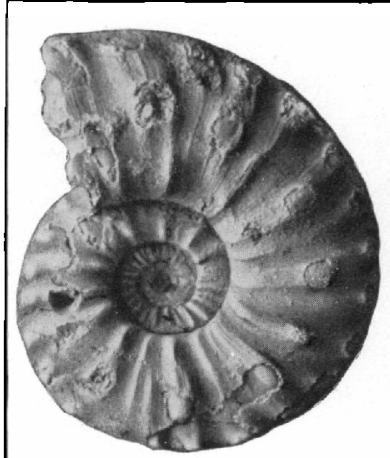

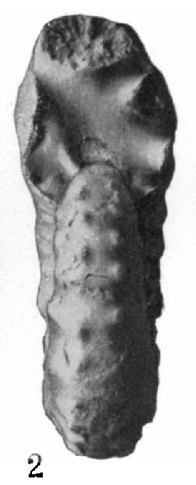

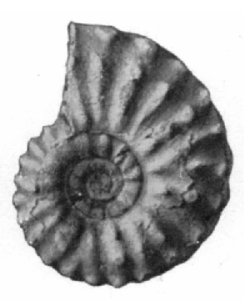

3

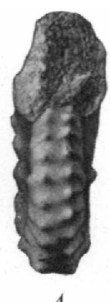

4
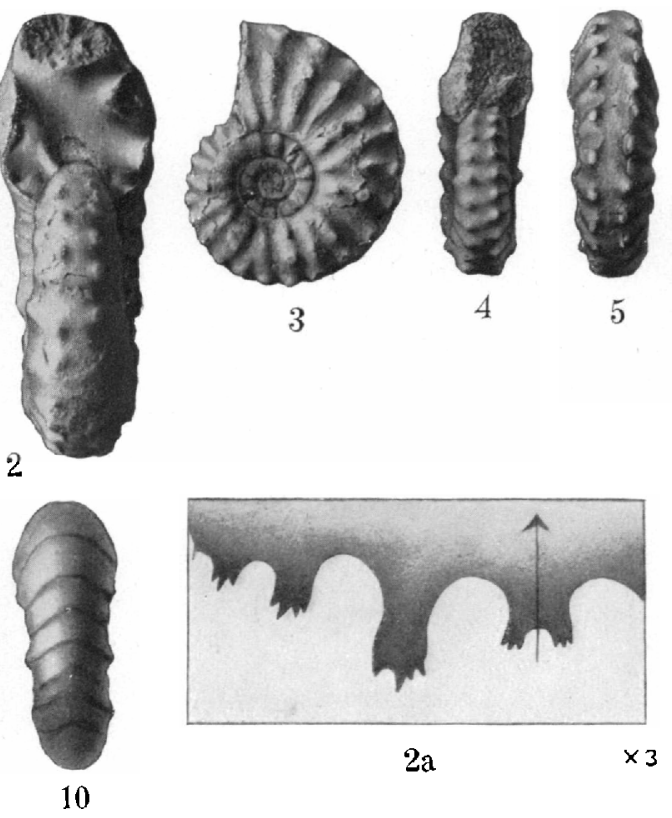

10

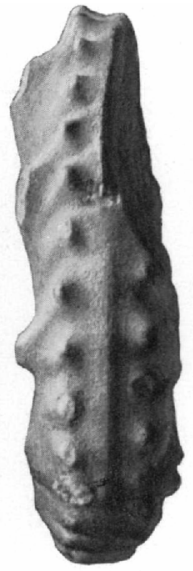

12

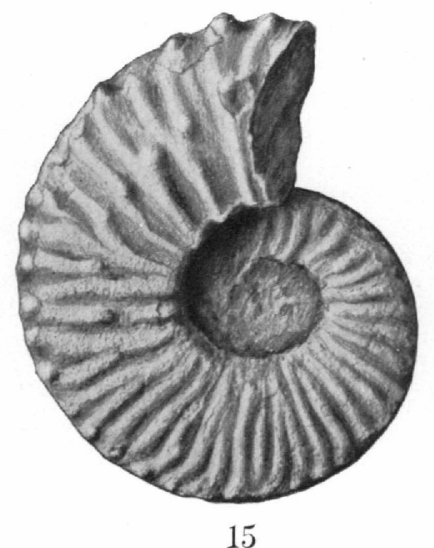

15
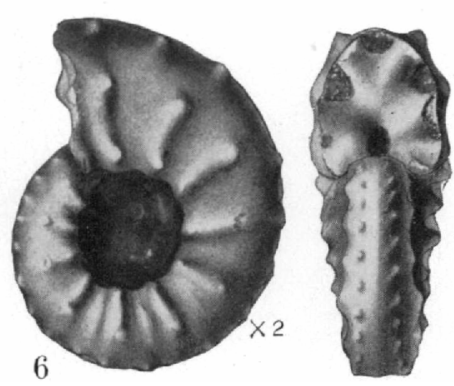

7

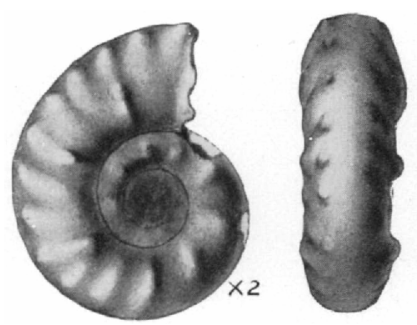

13

14

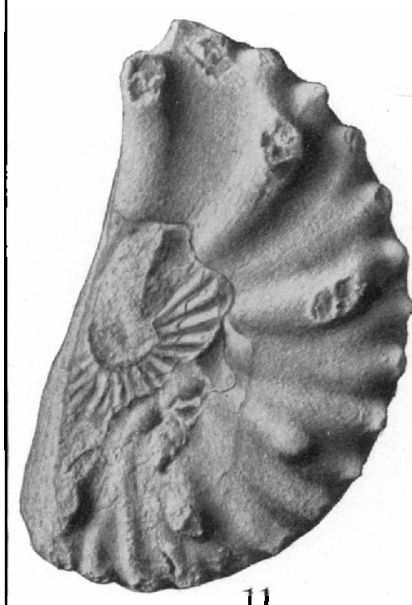

11

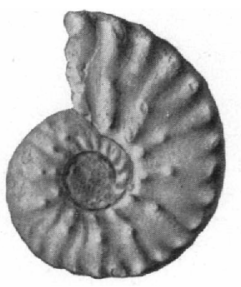

18

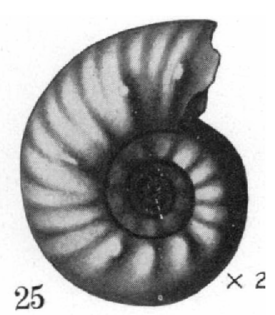

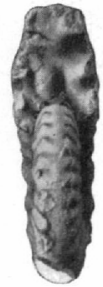

19

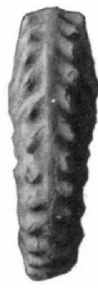

20

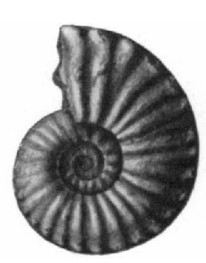

21

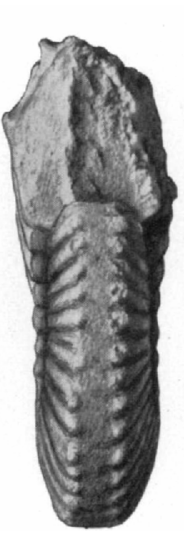

16

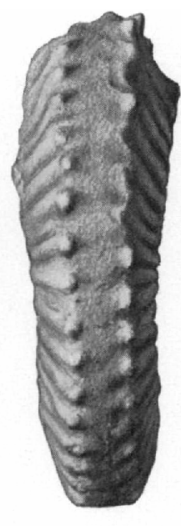

17
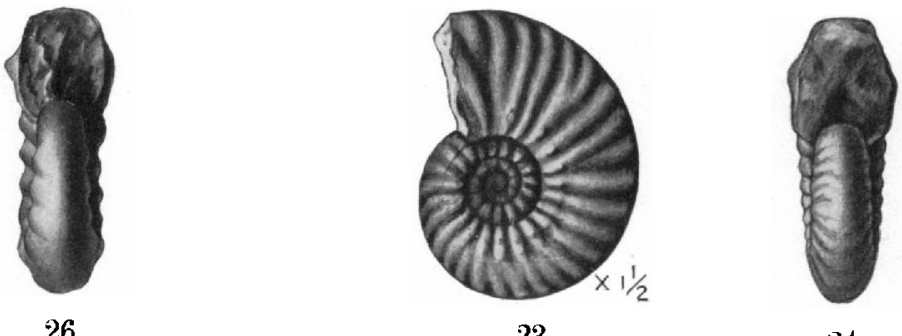

24 


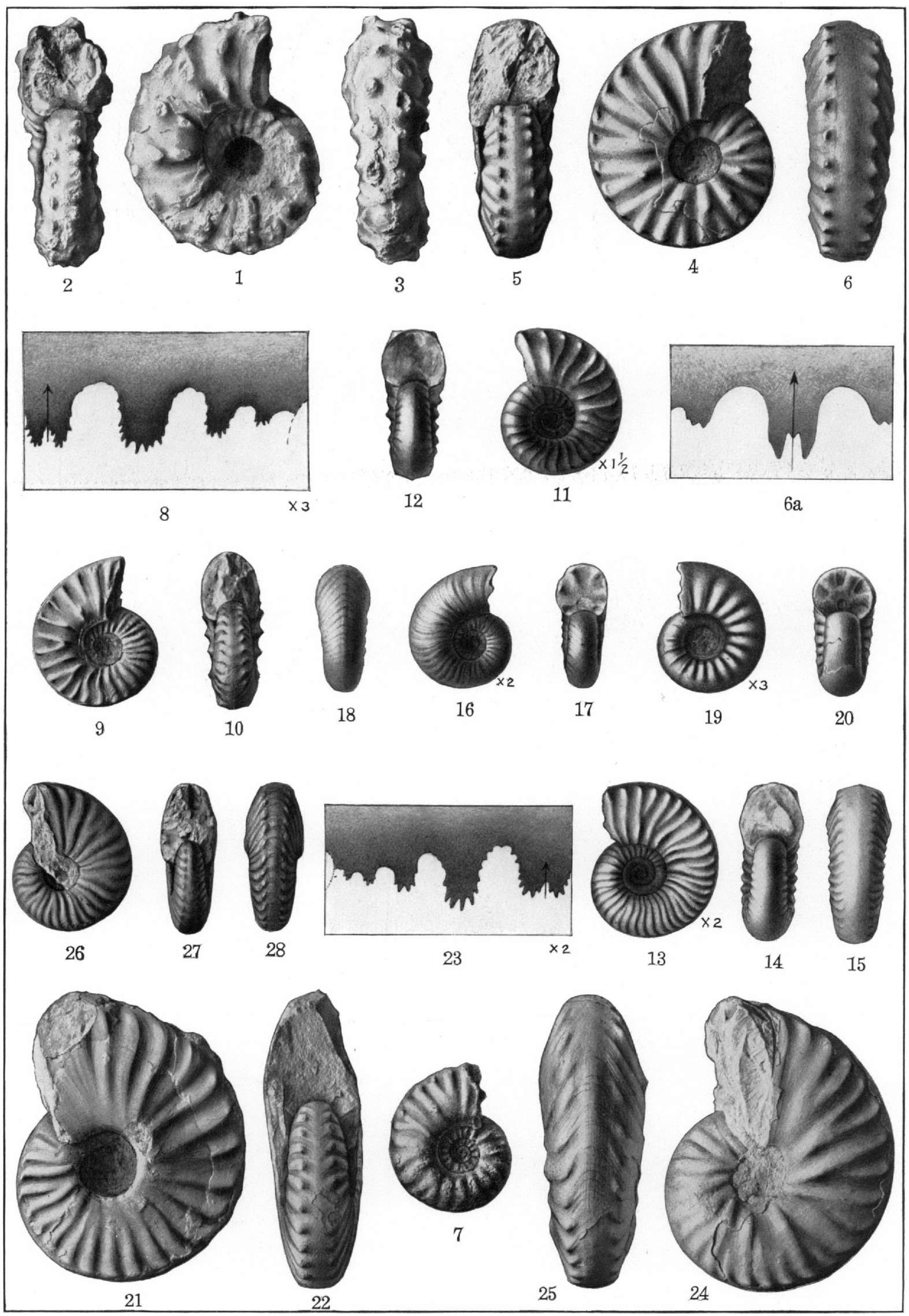




\section{PLATE XLIV.}

Ceratites marixatis Hauer (p. 96).

Figurf.s 1-3. Mature specimen.

Ceratites harpissky Smith, sp. nov. (p. 100).

Figures 4-6. 'Type specimen.

Figure 7. Early mature stage. showing septa.

Figt'Re 8. Septa of the same specimen $(\times 3)$.

Figcres 9, 10. Transition from adolescence to maturity.

Figdres 11, 12. Late adolescent stage $\left(\times 1 \frac{1}{2}\right)$; diameter 18 millimeters.

Figures 13-15. Adolescent stage $(\times 2)$ : diameter 14 millimeters, showing transition from Gymnotoceras? to Ceratites stage at diameter 9 millimeters.

Figures 16-18. Adolescent stage $(\times 2)$, showing stage resenbling Gymmotoceris; diameter 11 millimeters.

Figurs 19, 20. Adolescent stage ( $X 3$ ), showing stage resembling Danubites or Dinarites; diameter 7.5 millimeters.

Ceratites occidentalis smitli, sp. nov. (p. 8t).

Figurfs 21, 22. Type specimen.

Figure 23. Septa of the type ( $\times 2)$.

Figtres 24, 25. Complete specimen, showing the aperture.

Figures 26-28. Early mature stage.

All specimens figured on this plate are from the Middle Triassic. Dannclla dubia zone, Fossil Hill, south fork of American Canyon, West Humbolclt Range, Ner. The originals of figures 1-3 and 24-28 are in the collection of the Cnited States Geological Survey; those of figures 4-23 are in the collection of J. P. Smith.

$16279^{\circ}-$ No. $83-14-22$ 


\section{PLATE XIJ.}

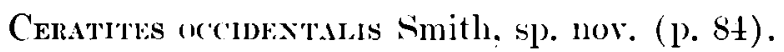

Figlers 1. 2. Old-age characters.

Figcri: 3. Litrly miture stilge.

Figtri 4. Septal of the same specimen $(\times 2)$.

Figtres $\overline{0}-\overline{7}$. Late adolescent stage $\left(X 1 \frac{1}{2}\right)$ : diameter 19.5 millimeters.

Figures 8, 9. Adolescent stage $(X 2)$; diameter 12 millimeters.

Figures 10, 11. Arlolescent st:lge $(X 2)$; diameter 7.5 millimeters.

Figures 12, 13. Adolescent stage ( $X 3$ ) ; diameter 5 millimeters.

Ceratites altilis Smith, sp. nov. (p. 83).

Figuris 14-16. Adult specimen.

Figckes 17,1 . Early mature stage $\left(X 1 \frac{1}{2}\right)$; diameter 30 millimeters.

Figures 19, 20. 'Transition from adolescence to maturity $\left(\times 1 \frac{1}{2}\right)$; diameter 2.5 millimeters.

Figures 21,22 . Adolescent stage $(\times 2)$; diameter 13 millimeters.

All sperimens figured on this plate are from the Middle Triassie, Danclla dubia zone, on Fossil Hill, south fork of Americtn Canyon. West IIumboldt Range. Nev, and are in the collection of the Lnited States Geological survey. excelt figure 1, which is in the collection of J. I'. Smith. 


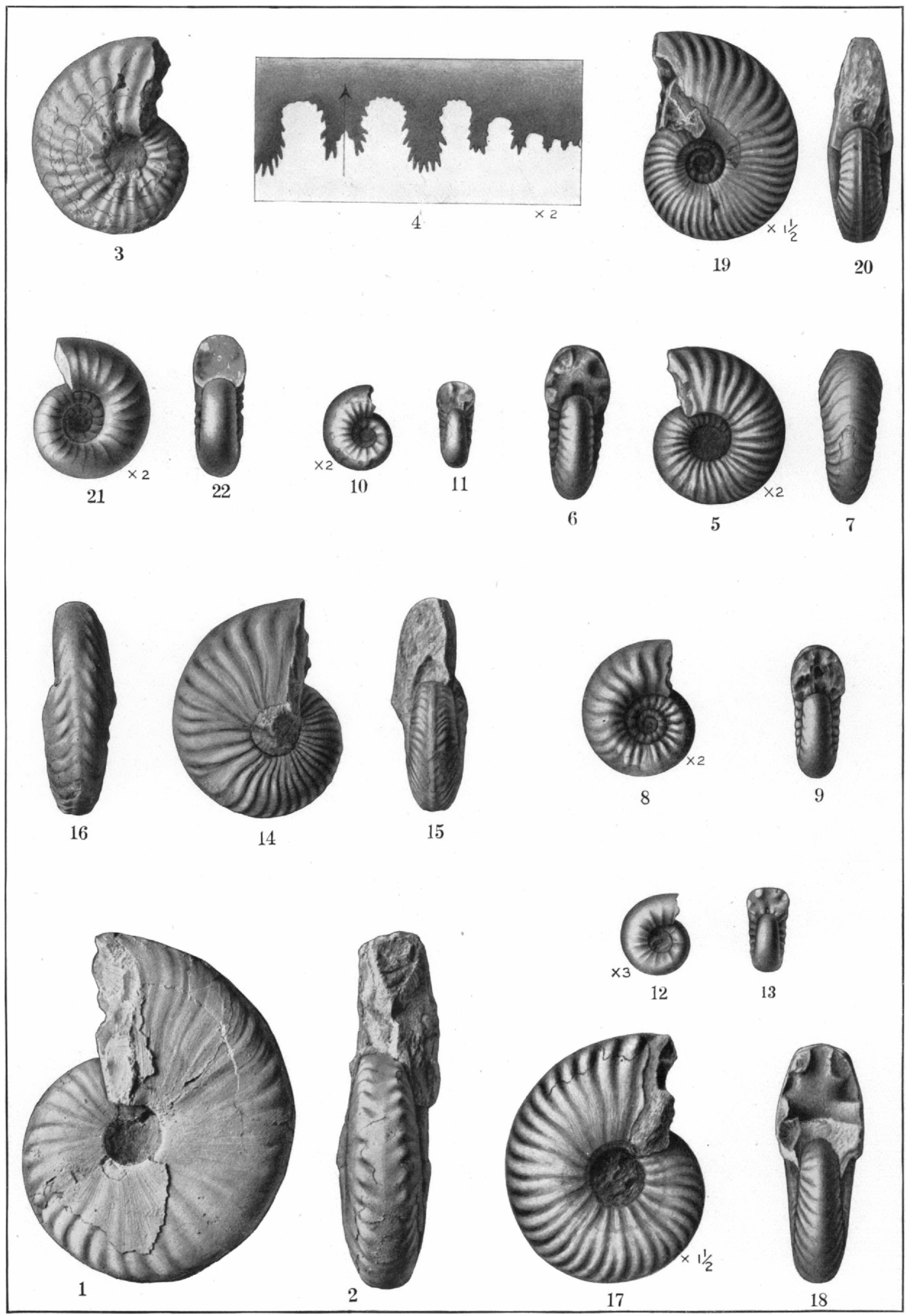




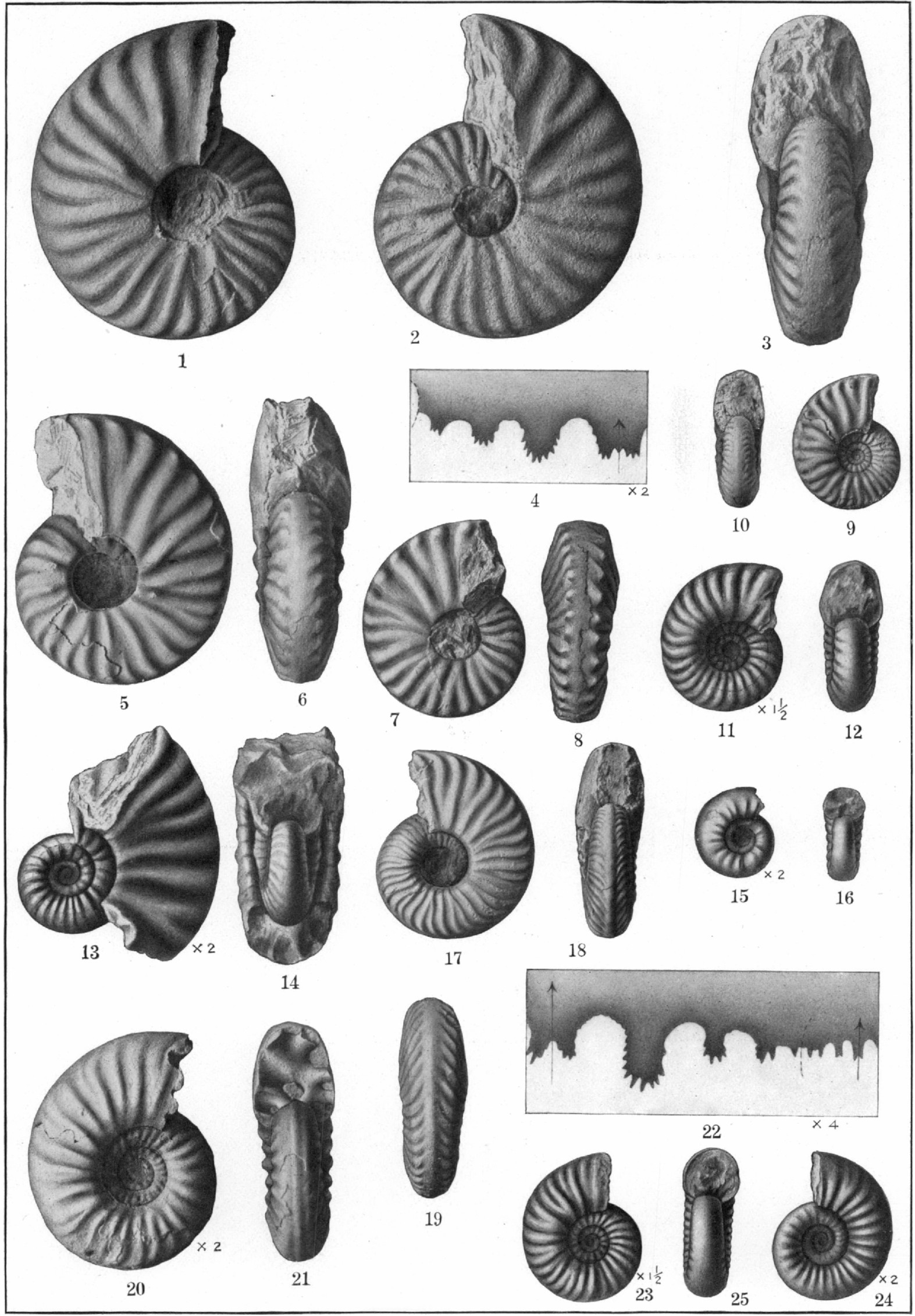




\title{
PLATE XLVI.
}

\author{
Ceratites Pilatus Smith, sp. nov. (p. 102).
}

Figures 1-3. Specimen showing septa and full length of body chamber.

Figure 4. Septa of same specimen $(X 2)$.

Figdres 5, 6. Sculpture of body chamber of a complete specinen.

Figures 7, 8. Early mature stage; diameter 36 millimeters.

Figures 9, 10. Late adolescent stige; diameter 24 millimeters.

Figures 11, 12. Adolescent stilge $\left(X 1 \frac{1}{2}\right)$; diameter 18 millimeters.

Figures 13, 14. Adolescent stage $(\times 2)$, obtained by breaking off part of the outer whorl, showing Gymnotoceras stage at diameter of 10 millimeters.

Figures 15, 16. Early adolescent stage $(X 2)$, showing stage resembling Danubites; diameter 8 millimeters.

Ceratites tenuispiralis Smith, sp. nov. (p. 81).

Figures 17-19. Tyje specimen (natural size).

Figures 20, 21. Early mature stage $(\times 2)$; diameter 22 millimeters.

Figure 22. Septa of the same specimen $(X 4)$.

Figure 23. Transition from adolescence to maturity $\left(\times 1 \frac{1}{2}\right)$; diameter 17 millimeters.

Figures 24, 25. Adolescent stage $(X 2)$, resembling Gynmotoceras; diameter 12 millimeters.

All specimens figured on this plate are from the Middle Triassic, Daonella dubia zone, on Fossil Hill, south fork of American Canyon, Nest Humboldt Range. Nev.; they are in the collection of the United States Geological Survey, except the original of figure 20 . which is in the collection of J. P. Smith. 


\section{PIATE XIVII.}

Ceratites motchomes Smith, sp. nor. (p. 80).

Figurfs 1-3. Type specinem.

Figures 4, 5. Sarly mature stage.

Fiüre 6. Early mature stage, showing septa (naturall size).

Figure 7 . Septa of the same specimen $(X: 2)$.

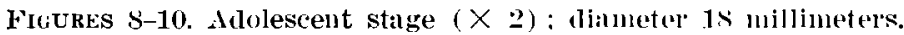

Ceratites whilicisis Smith, sp. noy. (p. 82).

Figures 11-14. Type specimen (Cottonwood Canyon).

Figures 15, 16. Early adult stage $(\times 2)$; di:meter 22 millimeters.

Figures 17, 19. Adolescent stage $(X 2) ;$ diameter 14 millimeters.

Cerattpes (Paracerattites) cricki Smith, sp. nov. (p. 87).

Figuris 1!-21. Adolescent stage ( $\left.X 1 \frac{1}{2}\right)$; diameter 31 millimeters.

Figures 2-24. Adolescent stage $(X 2)$; diameter 20 millimeters.

All specimens figured on this plate are from the Middle Triassic, Daonella aubia zone. The originals of figures 1-3 and 11-14 are from the north fork of Cottonwood Canyon. West Humboldt Range, Ner., and are in the collection of J. P. Smith; those of figures 4-10 and 15-2-t are from Fossil Hill, south fork of American Canyon, West Humboldt Range, Nev., and are in the collection of the United states Geological Survey. 


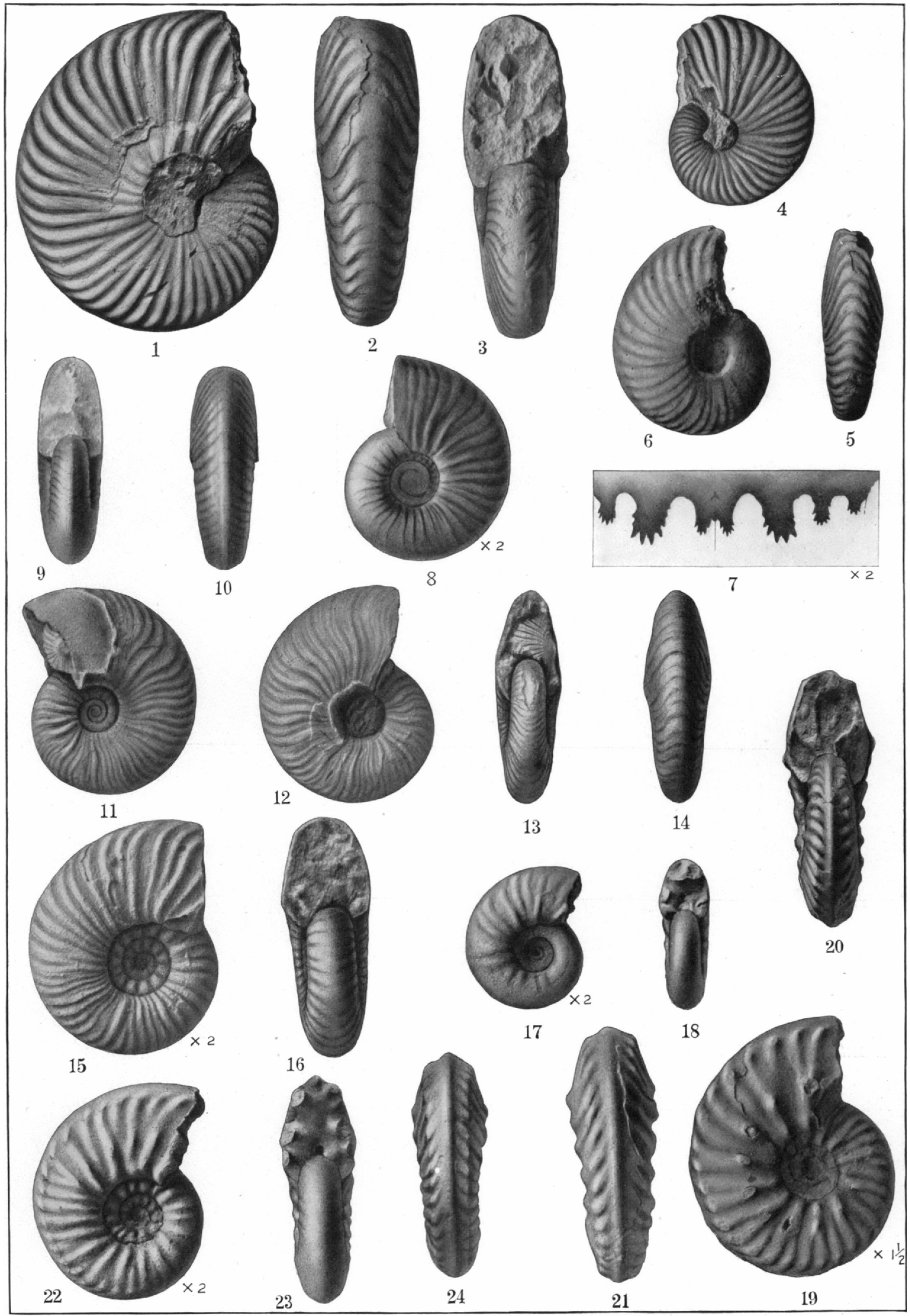




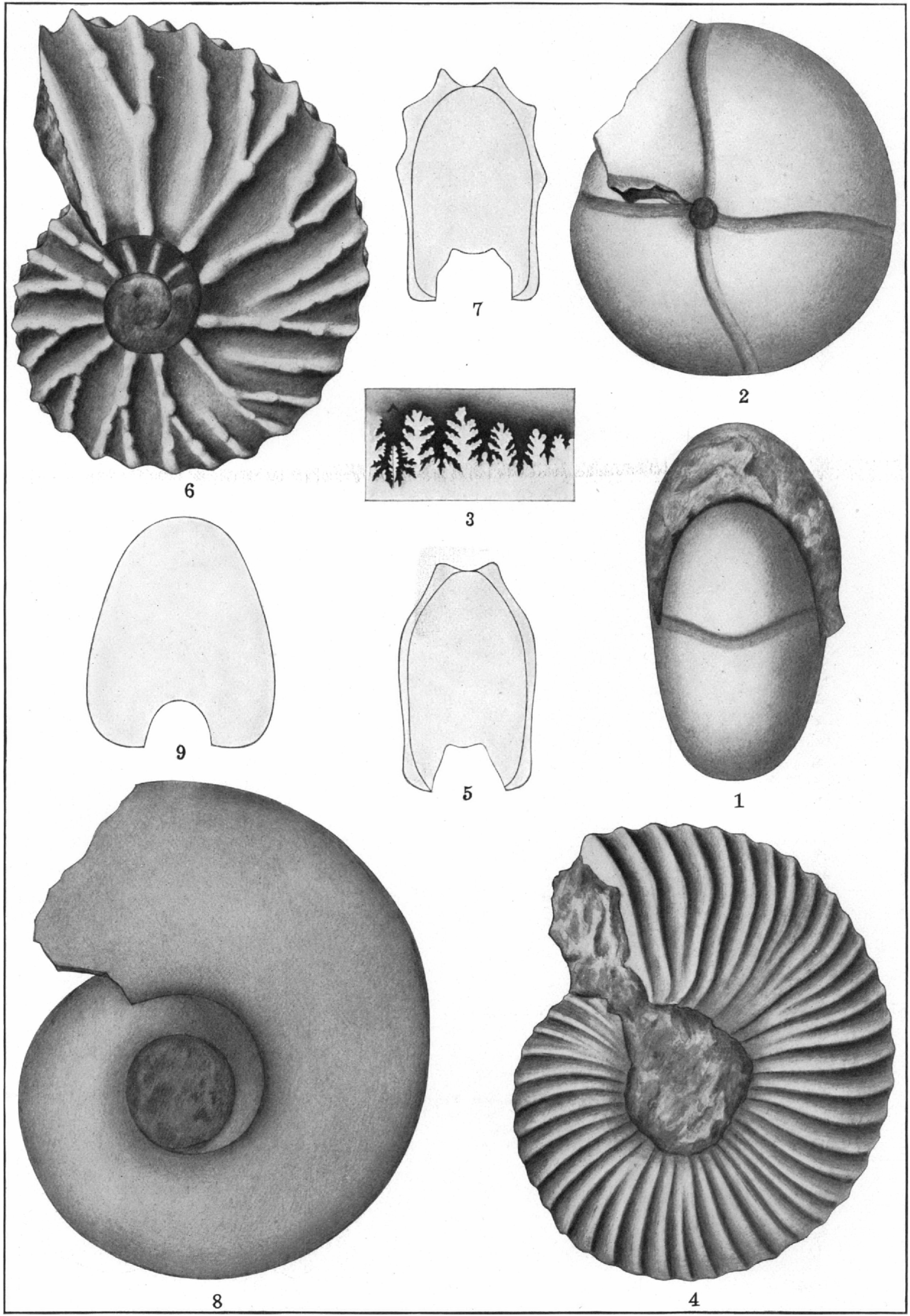




\section{PLATE XLVIII.}

Arcestes (Proancesites) gabibi Meek (p. 43).

Figures 1-3. After Gabb (Geol. Survey ('alifornia. I'alieontology, vol. 1, P'l. III. figs. 16 and 17).

$$
\text { Nevadites whitseyt Gabb (p. 126). }
$$

Figures 4, 5. After Gabb (Geol. Survey California, Paleontology, rol. 1, Pl. IV, figs. 11 and 11a).

Trachyceras (Protrachychas) americantm Mojsisovics (p. 133).

Figuris 6, 7. After Gabb (Geol. Survey California, P’alieontology, vol. 1, Pl. IV, figs. 12 and 12a).

MoxopHylltes miLlixgsiants Gabb (p. 48).

Figures 8, 9. After Gabb (Geol. Survey California, Palæontology, vol. 1, I'l. V, figs. 20 and $20 a$ ). $16279^{\circ}-$ No. $83-14-23$ 


\section{PLATE XLIX.}

Daonelita tindströMi Mojsisovies (p. 144).

Figuris 1, 2. Side and top view (natmal si\%e).

Frgure 3. The ribs $(X 4)$.

Daonela americaxa Smith, sp. nov. (p. 143).

Fugure 4. Type specimen (nitural size), from a plaster cast.

Figure 5. Adolescent stage of same specimen ( $X 3$ ).

Figure 6. Adolescent stages, three young specimens on the same slab.

Figure 7 . Adult shell $\left(X 1 \frac{1}{2}\right)$.

Figure 8. Adolescent stage $(X 4)$.

Figure 9. Adolescent and larval stage $(X 4)$.

Daonflea debia Gabb (p. 143).

Figure 10. Adult shell.

Figure. 11. Adult shell.

All specimens figured on this plate are from the Middle Triassic Daonella Iubia zone, of Fossi! Hill, south fork of American Canyon, West Humboldt Range, Nev. All are in the collection of the United States Geological Surrey. 


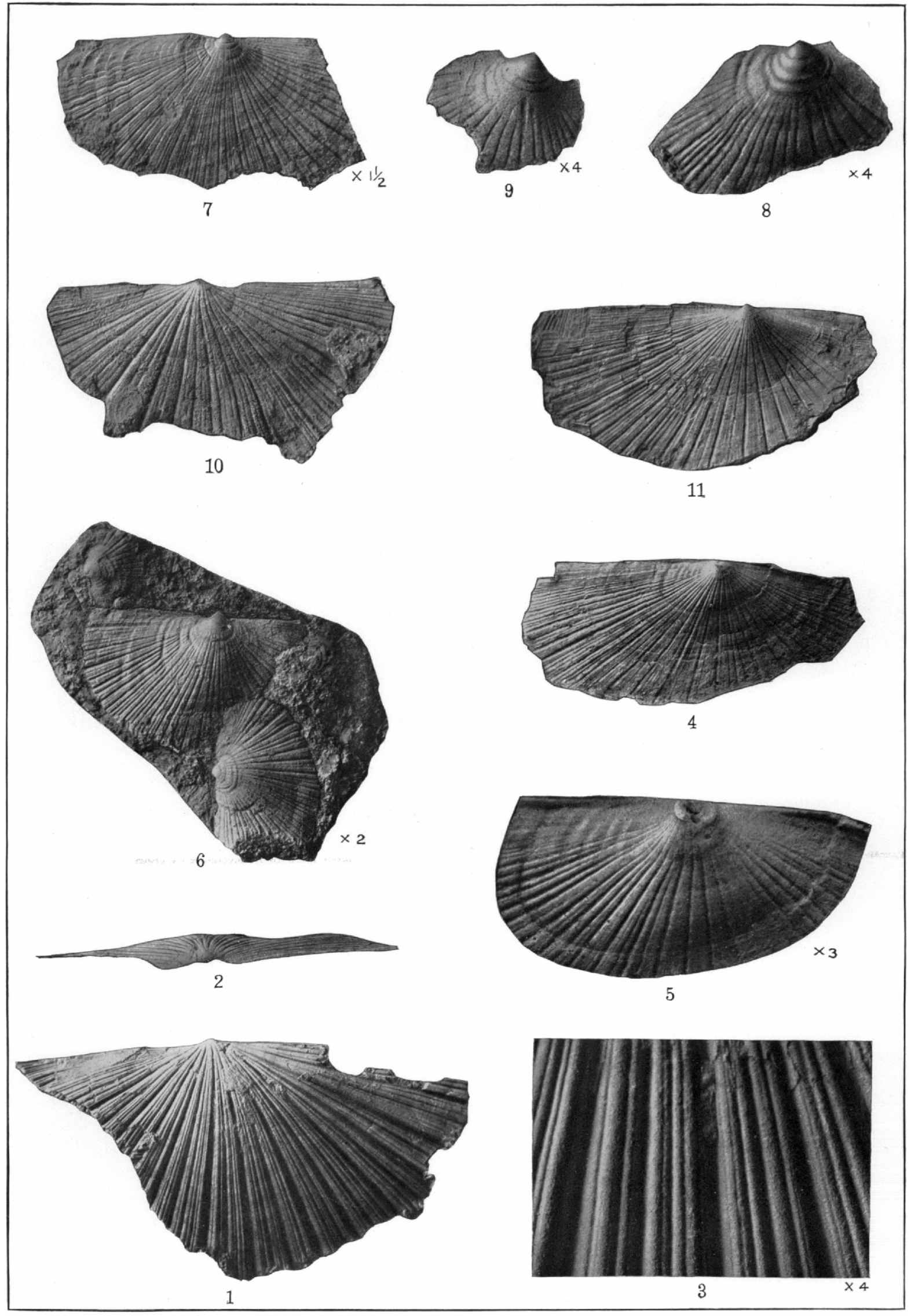




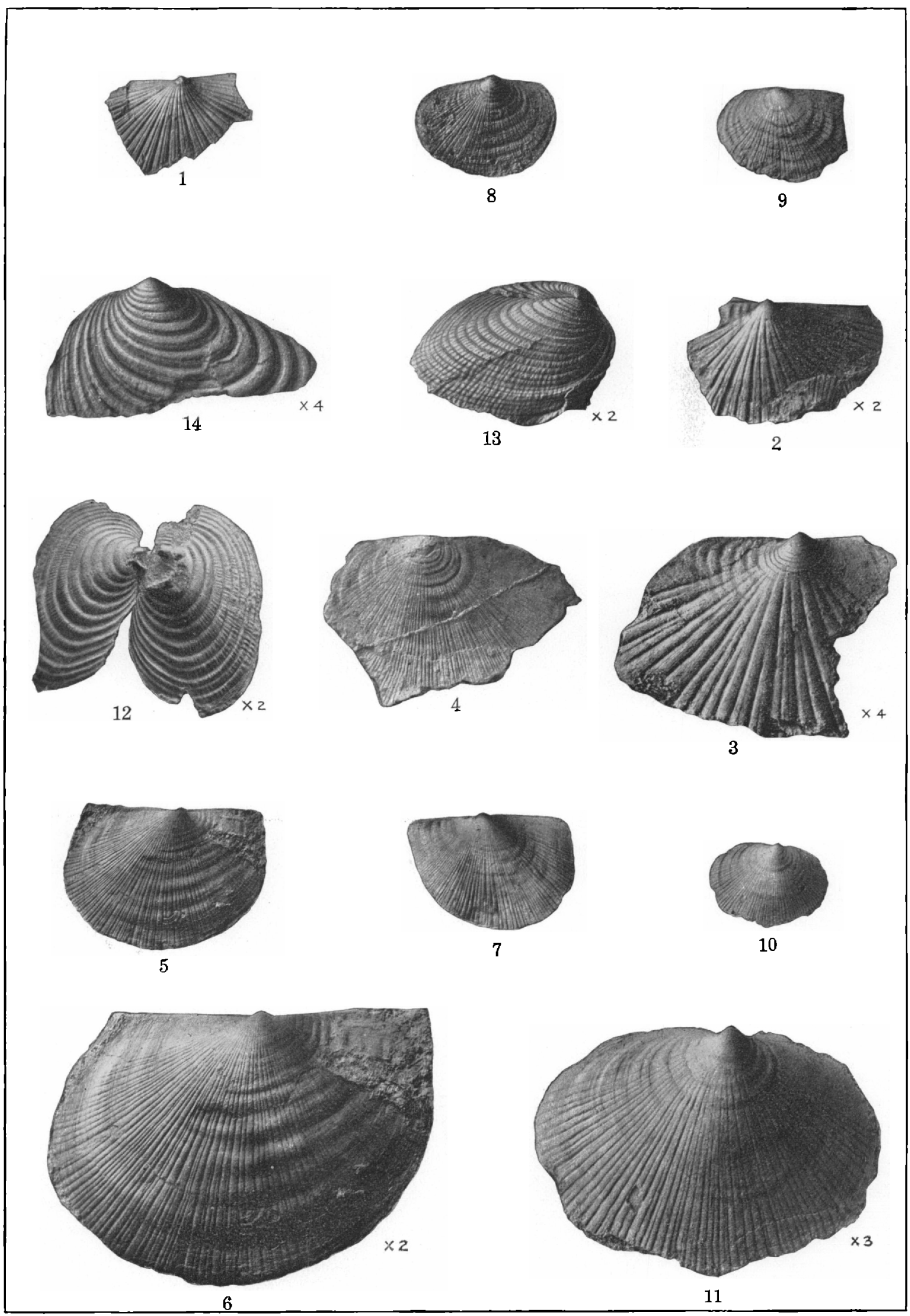




\section{PIATE L.}

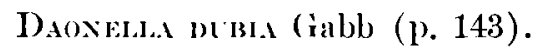

Figcre 1. Adolescent shell.

FIGURE 2. Early adolescent stage $(X: 2)$.

Figure 3. Early adolescent and larral stages $(X+4)$.

Daoxflat mocssoxi Merian (p. 144).

Figure 4. Adult shell, from a plaster cast.

FIgURe 5. Adult shell, showing right valve.

Figicre 6. Adult shell, same as figure $5(\times 2)$.

Figure 7. Adult shell, left valve

Figure 8. Eariy adult stage, right valve.

Figcre 9. Larly adult stage, left valve.

FigURE 10. Late adolescent stage. right valve.

Fiticke 11. Tlie same $(\times 3)$.

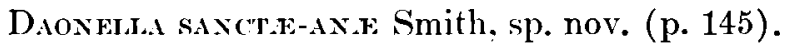

Figure 12. Type specimen, showing right and left valves $(\times 2)$.

Figure 13. Right valve $(\times 2)$.

Frguke 14. Beak of opposite valve of the same specimen, showing the larval stage $(X 4)$.

The specimens represented in figures 1-11 are from Fossil Hill, Nest Humboldt Range, Nev.; those represented in figures 12-14 are from Silverado Canyon, Sinta Ana Mountains. Orange County, Cal. The originals of figures 1-3 and 5-11 are in the collection of the United States Geological Survey; those of figure 4 and figures $12-14$ are in the geologic collection at Stanford University. 


\section{PLATE LI.}

Nevadites rontainei Smith, sp. nov. (p. 122).

Figures 1-3. Type specimen (natural size).

Figure 4. Septa of the same specimen $(X 4)$.

Figures 5-7. Early mature stige (natural size) ; diameter 37 millimeters.

Figures 8, 9. Same specimen, with half a revolution of the whorl removed $(X 2)$, showing the transition from Ceratites to Nevadites; diameter 27 millineters.

The specimens figured on this plate are from the Middle Triassic, Daonclla dubia zone, Fossil Hill, south fork of American Canyon, West Humboldt Range, Nev.; they are all in the collection of the United States Geological Survey. 

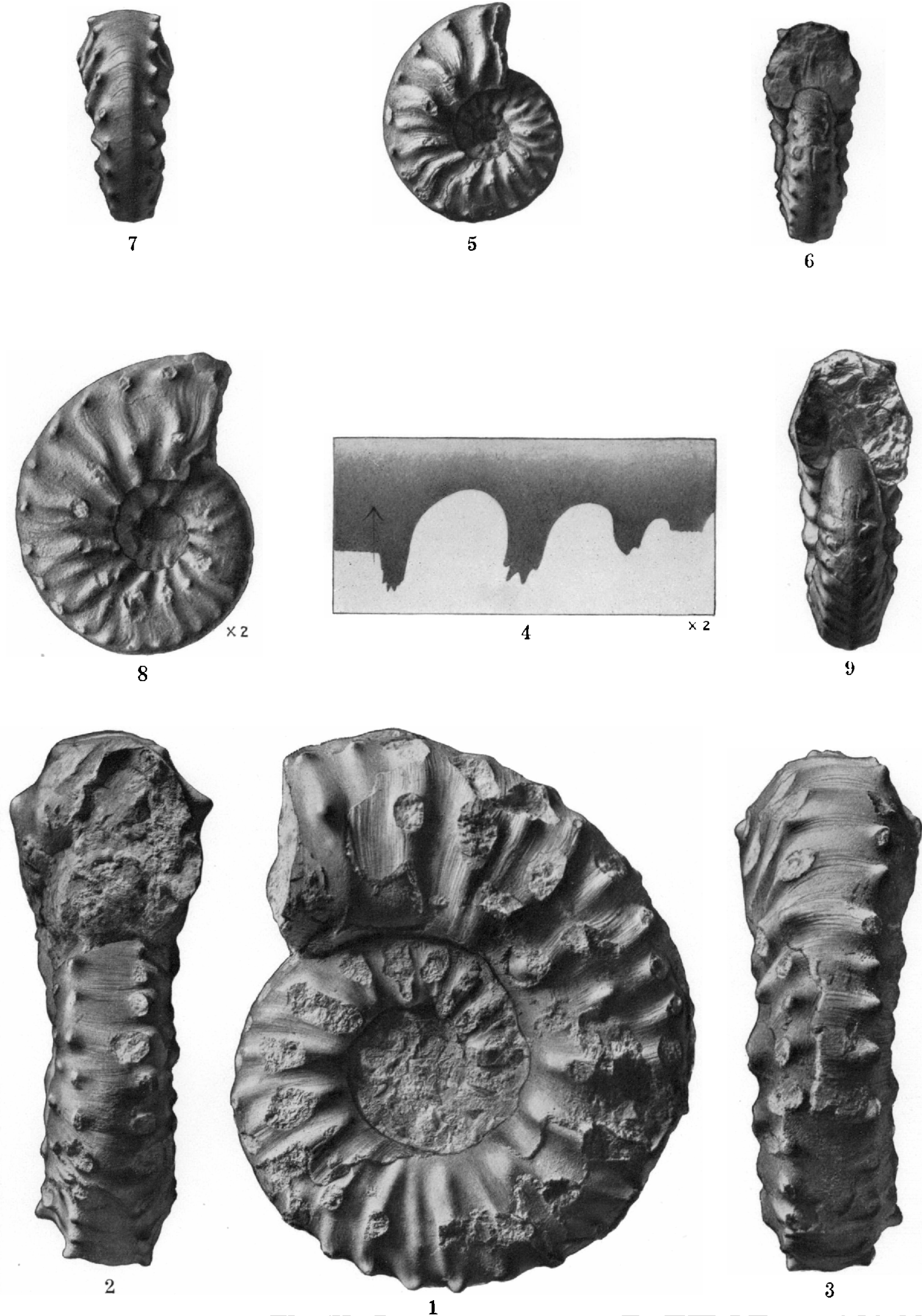


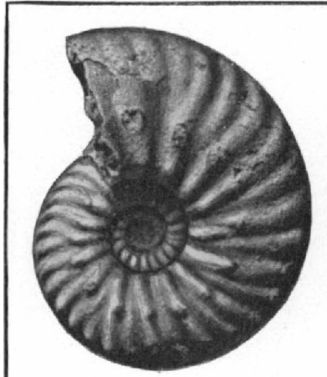

15

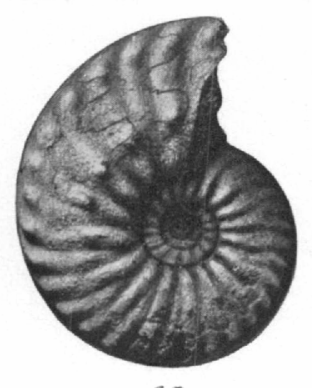

16
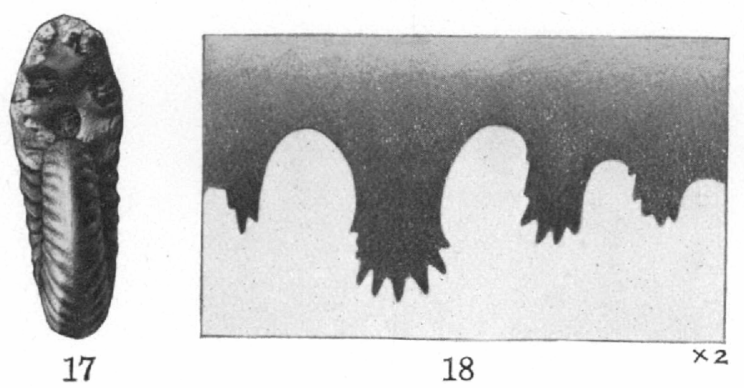

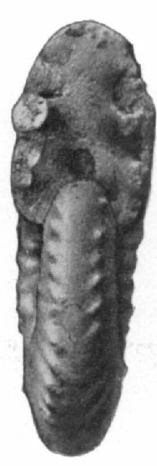

13

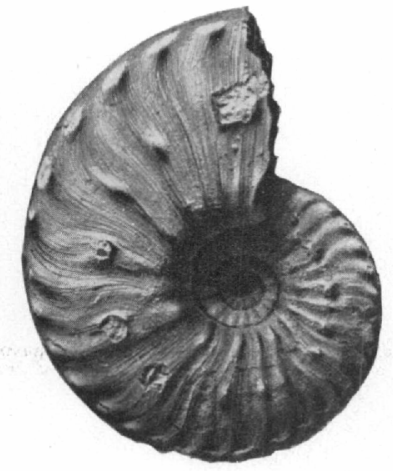

12

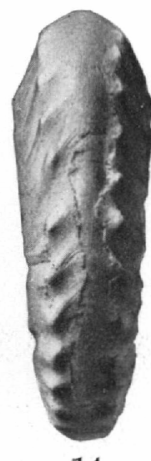

14

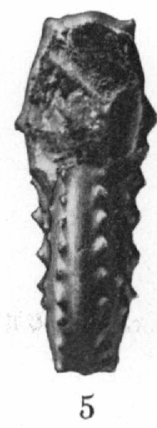

5
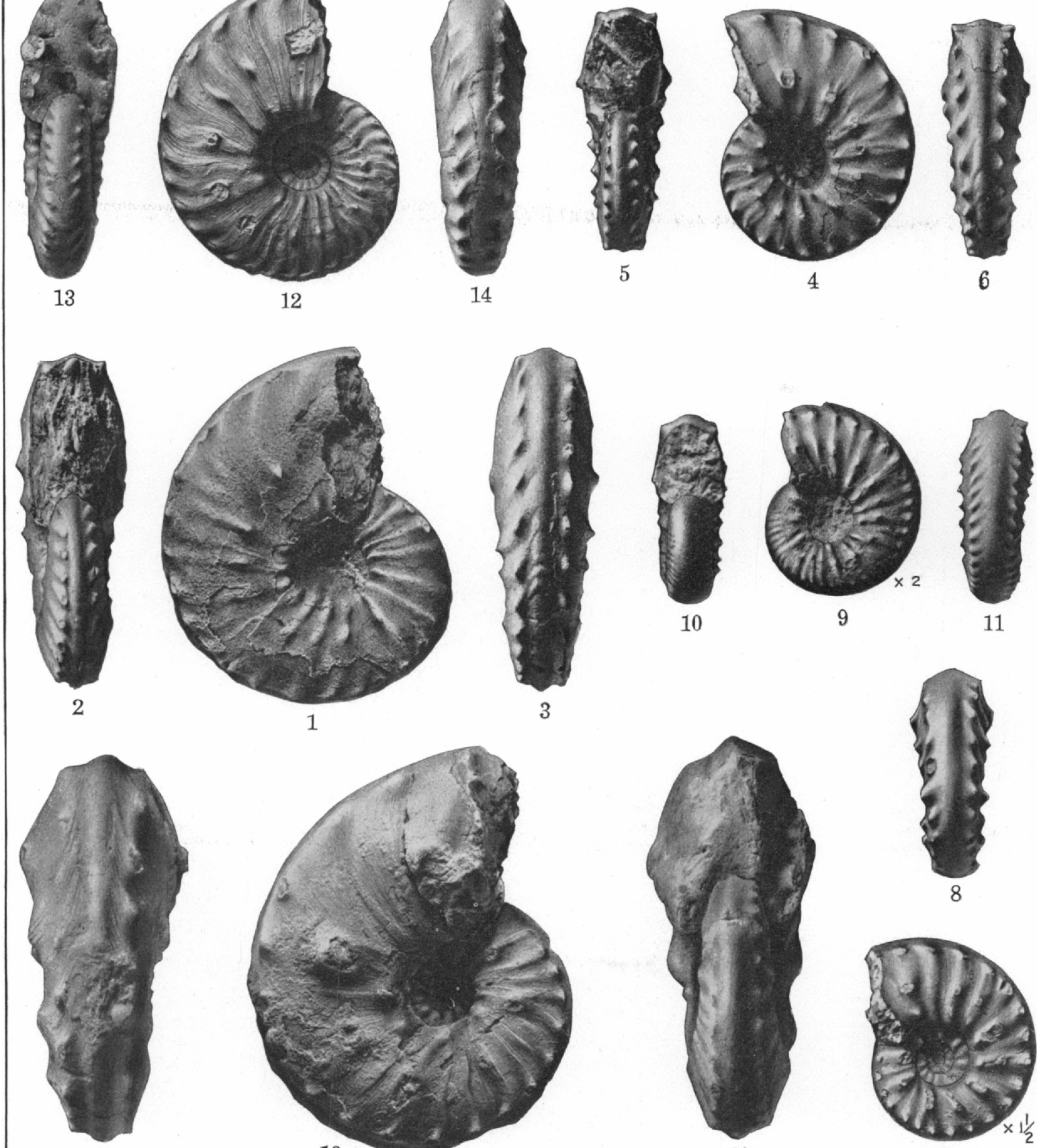

21
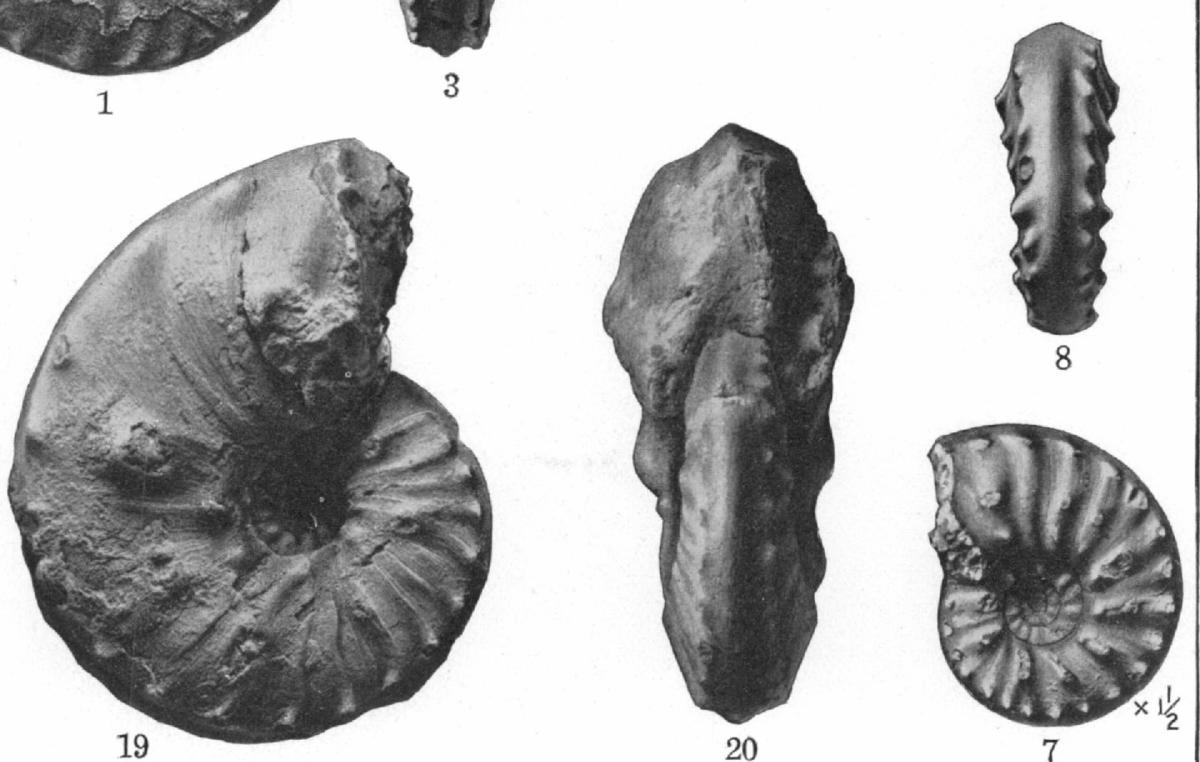


\section{PLATE LII.}

Ceratites (Paraceratites) clarkei Smith, sp. nov. (p. 91).

Figures 1-3. Adult stage.

Figukes 4-6. Larly adult stage; diameter 39 millimeters.

Figures 7 , 8. Adolescent stage $\left(X 1 \frac{1}{2}\right)$ : diameter 22 millimeters.

Figures 9-11. Adolescent stage $(X 2)$; diameter 15 millimeters.

Ceratites (Paraceratites) trinodoscs Mojsisovics (p. 92).

Figures 12-14. Adult stage.

FigUkrs 15-17. Early adult stage (natural size), showing the septa.

Figure 18. Septa of the sime specimen $(\times 2)$.

Ceratites (Paraceratites) burckhardti Smith, sp. nov. (p. 90).

FIgURES 19-21. Type specimen (natural size).

All specimens figured on this plate are from the Middle Triassic. Daonella dubia zone, Fossil Hill, south fork of American Canyon, West Humboldt Range, Nev.; all belong in the collection of the Inited States Geological Survey.

$16279^{\circ}-$ No. $83-14-24$ 


\section{PIATE TIIII.}

\section{Ceratites fissicostatus Hauer (p. 96).}

Figuris 1-3. Adult specimen (natural size).

Ceratites (Paraceratites) ward Smith, sp. nov. (p. 94).

Figures 4-6. Tyle specimens $\left(\times 1 \frac{1}{2}\right)$; diameter 39 millimeters.

Figures 7,8 . Diameter 43 millimeters $\left(\times 1 \frac{3}{2}\right)$.

Ceratites aprianates Smith, sp. nov. (p. 80).

Figures 0-11. Type specimen $\left(\times 1 \frac{1}{2}\right)$.

Figures 12,14 . Adolescent stage $(\times 2)$; diameter 15 millimeters.

All specinens figured on this plate are from the Middle Triassic, Daonclla dubia zone, of Fossil Hill, south fork of American ('anyon. West Humboldt Range, Nev., and belong in the collection of the United States Geological Surrey. 


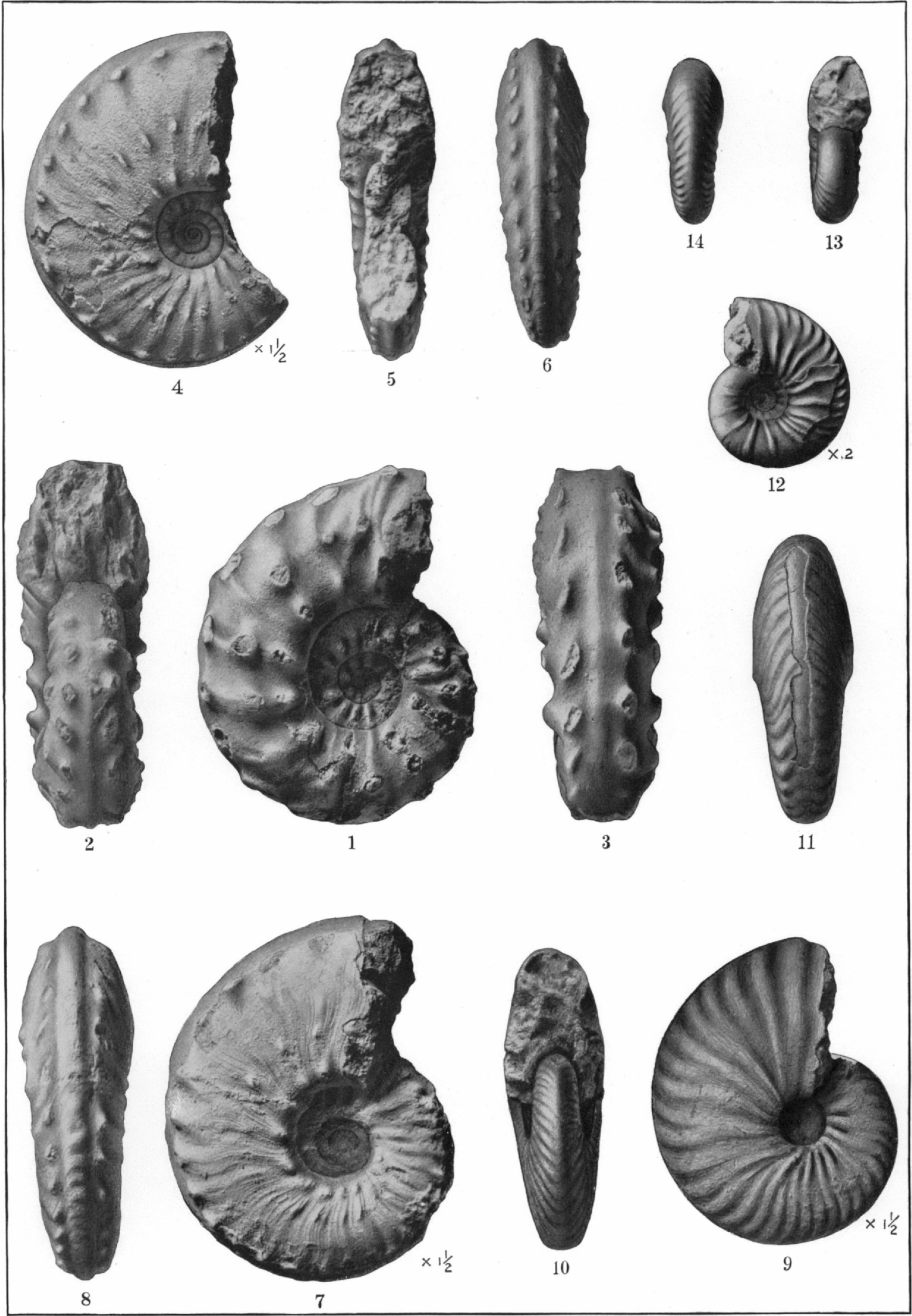




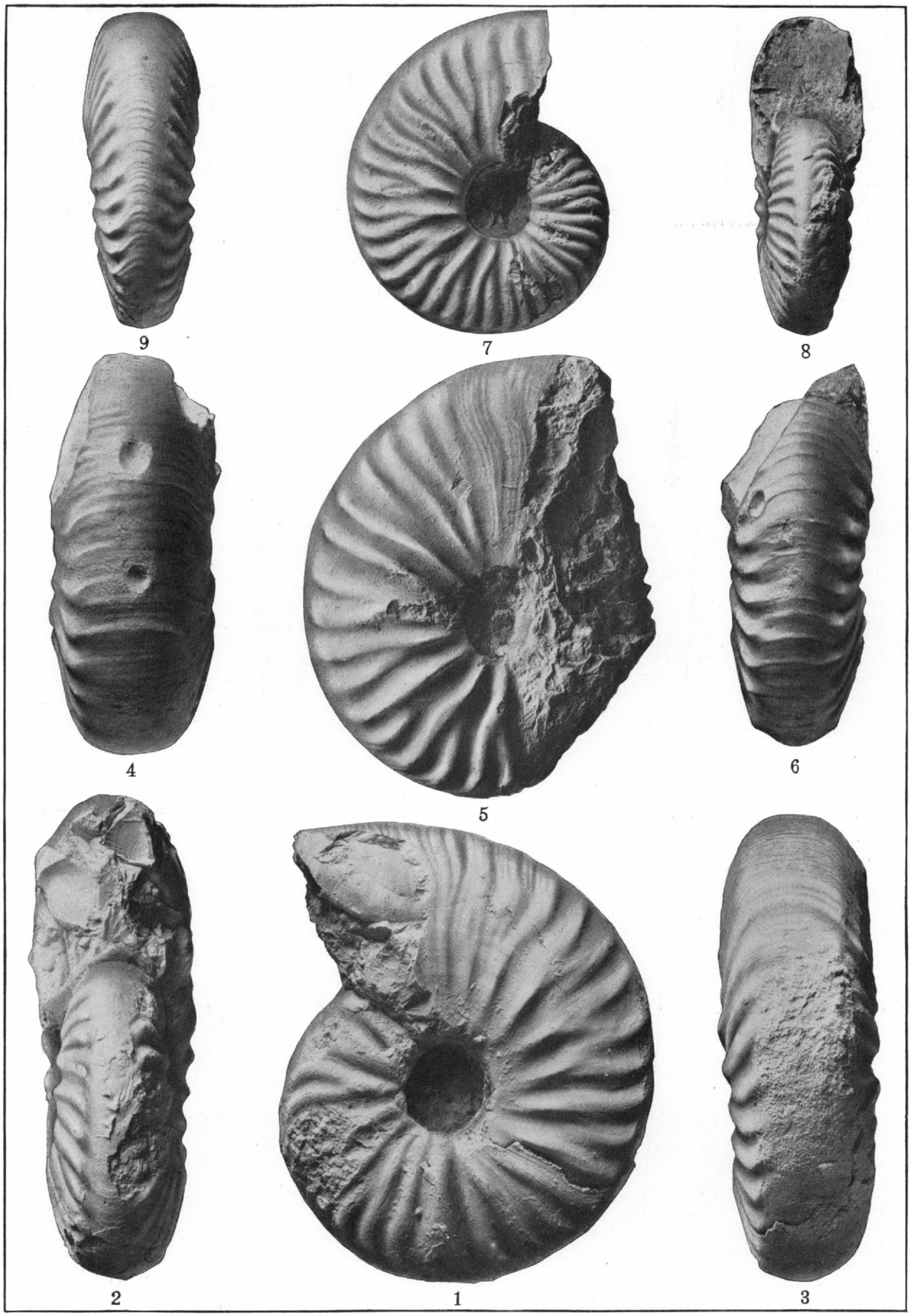




\section{PLATE LIV.}

Ceratites (Hollaxdites) orgaxi Smith, sp. nov. (p. 105).

Figures 1-4. Type specimen.

Figures 5, 6. Mature specimen, showing the sculpture crossing the venter.

Figures 7-9. Early mature stage, showing the beginning of the shoulder knots.

The originals of all specimens figured on this plate are from the Middle Triassic, Daonella dubia zone, Fossil Hill, south fork of American Canyon, West Humboldt Range, Nev., and are in the collection of the United States Geological Survey. 


\section{PLATE LV.}

\section{Ceratites (Hollandites) organi Smith, sp. nov. (p. 105).}

Figure 1. Mature stage, slowing the septia (uatural size).

Figure 2. Septa of the same specimen $(X 2)$.

Figure 3. Late adolescent stage (natural size); diameter 47 millimeters.

IIGURe 4. Septa of the sime $(X 2)$.

Figcres 5, 6. Adolescent stage (natural size); diameter 40 millimeters.

Figure 7. Septa of the same $(\times 2)$.

Figures 8,9 . Adolescent stage (natural size); diameter 32 millimeters.

Figure 10. Septa of the same $(\times 2)$.

Figures 11,12 . Alolescent stage $\left(X 1 \frac{1}{2}\right)$; diameter 20 millimeters.

Figtres 13-15. Adolescent stige $(X 2)$; diameter 15 millimeters.

Figures 16-18. Adolescent stage $(X 2)$, showing Danubites stage; diameter 11.5 millimeters.

Figure 19. Adolescent stage $(X 2)$; diameter 11 millimeters.

Figure 20. Septa of the same $(X 6)$.

Figures 21, 22. Larly adolescent stage $(X 3)$, showing the beginning of the septil at 7 millimeters; diameter 9 millimeters.

Figures 24-26. Iarval stage $(X 15)$; diameter 1.7 millimeters.

Figures 27-29. Larly adolescent stage $(X 2)$; diameter 12 millimeters.

Figure 30. Septa of the same $(\times 6)$.

The originals of all specimens figured on this plate are from the Middle Triassic, Daonclla dubia zone, Fossil Hill, south fork of American Canyon, West Humboldt Range, Ner. They are in the collection of the Tnited States Geologienl survey, with the exception of the original of figures 3 and 4, which is in the collection of J. P. Smith. 


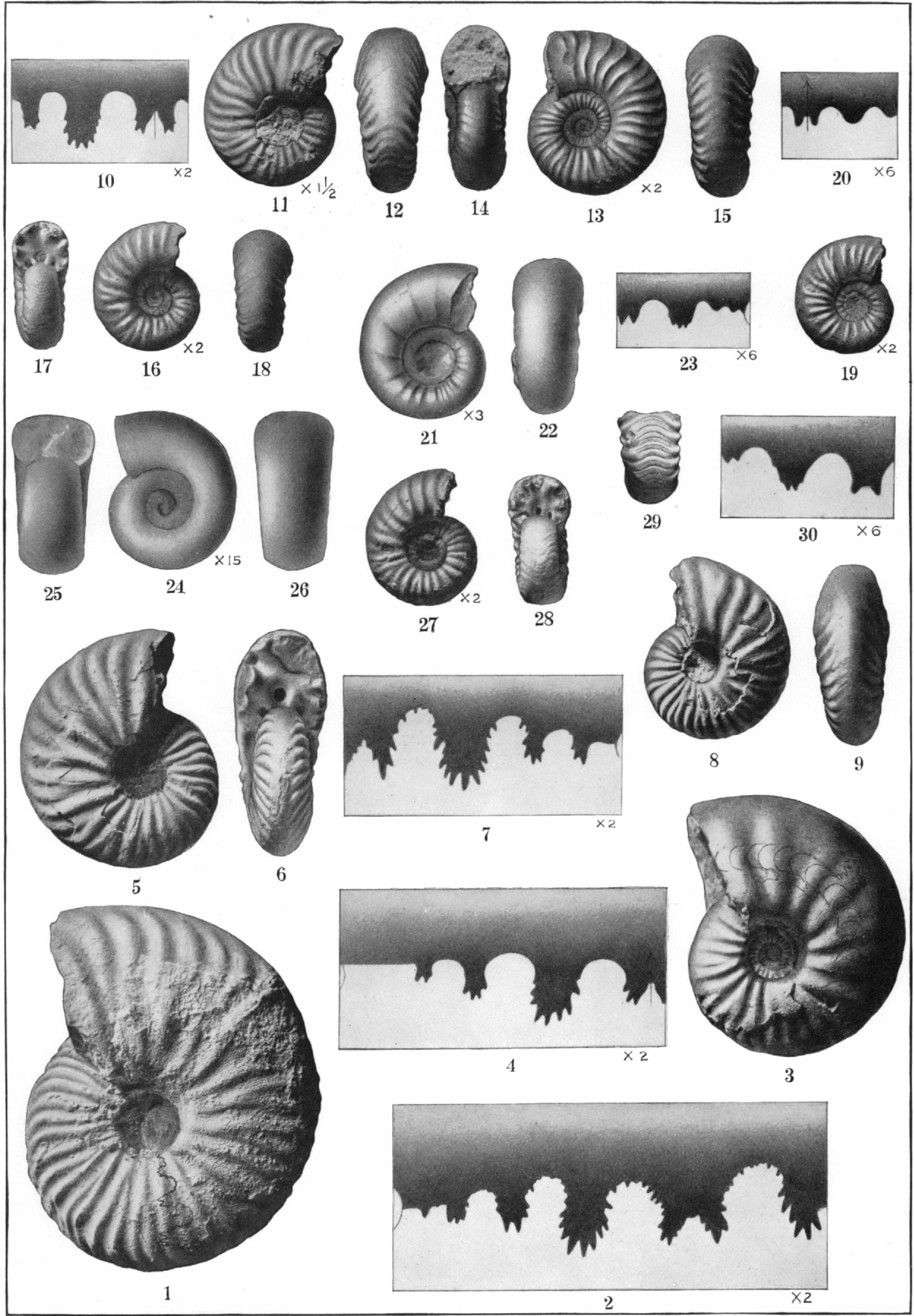



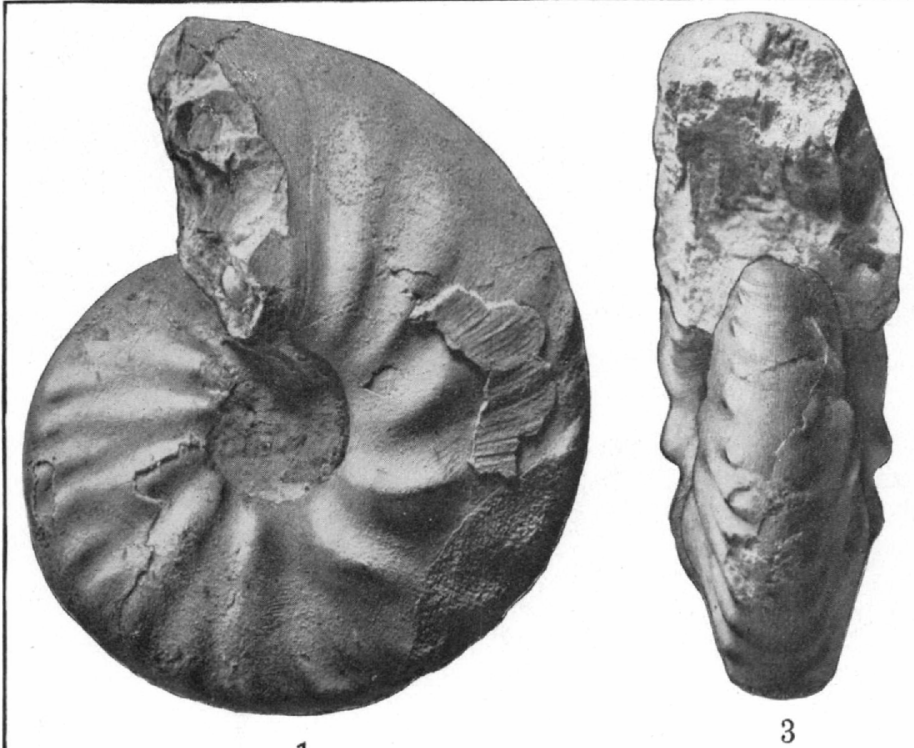

1
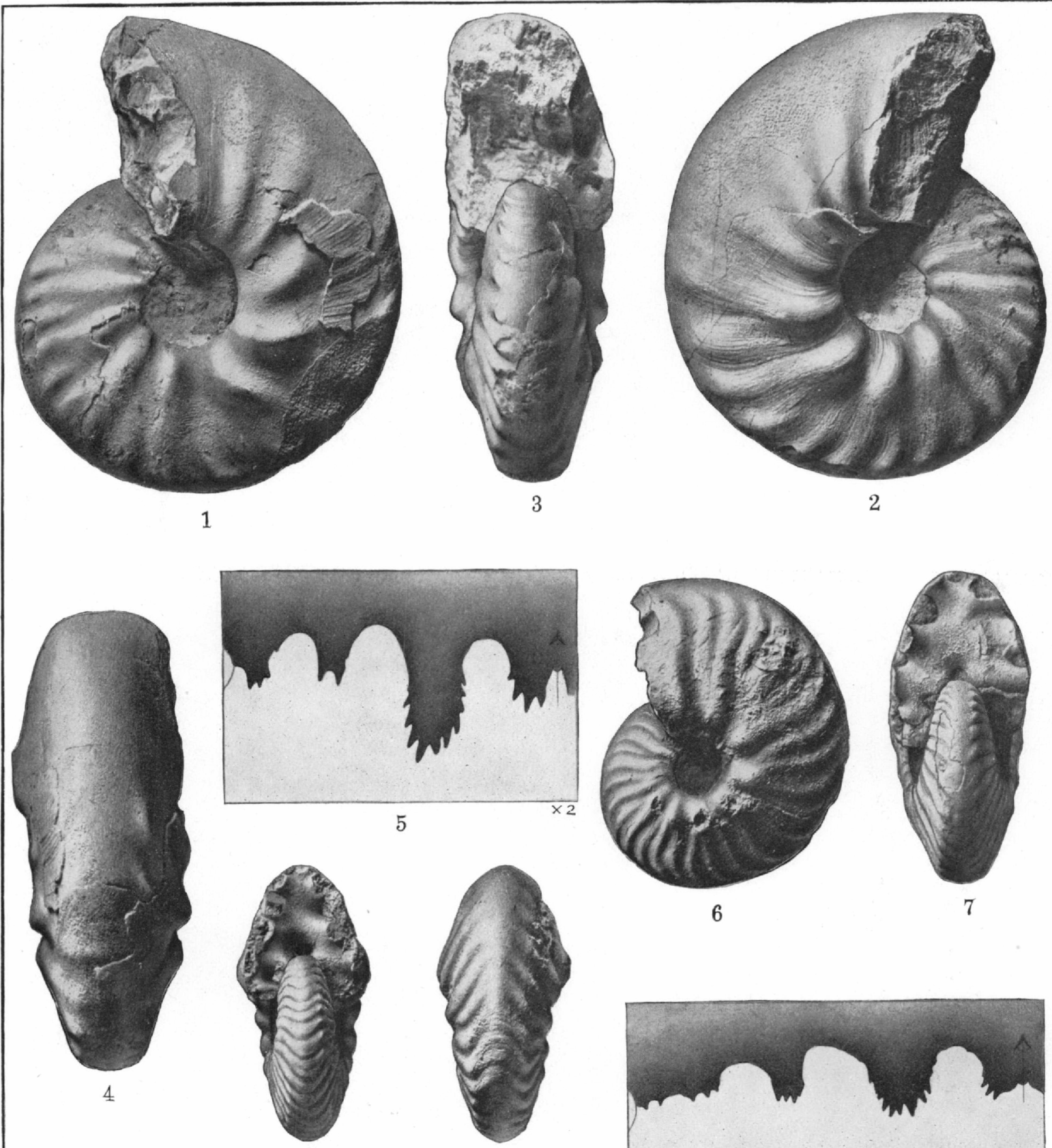

10

11
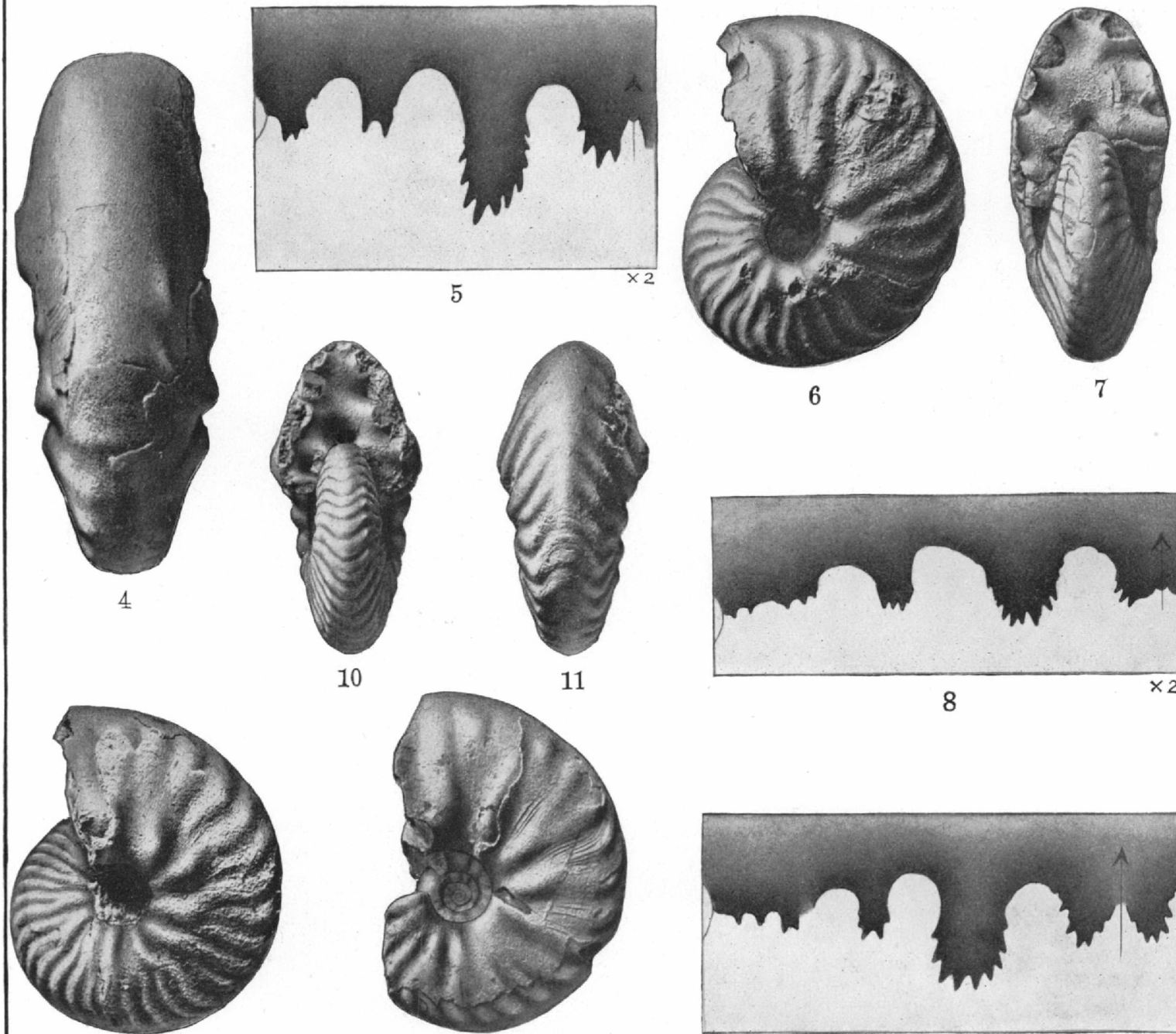

9

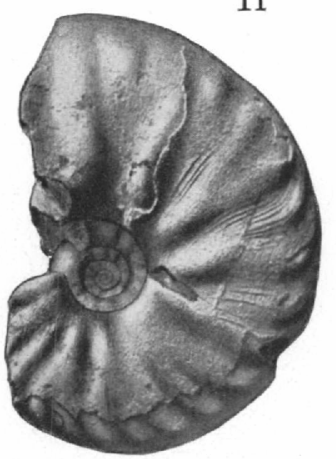

12

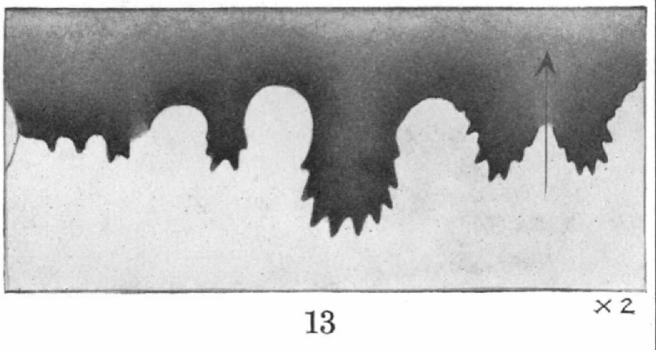




\section{PLATE LVI.}

Ceratites (Philiptites) lawsoni Smith, sp. nov. (p. 108).

Figtoris 1-4. Type (natural size).

Figure 5. Septa of the type $(\times 2)$.

Figcres 6, 7. Early nature stage (natural size).

Figure 8. Septa of the silme $(\times 2)$.

Figures 9-11. Early mature stage (natural size).

Figures 12, 13. Early mature stage, shell (natural size) and septa $(\times 2)$.

All specimens figured on this plate are from the Mildle 'lriassic, Daonella dubia zone, Fossil Hill, south fork of Americin Canyon, West Humboldt Ringe, Nev. They are in the collection of the Tnited States Genlogical Survey.

$16279^{\circ}-$ No. $83-14-25$ 


\section{PLATE LVII.}

Ceratites (Philiplites) lawsoni Smith, sp. nov. (p. 108).

Figures 1-3. Transition from adolescence to maturity (natural size); diameter 37 millimeters. Figures 4-6. Aclolescent stange $\left(\times 1 \frac{1}{2}\right)$; diameter 29 millimeters. Figures $7-9$. Adolescent stage $\left(\times 1 \frac{1}{2}\right)$; diameter 23 millimeters.

Figures 10-12. Adolescent stage $(X 3)$, resembling Keyserlingites; diameter 15 millimeters. Figure 13. Septal of the same $(X 6)$.

Figures 14-16. Farly adolescent stage $(X 6)$, resembling Olenikites; diameter 10 millimeters. Figure 17. Septa of the same $(X 8)$.

All specimens figured on this plate are from the Midlle Triassic, Daonclla dubia zone, Fossil Irill, sonth fork of American Canyon, West Humboldt Range, Nev. They are in the collection of the Lnited States Geological Survey. 


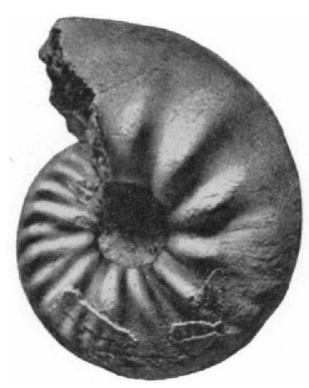

1

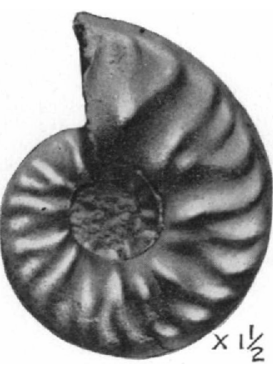

7

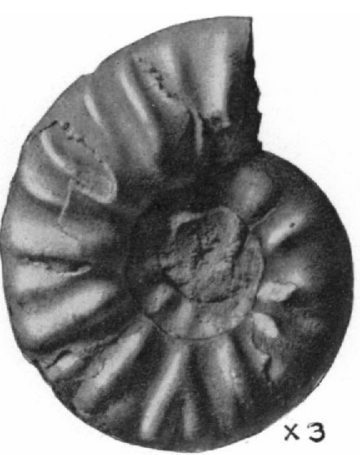

10

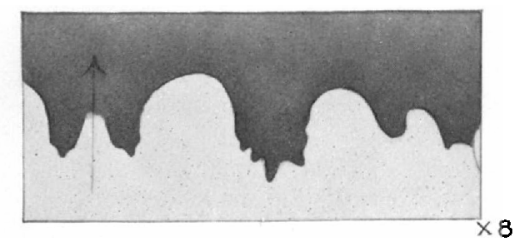

17

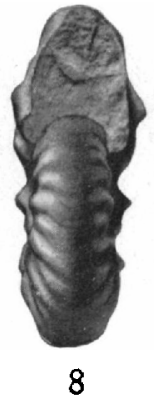

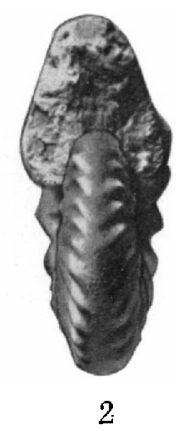
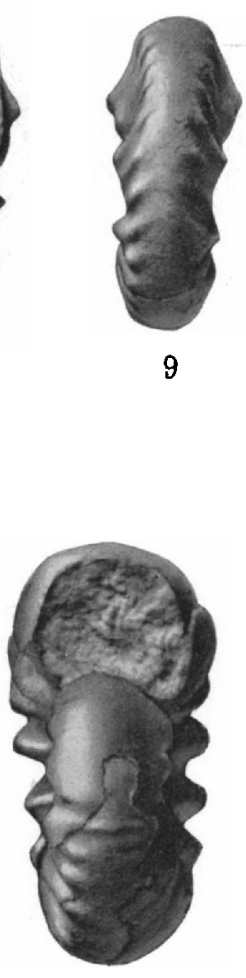

11

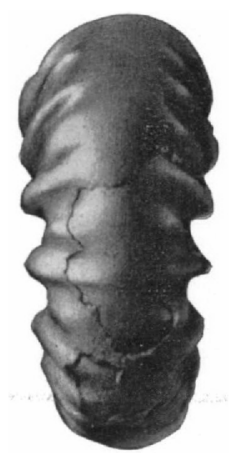

12
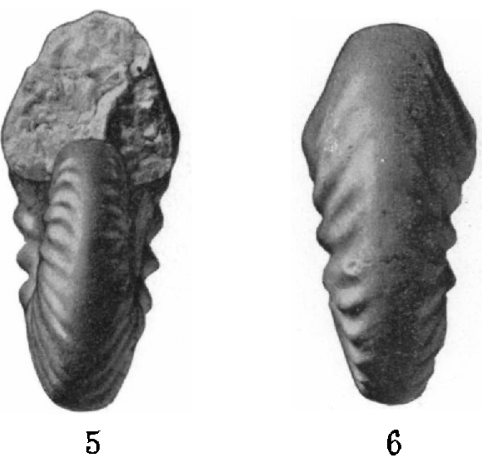

4

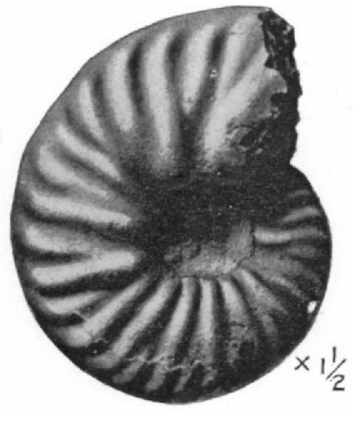




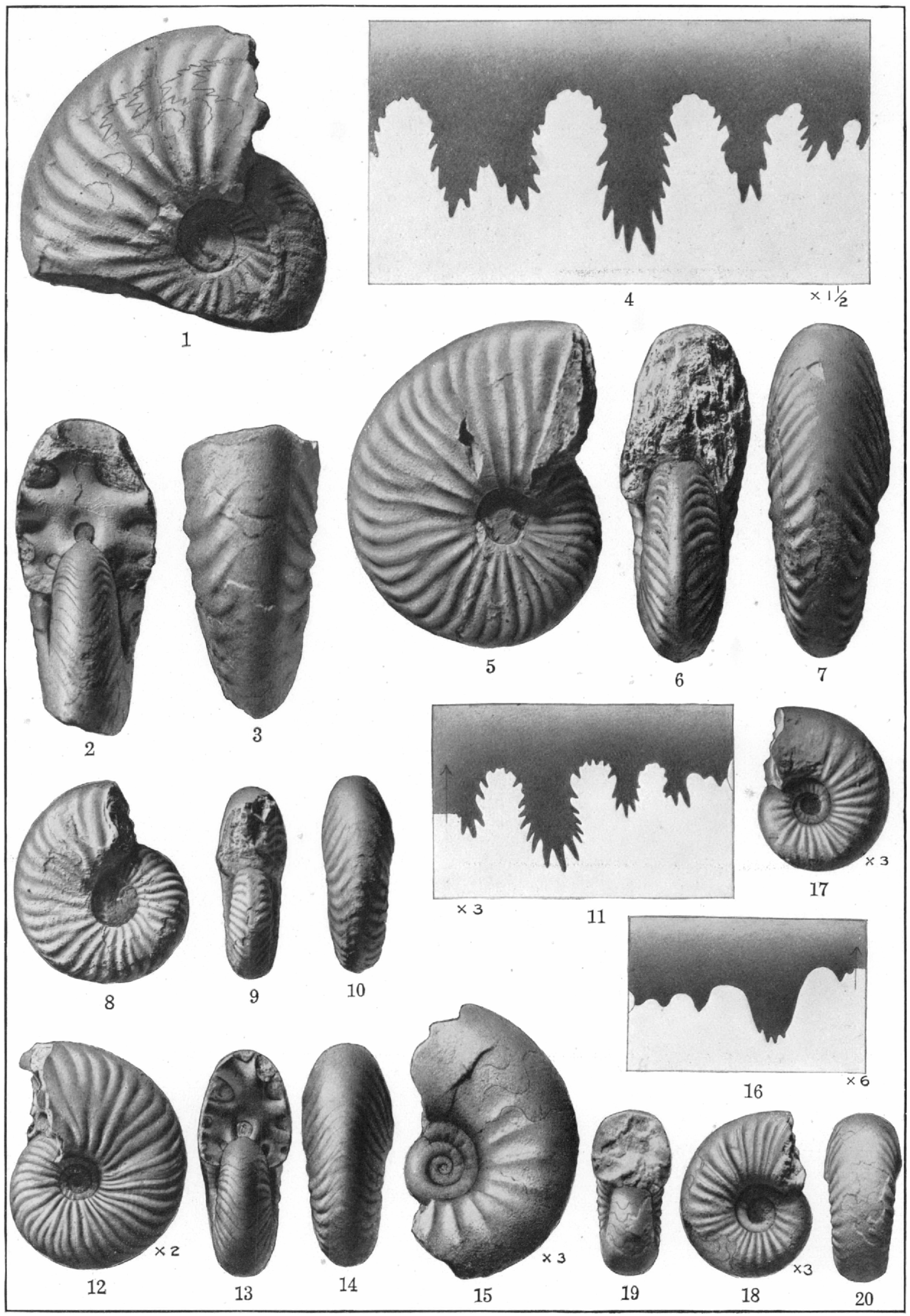




\section{PLATE LVIII.}

Ceratitrs (Holiandites) montis-bovis Smith, sp. nov. (p. 105).

Figures 1-3. Type (natural size).

Figure 4. Septa of the type ( $\left(1_{1}\right)$.

Figurss 5- - . Adult stage. slowing the sculpture.

Figures 8-10. Eilrly adult stage (natural size).

Figure 11. Septil of the same $(X 3)$.

Figures 12-14. Adolescent stage $(X 2)$; diameter 21 millimeters.

Figure 15. Adolescent stage $(X 3)$; diameter 16 millimeters.

Figure 16. Septa of the sime $(\times 6)$.

Figures 17-20. Adolescent stage $(X 3)$ : diameter 10 millimeters.

An specimens figured on this plate are from the Middle Triassic, Daonclla dubia zone, Fossil Hill, south fork of American Canyon, West IIumboldt Range, Ner. They are deposited in the collection of the Lnited States Geological Survey, except the original figures 1-4, which is in the collection of J. P. Smith. 


\section{PLATE LIX.}

Ceratites spinifer Smith, sp. nov. (p. 103).

Figures 1-3. Type.

Figures t-6. Cotype (natural size).

Figure 7. Septa of the cotype $\left(\times \frac{1}{2}\right)$.

Figures 8-10. Extreme maturity.

All specimens figured on this plate are from the Middle Triassic, Daonella dubia zone, Fossil Hill, south fork of Americaln Canyon. West Humboldt Range, Nev. They are in the collection of the United States Geological Surrey. 


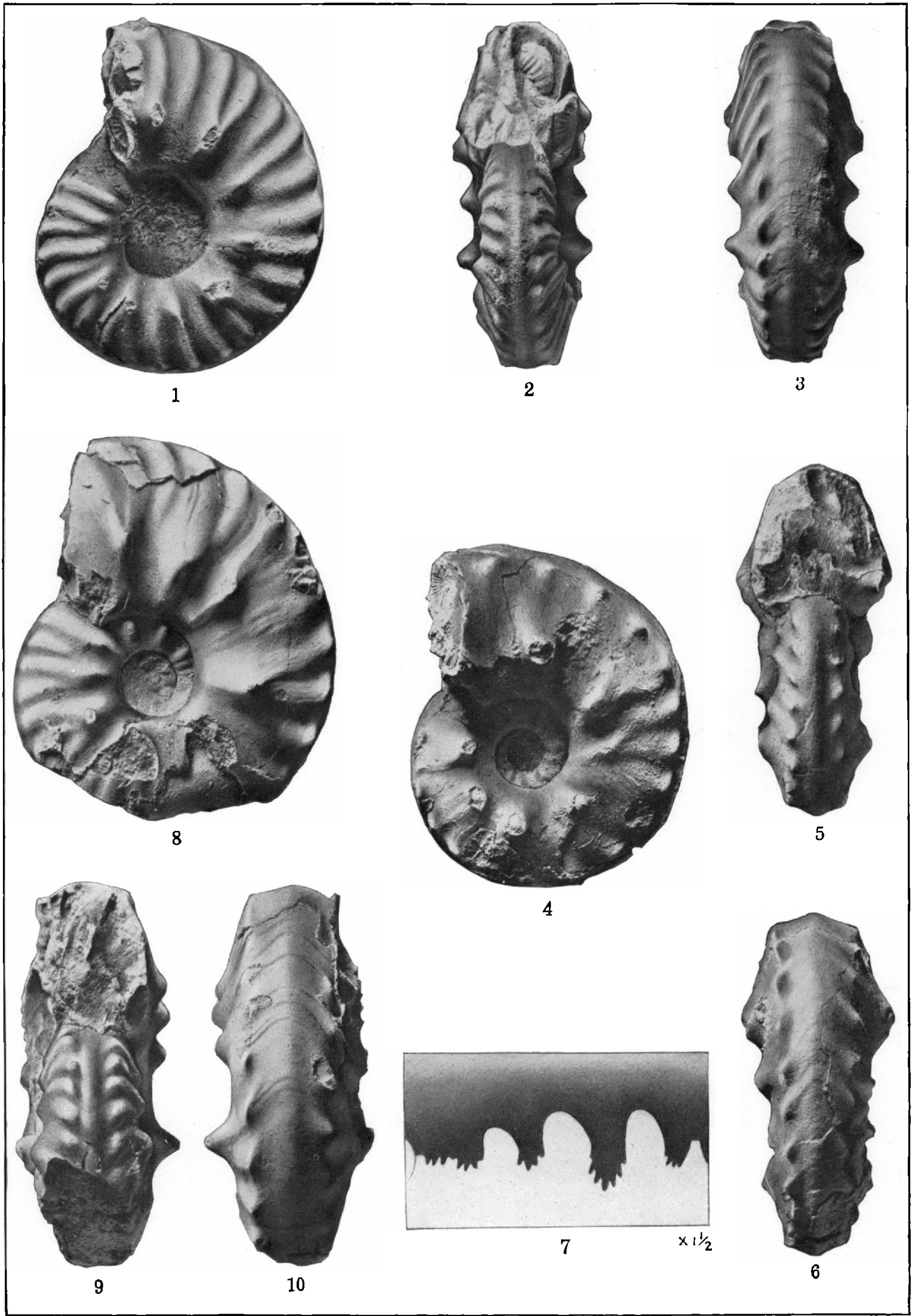




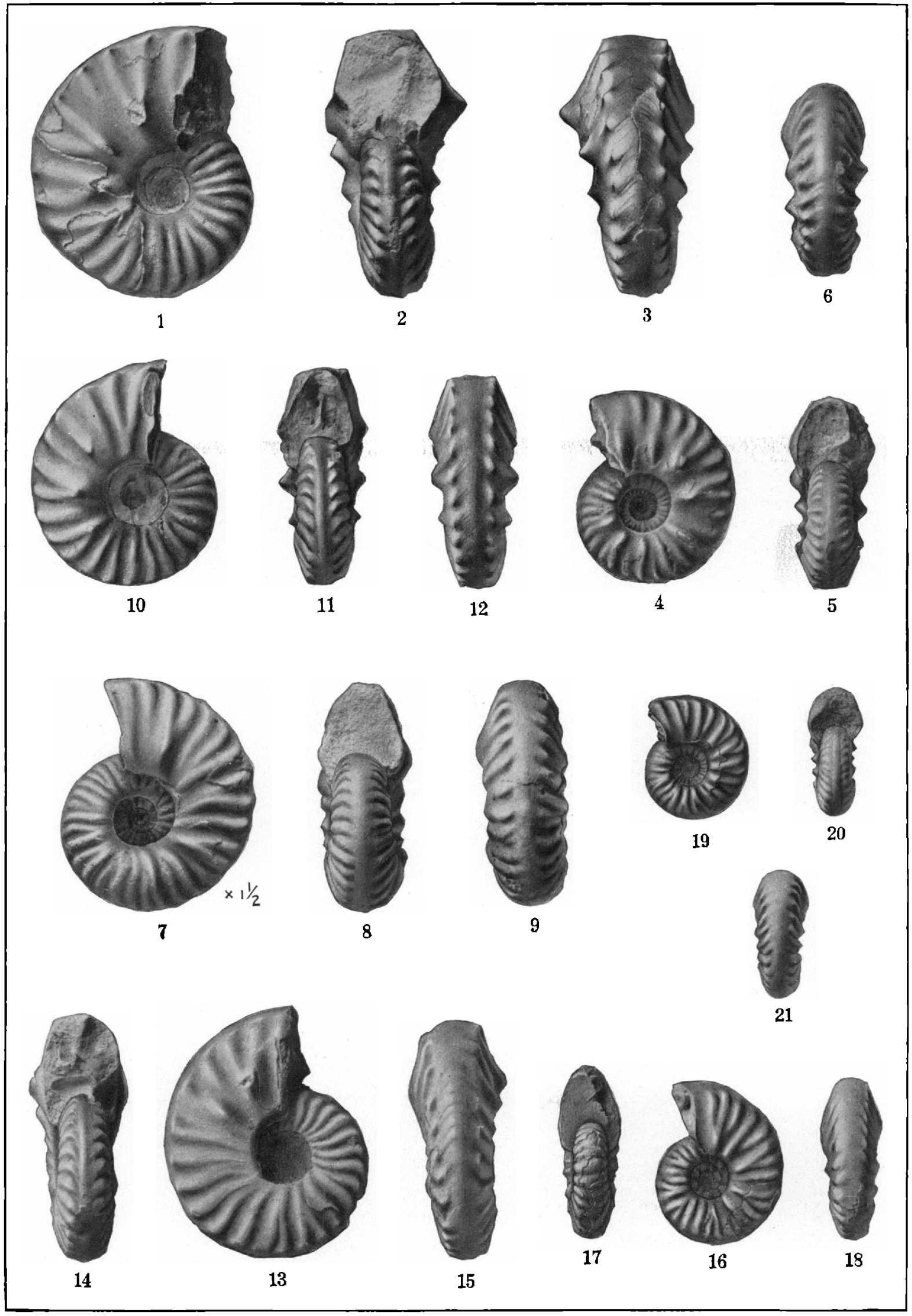




\section{PLATE LX.}

Ceratites spixirer Smith, sp. nov. (p. 103).

Figures 1-3. Farls mature stige.

FigCres 4-6. Transition from adolescence to maturity.

Figures 7-9. Transition from adolescent stage $\left(\times 1 \frac{1}{2}\right):$ diameter 29 millimeters.

Figures 10-12. Eirly mature stage (natural size); diameter to millimeters.

(Ceratites emansi Smith, sp. nov. (p. 98).

Figures 13-15. Trpe (natural size).

Figtras 16-18. Transition from adolescence to maturity.

Figures 10-21. Adolescent stage (nitural size); diameter 22 millimeters.

All specinens figured on this plate are from the Middle Triassic. Daonclla dubia zone, Fossil Hill, south fork of American ('alnyon. West Ilumboldt Range, Nev. They are in the collec. tion of the United States Geological Survey.

$16279^{\circ}-$ No. $83-14-26$ 


\section{PLATE LXI.}

Cenattres incmibolotensis Hyatt and Smith (p. 99).

Figures 1-3. Adult shell.

Figures 4, 5. Adult shell.

Figures 6, 7. Early adult stage.

Figures 8-11. Early adult stage (natural size).

Figure 12. Septa of the same $(\times 2)$.

Figures 13-15. Farly adult stage.

All specimens figured on this plate are from the Middle Triassic, Daonella a ubia zone, Fossil Hill, south fork of American Canyon, West IIumboldt Range, Nev. They belong in the collection of the Inited States Geological Survey, except the original of figures 6 and 7 , which is in the collection of J. P. Smith. 


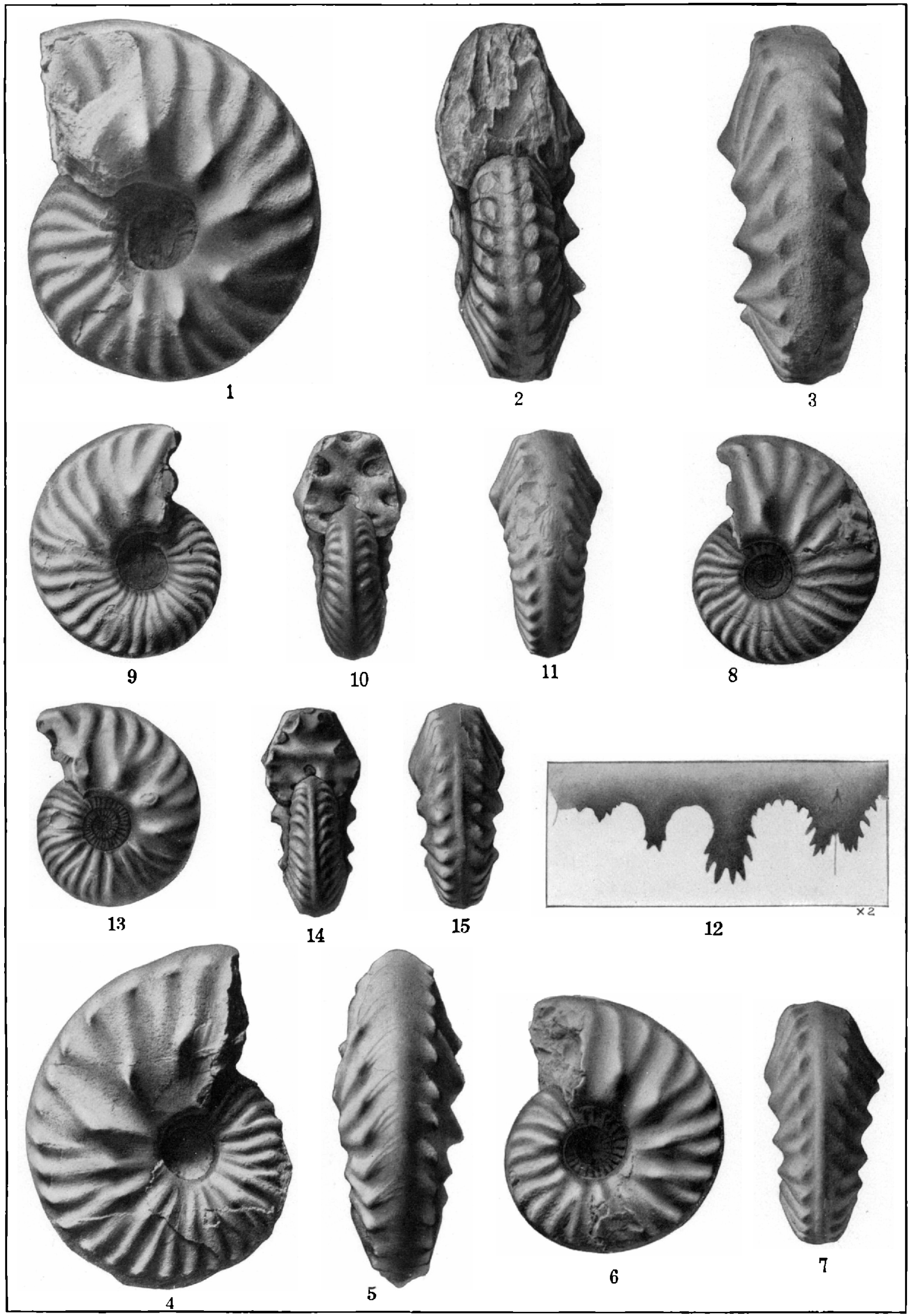




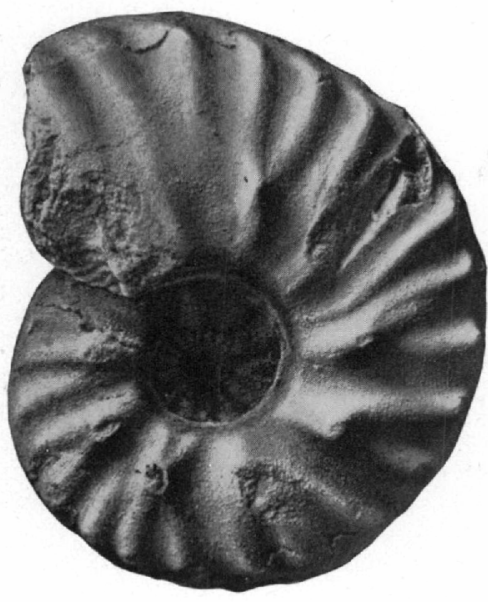

1
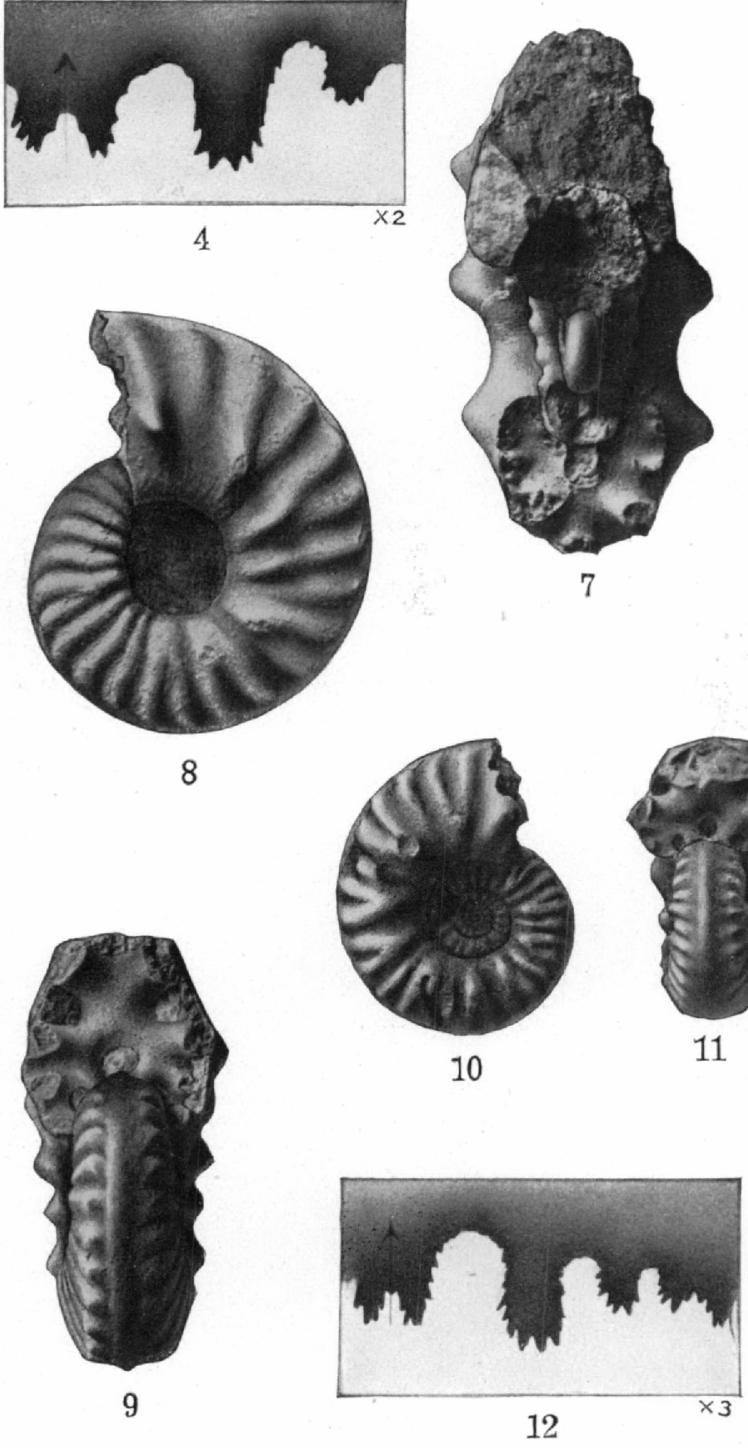

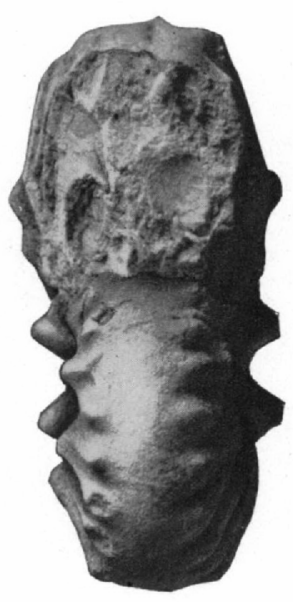

2
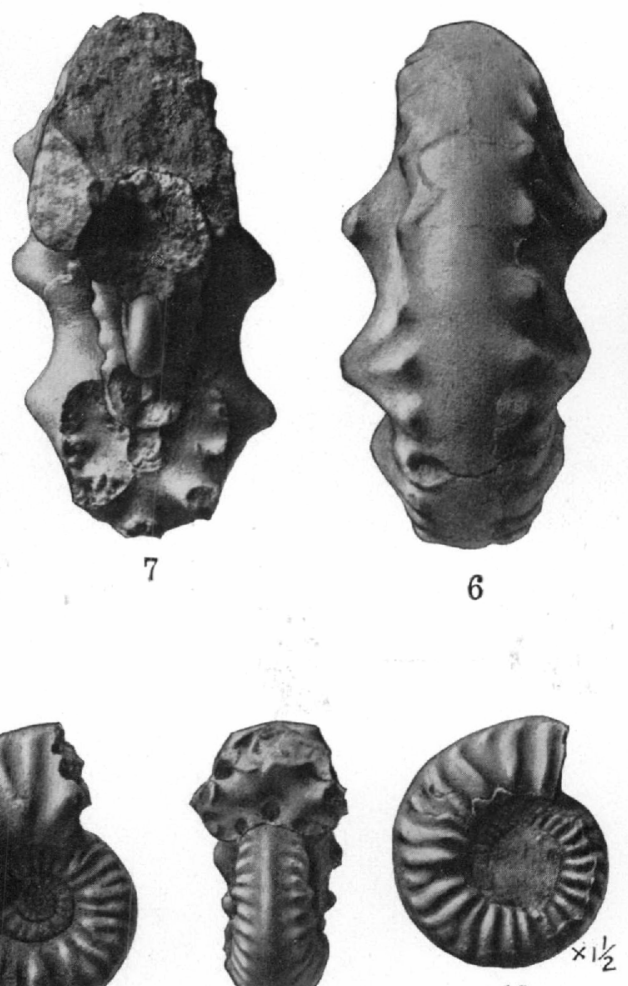

13

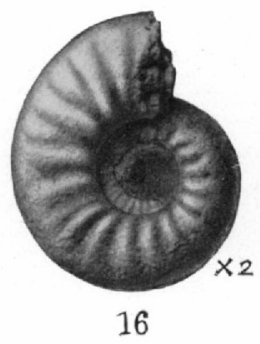

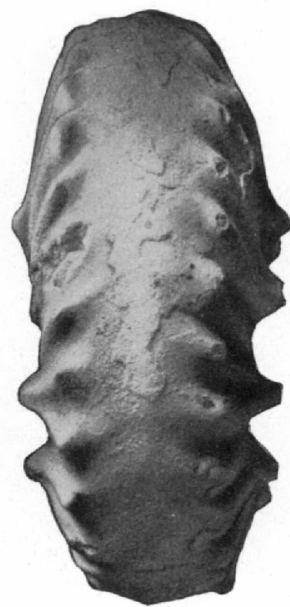

3
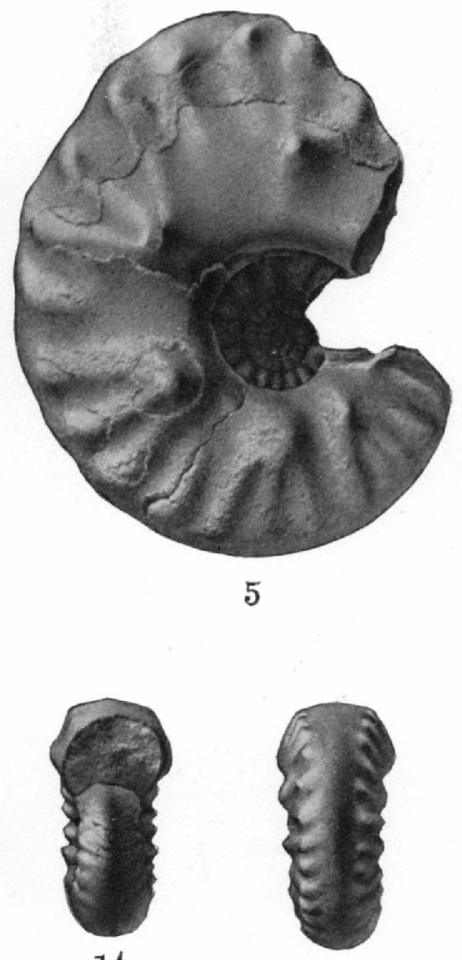

14

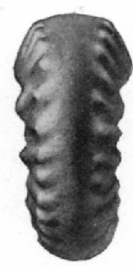

15

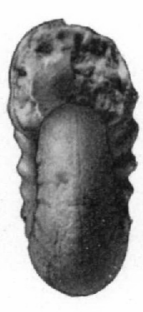




\section{PLATE LAII.}

Cerattites conxutus Smith, sp. nov. (p. 98).

Figures 1-3. Tyle (naturil size).

Figure 4. Septa of the type $(\times 2)$.

Figures $5-\bar{t}$. Adult stage, showing the adolescent whorls inside.

Figures 8, 9. Early adult stage.

Figures 10, 11. Transition from youth to maturity (natural size).

Figure 12. Septa of the sime $(X 2)$.

Figures 13-15. Adolescent stilge $\left(X 1 \frac{1}{2}\right)$ : diimeler 19 millineters.

Figures 16, 17. Early adolescent stage $(X 2)$ : diameter 14 millimeters.

All specimens figured on this plate are from the Middle Triassic. Daonella dubia zone, Fossil IIill, sonth fork of American Canyon. West IIumboldt Range, Nev. They are in the collection of the Thited States Geological survey. with the exception of the original of figures $1-4$, which is in the collection of J P. Smith. 


\section{PLATF LXIIT.}

Ceratites (Philippites) argentakils Smith, sp. not. (p. 107).

Figures 1-3. Type.

Figcress 4-6. Younger adult stage.

Figurrs 7 , 8. Early adult stage.

Figures 9-11. Late adolescent stage $\left(X 1 \frac{1}{2}\right)$; diameter. 30 millimeters.

Figdres 12-14. Adolescent stage $\left(X 1 \frac{1}{2}\right)$; diameter, 19 millimeters.

All specimens figured on this plate are from the Middle Triassic, Daonella dubia zone, Fossil Hill, south fork of American Canyon. West Humboldt Range, Nev. They are in the collection of the United States Geological Survey. 


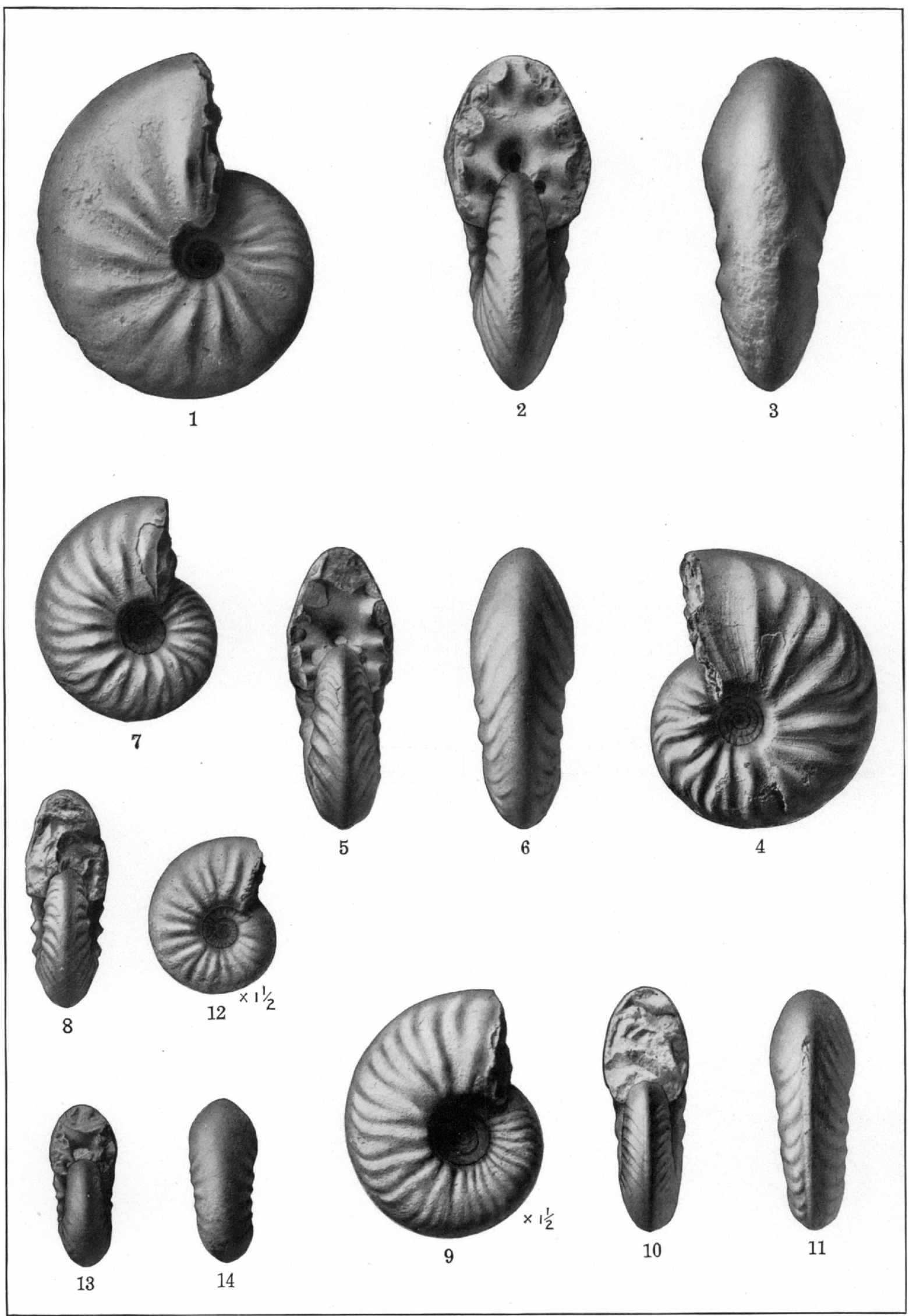




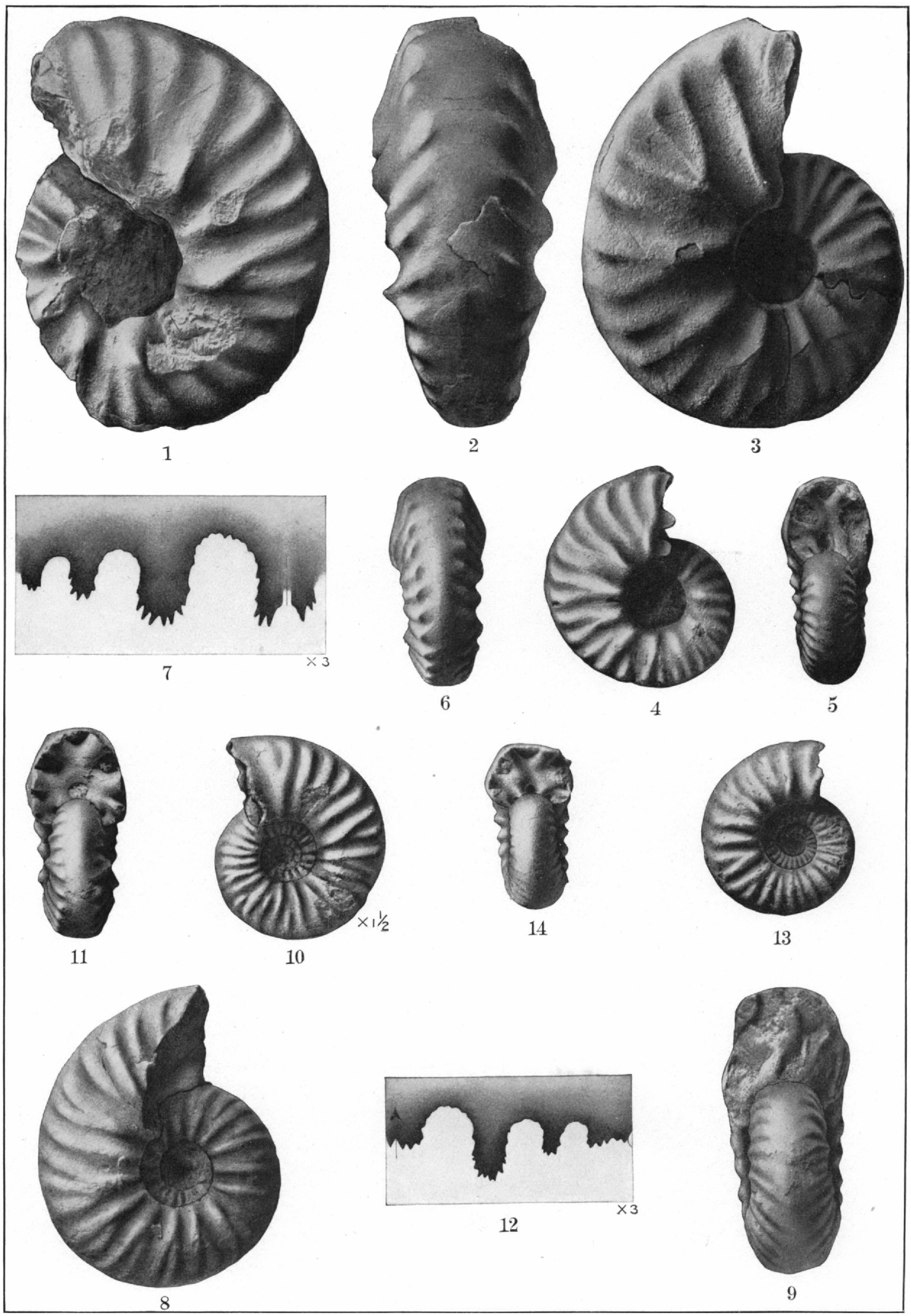




\section{PLATE LXIV.}

Ceratites nevadants Mojsisories (p. 101).

Figdres 1, 2. Side and rear view, milture stage.

Figure 3. Side view of a mature specimen.

Frgures 4-6. Inner whorl of the same specimen, showing early mature stage (natural size); diameter 39 millimeters.

Figure 7 . Septa of the same specimen $(X 3)$.

Figures 8, 9. Mature stage (natural size).

Figures 10,11 . Adolescent stage $\left(X 1 \frac{1}{2}\right)$; diameter 26 millimeters.

Figtre 12. Septal of the sime $(X 3)$.

Figures 13, 14. Adolescent stage $\left(X 1 \frac{1}{2}\right)$; diameter 20 millimeters.

All specimens figured on this jlate are from the Middle Triassic, Daonella dubia zone, Fossil Hill, south fork of American Canyon, West Humboldt Range, Nev. They are in the collection of the Cuited States Geological Survey.

$16279^{\circ}-$ No. $83-14-27$ 


\section{PLATE LXV.}

\section{Ceratites nevadaxes Mojsisovics (p. 101).}

FIgUres 1-3. Adolescent stage $\left(X 1 \frac{1}{2}\right)$; diameter 20 millimeters.

Figure 4. Septa of the same $(X 4)$.

Figures 5-7. Adolescent stage $(X 2)$; diameter 18 millimeters.

Figures 8,9 . Adolescent stage $(\times 2):$ diameter 13 millimeters.

Figures 10, 11. Adolescent stage $(X 3)$; diameter 10 millimeters.

Fıgcis 12, 13. Adolescent stage $(X+)$; diameter $S$ millimeters.

\section{Ceratites (Gy maxotoceras) blakei Gabb (p. 109).}

Figures 14-16. Adult form. slowing the falciform ribs and the fine growth lines crossing the venter. Figures 17, 18. Early mature stige (natural size).

Figure 19. Septa of the same $(\times 2)$.

All specimens figured on this plate are from the Middle Triassic, Daonella dubia zone, Fossil Hill, south fork of American Canyon. West Humboldt Range, Ner. They are in the collection of the United States Geological Survey. 


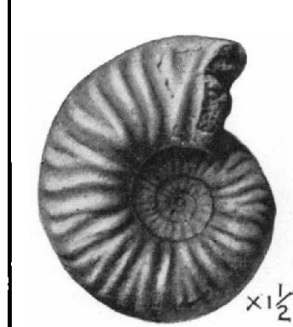

1
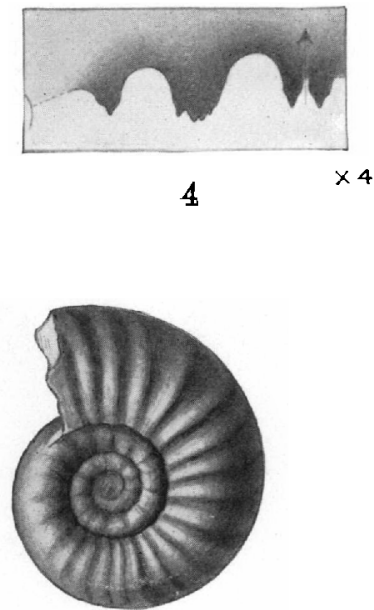

10
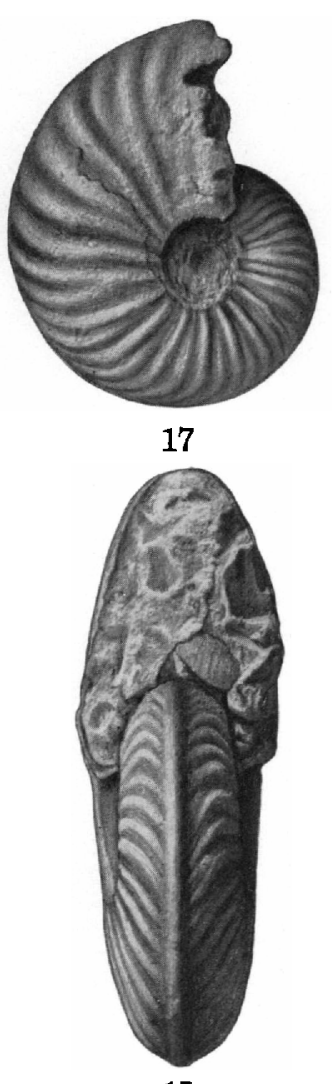

15

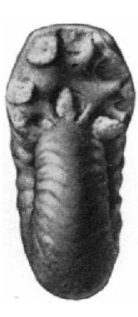

2

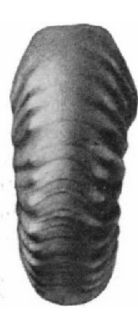

3

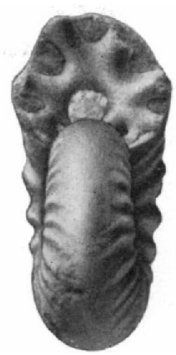

6

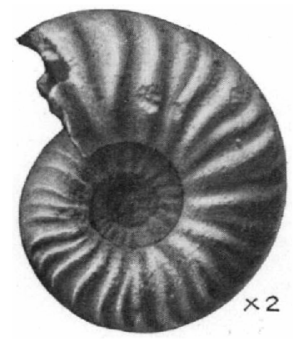

5
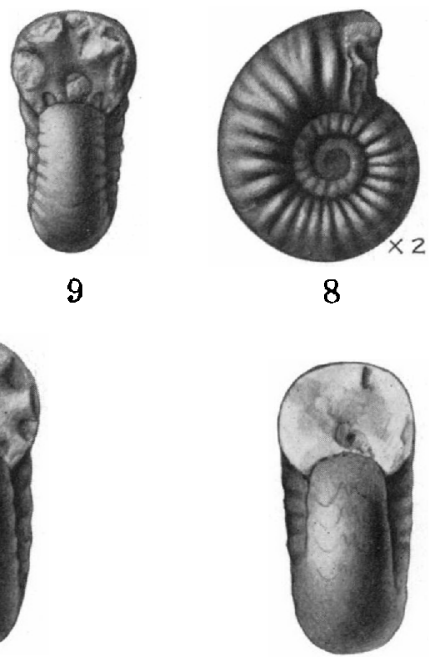

13

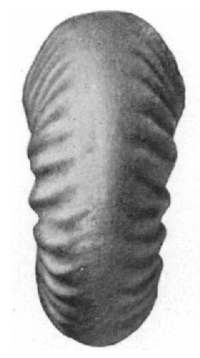

7

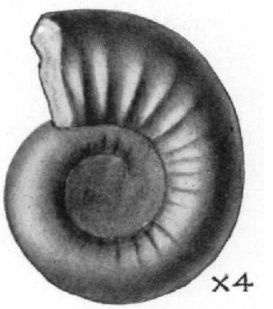

12

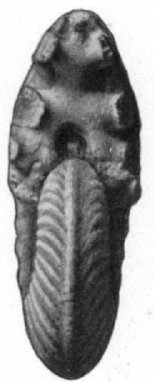

18

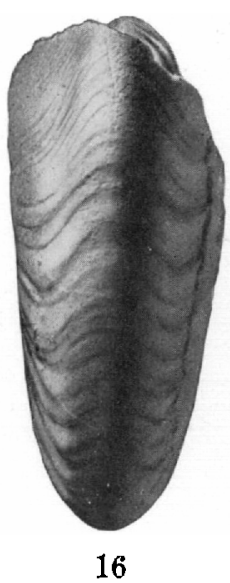




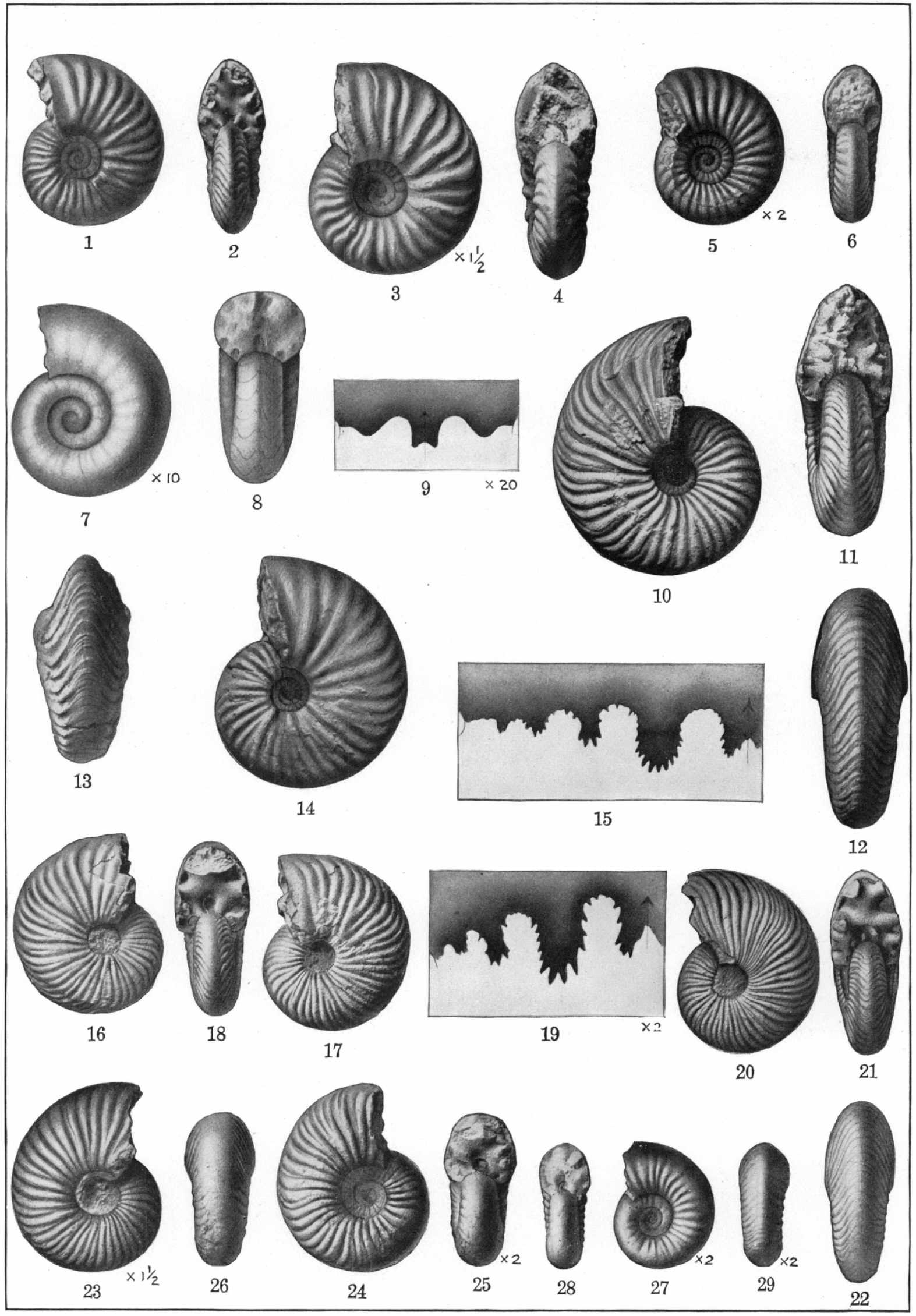




\section{PLATE LXVI.}

\section{Ceratites (Gymnotoceras) blakei Gabb (p. 109).}

Figures 1, 2. Early mature stage (natural size).

Figures 3, 4. Transition from adolescence to maturity $\left(\times 1 \frac{1}{2}\right)$ : diameter $2(;$ millimeters.

Figures 5, 6. Adolescent stige $(\times 2)$ : diameter 14 millimeter's.

Figures 7 , 8. Larval stage $(\times 10)$, corresponding to Lecanites: diameter 3 millimeters.

Figdre 9. Septa of the same $(\times 20)$.

Ceratites (Gymnotoceras) beckeri Smith, sp. nov. (p. 109).

Figures 10-13. Type specimen (figured in J. P. Smith. the complarative stratigraphy of the marine Trias of western America, Proc. Californja Acad. Sci., 3d ser., Geology, vol. 1, No. 10, 1904, Pl. XI.III, fig. 9, Pl. XLIV, fig. 2, as ( 1 . blakei).

Figure 14. Cotype (nitural size).

Figure 15. Septa of the silme $(\times 2)$.

Figures 20-22. Early miture stage (natural size).

Figure 19. Septa of the same $(\times 2)$.

Figuris 20-22. Larly mature stige (natural size).

Figure 23. Farly mature stige $(X 11)$ : diameter 23 millimeters.

Figubes 24-26. Late adolescent stage: side riew $\left(X 2 \frac{1}{2}\right)$ : front and rear $(\times 2)$; diameter 14 millimeters.

Figures $2 \bar{\tau}-29$. Adolescent stage $(X 2)$; diameter 11 millimeters.

All specimens figured on this plate are from the Middle Triassic Daonclla dubia zone, Fossil Hill, south fork of American Canyon. West Humboldt Range, Nev. They are in the collection of the T'nited States Geological Survey, except the originals of figures 10-15, which are in the collection of J. P. Snith. 


\section{PLATE LXVII.}

Ceratites (Gymotoceras) resselni Smith, sp. nov. (p. 111).

Figdres 1-3. Adult specimen.

Figures 4-6. Adult stage, showing the septa.

Figure 7 : Septa of the same $(X 2)$.

Figures 8, 9. Early adult stage, showing the aperture.

Figures 10-12. Late adolescent stage.

Figuri:s 13-15. Earlier adolescent stage $(X 2)$; diameter 16 millimeters.

Cerattes (Grinotochens) spleri Smith, sp. nov. (p. 112).

Figuris 16-18. Type specimen (natural size).

Ceratittes altilis Smith, sp. nov. (p. 83).

Figuris 19-21. Type specimen.

All specimens figured on this plate are from the Middle Triassic, Daonclla dubia zone. of Fossil Hill, south fork of American Canyon, West Humboldt Range, Nev. They all belong to the collection of the Tnited States Geological Survey.

216 

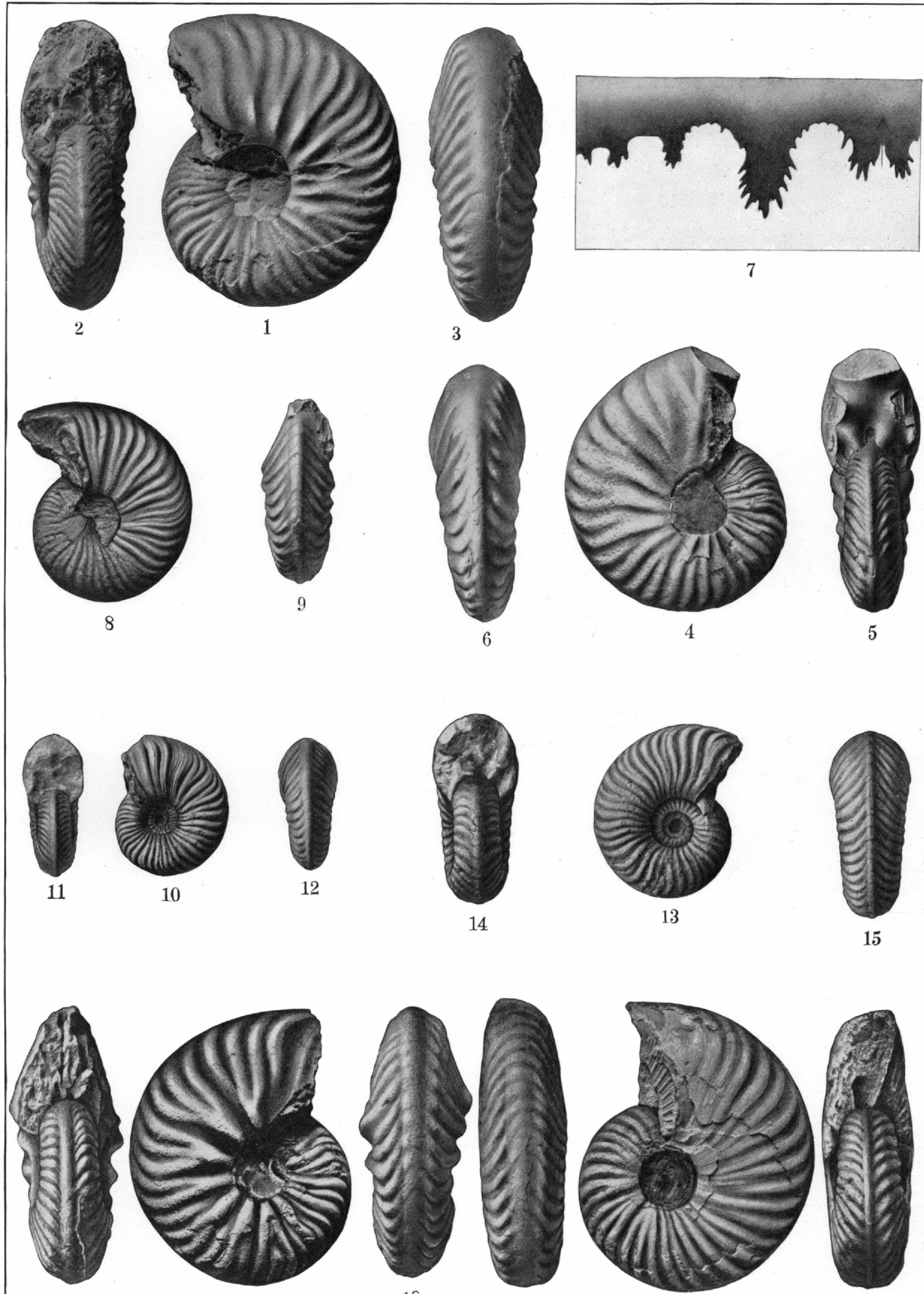

17

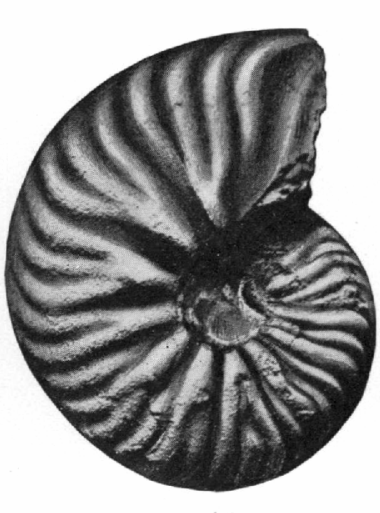

16
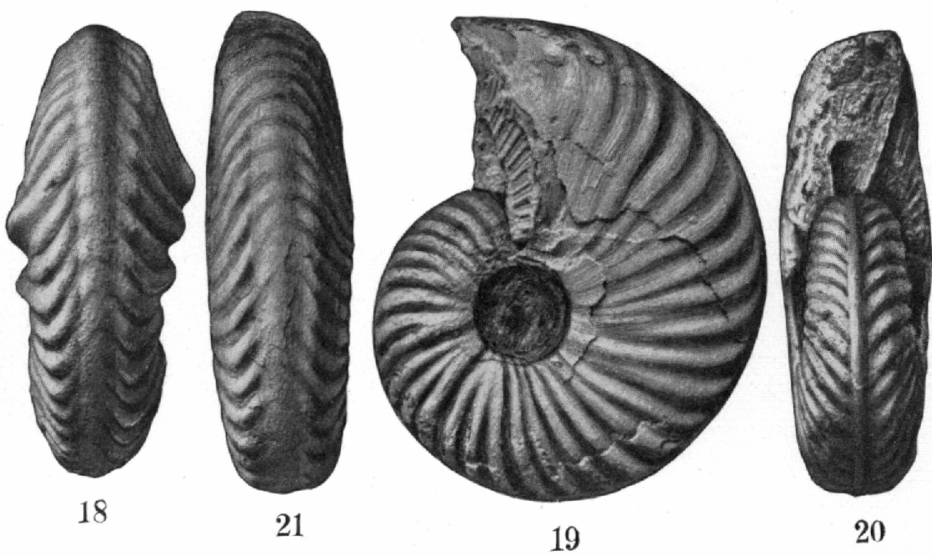

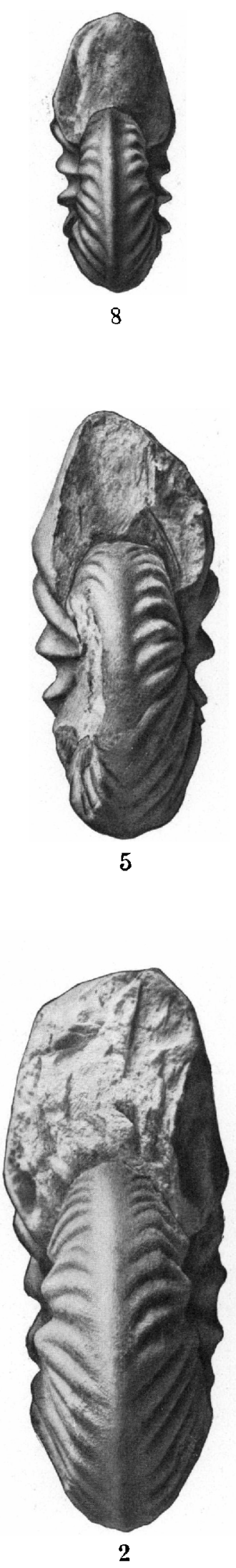
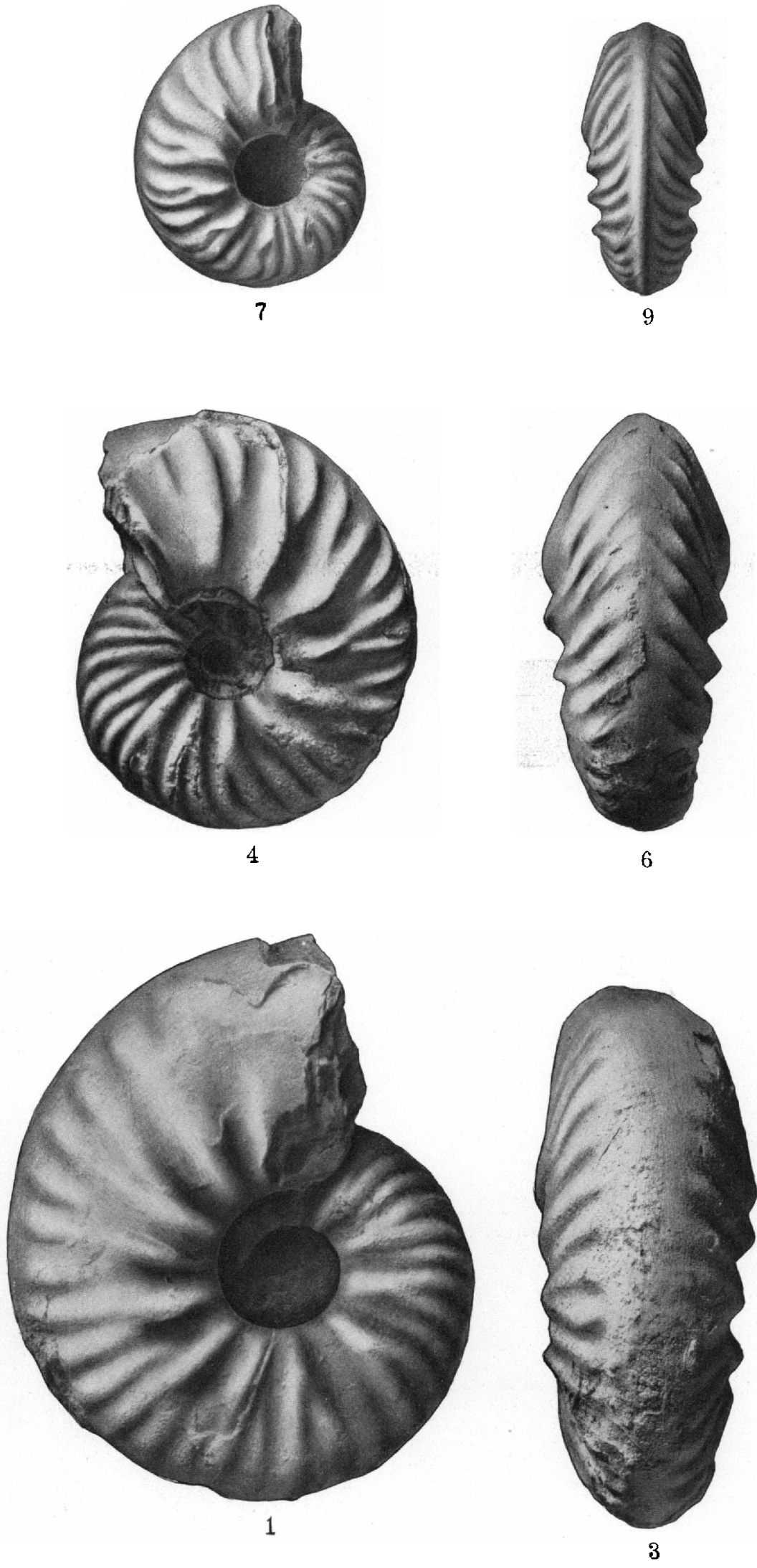


\section{PLATE LXVIII.}

Ceratites (Gyminotoceras) wemplei Smith, sp. nov. (p. 113).

Figures 1-3. Type specimen.

Figures 4-6. Smaller adult specimen.

Figures 7-9. Early mature stage.

All specimens figured on this plate are from the Middle Triassic. Damclla aubia zone, of Fossil Hill, south fork of American Canyon, West Humboldt Range, Nev. Tliey belong to the collection of the Lnited States Geological Surrey.

$16279^{\circ}-$ No. $83-14-28$ 


\section{PLATE LXIX.}

\section{Ceratites (Grinotoceras) meeki Mojsisovics (p. 111).}

Figcres 1, 2. Adult characters.

Figures 3, 4. More compressed specinen.

Figuri:s 5, 6. Early adult stage.

Figurs:s 7 , 8. Early mature stage (natural size).

Figure 9. Septa from the same specimen $(\times 2)$.

Figures 10-12. Larly nature stige (natural size).

Figure 13. Sepita of the same $(\times 2)$.

Figures 14-16. Early mature stage.

Figcres 17-19. Late adolescent stage $(X 2)$; diameter 18 nillimeters.

All specimens figured on this plate are from the Middle Triassic, Daonclla dubia zone, of Fossil Hill, south forli of American Canyon. West Humboldt Range, Ner. 'They belong to the collection of the Luited States Geological Survey. 


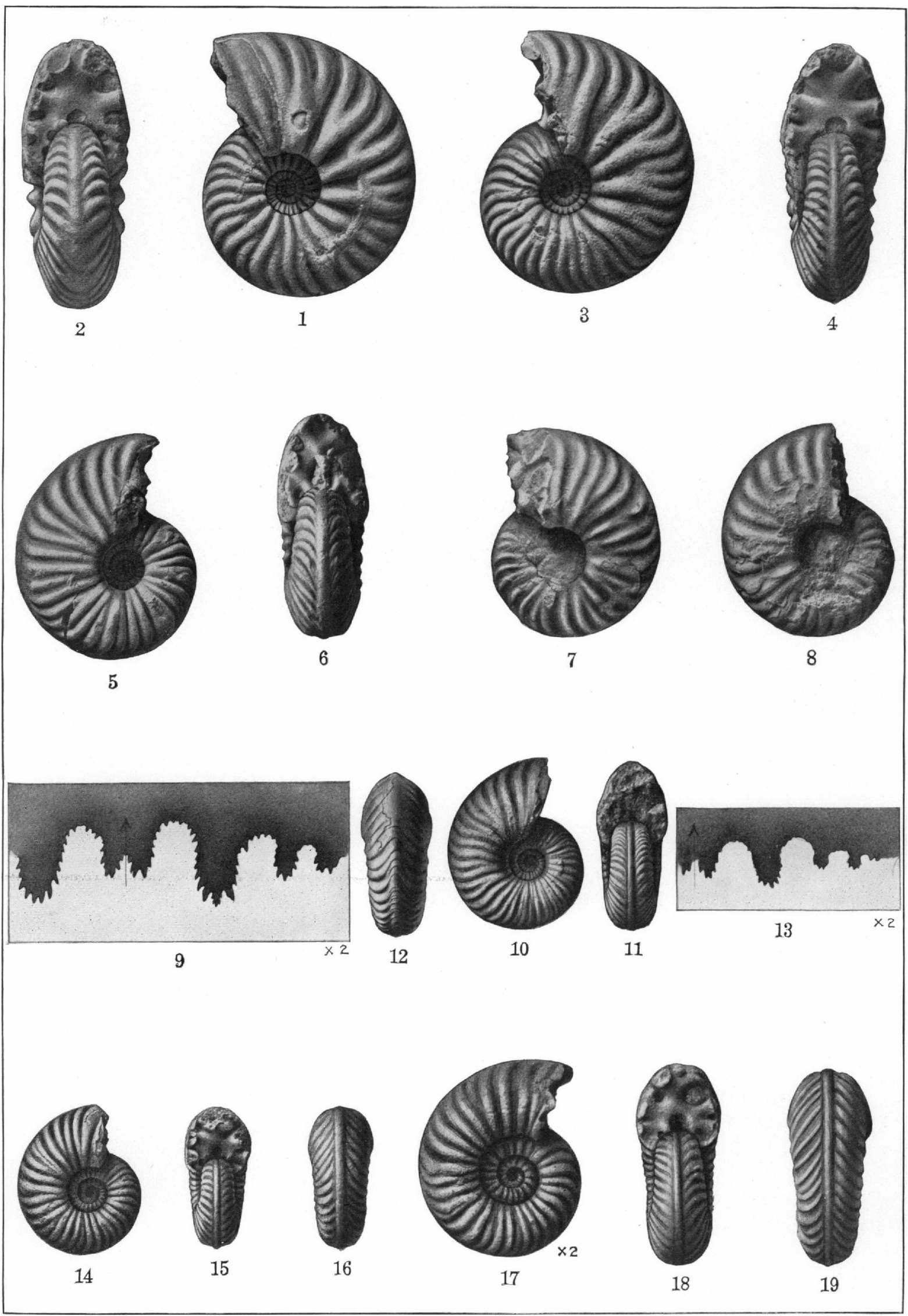




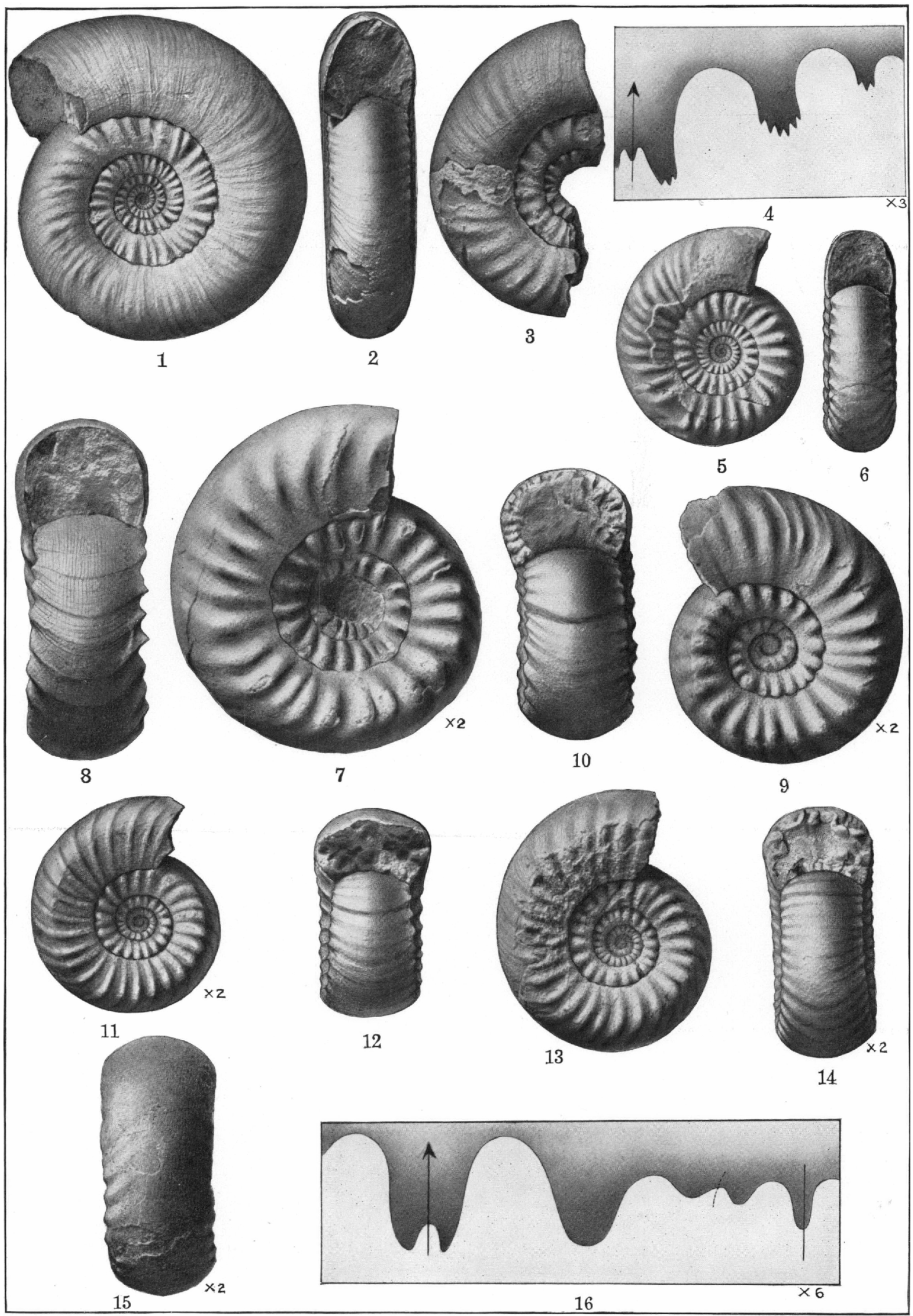




\section{PLATE LXX.}

Colunimites spencei Smith, sp. nov. (p. 36).

Figures 1, 2. Type specimen.

Figdre 3. Fragment of an adult specimen, showing septa.

Figure 4. Septa of the same specimen $(\times 3)$.

Figures 5, 6. Late adolescent stige; diameter 40 millimeters.

Figure $6 a$. Septa of the same specimen $(\times 3)$.

Fioures 7, 8. Adolescent stage $(\times 2)$; diameter 31 millimeters.

Figuris 9, 10. Adolescent stage $(\times 2)$; diameter 25 millimeters.

Figures 11, 12. Adolescent stage $(X 2)$, corresponding to Gastriocerns; diameter 20 millimeters.

Figures 13-15. Adolescent stage $(X 2)$; diameter 23 millimeters.

Figure 16. Septil of the same specimen $(\times 6)$, drawn at diameter of 15 millimeters.

Lower Triassic, Columbites zone. Paris Canyon, $1 \frac{1}{2}$ miles west of Iirris, Bear Lake County, Idaho. Collection of the United States Geological Surves. 


\section{PLATE LXXI.}

Columbites spexcei Smith, sp. nov. (p. 36).

Figdres 1-3. Adolescent gastrioceran stage $(\times 3$ ) ; diameter, 15 millimeters.

Figure $3 a$. Septa of the same $(\times 6)$.

Figures $4-6$. Adolescent stage $(X 3)$; diameter, 11 millimeters.

Figure $6 a$. Septa of the same $(\times 6)$.

Frgures 7-9. Early adolescent stage $(X+)$; diameter, 9.5 millimeters.

Figure $9 a$. Septa of the same $(X 8)$.

Figures 10-12. Diameter, 7.5 millimeters $(X 4)$.

Figure 12a. Septa of the same $(\times 8)$.

Figures 13,14 . Diameter, 4.5 millimeters $(X 6)$.

Figure 14a. Septa of the same $(\times 10)$.

Figures 15, 16. Diameter, 3 millimeters $(X 6)$.

Figure 16a. Septal of the same $(\times 10)$.

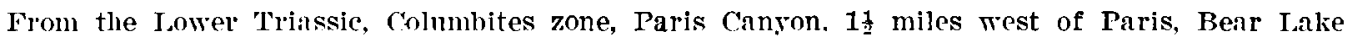
County, Idaho. Collection of the United States Geological Survey. 


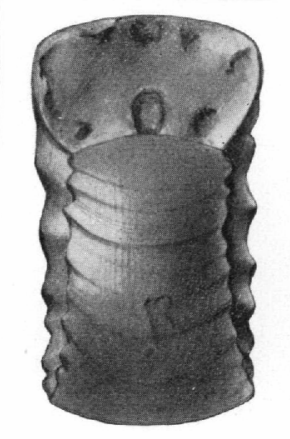

2

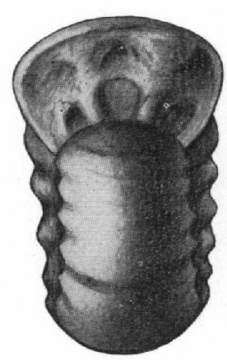

5

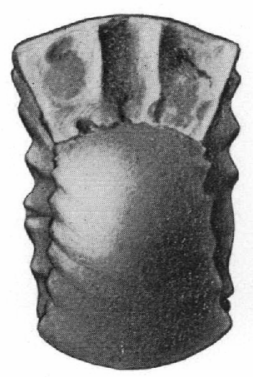

8

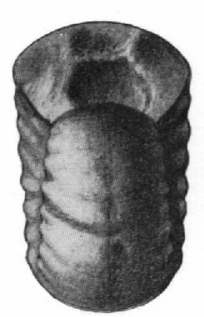

12

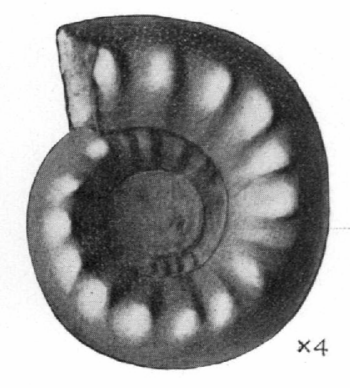

7
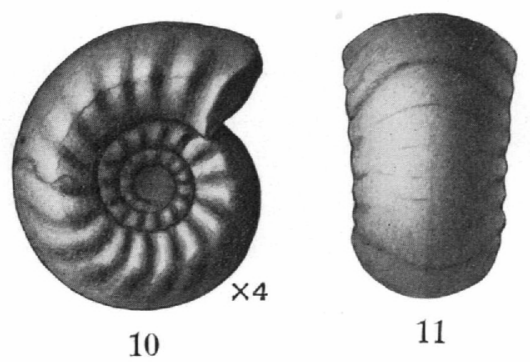

11
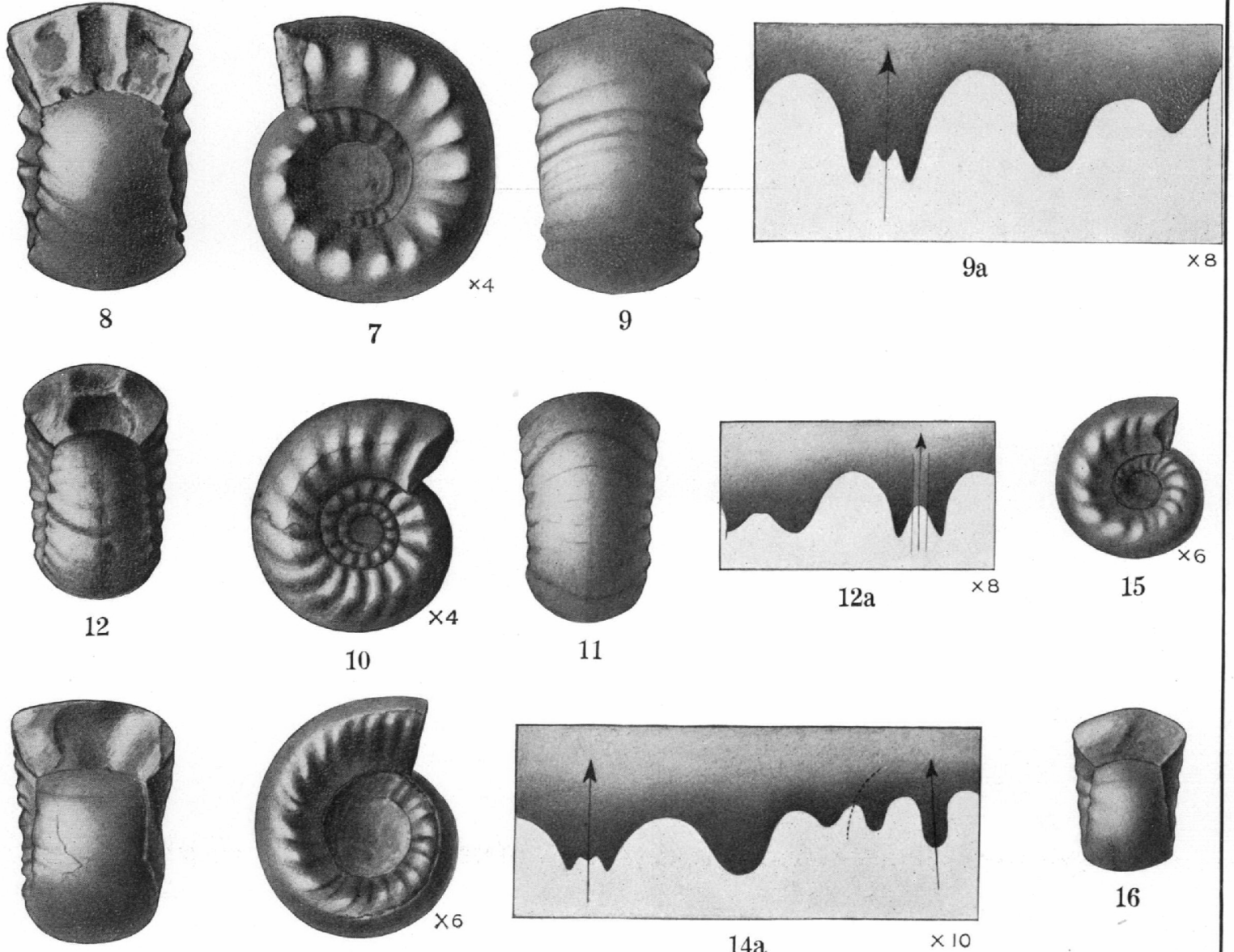

14

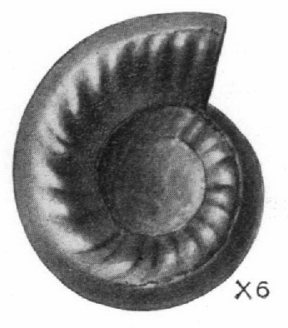

13
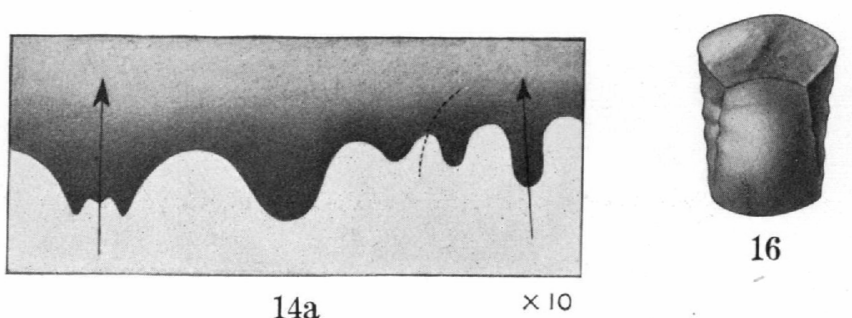

16 
PROFESSIONAL PAPER 83 PLATE LXXII

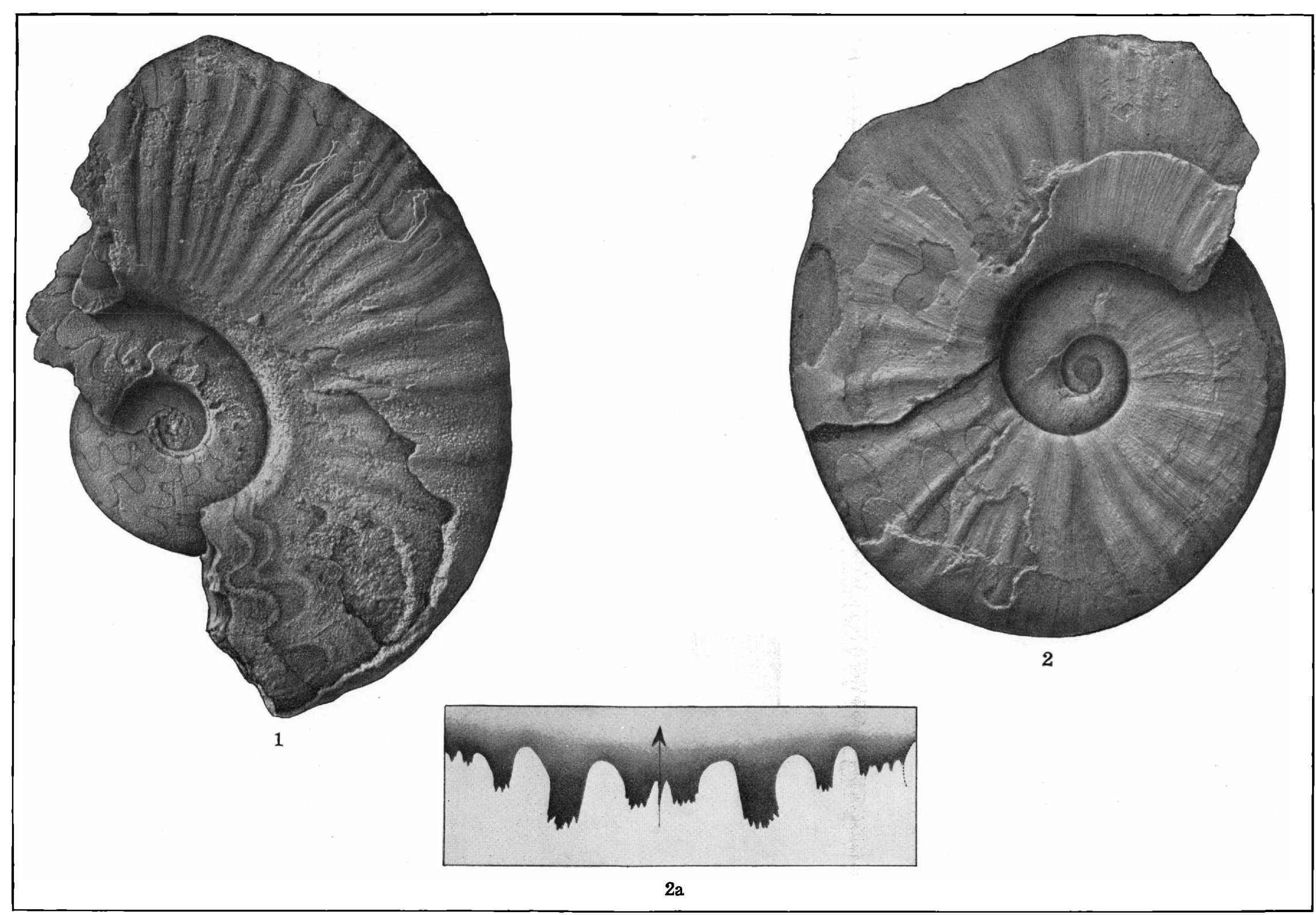




\section{PLATE LXXII.}

\section{Meemoceras meshbachanum White (p. 77).}

Figdre 1. Adult shell, showing the rough sculpture of the mature stage and the smooth flat adolescent whorls. Figures 2, 2a. Adult shell, showing the sculpture and septa of maturity.

Lower Triassic, Meeloceras zone, 5 miles sontheast of John Grays Lake, Idaho. Introduced here to show the transition between Meekoceras and Ceratites. Collection of the United States Geological Survey.

$16279^{\circ}-$ No. $83-14-29$ 


\section{PLATE LXXIII.}

Meenoceras mushibacianum White (p. 77).

Ficiure 1. Specimen showing the ribs of maturity and the nearly smooth flat inner whorl.

Figures 2, 3. Arlolescent inner whorl of the same specimen (uatural size): diameter, 25 millimeters.

Figures 4-6. Adult stage.

Lower Triassic, Bear Lake County, Idaho. Collection Cnited States Geological Survey. Speci. mens shown in figures 1-3 are from 5 miles sontheast of John Grays Lake. Those shown in figures $4-6$ are from $1 \frac{1}{2}$ miles east of Hot Springs. 


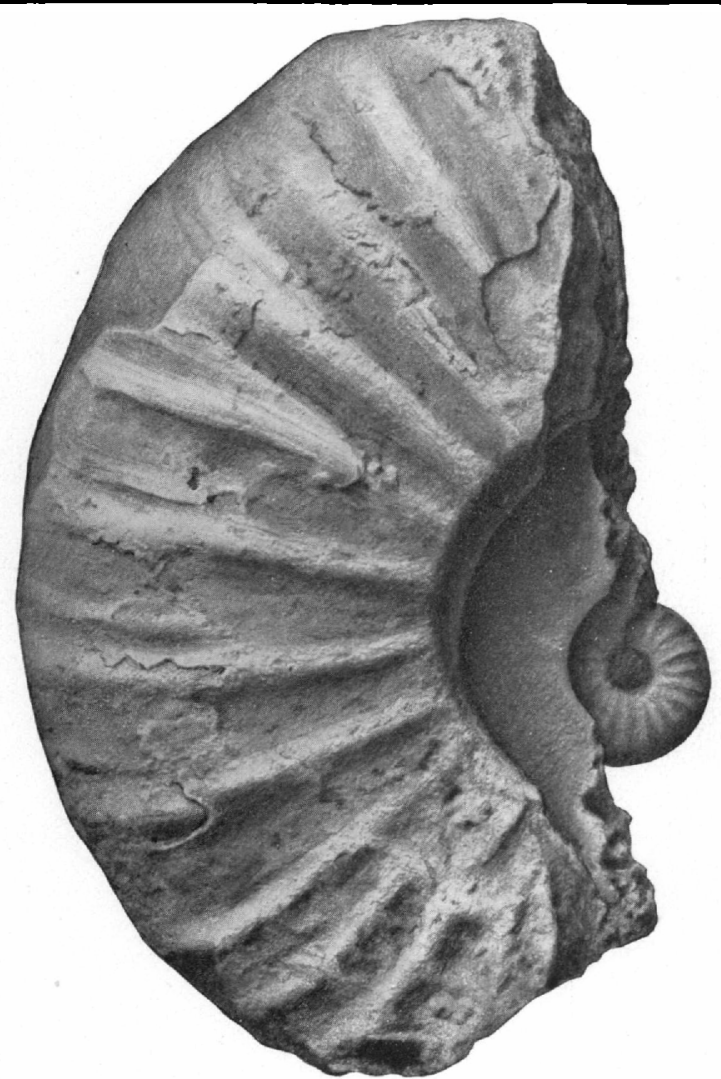

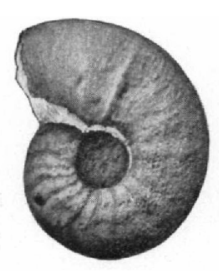

2
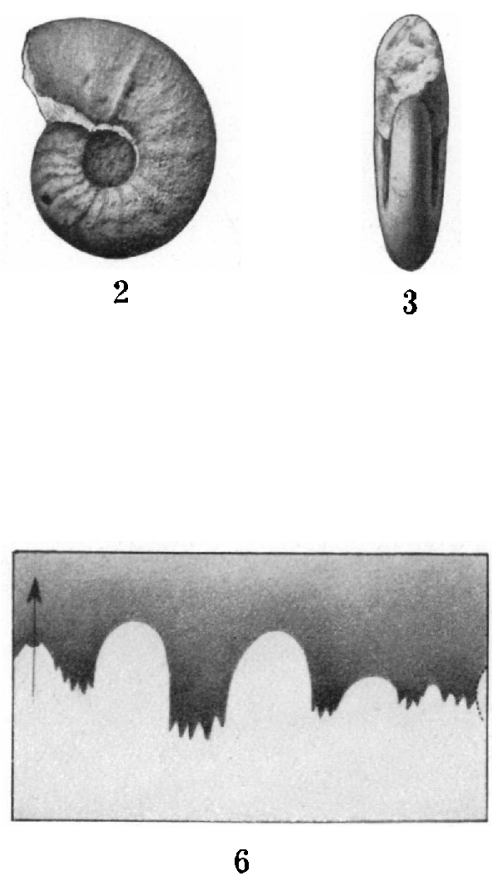

1
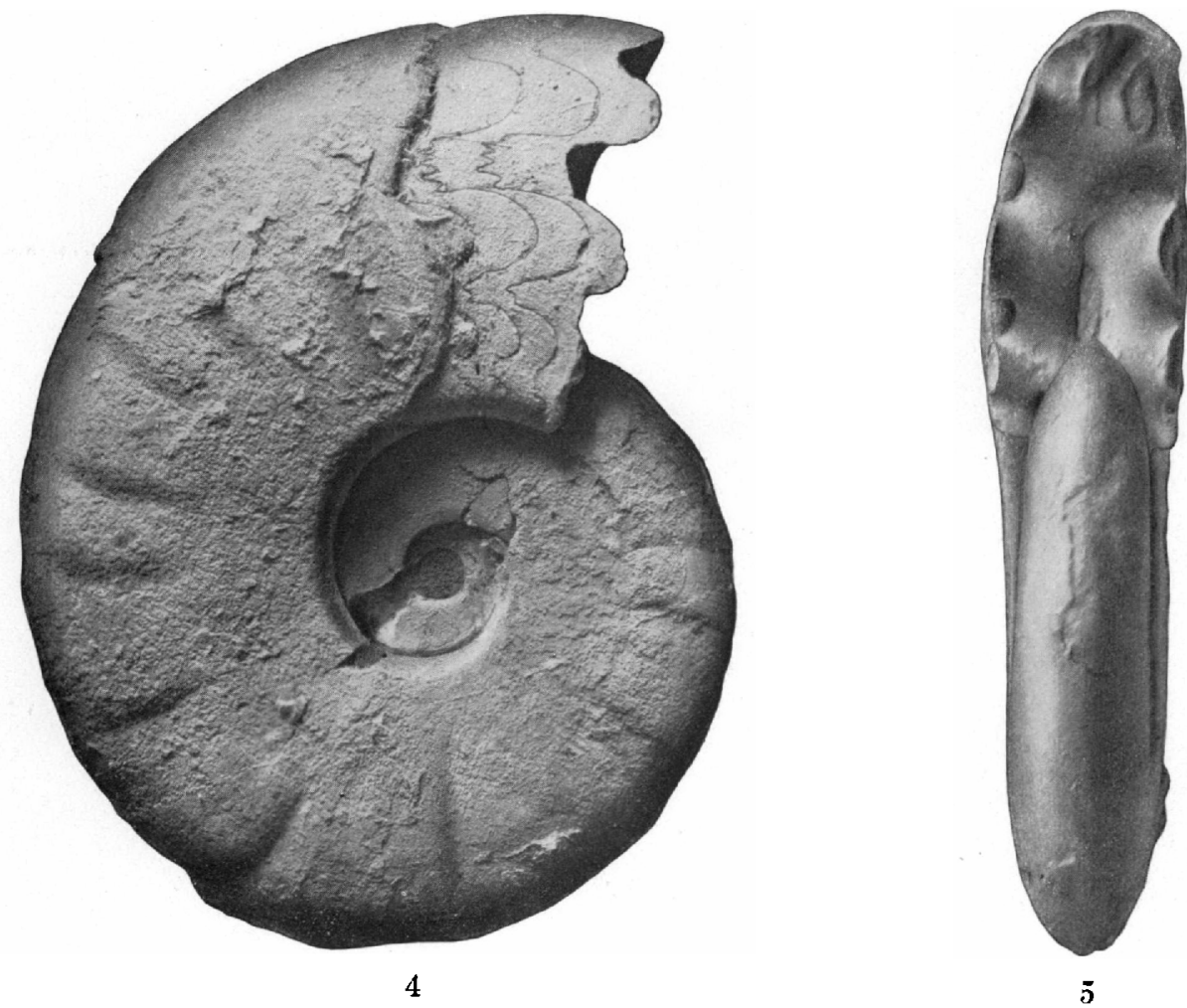


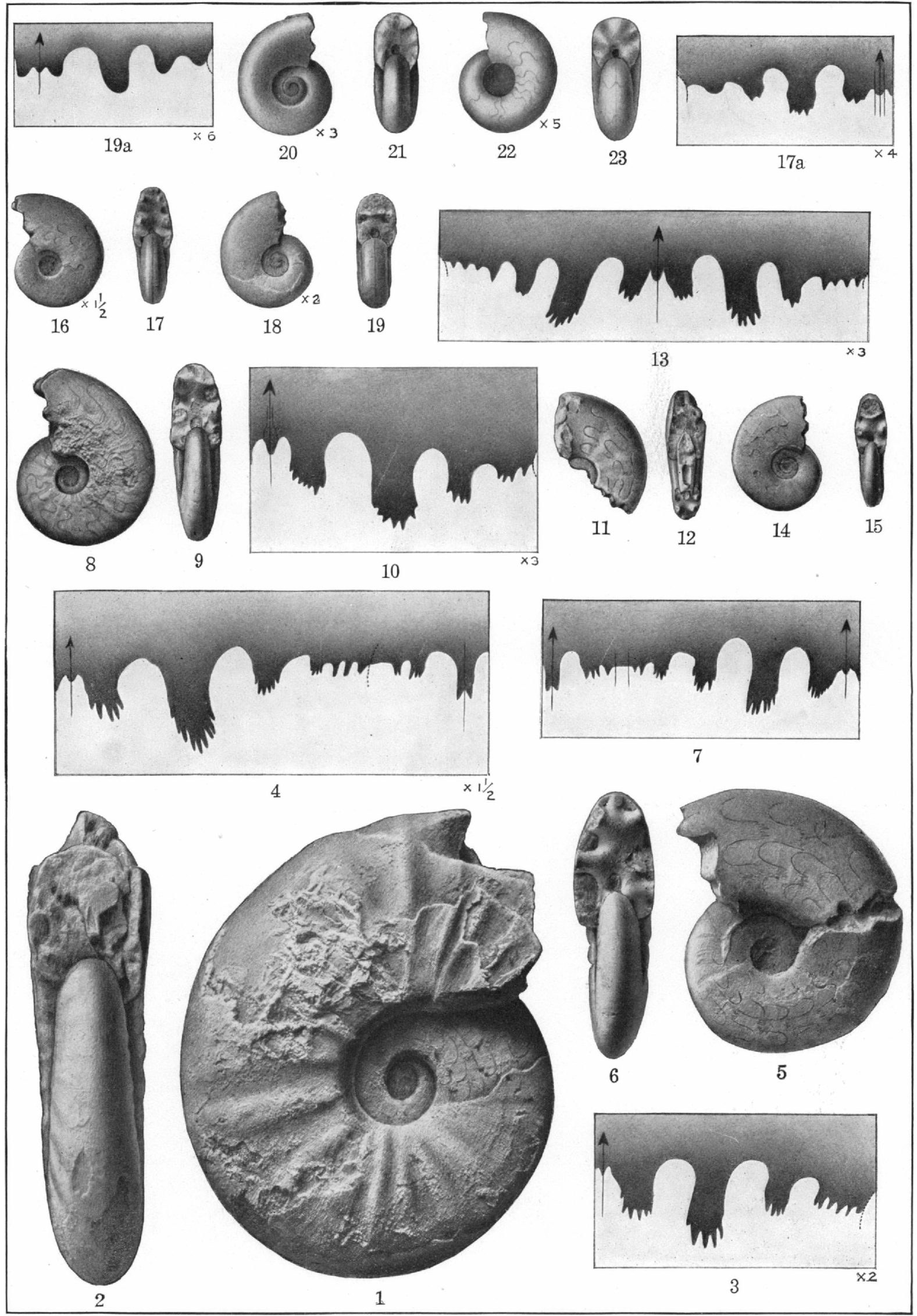




\section{PLATE LXXIV.}

\section{Meekoceras mishbachanum White (p. 77).}

FIGURES 1-3. Mature sculpture and septa, corresponding to Arctoceras.

Figure 4. Septa of another specimen ( $\left.X 1 \frac{1}{2}\right)$.

Figures 5. 6. Adolescent stage, slıowing the nearly smooth compressed whori (natural size).

FIGURE 7. Septa of the same specimen $\left(\times 1 \frac{1}{2}\right)$.

Figures 8, 9. Adolescent stage (natural size); diameter, 31 millineters.

Figure 10. Septa of the same specimen $(\times 3)$.

Figures 11, 12. Adolescent stage; diameter. 25 millimeters.

Figure 13. Septa of the same $(X 3)$.

Figures 14, 15. Adolescent stage (natural size); diameter, 20 millimeters.

Figures 16,17 . Adolescent stage $\left(X 1 \frac{1}{2}\right)$, showing the siplluncle; diameter, 14 millimeters.

Figure 17a. Septa of the same $(\times 4)$.

Figures 18, 19. Adolescent stage $(\times 2)$, showing goniatitic septa; diameter, 10 millimeters.

Figure 19a. Septa of the same $(\times 6)$.

Figures 20, 21. Adolescent stage $(X 3)$; diameter, 6.5 millimeters.

Figures 22. 23. End of larval stage $(X 5)$; diameter, 4 nillimeters.

Lower Triassic, Neekoceras zone, Rear Lake County, southwestern Idaho, 5 miles southeast of John Grays Lake. Introduced to show the transition from Meekoceras to Ceratites. 


\section{PLATE LXXV.}

Nevadites merriani Smith, sp. nov. (p. 125).

Figures 1-3. Type.

Figures 4-6. Larly mature stage.

Figures 7, 8. Early mature stage.

FIgtres 9-11. Transition from adolescence to maturity $\left(\times 1 \frac{1}{2}\right)$; diimeter, 29 millimeters.

Figures 12-14. Adolescent stage $(\times 2)$; diameter, 15 millimeters.

All specimens figured on this plate are from the Middle Triassic, Daonella dubia zone, of Fossil Hill, south fork of Imerican Canyon, West Humboldt Range, Nev. They are in the collection of the United States Geological Survey. 


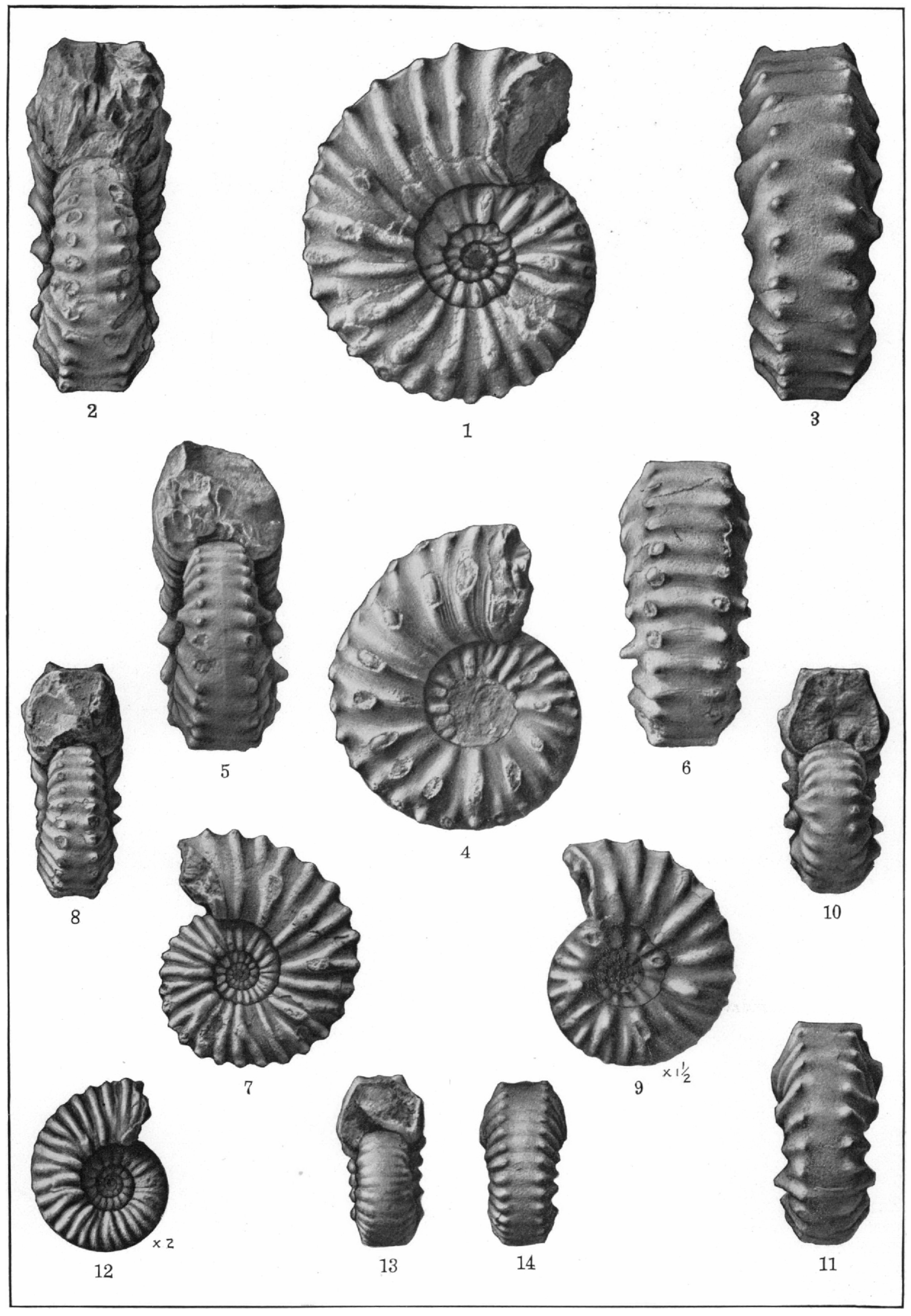




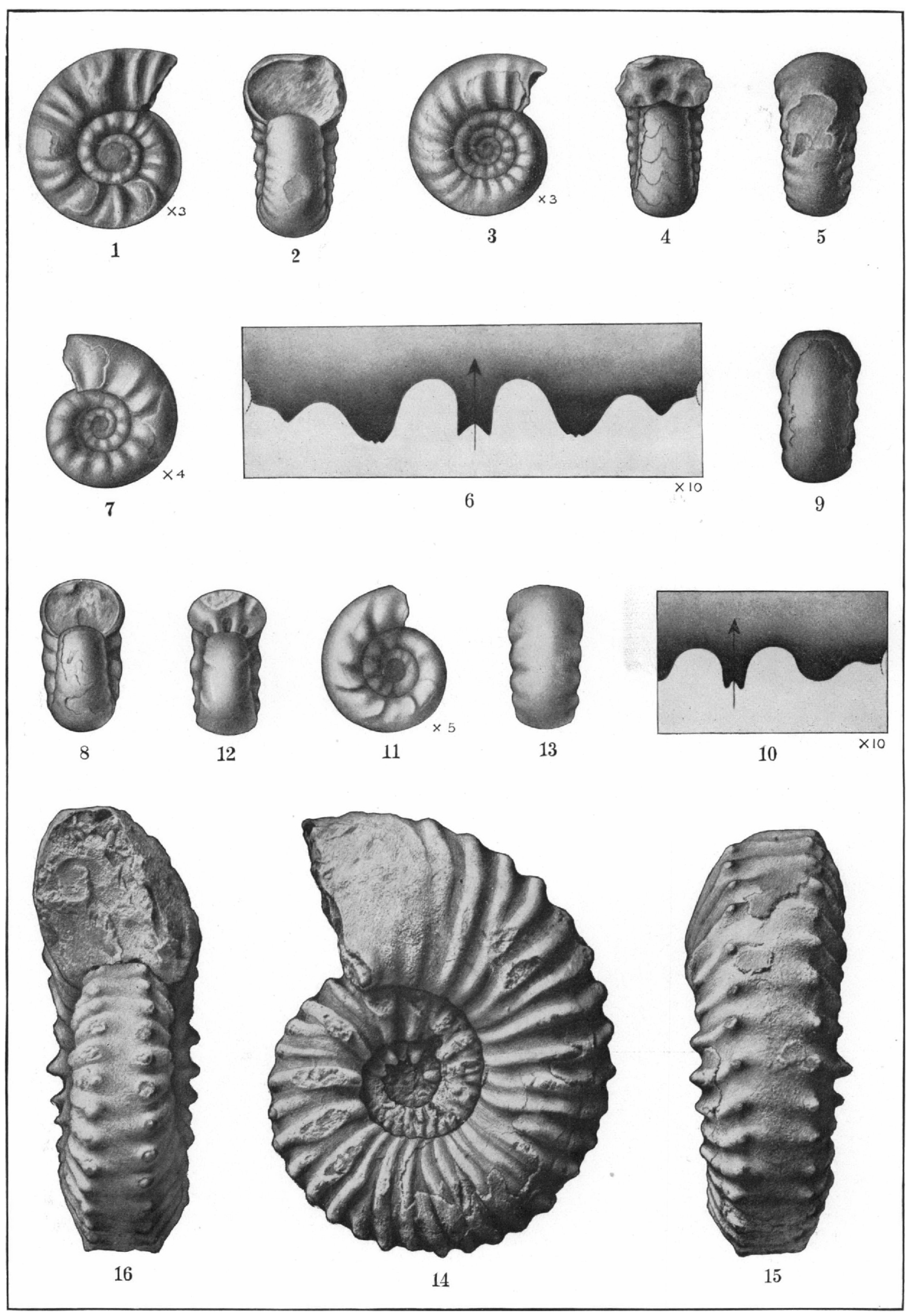




\section{PLATE LXXVI.}

Nevadites merriami Smith, sp. nov. (p. 125).

Figures 1, 2. Adolescent stage ( $X 3$ ), resembling Keyserlingites; diameter, 11 millimeters. Figcres 3-5. Adolescent stage $(\times 3)$; diameter, $9 . \overline{5}$ inillimeters.

Figure 6 . Septa of the same $(\times 10)$.

Figures $i-10$. Late larral stage (shell $\times 4$, septa $\times 10$ ), corresponding to Dinilrites or Danubites; diameter, 6.5 millimeters.

Figures 11-13. Larval stage ( $X 5$ ) ; diameter, 5 millimeters.

Figdres 14-16. Specimen showing old-age characters.

All specimens figured on this plate are from the IIiddle Triassic, Daonella dubia zone, of Fossil Hill, south fork of American Canyon, West Humboldt Range, Nev. They are in the collection of the Cnited States Geological Survey.

$16279^{\circ}$-No. 83-14-30 


\section{PLATE IXXXVII.}

\section{Nevadites hyatti Smith (p. 124).}

Figures 1-3. Adult specimen.

Figures 4, 5. Adolescent specimen $\left(\times 1 \frac{1}{2}\right)$; diameter, 31 millineters.

Figures 6-8. Adolescent specimen $(\times 2)$; diameter, 18 millimeters.

Figures $9-11$. Adolescent stage $(\times 2)$; diameter, 13 millimeters.

Figures 12, 13. Early adolescent stilge $(X 3)$; diameter, 10 millimeters.

All specimens figured on this plate are from the Middle Triassic, Daonella dubia zone, of Fossil Hill, south fork of American Canyon, West Humboldt Range, Nev. They are in the collection of the Cnited States Geological Survey. 


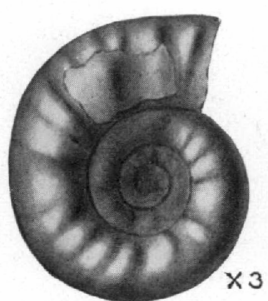

12

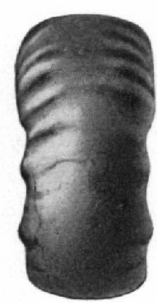

13

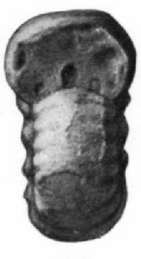

10
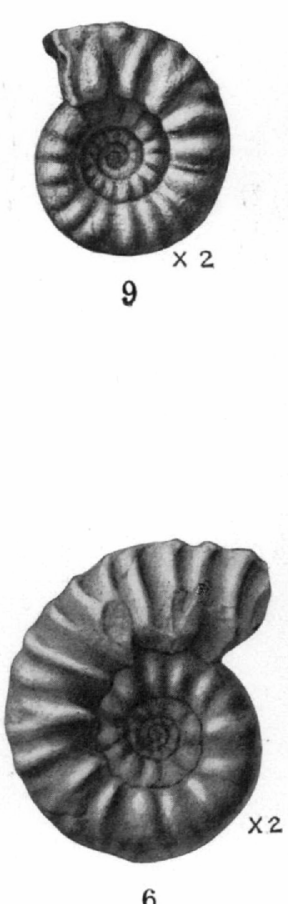

6

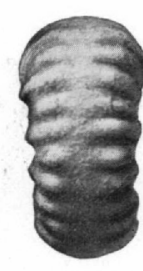

11

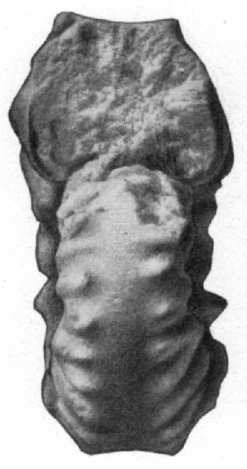

5
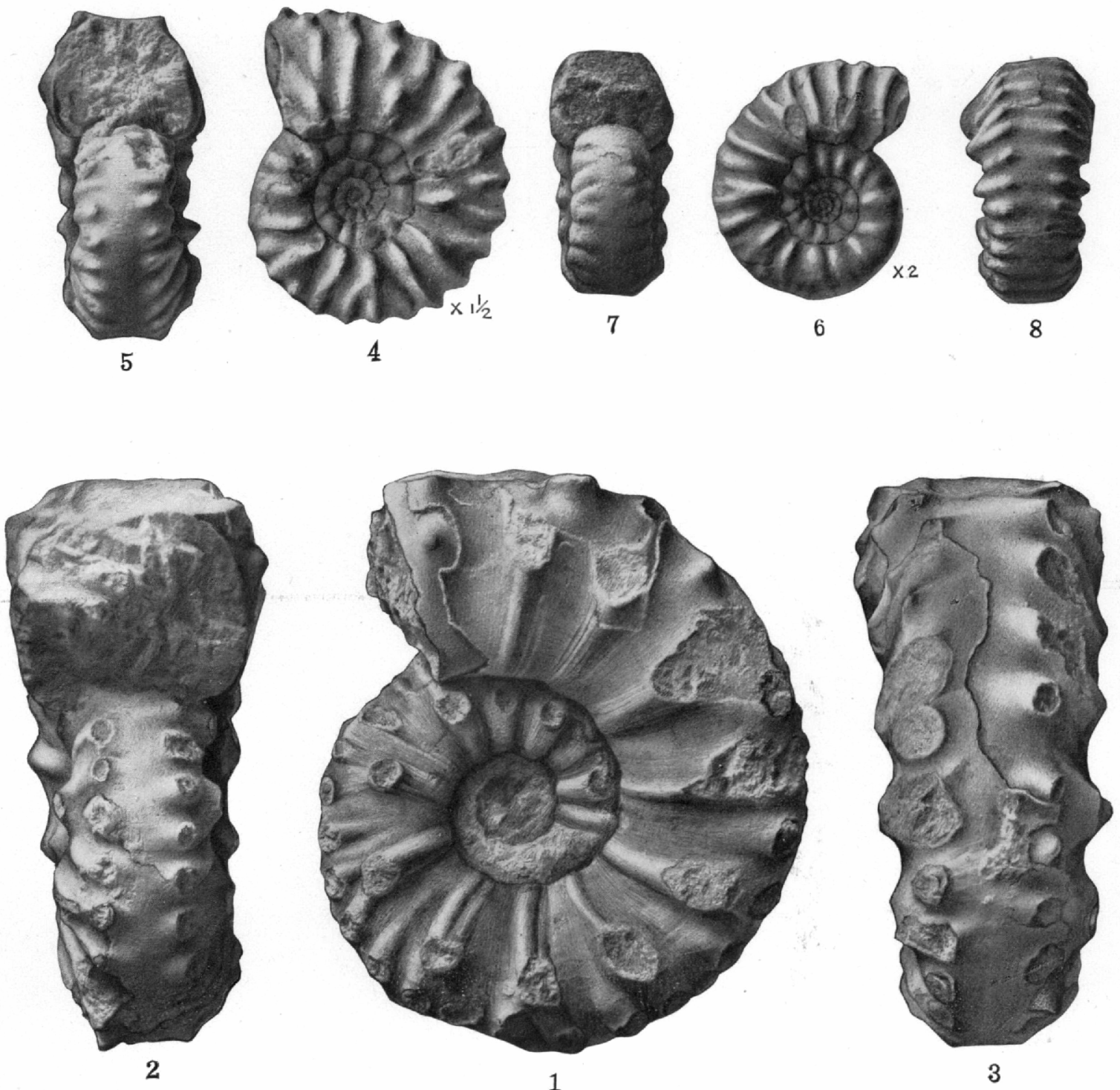

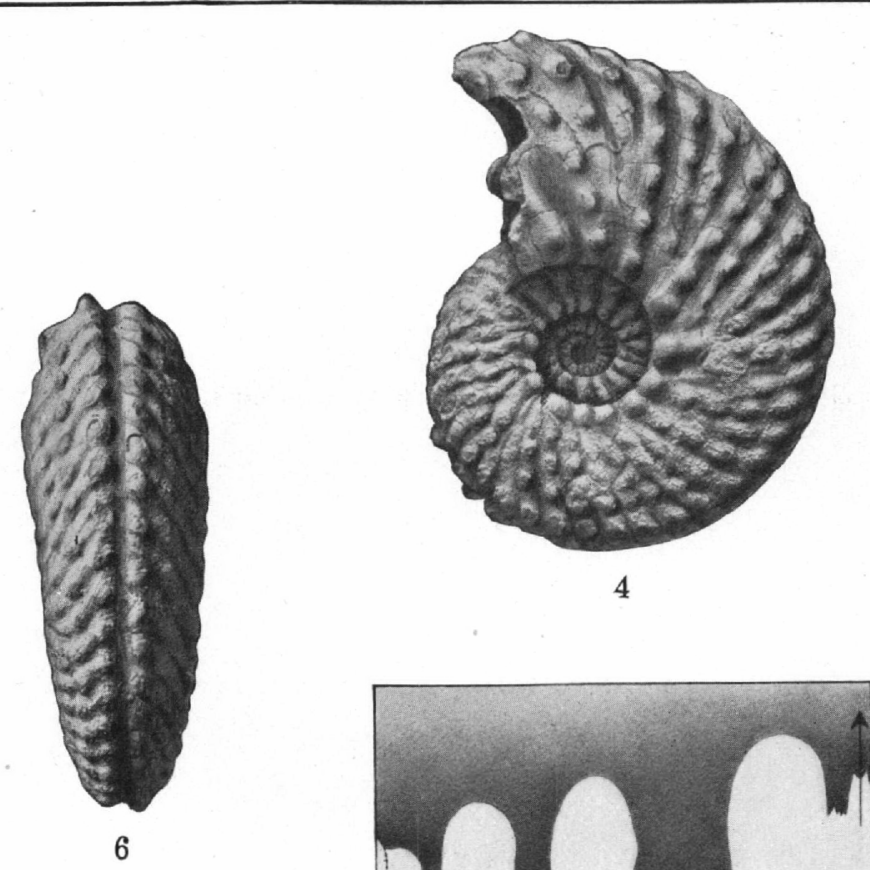

4
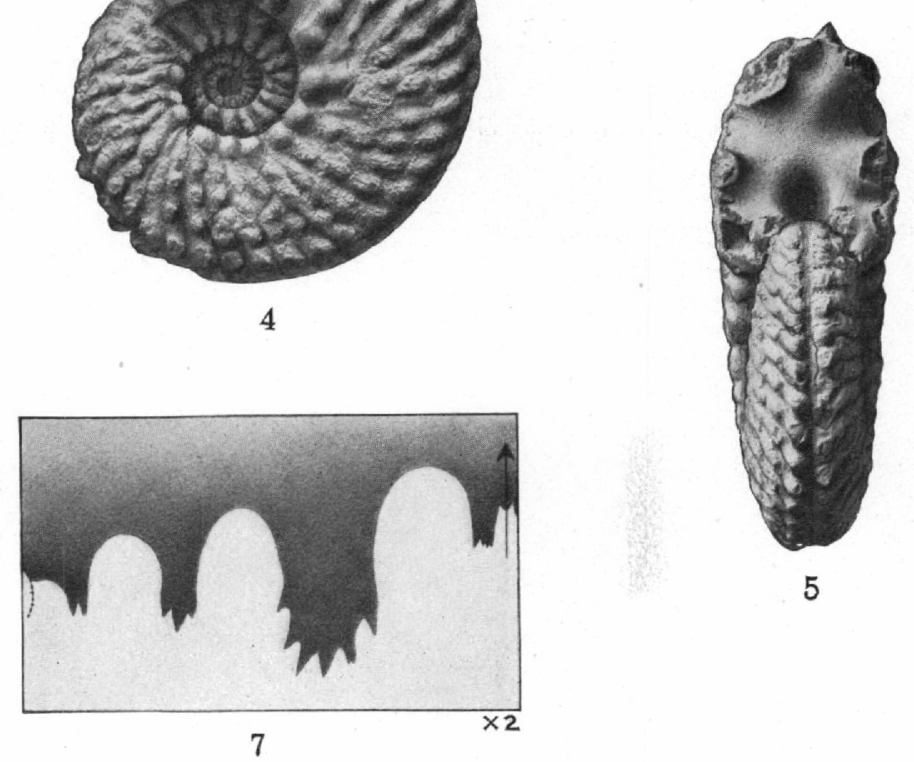

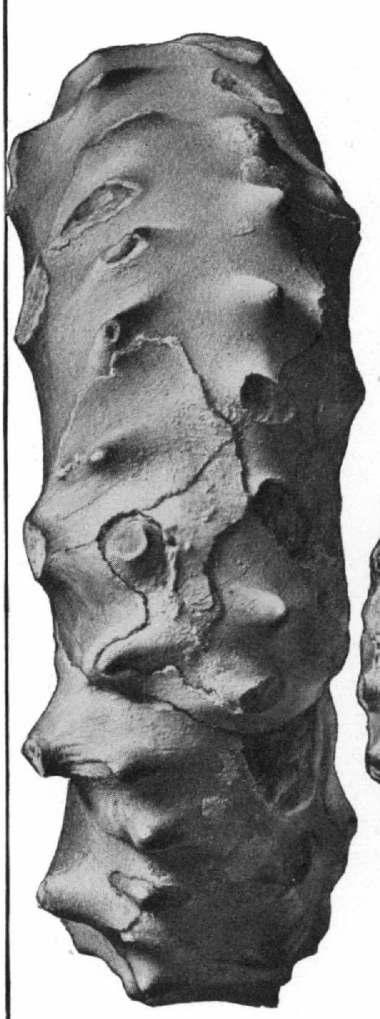

3
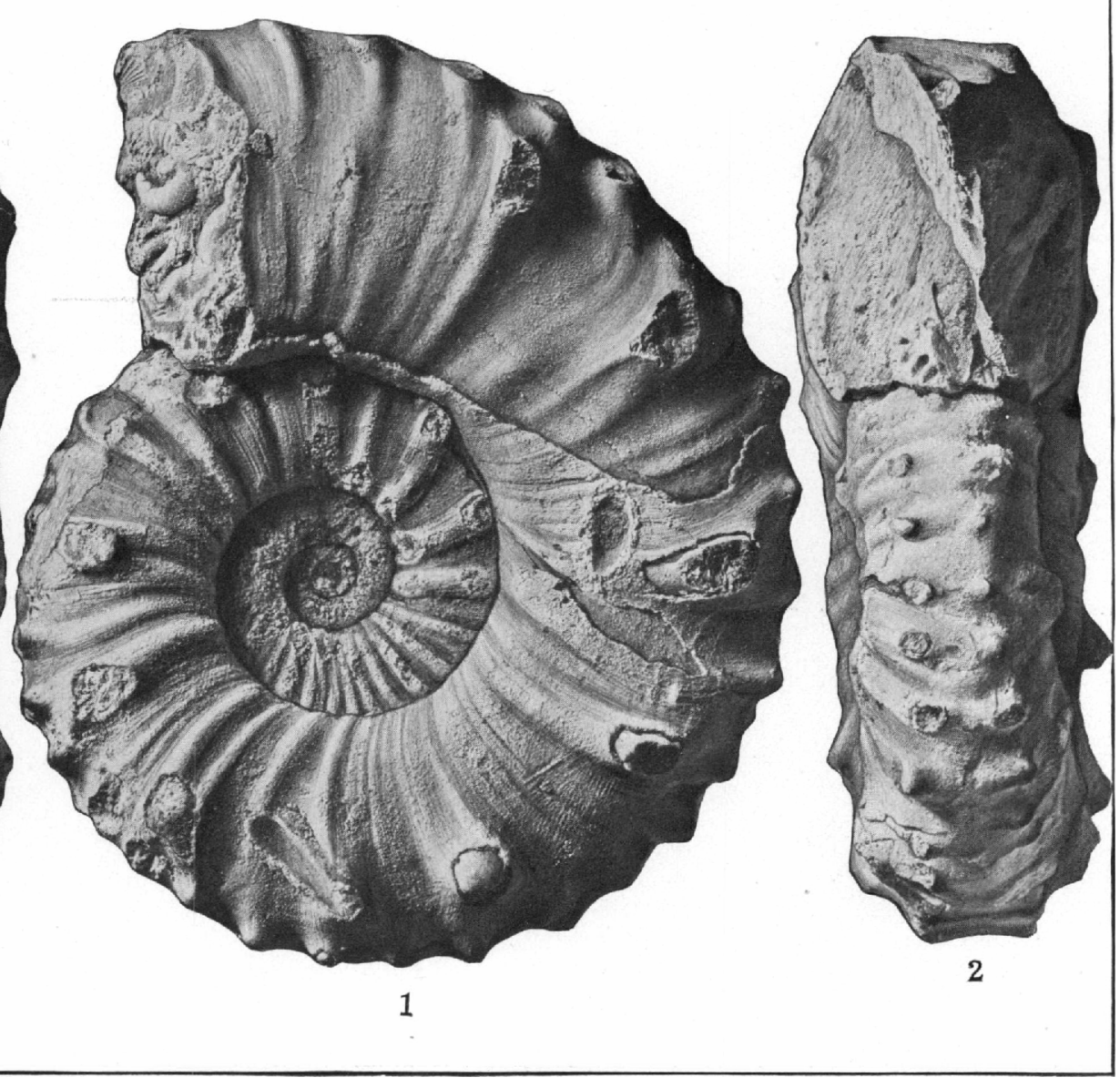


\section{PLATE LXXVIII.}

Nevadites huniboldensis Smith, sp. nov. (p. 123).

F'rgURes 1-3. Type.

Traciuyceras (Protrachyceras) meek Mojsisovics (p. 135).

Figdres 4-7. 'Type (septa $\times 2$ ).

Both specimens figured on this plate are from the Middle Triassic, Daonella dubia zone, of Fossil Hill, south fork of American Canyon, West Humboldt Range, Nev. Collection of the United States Geological Survey. 


\section{PLATE LXXIX.}

Nevadtes humboldtexsis Smith, sp. nov. (p. 123).

Frgures 1-3. Mature stage.

Figures 4-6. Late adolescent stage.

Figures 7, 8. Adolescent stage.

Figures 9, 10. Adolescent stage.

All specimens figured on this plate are from the Middle Triassic, Daonella dubia zone, of Fossil Hill, sonth fork of American Canyon, West Humboldt Range, Nev. They are in the collection of the United States Geological Survey. 

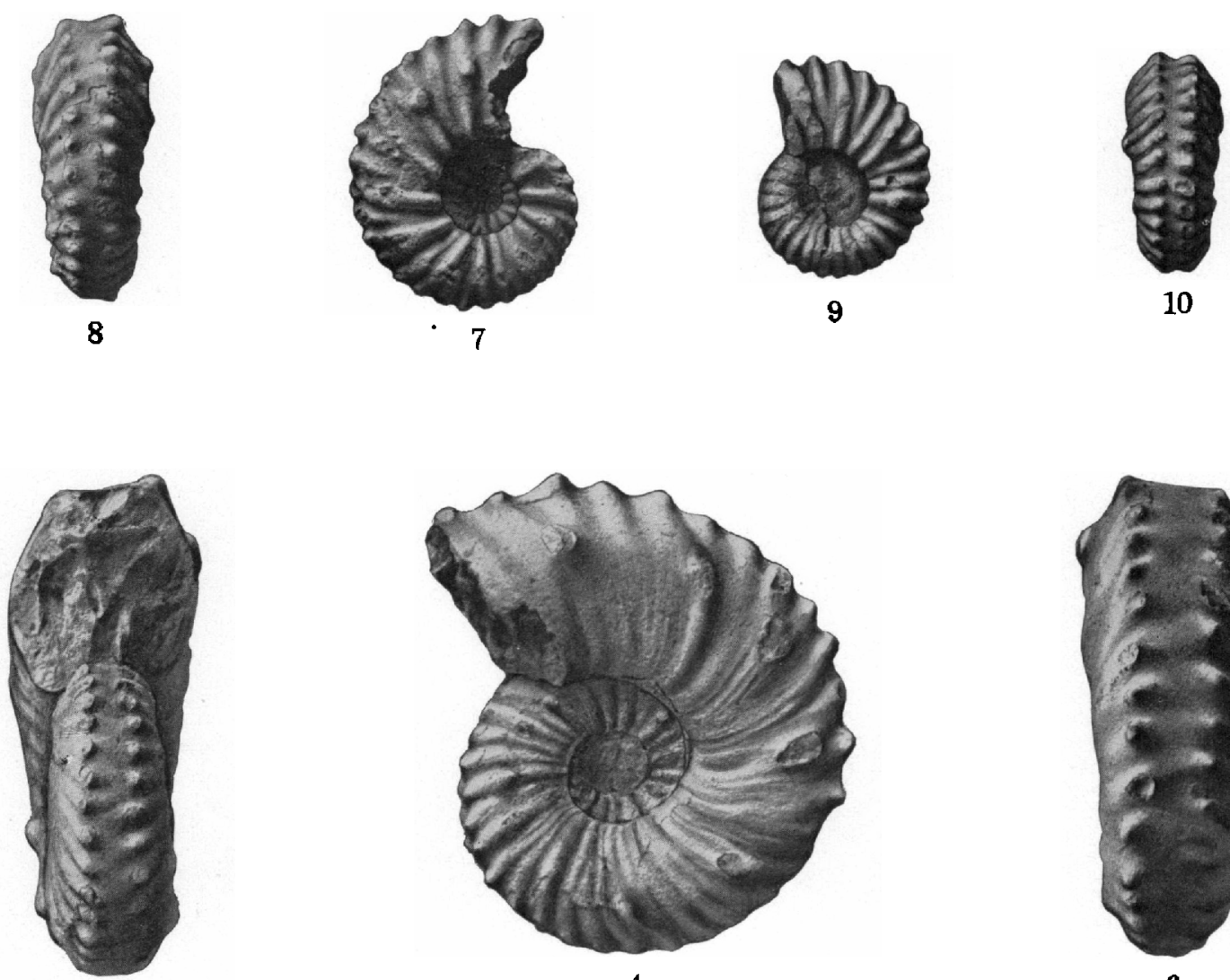

5

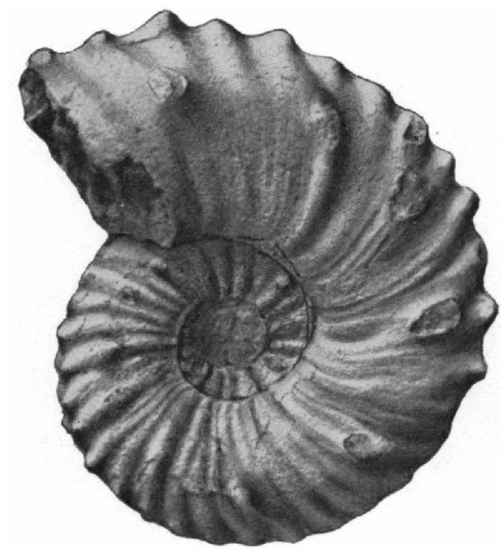

4
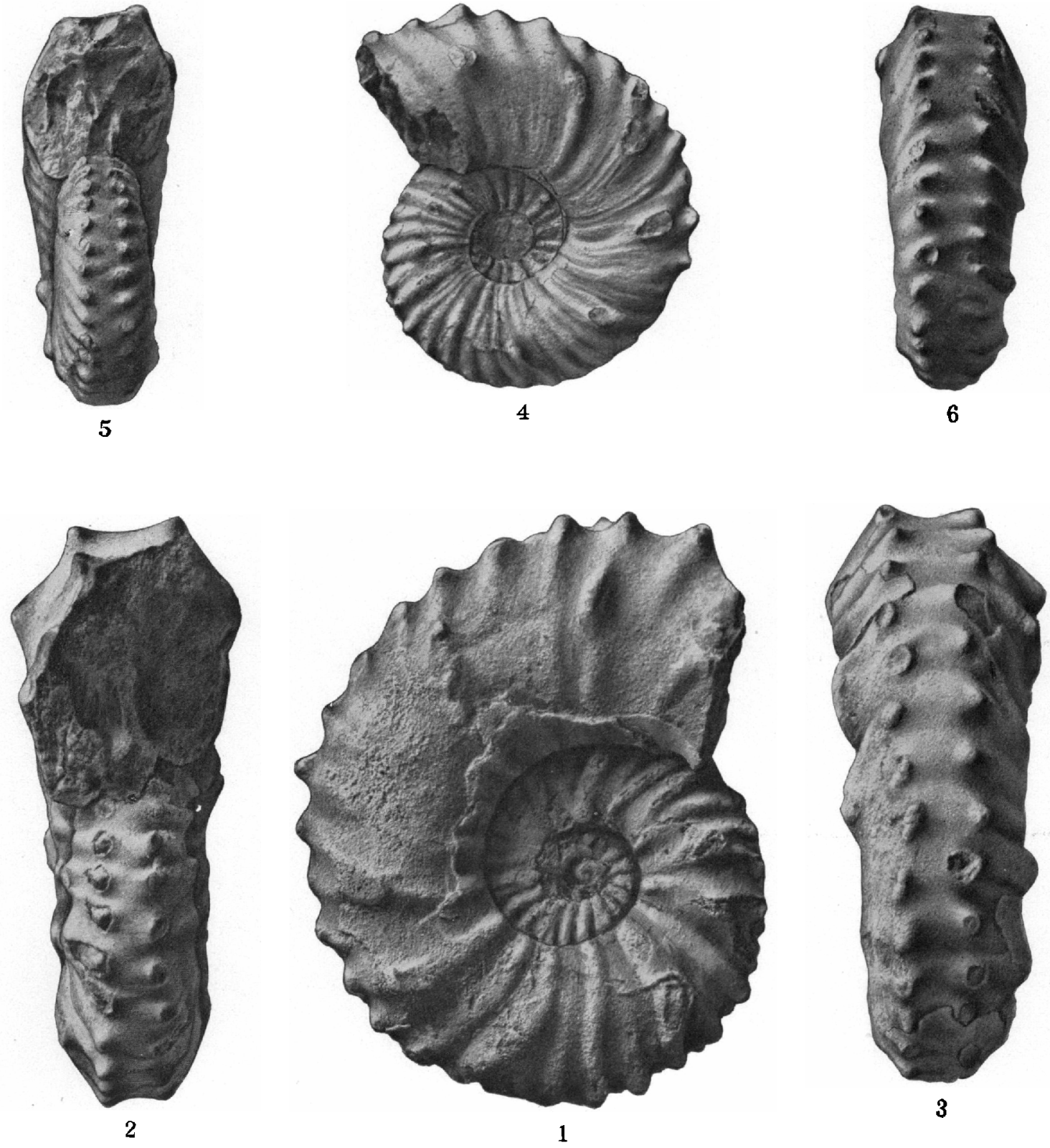


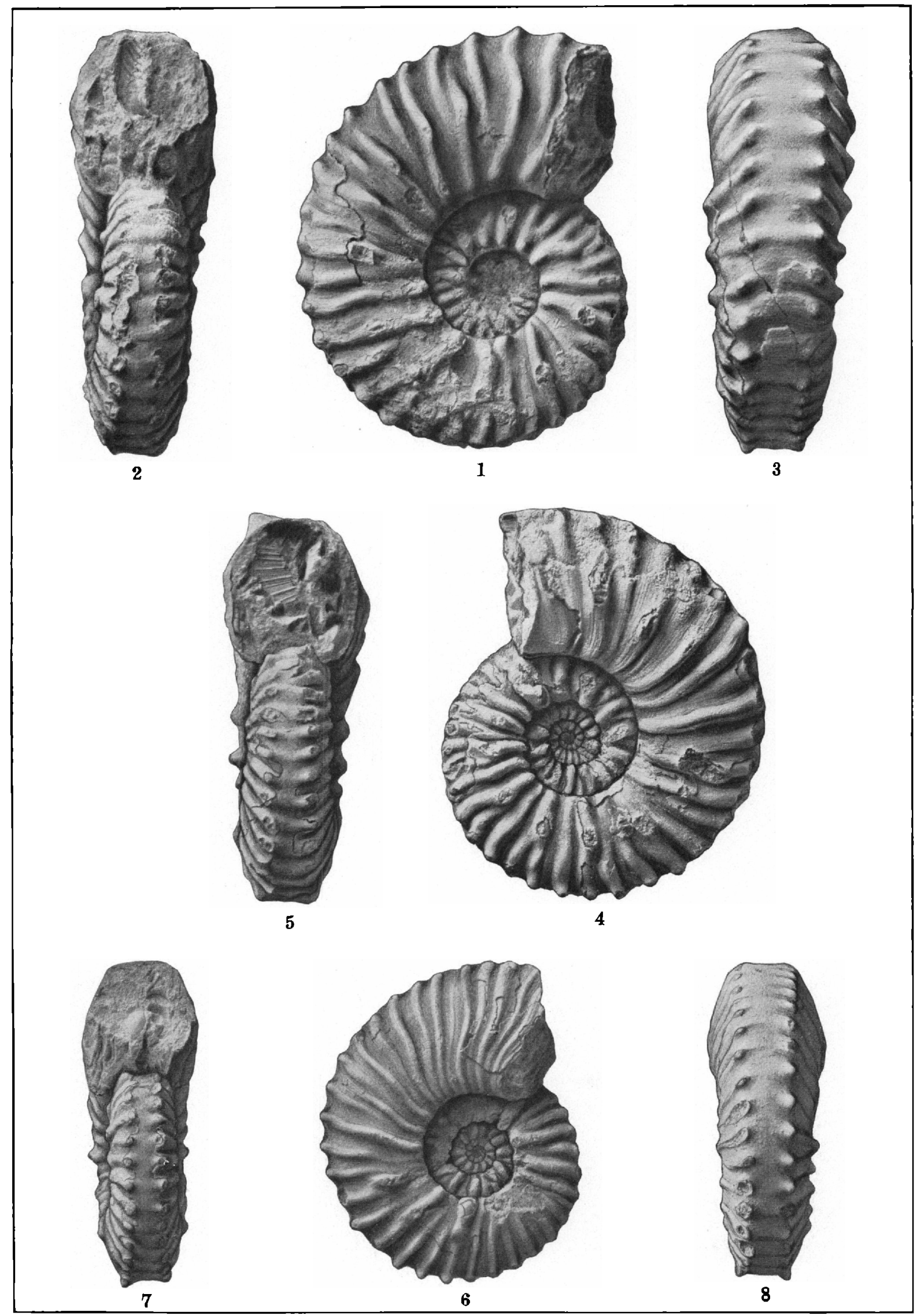




\section{PLATE LXXX.}

Nevadites whitneyi Gabb (p. 126).

Figures 1-3. Adult specimen.

Figcres 4, 5. Adult specimen.

Figures 6-8. Early mature stage.

These specimens are from the Middle Triassic, Daonclla dubia zone, of Fossil Hill, south fork of American Canyon, West Humboldt liange, Nev. They are in the collection of the United States Geological Survey.

$16279^{\circ}-$ No. $83-14-31$ 


\section{PLATE LXXXI.}

Nevadites whitneyi Gabb (p. 126).

Figures 1, 2. Early mature stilge (natural size).

Figure 3. Senta of the sime $(\times 2)$.

Figures 4, 5. Late adolescent stage.

Figures 6,7 . Adolescent stage $\left(X 1 \frac{1}{2}\right)$; diameter 25 millimeters.

Ficures 8 , 9. Adolescent stage $(X 2)$; diameter 21 millimeters.

Figures 10-12. Adolescent stage $(X 2)$; diameter 15 millimeters.

Figure 13. Septa of the sime $(X 6)$.

Figures 14, 15. Adolescent stage $(X 4)$; diameter 7 millimeters.

Figure 16. Septa of the same $(\times 10)$.

Nevadites sixclairi Smith, sp. nor. (p. 126).

Figures 17-19. Type.

All specimens figured on this plate are from the Middle Triassic, Daonella aubia zone, of Fossil Hill, south fork of American Canyon, West Humboldt Range, Ner. They are in the collection of the United States Geological Survey. 


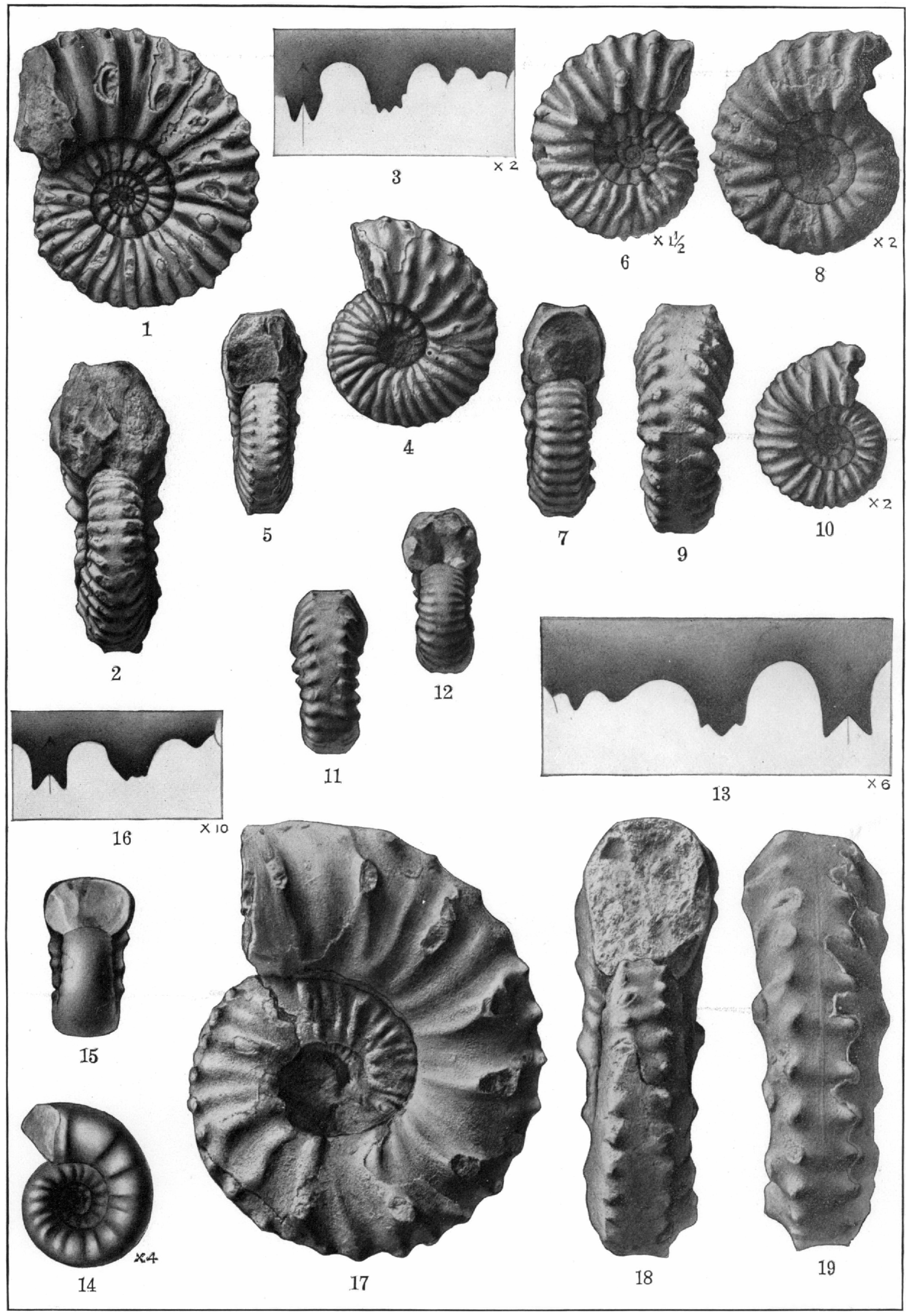



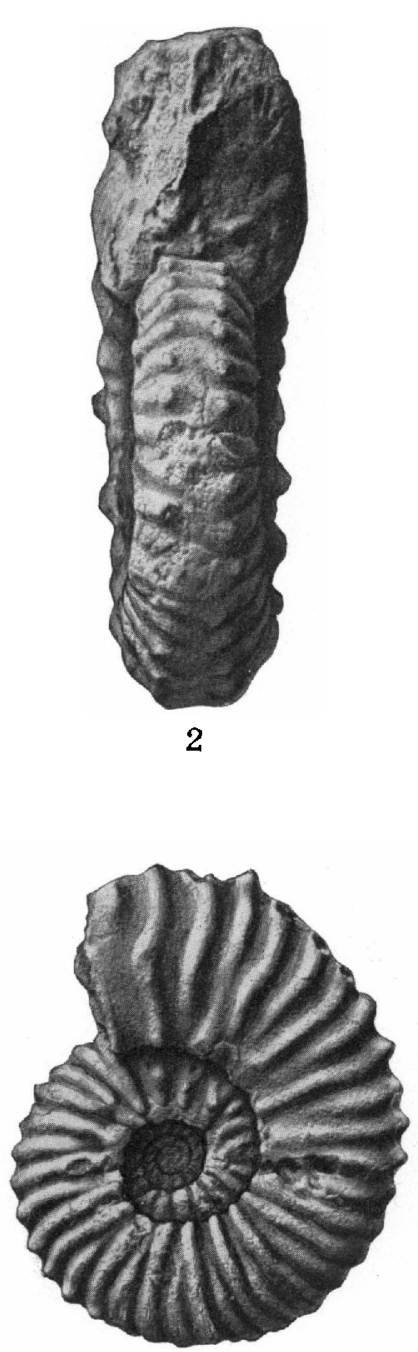

4

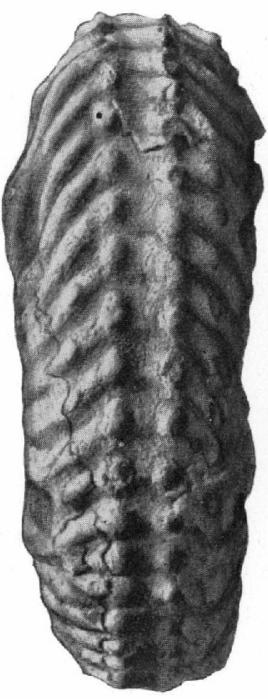

11

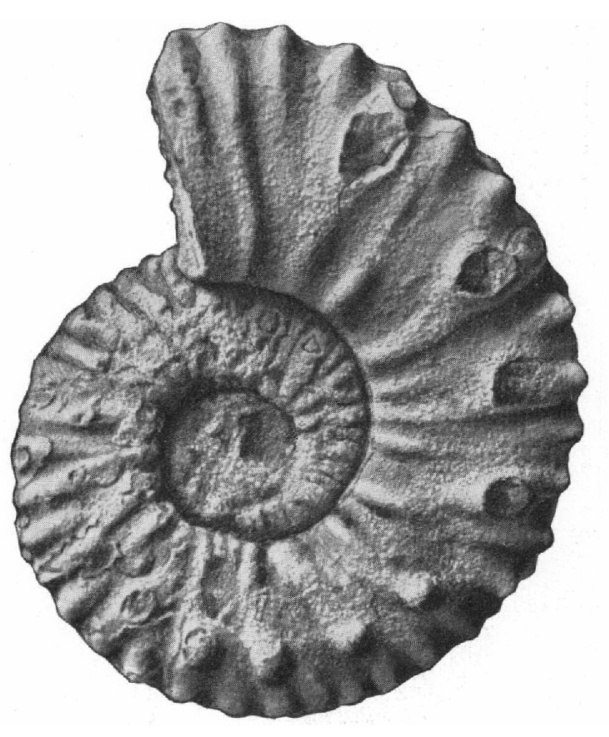

1
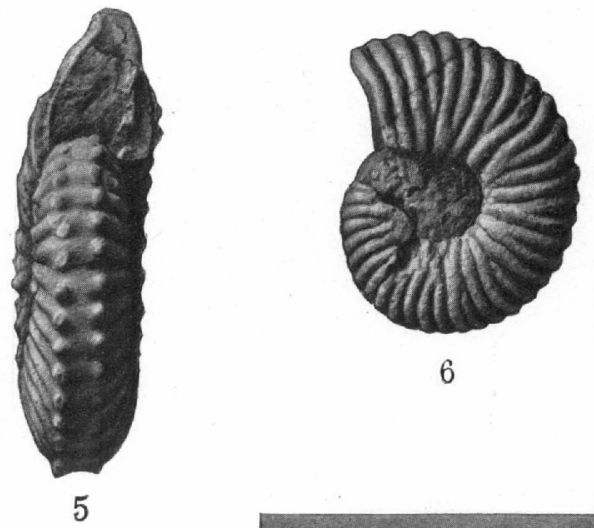

6
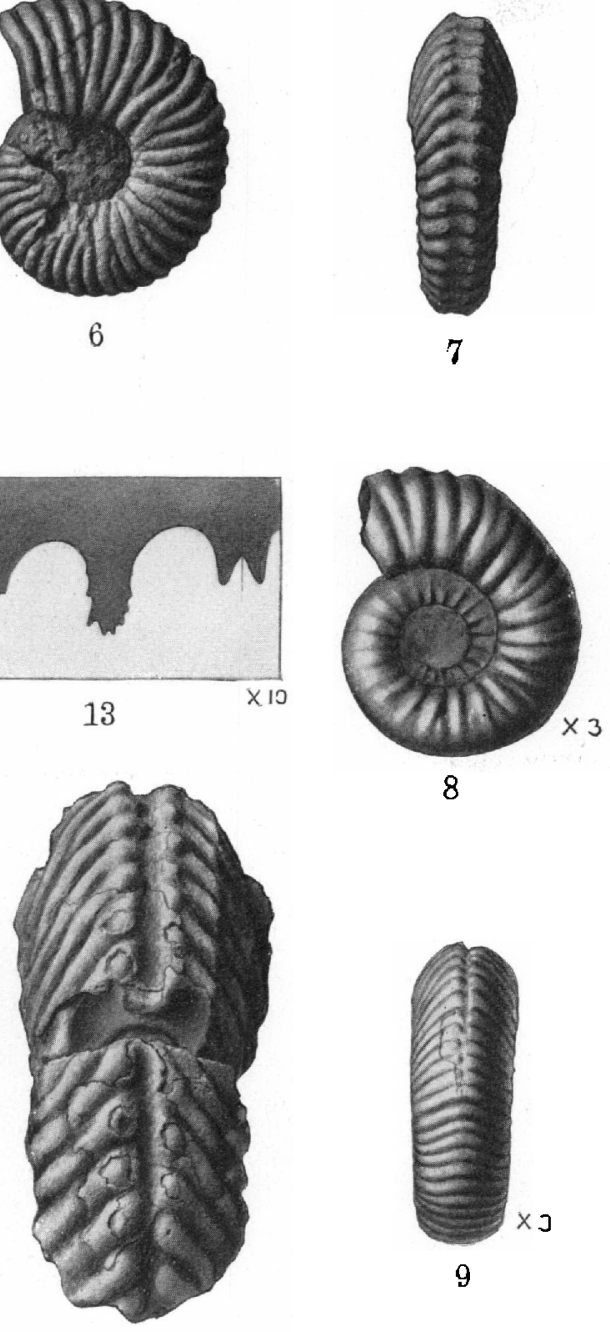

8
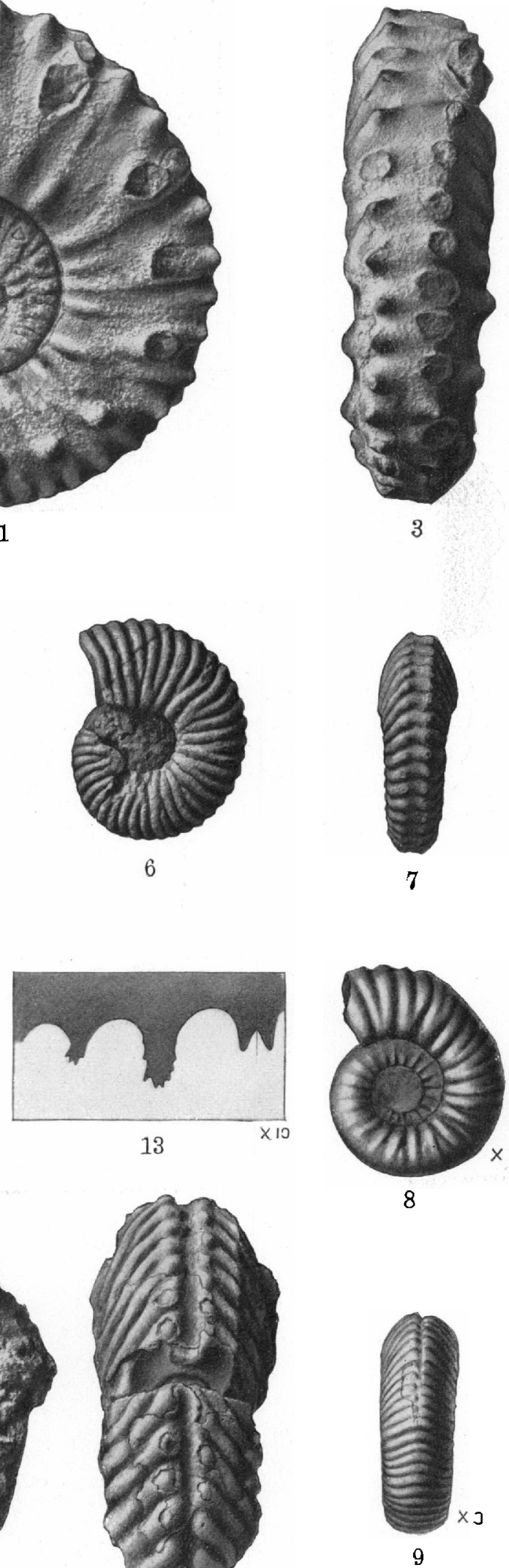

12 


\section{PLATE LXXXII.}

Nevadites sinclairi Smith, sp. nov. (p. 126).

Figures 1-3. Adult stage.

Trachyceras (ANolcites) Gracile Smith, sp .nov. (p. 132).

Figures 4, 5. Type.

Figures 6, T. Adolescent stage.

Figures 8, 9. Adolescent stage $(\times 3)$; diameter 10 millimeters.

Trachyceras (Protrachyceras) americaxcm Mojsisovics (p. 133).

Figures 10, 11. Adult stage.

Figure 12. Adult stage.

Figure 13. Septa of the same (natural size).

All specimens figured on this plate are from the Midlle Triassic, Daonclla dubia zone, of Fossil Hill, south fork of American Canyon. West Humboldt Range, Nev. They are in the collection of the United States Geological Survey. 
PLATE LXXXIII.

Trachyceras (A Nolcites) Furlongi Smith, sp. nov. (p. 130).

Figures 1-4. Type.

Figures 5-7. Adolescent stage.

The specimens figured on this plate are from the Middle Triassic, Daonella rlubia zone, of Fossil Hill, south fork of American Canyon, IVest Humboldt Range, Nev. They are in the collection of the United States Geological Survey. 


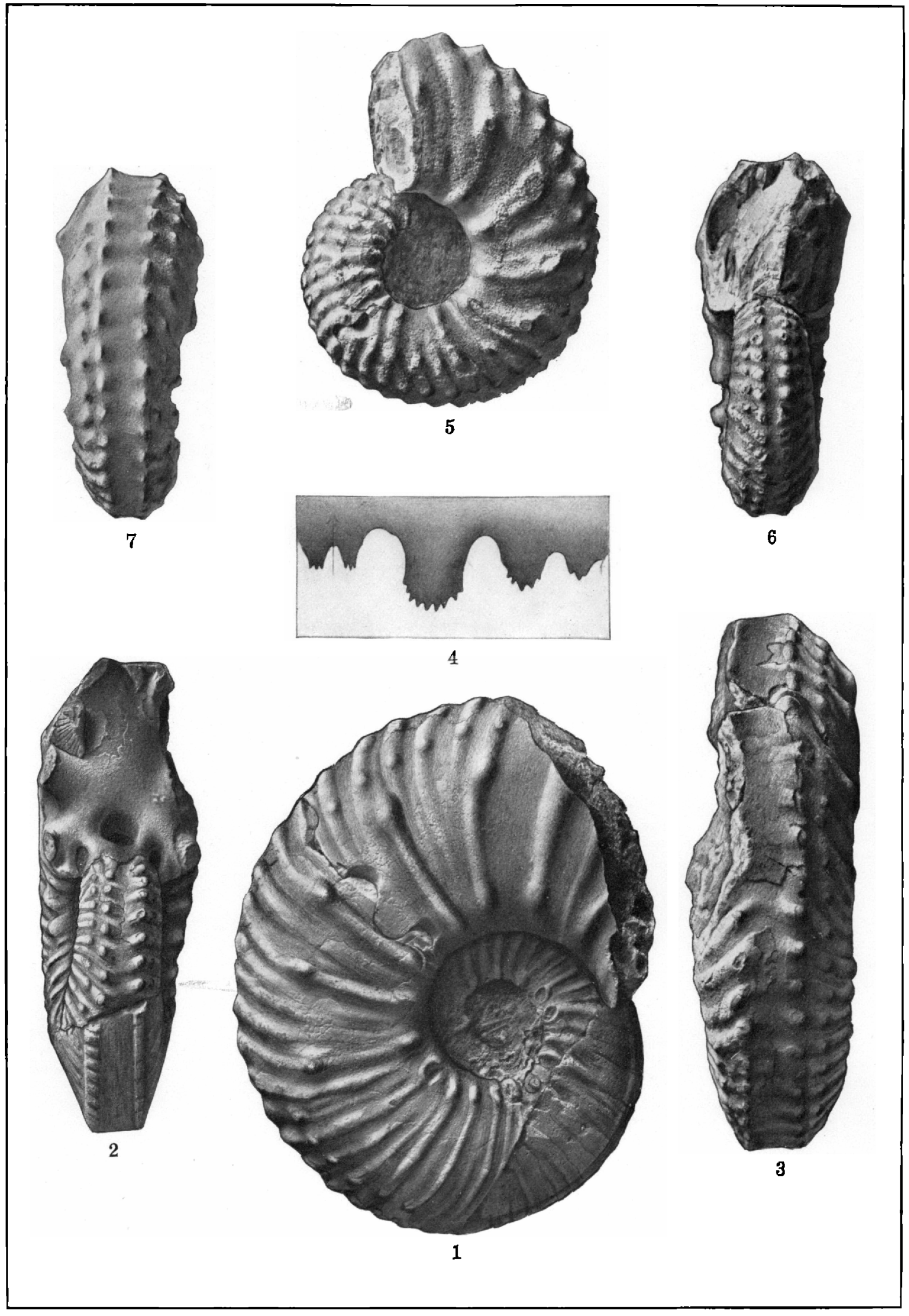




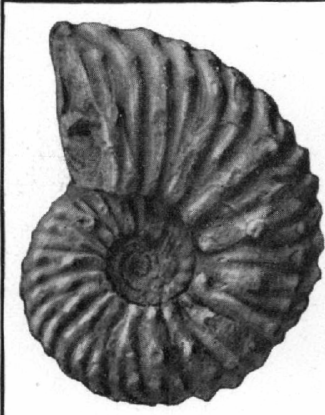

1

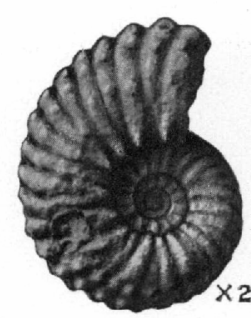

6

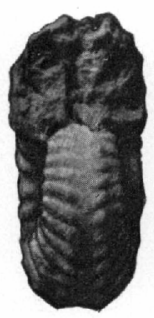

7

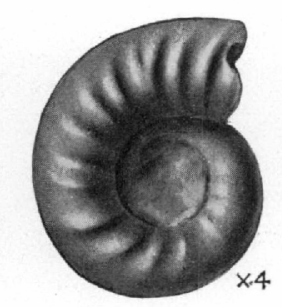

12

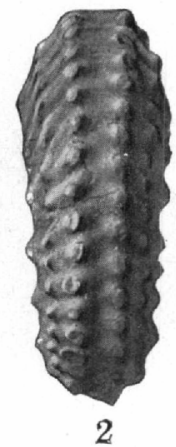

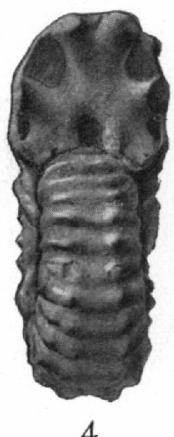

4
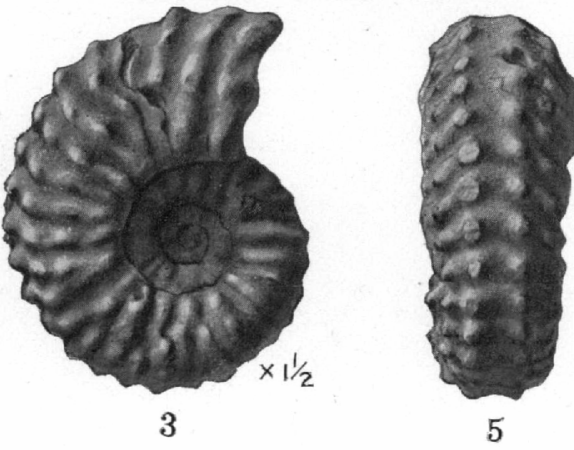

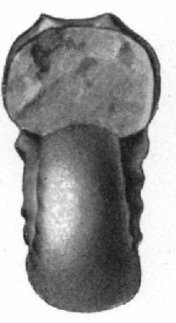

10

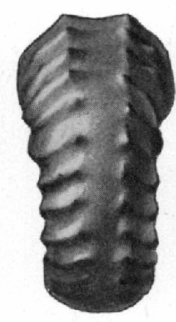

11
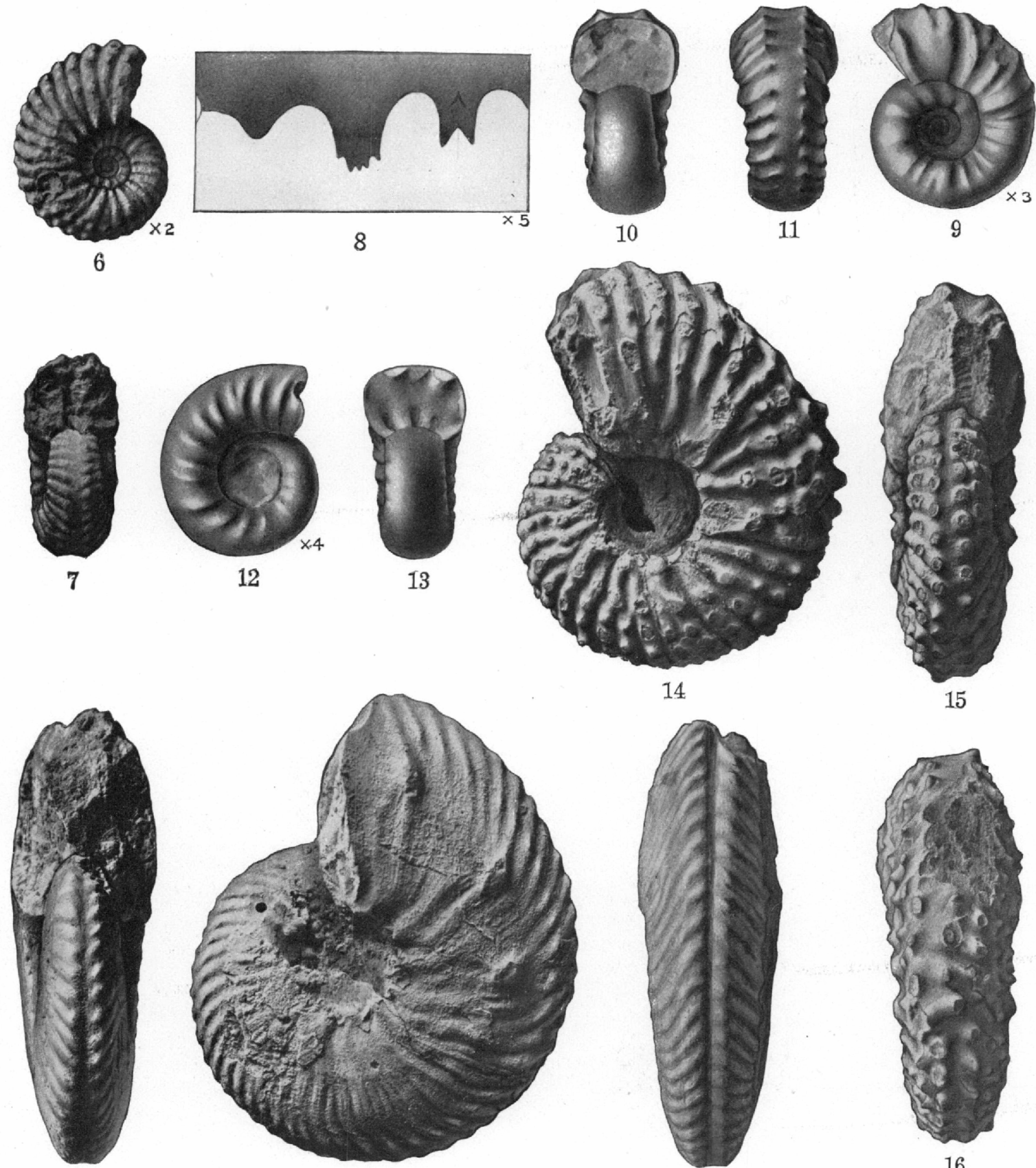

18

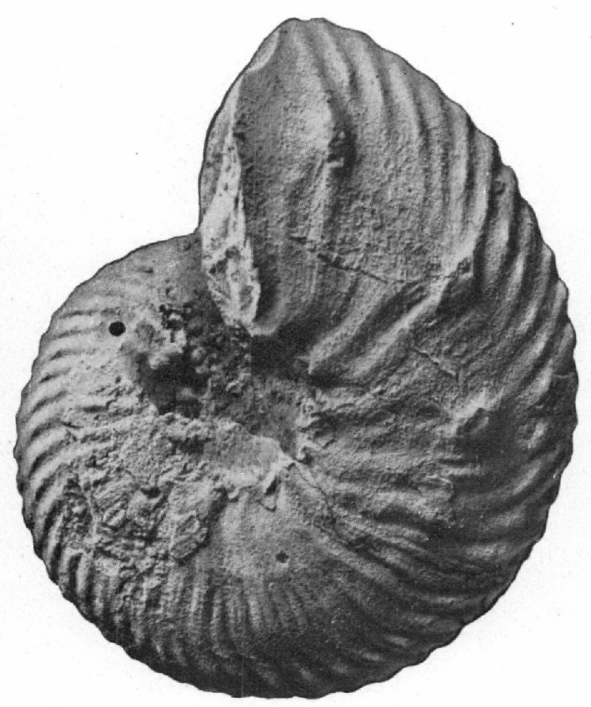

17

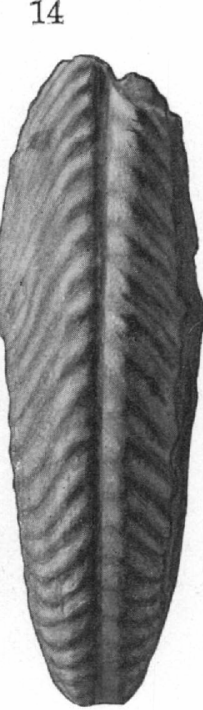

19

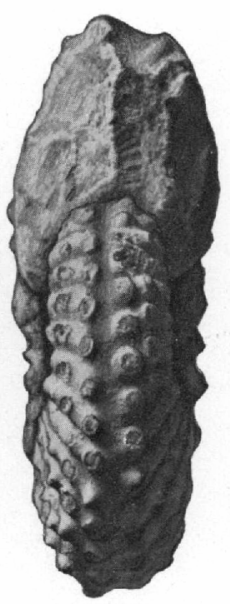

15

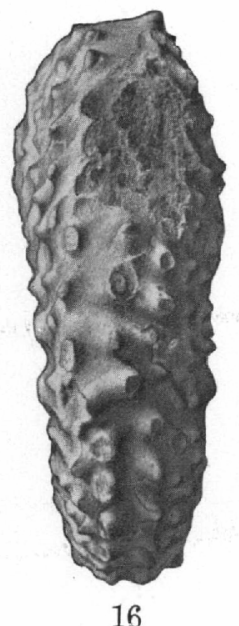




\section{PLATE LXXXIV.}

Trachyceras (Axolcites) furlongi Smith, sp. nov. (p. 130).

Figures 1, 2. Adolescent stage.

Figures 3-5. Adolescent stage $\left(\times 1 \frac{1}{2}\right)$; diameter 27 millimeters.

Figures 6,7 . Adolescent stage $(X 2)$; diameter 15 millineters.

Figure 8. Septa of the same. $(X 5)$.

Figures 9-11. Adolescent stage $(\times 3)$; diameter 10 millimeters.

Figures 12, 13. Adolescent stage $(X 4)$; diameter 7 millimeters.

Trachyceras (Protrachyceras) dixis Smith, sp. nov. (p. 134).

Fugures 14-16. Type.

Trachyceras (Protrachyceras) scbaspercim Meek (p. 137).

Figures 17-19. Adult specimen.

The specimens figured on this plate are from the Middle Triassic. Daonella dubia zone, of Fossil Hill. south fork of American Canyon, West Humboldt Range, Nev. They are in the collection of the United States Geological Survey.

$16279^{\circ}-$ No. $83-14-32$ 


\section{PLATE LXXXV.}

Trachyceras (Protrachyceras) lahontandm Smith, sp. nov. (p. 135).

Figures 1, 2. Type.

Figures 3, 4. Sculpture and septa.

Figure 5. Septa of the sime simecimen $(\times 2)$.

Trachiceras (Protrachyceras) springeri Smith, sp. nov. (p. 136).

Figures 6-8. Type $(\times \underline{2})$; septa $(\times 6)$.

Figure 9. Adult stage $(X 2)$.

Figure 10. Septa of the silme specimen $(X 4)$.

Trachyceras (Axolcites) gabbi Smith, sp. nov. (p. 132).

Figures 11, 12. 'Tyle.

The specimens shown in figures 1-5 and 11 and 12 are from the Middle Triassic, Daonella dubia zone, of Fossil Hill, south fork of American Cinyon, West Humboldt Range, Nev. They are in the collection of the United States Geological Survey. The originals of figures 6-10 are from the same beds, probably in Buena Vista Canyon, and are in the Whitney collection of Harvard Lniversity. 


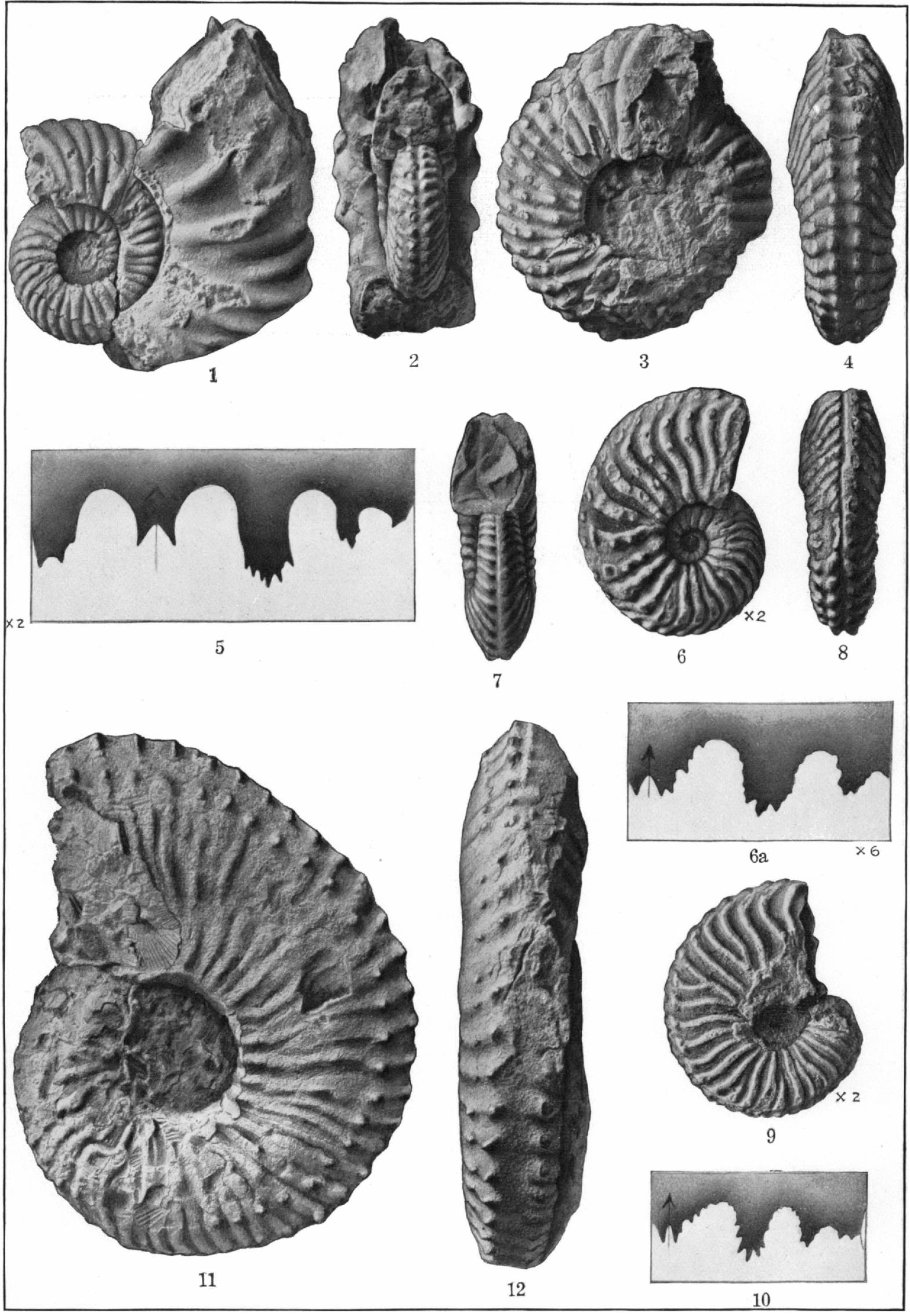




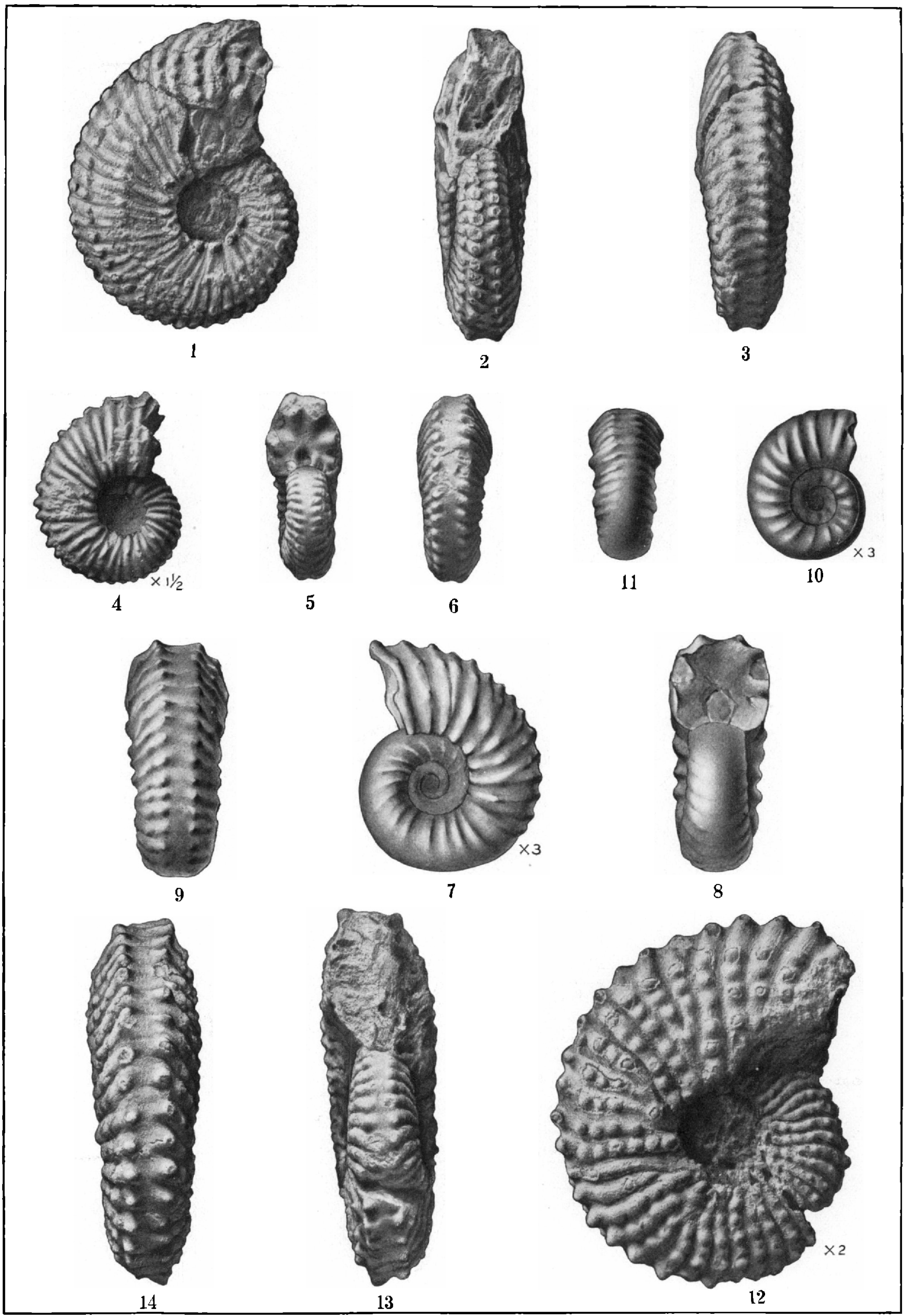




\section{PLATE LXXXVI.}

Trachyceras (Axolcites) gabbi Smith, sp. nov. (p. 132).

Figures 1-3. Early mature stage.

Figures $4-6$. Adolescent stage $\left(\times 1 \frac{1}{2}\right)$; diameter 23 millimeters.

Figures 7-9. Adolescent stage $(X 3)$; diameter 14 millimeters.

Figdres 10, 11. Adolescent stage $(X 3)$; diameter 9 millimeters.

Trachyceras (ANolcites) barberi Smith, sp. nov. (p. 130).

Figures 12-14. Type $(\times 2)$.

The specimens figured on this plate are from the Middle Triassic, Daonella dubia zone, of Fossil Hill, south fork of Americin Canyon, West Humboldt Range, Nev. They are in the collection of the Cnited States Geological Survey. 


\title{
PLATE LXXXVII.
}

\author{
Columbites humboldtexsis Smith, sp. nov. (p. 36).
}

Figures 1, 2. Type (natural size).

Ficure 3. Septa of the type $(X 4)$.

Figures 4, 5. Early wature stage $(X 2)$; diameter 18 millimeters.

Figdres 6, 7. Adolescent stage $(X 2)$; dianeter 13 millimeters.

Figure 8. Septa of the sume specimen $(X 5)$; diameter 9 millimeters.

Figure 9. Septa from a fragment of the same specimen $(X 5)$; diameter 17 millimeters.

Figure 10. Larral stige $(X 10)$; diameter 3.5 millimeters.

Figube 11. Septa of the same specimen $(X 20)$.

Figures 12, 13. Larval stage $(X 10)$; diameter 2.25 millimeters.

Figure 14. Septa of the same specimen $(\times 20)$.

\section{Colvarites Plicatile's Smith, sp. nov. (p. 37).}

Figures 15, 16. Adult stige $(\times 2)$.

Figures 17,18 . Adolescent stage $(\times 2)$; diameter 18 millimeters.

Figdres 19, 20. Adolescent stage $(X 2)$; diameter 11.5 millimeters.

FigURe 21. Septa from the inner whorl of the same specimen $(X 6)$; diameter 11 millimeters.

Figure 22. Inner septa from the same specimen $(X 6)$; diameter 10 millimeters.

Frgure 23. Inner lobes from the outer whorl of the same specinien $(\times 6)$; diameter 16 millimeters.

Tropigastrites rothipletzi Smith, sp. nov. (p. 31).

Figures 24, 25. Old specimen, showing digitate septa.

Figure 26. Septa of the same specimen $(X 4)$.

Tropigastrites ObLiteraxs Smith, sp. nov. (p. 30).

Figures 27, 2s. Type showing keel and septa.

Figure 29. Septa of the same specimen $(X 4)$.

Figures 30-32. Inner wholl of same specimen $(X 2)$; diameter 12.5 millimeters.

All specimens figured on this plate are from the Middle Triassic, Daonclla dubia zone, of Fossil Hill, south fork of American Canyon, West Hunboldt Range, Nev. They are in the collection of the United States Geological Survey. 


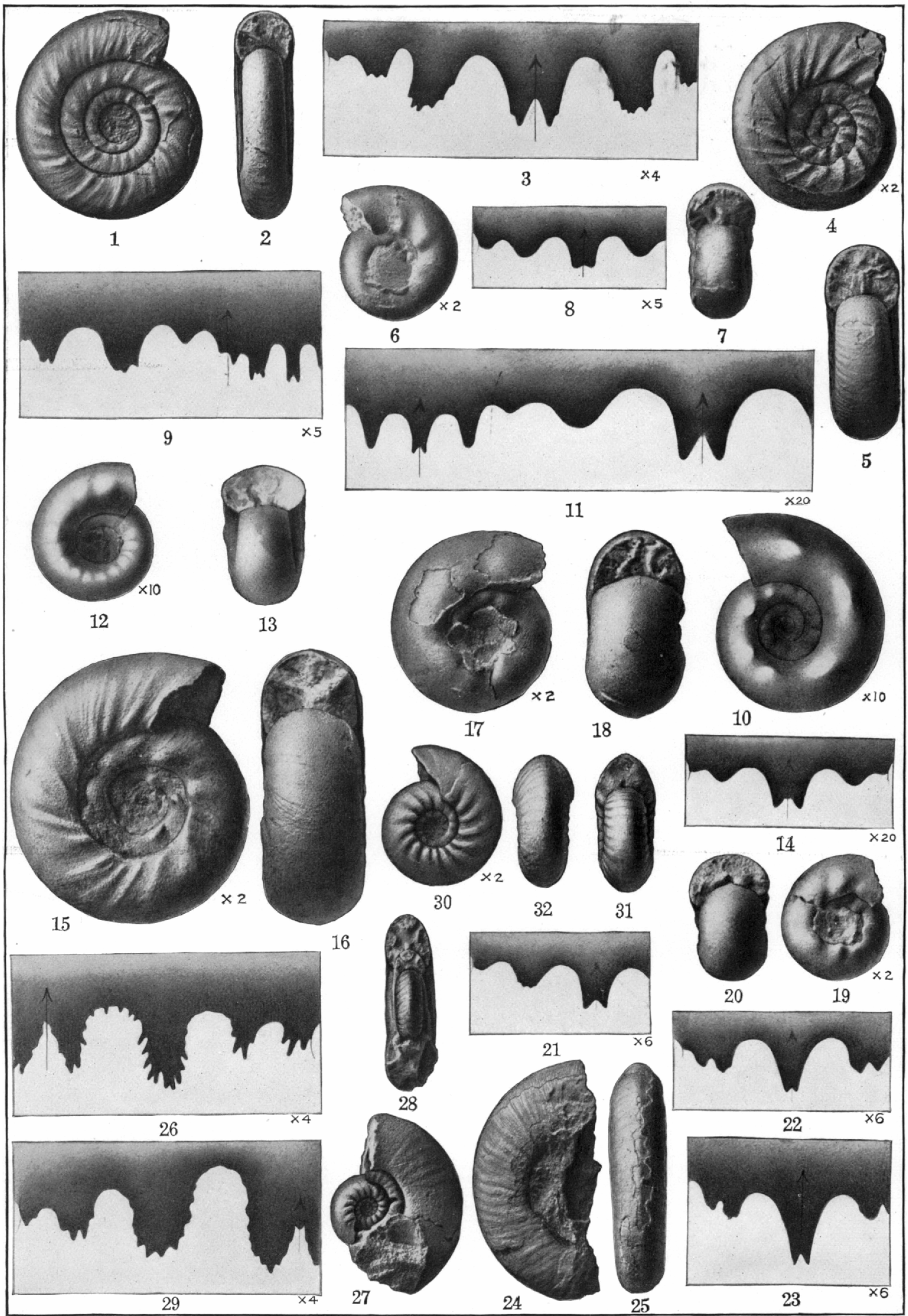




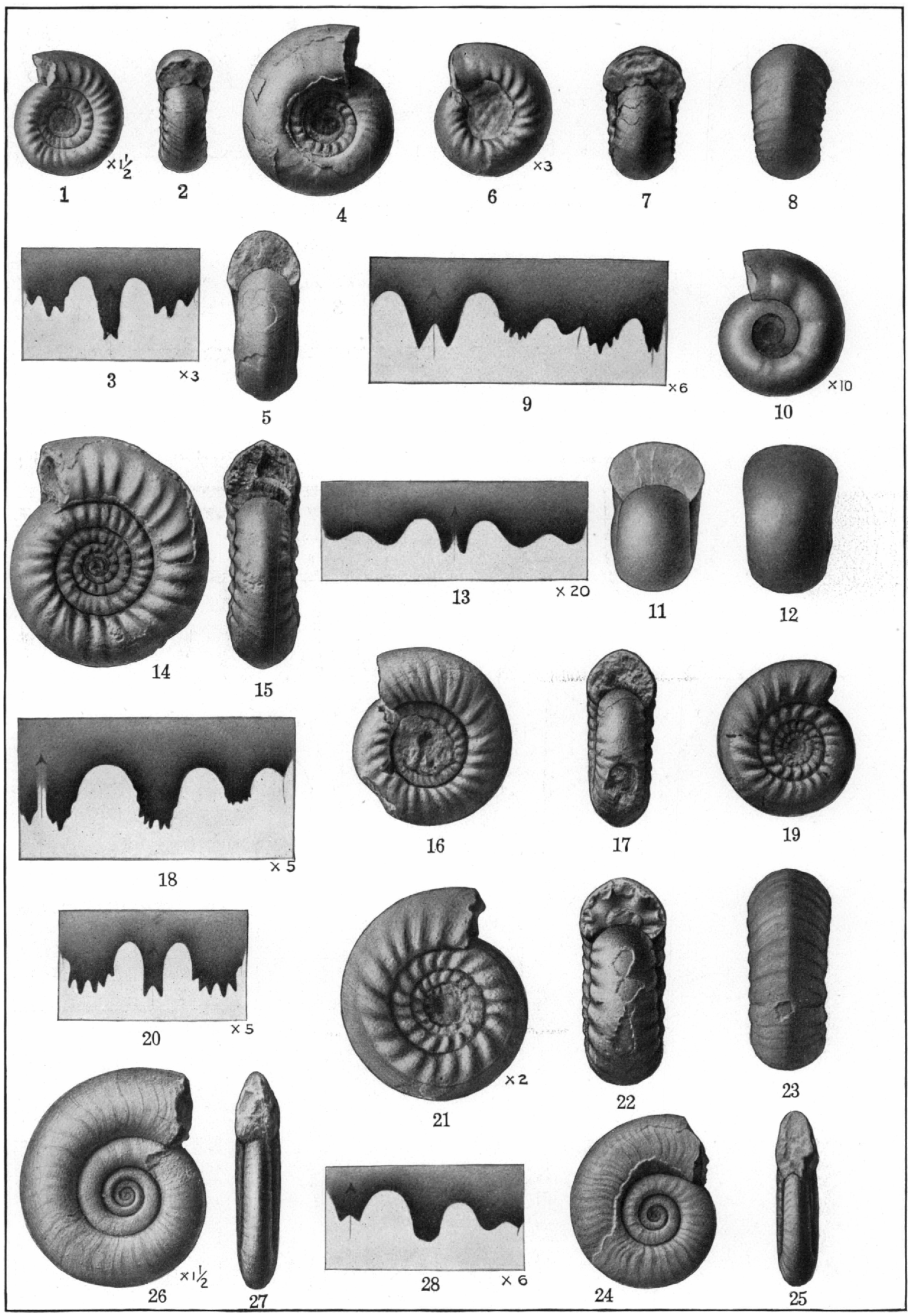




\section{PLATE LXXXVIII.}

Tropigastrites necmayri Mojsisovics (p. 29).

Figures 1, 2. Early mature stage $\left(\times 1 \frac{1}{2}\right)$.

Figdre 3. Inside sejta $(\times 6)$; diameter of specimen, 18 millimeters.

Tropigastrites locderbacki Hyatt and Smith (p. 29).

Figures 4 , 5. Adult stage.

Figures $6-8$. Adolescent stage $(X 3)$, showing the spiral lines; diameter 12 millimeters.

Figure 9. Septa of the same specimen ( $X$ i).

Figures 10-12. Larval stage ( $X 10)$; diameter, 2.35 millimeters.

Figure 13. Septa of the same specimen, $(X .20)$.

Tropigastrites halli Mojsisovics (p. 27).

Figubes 14, 15. Mature stage.

Figures 16, 17. Larly mature stage.

Figure 18. Septa of the sime specimen, $(\times 5)$.

Figure 19. Adult stage (natural size).

FIgURe 20. Septa of the same specimen, $(X 5)$.

Figures 21-23. Early mature stage $(\times 2)$; diameter 20 millimeters.

LeCANites rogidesi Hyatt and Smith (p. 67).

Figures 24, 25. Specimen showing fine sculpture.

LeCanites Parres Smith, sp. nov. (p. 66).

Figdres 26, 27. Adult specimen (type) $\left(X 1 \frac{1}{2}\right)$.

Figure 28. Septa of the type $(\times 6)$.

The originals of all figures on this plate are from the Middle Triassic, Daonella dubia zone, of Fossil Hill, West Humboldt Range, Nev. Collection of the United States Geological Survey. $16279^{\circ}$-No. $83-14-33$ 


\section{PLATE LXXXIX.}

LeCanites CRassus Smith, sp. nov. (p. 66).

Figures 1, 2. Type ( $\times 1$ 1 1 ).

Dinarites desertoryy Smith, sp. nov. (p. 69).

Figures 3, 4. Type $\left(\times 1 \frac{1}{2}\right)$.

Figunes 5. 6. Adult stage $\left(\times 1 \frac{1}{2}\right)$.

Figure 7 . Septa of the sime specimen $(X 5)$.

Dinarites PygMets Smith, sp. nov. (p. 70).

Figures S, 9. Type $\left(\times 1 \frac{1}{2}\right)$

Ceratites pilates Smith, sp. nov. (p. 102).

Figures 10-12. Type.

Figure 13. Septa of the type $(\times 2)$.

Beynicirtes osmonti Smith, sp. nov. (p. 117).

Figure 14. Strix of growth $(X 1 \stackrel{1}{1})$.

Beyricintes 'texicis Smith, sp. nov. (p. 119).

Frgores 15. 16. Adult stage, showing the septa.

Figurs: 17. Septil of the same specimen $(X 3)$.

Figure 18, 19. Early mature stage $(\times 1 \underline{1})$.

Figure 20. Septa of the same $(\times 4)$.

All specimens figured on this plate are from the Middle Triassic, Daonclla dubia zone, of Fossil Hill, south fork of American Canyon. West IIumboldt Range, Nev. They are in the collection of the United States Geological Survey. 


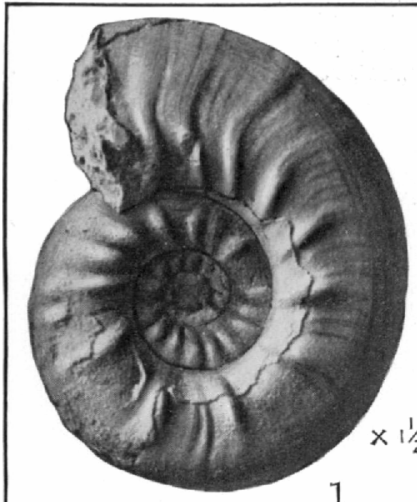

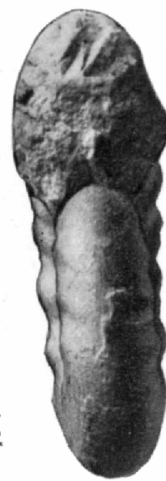

2

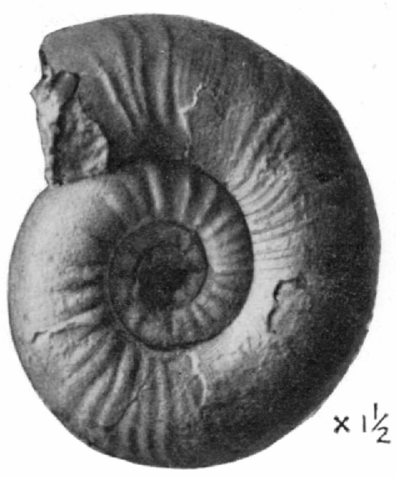

3

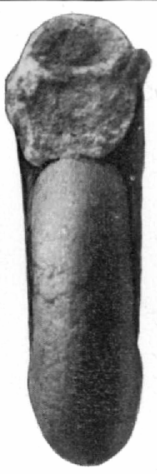

4

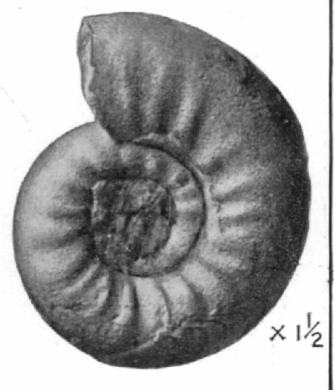

5

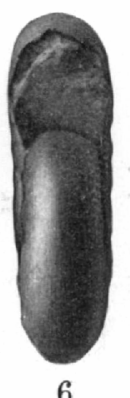

6

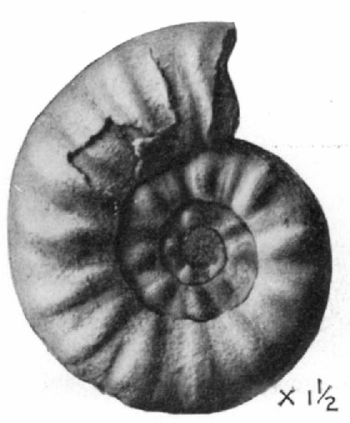

8

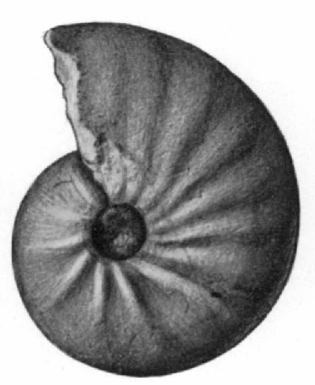

15

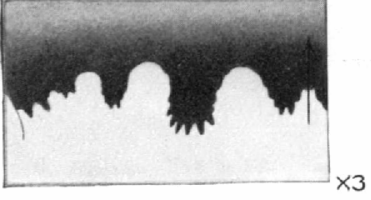

17

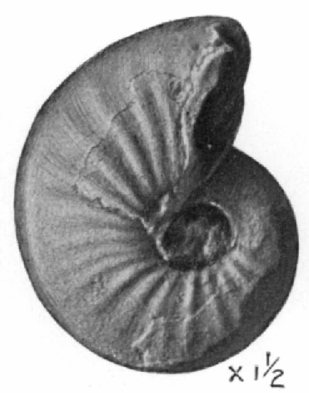

18

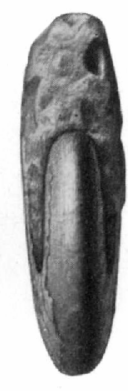

19

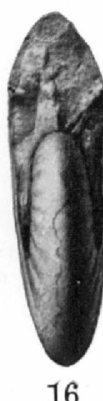

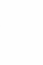
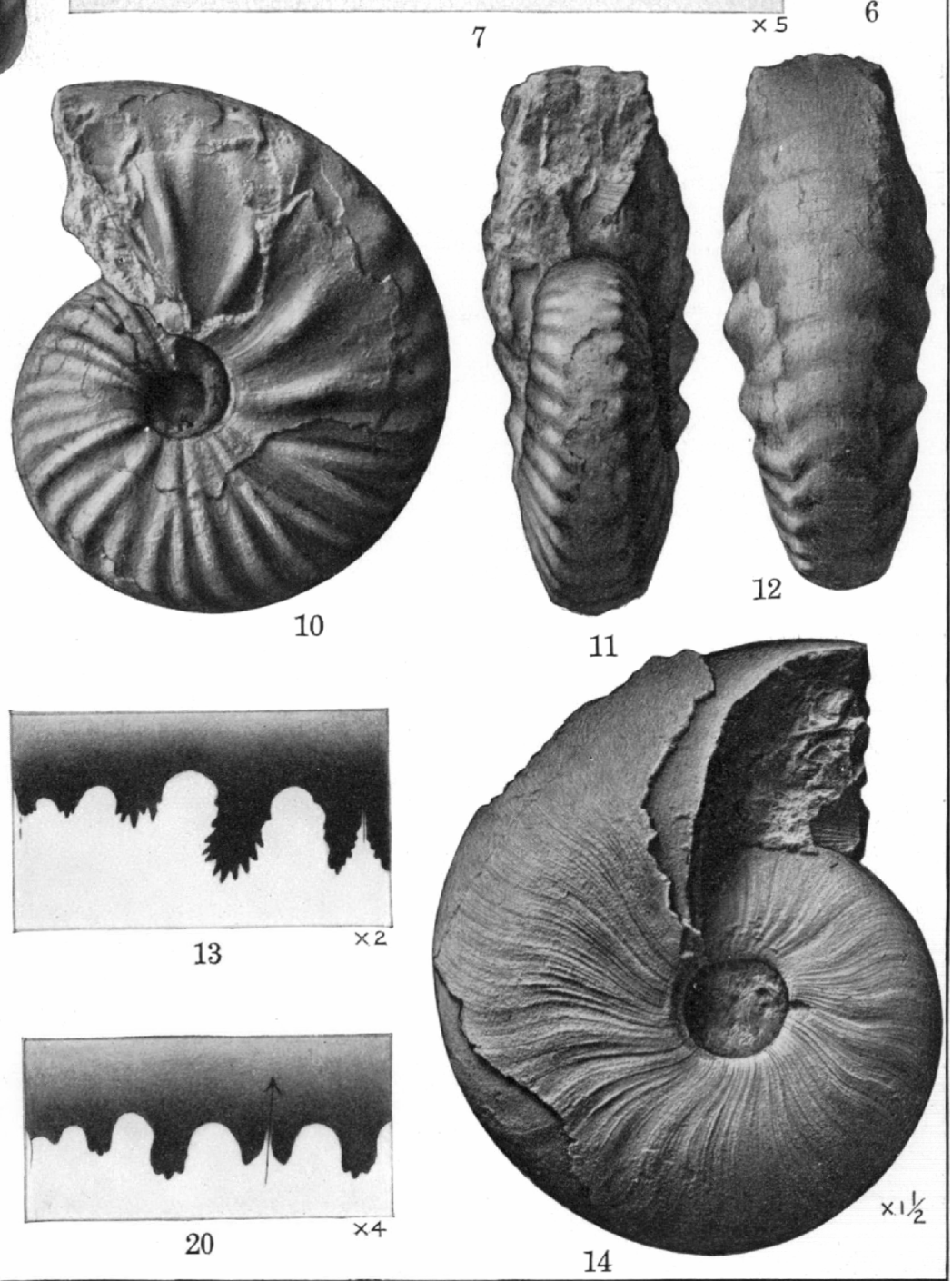


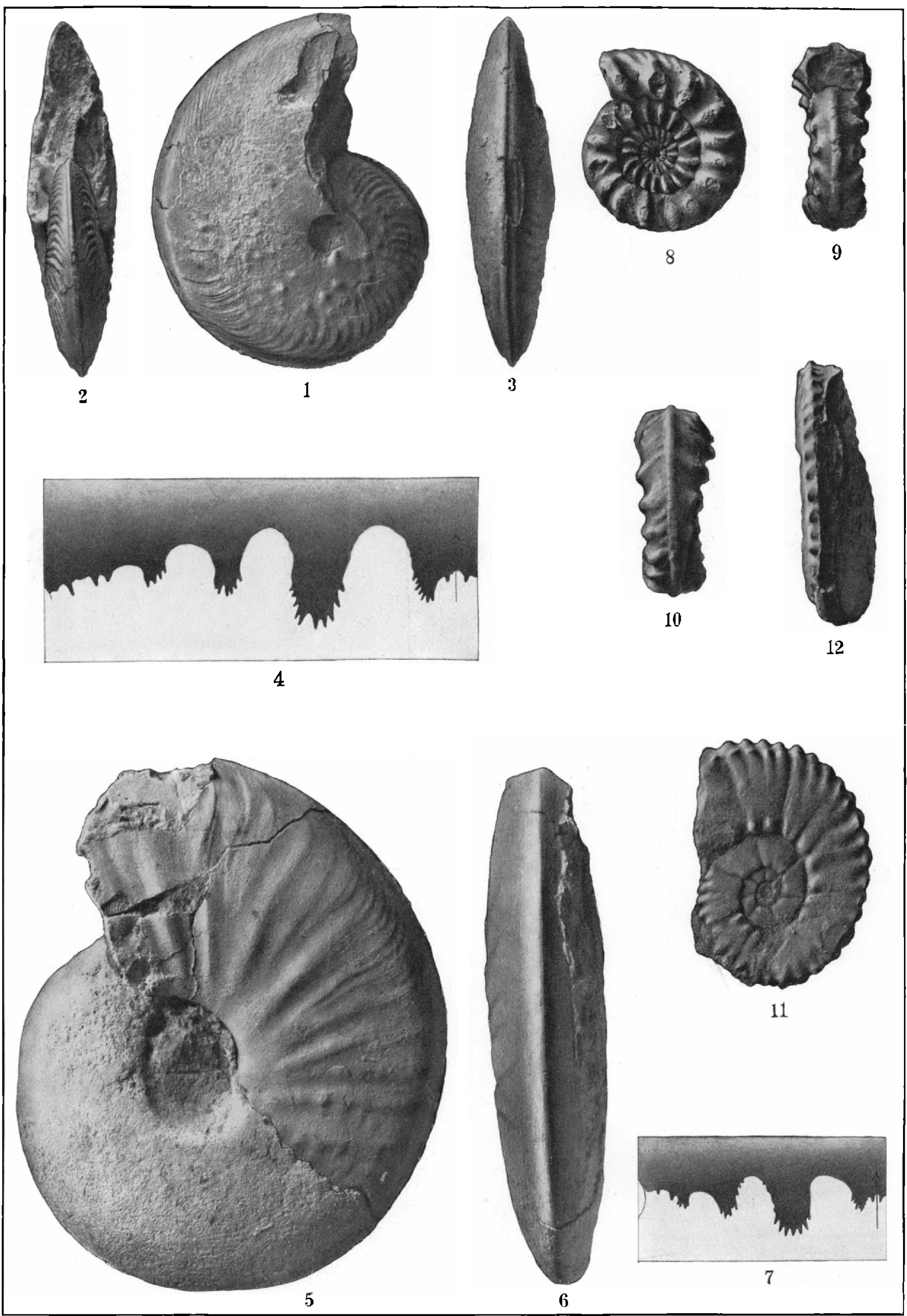




\section{PLATE XC.}

Eutonoceras latibi Meek (p. 63).

Figures 1-4. Adult specimen, showing sculpture and septa.

Hungarites fittixgensis Smith, sp. nov. (p. 58 ).

Figures 5-7. Type (natural size).

Balatonites hadieyi Smith, sp. nov. (p. 119).

Figures 8-10. Type.

BaLatonites Kingi Smith, sp. nor. (p. 120).

Figures 11, 12. Type.

The originals of figures $1-\tau$ are from the Middle Triassic, Daonella dubia zone, of Fossil Hill, south fork of American Canyon, West Humboldt Range, Nev. They are in the collection of the United States Geological Survey. The original of figures 8-10 is from the same horizon, near Lnionville, Buenal Vista Canyon, Nev., and is in the collection of J. P. Smith. The original of figures 11 and 12 is from the same horizon, probably from New Palss, Nev., Whitney collection, Harvard University. 


\section{PIAATE XCI.}

\section{Beyrichites RotTELLiformis Meek (p. 11S).}

Figure 1. Mature stage, showing sigmoidal folds and the'septa.

Figure 2. Septa of the sime specimen $(\times 2)$.

Figure 3. Adolescent stage $(X 2)$; diameter 22 millimeter's.

Figure 4. Septa of the same specimen $(\times 0)$; diameter 14 millimeters.

Figures 5, 6. Adolescent stage $(X 2)$; diameter 19 millimeters.

Figure 7. Septa of the same specimen $(\times 6)$; diameter 13 millimeters.

Figure 8. Adolescent stage $(\times 4)$; diameter 11 millimeters.

Figure 9. Adolescent stage $(X 4)$; diameter $8 . \overline{1}$ millimeter's.

Figure 10. Septa of the same specimen $(X 6)$.

BeYrichites faLciformis Smith, sp. nov. (p. 116).

Figures 11-13. Type.

The specimens figured on this plate are from the Middle Triassic, Daonclla dubia zone, of Fossil Hill, West Humboldt Range, Nev. They are in the collection of the Lnited States Geologica] Survey.

240 


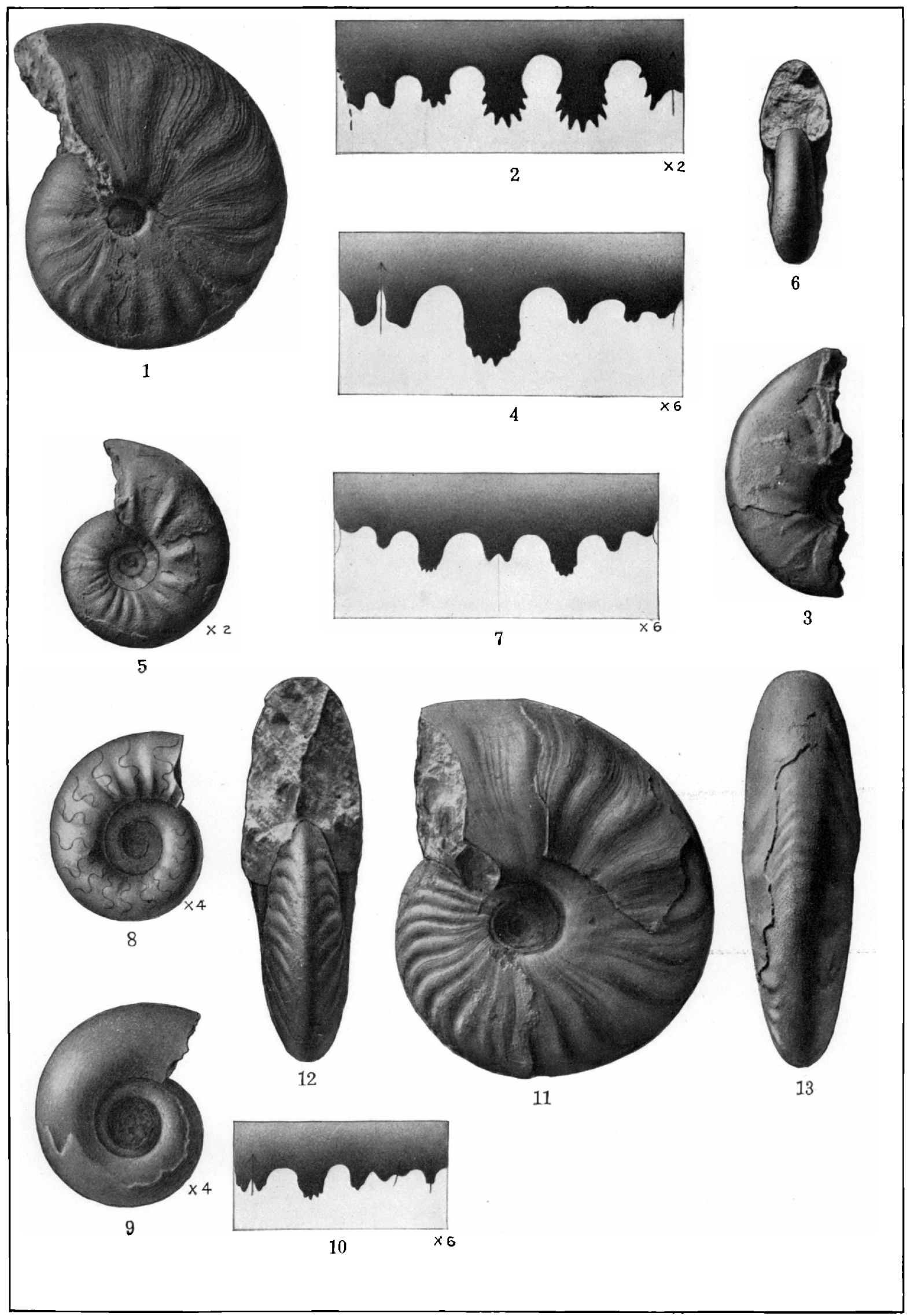




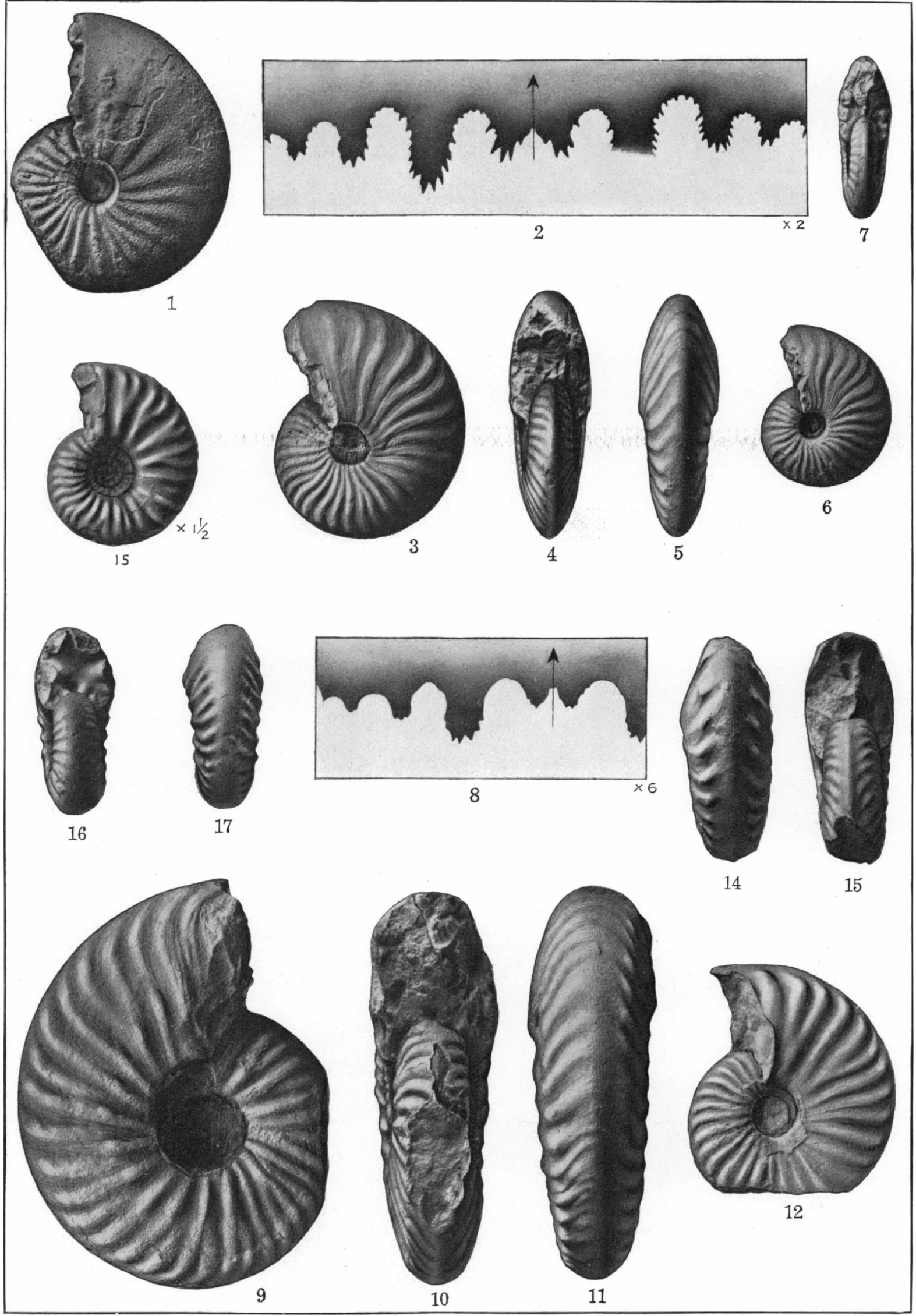




\section{PLATE XCII.}

Beyrichites falciformis Smith, sp. nov. (p. 116).

Figure 1. Cotype (natural size).

Figure 2. Septa of the cotype ( $\times 2$ ).

Figures 3-5. Late adolescent stage.

Figures 6, 7. Adolescent stage (natural size).

Figure 8. Septa of the same $(\times 6)$.

Ceratites washbernei Smith, sp. nov. (p. 103).

Figures 9-11. Type.

Figures 12-14. Early mature stage.

Figures 15-17. Adolescent stage ( $\left.\times 1 \frac{1}{2}\right)$; diameter 22 millimeters.

The specimens figured on this plate are from the Middle Triassic, Daonella aubia zone, of Fossil Hill, south fork of American Canyon, West Humboldt Range, Nev. They are in the collection of the United States Geological Survey.

$16279^{\circ}-$ No. $83-14-34$ 


\section{PLATE XCIII.}

Ceratites (Grmxotoceras) hersheyi Smith, sp. nov. (p. 110).

Figures 1-3. Type.

Figcres 4 , 5. Early adult stage (natural size).

Figures 6 . Septa of the same $(\times 4)$.

Figures 7,8 . Early mature stage showing the shape of the aperture

Figures 9, 10. Early mature stage, showing the aperture.

Figures 11, 12. Adolescent stage $\left(\times 1 \frac{1}{2}\right)$; diameter 17 millimeters.

Figures 13, 14. Adolescent stage $(\times 3)$; diameter 9 millimeters.

Arcestes (Proarcestes) quadrilabiatus Hauer (p. 44).

Figures 15, 16. Adult shell.

Arcestes (Proarcestes) hartzelli Smith, sp. nov. (p. 43).

Figures 17, 18. 'Type.

Arcestes (Proarcestrs) gabbi Meek (p. 43).

Figure 19. Early mature stage (natural size).

Figcre $19 a$. Septa of the same $(\times 3)$.

Figure 20. Septa of another specimen.

The specimens figurerl on this plite are from the Middle Triassic, Daonella dubia zone, of Fossil Hill, sonth fork of American Canyon, West Ilumboldt Range, Ner. They are in the collection of the United States Geological Survey. 


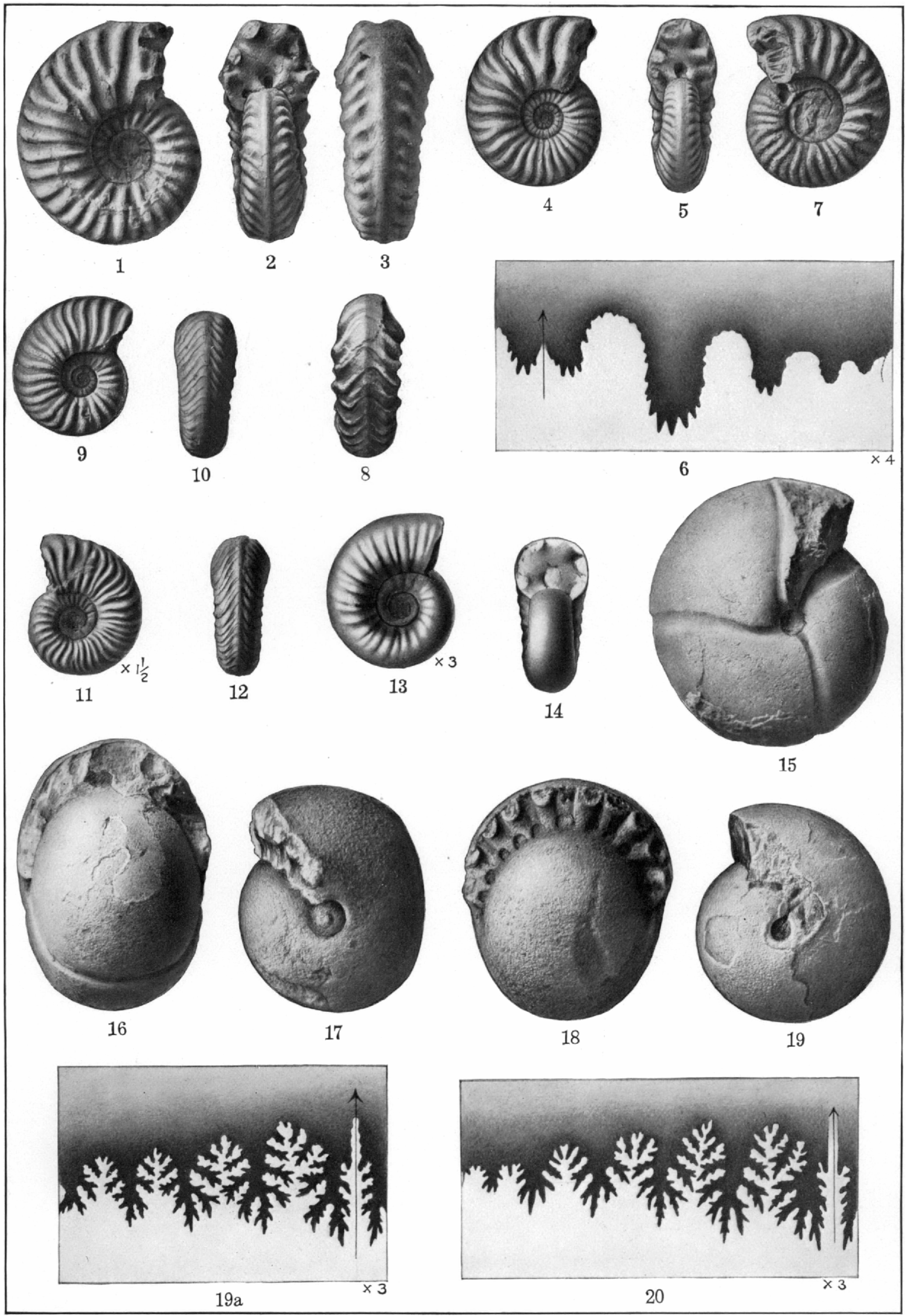




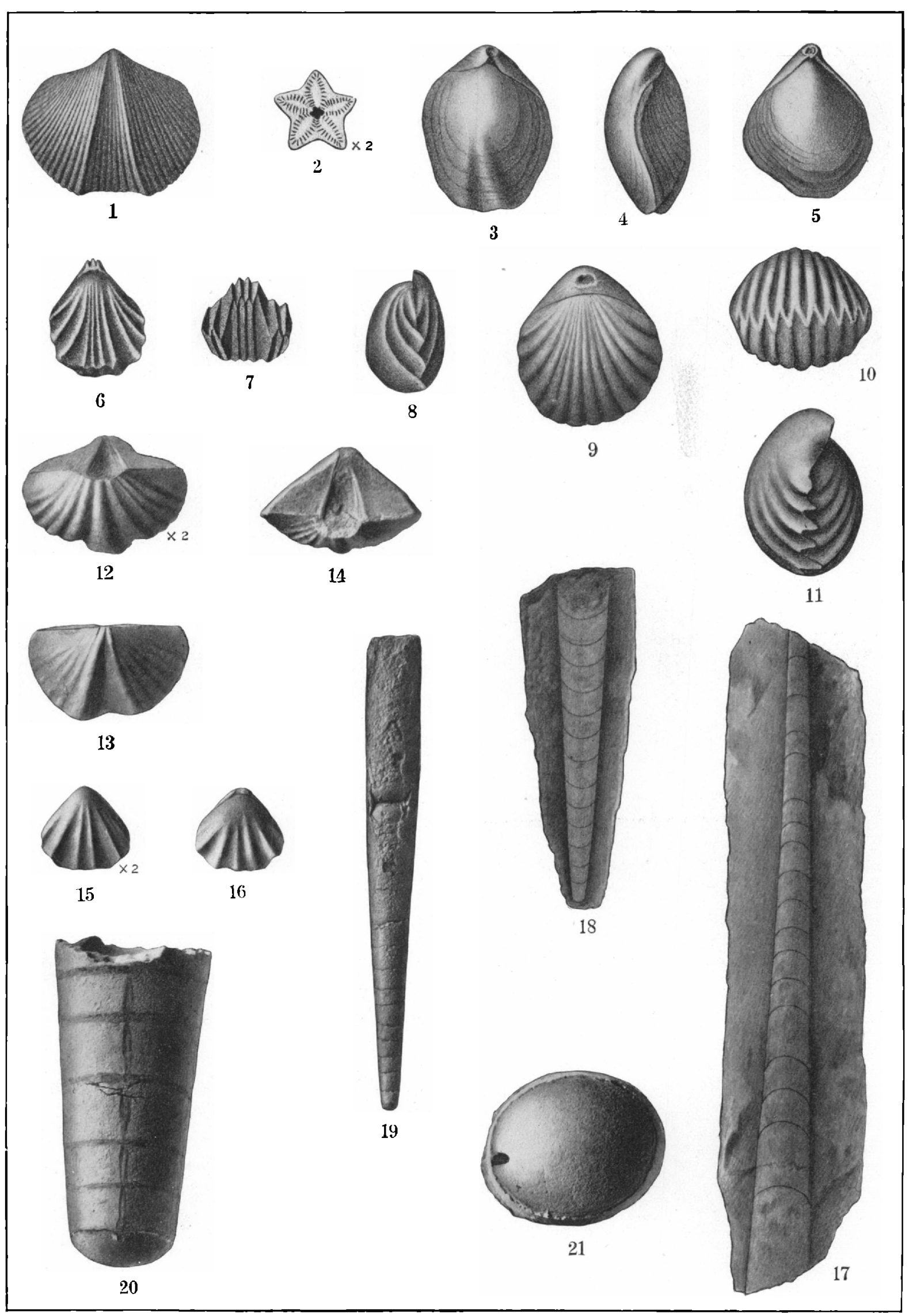




\section{PLATE XCIV.}

\section{Spiriferina Alia Hall and Whitfield (p. 147).}

Figure 1. From Dun Glen, East Range, Ner., after Hall and Whitfield (U. S. Geol. Expl. 40th Par. vol. 4, pt. 2, Pl. VI, fig. 17).

\section{Pentacrinus asteriscus? Hall and Whitfield (p. 148).}

Figure 2. From Dun Glen, East Range, Nev., after Hall and Whitfield (op. cit., Pl. VI, fig. 16).

Terebratcla humboldtensis Gabb (p. 147).

Figures 3-5. From Dun Glen, Ealst Range, Ner., after Hall and Whitfield (op. cit., Pl. VI, figs. 22-24).

Rhynchonella lingulata Gabb (p. 147).

Frgures 6-8. From Star Canyon, West Humboldt Range, Nev., after Gabb (Geol. Survey California Palæontology, vol. 1, figs. 36a-b).

\section{Rhynchonella eqUiPlicata Gabb (p. 146).}

Figcres 9-11. From Cinnahar district, East Range, Ner., after Gabb (Geol. Survey California Palaentology vol. 1, Pl. VI, figs. $37 a-b)$.

Spiriferina homfrayi Gabb (p. 147).

Figures 12-14. From New Pass, Desatoya Mountains, Nev., collection of J. P. Smith.

Rhychonella ALteplecta Böckh (p. 146).

Figurfs 15, 16. From New Pass, Desatoya Momntains, Ner., collection of J. P. Smith.

Orthoceras campanile Mojsisovies (p. 141).

Figure 17. rengthwise section, adult stage.

Figure 18. Iengthwise section, young stage.

Figure 19. Adult specimen.

From Fossil Hill, West Humboldt Range, Nev., collection of United States Geological Survey.

Atractites вöckiri Stürzenbaum (p. 138).

Figure 20. Front view, showing siphuncle

Figure 21. Fnd view of another specimen.

From Fossil Hill, West Humboldt Range, Ner., collection of United States Geological Surver. 


\section{PLATE XCV.}

Germanonadtilcs furlongi Smith, sp. nov. (p. 142).

Figures 1, 2. Type specimen, from Fossil Hill, West Humboldt Range, Ner., Middle Triassic, collection of J. P. Smith.

\section{Paranautilus multicameratus Gabb (p. 113 ).}

Figures 3, 4. Adult specimen, from the Middle Triassic, Fossil IHill, West Humboldt Range, Nev., collection of United States Geological Survey.

244 


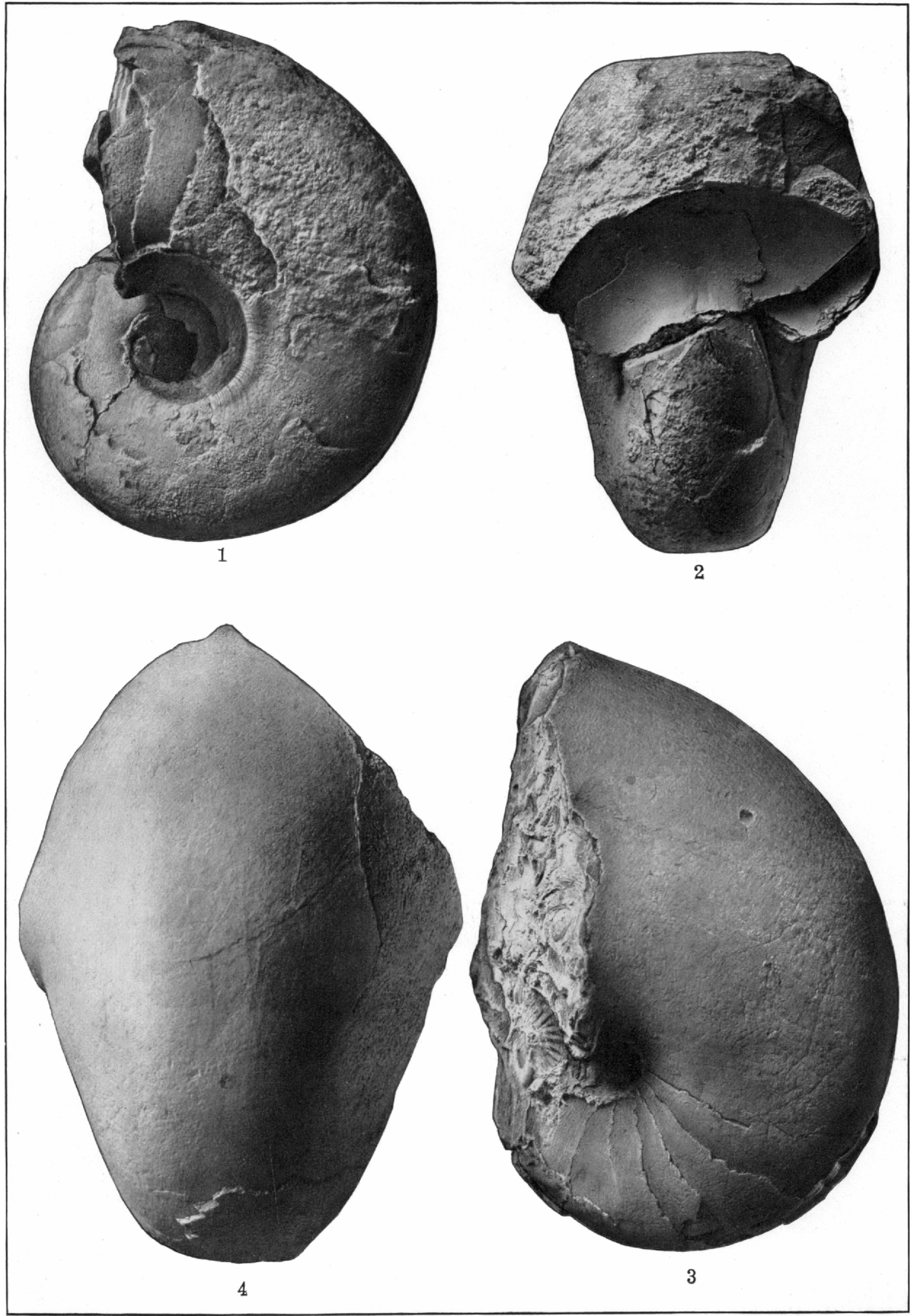




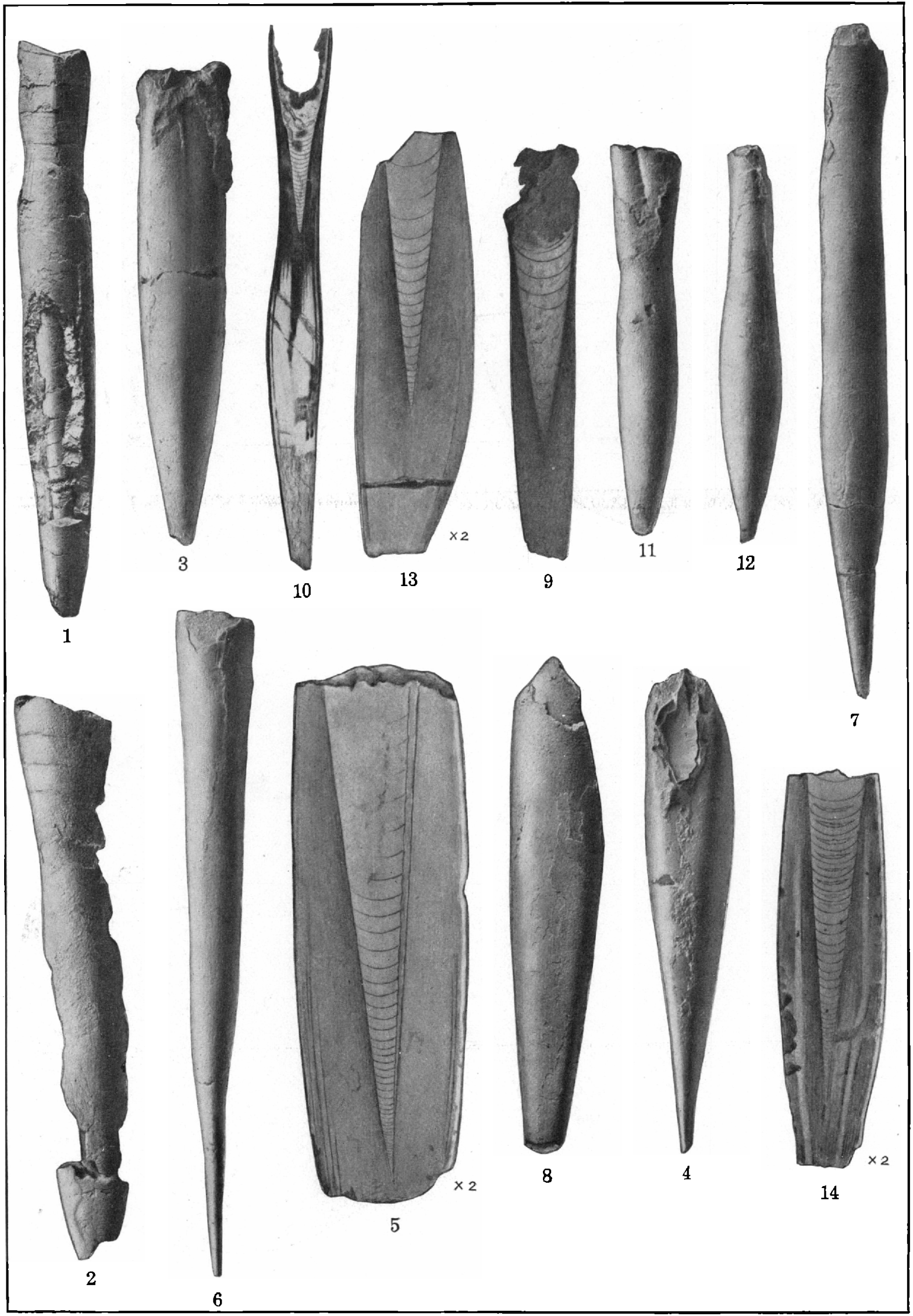




\section{PLATE XCVI.}

Atractites solidus Smith, sp. nov. (p. 140).

Figures 1, 2. Type, front and side views.

Figures 3, 4. Cotype, showing the beak of the guard.

FIGURE 5. Lengthwise section $(X 2)$, showing the phragmocone.

Atractites burckhardti Smith, sp. nov. (p. 138).

Figures 6, 7. Type, front and side views.

Atractites nevadexsis Meek (p. 139).

FIgures 8, 9. Showing the guard and the phragmocone.

Atractites elegans Smith, sp. nov. (p. 139).

FIGURE 10. Type, lengthwise section.

Atractites clavatulus Smith, sp. nov. (p. 139).

Figures 11, 12. Type.

FIgURe 13. Lengthwise section $(X 2)$.

FIGURE 14. Lengthwise section $(X 2)$.

All specimens figured on this plate are from the Middle Triassic of Fossil Hill, West Humboldt Range, Nev. They are in the collection of the United States Geological Survey.

$16279^{\circ}-$ No. $83-14-35$ 


\section{PLATE XCVII.}

Tropigastrites Poweldi Smith, sp. nov. (p. 31).

Figures 1-3. Type (natural size).

Figure 4. Septa of the same $(\times 3)$.

Figures 5, 6. An older specimen than the type.

Figures 7, 8. Early mature stage (natural size).

Figures 9, 10. Adolescent stage $(\times 2)$, showing transition from Gastrioceras to Tropigastrites; diameter 20 millimeters.

Figures 11, 12. Adolescent, gastrioceran stage $(X 3)$; diameter 11 millimeters.

Gymnites (Anagymnites) cf. acutus Hauer (p. 54).

Figunes 13, 14. Side and rear views.

Trachyceras (AnOlcites) drakei Smith, sp. nov. (p. 129).

Figures 15-17. Type.

All specimens figured on this plate are from the Middle Triassic, Daonella dubia zone of Fossil Hill, West Humboldt Range, Nev. They belong to the collection of the United States Geological Survey. 


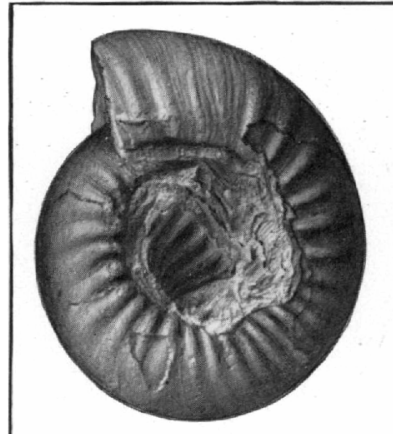

1

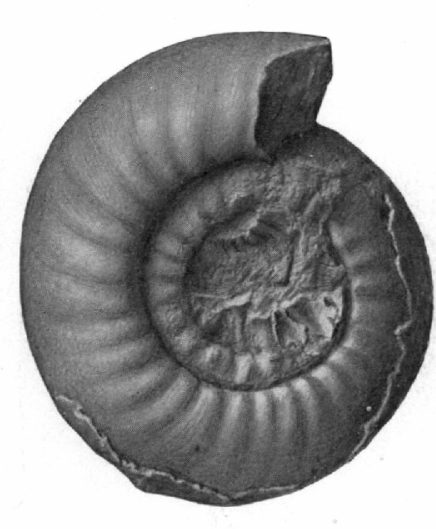

5

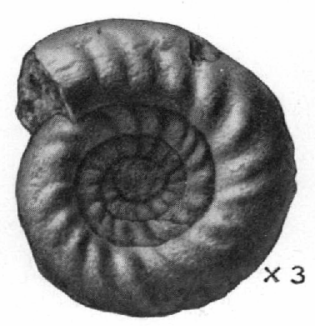

11

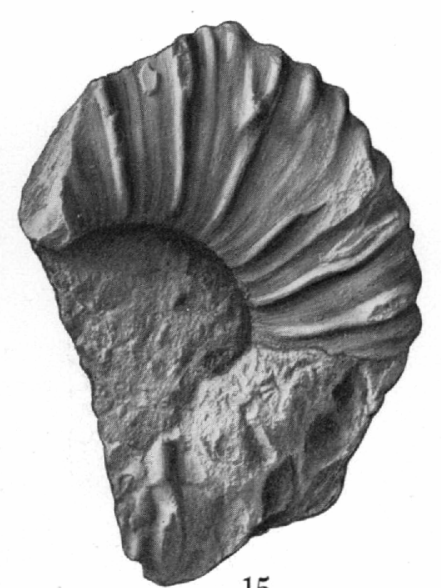

15

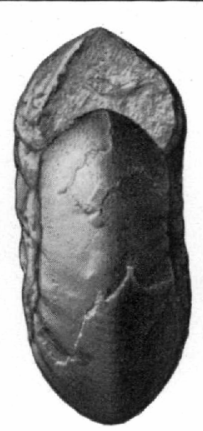

2
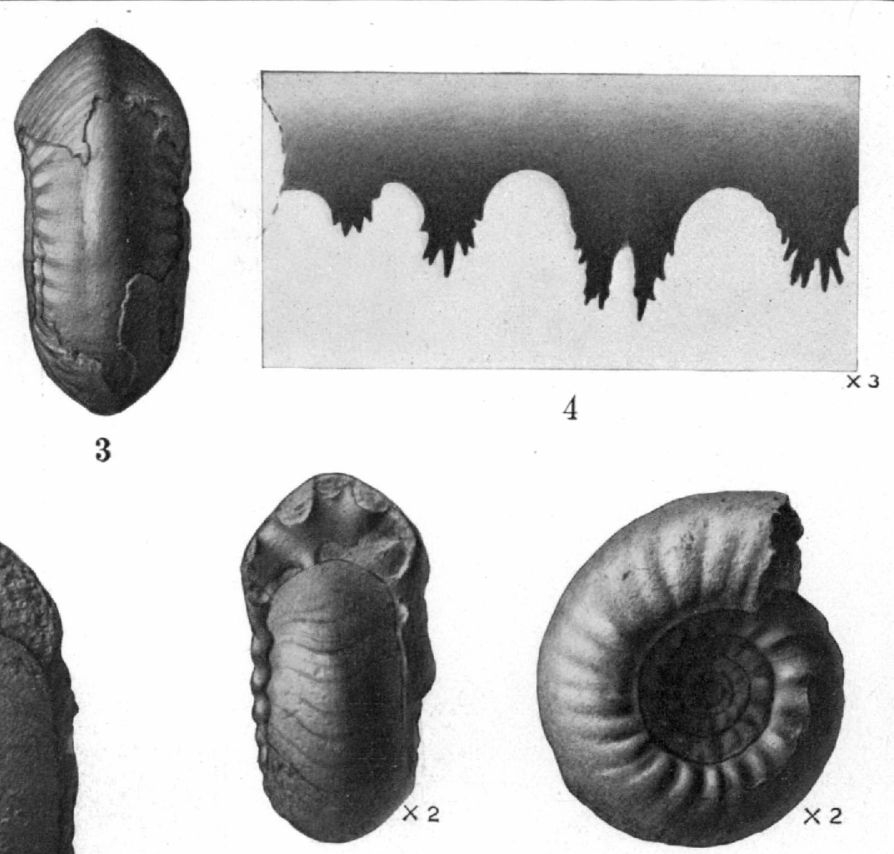

10

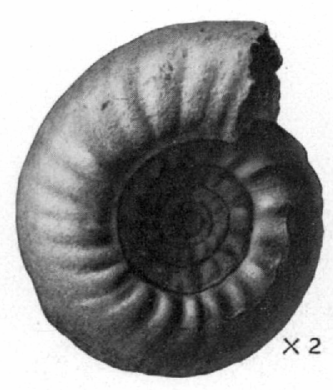

9

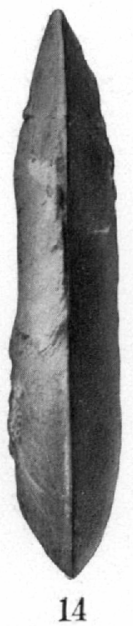

13
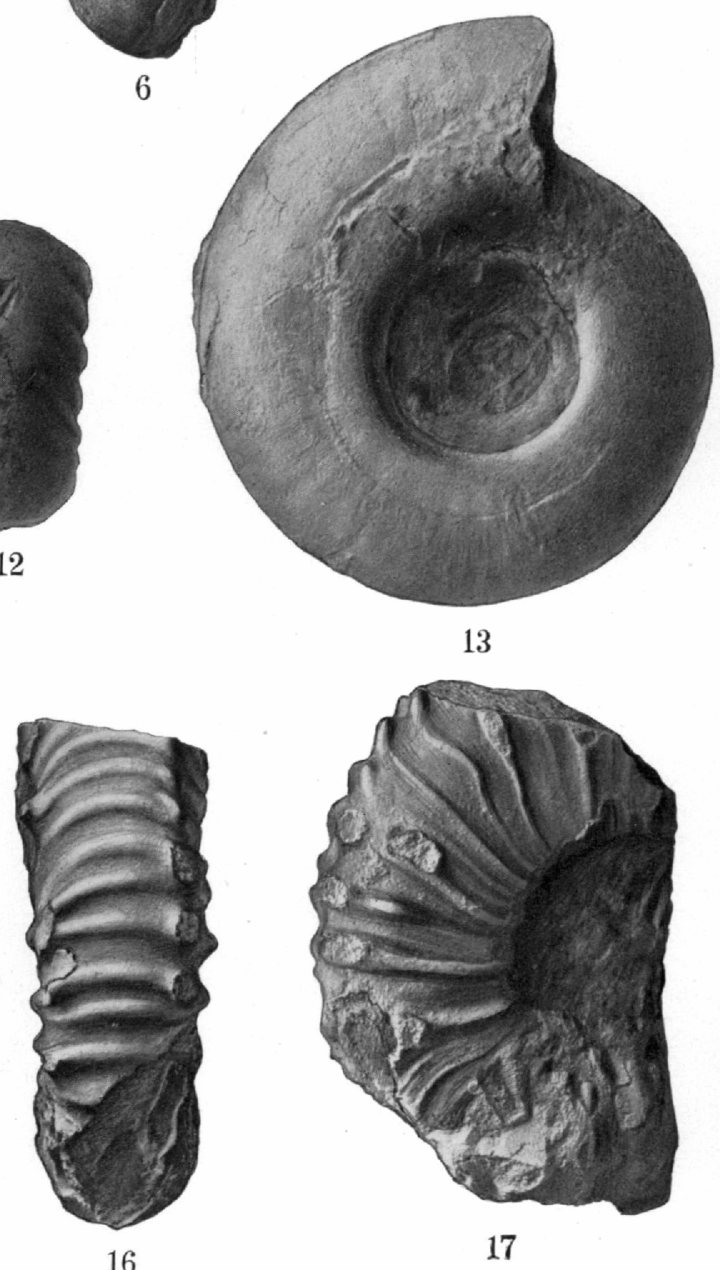

17

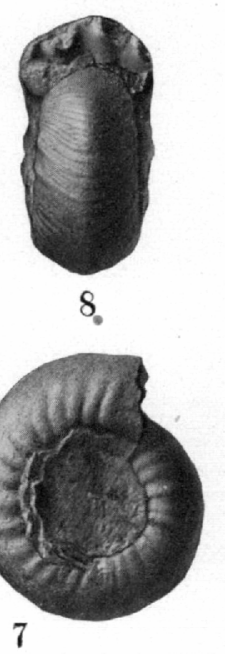




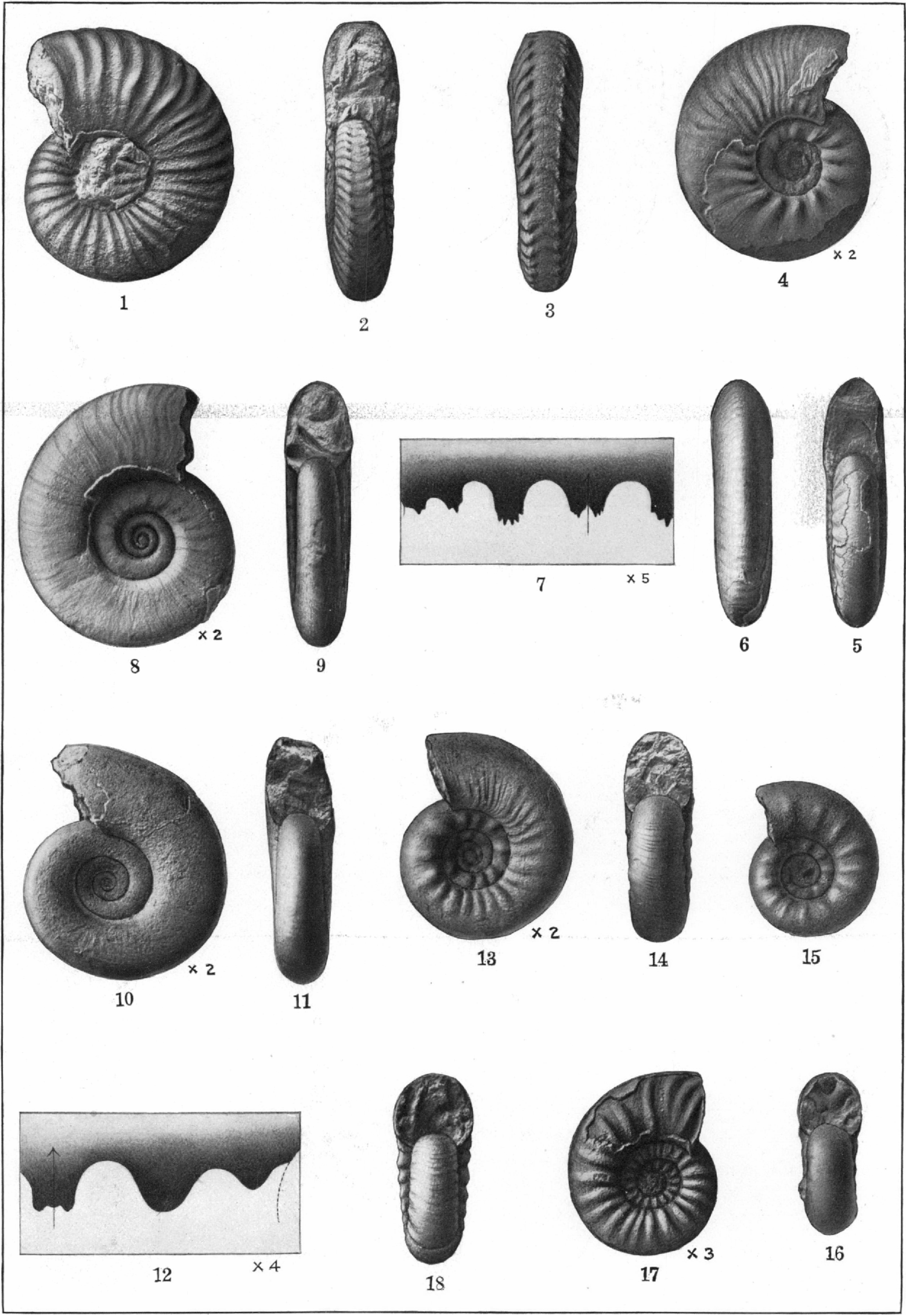




\section{PLATE XCVIII.}

Ceratites gilberti Smith, sp. nov. (p. 84).

Figures 1-3. Type $\left(\times 1 \frac{1}{2}\right)$, from Fossil Hill, West Humboldt Range.

Ceratites weaveri Smith, sp. nov. (p. 82).

Figures 4-6. Type $(\times 2)$, from New Pass, Desatoya Mountains.

Figure 7 . Septa of the type $(X 5)$.

LeCanites nudes Smith, sp. nov. (p. 66).

Figures 8, 9. Type $(\times 2)$, from Fossil Hill, West Humboldt Range.

Figures 10, 11. Cotype $(\times 2)$, from Fossil Hill, West Humboldt Range.

Frgure 12. Septa of the cotype $(\times 4)$.

Dinarites desertorum Smith, sp. nov. (p. 69).

Figures 13, 14. Transition from adolescence to maturity $(X 2)$.

Figures 15, 16. Adolescent stage $(\times 2)$; diameter 15 millimeters.

FIGUREs 17, 18. Adolescent stage $(X 3)$; diameter 11 millimeters.

All specinens figured on this plate are from the Middle Triassic, Daonella dubia zone of Nevada. The originals of figures 1-3 and 8-18 are from Fossil Hill, West Humboldt Range, Nev, and belong to the collection of the United States Geological Survey. The original of figures 4-7 is from New Pass, Desatoya Mountains, and is in the collection of J. P. Smith. 


\section{PLATE XCIX.}

Ceratites (Philippites) ransomei Smith, sp. nov. (p. 108).

Figures 1-3. Type.

Figure 4. Septa of another specimen $\left(\times 1 \frac{1}{2}\right)$.

Grypoceras whitneyi Gabb (p. 141).

Figures 5-7. Characteristic sculpture and the loug dorsil lobe.

The specimens shown in this plate are from the Middle Triassic, zone of Ceratites trinodosus, Wheeler mine, Buena Vista Canyon, near Unionville, West Humboldt Ringe, Nev., and were collected by F. I. Ransome. They are in the collection of the United States Geological Survey. 


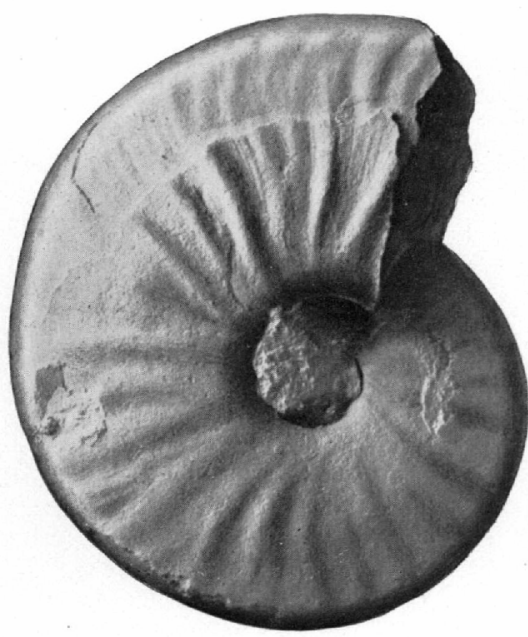

1

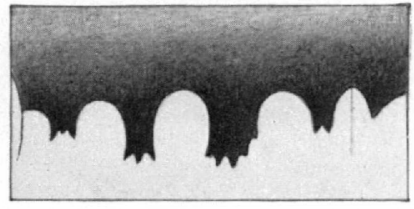

4
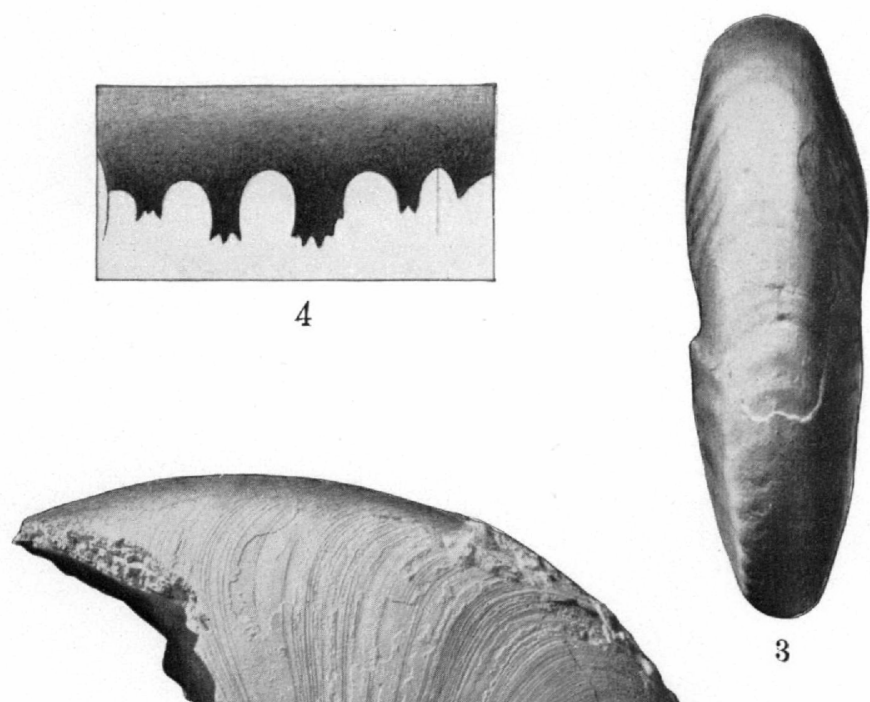
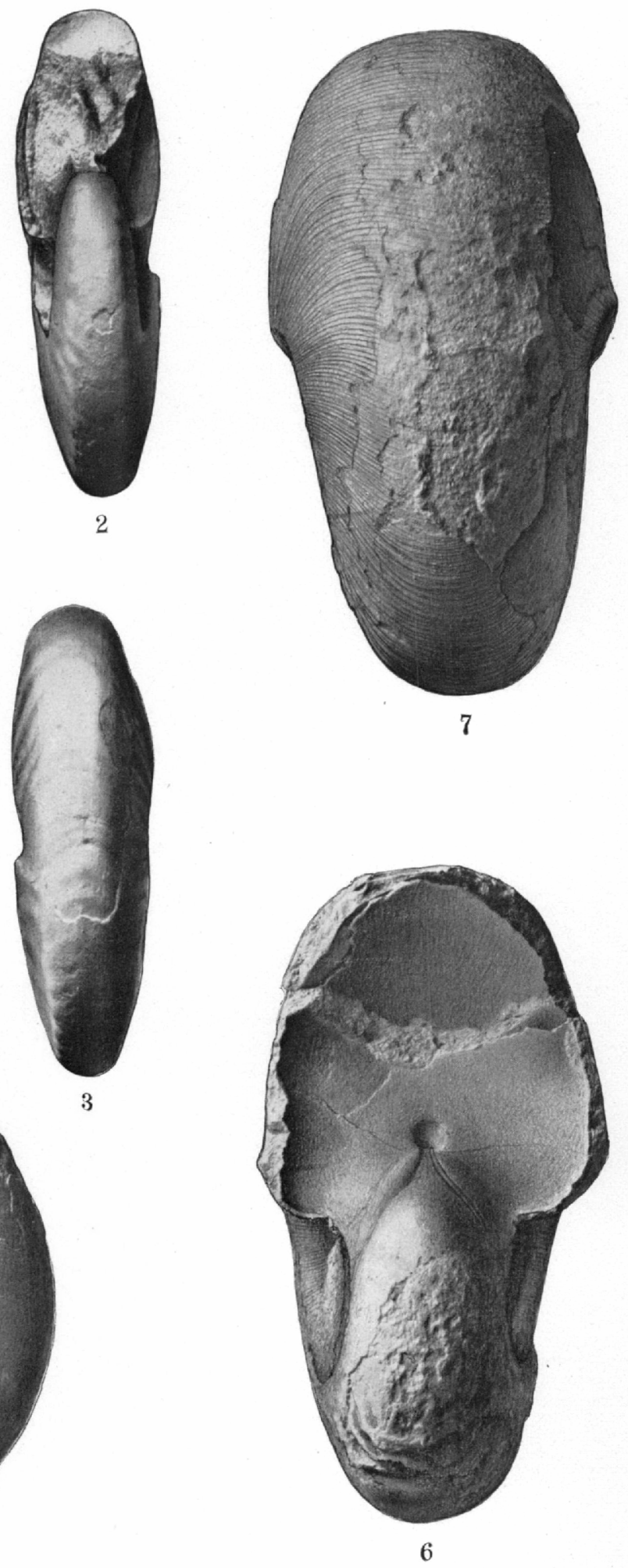



\section{INDEX.}

Names in italic are synonyms; figures in italic denote illustrations; figures in black face refer to descriptions.

A.

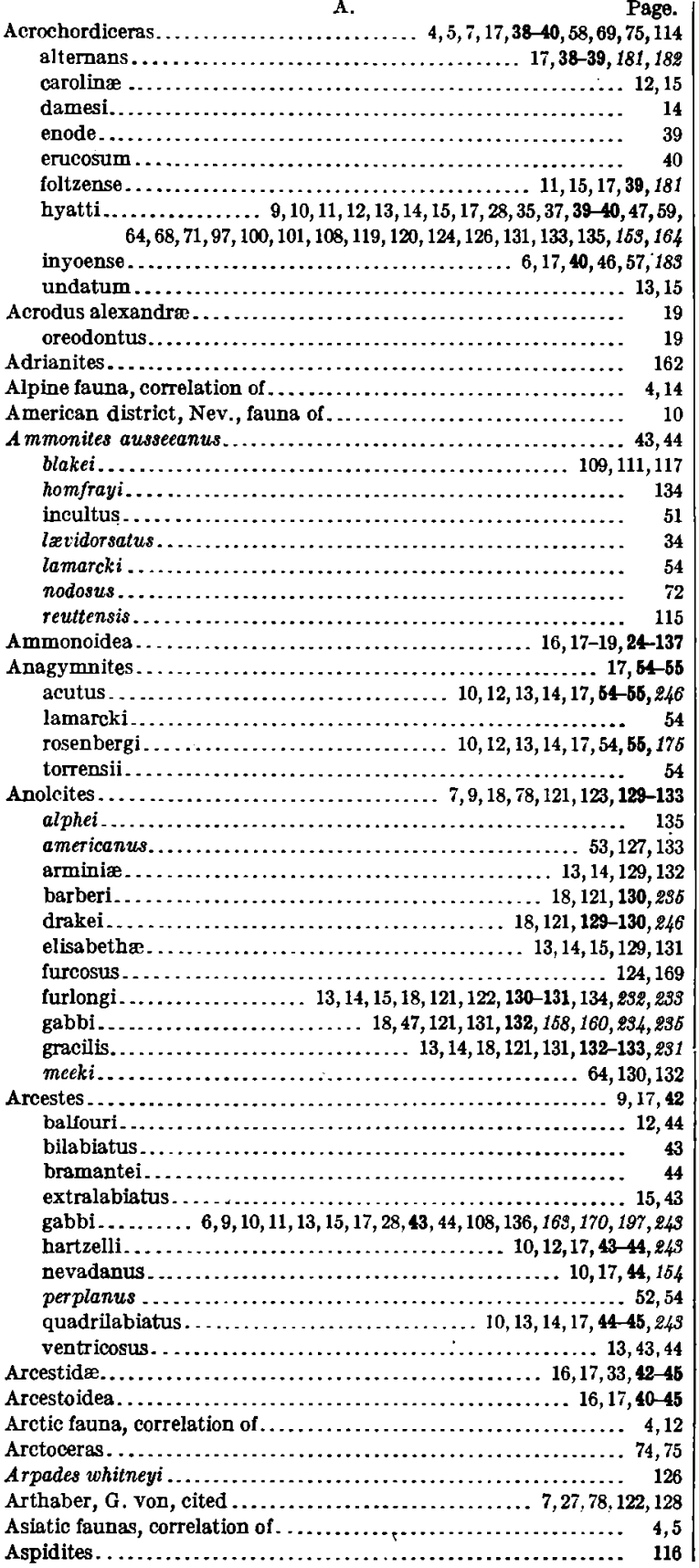

A A tractites. . burckhardti..................... 11,13,14,19,138-139,140,245 clavatulus. .................................. $11,19,139,245$ crassirostris................................. 13,14,140 cylindricus.................................... 13,14,140 elegans . .............................. 11, 13,14,19,139,245 macilentus .......................................... 138 nevadensis...................... 10,11,13,14, 19, 139-140, 245 pusillus..................................... 13, 14,139 solidus......................... 11, 13,14,19,138, 139, 140,245 tenuirostris. ..............................13.14,138, 139 Aulococcras . ............................................ 138 Avicula homfrayi . . . . . . . . . . . . . . Balatonites........................ $7,18,73,119-121,122,128$ hadleyi. . ............................. 9,18,119-120,2s9

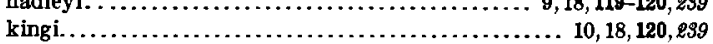
shoshonensis ............................ 10, 18, 120-121, 155 Balatonites (group) gemmati ......................... 121 Belemnites nevadanus. . . . . ............................... 139

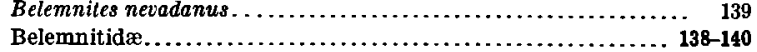
Belemnoidea................................... 19, 138-140

Beyrichites. . .......................... 7,9, 18, 76, 107, 115-119 affinis........................................... 110 dunni...............................11, 18,116,117,118,181 falciformis. . . . . . . . . . . . . 11,12,18,115, 116-117, 118,119,240,24t khanikofi........................................ 12, 118 nanda............................................ 12, 110,117 osmonti.....................11,18,115, 116,117-118, 119,180,234 reuttensis .......................................13,15 rotelliformis............. passim 9-136, 118-119, 158, 157, 16s, 180,240 tenuis.......................... 11, 18, 80,115,117,118,181,238

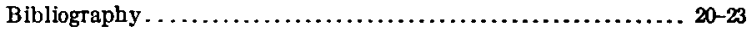

Bosnia fauna, correlation of . ............................ 4,14

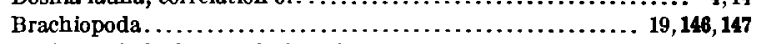
Buchenstein beds, correlation of........................ 4,7 Buena Vista Canyon, Nev, fauna at.................... 9-10 Bulogites. . ........................................ 78 c.

California, Middle Triassic fauna of. .................. 5-6,17-19 Cassian beds, correlation of . ............................ Celtites $\ldots \ldots \ldots \ldots \ldots \ldots \ldots \ldots \ldots \ldots \ldots \ldots \ldots \ldots, 17,25,26,30,33,34-35$ epolensis ..................................... 30,35 gabbi........................... 10,11,17,27,34-35,166,169 gemmellaroi .................................... 27 halli..............................................

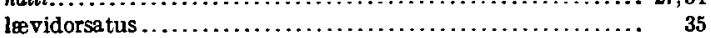

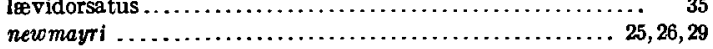
polygyratus.................................... 17, 34, 35,169 Celtitidæ $\ldots \ldots \ldots \ldots \ldots \ldots \ldots \ldots \ldots \ldots \ldots \ldots \ldots 16,17,24,32,33-37,38$ Cephalopoda ................................... 16-19, 24-143 Cephalopod genera, distribution of........................ 16-19 Ceratite beds, correlation of . . . . . . . .

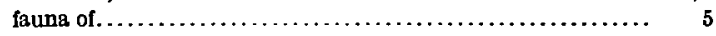
Ceratites . . ................ 7,9, 18, 58,61, 64, 72-114, 121, 122, 123, 223

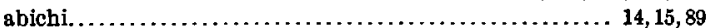

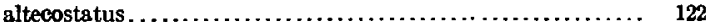
altilis.............................. 11, 18,83-84,194,216

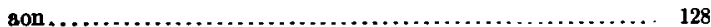


Page.

Cera tites applanatus. argentarius.......................... 11, 13,14,15, 18,79,107, 108, 212 arietiformis.

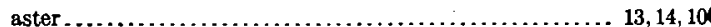

aviticus.......................................13, 15, 85

barrandei.

beckeri.

beecheri

beneckei.

binodosus................................................., $84,92,93$

blakei. . $9,10,11,18,28,62,80,109-114,109-110,118,152,168,165,214,215$

böckh

bosnensis . . . . . . . . . . . $13,14,76,78,79,90,94-97,121,122,123,128,129$ brembanus.............................. 15, 86, 91, 94, 100 burckhard ti. ........................... 11, 18, 79, 86, 90-91, 201 clarkei ................. 10, 13, 14, 15, 18, 79, 86, 91, 92, 93,94, 189, 201 cordevolicus . . ............................................. 78 cornutus . . . . . . . . costatus. crassicornu............................... 11, 18, 79, 96-96, 97, 198 crassus.......................................... 122, 125 cricki . ..... 11, 12,13,15, 18, 76, 79, 86, 87, 88, 89, 90, 93, 114, 186, 187, 196

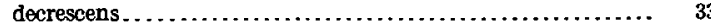
ecarinatus. ........................... 11, 13,14,18, 79, 96,97, 124, 199 elegans............................ 7,13,15,74, 79,86-94, 122 ellipticus...................................... 97 emmonsi............................. 11, 18, 79, 98-99, 209 erasmi $\ldots \ldots \ldots \ldots \ldots \ldots \ldots \ldots \ldots \ldots \ldots \ldots \ldots 13,75,79,106-108$

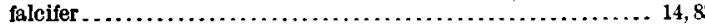

fissicostatus.......................11, 13, 14, 18, 79, 96-97, 202 floriani........................................... gabbi................................. 10,11, 18, 79, 86, 88, 154, 164 gilberti................................11,13, 18,84,247

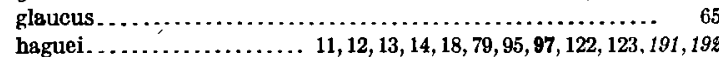
haguei................... 11, 12, 13,14,18,79, 95, 97, 122, 123,191,198

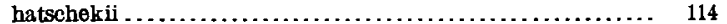
hersheyi........................... 11, 18, 80,110-111, 242 hidimba.

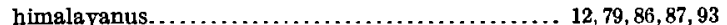
humbold tensis. ................ passim 4-144, 98-104, 99-100, 156, 210 hungaricus................................. $79,86,91,94$

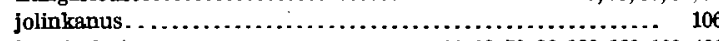
karpinskyi....................... 11, 18, 79,86, 100-101, 102,199 kingi $\ldots \ldots \ldots \ldots \ldots \ldots \ldots \ldots .11,13,15,18,76,78,79,84,85,86-86,190$ kuvera.................................... 12,97 lawsoni: . ....................... 11, 13, 18, 79, 107, 108, 205,206

lenis

lindströmi.

loczyi.

13, 15,74,79,86,87 meeki................................ 11, 18, 80,109, 111,112,168, 218 montis-bovis.......................... 11, 18, 79, 104, 105, 106, 207 nathorsti...

nevadanus............... 11, 18,64,79,101-102,103,110,164,218,214 newberryi...................... 11, 13,14, 18, 79,86,90, 92,93,189 obliquus.

occidentalis .

$13,14,15,18,76,78,81,83-84,84,100,101,102,104,193,194$ organi.................... 10,11, 18.79, 104, 105-106, 108, 208, 204 petersi.

pilatus.............................. 11, 18, 79, 102, 195, 238 planiplicatus

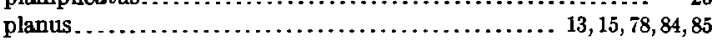
polaris................................... 74, 75,77,78

prettoi....................................... 78,81,85

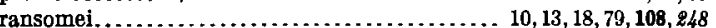
ravana........................................ 105, 106 rectangularis................................... 11, 18, 85-86, 190

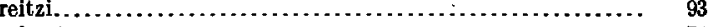

robustus.

rotuloides................. 11, 18,75, 78, 80-81, 80-83,84,85, 116,196 russelli............................ 11, 18, 80, 109, 111-112, 152,216 rusticus......................................6. 61,86 simplex.

spinifer $\ldots \ldots \ldots \ldots \ldots \ldots \ldots \ldots \ldots \ldots \ldots \ldots \ldots .11,18,79,98,99,103,208,209$ spurri. subnodosus $\ldots \ldots \ldots \ldots \ldots \ldots \ldots \ldots \ldots \ldots \ldots \ldots 13,14,15,79,100$

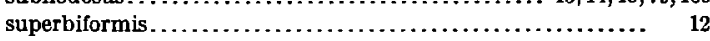

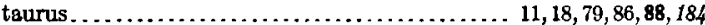
tenuispiralis............................. 11, 18, 81-82,83, 195 thuillieri...................................... 93 trinodosus.................... passim 4-145, 90-94, 92-94, 188. 201 trojanus..............11, 12, 14, 15, 18,79, 86, 87, 88-89,90,93, 185, 186 tuberosus................................. 13, 15, 106, 107 vicarius........................................ 81 vogdesi....................... 11, 18,79,86,87,89-90, 93, 123, 184 voiti ........................................ wardi............................................... $11,79,86,94,200$ washburnei........................... 11, 18,79, 103-104 241 weaveri................................... 11, 18, 82,247 wemplei............................ 11,18,80,113-114, 217 wetsoni $\ldots \ldots \ldots \ldots \ldots \ldots \ldots \ldots \ldots \ldots \ldots \ldots \ldots \ldots \ldots \ldots \ldots, 12$ whitei.............................................. 77 whitneyi...................................... 126,133 williamsi..................................... 11, 18, 82-83, 198 zezianus.

Ceratites (group) circumplicati . $274,76,79,104-108$ geminati........................... 74, 75,76,80, 105, 109-114 nodosi . ............. 73, 76, 78-79, 80-104, 87, 97, 101, 103, 111, 122, 129 obsoleti. subrobusti.

Ceratites binodosus zone, correlation of

Ceratites trinodosus zone, correlation of. fauna of

passim 4-148, 248 Ceratitoidea ............................. 17-19, 25,33, 51-137 Clionites.

Clydonetes lavidorsatus.

Columbites........................ 4, 17,24, 25, 26, 32, 33, 34, 36-37, 28 humboldtensis .............................. 10,17,36-37,169,286 parisianus........................................ 36 plicatulus............................ 10,17,36,37, 169,286 spencei................................... 36, 219,280

Columbites zone, correlation of ....................... 4,5 feuna of Corbula blakei. . .................................... 19,146,165 Corderillerites angulatus

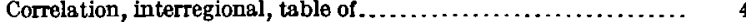

Cottonwood Canyon, Nev., fauna at.................... 9, 10 Coyote Canyon, Nev., fauna at........................ 9,10 Cuccoceras......................................... $7, \mathbf{7 0 - 7 1}$ bonæ-vistæ $\ldots \ldots \ldots \ldots \ldots \ldots \ldots .9,11,12,13,14,18,39,71,114,120,159$

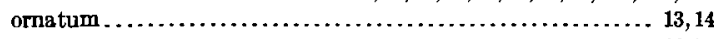

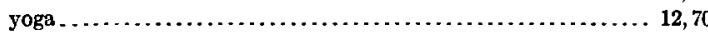
Cyclolobidæ.................................... 16, 13, 11-42

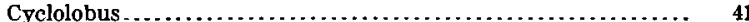
Cymbospondylus...................................... 19

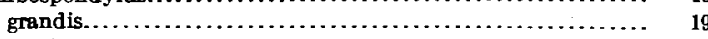
petrinus........................................ 10,11,19 piscosus........................................ 10,11,19

D.

Dalmanites . . . .

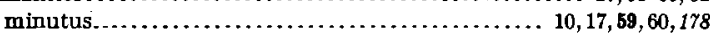
morlaccus...................................... 59,60 parvus .

Danubites ................. 27, 55, 74, 75, 98,99, 100, 101, 103, 163, 193, 204 dritarashtra......................................... $25,26,33$ halli........................................ 27,34

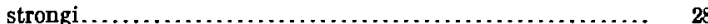

Daonella ............................................. 8-9,19,143-145 americana............................... 11, 13,19,143,198 böckhi....................................... 145 dubia ....... 4,9,10,11,13,19, passim 28-143,143-144, 168, 198, 199 indica. lindströmi.

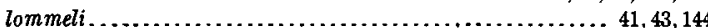
moussoni............................. 10,11,13,19, 143, 144-145, 199 paucicostata .................................... 13, 144

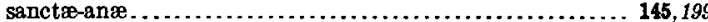
taramellii...................................... 13,143 
Page.

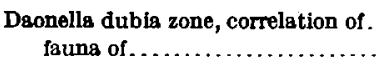

Danella zone, correlation of

fauna of

Daraelites.

Dawsonites zone, correlation of

Desatoya Mountains, Nev., fauna of

Diener, C., cited.

8,11

Dinarites.

avisianus.

bonz-vistz.

desertorum

fissiplicatus

labiatus.

ornatus.

pygmæus.

spiniplicatus

Dinarites (group) circumplicati

Discing

Discotropites.

Dun Glen, Nev., fauna at

E.

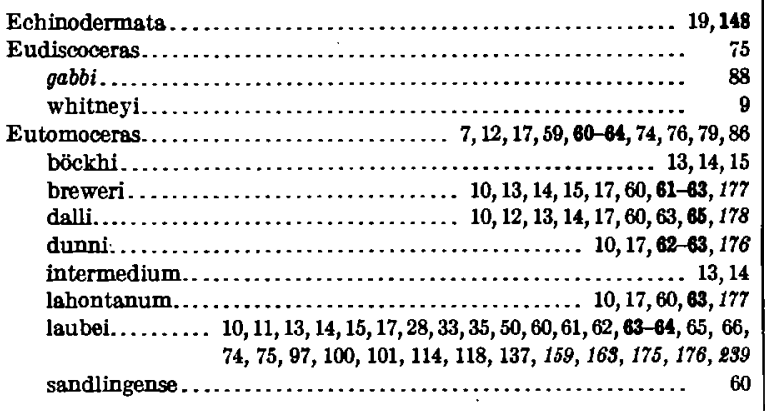

F.

Flemingites

russelli

Flemingites

Florianites.

Fossil Hill, Nev, fauna at.

Frech, B., cited

$7,55,61$

G.

Gabb, W. M., cited

$6,28,133,135$

Gastrioceras. . .......................... 25, 26, 29, 32, 33, 34, 37, 162, 219 listeri.

Geography of American Triassic..

Geography, taunal, of American Triassic

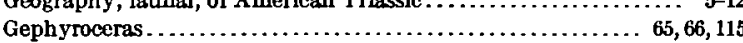
uch tense.

Gephyroceratidæ furlongi ................................. 11,12,13,14,15,142,24 salinarius.

whitneyi.

Glyphioceratidæe

Goniatiles haidingeri. lævidorsatus.

$24,25,32,33,38,55,115,128$

.

Grypoceras....................................... 19, 141

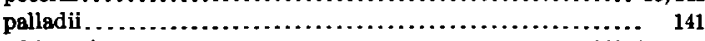
whitneyi $\ldots \ldots \ldots \ldots \ldots \ldots \ldots \ldots \ldots \ldots \ldots \ldots \ldots \ldots, 11, \mathbf{1 4 1}, \mathbf{1 6 5}, \mathbf{2 4 8}$

Gymnites.

acutus.

alexandræ

bosnensis

$17,64-55,240$

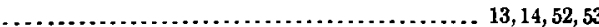

calli. ................................... 10,17,52,53, 17,

credneri. . . ........................................ 13,52,53

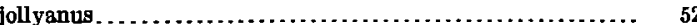

perplanus..................................9, 10, 17, 64, 164

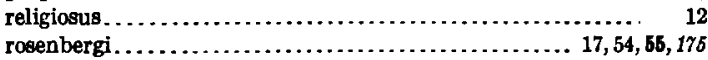

Gymnitidø..
Gymnotoceras................................. Page. $74,75,78,79,80,98,100.101,103,100-114115,116,118,193.195$ beckeri .............. blakei............... passim $11-141,109-110,102,163,165,214,215$ falcatum...................................... 12 hersheyi .................................... 11,18,110-111, 242

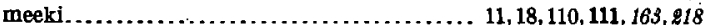

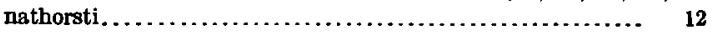

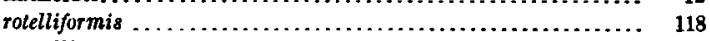
russelli............................. 11, 18,110,111-112, 158, 216 spurri................................. 11, 18, 112-113, 218 wemplei .....................................11,12,18,113-114 217

H.

Halilucites $\ldots \ldots \ldots \ldots \ldots \ldots \ldots \ldots \ldots \ldots \ldots \ldots \ldots, 12,58,60,61,64-65,75,86$ arietiforme................................................ dalli................................ 12, 13, 65, 178 intermedium....

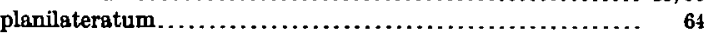
rusticum.................................................

Halobia $\boldsymbol{d} u$ bia . ......................................... 143

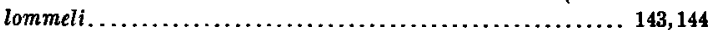
superba.

alobia beds, correlation of . . .

Halobia superba zone, correlation of . . . . . . . . . . . . .

Halorites. ......................................, 5, 38 ramsaueri.

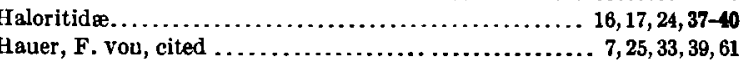

Haydenites. . . c........................... 18, 75, 78, 114

hatscheki1 ................................. 11, 12, 18,114, $18 \varepsilon$

Hedenstromia beds, correlation of.

Hollandites $. \ldots \ldots \ldots \ldots \ldots \ldots \ldots \ldots \ldots \ldots \ldots .7,18,75,76,78,79,104-108,107$ montis-bovis...............................11, 12,18, 106, 207

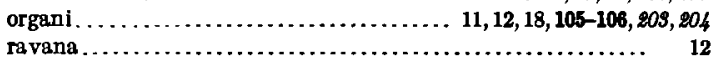

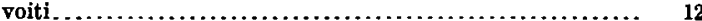

Homerites..... .

Hosselkus limestone, correlation of . . .........................

Humboldt Range, Nev., fauna of . . . . . . fauna of, correlation of ..................................... localities of $\ldots \ldots \ldots \ldots \ldots \ldots \ldots \ldots \ldots \ldots \ldots \ldots \ldots, 8-11$

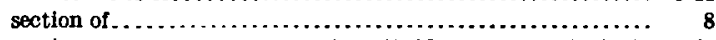
Hungarites . . . . . . . . . 4, 5, 7, 17, 57-58, 59, 60, 61, 69, 73, 74, 75, 79, 86 arietiform is . . . . . . . . . . . böckhi.............................................61, 62

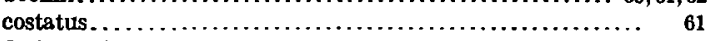
fltingensis $\ldots \ldots \ldots \ldots \ldots \ldots \ldots \ldots \ldots \ldots \ldots .10,13,14,17,68,178,299$

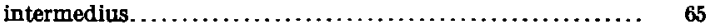

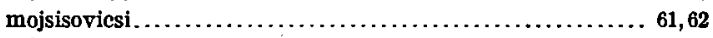

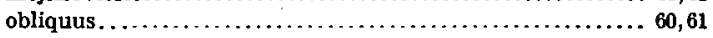
plicatus $\ldots \ldots \ldots \ldots \ldots \ldots \ldots \ldots \ldots \ldots \ldots \ldots \ldots \ldots \ldots, 13,14,58,60$ pradoi ....................................... 58,61 rusticus..................................... $68,61,64$ strombecki.

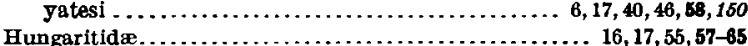

$6,17,40,46,58,150$

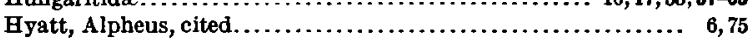
work of..

Hyatt, A., and Smith, J. P., quoted . ................... 39 , $41,44,47,48,49,50,56,58,63-64,68-69,99,120-121$ work of...

Hyattoceras.........

Hypodus nevadensis .

I.

Indian fauns, correlation of $\ldots \ldots \ldots \ldots \ldots \ldots \ldots \ldots \ldots \ldots \ldots, \mathbf{4 , 5 , 1 2}$ Inyo County, Cal., launs of . . . . . . . . . . . . . . . . .

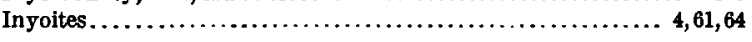

J.

Japan, fauna of, correlation of . . . . . . . . . . . . . .

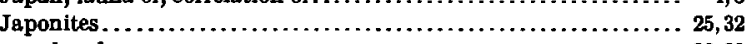

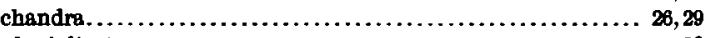
planiplicstus. 


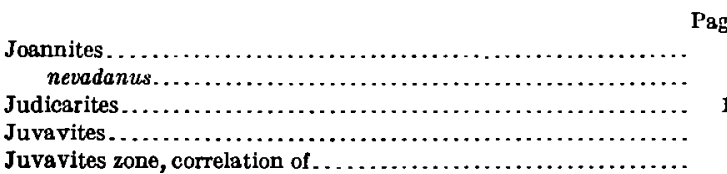

K.

Kellnerites.

Keyserlingites . . Koipato formation, fauna of................................

Koninckites

L.

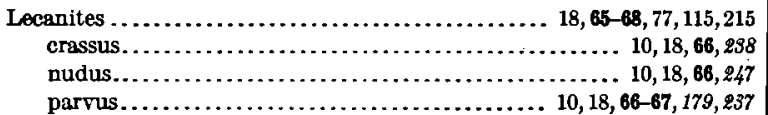
vogdesi. . ................... 10, 18,65,66,67-68,159,161,179,2s7 Leconteia...

Leconteiceras.

Leiostraca.

Leontia.

Longobardites.

breguzzanus.

nevadanus

zsigmondyi.

Lytoceratidæ.

Lytoceratoidea.

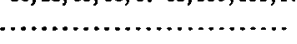

38

M.

Margarites.

Mediterranean faunas, correlation of ......................... 4,5,8,13

Medlicottia.

Meek, F. B., cited . . ............................ 6, 128, 136, 144

Meekoceras. . .............................. 4, 75, 77, 78, 115, 117, 228 gracilitatis . . ................................. 5,77

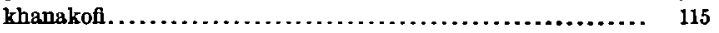
maturum................... 115 mushbachanum...................... 78, 221 , 228,223 pilatum.

reuttensis.

Meekoceras zone correlation of ...... fauna of ......................................... $5,64,221$

Meekoceratidæ. . . . . . . . . . . . . . 16, 18, 53, 55, 65-68, 77, 78, 103, 105, 115

Megaphyllites..................................... 17, 11-12 obolus. sandalinus. $13,14,15,41.42$ septentrionalis.

$10,13,14,15,17,42,170$

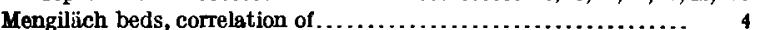

Metasibirites.......................................... 38

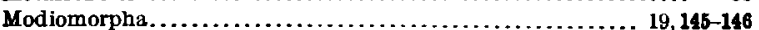
lata $\ldots \ldots \ldots \ldots \ldots \ldots \ldots \ldots \ldots \ldots \ldots \ldots \ldots \ldots 10,11,19,146,163$

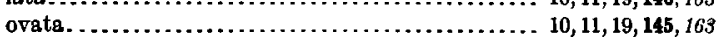

Mojsisovics, E. von, cited ............. $7,27,51,74,77,115,121,128,133$

Monophyllites................................ 17, 48-49 billingsianus.....99, 10,11, 12,13,14,17,48-49, 108, 127, 135, 154, 171, 197 sichoticus. sphærophyllus

Monotis beds, correlation of.

Myacites humboldtensis.

Myophoria alta.

N.

Nannites

Nannitinæ...

Nautiloidea.

Nautilus bidorsatus. multicameratus. whitneyi...

Nevada, Middle Triassic fauns of, affinities of ..... 6-8 Middle 'Triassic fauna of, distribution of.................. 16-19 localities of.. species of, allied to foreign species
Nevadites.

Hage. ... 7, 9, 18, 78, 79, 121-127, 128, 129 altecostatus. cautleyi. crassus... $11,18,121,122-123,180,200$ humboldtensis . . . . . . . . . . . 11, 12, 18, 121, 122, 123-124, 125, 22\%, 228 hyatti ............. 11, 14.18,62,87,101,121,122,123,124,125, 127, 226 merriami............. 11, 13, 14, 18, 121, 122, 123, 124, 125, 127, 224, 225 sinclairi ........................ 11, 18, 121,122,123, 125, 230,281 whitneyi.................. passim 4-144, 128-127, 197, 228, 229, 230 New Pass, Nev., fauna at............................... 9,11 Nicomedites. . . . . . . . . . .

Noric limestone, correlation of..........................

O.

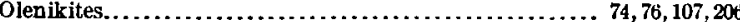
Omphalosaurus nevadanus................................. 19

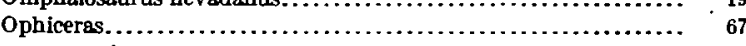
spencei.

Orthoceras.......................... 190-141 blakei.................................. 9, 10,11,19,140,169, 165 böckhi....................................... 138 campanile..........................11, 12, 13, 14, 19, 140,141, 249 Otoceras beds, correlation of Owenites

P.

Panopara humboldtensis.................................. 143 Paraceltites.

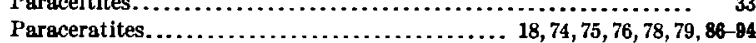
burckhardti................................. 11, 18,90-91, 200 clarkei................................. 11, 18,91, 189,201 cricki.......................................11, 18,87,186,187,196 gabbi.................................... 11, 18, 154, 164 newberry $\ldots \ldots \ldots \ldots \ldots \ldots \ldots \ldots \ldots \ldots \ldots \ldots \ldots \ldots \ldots, 11,18,92,189$ taurus. . . . . . . . . . . . . . . . . . . . . . . . . . . . trinodosus. ............................. 11, 18, 92-94, 188, 201 trojanus................................ 11, 18,88-89, 185, 186 vogdesi................................. 11, 18, 89-90,184 wardi.................................... 11, 18, 94, 202 Paralecanites........................................ 68, 103 Paralegoceras....................................... 162

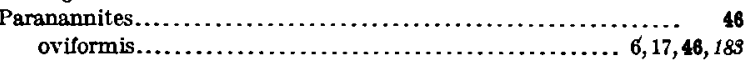

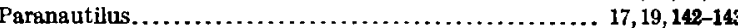
multicameratus. .......................... 10,11,143, 165, 244 simonyi....................................... 142 Parapopanoceras.......................... 4, 5, 17,40-41, 58,69 haugi . ..........................6, 17, 40,41, 46,57,168,189 Parapopanoceras zone, correlation of....................... 5 fauns of........................................... 40, 46, 57 Paratropites......................................... 24,61

Pelecypoda.................................... 19, 143-146

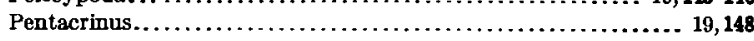
asteriscus $\ldots \ldots \ldots \ldots \ldots \ldots \ldots \ldots \ldots \ldots \ldots \ldots \ldots \ldots, 10,19,148,249$

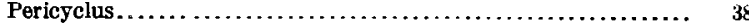
Peripleurocyclus................................ 75,105 Philippi, E., cited.......................... 33, 73, 75, 77, 104-105 Philippites........................... 18, 75, 76, 79, 106-108 argentarius............................. 11, 13, 18, 107-108, 1212 jolinkanus........................................ 12 lawsoni.............................. 11, 12, 18, 108, 205, 206 ransomei.................................... 13, 18, 108, 248

Pinacoceratidæ............................. 16, 17, 49-50,51 Pinacoceratoidea....................................... 16, 17, 49-60 Pit shale, correlation of .................................

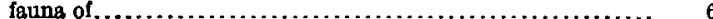

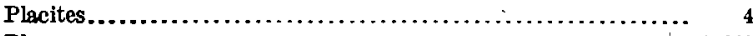

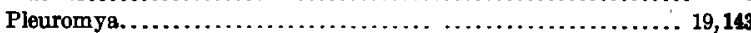

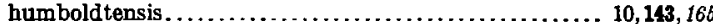

Plococeras........................................... 69

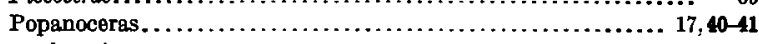
haugi................................17, 168, 18s 


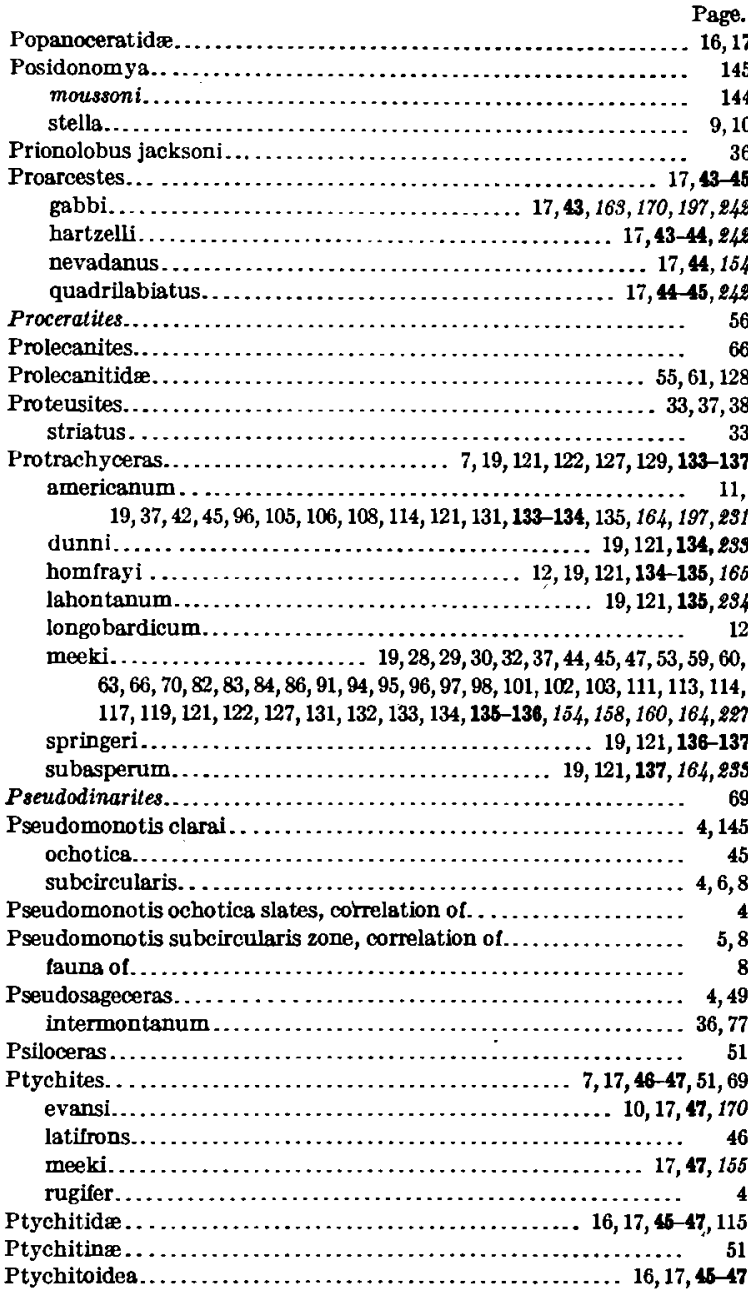

R.

Raibi beds, correlation of..

Red Beds, geologic position of...

Reifling limestone, correlation of.

Reiflingites.

Rhabdoceras

Rhynchonella.

.

alteplects. . ................................ 11, 19, 146, 248

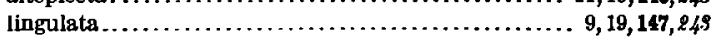

Rhynchopterus.................................. 19,145

obesus..................................11, 19, 145, 166

Rikusen beds, correlation of ............................. 4,7

Robustites.

s. passim $10-145,49-50,155,160,161,170$

Sageceras.

gabbi. haidingeri.$$
\text { walteri. }
$$

Sagenites.

Salterites.

Sandling beds, correlation of

Semiornites

Shasta County, Cal., fauna of.

Shoshone Mountains, Nev., fauna at.

Shumardites

Sibilites. .......... 25, 29

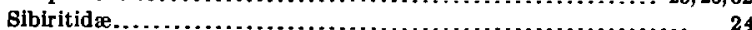

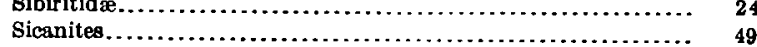

Silverthorns Ferry, Cal., fauna at............................. 6

Sirenites............................................. 121

Smith, J. P., and Hyatt, A., quoted ......................... 39 ,

$41,44,47,49,50,56,58,63-64,68-69,99,120-121$

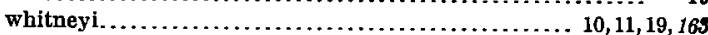

Spirifer homjrayi......................................... 147

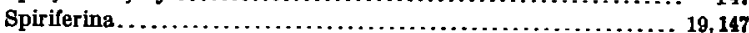

alia...................................... 10,19, 147, 249

homirayi............................. 9.10,11,19, 147, 249 Spiriferina zone, correlation of ..............................

Stacheoceras............................................ 41

Star Canyon, Nev., fauna from.............................

Star Peak formation, fauna of ................................ 8

Stephanites........................................ 38

Stephanites beds, correlation of ...........................

Styrites...................................................

Systematic descriptions $. \ldots \ldots \ldots \ldots \ldots \ldots \ldots \ldots \ldots \ldots \ldots \ldots \ldots, 24-148$

T.

Terebratula $\ldots \ldots \ldots \ldots \ldots \ldots \ldots \ldots \ldots \ldots \ldots \ldots \ldots \ldots \ldots \ldots \ldots, \quad 147$ humboldtensis $\ldots \ldots \ldots \ldots \ldots \ldots \ldots \ldots \ldots \ldots \ldots \ldots \ldots, 11,19,147,849$

Tirolites............................... 18, 58, 68-69, 121, 128

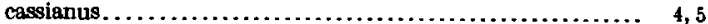
pacificus. ................................... 18, 68-69, 151

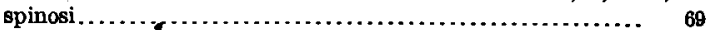

Tirolites zone, correlation of........................... 4,5

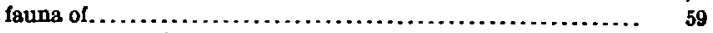
Tornquist, A., cited.............................. $73,75,81$ Trachyceras...................... 4, 18-19, 73, 79, 97, 121, 122, 127-128 americanum............... 11, 19, 82, 131, 133-134, 135, 164, 197, 291 ann....

aonides.

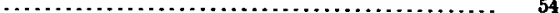

barberi................................... 11, 18, 130, 235

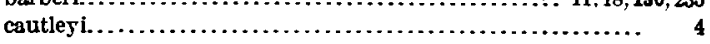
cuccense . . . . .

drakei................................... 11,18, 129-130, 246 dunni............................................ 11, 19, 134, 299. elisabethæ. . . . . . . . . . . . . . . . . epolense........................................... 34 furlongi. . . ....................... 11, 18, 130-131,132,232,299 gabbi..................... 11,18,130,131,132,158,160,284, 235 gracile................................. 11, 18, 132-133. 231 hispanicum ................................. homfrayi............................ 10,11,19, 134-135, 165

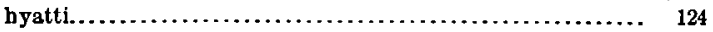
judicaricum................................. 135, 136, 137 var. asperum................................ 137

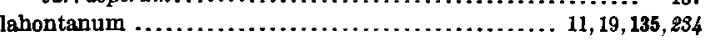
meeki...... 9, 10, 11, 19, 131, 132, 134, 135-136, 137, 154, 158, 160, 164.297 reitzii............... 4,124 springeri................................... 136-137, 285 subasperum........................... 9,11, 19, 137, 164, 299 taramelli............................................. tibeticum..................... 70 whitneyi $\ldots \ldots \ldots \ldots \ldots \ldots \ldots \ldots \ldots \ldots \ldots \ldots \ldots \ldots \ldots \ldots \ldots \ldots \ldots \ldots \ldots \ldots \ldots, 127,133$ Trachyceratea. ................................ 778, 121-138 Tropigastrites...............................9, 17, 24, 25-33,34 halli. ........... 9, 10,12,17, 26, 27-28, 30,31.37,156,161,169, 167, 237 lahontanus................................ 10, 17, 26, 28, 168 louderbacki..................... 10,17,28. 28,29,31,160,167,287 neumayri................... 10,11,13,14,17,26,28,29-30,167,287 obliterans . . . . . . . . . . . . .

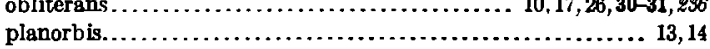
powelli................................ 10,17.26, 31, 167,246 rothpletzi. $\quad 10,13,14,17,26,27,30,31-32,168,236$ trojanus....................... 10,17, 25, 26, 29, 30,31,32-33,166

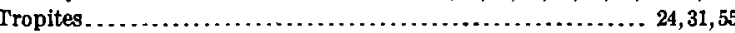

subbullatus.................................. 4, 25, 122, 129

Tropites subbullatus zone, correlation of .................. 5 
INDEX.

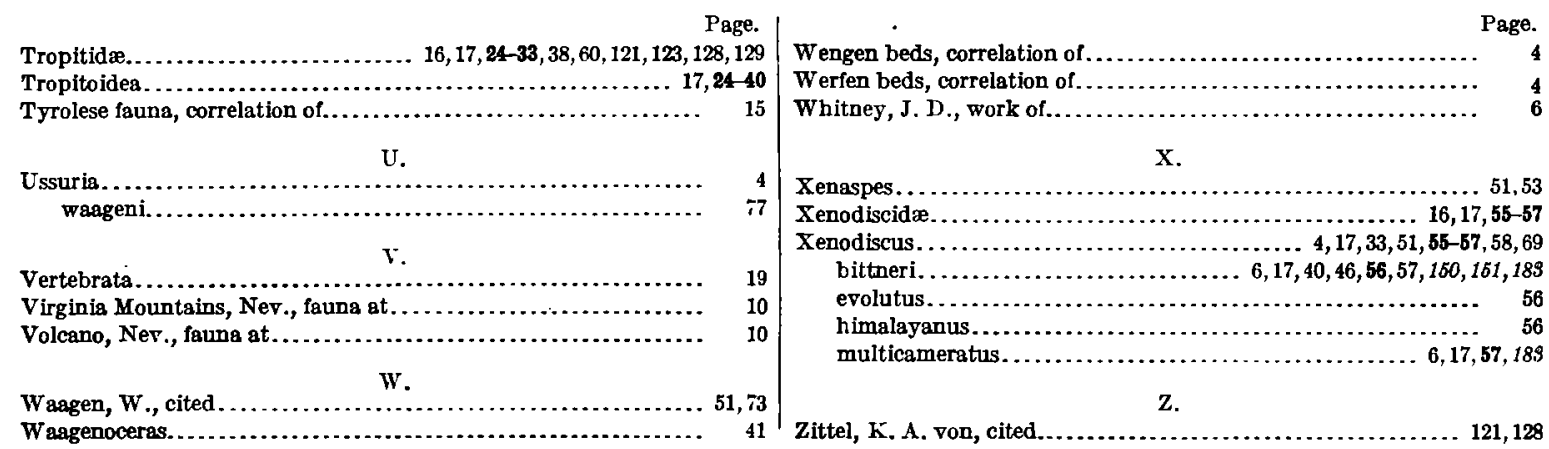



